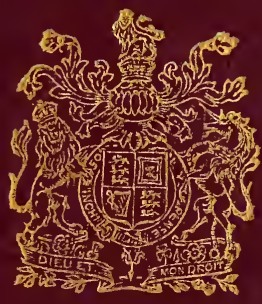

HANDBOOK OF NYASALAND. 

$\$ 922 \mathrm{NCll}$ 



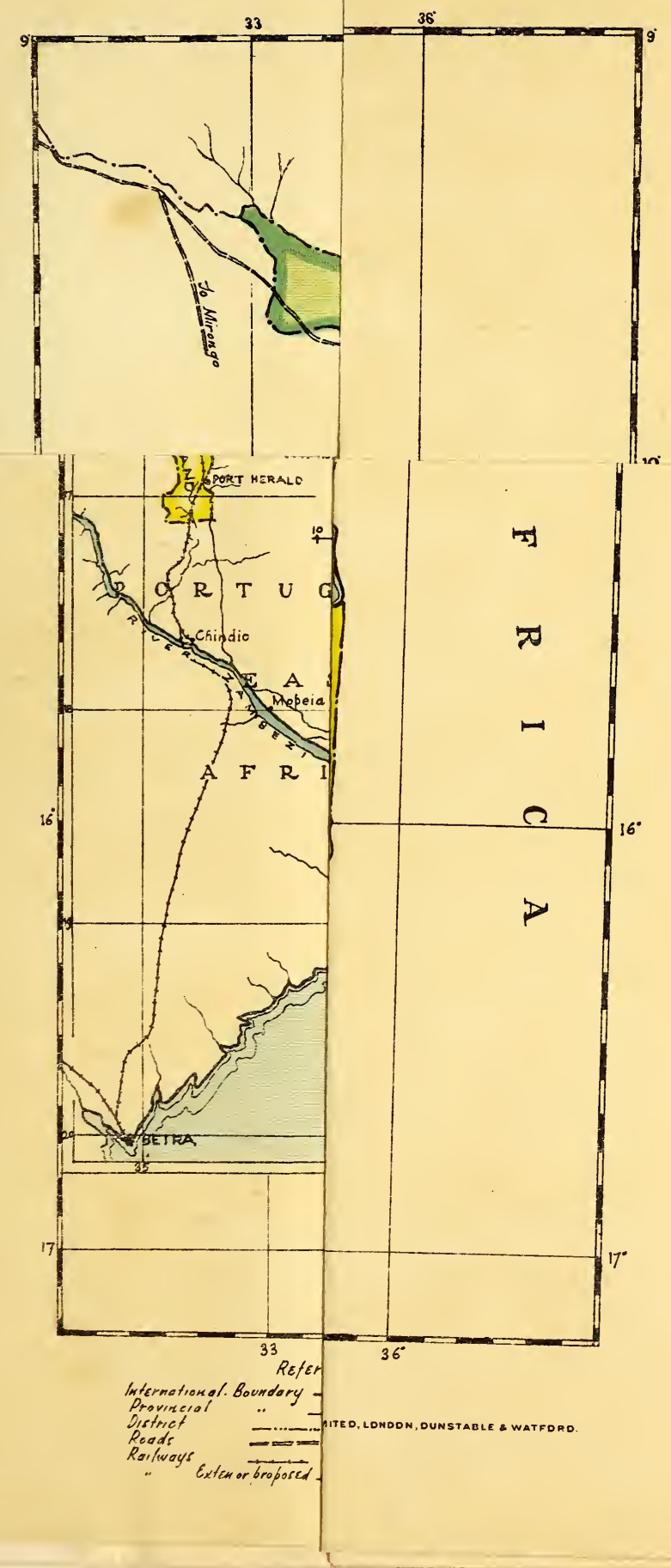







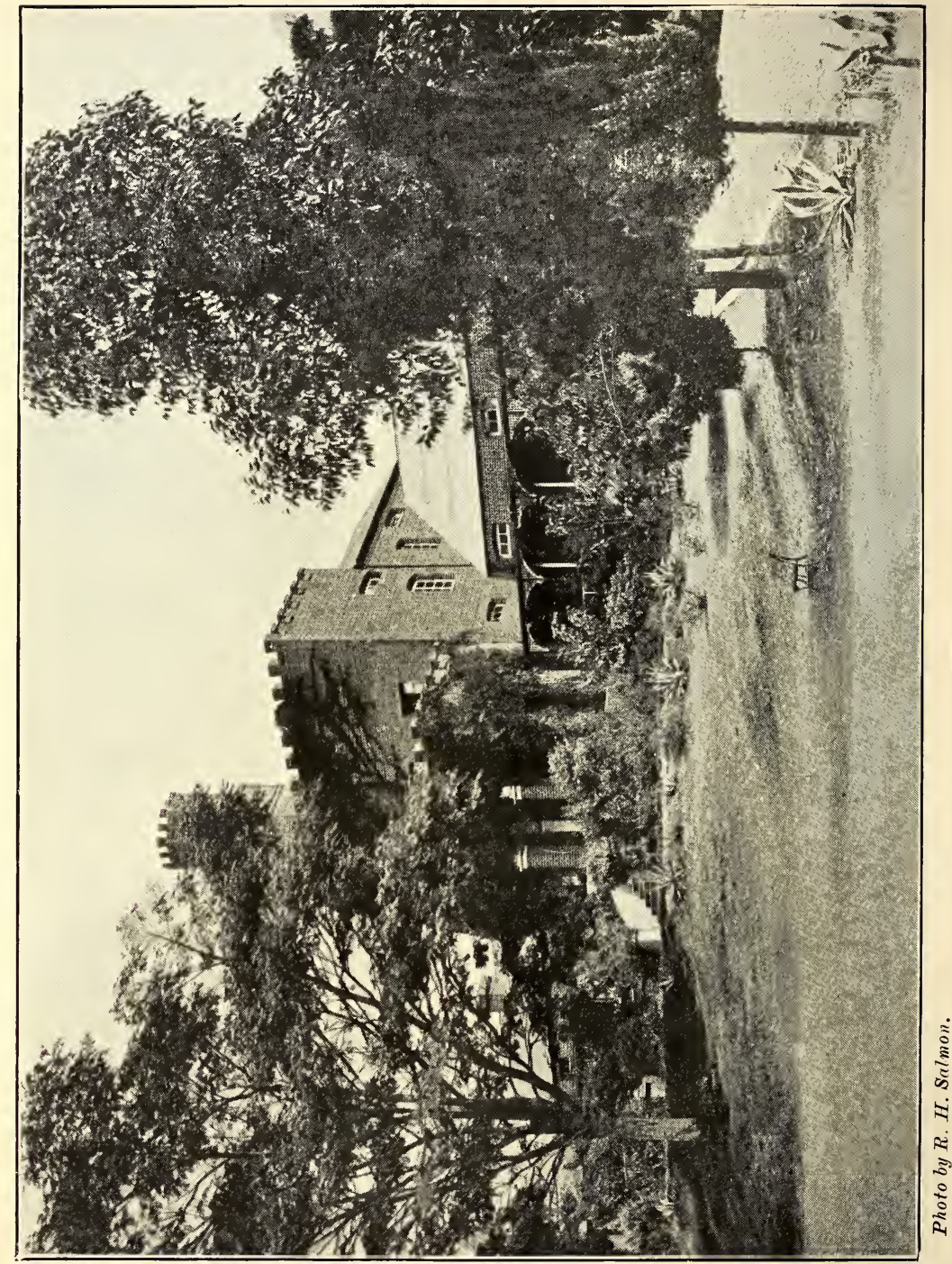

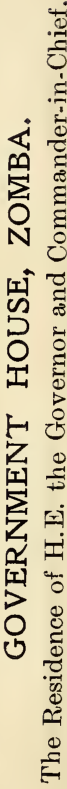




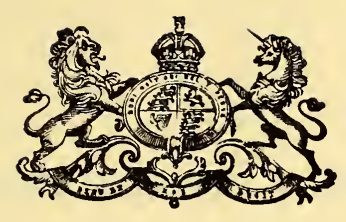

A

\section{Handbook of Nyasaland,}

compiled by

S. S. MURRAY,

Chief Clerk, Nyasaland Government.

\section{Price 5/- nett.}

(Postage extra.)

Published for the Government of Nyasaland by the

Crown Agents for the Colonies, 4, Millbank, London, S.W.1.

\section{Also TO BE OBTAINED FROM}

The Governaent Printer, Zomba, Nyasaland Protectorate.

NOV 281988

\section{LBEFARIES}




\section{COLONIAL PUBLICATIONS.}

Price. Postage.

Commercial Handbook of BRITISH GUIANA, compiled by Captain J. M. REID . . . 36 cents. 3 d.

Handbook of the FALKLAND ISI.ANDS .. 2s. 6d. $3 \mathrm{~d}$.

Handbook of GRENADA, compiled by The Colonial Secretary .. $\quad \ldots \quad$.. $2 \mathrm{~s}$. $6 \mathrm{~d}$. $4 \mathrm{~d}$.

Handbook of JAMAICA, compiled by F. Cundall, Esq., F.S.A. .. $\quad$. $\quad$. 8 8s. 0d. $9 \mathrm{~d}$.

Handbook of NIGERIA, compiled by A. C.

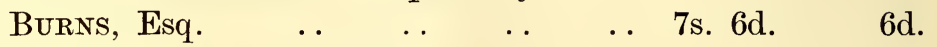

Handbook of ST. KITTS, compiled by

Mrs. K. J. BURdoN $\quad . . \quad \ldots \quad$.. 5 s. 0d.

$4 d$.

Year Book of TRINIDAD, compiled by

C. B. Franklin, Esq. . . $\quad$.. $\quad$. 3 3s. $6 \mathrm{~d}$. $6 \mathrm{~d}$.

Handbook of UGANDA, compiled by H. R.

Wallis, Esq., C.M.G., C.B.E. .. . . 7s. 6d.

$6 \mathrm{~d}$.

The above are on sale at the Office of the Crown Agents For THE Colonies, 4, Millbank, London, S.W.1, from whom other Colonial Government publications (Blue Books, Laws, Departmental Reports, etc.) may also be obtained.

Fe. Ca. 3. 
PRINTED BY

WATRRLOW AND SONS LIMITED, LONDON WALL, LONDON, E.C. 


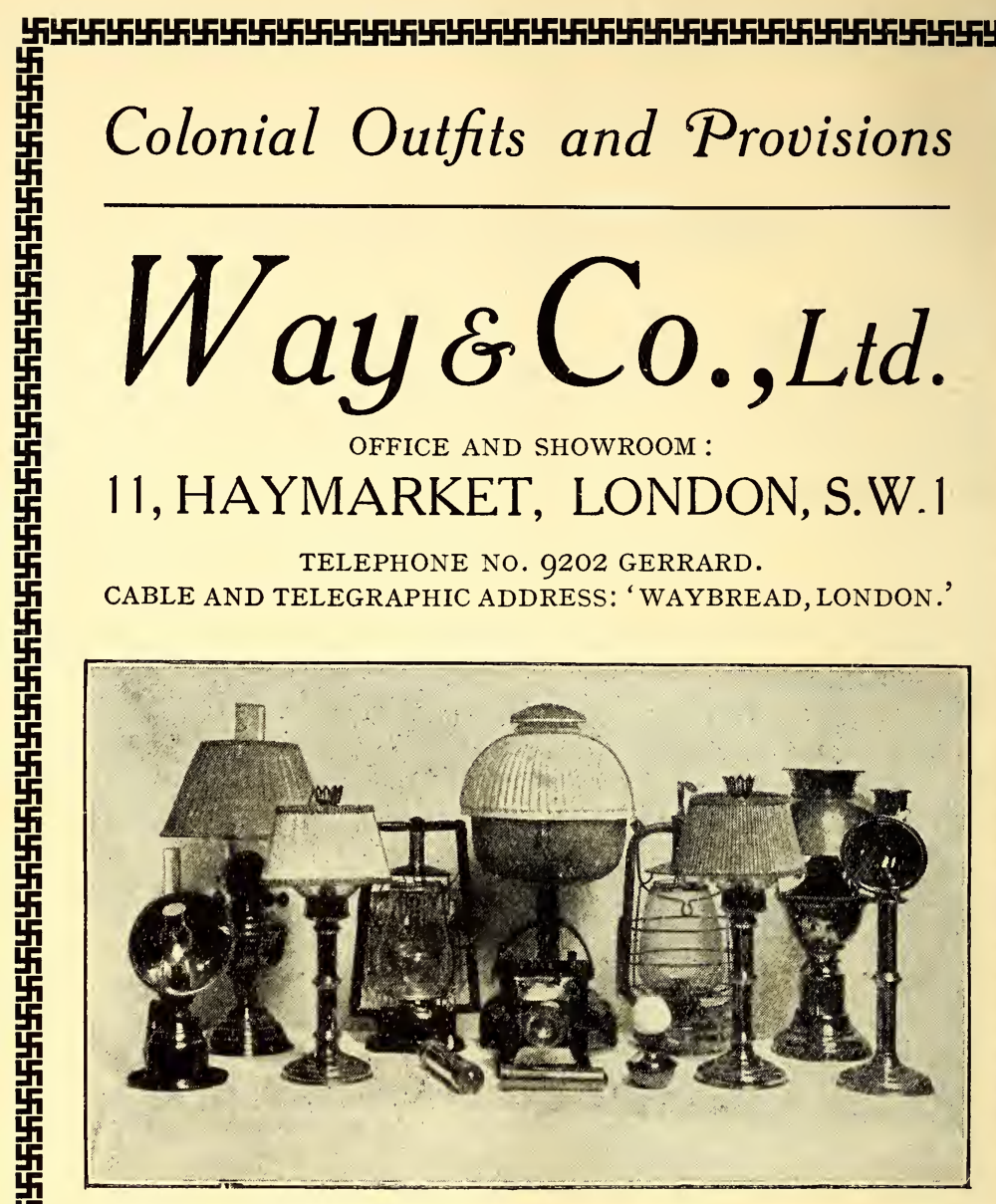

The question of Lighting is always a difficulty, the above shows a vange of various Lamps suitable for most tropical countries.

ESTABLISHED IgOI

Contractors to the Crown Agents for the Colonies COMPLETE OUTFITS-

UNIFORM CASES MOSQUITO NETS FILTERS BOOTS

PORTABLE FURNITURE HELMETS

CLOTHING

LAMPS

COOKING POTS, \&c. PROVISIONS AND WINES-

ALL THE BEST KNOWN BRANDS.

Write for our Latest Catalogue 


\section{CONTENTS.}

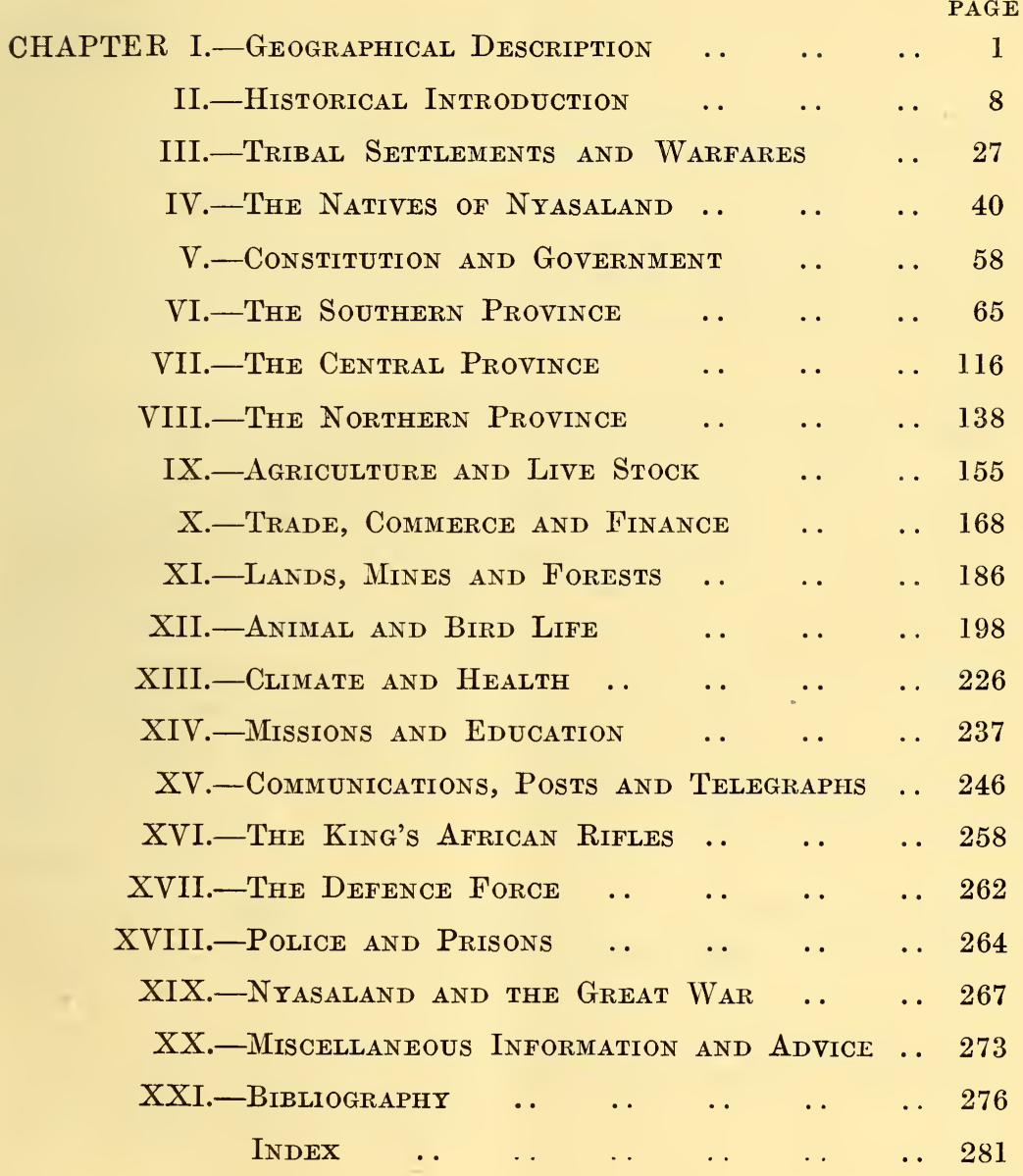





\section{PREFATORY NOTE.}

It was at first intended merely to revise and bring up to date the second edition of the Handbook of Nyasaland published in 1910. So much of that work was found, however, to be out of date; so much appeared unsuitable for reproduction in a book intended for general use; and so many subjects were inadequately dealt with, that it was felt to be more convenient to re-write the whole Handbook on different lines.

District Residents and departmental officers such as the Chief Forestry and Veterinary Officers have contributed directly; others through their reports and returns, and the Heads of Missions have supplied notes on the institutions under their charge. It is gratifying to record that the authorities on the various subjects connected with Nyasaland most willingly supplied information and contributions. Special thanks are due to the following:- the Rev. A. Hetherwick, D.D., for his notes on the Anyanja, Mr. C. A. Cardew, C.M.G., for notes on the Angoni and Swahili, Mr. W. P. Ronaldson and the Rev. E. D. Bowman for notes on the Anguru, and Mr. C. T. Verry for notes on the Yao. Mr. W. Kirby Green supplied the interesting information on the habits of game, and Mr. C. F. Belcher, M.B.E., that relating to birds.

The bibliography makes no pretension to completeness, but it will serve to indicate some of the principal works on the country to those who wish to learn more about it.

In a work of this nature omissions and inaccuracies are inevitable, and the compiler will be grateful if readers will bring to his notice any they may discover. 



\section{CHAPTER I.}

\section{GEOGRAPHICAL DESCRIPTION.}

Nvasaland consists of a strip of larid some 40,000 square miles in extent, or about one-third the area of the British Isles, lying approximately between latitude S. $9^{\circ} 45^{\prime}$ and $17^{\circ} 15^{\prime}$, and longitude E. $33^{\circ}$ and $36^{\circ}$. The Protectorate is about 520 miles long, and varies from 50 to 100 miles in width; the most southerly point is about 130 miles from the sea in a direct line. Some idea of the position of the country may be gained by noting that Beira, Jinja in Uganda, Addis Ababa in Abyssinia, Jerusalem, Nicosia in Cyprus, and Sebastopol in the Crimea, lie on lines of longitude passing through Nyasaland; while such places as Northern Fiji, Cape York Peninsula in Queensland, the Friendly Islands, Mozambique, Tete and Mossamedes in Africa, Bahia in Brazil, and Lima in Peru, are on parallels of latitude which traverse some part or other of the Protectorate.

The limits of the Protectorate were laid down in the Proclamation of the 14th of May, 1891, and the respective spheres of influence of Great Britain, Germany and Portugal were defined in agreements of 1st July, 1890, and 11th June, 1891.

The boundaries of the British sphere of influence were fixed in the Convention with Portugal of June 11th, 1891, to be as follows pending formal survey :-

From a point on the eastern shore of Lake Nyasa where it is intersected by parallel of latitude $\mathrm{S} .13^{\circ} 30^{\prime}$ the boundary runs in a south-easterly direction to the eastern shore of Lake Chiuta, which it follows. Thence in a direct line to the eastern shore of Lake Shirwa, which it follows to its south-easternmost point; thence in a direct line to the easternmost affluent of the River Ruo, and thence follows that affluent, and, subsequently, the centre of the channel of the Ruo to its confluence with the Shire. Thence along the centre of the channel of the latter river to a point just below Chiwanga. Thence due westward until it reaches the watershed between the Zambesi and the Shire, and follows that watershed and afterwards the watershed between the Zambesi and Lake Nyasa until it reaches parallel $14^{\circ}$ of south latitude. (Here the boundary continues round Northern Rhodesia; but the boundary between that territory and Nyasaland now continues along the watershed between Lake Nyasa and the affluents of the Zambesi until it reaches the Songwe River, which forms the northern boundary of the Protectorate as defined in the agreement with Germany of July 1st, 1890).

Nyasaland is bounded on the east by Lake Nyasa, on the south by Portuguese East Africa, on the west by North-Eastern Rhodesia, and on the north by the Tanganyika Territory. It falls naturally into two geographical divisions: the Shire Highlands, and the western shore of Lake Nyasa with the table lands separating the Protectorate from Rhodesia. 


\section{MOUNTAINS.}

A very large proportion of the Protectorate is of a mountainous or hilly nature, which generally takes the form of lofty plateaux, rising more or less abruptly from the lower ground.

The principal ranges are as follows :-

1. Mlanje.-A magnificent mass, situated in the extreme south-east of the Protectorate between Lake Shirwa and the River Ruo. It consists of a great tableland, with an area of about 200 square miles, and an altitude, for the most part, of upwards of 6,000 feet. From this tableland rise several granite peaks, bare of vegetation, and probably of volcanic origin. the highest of which is 9,843 fect. The twin peaks at the south end are named Harris Peaks.

2. Shire Highlands.-An irregular chain of mountainous country on the east of the Shire river above its confluence with the Ruo. This chain has a length from north to south of about 90 miles, and a width of 20 to 30 ; the highest portion is found in Mount Zomba, lying at the northern end, midway between Lake Shirwa and the Shire. Mount Zomba, like Mlanje, is a plateau, with an average altitude of 4,000 feet, and rising at its highest point to 7,000 feet. Chiradzulu, 5,300 feet, is another prominent peak in this range, and is situated about 30 miles south of Mount Zomba.

3. The Kirk Range.-A high plateau on the west of the Shire, and approaching the south-western end of Lake Nyasa. It attains its greatest altitude, about 7,000 feet, in Mounts Dedza and Chongoni at its northern end.

4. The Angoniland Plateau. - West of Nyasa, is another lofty tableland, the highest peaks of which range between 5,000 and 6,000 feet.

5. The Nyika Plateau.--At the north-western end of the lake, much of which exceeds 7,000 feet, the highest point rising to over 8,000 feet.

6. The Nkonde Mountains.-On the north-western edge of the Protectorate, a small but important group, ranging between 6,000 and 7,000 feet.

7. Mangoche Mountain.-4,700 feet, between Nyasa and Lake Chiuta. It is the southern extremity of the watershed of the Lujenda, on the east side of Nyasa.

\section{LAKFS.}

Nyasa.-Lake Nyasa, the third largest lake in Africa, is a deep basin 360 miles long and 15 to 50 wide, lying at an altitude of 1,645 feet above the sea and closely approached, especially on the northern and eastern sides, by lofty mountains and tablelands which rise several thousand feet above it. Its greatest depth is 386 fathoms at longitude E. $34^{\circ} 19^{\prime}$, latitude S. $11^{\circ} 11^{\prime} 30^{\prime \prime}$. 
Its principal affluents, the Songwe, Rukuru, Bua and Lintipi are on the western coast, but are of no great size. It finds an outlet at its southern extremity in the River Shire, by which its waters are carried to the Zambesi, and ultimately to the Indian Ocean.

Islands are few and of small area. The best known are those of the Likoma group about midway up the lake, which are the head-quarters of the Universities Mission.

The level of the lake varies somewhat in proportion to the annual rainfall ; in an exceptionally dry season it has fallen over six feet.

The water is fresh and drinkable.

Navigation is everywhere practicable, but owing to the existence of sand bars most of the harbours can only be entered by vessels of light draught. During the dry season the lake is liable to severe south-easterly gales, which cause a heavy sea.

Lake Nyasa possesses few good harbours. The anchorages of the various ports are, in most cases, much exposed to the north or south winds, which sweep the lake from end to end, and often cause a troublesome sea. The approaches are hampered by sandbanks and bars formed at the river mouths. The island of Likoma possesses a fair anchorage.

Fort Johnston, the principal port and the headquarters of the Protectorate's Marine Transport Department, is at the outlet of the lake, but lies about 5 miles distant from it up the River Shire. Other ports are, on the west coast, Domira Bay, KotaKota, Nkata Bay, Florence Bay, Nkudzi, Chinteche, Mwaya, Chisiombe and Karonga. Of these Kota-Kota and Karonga are the most important: both are customs stations and stations of the Trans-Continental Telegraph Line.

On the east coast are Manda and Mbamba Bay, both in Tanganyika Territory; Mtengula, where there is an excellent harbour, in Portuguese territory, and Fort Maguire in South Nyasa district.

Shirwa.-Lake Chilwa, or Shirwa, south-east of Nyasa on the Portuguese border, receives the drainage of the eastern slopes of the Shire Highlands and the northern slopes of Mlanje. It contracts to a large degree in the dry season and does not exceed much more than 100 square miles in the height of the rainy season. The water is brackish, and very shallow.

Chiuta.-Lake Chiuta, a few miles north of Shirwa, and also on the Portuguese boundary, is about 30 miles long, and 2 to 8 miles wide. The water is fresh, and it forms the source of the River Lujenda, which flows northward from it. This lake, in the dry season, is greatly reduced in area.

Pamalombe.-Lake Pamalombe, through which the Shire flows soon after issuing from Nyasa, had, some years ago, a considerable area, but is now practically filled up by the formation of a reedy and sandy island and is little more than a marsh. 


\section{RIVERS.}

The Shire.-The only important river in the Protectorate is the Shire, which issues from the south end of Lake Nyasa, and, passing through the reedy swamps of Lake Pamalombe, takes a southerly course as far as the Murchison Falls, 80 miles below the lake. Here it is deflected for a time by the western portion of the Shire Highlands, which it skirts for the next 64 miles in a series of falls and rapids, rendering navigation impossible. Below the rapids it takes a south-easterly direction as far as its junction with the Ruo 60 miles lower down, whence it once more flows southward for about 90 miles to its meeting with the Zambesi, 110 miles from the sea. The total course of the Shire is about 295 miles, the last 50 of which are in Portuguese territory.

Navigation on the Upper Shire has practically ceased of late years as the overflow from Lake Nyasa has not been sufficient to keep open a navigable channel. It is thought by some that the outlets from the lake become periodically choked up by the silting of sand, until the accumulating waters wash away the obstruction and find their way into the old channels again.

The Lower Shire is navigable in the rainy season as far as Port Herald, about 60 miles above its junction with the Zambesi. In the dry season the river steamers keep to the Zambesi, loading and discharging cargo at Chindio, the terminus of the Central African Railway. Barges sometimes use the rivers where they are impassable for steamers.

Other rivers are as follows :-

Ruo.-The Ruo, the principal affluent of the Shire, rises on Mount Mlanje and joins the Shire at Chiromo. For about the last 80 miles of its course it forms the south-eastern boundary of the Protectorate. There are some fine falls at Zoa, a point about 25 miles above Chiromo, where it is joined by the Lifuluni. The Ruo is navigable for canoes for about 12 miles above Chiromo.

Lintipi, Rukuru, Songwe.-The Lintipi, Bua, South Rukuru and North Rukuru, and Songwe, western feeders of Nyasa, take their rise in the mountain region west of the lake, each having a course of upwards of 100 miles. They all have a considerable volume of water in the wet season, but are navigable only for canoes. The Songwe forms a portion of the northern boundary of the Protectorate.

\section{GEOLOGY AND MINERALS.}

The rock formations which make up the surface of the Nyasaland Protectorate comprise 3 great groups :-

(1). An igneous group.

(2). A sedimentary group.

(3). A metamorphic group.

Metamorphic Group.--In common with most of the continent of Africa, the surface of Nyasaland is composed chiefly of metamorphic gneisses and schists. 
The most frequent of the gneisses is black and white rock, usually soft and crumbly, which is composed of alternating layers or folia of black mica (biotite), often with hornblende and white felspar together with some quartz.

Another common gneiss is a basic hornblendic gneiss, often composed of hornblende alone, but usually with an admixture of quartz and felspar. By a decrease in the amount of hornblende, and a consequent increase in the quartz and felspar present, this basic gneiss graduates in appearance towards the more common gneiss just mentioned. Sometimes the hornblende is changed into serpentine, talc or asbestos.

Graphitic gneiss, or gneiss containing graphite, is of fairly frequent occurrence, but the graphite is disseminated along the foliation planes of the rock, and only very occasionally does it occur in definable seams.

Garnetiferous gneiss is fairly common. The crystals of garnets may be up to 1 pound in weight, but usually they are about the size of a pin's head. The variety of garnet is Andradite, common or black garnet, and is of very little value.

Iron ores, ilmenite and magnetite often occur in the gneiss. As a rule they are finely disseminated or in thin seams among those gneisses which contain a large proportion of quartz. At times, however, the seams swell out into great masses, forming small ridges on the surface of the ground. Where these iron ores occur, the surface of the ground is thickly strewn with angular fragments of ore ; these the natives use to smelt, although their chief source was a hematite or limonite to be mentioned later.

Crystalline limestone is in a few places found forming massive seams in the gneiss. In various parts of the Protectorate this limestone is quarried and burnt. The limestone is as a rule quite white, but it is also pinkish and yellowish. As a rule it is pure, but it may be associated with accessory minerals in quantity sufficient to destroy its commercial value.

In addition to the gneisses there is a series of metamorphic schists, which have by no means so wide an extension as the gneisses. They comprise mica schists, composed of mica and quartz, and talc schists, composed of talc and a greater or less quantity of quartz.

These gneisses and schists form the basement of the country, and through this basement igneous rocks have been intruded. These rocks have all been more or less affected by the agencies which brought about the metamorphism of the gneisses and schists, and are consequently looked on as belonging to the metamorphic group. As a rule these rocks form the upstanding features of the country.

Probably at the same time as the igneous were intruded, pegmatitic veins and seams were forced along the planes of the gneiss, and now form seams of quartz, often with a little muscovite. These pegmatites often consist of quartz, felspar and muscovite or white mica, and the individual crystals may be of very large dimensions. 
Sedimentary group. The sedimentary rocks of Nyasaland occupy a comparatively small part of the country. They may be grouped together thus:-

A. Recent gravels, marls and alluvium.

B. Coal bearing formation of Karroo age (permo-carbondiferous).

C. Older beds of possibly Cape age (Devonian).

\section{Older Beds of Cape (?) Age.}

These have so far been found only in one corner of the Protectorate, in the Namitawa or Mafingi hill. They consist of a great thickness of quartzites, conglomerates, greywackes, shales and flags. No fossils have been found in the beds, so that their age cannot be justly determined. They are, however, older than the coal-bearing formation, and possibly were formed at the same time as the Cape beds of South Africa.

\section{Coal Bearing Formation.}

This sedimentary series consists of an assemblage of conglomerates, pebbly sandstones, sandstones, shales, coal, mudstones and limestones. These beds have been long known at Mt. Waller, where they were described by the late Mr. Henry Drummond.

The limestone of the North Nyasa district is in part argillaceous; it is in places burnt and used as a building lime.

Fossils are not abundant in this formation. but Glossopteris has been identified, and it is practically certain that this formation in Nyasaland is of similar age to the Karroo formation of South Africa.

Beside the localities in the North Nyasa district the West Shire district also contains what is presumably the same formation. Here the formation consists of a great thickness of sandstones, together with coal seams and shales.

\section{Recent Deposits.}

The formations that come under this head consist of gravels, sands and marl, river alluvium, and lateritic deposit. Fossil Gasteropods have been found in the marls, which, with gravels, occur in the North Nyasa district at some distance from the lake, and in the West Shire district. Alluvium, as might be expected, is abundant along the shores of Lake Nyasa and the courses of the rivers. Along the streams which rise in the high plateaux, deposits of dark red laterite are encountered, consisting of quartz pebbles and fine soil cemented with limonite. The iron of this laterite was formerly smelted by natives.

Igneous group. Volcanic action must have manifested itself in Nyasaland to produce the intrusion of igneous rocks into the metamorphic group mentioned above. There must also have been another period of such action when the eruption took place of the basaltic lavas found bedded with sandstones of Karroo age in the southern part of the Protectorate. The top of Mlanje 
mountain may also be of volcanic origin, and, although no activity is manifested at present, the hot springs of Liwonde and KotaKota bear witness to volcanic agency in the past.

\section{General.}

It cannot be said that the geology and mineral resources of the Protectorate have as yet been exhaustively explored. A mineral survey was made during the years 1906-09, and a Government geologist has been employed since 1918; but much remains to be done before it can be stated that our knowledge of the geology of Nyasaland is complete.

Coal, graphite, limestones, ores of iron and tin, and corundum have been located, although no deposits have been discovered sufficiently rich or extensive as to be of industrial importance in the existing state of development of the country. The presence of iron ore and coal may, however, prove of considerable importance in the future. Limestone is found in considerable quantities and is already proving of value locally in connection with the problem of the manufacture of cement. Traces of gold are also in evidence in various parts of the country, although it has not been discovered in payable quantities. Garnets and tourmaline of little value exist in the rocks and pegmatite veins of the gneisses, which form the geological basis of Africa. Coal is found in the sedimentary rocks in Portuguese territory west of Lower Shire. Galena exists near Dowa, but it is very poor in lead and silver. Mica and kaolin have been found in various deposits, but the latter is too impure and gritty for use in pottery manufacture.

Coal has also been found in the lake regions, in sedimentary deposits of Karroo age, and usually associated with limestone. It exists both in its bituminous and its lignite character. The coal in the Mount Waller area of North Nyasa is of good quality, whether for fuel or for the manufacture of coke and gas. Fair quality coal is also to be found near the North Rukuru in the same district. Graphite of first rate quality occurs in Angoniland, but transport difficulties at present stand in the way of its being worked on a commercial basis.

It should be noted that the British South Africa Company holds the mining rights over the North Nyasa, as well as over the Dedza, Dowa, Lilongwe, Fort Manning, Kota-Kota and Ngara districts. The opportunities for prospectors are therefore very limited. The regulations concerned with mining will be found in the chapter on Lands, Mines, and Forests. 


\section{CHAPTER II.}

\section{HISTORICAL INTRODUCTION.}

But little is known of the early history of Nyasaland. The Bantu races possess no written records concerning their past, and the tribes that at present inhabit the Protectorate are, for the most part, not indigenous to the locality; they are the descendants of peoples who invaded and occupied the country within quite recent times.

There are some indications that the earliest inhabitants of Nyasaland were probably akin to the Bushmen type of South Africa. The entry of the bigger and darker races of negroes into the southern half of Africa took place probably about the beginning of the Christian era. If the theory is true that the negro had his origin in Asia, the reputed cradle of the human race, then the descent of this later wave into Central and Southern Africa must have been considerably delayed, either by the dense forests of the Congo Basin, or by the protracted resistance of the earlier Bushman type, which, as stated above, was the first to inhabit the country. It would seem that each successive wave which crossed from Asia to North-Eastern Africa by way of the then fertile Arabia was of a higher physical type and was more advanced in civilisation than its predecessors; but that as it passed southwards in its turn, and mixed with inferior types formerly settled there, it deteriorated. Evidence is not wanting that the negro stock, moving southwards as stated above, reached and occupied these territories some ten centuries ago. Their admixture with the Bushman type of natives whom they found in occupation of the country appears, from the scanty material available on which to base a judgment, to have resulted in a loss of such culture as they had brought with them from the north. They may have received an occasional visit from an Arab explorer or slave trader, but it is hardly likely. Until the Portuguese came to the East Coast of Africa at the close of the fifteenth century the negro races of Central Africa were shut off from the outer world. From their settlements on the coast Portuguese adventurers and Jesuit Missionaries penetrated the interior from the sixteenth century onwards and were not long in reaching the watershed of Lake Nyasa, where for some centuries they worked the gold and silver mines lying north of the Zambesi. These Portuguese adventurers were not on the best of terms with the Government at Moçambique, which was controlled by the Viceroy of Portuguese India, and in 1616 Jaspar Bocarro set out with samples of Zambesi silver which he undertook to carry overland to Malindi, near Mombasa, without passing through the neighbourhood of Moçambique. In his journey from the site where Tete now stands he crossed the Upper Shire river somewhere near the present Chiromo, went across to Lake 
Shirwa, and so by the Lujenda valley and the Rovuma river to the coast at Mikindani. We have no reliable records of any European entering Nyasaland previous to Bocarro. The Jesuits, working northwards from the Zambesi up the Luangwa valley, had sent back rumours of a great lake; but their activity was brought to an abrupt conclusion in the middle of the eighteenth century, when Jesuits were expelled from all Portuguese dominions.

Portuguese interest in Africa, which flagged after this event, was revived in 1795, when the English seized Cape Town at the outbreak of the war with France. A man of science, endowed with remarkable prevision, Dr. Francisco Lacerda, foresaw that the result of this step would eventually be the creation of a great British South Africa which, spreading northwards, would strike a wedge between the Portuguese possessions on the east and west coasts of Africa. The Portuguese Government immediately recognised the force of Dr. Lacerda's arguments, and created him Governor of the Zambesi. He was also authorized to undertake an expedition from coast to coast between Mozambique Territory and Angola, establishing Portuguese sovereignty as he went. Had this project succeeded the whole history of South Africa might have been changed; but Dr. Lacerda died at Lake Mweru, between what are now known as Northern Rhodesia and the Belgian Congo, in October, 1798. The expedition thereupon broke up and returned to Tete. Other Portuguese explorers and adventurers during the nineteenth century wandered in Central Africa and one of them, Candido de Costa Cardoso claimed to have sighted the south-west corner of Lake Nyasa in 1846. None of these journeys, however, had any scientific or political significance.

In the meantime changes had been taking place in Central Africa. A tribe of the Zulus, partially conquered by Chaka early in the nineteenth century, assumed the name of Ngoni. Dissatisfied with Chaka's autocratic rule, the tribe moved northwards in a body, crossed the Zambesi, and eventually settled in the country lying to the south-east of Lake Tanganyika. Here they remained for some time sending out branches northwards to Victoria Nyanza in one direction, and south-east to the east side of Lake Nyasa in another. Eventually the main stock turned southward again to the west side of the lake, one section settling in the district now known as Momberas from the chief of that name who led them there. Another section under Mpezeni occupied what is now Northern Rhodesia; a third section had already established itself in that part of Nyasaland known as Central Angoniland. At the south end of Lake Nyasa a fourth section settled; but whether during the original northward movement from Zululand in 1825 , or on the return movement above described is not certain.

About the middle of last century the Yao tribes first began to enter Nyasaland, driven from their homes east of Lake Nyasa by pressure from their neighbours. The Yao tribes, driven southwards, sent out branches in three directions :--one division settled 
in Blantyre and Chiradzulu, where they dispossessed the indigenous Anyanja. A second division entered this country by way of Lake Shirwa and settled in the Mlanje district. This section, although small in numbers, was of considerable importance as it commanded the slave route to Quelimane. The third division became established between Matope on the Upper Shire and Blantyre. The main body of the invading Yao remained, however, in the district round the south end of Lake Nyasa, and to this day South Nyasa is the most important Yao district of the Protectorate, and it is no doubt from there that the branch now settled in Liwonde district originated.

It was while this period of warfare and migration was in full swing that Livingstone undertook that expedition which resulted in the discovery of Lake Nyasa on the 16th of September, 1859. The name Nyasa like Nyanja and Nyanza simply means "broad water." It was not long before the discovery was followed by practical steps, for while Livingstone and his companions were still engaged in exploring the Shire Highlands, they were joined by Bishop Mackenzie and his fellow missionaries, who founded near Zomba the mission now known as the "Universities Mission to Central Africa." Their arrival in 1860 synchronized with the beginning of the Yao raids into the Shire Highlands, and after vainly struggling against them, the party, having lost from fever the Bishop and three of his companions, withdrew first to the Lower Shire and eventually to Zanzibar. Livingstone's party was recalled by the British Government, and left the Zambesi in 1864. The recall was probably due to political opposition on the part of the Portuguese.

Before describing in detail the events which occurred after the discovery of Central Africa it is necessary to revert for a moment to the Portuguese expeditions at the end of the eighteenth century into that part of Africa now known as Northern Rhodesia.

The Babisa tribes had acquired guns from the Portuguese and thus armed were easily superior to the other natives with whom they came into contact. They resolved to trade directly with the Coast, and not through the medium of the Portuguese. In this way they opened up intercourse with the Arabs of Zanzibar, at that time increasing in power, some of whom returned with the Babisa to see for themselves the country of whose fertility and resources they had received such glowing accounts. They thus came in contact with the Yao, whose home lay in their path from the Indian Ocean to the Babisa country west of the Luangwa river. The Yao entered with enthusiasm into the idea of the slave trade and after the Babisa had fallen victims to neighbouring tribes armed with guns by the Arabs, the latter and their Yao confederates began to dominate Nyasaland. The Anyanja, indigenous to almost the whole of the Protectorate, were caught between the Angoni of the west and south-west, and the Yao driven down from the north-east as previously described. It is a coincidence that this slave raiding and invasion by the Yao and Angoni should have started about the time that Nyasaland 
was discovered by Europeans, for much of the early history of the Protectorate is the story of the suppression of the slave trade. The Portuguese were not the only people who viewed with interest the travels and discoveries of Dr. Livingstone in Central Africa. German Missionaries had discovered the snow-clad mountains of Kenya and Kilimanjaro in East Africa, and had reported to their headquarters the native rumours concerning the existence of the great lakes. However, it fell to the English to discover Tanganyika, for Burton and Speke were the first recorded Europeans to set foot on its shores, and in 1860 Speke, having been sent on by Burton, also discovered the southern end of Victoria Nyanza. A French explorer who had just previously set out from Zanzibar to discover Tanganyika was murdered on the way. A German doctor, Ernst Roscher, disguised as an Arab, reached the eastern shore of Lake Nyasa two months after Livingstone's discovery; but he was murdered by the Yao on his way back to the coast. Another German, Von der Decken also attempted, but without success, to reach Lake Nyasa.

Livingstone returned to Africa again in March, 1866, landing at Mikindani, the place where Jaspar Bocarro, as mentioned above, reached the coast on his overland journey from Tete 250 years earlier. This journey of Livingstone, although he reached Lake Nyasa again on the 8th of August, was for the most part outside the bounds of Nyasaland.

The country did not remain unvisited, however. In 186. Lieutenant Young led a party to Lake Nyasa to enquire into a report that Livingstone had been murdered by the Angoni. $\mathrm{He}$ travelled up the Zambesi and Shire to the Murchison cataracts, and thence overland to the south end of Lake Nyasa. One of his party, Mr. Faulkner, returned to shoot big game in 1874 .

The work of settlement in Nyasaland was now actively taken up by the Scotch Missions. The Livingstonia Free Church Mission, founded in 1874, sent out its first party with a small steamer in sections, in 1875. Dr. Robert Laws who came out with that missionary enterprise is still head of the Livingstonia Mission after 47 years of active labour in Nyasaland. The Church of Scotland Mission followed in 1876, the present head, Dr. A. Hetherwick, arriving in 1881.

In 1878 Captain F. Elton, Consul at Mozambique, obtained permission to conduct an expedition to Lake Nyasa to enquire into the slave trade. He was accompanied, among others, by Mr. H. Rhodes (a brother of Cecil Rhodes), who remained behind on the Upper Shire after the expedition was over, and established himself as an elephant hunter, until he was accidently burned to death in a native hut in 1880 . Consul Elton made many valuable geographical discoveries, including the Livingstone mountains; but, unfortunately he died on his journey to Zanzibar.

The Church of Scotland Mission had not been long in existence before it was discovered that the efficient discharge of its proper functions was hindered by the necessity for dissipating valuable 
effort in the direction of native trade, to procure the means of subsistence, and transport work between the coast and Lake Nyasa. A small company was accordingly founded in Scotland to relieve the Mission of these extraneous duties. This company, widely known in Central Africa at the present day as the African Lakes Corporation, fixed its headquarters near Blantyre. It may be of interest to note that "Mandala," the official name of the headquarters, and the name by which the Corporation is commonly known, has its origin in a nickname given to Mr. John Moir, the original joint manager, by the natives, who applied to him the native name for glass on account of the spectacles he wore. $\mathrm{Mr}$. F. M. Moir, joint manager with his brother John of the original venture launched in 1878, is another of the pioneers of Nyasaland who is still alive, and during 1921 he re-visited the scenes of his early labours.

It is a regrettable fact that, although the responsible heads of the Church of Scotland Mission were men of the highest character, some of the laymen attached to it were cast in a different mould. By their harsh treatment of the natives a considerable amount of trouble was caused which eventually resulted in an official enquiry and, as a consequence, the dismissal of George Fenwick and some of his associates. An indirect sequence to the affair was the establishment of a British Consul at Blantyre in 1883, in view of the increasing number of British settlers in the country. Captain Foot. of the Royal Navy, was the first occupant of this office, and Mr. D. Rankin, who afterwards discovered the Chinde mouth of the Zambezi, went with him as private secretary. Livingstone, after his journeys through Zambezia, had left behind in the Shire Highlands some of his Makololo porters, natives of mixed origin from Barotseland. These men, being armed, soon dominated the timid Anyanja and constituted themselves a ruling caste. At first they did good work in stemming the tide of invasion of the Yao and Angoni raiders, and seemed friendlily disposed towards the British settlers. Later on they became arrogant, although a useful foil to set off against the aggressive Yao. Two of these Makololo chiefs were specially prominent-Ramakukane (in whose hut Mr. Rhodes was burnt to death in 1880) and Chipatula. The George Fenwick just mentioned turned hunter and trader after his dismissal from the Mission, and, in 1884, in a drunken quarrel with Chipatula over dealings in ivory the latter was shot dead by Fenwick, who was pursued by Chipatula's followers, at whose hands he was killed on Malo island near where Chiromo now stands. This affair seems to have set the Makololo against the British and, having sunk the little Lady Nyasa steamer of the African Lakes Company, they sent into Blantyre to demand that Mrs. Fenwick together with a large sum should be handed over to them as compensation for the murder of Chipatula. Consul Foot, with the help of Ramakukane, succeeded in righting matters, although he died soon afterwards from the results of fatigue and anxiety, and the attitude of the Makololo became increasingly truculent as time went by. 
It will be remembered that the Universities Mission to Central Africa had withdrawn to Zanzibar after the death of Bishop Mackenzie in 1862. In the year 1881 it resumed its labours in Nyasaland under the Rev. W. P. Johnson and Mr. C. Janson, the latter of whom soon fell ill and died, bequeathing a sum of money to build a steamer for Lake Nyasa. The Rev. Chauncey Maples had in the meantime joined Mr. Johnson and the headquarters of the Mission were established on Likoma island, eight miles from the eastern shore, and about half way up the lake.

In the meantime the Livingstonia Mission under Dr. Laws had, after experimenting in various places, established itself at Bandawe on the western shore of the lake, almost opposite to Likoma island. This Mission exerted its influence with some degree of success to protect the Atonga of West Nyasa from the Angoni raiders.

The first real menace to the advance of the white settlers in Nyasaland now arose in the form of conflict with the Arab slave traders settled at the north end of the lake. Some of these Arabs had cast envious glances on the rich cattle country they passed through in their journeys between Zanzibar and the Luangwa Valley, and under the leadership of Mlozi began by trading, but eventually erected stockades and seized the land round about Karonga. His enterprise clashed, however, with the projects of the African Lakes Corporation, who about the same time had established themselves at Karonga in connection with the scheme for uniting Lakes Tanganyika and Nyasa by a road. The Corporation had just previously carried out a contract on behalf of the London Missionary Society for the transport of a steamer in sections to Tanganyika via Lake Nyasa, and among other Europeans who had been engaged in this work were two who were destined to play an important part in the early affairs of Nyasaland. They were Mr. Monteith Fotheringham and Mr. J. L. Nicoll. At the time when Mlozi was engaged in consolidating his position in North Nyasa, Fotlieringham was settled at Karonga as the agent of the African Lakes Corporation, while Nicoll was occupied principally on journeying backwards and forwards between the two lakes. When the Arabs began to force their authority upon the Nkonde people of North Nyasa, the latter turned to Monteith Fotheringham for protection, and although in the interests of his Company he wished to keep out of the quarrel, he was left no choice in the matter. The Arabs had come to the conclusion that a necessary preliminary to the establishment of their rule was the expulsion of the white men from the locality. Mr. Fotheringham's refusal to surrender Wankonde refugees, and his preparations to fortify Karonga, precipitated the collision, although, fortunately, not before reinforcements arrived in the shape of Mr. Nicoll from the north and the little steamer Ilala of the Livingstonia Mission from the south, with Consul O'Neill of Mozambique, Mr. Alfred Sharpe and two other volunteers. The attack on Karonga lasted several days and, although the Arabs were repulsed, the position became untenable, and 
Fotheringham withdrew with his European helpers and the Wankonde chiefs to a more sheltered place. They remained at the extreme north end of the lake until reinforcements, including Consul Hawes and Mr. J. Moir, arrived. Then, with the aid of 5,000 natives they attacked and partially destroyed Mlozi's stockade at Mpata, Messrs. Sharpe and Moir both being wounded. The departure of the native allies with their loot prevented the complete destruction of Mlozi's fortifications, and the volunteers withdrew to South Nyasa, while Fotheringham, Nicoll and Dr. Kerr-Cross established themselves to the north-west of Nyasa, and the Arabs continued much as before without, howerer, engaging in active hostility. After a time more volunteers arrived from South Nyasa, including Mr. F. M. Moir and Mr. John Buchanan, the Acting Consul, who unsuccessfully attempted to negotiate with the Arabs. In the hostilities which thereupon ensued Mr. F. M. Moir was severely wounded, and the British were once more robbed of a decisive victory by the attitude of their native allies. In the meantime the news of these struggles had reached the outer world and, early in 1888, Captain Lugard, D.S.O. (now the Right Hon. Sir Frederick Lugard), arrived in Africa, and was put in command of their forces in North Nyasa by the African Lakes Company. Mr. A. Sharpe and Mr. R. Crawshay, who had both come to the country as hunters, together with Mr. J. Moir, joined forces with Captain Lugard. Mr. T. Moir whose wounds were so severe that he was compelled to return to Scotland, succeeded in despatching thence a 7 -pounder gun which, however, was only supplied with ammunition of a kind which merely drilled round holes in the stockade fences. Nevertheless, the Arabs were seriously damaged and inconvenienced, although the British on their side had one killed and several incapacitated by wounds and sickness. Captain Lugard was among the wounded, and in the next year he left Nyasaland, impressed with the futility of attempting to subdue Mlozi without efficient soldiers adequately equipped. In this same year, 1889, an envoy whom the Sultan of Zanzibar had sent on the instigation of Sir C. Euan-Smith, Consul-General at that place, to induce the Arabs to come to terms, met with no success, as these Arabs disowned the sovereignty of the Sultan over their territory.

The natives of Nyasaland were fully aware that what was going on was a war for the suppression of the slave trade, and the Yao of the east and south-east of Lake Nyasa began to exhibit considerable hostility to the British. Mr. Joln Buchanan, Acting Consul, accompanied by the Rev. W. P. Johnson, of the Universities Mission, paid a visit to the Yao chief, Makanjira, with a view to entering into friendly relations with him. As soon as they landed, however, they were seized, stripped, maltreated and imprisoned. Only the intervention of some Zanzibar Arabs saved their lives, and Makanjira contented himself with holding them up to ransom for an enormous supply of trade goods and ships' stores which they were compelled to write to the engineer of the Charles Janson to send ashore. 
It must not be supposed that all the Arabs were hostile to the British. Indeed, one section of them announced their intention of protecting the British Missionaries on Lake Tanganyika when the Arabs in general rose against the Germans. In the same way the Arabs round about Kota-Kota, under the third Jumbe in succession from that Jumbe or Sultan whom Livingstone found established there as the vassal of the Sultan of Zanzibar, likewise remained neutral.

Such was the state of affairs when Mr. (now Sir) H. H. Johnston, who had been appointed Consul at Mozambique, arrived in Nyasaland in the autumn of 1889 to report on the troubles that had arisen with the Arabs and the Portuguese. This year was in many ways the most eventful in the whole history of Nyasaland. The British Government had been in a difficult position as regards the happenings that had taken place round Lake Nyasa. They desired that the territory which was the scene of the struggles between the Arabs and their slavetrading allies on the one hand, and the British pioneers on the other, should not fall under the dominion of any foreign power. The Portuguese naturally viewed our activities in this direction with considerable suspicion, and it was undoubtedly through representations made from Lisbon that Dr. Livingstone's first expedition had been recalled. However sympathetic the Government at home might be, the insuperable difficulty was that Nyasaland was practically inaccessible without passing through Portuguese possessions. The discovery by Mr. D. J Rankin, in the spring of 1889, of the navigable Chinde mouth of the Zambesi, whose waters had long been recognised as international, completely changed the political situation. Another event occurred in this year which focussed attention on Central Africa, and that was the arrival in England of Cecil Rhodes with the object of obtaining a charter for the British South Africa Company. $\mathrm{He}$ assured the Foreign Office that his Company would be able to find $£ 10,000$ annually for some years for the purpose of developing and administering Nyasaland. Finally, the Portuguese, whose slumbering ambitions of an empire stretching across Africa from Angola to Mozambique had been re-awakened by the adventures of their later explorers, sent out in this same year an expedition of considerable magnitude under Major Serpa Pinto. The Portuguese Government had been asked for an explanation; but had merely replied that Major Pinto would not enter the Shire Highlands.

Mr. Johnston steamed over Chinde Bar on the 28th of July, 1889, in H.M.S. Stork. Proceeding up the Zambesi and into the Shire in small boats, he came up with and boarded the African Lakes Company's stern-wheeler James Stevenson, in which he continued until he came up with Major Serpa Pinto's camp near the confluence of the Shire with the Ruo. The Portuguese leader sent a boat off so that Mr. Johnston could land, and on doing so he found that the expedition consisted of several white officers and a large force of native soldiers. Major Pinto asserted that 
the expedition was a scientific one, and asked for the good offices of the English in securing an unmolested passage through the Makololo country. He was assured that the very size of the expedition would excite the suspicions of the Makololo, reminded that his Government had stated that the expedition was bound for the Upper Zambesi, and informed that political action on his part north of the Ruo would compel Mr. Johnston to take steps to protect the interests of the British Government. With no definite conclusions having been arrived at, the two expeditions parted company.

Passing on up the Shire Mr. Johnston went on shore, with Dr. A. Hetherwick as interpreter, to speak to the powerfui and aggressive Makololo Chief Mlauri, who, from his dominating position on the high bank, commanded the navigation of the river. It was his pleasure to show his authority by calling upon passing steamers to give him presents or await his convenience. The reception, though rude, was not actually hostile; but Mlauri expressed his determination of attacking the Portuguese if they passed that way. At Katungas, where the steamer journey ended, Mr. Johnston was met by Acting Consul J. Buchanan and others, and treaties of friendship were signed there with the Yao chiefs and the Makololo chiefs, with the exception of Mlauri, although he also came in after his first defeat at the hands of the Portuguese. Treaties were also signed with the Yao chiefs at Blantyre, and Mr. Johnston then proceeded on his expedition to North Nyasa. Subsequently Major Serpa Pinto advanced northwards and was attacked by the Makololo under Mlauri on the 8th of November, 1889. Mlauri was heavily defeated. Major Pinto hesitated, however, to enter the hypothetical British sphere north of the Ruo, and returned to Mozambique for further instructions, leaving his expedition in charge of Lieutenant Coutinho. This officer was bolder than the leader he had temporarily replaced. He suddenly crossed the Ruo and attacked the Makololo of Chiromo, destroyed their village, and erected strong fortifications on the spit of land between the Ruo and the Shire. Coutinho then led his forces up both banks of the Shire as far as Katungas, from which place Blantyre lies about twenty-five miles distant across the hills. In the meantime, on the 2lst of September, 1889, Mr. J. Buchanan had declared a British Protectorate over the Shire Highlands, acting on instructions left with him by Mr. Johnston. The Portuguese expedition was recalled south of the Ruo as the result of an ultimatum from Great Britain to Portugal. Thus, in more or less adventitious circumstances, Nyasaland became part of the British Empire.

In $1890 \mathrm{Mr}$. A. Sharpe and others were busily occupied in making further treaties with the native chiefs in Central Africa, which were afterwards ratified by the Anglo-Portuguese Convention of June, 1891. Mr. Johnston himself had reached the south end of Lake Nyasa, where he found the Yao in a state of civil war. Mponda, the leader of one faction, refused at that time to treat with the British, and Mr. Johnston beat a somewhat hasty retreat 
to Likoma on the mission steamer, which he afterwards borrowed to transport his expedition to Kota-Kota. Mr. Nicoll went on to Karonga in the Ilala, which had passed into the possession of the Lakes Company, with letters to the North Nyasa Arabs. Mr. Johnston, after making treaties with the Atonga chiefs of West Nyasa, went in the Charles Janson to a point on the lake shore some 15 miles south of the Jumbe's capital at Kota-Kota. The Jumbe agreed to put his territory under British protection; to abolish the slave trade therein; and to aid in inducing the Arabs of North Nyasa to make similar terms. For this he was to receive a subsidy of $£ 200$ a year. Proceeding to Karonga, Mr. Johnston found that the way to an agreement had been paved by the excellent work of Mr. Nicoll, and Mlozi and other Arab and native chiefs signed the treaties laid before them. After travelling northwards to Lake Tanganyika, making treaties with the native chiefs on the way, Mr. Johnston retraced his steps. Finding the Yao chief Mponda, at the south end of Lake Nyasa, in a more agreeable mood, he persuaded him to sign a treaty of friendship, and was back in Mozambique by the end of January, 1890. As a result of the work of all these pioneers the Anglo-German Convention of July, 1890, and the Convention with Portugal a year later, prepared the ground for the Proclamation of a British Protectorate over the territories adjoining Lake Nyasa which was promulgated on the 14th of Nay, 1891.

It was decided to confine the actual Protectorate to the regions adjoining Lake Nyasa and the Shire river, and to place it in charge of a Commissioner responsible to the Foreign Office. The remainder of the territories north of the Zambezi which these assiduous pioneers had brought under the British flag, were placed under the Charter of the British South Africa Company which had just been granted. Mr. Johnston was appointed the first Commissioner and Consul-General of British Central Africa on the 1st of February, 1891, and for about five years he also administered the trans-Zambezi territories of the Chartered Company. During this period the Company contributed a sum of about $£ 10,000$ a year for the maintenance of a combined police force in the Protectorate and in its own territory, as well as allowing the free use of its boats and steamers. On the 1st of July, 1895, this arrangement ceased, and Mr. Johnston handed over his powers as Administrator of the British South Africa Company's territories north of the Zambezi to Major W. P. Forbes, the delegate of Dr. Jameson. The Company continued its contribution, however, until the year 1910-11, and the control of Nyasaland over the affairs of the neighbouring territory was not finally removed until the North Eastern Rhodesia Order in Council of the 18th of October, 1909, substituted the High Commissioner of South Africa for the Governor of Nyasaland as the supreme local authority in North Eastern Rhodesia.

The Commissioner and Consul-General arrived at Chiromo in July, 1891, with his staff, having travelled up the Zambezi and Shire in H.M.S. Herald and Mosquito, the two gunboats placed 
on these rivers by the British Government. The staff consisted of Lieutenant B. L. Sclater, of the Royal Engineers, who had with him three British Non-Commissioned Officers : Mr. A. Whyte, F.Z.S., who subsequently did excellent scientific work in the Protectorate; and Captain C. M. Maguire, an officer lent by the Government of India to raise volunteers in India to form the nucleus of a police force. The first news that met the expedition at Chiromo was that the European coffee planters in the Mlanje mountains had been attacked by a powerful slave trading Yao chief named Chikumbu, who had settled among and gradually subjugated the peaceful Nyanja people. Captain Maguire therefore set out with a body of his Indian soldiers and, after a brief but somewhat hotly contested campaign, Chikumbu fled, and his brother, afterwards appointed chief in Chikumbu's place on promises of good behaviour, was captured. The Commissioner remained at Chiromo about two months settling matters connected with the Anglo-Portuguese Convention, and joined up with Captain Maguire at Zomba in September.

Before long it became necessary to move a strong force including 70 Indian soldiers with a 7-pounder mountain gun to South Nyasa to deal with a complex trouble which Mponda had raised with other Yao chiefs on the one hand and with Chikusi's Angoni on the other. Mponda was in the habit of raising these wars with all and sundry, chiefly for the purpose of capturing slaves to send to the coast. Captain Maguire stealthily threw up fortifications round the camp which the British forces had pitched opposite Mponda's main town on the east bank of the Shire, some three miles south of the lake. While this was being done envoys had been sent to another Yao chief, Makandanji, living in the south-east corber of Nyasa about seven miles from Fort Johnston, as Maguire had named his camp. Makandanji seized and imprisoned the envoys. Captain Maguire suddenly attacked him, scattered his forces effectually and finally, and released the prisoners. Mponda seized the opportunity to capture the runaways from Makandanji's army and sell them to the Swahili slavers. He was called upon to release these captives; but he declined to do so, and prepared to attack the British. A few shells from the 7-pounder, which set his town on fire, soon impelled him to seek for peace. His town was destroyed, and terms were offered him which he accepted and kept for four years, when he unwisely revolted again. Zarafi, a powerful chief some 20 miles to the east, sent envoys to treat for peace on hearing of Makandanji's defeat. South Nyasa seemed pacified.

These fights with Makandanji and Mponda were more accidental than deliberately planned. It was decided, however, as a matter of policy, to punish Makanjira for his outrage on Acting Consul Buchanan some two years earlier, and for other attacks on the Missions since then. The Commissioner chartered the Lakes Company's Domira, mounted the 7-pounder in the bows, and made for Makanjira's town. A single shell was sufficient to disperse the crowds of fighting men 
who harl greeted the steamer's arrival with a volley. They returned, however, when a landing was made, and it was only after two days of hard fighting that the town was captured and destroyed. After crossing the lake, at this its narrowest point, where it is not much more than fifteen miles across, and having come to an understanding with Kazembe, a near relation of Makanjira's and one who had made peace with Mr. Johnston in 1890, the party returned to the east side. Captain Maguire landed at the town of Saidi Mwazungu, a vassal of Makanjira's, in search of information. He had a narrow escape from death at the hands of a treacherous Arab, and the town was thereupon seized and destroyed.

The Commissioner and his party now returned to Zomba, where they immediately received news of trouble with Kawinga, a Yao chief of that neighbourhood. Mr. Buchanan and Captain Maguire, after heavy fighting in which the latter was wounded, brought Kawinga to terms. Captain Maguire then returned to Fort Johnston with the intention of completing the buildings there. Receiving news of the hiding place of two of Makanjira's dhows, he proceeded in the Domira to destroy them on the 15th of December, 1891. While so doing his small force was attacked by Makanjira's army, and Captain Maguire retreated to his boat. This, however, had been destroyed by a sudden storm, and the Domira was stuck fast on a sand-bank and unable to get close in-shore. While attempting to reach the ship, after seeing off his Indian soldiers, Captain Maguire was fatally wounded. The master and the second engineer of the Domira were injured by the firing, and after two days of incessant fighting the Indian doctor and the first engineer were induced to go ashore for the purpose of negotiating peace with Makanjira. There they were brutally murdered, and it was only by the heroic efforts of the second engineer that the steamer was floated and the rest of the party saved. The Commissioner and Mr. Fotheringham, by this time manager of the Lakes Company, hurried to Fort Johnston, as did many rolunteers attracted by the bad news. Msamara, a Yao chief living just south of Mponda, had joined with Zarafi in an attack on Fort Johnston which, however, proved abortive owing to the loyalty of Mponda to the British. Msamara was captured, but afterwards poisoned himself in prison. Zarafi's villages in the plains were easily subdued. His positions in the hills were less vulnerable, and the difficulty of dealing effectively with them was increased by the desertion of the native porters. Chifisi's Angoni came down to help the British against Zarafi; but they did not prove to be of much military value. However, the enemy became nervous and treated for a peace which lasted but a short time, for in February, 1892, the official in charge of Fort Johnston station led a large army of Angoni volunteers against Zarafi, who had again given trouble. The expedition met with a complete reverse, several Sikhs and Zanzibaris were killed, two Europeans were wounded, and the 7-pounder gun was abandoned and captured by the enemy. 
A great deal of trouble was encountered about this time. The slave-trading Yaos of Chiradzulu indulged in open highway robbery on the Zomba-Blantyre road; the natives round Blantyre joined in this conduct; the Mlanje Yaos, aided by Kawinga, robbed the caravans and carried off slaves; Makanjira, strengthened in prestige by his unpunished victory over Captain Maguire, crossed the lake and drove out the British ally, Kazembe, who fled south. Makanjira then proceeded to attack the Jumbe of Kota-Kota, and by the following year had dispossessed him of all his territory except the capital town. The loyalty of Mponda, and the unpreparedness of the North Nyasa Arabs for further warfare, prevented the trouble from spreading further for the moment.

In May, 1892, Mr. J. I. Nicoll assumed charge of the South Nyasa district and during the next three years he gradually checked the raids of Zarafi, and introduced peace and order into the neighbourhood. About this time, too, three gun-boats arrived in sections for use on the lake and Upper Shire. The circumstances attending the death of Captain Maguire had induced the Foreign Office to obtain these boats from the Admiralty. In this year a large German expedition under the auspices of the German Anti-Slavery Society also arrived at Lake Nyasa with a steamer named after the leader of the expedition, the Hermann von Wissmann. (This vessel afterwards belonged to the Government of German East Africa, and was captured by the British during the late war.)

The lull that ensued was quite temporary, for in February, 1893, Liwonde, a Yao chief on the Upper Shire and a relation of Kawinga's, captured some Zomba natives. The Europeans and their followers who hurried to the rescue succeeded in releasing these and other slaves; but they were attacked by Iiwonde on their return. This was the signal for a general rising of the Upper Shire Yaos, and the forces which went to the assistance of the Domira, aground opposite one of Liwonde's towns, were in a very critical position between two fires until they were relieved by the arrival of reinforcements. Iiwonde's capital was then captured and burnt; he himself escaped and continued to give occasional trouble for the next few years.

The Indian soldiers who had come into the country with the Commissioner were by now nearly time expired, and during 1893 two contingents of Sikhs each consisting of 100 men arrived to relieve them. At the same time the services of the Zanzibaris were dispensed with, and the police were recruited from among the Atonga of West Nyasa and the Makua of Portuguese East Africa. Advantage was taken of the arrival of the Indian troops to control the troublesome Yaos settled in the Mlanje district on the main slave route to the east coast, and Fort Lister and Fort Anderson were constructed and garrisoned at the north and south ends respectively of the Mlanje range. The Yaos were naturally opposed to this project and Nyaserera, one of their 
chiefs, was particularly hostile. The other chiefs, however, were detached from his cause by diplomacy and he was easily subdued. Another chief, Nkanda, gave some trouble in connection with highway robbery and slave raiding; but after some fighting in the hills he was defeated and fled. Both Nyaserera and Nkanda afterwards returned as rulers under British tutelage, and gave no further trouble.

The time had now come to settle with Makanjira. The gunboats were ready, and Jumbe could hold out no longer at KotaKota, whither he had retired when one of his Yao headmen, Chiwaura, revolted and joined forces with Makanjira. The expedition therefore decided in the first place to relieve Jumbe, and Chiwaura's fortified town some 5 miles inland from KotaKota was accordingly bombarded and afterwards taken by assault. Chiwaura himself was killed during the attack. The party then steamed down the western shore of the lake to Rifu, opposite Makanjira's, where his female relation Kuluundu had displaced her nephew Kazembe, an ally of the British. While this place was being attacked Makanjira crossed in a large dhow to help Kuluundu, and at the same time a large Arab slave caravan joined forces with the enemy. Most of them, however, surrendered or were captured, and some of Jumbe's followers having been left behind to deal with the remainder, the punitive expedition crossed to Makanjira's town. His forces soon dispersed under the combined attack from infantry and artillery and, as Makanjira would not accept the terms of peace, the village where Captain Maguire had been killed and the others murdered was destroyed. Other towns and villages were also burnt down. Fort Maguire was then erected on the Lake Shore and garrisoned with Sikhs to occupy the country. At the beginning of 1891 Makanjira attacked the Fort, but he was defeated with heavy losses.

Early in 1895 the Yao chief, Kawinga, of the north-west end of Lake Chilwa, who had long been sullen towards the British rule, attempted a serious attack. He began by raiding the territory of Malemia, a friend of the Government, and Mr. Sharpe sent a small force of Sikhs and Atonga to protect the missionaries settled at Domasi in Malemia's country. This party was attacked by Kawinga, who was aided by a large army of Anguru from Portuguese territory east of Chilwa. The whole affair was part of a concerted plan on the part of Kawinga, Zarafi, and Matipwiri to drive the white men from the country. Their ambitious plan of campaign was, however, foiled by the splendid defence of this handful of Sikhs and Atonga behind a hastily constructed stockade, who kept off the enemy and inflicted heavy losses on them. When reinforcements arrived, the little force charged the demoralized Yao and Anguru and pursued them for miles. Malemia, no doubt sitting on the fence, was quite decided by these events, joined in the chase, and executed a son of Zarafi whom he captured. Kawinga retired to the mountain fastness of Chikala; but his stronghold was approached by a new route and captured. 
Kawinga's downfall resulted in the spread of a feeling of security in the Zomba district which had not hitherto been enjoyed; and, except for the Mlanje district, organized road robberies ceased in the Shire Highlands. Matipwiri and his brother Kumtiramanja attacked a patrol in the Mlanje hills, and in the resultant fighting they were both captured. Thereafter, this part of the Protectorate also enjoyed an unwonted sense of peace.

In the attack on Matipwiri the newly organized native army had first been used, and its success encouraged the preparations for the final attack about to be made on Zarafi. The expedition was entirely successful, and in a week Mangoche mountain was taken by storm, the lost 7-pounder recovered, and Zarafi was a refugee in Portuguese East Africa. Mponda, after several years alliance with the British, had by this time made up his mind for another attack. However, at the last moment before the attack, discretion overcame his valour and he surrendered. Makanjira had in the meantime built a new capital just within the British border, and from this point of vantage had renewed his raids. This town was now taken and destroyed and the enemy forces driven in disorder into Portuguese territory.

The north end of Lake Nyasa now became the seat of trouble, for Mlozi and his Arabs were slave raiding in the most ruthless manner, and openly declared their intention of driving out the British. The missionaries of the neighbourhood had been threatened and even ill-treated by Mlozi, who had allied himself with the Awemba tribes. It was decided to catch the Arabs unawares, and an expedition of 100 Sikhs and 300 native troops with the officers and European volunteers set out from Fort Johnston on the 24th of November, 1895. Every available steamer on the lake was chartered for the occasion. Mlozi's stockade was about 11 miles inland from Karonga and the approaches to it and the passage of the Rukuru river were guarded by Msalemu and Kopakopa, whose fortified towns lay about half-way between Mlozi's and the lake. The plans for a combined military and naval brigade attack were successfully carried into effect, and at the end of an exciting siege lasting for 3 days Mlozi's strongly defended town was captured on the 31st of November. Mlozi was discovered in a secret hiding place under the floor of his house, found guilty of the murder of hostages during the bombardment, and hanged next day. The remainder of the Arab stockades in North Nyasa were soon subdued, and Fort Hill was erected on the western edge of the Protectorate to keep order at the north end of the lake, and to protect the country from the Awemba allies of the Arabs. A little later Saidi Mwazungu, who had stirred up Mwasi, a chief in the interior of Kota-Kota district, against the British, was captured. Mwasi escaped, but soon afterwards committed suicide. This brilliant campaign of the end of 1895 closed with the defeat of Tambala and Mpemba, two Yao robber chiefs who had settled in Central Angoniland.

In the autumn of 1896 the Angoni under Chikusi and Odete raided the south-western portion of the Protectorate, but were 



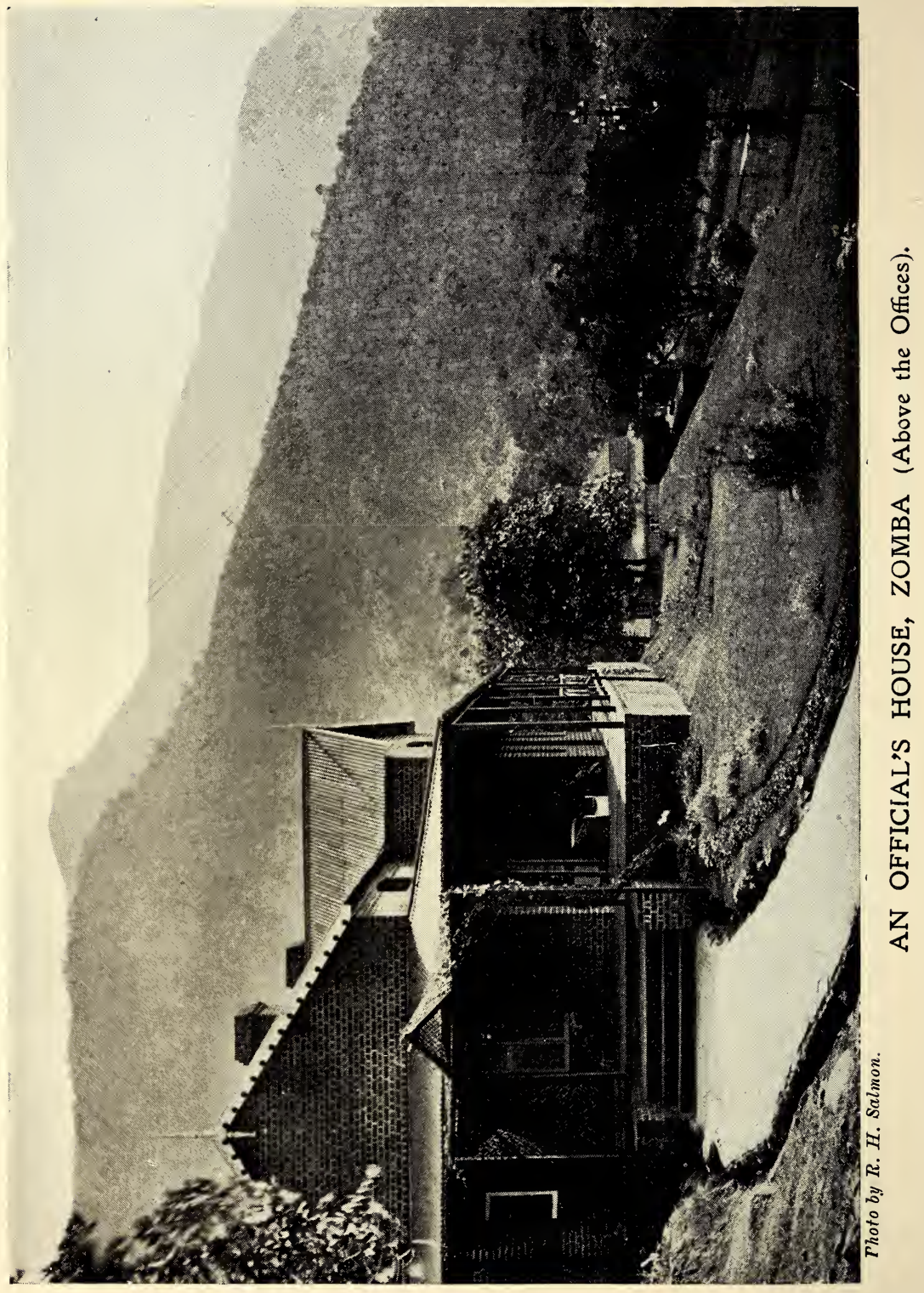


severely punished, and about this time Katuri, the last of Zarafi's adherents to be conquered, was captured near Fort Mangoche, which had been erected on the site of Zarafi's principal town. During 1897 the Anguru caused some trouble round about Lake Shirwa by highway robbery, and an expedition was despatched to deal with them in August of that year. Mpezeni, chief of the Angoni-Zulus, threatened the European settlers on the borders of the Protectorate, in the district where Fort Jameson now stands. An imposing force was sent under Colonel (afterwards General Sir) William Manning, the settlers at Loangweni were relieved, and Fort Manning was erected to keep the district in order. With the exception of the semi-religious rising in January, 1915, the Protectorate has been free from internal trouble since 1897.

It would perhaps appear from the foregoing record of almost incessant warfare from 1884 to 1897 that the Protectorate Government had done nothing except fight its way into power in the face of a hostile population. Such a view of the early history of Nyasaland would, however, be entirely erroneous. The founding of the Protectorate was, as stated above, more or less accidental, and was hardly more than an incident in the struggle which Europe in general and Great Britain in particular was at that time waging against the African slave trade. Political factors entered into the situation; but as soon as the early missionaries and pioneers came into direct conflict with the slave trade as it then existed with all its horrors, it was inevitable that the fight would be to a finish. And, as a matter of fact, the indigenous population welcomed the English. Our conflicts were almost confined to those with tribes dominated by ruthless alien chiefs, whether Arab, Yao or Angoni, and it is noticeable how soon the country became pacified and how loyally it remained so, when once these slave raiding chiefs surrendered to the English or fled from the country.

Nor must this record of warfare and restless movement blind us to the material progress of the country under those indefatigable pioneers. It is 33 years or so since Mr. John Buchanan declared a British Protectorate over the Shire districts on the 21 st of September, 18\$9. If a settler who came into the country half that time ago, say in 1906, will compare what he found already accomplished with what has been done since his arrival, he will be astonisherl at the results of those early years. In the face of almost insuperable: transport difficulties, and in the absence of proper roads, the steamers were placed on the rivers and on Lake Nyasa. Artisans were trained in their various avocations, and townships with fine churches, forts and stations erected throughout the country. Printing presses were introducer, both by Government and by the Missions, and in scores of ways the native was trained to carry out the ideas which the Europeans introduced into Africa. As early as 1892 courts of justice had been instituted, and in the following year the Protectorate was divided into administrative districts, and the system of government introduced therein, which still remains in force, but little modified in principle since its inception. 
Having dealt with the military aspect of the founding of the Protectorate, the chief landmarks in its material development may be noted briefly. The earliest agricultural product to be introduced into Nyasaland by the settlers was coffee. To Mr. Buchanan was due the idea of introducing the berry; but Mr. J. Duncan, a gardener attached to Blantyre Mission, actually brought the coffee plant into the Protectorate from the Botanical Gardens at Edinburgh. One plant alone survived, but two years afterwards it bore about 1,000 beans, from which some 400 seedlings were reared, and these yielded $14 \frac{1}{2}$ cwts. of coffee in 1883 . For many years little was grown except coffee, although tea was started on one estate as early as 1891, and cotton and tobacco were introduced on a small scale a few years later. Agriculture will, however, be more fully dealt with in the chapter devoted to that subject.

On the 14th of May, 1891, the whole of the territories now known as Nyasaland were declared a Protectorate of Great Britain, and on the 22nd of February, 1893, the name of the Protectorate was changed to the British Central Africa Protectorate. During those two years the Government of the country assumed a definite shape. A customs system was inaugurated, and a beginning made of the institution of a hut tax, fixed at $3 \mathrm{~s}$. The claims of Europeans to land and mineral rights purchased by them from native chiefs were investigated and settled, so that the root of the title to almost all the large estates in Nyasaland is the "Certificate of Claim," which was jssued as a result of these investigations. Courts of Justice were also created, and judicial officers appointed. In 1891 no roads existed over which wheeled traffic could pass; but the KatungaBlantyre road was made in 1892, and the Blantyre-Zomba road in the following summer. By the end of 1896 there were 390 miles of main roads and 80 miles of broad hoed paths in existence. In 1893 the Protectorate was divided into 12 administrative districts, the civil service was organized, and the postal service placed on a satisfactory footing. In 1892 and 1893 English coin was put into circulation among the natives, who had previously been accustomed only to barter, and was readily accepted. In 1894 the Protectorate adopted its own postage stamps. About this time, too, natives were organized into a military force from which the King's African Rifles ultimately took its origin, and a native police force was established whose units were attached to the headquarters of the various administrative districts.

It may be pointed out that the administration in its early days was not entirely popular. The wholesale purchasing of large tracts of country from native chiefs, whose right to sell the communal land was open to doubt, was of course stopped as soon as the Protectorate was declared. This was not much to the taste of some of the pioneers who had been in the habit of making treaties direct with the chiefs. Some of the missionaries, too, had acquired great influence over the natives and enjoyed a considerable amount of temporal power. It was, perhaps, only human that they rather resented the setting up of formal courts of justice to which natives were compelled to resort, rather than to the informal and paternal 
procedure of the mission stations. It may be, too, that the Lakes Company was attracted by the idea of a charter such as Rhodes had just obtained for the British South Africa Company. However, all these conflicting elements were soon reconciled and, as soon as it became an accomplished fact, the Government was warmly supported by all sections of the European population. In 1891 this European population numbered about 57 in British Central Africa and Northern Rhodesia combined. By 1896 it had increased to 300 in the Protectorate alone. Indians increased during the same 5 years from nil to 263 . In 1901, 1911, and 1921, respectively, the figures for Europeans were 314, 766, and 1,486, and for Indians 115,481 , and 563 .

Including two gun-boats, there were four British steamboats on the Zambesi in 1891 ; there were seventeen in 1896, a striking tribute to the energy of those early days when it is considered that even now the number is only 25. On Lake Nyasa the number of steamers was 3 in 1891, 6 in 1896, and at present there are the same number.

Land under cultivation rose from 1,600 acres in 1891 to 5,700 acres in 1896 . In 1909 there were 12,000 acres under cotton alone, over 2,000 under tobacco, and 6,000 under coffee. Altogether there are at present some 50,000 acres under cultivation by Europeans.

There is little of interest in the annals of the Protectorate until December, 1902, when a contract was signed for the contruction of the Shire Highlands Railway from Chiromo to Blantyre. The line was, as a matter of fact, constructed from Port Herald to Blantyre, and on the 31st of March, 1908, the first train arrived at Blantyre with Sir Alfred Sharpe, who had succeeded Sir Harry Johnston as Commissioner in July, 1897, and whose title was changed to Gorernor in July, 1907. In 1915, the Central Africa Railway was opened, connecting Port Herald with Chindio on the Zambezi, and early in 1922 the Trans-Zambesia Railway was completed, uniting Beira with the Zambesi near Chindio, and thus giving through railway communication between Nyasaland and the Fast Coast of Africa. The construction of a railway from Luchenza on the Shire Highlands Railway to the south end of Lake Nyasa has also been approved.

In July, 1907, the Nyasaland Order in Council of that year changed the title of the Protectorate to Nyasaland, and that of the administrator from Commissioner and Consul-General to Governor and Commander-in-Chief. It also provided for the creation of Executive and Legislative Councils, the latter to include nominated unofficial members.

Sir William Manning, K.C.M.G., was appointed Governor in November, 1910, and was succeeded in May, 1913, by Sir George Smith, K.C.M.G. In 1921, the Protectorate was divided into three provinces, each in charge of a Provincial Commissioner, and these provinces will be described in detail in following chapters. 
The police force was re-organised in 1920 and placed under a Commissioner of Police, with European officers in charge of the native rank and file.

Mention may perhaps be made of the rapid strides made in mechanical transport of recent years. In 1908 the Governor imported a small Rover car, probably the first motor car to be used in the Protectorate. A year or so later the Transport Department brought in a 30-cwt. Wolseley lorry which turned out to be unsuitable for the country. In 1911 a $2 \frac{1}{2}$ ton Albion was purchased and proved to be a great success; it was still in use in 1921. In 1910 there were some 40 motor cycles in the country. The war, however, gave such impetus to mechanical transport, and so many vehicles were disposed of locally by the Salvage Commission, that it is probably a low estimate to say that 75 per cent. of the male European population own a motor vehicle of some kind, without mentioning the lorries and passenger cars owned by Government and commercial firms. A Motor Traffic Ordinance was passed in 1920 with stringent provisions regarding the licensing and use of motor vehicles.

The part played by Nyasaland in the great war forms the subject of Chapter XIX; and the agricultural progress of the country will be dealt with in the course of Chapter IX. There are no other outstanding social or political events during the past few years that call for mention in these introductory notes. 


\section{CHAPTER III.}

\section{TRIBAL SETTLEMENTS AND - WARFARES.}

The brief notes contained in the preceding chapter may conveniently be amplified by a more detailed account of the manner in which the present tribal distribution of the native population was accomplished. It is probable that too much stress has hitherto been laid on purely local events in bringing about the movements of Nyanja, Yao and Ngoni peoples in Central Africa. The Ngoni wanderings, devastating as they were, can hardly account for the movements of whole tribes over vast areas. It is not unlikely that the occupation of Africa by European nations put an end to extensive movements that had been in progress for centuries, and which would still have continued had the natives been left undisturbed. In fact the movement of the so called Anguru from Portuguese East Africa continues unabated to this day, probably following the methods of peaceful pentration that have been in force in Africa for centuries. The impelling forces were probably the same as those which brought about the settlement of the Teutonic races over the whole of western Europe and the Slavs in the east of that continent. The struggles of Anyanja and Angoni, like those between Danes and Saxons in England, are but eddies in a wider and more general movement. For a native horde to move hundreds of miles to a new locality is not such a serious undertaking as it would be to shift a village from one county to another in England. Native tribes have little or no impedimenta, no intricate land problems. no imposing buildings to re-erect on a new site. Like all primitive peoples they are nomadic.

When a village became too unsanitary in its surroundings for even natives to bear, when fuel became scarce or pasturage suffered from cirought, the tribe would either move in a body or, like Abraham and Lot, separate and go their various ways. Hunting tribes would follow the game as it moved away before their incessant attacks; agricultural peoples, having exhausted the soil, would move to more fertile lands. Added to all these motives would be mere natural restlessness. But in east and central Africa from the eighteenth century onward the easy movement of the natives was undoubtedly accelerated by the slave raiding of Portuguese, Swahili and Arabs. A movement arose from the coast inwards and, as various tribes, Yao, Nyamwesi, Awemba joined with the Arabs in the lucrative trade, the regular nomadic wanderings degenerated into spasmodic searches for remote and uninhabited countries. Whole tribes would probably move away in haste before the approach of others, fearing an internecine struggle with better armed enemies intent on enslaving them. 
In this way the Anyanja people moved up from the neighbourhood of the Zambesi from what was known as Amaraviland. At the time when Central Africa first became known to Europeans, practically the whole of the Protectorate was occupied by various branches of this main stock, Mang'anja on the Lower Shire ; Ambo, Antumba, Ampotola, Amaravi, round the south end of the lake; Nyanja proper on the lake shore and round Lake Shirwa, as well as in the Shire Highlands and Mlanje neighbourhood; the Achewa and Achipeta in what is now known as Central Angoniland. The Tumbuka, Tonga and Konde tribes to the north and west of Lake Nyasa are probably of different stock from the Nyanja.

The Yaos were the next to settle in the Protectorate south of the lake, starting about 1860. The name of this tribe is said to be derived from that of a hill near Mwembe in Portuguese East Africa. About 1860, the Walolo, a branch of the Makua began to press on the Yaos, who thereupon moved southwards. The two main branches of the Yaos were the Machinga and the Mangoche.

The origin of the Angoni ( ${ }^{1}$ ) is usually stated to be more or less as follows. Somewhere near the northern boundary of Natal there was born about the beginning of the nineteenth century the famous Chaka, of reputed miraculous origin. Taken in early years to the court of the neighbouring Amatetwa chief, Dingiswayo, he was brought up to manhood by the latter, at that time the most powerful chief from Natal to Delagoa Bay. It was this chief who, during exile in Cape Colony, gained that knowledge of organized warfare which was later on to be made such an effective instrument by the Zulus. Chaka, by causing the death of his brother, succeeded his adopted father, Senzangakoma, as chief of the then insignificant Zulu tribe. Dingiswayo, his protector, he also had killed as a result of differences of opinion on the subject of the treatment of conquered enemies.

Chaka now set out on that career of conquest and bloodshed which lasted until his death in 1828. The last of the chiefs to be conquered by him was a certain Zwide, under whom Zongandaba and other formerly independent rulers acted as underlords and military leaders. After Zwide's defeat, his various vassals sought to regain their former independence by leaving the country, conquering new lands by following Chaka's methods of warfare, and probably by appropriating his fame in order to terrify their opponents. Zongandaba it was who ruled and led the Angoni. They passed through Swaziland, capturing cattle and gaining adherents, and thence into Amatongaland, where they dwelt for a time on the lower reaches of the Limpopo river. Crossing the Nkomati river, they drove back an army under one of Chaka's chiefs, but feeling unsafe from an attack by the main Zulu body, they moved westwards and attacked the Karanga tribe. Following

(1) NorE.- It is interesting to compare this outburst of the Zulus with that of the Zimba Zulus in the 16th century, when they crossed the Zambesi and sacked most of the coast towns as far north as Mombasa, where they were defeated by the Portuguese who had first used them as allies against Turkish pirates. 
their usual method of collecting cattle and training the conquered, the Angoni proceeded northwards and crossed the Zambesi between Zumbo and Tete in June, 1825. Considerably increased by the addition of warriers from all the peoples they subjugated, the hordes continued northwards up the Luangwa valley until they reached the wide area covered by the scattered Tumbuka tribe, among whom they are said to have dwelt for some years. Here the original Angoni are said to have exhibited jealousy of Zongandaba's attitude towards councillors whom he raised up from among the conquered tribes incorporated in his army. By the aid of Tumbuka witch-doctors these Angoni stirred up trouble and repeatedly persuaded Zongandaba to massacre whole villages of his non-Ngoni following.

Eventually moving northwards again, the heterogeneous multitude reached the south end of Tanganyika, where Zongandaba died. While settled in this neighbourhood they raided northwards along the east side of Tanganyika, eastwards to the Wankonde country at the north end of Nyasa, and southeastwards to the lienga, who at that time lived in the mountains near the Rukuru river. After Zongandaba's death the tribe split up into several sections. One, under Ntabeni, went northwards on the west side of Tanganyika, where they were heard of in 1879 by Mr. James Stewart. Chief Ntutu led another party up the east side of Tanganyika, and these under the names Watuta and Maviti overran large portions of what is now known as Tanganyika territory, reaching as far north as Victoria Nyanza. (1) They ultimately settled in the neighbourhood of the Nyamwezi. The third section is that which gave its name to Momberas district. The chief should normally have been Mtwaro, but he was of a quiet disposition and gave way to Mombera. This tribe, under IIombera, was ruled by his brothers Mtwaro, Mperembe, Mpezeni and Maurau, and it settled somewhere about the north end of Nvasa. Here some dissension must have occurred, for the Nagwangwara (2) overcame the other Angoni under Mombera and drove them south. The Magwangwara settled on the east side of Nyasa and raided far southwards among the Yaos. Miperembe and Mpezeni now broke away from Mombera, the former returning to attack the Bemba at the south end of Tanganyika, and the latter moving to the neighbourhood of what is now known as Fort Jameson in North Eastern Rhodesia. A headman, Chiwere, also went off with a following and settled west of Kota-Kota. Mombera himself first settled on the lower reaches of the Rukuru river, subjugated the Henga section of the Tumbuka tribe dwelling there, and then moved to the Tumbuka country proper, south-west of Choma mountain. Mperembe having rejoined him, the Angoni occupied the villages of the Lunyangwa, Kasitu and Rukuru rivers, defeating and ruling the Tumbuka and Tonga peoples.

(1) Note.-A small group of Watuta live there to this day.

(2) NoтE.-Wagwangwara, " dreaded ones," is what the East African natives called the Angoni. 
Mombera died in 1891 , but owing to friction between his subchiefs, his place was not filled until the question of facing the British Administration made it necessary to appoint a supreme leader. Mperembe had desired the position, but in 1897 he supported Mbalekelwa, Mombera's eldest son, who was duly elected. It is worthy of note that Mombera's Angoni did not oppose the British Administration and refused to join Mpezeni when he threatened the Europeans in 1897.

Soon after Zongandaba had crossed the Zambesi, a chief named Mputa separated from him and moved with his army and followers to Domwe mountain in what is now Portuguese territory, south-west of Lake Nyasa. This branch of the Angoni soon subjugated the Amalawi tribes living there, and took possession of the country. Following their usual method of training warriors from among the conquered races, they soon moved off with a re-inforced army, crossed the Shire south of Lake Malombe, and passed up the east side of Lake Nyasa, into the rich cattle lands of the Matengo, whom they easily subdued. Subsequently they came into contact with another branch of the Angoni, probably the Magwangwara mentioned above, under a chief said to be called Zulu, and Mputa was defeated and killed. Chidiaonga, his brother, succeeded him, and the tribe wandered for years even, it is stated, reaching the east coast of Africa near Mozambique. In course of time Chidiaonga returned to the Shire river near Chinamvuu, where a Nyanja chief Kalimakudzuru persuaded him to help in driving out the Yaos, who by this time had formed a large settlement at Kongwe (Chiripa's). The defeated Yaos retired to Chikala, and Chidiaonga gradually took possession of the country between the Lintipe, on the north, and the Lisungwe on the south, with headquarters at Domwe.

Chikuse, the son of Mputa, ruled the southern portion and, when Chidiaonga died, his eldest son Chifisi succeeded him as ruler of the northern part. In 1891 both Chikuse and Chifisi died and were respectively succeeded by their sons Gomani and Kachindamoto. Civil war supervened and lasted for several years, until in 1893 Gomani drove Kachindamoto to the place on the lake shore in Dedza district which still bears his name. Gomani and his brother Mandala now ruled north and south of Domwe respectively. The oppressive government of the former drove many of his people into British territory and his raids on the refugees necessitated an expedition against him in 1896, as a result of which he was captured and shot. Gomani's grandmother, Namlangeni, then divided the kingdom with Mandala. Resistance on their part to the Portuguese administration which was being formed at the time led to their being captured in 1900. Both died in captivity at Tete.

The only other peoples who have entered the Protectorate in large numbers during recent years are the so-called Anguru, a term used both by Europeans and by natives to describe any members of the Makua-Lomwe stock inhabiting Portuguese East Africa north of the Zambesi, between British territory and the coast. The Walolo, sometimes confused with Anguru, are strictly speaking 
the Atakwani and Akokola peoples who came originally from the neighbourhood of Quelimane. All these immigrants have settled chiefly in the southern part of the Protectorate from Lake Shirwa to Chiromo, round Lake Chiuta, and in the northern part of Mlanje district, also as far west as Chiradzulu and Malabvi near Blantyre.

A fuller account of the inter-tribal warfares which resulted from the Yao and Ngoni aggressions, and from other causes, may perhaps be of interest.

The original inhabitants of the Protectorate were, as stated, for the most part, Anyanja in some form or other, and it is along the Lower river, in the Lower Shire and Ruo districts, that they have been least disturbed by invading tribes. Scattered among them are various tribes who have during the past 60 years immigrated to this neighbourhood from the Zambesi and south of it, and have settled quite peacefully. These foreign tribes are not numerically strong and the following only call for mention. The Azimba, who came originally from the region of Nkoto in Southern Rhodesia, hunting elephants with axes. The Asena from south of the Zambesi, who have been trained for generations as goldsmiths and silversmiths. The Achikunda do not constitute a tribe. It is a name, often contemptuously applied, which covers the members of many trans-Zambesi tribes now settled on the Lower Shire, such as the Asena and Zambesi Atonga (who are in no way connected with the Atonga of West Nyasa). The word Chikunda really means "Msikari" or soldier, and the members of this so-called tribe were originally employed in slave raiding by a half-caste Portuguese named Matekenya. These Achikunda are skilful workers in metal and some of their ornaments and their mode of dress show a certain crude artistic feeling. In fact, centuries of subjection to Portuguese influence has given them a degree of refinement in contrast to the surrounding Mang anja slovenliness. They are of quicker intelligence and more clean and neat than the Amang'anja, whom they hold in some contempt. The arrival of new comers from the Zambesi, and the visits paid by local Achikunda to their relatives there, render it improbable that the clearly marked distinction between them and the surrounding Amang'anja will disappear. On the other hand the Asena and more especially the Azimba mix freely with the Achikunda and will probably in a generation or two be merged in the composite tribe now universally known by that name.

To return to the Amang'anja. Our earliest knowledge of the Lower Shire natives dates from 1863, when Livingstone left behind him some 16 Makololo who settled along the river. At that time the Amang'anja who formed its sole population seem to have lived peacefully and hardly disturbed by the wars and slave raids which disturbed their fellow tribesmen in the hills. It is probable that many of the principal villages have remained on or near their existing sites for centuries, the inhabitants leading a lazy and peaceful life, hoeing just sufficient land to supply their wants for food and beer and keeping a few goats, sheep, pigs and fowls. From time to time great numbers must have died as the result 
of occasional famines and epidemics. Carnivora and crocodiles have also aided in checking the natural increase of the population.

In 1863, the Makololo above mentioned soon usurped the power of the chiefs, probably in bloodless fashion except for the removal of a few Mang'anja headmen whom they replaced either by favourites of their own or, more usually, by children in the direct line of the men who were killed. Such action was probably nothing more than the usual precautionary methods adopted by usurpers, as there is no record of any resistance having been offered by the Mang'anja.

The only Makololo chief who directly affected the history of the Lower river was that Chiputula mentioned in the previous chapter as being killed in 1884 by the ex-missionary Fenwick during a quarrel. No impression remains on the minds of the old natives of any fighting during Chiputula's time, so that it was probably as peaceable as the periods it succeeded, although the Makololo continually intervened in the struggles going on in the Shire Highlands. It is said by the Mang'anja that the rule, both of Chiputula and of his son and successor, Makwira, was a harsh one, chiefly on the grounds that whole villages were often called out to work for them. Apart from this there is no record of hardship, although they probably received but little consideration from the Makololo. Makwira ruled on the same lines as his father had done until in $1891 \mathrm{Mr}$. Marshall was appointed the first collector of the Ruo district.

The Amang'anja of the Lower Shire district are said to have come from the Chipeta country in Central Angoniland, many generations before Livingstone's visit in 1859, under a chief named Mbona, whose story has now passed into a superstitious legend. Another section came a little later from Lundu, west of the Shire, under the original Tengani, who was a vassal of that chief, then paramount over all the Amang'anja, whose representative is now an unimportant village headman in the West Shire district.

During the aggressions of the Yaos in the Blantyre hills many of the hunted Anyanja took refuge under the powerful Makololo chiefs, and thus replenished the population which had been devastated by the plague and famine of 1863 .

As regards the Anyanja of the Shire Highlands the supreme chief in the early nineteenth century was Kapwiti, with his headquarters west of the Shire beyond Neno in the old Maravi country. On his death the power broke up and the various local chiefs became paramount in their several districts, e.g., Chibisa and Maka iwe on the Lower Shire and the country to the west, Mbalame on Michiru and Kankomba, his brother, on Soche near Blantyre. Ndima ruled the area divided from Kankomba's by the Namatope stream between Ulumba and the Ntondwe, Kankomba's land stretching from the top of Zomba mountain to Chanda hill and past Chiradzulu to Mbalame's boundary. A chieftainess, Nkata, lived near Kankomba on the slopes of Zomba mountain. She was a rainmaker, and her sway extended from Zomba to the Palombe, and even at one time to Blantyre. 
The Anyanja of the Liwonde district were alarmed by the settlements of the Machinga Yaos at Kongwe in South Nyasa, and Kalimakuzuru, one of their chiefs, invited the Angoni leader, Chidiaonga, to settle in what is now known as Southern Angoniland. Kalimakuzuru hoped that in doing so the Angoni would drive the Yaos from Kongwe. Kawinga, the Yao chief, was defeated and driven from Kongwe, retiring to Chikala in the north of Zomba district, whilst Chidiaonga settled near Mlangeni in Upper Shire district until he made his headquarters at Domwe. A few years later Kawinga was attacked by the Magwangwara from the east side of Lake Nyasa. The Yao chief Liwonde, brother of Kawinga, drove off the Magwangwara, but settled at Liwonde so as to be more secure from future attacks. The Yaos eventually extended their settlements and expelled the Anyanja from most of the Upper Shire valley. In the early eighties the Chingwarungwaru civil war between the Yaos of this region resulted in much slaughter.

The branch of Anyanja originally settled in the Upper Shire were known as Amalawi, of whom Ambo, Ntumba, \&c., are later divisions. The followers of Mputa, the Angoni leader who parted, probably after a quarrel, from Zongandaba, the original paramount chief who came from Zululand, after various wanderings settled at Domwe, south-west of Lake Nyasa, subjugated the Anyanja and occupied that part of the country.

Tradition has it that part of the main stock of the Anyanja, the Amalawi from the country west of West Shire had long ago spread to the western shores of Lake Nyasa. Finding the coastal strip too narrow for their increasing population they ascended the plateau into what afterwards became known as the Central Angoniland district. By this time they had assumed the names of Achipeta and Achewa. Chipeta signifies the tall rank grass which they found growing all over the plateau. Kumalawi is a term still used by the natives in describing the Lake Shore from which the Amalawi moved years ago. Upon these sections of the Anyanja the Angoni came down under their chief Kaniangere from the north and the original Zongandaba and Mpezeni from the north-west. Between the Bua river and Fort Manning the inhabitants were quickly subdued; while Chiwere and Msakambewa conquered the Achipeta living round Dowa. Odete, Kabuma and Tambala, however, resisted the Angoni with poisoned arrows fired from behind mud walls and appear not to have been subjugated.

In the districts now known as Kota-Kota and Kasungu (formerly Ngara) the original inhabitants have probably been more harassed than those even of the Shire Highlands, and the population must have dwindled away considerably under successive persecutions. Mwasi, the principal chief of Kasungu, led the Achewa from the Lake Shore through Central Angoniland to the Mchinji mountains, thence into North-Eastern Rhodesia and ultimately into Kasungu from the north and west. Here they appear to have remained peacefully for many years until 
Zongandaba, the Angoni leader, passed northwards, to the east of Mwasi. Mwasi, it is said, superseded the original chief of the neighbourhood, Chulu, who resigned in Mwasi's favour owing to his ability in withstanding the Angoni. Zongandaba is stated to have remained about 3 years at the confluence of the Lundazi and Rukuru rivers in Momberas district, during which time he ravaged the Achewa unmercifully and looted practically all their cattle. A further period of peace supervened until the Angoni turned south again under Mombera, who constantly raided Mwasi's country until the British took him under their protection. in 1897 .

The Achipeta, another branch of the Amalawi who came to the Lake Shore from the Zambesi, moved up from the lowlands under chiefs Kanyenda and Zeole, entering the interior of KotaKota district from the south-east, and settled on the Kasangadzi river. The position of the peoples settled in this area must have been precarious. Mombera, Mpezeni and Chiwere all raided for slaves, and Mwasi himself was a great slave and ivory trader. The Jumbes, self-styled sultans of Kota-Kota, came from the east coast of Africa and settled on the lake shore. They professed to be rulers of the whole district and sold the mineral rights. As a matter of fact, they never ruled land or people more than for a few miles round their stronghold at Kota-Kota. Their sole object was to devastate the country by slave raids, retiring to their fortress when seriously opposed. These Arabs provided the market for all slaves captured by the various tribes as far inland as the Loangwa river.

Had the Angoni remained united and not separated into factions, it is probable that the Achipeta and Achewa would have been completely exterminated in those districts now known as Kota-Kota, Kasungu, Dowa, Dedza, Lilongwe and Upper Shire. As it is they have survived either intact or incorporated in the Angoni, whose language has been completely lost in that of the conquered. It is difficult to say how much Angoni blood remains. in what is known as Central Angoniland. Probably not a great deal.

No other part of the Protectorate has enjoyed the peaceful dulness of the Lower Shire, Ruo, and West Shire districts, and the native history of Nyasaland, more especially the Shire Highlands, is very complicated. It deals chiefly with the aggressions of the Yao, the Angoni, and the Anguru on the timid Anyanja occupants. of the country and on each other.

The southwards movement of the Yaos, which resulted from the attacks of the neighbouring tribes, took place in three divisions. The first, led by Nkata, Malunga, Manjombe and Matenje, settled on the slopes of Ndirande, near Blantyre, having driven out the original Anyanja with the help of Kapeni who followed in their tracks. Kapeni afterwards moved across from Ndirande to Sochi. Kumpama who came in the wake of Kapeni eventually settled at Chiradzulu.

The second division of the Mangoche Yaos was led by Matipwiri, Kaduya, Mtiramanja and others. They moved by way of 
the shores of Lake Shirwa to the north of Mlanje district. Although few in numbers they became important as they settled astride the old slave route to Quelimane. Later on, Matipwiri and Mtiramanja moved to the Tuchila river in the south end of Mlanje district, where their successors still reside. The third division, under Njowe and Lundu, settled on the Linjisi river near Matope, some thirty miles north of Blantyre. This section became the most important one of the whole tribe, and was frequently called upon to help Kapeni and other fellow tribesmen in the Blantyre hills.

Several of these Yao chiefs became notable figures in the history of the Shire Highlands. Among others who, with Kapeni, halted at Ndirande were Che-Somba and his mother Ashiwambara. These two accompanied Kapeni to Sochi and he as well as Achiwambara eventually died there. Che-Somha moved on to Makungwa near Limbe, but ultimately returned and settled permanently at Sochi where he attracted to himself many of Kapeni's people. Kapeni himself also tried Makungwa but found the land unfertile and he too returned to Sochi somewhat later than CheSomba. Kapeni was jealous of Che-Somba's growing powers and attempted to foment a tribal war, which, however, was averted by the mediation of Kumisesa, Kapeni's sister. The hostile feelings remained in evidence however for many years although open warfare was avoided. In 1886 old Kapeni died and was succeeded by Kumisesa's son, who continued his uncle's claim to paramountcy until in 1899 the Resident, Blantyre, intervened and settled their boundaries.

Malika was another Machinga Yao who settled with Kapeni at Ndirande and parted from him there. He first moved to Chizumulu, south of the I.ujenda river, thence to Mangolwe near Mangoche in South Nyasa, thence to the Mvuu Marsh. Njowe and Mwangala accompanied him, and they were killed in the Angoni raid which took place later. Malika and Kumpama about this time joined Che-Somba and Kapeni at Ndirande, and on the division of territory which took place Malika and Kumpama settled at Chiradzulu. Chikoja, another Machinga Yao, also settled there by their permission. Kumpama from the east of Chiradzulu was at first a great freebooter against the Anguru but ultimately declined in power and was called in derision Malika's capitao. $\mathrm{He}$ still, however, maintained his independence, and the exact boundaries of their territories were never accurately defined.

Somewhat later than the three main divisions above described large bodies of Mangoche Yaos under Mlumbe and his brother Chikowe settled at Zomba, and shortly afterwards Malemia, a Machinga Yao, came to Domasi. The latter ruled the northern part of the district and Mlumbe the remainder. The Anyanja were partly absorbed by the conquerors; others moved away to Lake Shirwa and the plains of Palombe and Ntondwe.

A small section of the Yaos from the east coast of Nyasa crossed the lake and settled in the Dedza district and a portion of the Makanjira clan also settled on the western shore at Rifu near Domira Bay under Kazembe, a nephew of that Makanjira who 
gave so much trouble to the British. Kazembe, however, was our ally, and Kuluundu, his aunt, appears to have crossed the lake and dispossessed him. After the mixed fighting there in which the forces of the Administration protected Kazembe from the Arab slavers and their Yao confederates, Kuluundu was captured and exiled to Port Herald. In 1896, however, she was allowed to return and became chieftainess of the Yaos round Domira Bay. Kazembe succeeded his uncle Makanjira on the east coast rof Nyasa after the latter had been killed by another nephew who was disgusted by a cannibalistic feast which Makanjira had arranged.

Most of the Machinga Yaos remained in the districts round the south end of Lake Nyasa where they first settled and at Liwonde, where the chief of that name, brother of Kawinga, made a strong post after the Magwangwara Angoni had attacked the Yaos who had settled at Chikala when Kawinga was driven from Kongwe by the Angoni under Chidiaonga.

Later on the Angoni moved again and raided the tribes inhabiting the hills to the west of the Shire, especially the Yaos settled in the Mvuu Marsh near Matope, many of whom fled to the Makololo on the Lower Shire. Kapeni managed to maintain his position against the Angoni on the one hand and the Makololo on the other. Repeated raids by the Angoni laid waste the country between Blantyre and Zomba, although the annihilating attack on the Yaos in the Mvuu Marsh is the only one that the natives seem to remember. Somewhat later Chikumbu, a Yao chief from the south-west of Lake Nyasa, settled at Nguludi, near the BlantyreMlanje road and became a terror to the whole district by his slave raids and highway robbery. Kapeni was forced to entreat the aid of the Makololo in dealing with this new comer, and Chikumbu was driven out and settled in Chipoka's country in Mlanje where his aggressions continued until he was persuaded to desist by $\mathrm{Mr}$. Robert Cleland, a missionary of Mlanje.

The Yaos, displaced by the raiding Angoni, penetrated farther into the Shire Highlands, driving the Anyanja before them into the hills, more especially in the directions of Cholo, Mlanje, and Chipironi in Portuguese territory. Kasisi, one of the Makololo chiefs of the Lower River sent various Anyanja vassals of his to form settlements at the various fords across the Shire so as to act as outposts to ward off any future Angoni attacks such as the one which had just destroyed the Yaos in the Mvuu Marsh. With them he sent a stiffening of his own Makololo, notably Mlauri. Gwaza and Mpimbi were two of the leading Anyanja chiefs employed in this project and they established themselves above Matope. Chigaru, another of them, settled a few miles below Matope, near the Pampinda rapids on the left bank of the river. Chigaru soon collected a very large and mixed following of Anyanja, Achipeta and others.

When, therefore, in 1884, the Angoni madc the last and greatest of their raids, they found these preparations made to withstand them. They made no attempt to force the passage of the Shire, but ultimately Nyamuka, a headman of the great Angoni chief 
Chikuse, resorted to bribery and intrigue. He paid Gwaza a large sum in cloth to give him a clear passage across the Shire on the understanding that he would not molest the Anyanja settlements on the banks, but would proceed at once to the Highlands beyond. Otherwise he threatened to cross the river at all costs and destroy utterly the settlements posted along the banks by Kasisi. Gwaza assented, and finally he persuaded Kasisi himself to accept the terms. The arrangement seems to have been kept with good faith by both sides; the Anyanja remained neutral and the Angoni forded the river in immense numbers and passed on towards the hills under the command of Nyamuka. They ravaged the whole country round Zomba, and, destroying as they went, passed Chiradzulu and advanced as far as Malabvi near Limbe, Manje, and even for some distance into Portuguese Anguruland. Yaos and Anyanja alike fell victims to the assailants who, contrary to their usual habit of falling back after they had obtained sufficient loot for their immediate needs, advanced for miles against the totally unprepared villages. It is said that the Angoni vanguard was entirely composed of vigorous young warriors who pressed forward with such impetuosity, disorganising the country as they went and leaving it at the mercy of the main body, that they reached Malabvi, a distance of over 40 miles, on the afternoon of the same day that they left Zomba. The main body passed to the east of Chiradzulu burning every village as they passed. Finally it halted at Ndirande where they were met by Mr. John Moir who had ridden out to meet them. He, however, saw none of the Angoni headmen, neither Nyamuka nor Kanono, nor Mpalale.

Two missionaries, Messrs. David Clement Scott and Henry Henderson, went out with two native headmen as far as the valley on the Blantyre side of Malabvi and right into the Angoni camp. At first some minor leaders came out who pretended that they were the real leaders of the expedition, but one of the headmen with the missionaries warned them that they were being deceived. After a considerable time the actual leaders came out and negotiations with the Europeans continued for several hours. At length, the Angoni consented to return home at the end of 10 days. They kept their promise, and thus ended the last Angoni raid into the Shire Highlands.

Two months before, Mr. and Mrs. Scott and Dr. Peden had visited the principal Angoni chief, Chikuse, in his own home, and had made friends with him. As a consequence, when Chikuse despatched his army, he issued orders that his friends, the white men, were not to be molested. Dr. Hetherwick, of Blantyre Mission, while on his way from Blantyre to Zomba, met the Angoni at the Nkanda stream, a few miles outside Zomba. They were burning and looting the villages, and as Dr. Hetherwick's native carriers refused to proceed, he went on alone. The carriers were captured by the Angoni and taken before Nyamuka, whom they told that they were the servants of the white men. Nyamuka sent them back under escort to Dr. Hetherwick, whom they reached in Zomba, and it was thus possible for a message to be 
sent to Blantyre explaining the attitude of the Angoni. The Mission there warned all the women to come in for protection, which they did in hundreds, while the men fled to the hills. In this way the Angoni made only about 800 captives instead of the hordes they expected to take into slavery. From Mungusi house, Zomba, Dr. Hetherwick and Mr. Buchanan watched a fight between the Yaos and the Angoni on the site of the present sports ground, while the rest of the natives of Zomba were camped on top of the mountain where the rest houses now stand. The Yaos and Anyanja suffered terrible losses in this raid, and for some years the survivors kept to hiding places in the clefts and caves of the hills.

Another account of this raid says that the Angoni were invited by the Yao chief, Malemia, of Zomba district to aid him in dealing with a rebellious brother. The Angoni thereupon took advantage of being across the Shire to raid the Blantyre Yaos. The two narratives may be reconciled on the assumption that it was on receipt of Malemia's invitation that the Angoni opened negotiations with the Anyanja and Makololo guarding the fords.

Kalindankoo, a Chipeta slave captured in war by Chidiaonga, brother of the Angoni chief Chikuse, was sold to Chikumbu, the Yao robber chief at Mlanje. Kalindankoo with other Chipeta slaves ran away and sought the protection of the Makololo chief Kasisi, whom they adopted as their paramount chief. Kalindankoo was eventually made a sub-chief at Mpemba, near Blantyre, and finally became independent chief of the whole Likubula valley. His importance was increased by the adherance of large numbers of Anyanja of the Ambo branch of the tribe from West Shire. This accounts for the presence of Achipeta in Blantyre district.

A branch of Mombera's Angoni, led by Chiwere, settled originally at Bango near Nchisi mountain in Kota-Kota district, but a few years later most of them moved into Dowa district and occupied the country near Mvera, just west of Kasu hill, easily subduing the Achipeta dwelling in the central highlands round Dowa and as far as the Lilongwe river. Chiwere was at the height of his powers at the end of the eighties, when he granted the Dutch Reformed Mission the land on which Mvera Mission now stands.

As regards the northern part of the Protectorate, the history of the native settlement seems to be as follows:-

The indigenous occupants of the districts now known as Momberas and West Nyasa appear to have been members of the Tumbuka stock, including the Akamanga, Wahenga, Afulirwa, Apoka, Anyika, Ahewa, Asisya, \&c. A people calling themselves Batumbuka were encountered in the Senga country by the Portuguese explorer, Dr. Lacerda, about the year 1790, and in 1863 Livingstone found them occupying the country south of the Dwangwa. The Akamanga assert that they formerly held the whole country comprised in Momberas and West Nyasa, while the Wahenga claim that they were dwelling in the Henga valley to which they gave their name long before the arrival of 
the first Chikulamayembe from the east side of Lake Nyasa. These Tumbuka tribes were attacked by the Angoni from the south and the Awemba from the north, and appear to have taken refuge in the Wankonde country to the north. Those who remained behind localized their name to Afulirwa. Since 1895 the settlement of the Angoni has permitted the Tumbuka tribes gradually to drift back southwards.

The Wankonde just mentioned, including among other divisions the Wankana, Wasukwa, Awandia, Alambia and the Awanyamwanga, are probably the earliest native settlers in Nyasaland who still remain. Under successive chiefs always called Chungu (great man) they have dwelt in North Nyasa for as far back as can be traced with any degree of historical accuracy. They themselves state that they originated in the adjacent Ukinga mountains at the north end of the lake, and having crossed the Songwe, settled in the fertile plains round about Karonga. Others migrated westward into the hills and adopted local names, e.g., Wankana and Wasukwa. The Wahenga who, as stated above, fled to the Wankonde before the Angoni raiders, proved to be treacherous to the people whose hospitality they had accepted, and joined with the Arab slave traders and their Awemba allies in raiding the peaceful Wankonde. It was the desire of the early European settlers to protect these people who appealed to them for help that caused the bitter fighting that was only finally ended with the capture and execution of the Arab leader Mlosi in 1895.

In West Nyasa the predominent tribe is the Atonga, a branch of the Mang'anja stock, whose history is very vague. They are said to have come from the north and to have split up at some unknown rocky pass. Some reached the Dwangwa and others came to Usisya, while the more dominant Atonga appear to have united with the Angoni from whom they afterwards severed and settled at Bandawe upon learning that their allies, jealous of their increasing numbers and strength, were plotting to annihilate them. In after times they appear to have protected themselves more or less successfully from the Angoni, although it is probable that they would eventually have been annihilated by the Angoni but for the advent of the British Administration.

These notes, disjointed as they are, give some idea of the whirlpool that was set up in Central Africa by the meeting of the various waves of Bantu natives moving for some reason or other from their sources of origin, often many hundreds of miles from the locality where they eventually met in struggle for the fertile lands now occupied by them. They will also show that in view of the numbers of men carried off by the victors as slaves and the women taken as wives, the tribes in Nyasaland must be of very mixed origin. Taken in conjunction with the peaceful mixture and intermarriage of recent years it may almost be said that tribal names in the Protectorate now have little or no actual meaning. 


\section{CHAPTER IV.}

\section{THE NATIVES OF NYASALAND.}

At the census taken in April. 1921, there were found to be $1,199,934$ natives domiciled in Nyasaland, $\left(^{1}\right)$ inciuding those who, at the time, were actually residing elsewhere, in Northern and Southern Rhodesia and the Union of South Africa. All the various tribes in the Protectorate belong to what is known as the Bantu race. This race does not constitute any physical division of the human species. There are tall and short, intelligent and ape-like, dark and pale-skinned varieties of negroes all classed under this head. Bantu is a name invented by the philologist Wilhelm Bleek, in 1856 , to include the various members of the great language family which was at that time discovered to be in existence over practically the whole of South and Central Africa. The term Bantu is merely derived from the word used almost universally among the various languages composing this family to denote the English word men.

It is said that a negro people thousands of years ago entered Africa from southern Asia. They introduced the banana and various edible roots, and were the ancesters of the negroes now living in the Sudan. Following these are believed to have come from a more north-westerly part of Asia a Hamitic race with a language whose syntax was formed, like modern Bantu, by the addition of prefixes and suffixes to the root. They thus formed a linguistical contrast to the monosyllabic negroes who preceded them. These people brought with them the goat and the dog and different kinds of grain. The mixture of these two races produced the earliest Bantu stock. Next there came into Africa light coloured Hamites crossing either by Suez or the narrow straight at the south end of the Red Sea. Ethnographists place the earliest of these light Hamite invasions at a date certainly before the year 5,000 B.C The ancient Egyptians are the must noteworthy representatives of this stock. Other branches spread southwards and some reached the extreme south of Africa where they mixed with the dwarf-like aboriginees, the Bushmen, and thereby produced the Hottentots. Some of these light Hamites mingled with the earlier settlers, negroes and early Hamites, and became the forefathers of the later Bantus. By the Hamites the ox and the fat tailed sheep were brought into Africa.

The present habitat of the Bantu race may very roughly be taken as all that part of Africa which forms the tapering portion south of where the west coast takes its southern bend at Calabar, and south of Mombasa and Malindi on the east coast. In this region there are, of course, semi-Bantu tribes to be found and in the south-western corner the Bushman and Hottentot races are not of Bantu stock at all.

(1) NoтE.-As against 736,724 in 1901, and 969,183 in 1911. 


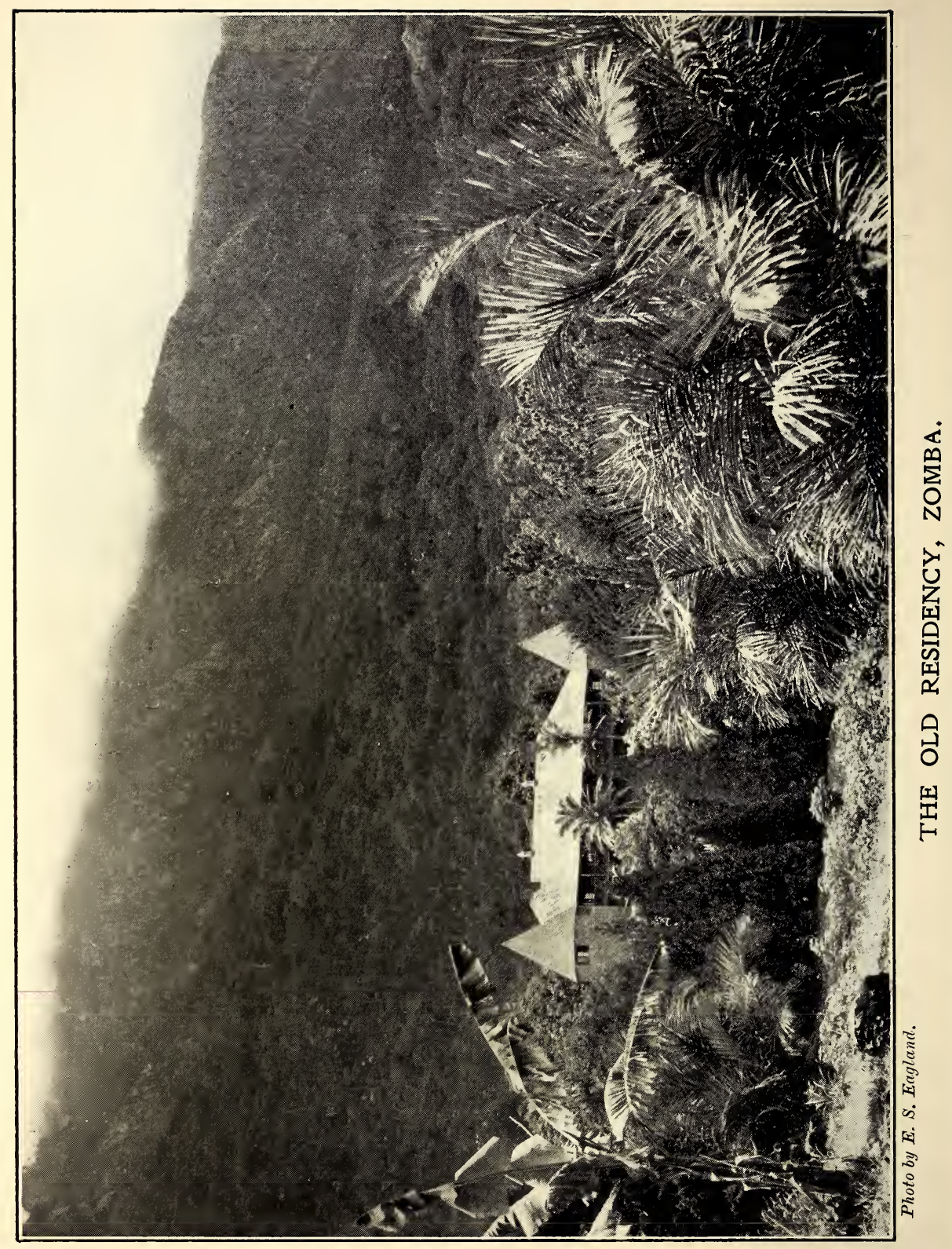


It may be that the Bantu language type had its origin somewhere south-east of Lake Chad and, spreading south-eastwards, reached the Great Lakes and the valley of the Upper Nile. Certainly the most archaic forms of the language are to be found to-day in Uganda among the Bakonjo of the neighbourhood of Lake Edward, and the Masaba of the Mount Elgon region north-east of Victoria Nyanza. From these regions it is not improbable that the Bantu peoples set out on their career of conquest in the southern part of the continent. In Central Africa they most likely found some previously established race of negroes, perhaps of the HottentotBushman type, perhaps of some later invaders who had driven the Hottentots southwards. These Bantu invasions were influenced by contact with the superior races from the north-east who had come from Asia by way of Arabia but had not mixed much with the negro-stock. Such races would no doubt have supplied leaders and ruling families; and were no doubt the ancestors of the better looking types of negroes that are not infrequently encountered in Africa. Early travellers in particular were struck with this feature of the ruling castes and families of the tribes through which they passed. And there is no doubt that these non-negro interlopers influenced to a considerable degree the Bantu language and culture, introducing iron weapons as well as agricultural and pastoral knowledge. As time went on the Bantu language split up into the 400 or so dialects now spoken, and the civilizing influence of the non-negro admixture was counteracted by the inferior tribes whom the Bantu hordes conquered and in whom they became merged.

The peculiarities of this Bantu form of language which, taken together, differentiate it from other groups lie chiefly in the fact that syntax takes place by the addition to the root of prefixes and suffixes rather than by changes in the root itself, and that nouns are divided into various classes indicated by particles prefixed to the root. An especial feature of Bantu languages is the system of concord by means of which nouns are joined to the words relating to them by particles which are generally similar to their class prefixes.

Politically, the existence of this Bantu family of languages over such a vast area is of the greatest importance. The similarity of structure and the number of root words common to most of the dialects facilitates intercourse between neighbouring tribes, and enables the traveller, European or native, to make himself more or less understood wherever he may be, until he has had time to acquaint himself with the local vocabulary and dialectical peculiarities.

In this way natives leaving their homes to seek work elsewhere readily acquire either the language spoken in the districts where they temporarily settle, or a language that they find will be easily understood wherever they may go. Examples may easily be furnished. Swahili has become the commercial language of the east coast of Africa chiefly by its religious associations, and, by recognising Chinyanja as an official language, the Government of 
Nyasaland has spread its use throughout the Protectorate. There is no doubt that many of the dialects of Nyasaland will be completely lost before many years have passed, and that a Chinyanja, enriched by its borrowings from the languages it supplants, will be universally used by the natives of Nyasaland. Some of the tribes, Wayao, Anguru, and those of North Nyasa will no doubt retain their own tongues longer than others; but, as the country develops, the tendency will be for all the tongues to merge into one.

Although this merging of all the natives in the Protectorate into one language group may have many advantages, it may also have the undesirable effect of eliminating tribal distinctions in other ways, so that the rivalries and jealousies of the various tribes will not, as at present, counteract each other so as to produce a resultant law abiding and loyal community.

Of the 40 or more tribes that were enumerated at the last census, descriptions are given in this chapter of the most important the Anyanja, Wayao, Anguru, Swahili and the Angoni. Particulars relating to most of the others will be found in chapters VI. to VIII., but many of them are closely allied to the Anyanja, the tribe that occupied the greater part of the Protectorate before the others mentioned above conquered or settled in the country.

\section{The Nyanja Peoples.}

To be right "Nyasaland " should be "Nyanjaland," and the name "Lake Nyasa" should be "Lake Nyanja," for both "Nyasa" and "Nyanja" mean the same, the one being in the Yao tongue and the other in the Nyanja. When Livingstone first came into the country he asked a Yao man, and by him was told that the name of the big sheet of water away to the north was "Nyasa," that is, "The Lake." Had he met a Nyanja man he would have been told that its name was "Nyanja," and then to-day the lake would have been called "Lake Nyanja," and the Protectorate would have been "Nyanjaland," the "Land of the Lake " and the home of the "Lake people."

These were the original inhabitants of the country to the south of the lake, and continued the only inhabitants until 1860, when the Yaos came down from the north and occupied the Shire Highlands, and 1868 when the Angoni who had come from the south of the Zambesi some time before and had been wandering in East Africa for several years, returned to this district and under their chief Chidiaonga settled round Domwe mountain in what is now called Angoniland.

The Nyanja people are closely allied in speech to the Sena and Tette or Nyungwe people on the Zambesi, and to the Senga on the Lowangwa. From the other tribes in the Protectorate, Yao, Tumbuka, Tonga and Konde, their speech is much more remote.

The tribe originally consisted of several divisions, the Mang'anja on the Lower Shire, the Ambo, Antumba, Ampotola, Amaravi who lived in the country round the south end of the 
lake, the Nyanja proper who lived on the shore of the lake, in the Shire Highlands and round Lake Shirwa and Mount Mlanje, together with the Achewa and Achipeta, who inhabited what is now known as Central Angoniland.

Since within historical knowledge the Nyanja people have been broken up into a number of petty chieftainships. But tradition tells that at one time the whole of the Nyanja proper in the south of the Protectorate were under the rule of a powerful chief named Kapwiti, who lived in what is now known as Undi's country.

The country and people were not visited by Europeans till Livingstone and his party made their expedition of 1858-64. They explored the Shire Valley, the Shire Highlands, discovered Lakes Shirwa and Nyasa, followed up the west shore of the lake to as far north as Chinteche, and on another occasion penetrated as far west as Kasungu.

The country at that time was in a very disturbed state, being subject to invasion from the Yaos driven from the north-east by the pressure of other tribes. This was the incursion of the Yaos led by their chiefs Kapeni and Kumpama, who caused the trouble to the Universities Mission when they first settled at Magomero, and finally brought about their removal first to the Lower Shire at Chikwawa, thence to Morumbala, and afterwards to Zanzibar.

On Livingstone's return to the country in the course of his last journey-1866-73-he found it still disturbed by raids of the Angoni called by him Maviti and Masitu, parties of whom were raiding the country to the south-west of the lake.

The next Europeans to visit the Nyanja people were Lieutenant Young and Captain Faulkner in their search after Livingstone, who had been reported dead by some of his deserting followers. They found traces of Livingstone long after the time of his reported death, and so they returned. The story of this expedition is found in Young's "Search after Livingstone."

The next European arrivals in the country were the pioneer parties of the Livingstonia and Blantyre Missions, who settled the one at Cape Maclear on the lake in 1875 and the other at Blantyre on the Shire Highlands in the year 1876.

Like most Central African tribes the Nyanjas have no history sare a vague tradition that they originally came from the northwest from a place called Kapirimtiya, where they say the place of their origin is marked by the footprints of men and animals on the rock as they came from the Creator's hand.

The Nyanja believe in the existence of a Supreme Being who is the recognised Creator of all things. $\mathrm{He}$ is commonly known as Mulungu, but is also sometimes spoken of as Chiuta, Lesa, Chanjiri, Chinsumpi and Mpambe. There are other inferior spirits worshipped in certain localities, but these are without doubt the spirits of chiefs of former days to whom worship is paid in times of difficulty or stress.

The basis of their religion is animistic-the cult of the spirits of the dead, to whom offerings are made either at the ruins of 
the huts where they lived, or at the grave, or in some shrine or kachisi in or near the village. Among the northern branches of the tribe there is a form of fetichism-each household having its own fetich in which is enshrined the spirit of the dead relative to which, on family occasions, offerings of flour, beer or cloth are made.

Belief in witchcraft was universal and strong, and almost all forms of disease as well as mishap or misfortune of any kind were ascribed to this cause. For detection of this, as of almost all other forms of crime, resort was had to the lot. Generally the accused had the chance of clearing himself by appeal to the mwavi or poisoned ordeal. Among the Angoni branches of the tribe the practice of mwavi drinking was very frequent, often whole villages having been compelled to purge themselves in this way from the suspicion of having done some harm to the chief or his relatives. Many hundreds of deaths occurred from this cause every year among the Angoni villages.

Skins or bark cloth were the original clothing of the Nyanjas till contact with coast trade brought cloth which was bartered for ivory or food or slaves. Not a few villages, however, especially in the Maravi country, had their little patches of cotton from which they made a course kind of cloth to form a garment by day and a blanket by night.

Iron ore is to be found in almost all parts of the country. and the blacksmith's smelting furnace and forge were to be found in or near almost every chief's village. A stone for an anvil, a goatskin for a bellows, a small iron hammer, a bamboo for a tong formed their whole kit of tools, and with these they made hoes, knives, spears, axes, \&c., suitable for native needs.

The Nyanjas are a quiet and peaceloving people, and it was not till the Angoni who had conquered them trained them to the art of war that they were looked upon as a warring people. Even then they were feared not from their own name but because they were recognised as Angoni. Fighting with spear and shield they were more than a match for their bow and arrow using neighbours. Even the introduction of firearms from the coast gave their neighbours little protection from Angoni raids, and the very whisper of an Angoni invasion of the Shire Highlands was enough to send all the people to the hills for refuge. There is no doubt that but for the arrival of the Europeans the whole of the Shire Highlands would have been devastated or its inhabitants made tributary to the Angoni.

In their own native life the Nyanjas are an industrious people -on the hills they cultivate crops of maize, cassava, kaffir corn and beans, and among the Angoni they have large herds of cattle. The care of these they have been taught by their Angoni masters. Down on the Shire river they grew crops of oil seeds which they took down, in their large dug-out canoes, to the Zambesi to sell to the Banian traders in the Portuguese country. Compared with the Yaos they are not physically a strong people, and in the River valley a considerable number have fallen victims to 
tuberculosis, a disease indigenous to the country, but which has greatly increased owing to the return from the mines of natives who had been infected there. Some districts, as for instance Mlanje, seem to be more infected than others.

The advent of the European has brought many changes. Instead of the native of Nyasaland being confined to his own district, and in some cases to his own village, he is now at liberty to wander wherever his desire may prompt him. That he does so is to be expected, and hence the migration of many of the tribe to the wider labour fields of the south. But their own country has not been without the results of the labour of the Nyanja people. The "Angoni," as the northern branches of the tribe are commonly called, have been and still are the main source of the labour supply for the plantations of the Shire Highlands. The Nyanja has not the physique nor the brains of the Yao, nor the agricultural perseverance of the Nguru, but with his hoe, and in the early days of communication with the coast with his paddle and punting pole, he contributed not a small share to the development of the Protectorate. $\mathrm{He}$ is easily impressionable-witness how soon he adapted himself to the warlike habits and character of his Angoni conqueror, and as readily put them off. In this respect he compares with the far less impressionable Yao, but he has not the staying power of the Yao when once he is impressed.

No doubt the advent of direct communication by rail with the south through the opening of the Blantyre-Beira line of railway will introduce to the Nyanja as to the other tribes a new element in their native life, but the changes in the future can be no greater than those of the past, and the native will no doubt come through the former as well as he has come through the latter, and the future of the people may therefore be looked forward to with hope.

\section{The Yao Tribe.}

The Yao tribe derives its names from the hill Yao, which is situate near Mwembe in Portuguese East Africa. There are several branches of this tribe, and those Yaos who have settled in Nyasaland are the Amachinga from the Machinga hills and the Amangoche from Mangoche. Between 1860 and 1870 there was internal strife, owing to famine among the Amakua Walolo who lived near the original home of the Yaos, and the defeated section of the Amakua attacked the Amachinga, who fled southwards, as did the Amangoche. The Amangoche came furthest south and settled in the present Chiradzulu and Blantyre districts, others came to Zomba, Chikala and Mlanje, while a small number crossed Lake Nyasa and settled at Dedza, and the Amachinga stayed in the Fort Johnston and Liwonde areas. It was not until after the Yaos had fled south that raids were made upon them by the Angoni from the west, Angoni aggression being in no way responsible for the great Yao migration from their own country in the north. There are also in Nyasaland natives of the Makanjila clan, so named after the founder of the 
family, who crossed the lake under a woman, Bibi Kuluunda, owing to her quarrel with the ruling chief, and settled near Domira Bay, where there is to-day a large Yao village called Kachulu. Bibi Kuluunda died as recently as 1919, when she was probably 80 years of age, and, as she must have been 40 when she crossed the lake, the date of the migration of the Makanjila Yaos into this country would be about 1880 . It is interesting to record that this old woman a year before her death made a journey to Zomba to pay her respects to His Excellency the Governor.* The present Yao chiefs in the various districts are in most cases the third of their line since the great Yao migration into Nyasaland. In the event of a chief's death succession passes to his sister's son, usually, but not necessarily to the eldest son of his eldest sister, but the choice may fall on some other nephew who has shown himself suitable for the position.

The tribal markings of the Yaos are three vertical cuts on the temples, the Amachinga generally making their marks longer and more conspicuous than the Amangoche, but amongst Yaos who are brought up in the Mahomedan faith the practice is falling into disuse. Tattooing is exceedingly popular amongst the women, who cut patterns on various parts of their bodies, mainly on the thighs and buttocks, and the nose button of lead, bone or wood, an introduction from the coastal tribes, is generally worn by them. The "lupelele" or lip ring, commonly supposed to be of Yao origin and worn by many old women, is an adornment, or rather disfigurement, which has been adopted from the Walolo. It should here be noted that the name Walolo is not that of a distinct tribe but of a number of kindred tribes, to all of whom it was given by the old Yaos as being descriptive in sound of the unintelligible tongues spoken by these people. Many years later, when these so called Walolo began to migrate to Nyasaland and were greeted as such by the Yaos, the latter say that the Walolo resented the name and called themselves Anguru. This explanation seems more likely than one sometimes put forward that the name Anguru was originally given to natives of mixed tribe and tongue who lived near a hill of doubtful locality called Mangulu.

The Yaos are now very lax as regards their marriage customs, and marry without the old formalities at a much earlier age than in times gone by, with a detrimental effect on the hardiness of the race. It was not the old practice for a native to have more than one wife, unless he were a person of some importance, but. now any native will marry two or more wives provided he is earning sufficient money to clothe them. The Amachinga of Fort Johnston and Liwonde are of a better stamp than the Amangoche who have settled in the Shire Highlands, they are possessed of finer features, and have not inter-married with other tribes to any extent. The Amangoche on the other hand have inter-married largely with Anyanja, Anguru, and in a less degree with Angoni. As a consequence the Yaos of the Shire Highlands.

* Compare, however, the account on pages 35 and 36. 
have lost their pride of race, they do not observe, and younger generations do not know, the customs of their ancestors, and so much inter-marriage has taken place, largely due to Anguru immigration, that it may not be many years before all the pure Yaos have disappeared from this area, and in their place will remain a hybrid community. Even to-day many of the natives in the highlands are of doubtful origin, and the majority of the so-called Yaos have little claim to the name. Amongst them the Yao tongue is poorly spoken and shows signs of disappearance, and, though this may be partially due to European employers, who find the Chinyanja language far easier to learn and more generally useful, inter-marriage is the greater cause.

They are intelligent and quick to learn a trade or craft, being particularly useful as mechanics, they make excellent servants, and as soldiers they have proved of inestimable value. As cultivators of the soil they are rather slovenly and do not devote that careful attention to their gardens which is noticeable amongst the Angoni, so that Europeans do not find them very satisfactory labourers. The Yaos of old were noted for their courtesy and hospitality, but the present generation are deficient in these excellent qualities. Great respect used to be entertained for chiefs, to whom it was the invariable custom to hand food, tobacco or any article with both hands from a kneeling position, and the same practice was also observed by a native towards an aged relation, but nowadays these customs are more often observed by women than by men. A Yao was always glad to accommodate a stranger at his village, but now that his trading instinct has had opportunities for development he does not recognise the same duty towards his neighbour and is not so ready to share his goods or food with another. The custom still survives, however, of one native seeing off another who has visited his village by accompanying him part of the way on the road, and is universally practiced. The "unyago" or initiation ceremony, through which every Yao boy or girl must pass, comprised a very careful course of instruction, some details: of which are repungnant to European ideas, but it is certain that this course held many favourable features, such as tuition in the duties of husband and wife, and respect for their elders and superiors. To-day these ceremonies are not conducted with their pristine formality, and greater attention is paid to the festivities held by the adults on their conclusion.

Like all African natives the Yao is most superstitious and has a great regard for omens, mainly those portending evil, "mpingu." If a native met a chameleon motionless on the path or two snakes fighting together, or if he heard the bark of a baboon in the bush, it would be enough to cause him to return to his village without completing his journey, lest ill should befall. Again, the fall of a lizard from the roof of a hut to the floor is a portent of evil, and, should a mole's burrow make its appearance through the floor, the hut would be permanently vacated. On the other hand, to meet the small black ants following one another across one's path, or to hear the call of the "nkulukulu" (Eng. Turaco) 
is regarded as a sign of good luck. These are but a few of his many superstitions, and a parallel to the evil omen of the lizard may be found in the fear of ill luck felt by many a European in the event of the sudden fall of a picture from the wall. In order to bring good luck it is a common practice to mix flour and water in a gourd and to pour the mixture into a small hole at the foot of a tree. The Yao is a believer in the spirits of the dead, "Msimu," so that if a native dreams of the appearance of some deceased relative or friend he reports to the headman of the village, and about a week later a peculiar ceremony takes place. Beer having been made at the village the dreamer takes a cup of it, which he pours over the site of the deceased's old hut, calling upon the deceased to drink, and he also places there a pot of beer, which remains all night. The following morning this pot of beer is consumed by those who performed the burial rites of the deceased, and, the spirits having now been propitiated, the villagers then take part in a beer feast. Should the site of the old hut not be still in evidence the ceremony is performed at the foot of a tree.

There is a legend known to the older Yaos concerning "Kapilintiya," which is the name given to a hill supposed to be situated in the north country west of Lake Nyasa. From this hill the first natives are said to have sprung, and it is maintained that a large sloping rock bears the impress of two pairs of feet, the feet of a man and woman, the latter being of smaller size. Others say that also may be seen the shape of the hoe which man was to use, the impression of a sifting basket and of the woman's knees and under sides of her toes as she kneels in her work of sifting flour, the shape of the bottom of the pounding mortar, and a small well. Here, too, is the mark made by the lion crouching to spring upon his prey, and the trace of every kind of animal and bird as they came out of the hill and trod upon the rock. Old Yaos will tell how their grandfathers made pilgrimages to view the rock of "Kapilintiya," and, though the legend has no doubt been embellished with the passing of time, this ancient native idea as to the origin of man is none the less pleasing and interesting.

\section{The Swahili.}

The Swahili properly belong to the coastlands of East Africa. They do not form a large class of the native inhabitants of the Protectorate and were never very numerous. Their first connection with Nyasaland arose from the slave trade. They formed the fighting forces of the Arab slave-raiders. Afterwards they took to slave trading on their own account and established settlements at various centres on the coast of Lake Nyasa and on the Upper Shire, principally at Karonga, Kota-Kota and Fort Johnston. They had at one time several dhows on Lake Nyasa for the transport of slaves, ivory and goods across the lake. When the slave trade had been definitely suppressed the greater part of these Swahili drifted back to the East Coast. They had intermarried extensively with the indigenous natives and left behind them a considerable 
sprinkling of descendants of Swahili blood. Their language was largely adopted in the districts in which they settled and they converted the pagan inhabitants of those districts to the Muhamadan religion. The Swahili language, which at one time was almost the lingua franca of the Upper River and Lake, is gradually dying out and is now only preserved in those communities which profess Muhamadanism. The influence of this religion seems to remain more or less stationary. It may spread to some small extent within the communities or tribes which originally adopted it. It certainly does not spread to other tribes. It is a form of religion which commends itself to the natives because it permits the practice of polygamy, but as it is entirely under native organization it is conducted in a half-hearted and slipshod fashion and probably for that reason finds few fresh converts.

\section{The Angoni.}

The history of the Angoni is given in the preceding chapter. The following is a description of the natives of the tribe. When a man wishes to marry, and has chosen the woman whom he desires to make his wife, he first becomes acquainted with the woman and then sends a "witness" (Nkhoswe)(1) to the parents of the woman to ask for her in marriage. The parents question their daughter, and if she consents to the marriage and they also approve, they go and inform the "witness" that the narriage is sanctioned. Each party to the marriage then provides two "witnesses." The parties and their relations and their respective witnesses then gather together to confirm the marriage. There is no particular form of ceremony. The witnesses give both parties advice as to the proper conduct and the responsibilities of married persons and warn them against infidelity and neglect of the obligations of husband and wife.

Usually the woman must live at the village of her parents, and the husband builds a hut for her there. If, however, the husband makes a payment to the parents on account of the marriage, he is permitted to take the woman to his own village. Such payment is made in cattle, goats or sheep. It is not often that payment is required by the parents. The "Ankhoswe" (witnesses) act more or less as sponsors for the parties to the marriage. In any subsequent dispute between the parties or in questions of adultery or divorce, these witnesses are summoned to discuss and adjust such disputes.

When a native dies the headman and elders of the village are informed. The relatives wash the body and prepare it for burial. The headman, elders, relatives and other interested natives gather together in the hut of the deceased and lament. The nearest relative of the deceased leads these lamentations and the others respond in chorus. After about half-an-hour of lamentation the company leave the hut and discuss and arrange for the burial. Someone goes to the hut where the body is lying and measures the body. Flour for sacrifice at the grave is prepared. When the grave has been dug the mourners take the

(1) NotE.-Or, more properly, a sort of marriage broker. 
body to the grave for burial. The body is usually laid in the grave in a reclining position, and is covered with a cloth and a mat. The small personal articles of the deceased such as snuffbox or pipe are placed in the grave with him. When the grave has been filled in, the pots of the deceased are broken upon it. By the old Angoni custom the bodies of warriors were placed in the grave in a sitting posture facing west, and their weapons were buried with them. This custom is sometimes still followed at the burial of the sons of the old warriors.

When the body has been buried the mourners bathe themselves, and in the evening assemble at the hut of the deceased to mourn. Next morning they shave their heads (usually the whole head). Goats, sheep or cattle are killed for the funeral feast. For a Chief's funeral one or more oxen are always killed. The widow or widows of the deceased plait bands of fibre or string and wear them round their heads. A period of one or two months passes until the time for "the second shaving of the head." During this period the relations of the deceased must not have connection with their wives. At the end of this period the "funeral beer" is brewed, and the mourners shave their heads a second time, and beer drinking and dancing are indulged in. The widows take off their head bands, and wear instead a string head dress smeared in oil and woven into their hair. This unpleasant head dress must be worn continually until the period of widowhood is over (usually two years).

There are certain superstitions in connection with the use of salt. If a woman has committed adultery she usually is careful to avoid putting salt into the food which she cooks for her husband. If she puts salt into his food herself her husband will be attacked by a disease called "Tsempo" (symptoms-perpetual cough or a swelling of the body). Again, if a man is away buying salt, and on his return to the village he finds that his wife has. committed adultery while he has been absent buying salt, none of the salt which he has bought must be put into his food, otherwise he will be attacked by "tsempo."

In former days when parties of villagers went to obtain salt from salt-pans or from the ashes of certain herbs, none of the natives remaining in the village were permitted to have connection with their wives until the salt-gatherers returned.

Witcheraft is still firmly believed in by the average native. Sickness and death are often attributed to witchcraft, even when death has been caused by some well known disease or by a lion. In such cases it is often maintained that a wizard has sent the disease or the lion to cause the death of the person whom he wishes to remove. Extensive epidemics often result in accusations of witcheraft and ordeals by mwabvi poison. It is believed that there are certain evilly disposed persons who practice witcheraft. at night, that they prepare certain medicines and put them into duiker or bushbuck horns, that they blow or sound the horns during the night, mentioning the names of those they wish to be sick or die, and thereby accomplish the sickness or death of their enemies. 
A person accused of witchcraft is required to prove his (or her) innocence by submitting to the mwabvi poison ordeal. The ordeal may also be used in connection with other offences such as adultery or theft, but not frequently.

An ordeal may follow an individual accusation of witchcraft or, where an unusual number of deaths has occurred in a village, all the adult members of the community may be invited to undergo the ordeal in order to find out who has caused the deaths. In former days extensive ordeals comprising a group of villages would be held resulting in heavy mortality.

The usual procedure in such ordeals is as follows:-A professional "Mapondera" (pounder of the poison) is engaged to mix and dispense the poison. He is usually paid a goat or two for his services. All concerned in the ordeal proceed to the spot selected for it, probably accompanied by a number of other interested persons. The "Mapondera" pounds the poison (bark of the mwabvi tree) in a small mortar, at the same time giving the company an explanatory harangue. When the pounding is completed he adds water to the poison, stirs it and pours it into gourd cups and hands them to those who are required to undergo the ordeal. They all drink. One or two perhaps die of the poison. They are held to have been the guilty persons. The others vomit up the poison and so establish their innocence. Even now-a-days it is easy to persuade natives to take part in this foolish and dangerous custom. If accused of witchcraft they feel bound to undergo the test. Ordeals are now of rare occurrence as practically all the professional "Mapondera" have been convicted and sentenced to long terms of imprisonment. They still, however, occasionaliy hold ordeals over the border in Portuguese territory, where "Mapondera" abound and exercise their profession with comparative impunity.

An accusation of witchcraft is often led up to by the casting of lots. Such method is also used for detecting thieves and adulterers. Lots are generally cast by professional medicine men. These lots are in various forms such as :-

(1.) A small gourd filled with medicinal roots and castor oil and ornamented with beads. The operator has a bag of castor oil seeds or other noise producing substance under his arm and pretends that the gourd talks to him and indicates the guilty person.

(2.) A gourd in which a duiker horn filled with medicine is placed. The operator agitates the gourd and causes the horn to point to the guilty person.

(3.) A tortoise shell filled with medicinal roots; a feather is fastened to the tail end of the shell. The operator manipulates the feather so that the shell moves about. He interprets the movements of the tortoise-shell.

The successful manipulation of these contrivances probably requires considerable dexterity.

The professional thief has "medicine" to protect him from discovery and to render him invisible. The natives believe firmly 
in the efficacy of this medicine, which consists of a hyena's tail, the stem of which is stuffed with some powdered medicine. When a gang of thieves meditates burglary in a village, or robbery of loads from carriers at night, or burglary of a store, \&c., one of the gang remains at a little distance from the scene of operations while his companions go to carry out the robbery. He'keeps the hyena's tail pressed firmly on the ground until the others have completed the robbery and have got clear away. He then makes his escape.

This form of "medicine" is prompted by the idea that when a hyena prowls round a village at night, he renders himself invisible by holding his tail down tightly. An absurd idea, but one which illustrates the credulity of the native, and the strange notions which possess him.

The religion of the pagan natives is confined to the worship of the spirits of their deceased fathers or grandfathers, or, in rare cases, mothers. Sometimes separate huts are built for the spirits in which sacrifices of cloth, meat, flour or beer are made. Such sacrifices are left in the hut for one night, if they consist of food, which is then consumed by the person making the sacrifice. The object of the sacrifice is to appease the spirits and to secure their good will. If the spirits are suspected of causing sickness in the village, lots are cast to find out whose spirit is responsible, and sacrifices are made to that spirit.

Generally speaking, the first-born son succeeds to the property of the deceased. Failing a first-born son the following relatives would have claim to the estate of the deceased in the order in which they are mentioned below :-

1. The eldest surviving son.

2. The first-born daughter.

3. The eldest surviving daughter.

4. The eldest brother.

5. The eldest surviving brother.

6 . The eldest sister.

7. The eldest surviving sister.

If there were no sons, daughters, brothers or sisters surviving the deceased his property would go to (1) his father, (2) mother or (3) uncle.

Wives obtained (1) by payment of livestock or goods to their fathers, or (2) captured by the husband in war, had precedence over wives (3) married in the ordinary way by mutual agreement and without any marriage payment. The reason for this was that wives (1) and (2) were obliged always to live in their husbands' village, even after his death, whereas wives (3) resided in the village of their parents and could not be removed therefrom by the husband. Wives (1) and (2) were regarded as inheritable property and could be disposed of in marriage by the heir of their deceased husband.

If a man died and left children by wives (1) and (2) such children would have claim to his estate to the exclusion of children 
by wives (3), even though they were female children they would have preference over the male children of wives (3).

The mode of life of the ordinary Ngoni native has not changed very greatly since the establishment of the Protectorate. His huts, utensils, methods of cooking, diet and system of agriculture are much the same as formerly. In the matter of clothing the use of skins, bark cloth and home-made cotton cloth has given place to the adoption of imported cotton goods. His implements and weapons are unchanged. His bed is still a reed mat spread upon the earthern floor of his hut ; his covering a cloth, or possibly a cheap trade blanket. He relies for warmth at night mainly upon the wood fire in his hut. Generally speaking his mode of life is as simple and as devoid of comfort as it always was. In sickness he still relies for the most part upon the services of the native medicine men.

There is, however, a small but increasing class of educated natives who are inclined to adopt to some extent European methods. They wear European clothing, build better houses with wooden doors, use rough tables, chairs and beds, and generally endeavour to attain a higher standard of comfort.

The arts of cotton weaving and iron smelting which were at one time universal have practically died out with the introduction of imported cloth, hoes and axes. A few blacksmiths still ply their trade, but the iron which they use is scrap-iron, and is not obtained by smelting.

Although the old martial spirit of the Angoni which was maintained by constant warfare has declined after decades of peaceful existence, they are by no means deficient in courage. They make good soldiers, and during the War in East Africa furnished some 3,000 front line carriers, who were conspicucus for their steadiness under fire and in all times of danger. The Angoni companies of the King's African Rifles also excelled as brave and efficient soldiers.

The Angoni have given up the general use of their war dress and weapons (cow-hide shields and spears); such are now reserved for tribal dances. They still retain the knobkerry, and many of them still have spears and bows and arrows for protection and for hunting game. The war dress consists of a black, bushy headdress of crow's feathers, a kilt of monkey skins, a broad band of beadwork round the chest, and fringed bands of white goat's hair round the upper arms, under the knees and round the ankles. This costume is very striking, and a full company of tall and splendidly built Angoni warriors dressed in this way and armed with spears and shields is a most imposing sight. One can imagine how the advent of regiments of such fierce-looking warriors must have terrorized the less warlike aboriginal inhabitants of Nyasaland. The shields and spears are of the Zulu pattern.

As regards change of character, the tribe is not so moral or so honest as in the old days. The removal of the heavy punishments imposed under native law for adultery and theft, and the substitution of milder penalties, have led to greater laxity in such 
matters. Apart from the severity of such punishments, the power of life and death which the old chiefs exercised, and their autocratic and often tyrannous rule effected a very rigid observance of tribal law and custom. The native marriage tie is not nearly so binding as formerly and adultery is prevalent and on the increase. Prostitution, probably unknown in the old days, is gaining ground, and is doubtless due to intercourse with the less moral tribes, and to loose habits acquired in Southern Rhodesia, to which country so many Angoni go for employment.

The old punishments for adultery were very severe. If the wife of a chief were one of the guilty parties, both the woman and the adulterer were probably put to death. In other cases both the man and the woman were often sold as slaves and the purchase price was given as compensation to the injured husband. In some cases the adulterer was permitted to compensate the injured husband by providing him with another wife or by payment of goods. This course was usually adopted where the adulterer was a man of influence. Sometimes the ears of the woman were cut off to mark her as an adulterous woman.

These drastic punishments were directed entirely towards the prevention of adultery and the protection of husbands against infidelity on the part of their wives. The morality of unmarried women and girls was not held to be a matter of such vital importance, but was safeguarded by a superstitious fear that illicit sexual intercourse would bring upon the offenders a mysterious disease called "Tsempo."

Theft was often severely punished; for the first offence by payment of compensation in goods or livestock. Confirmed thieves were punished by the loss of a hand or by being sold into slavery.

The establishment of peace in the Protectorate had probably more effect upon the life of the natives than any other factor. In the old times of constant war they travelled very little. and then only in strong, armed parties. With the advent of peace and security they began to visit other districts and eventually other countries. Their outlook was enlarged by contact with other tribes, with whom trade was established in livestock, foodstuffs and other commodities. The emigration of Angoni to Southern Rhodesia, to which country large numbers proceed annually in search of employment, has also improved their knowledge of the world. Such emigration is not, however, entirely beneficial, for they acquire bad habits in the South African townships, and are apt to become discontented with the primitive life of their own villages. Prolonged periods of residence in South Africa lead to rupture of family and marriage ties, and loss of the good influence which such ties afford.

The young men of the present day are impatient of restraint, and are not so amenable to the dictates of custom or to the advice or orders of their elders as they were in former days. 


\section{The Anguru.}

The term "Anguru," which would appear to be almost as vague as "Azungu," is used generally to describe all the MakuwaLomwe type of peoples inhabiting Portuguese East Africa north of the Zambesi between British Territory and the Coast.

The name "Alolo," which sometimes seems to be used as synonymous with Anguru, is so used incorrectly, and can only strictly be applied to the Atakwani and Akokola peoples who came originally from the neighbourhood of Quilimane and who are hence also known as Achuambo, Chuambo being a native name either for Quilimane or its vicinity.

From what one can learn, these people came in force from the neighbourhood of Quilimane and settled to the east of Mlanje mountain at no very distant date. (It is worthy of note that these people call a lion "potokoma" or "podogoma," and that passing through many intervening tribes and dialects using such words as "mwato," "kalamu," "mkango," " lisimba," "simba," \&c., one finds a word "pologoma "-which is manifestly the same-used again in Uganda.)

The majority of the "Anguru" natives who have settled in British Territory, however, belong to the Amihawani tribe, and their language appears to be the most generally used.

When such terms as Akokola, Atakwani, Ameto, Amihawani, Amarata, Anikuku, Anitukwi, \&c., are heard it can be seen that it is impossible to speak with any degree of exactness, either of the "Anguru language" or of "Anguru tribal marks."

Four or five distinct types of tribal marks are seen according to the main tribes, e.g., the Amihawani, Amarata, Akokola and Ampotola have numerous dots on the forehead and lower part of the back, and their teeth are pointed. The Atakwani have two lines cut on the temples, and the Amanyawa small crosses on the back and abdomen, the latter having also a V-shaped cut between the two middle front teeth. Dialects differ in degrees varying according to locality; thus, representing tribes alphabetically, say from north to south; while the tribe $\mathrm{C}$ will have little difficulty in communicating with the tribes $B$ and $D$, the tribes $\mathrm{A}$ and $\mathrm{H}$. will speak almost totally difierent languages.

In the case of such very common everyday words as "big," "fetch," and "maize," the "Chinguru" spoken in the Shire Highlands-which is approximately Chi Mihawani or, as they say, Emihawani--differs entirely from the Makuwa spoken at Mauwa.

Among the large numbers of immigrant Anguru labourers who formerly worked for some months of the year on plantations in this country, were occasionally found small parties whose speech differed so definitely from that of the bulk of their fellows that interpretation became a considerable difficulty, and gave rise to the sage dictum "the Anguru don't know their own language."

These men, no doubt, came from some shy and unenterprising tribe or sub-tribe rather more remote than the others, but there 
could usually be found some man among the other labourers who had some idea of their language.

The Makuwa from the Medo district, usually styled "Ameto" here, are perhaps the best type of Anguru in the Protectorate, both as to physique and intelligence, but in British Nyasaland their numbers are much smaller than those of the other tribes.

The Amarata, on the other hand, are about the lowest type and are looked down on by the other Anguru.

Considered in the aggregate, however, the Anguru can hold their own in most things with other natives, and many house boys, capitaos, office boys, \&c., are either half or pure Anguru who are accepted by their employers as Yao, Mang'anja, \&c., if their teeth are not filed.

The term "Anguru" being used by other natives (who are in no way better) in an opprobrious sense, and they themselves having severed connection with their homes, the Anguru who have settled in British Territory are rapidly losing their tribal and social characteristics.

Of the children born in the Protectorate, few of the boys or girls have their teeth filed, and almost none of the girls have their lips pierced for the lip ring.

Most of the girls later adopt what are accepted as "Yao" markings and wear a nose button (frequently on the right, or incorrect side) and they intermarry, not only among their own different tribes, but also among the Mang'anja, Anyanja, and Yao as far as possible.

The language readily adopts Mang'anja words, sometimes in a more or less modified form, as for example, a verb with the Lonwe $\mathrm{O}$ instead of $\mathrm{Ku}$ for the infinitive and with the stress in the wrong place, \&c., but the majority of the younger generation speak Chinyanja or Shire Highlands "Yao" with considerable fluency.

The women still adhere very strictly (so far as can be learnt), to the custom of giving birth in the open air, from a belief that evil would result to the husband should a child be born in the house. So strong is this belief that, if a birth inadvertently takes place in a house, the house is destroyed and the husband must build another.

As to initiation ceremonies, however, it is not unknown, at any rate in the Tuchila Plain, for a father to send his son to the Nyarija ceremony simply because a Mnyanja instructor happens to be getting names together for a "Class" when the father is thinking of having his son initiated.

Anguru, when freshly arrived from their own country, are industrious, cheerful, and thrifty to a degree; while as regards truth and honesty, they compare-whatever be their motivesvery favourably with other peoples.

These good qualities, however, they lose after being settled for some years in the Protectorate, and nowadays the Anguru are represented among the idle and criminal classes to a disproportionate extent. 



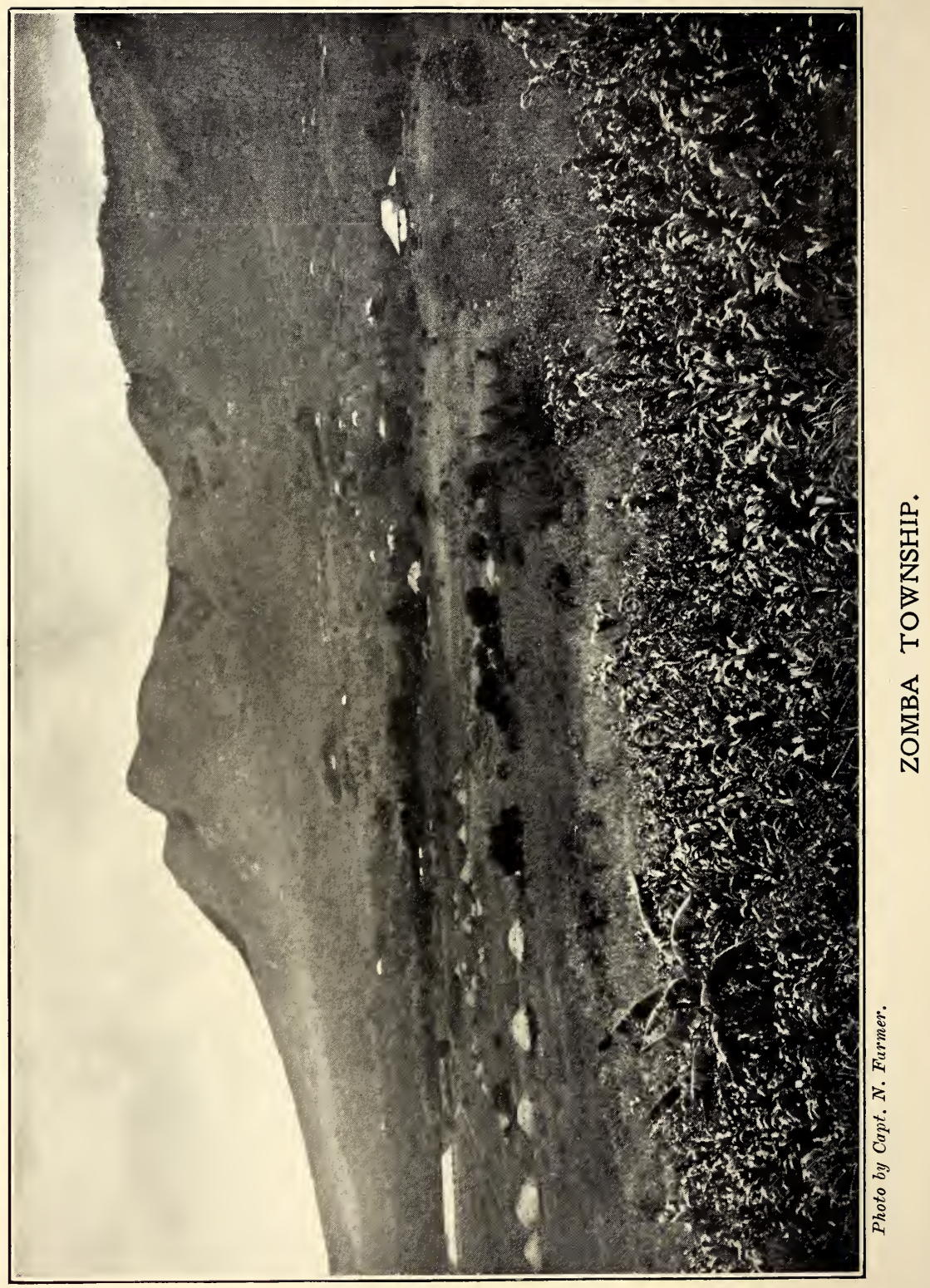


From the point of view of the employer, when dealing with " raw" Anyuru, there are no natives who will respond more loyally to kindly and considerate treatment, and a European who shows a little interest in his Anguru will be amply repaid.

In common with other natives, however, and perhaps to a greater degree, the Anguru are very susceptible to bad influence and example, and any laxity when a Nguru has actually committed an offence is little short of criminal. If a Nguru be merely cautioned after doing something wrong or given a trivial and nominal punishment "as a warning," he simply considers that he has still a "clean sheet," and repeats the offence, possibly the same day.

While Anguru might, if properly controlled, be a very considerable asset to the country as agricultural labourers, it cannot be denied that they are wasteful and destructive of timber to an enormous degree. Huge areas have been utterly devasted by them, which are remembered by many Europeans still resident in the country to have been covered with trees.

In their own country these tribes cultivate cassava, millet, rice, and kaffir corn as their principal food crops, maize being very little grown. In customs and beliefs they differ very little from the other Bantu tribes; spirit worship, belief in witcheraft, the medicine man, the casting of lots, the wearing of charms, the various trials by ordeal are all found with differences of detail. 


\section{CHAPTER V.}

\section{CONSTITUTION AND GOVERNMENT.}

On the 14th of May, 1891, Great Britain declared a Protectorate over the "Nyasaland Districts." By instructions issued on the 31st of July, 1891, the British sphere north of the Zambesi was constituted a local jurisdiction under the Africa Order in Council, 1889, and the Supreme Court of the Colony of the Cape of Good Hope was created the Court of Appeal therefrom. On the 28th of June, 1892, the provisions of the Africa Order in Council, 1889, having reference to British subjects, except Part XIV., were extended to foreigners who were subjects of any of the powers who were parties to the General Act of the Conference of Berlin, 1885, or who have consented that their subjects shall be justiceable under the 1889 or 1892 Orders in Council. The Order of July 17th, 1893, laid it down that natives of any Protectorate outside the local jurisdictions constituted under the Order of 1889 shall, when within a local jurisdiction, be deemed to be British-protected persons.

On the 22nd of February, 1893, the title of the Protectorate was changed to that of the "British Central Africa Protectorate." On the lst of February, 1894, in conformity with the General Act of the Brussels Conference of the 2nd of July, 1890, regulations were issued under the Africa Orders in Council, 1889 and 1893, respecting Customs Duties and Licences. On June the 18th, 1894, the Protectorate was placed within the zone of the Brussels Act, in which the sale of alcohol to natives is prohibited. By the Agreement of the 24th of November, 1894, the British South Africa Company assumed direct control of Northern Rhodesia, with effect from the 30th of June, 1895.( $\left.{ }^{1}\right)$

Regulations concerning the employnent of native labour were made on the 20th of March, 1895, and respecting Government Land Sales on the 10th of April and 20th of December of the same year. Further regulations regarding native labour were issued on the 22nd of October, 1898.

The procedure with regard to the carrying into effect of capital sentences was declared by the Order in Council of the 20th of October, 1898. Liquor traffic in Africa was further controlled by the Convention signed at Brussels on the 8th of June, 1899, and ratified on the 8th of June, 1900. The Customs Duties were revised by a notice issued by the Commissioner and Consul General on the lst of April, 1896, and on the 31st of December, 1898, the mining laws of Zululand were applied to the Protectorate, with necessary modifications, under the name of the "British Central Africa Mining Ordinance, 1898." Regulations respecting the manufacture and sale of rubber were promulgated on the 24th of August, 1899, and power was given to the Courts of British Central Africa to impose sentences of imprisonment with hard labour by

(1) Note,-See also page 17. 



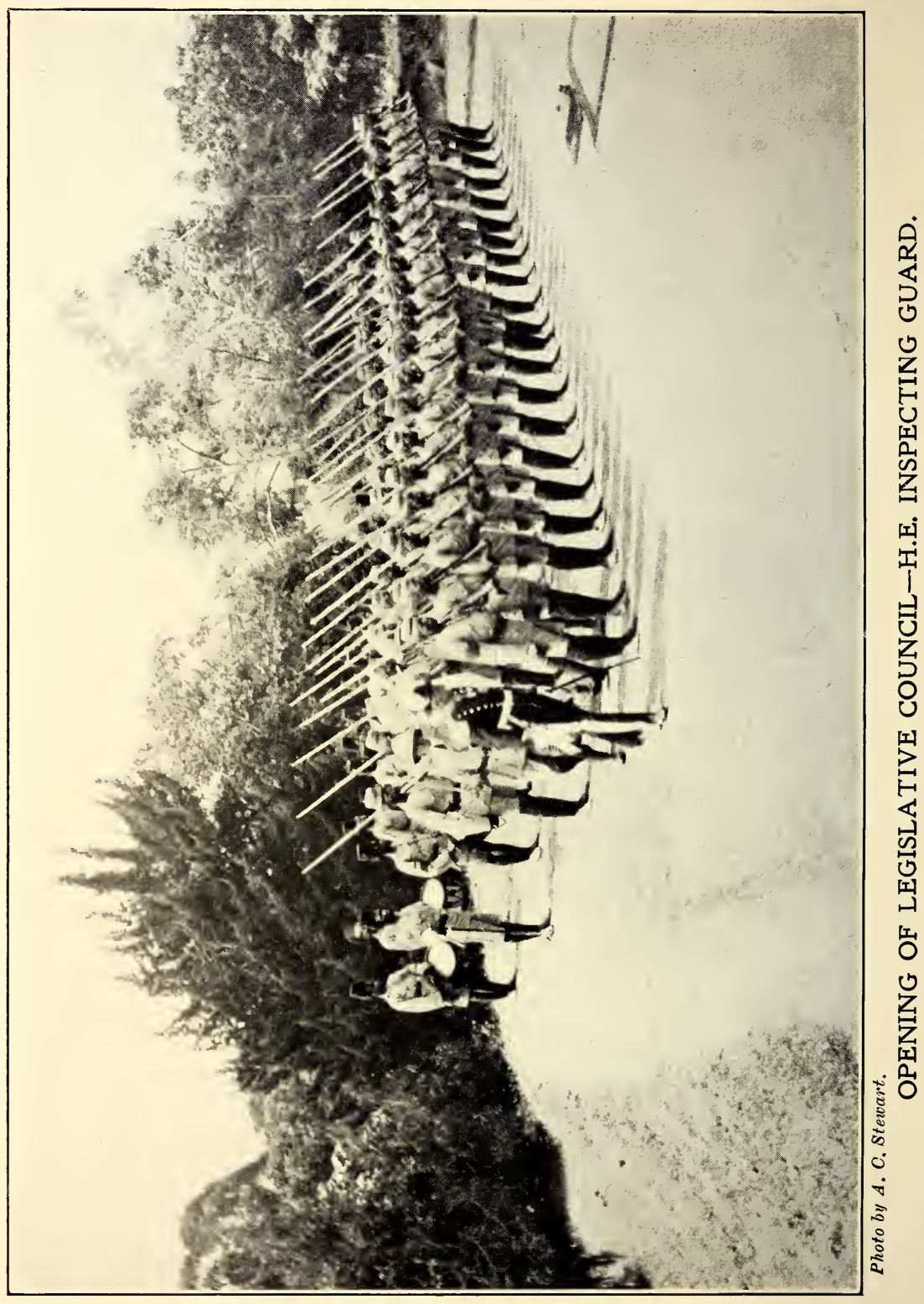


an Order of the Secretary of State for Foreign Affairs dated the 9th of September, 1899. An amended table of Court Fees was issued by the Commissioner on the 24th of April, 1899. Shipping Regulations were brought into force on the 1st of March, 1900, and Regulations respecting the Registration of Land on the 1st of August, 1901.

The modern constitution of the Protectorate is founded on the British Central Africa Order in Council of the 11th of August, 1902 ; but so much of the policy and legislation of Nyasaland has been based on the orders and regulations briefly outlined above, that it has been thought worth while to mention them.

The British Central Africa Order in Council, 1902, so far as it has not been repealed by the Nyasaland Orders in Council, 1907 and 1912, delimits the territories comprised within the Protectorate, and after the formal definitions proceeds to deal with :-

(a) Administration.

Power was given to the Commissioner to define boundaries and to divide the Protectorate into provinces and districts, to grant or lease Crown Lands and mineral rights.

(b) Application of Law.

The enactments described in the First Schedule to the Foreign Jurisdiction Act, 1890, were applied to British Central Africa, with certain modifications.

\section{(c) Courts of Justice.}

A High Court was constituted, as well as Subordinate Courts with appeal to the High Court. Native law is to be applied in native cases so far as it is applicable and not repugnant to justice and morality or inconsistent with published law. Instances of the application of Native Law are (1) that adultery is treated as a criminal offence, and (2) that death caused by a bona fide poison ordeal is not triable as murder. Undue regard is not to be paid to technicalities of procedure. Sentence of death is only to be carried out after confirmation by the Commissioner. The High Court is empowered to make Rules of Court for regulating the practice and procedure of all Courts in the Protectorate, including fees and remuneration, and the admission of Pleaders to practice.

\section{(d) Deportation.}

The Commissioner has power to order the removal of a convicted offender to serve his sentence outside the Protectorate; he may also deport dangerous or intriguing persons

(e) Supplementary.

The following Orders in Council were repealed in so far as the Protectorate is concerned:-

The Africa Orders in Council of 1889, 1892, 1893.

The Africa (Acquisition of Land) Order in Council, 1898.

The Africa Protectorate (Capital Sentences) Order in Council, 1898. 
Repealed provisions under the Order in Council, 1902, gave power to the Commissioner to make Ordinances, and those so made which are still in force are :-

The Banking Ordinance, 1902.

The Shipping Ordinance, 1902.

The Marriage Ordinance, 1902.

The Patents, Designs and Trade Marks Ordinance, 1903.

The Epidemic and Contagious Diseases Ordinance, 1903.

The Diseases of Animals Ordinance, 1903.(1)

The Credit Trade with Natives Ordinance, 1903.

The Births and Deaths Registration Ordinance, 1904.

The Lands Ordinance (Native Locations), 1904.

The Divorce Ordinance, 1905.

The Weights and Measures Ordinance, 1905.

The High Court Practice and Procedure Ordinance, 1906. $\left({ }^{2}\right)$

The Subordinate Courts Ordinance, 1906.(2)

The Medical Practitioners Ordinance, 1906.

The Mining Ordinance, 1906. $\left({ }^{2}\right)$

The Customs Ordinance, 1906.(2)

The Fugitive Criminals Surrender Ordinance, 1907.

The Acquisition of Land for Public Purposes Ordinance, 1907.

The Railway Ordinance, 1907.

The only Ordinance made prior to the 1902 Order in Council which still remains in force is the Stolen Property Ordinance, 1898. $\left({ }^{3}\right)$

In March, 1904, the Administration of the Protectorate passed from the control of the Foreign Office to that of the Colonial Office, and the post of Consul General was abolished.

The next important modification of the constitution was effected by the Nyasaland Order in Council of the 6th of July, 1907. It repealed certain sections of the 1902 Order, changed the name of the Protectorate to Nyasaland, and the title of the officer administering the Government from Commissioner to Governor and Commander-in-Chief. The powers of the Governor are defined by the Order, which also prescribes the use of a Public Seal, provides for Executive and Legislative Councils and lays down the duties of the latter. The Order continues the powers of the Governor to dispose of Crown Lands, and authorizes him to appoint and suspend Public Officers. The right of pardon and remission of sentences is reserved to the Governor, and provision made for succession to the office of Governor if it becomes vacant, and for the appointment of a Deputy during the absence of the Governor from the seat of Government. The Nyasaland Order in Council, 1907 (No. 2) of the 21st of December, orders that civil and criminal jurisdiction shall, so far as circurnstances permit, be exercised in conformity with the substance of the common law, doctrines of equity, and statutes of general application in force

( ${ }^{1}$ Note.-Legislation to replace this Ordinance is under consideration.

${ }^{(2)}$ " - There have been subsequent amendments to these Ordinances.

${ }^{3}$ ) . - - Practically superseded by the Nyasaland Police Ordinance, 1921 
in England on the 11th of August, 1902, except as modified by Order in Council or local Ordinance.

The Instructions to the Governor issued under the 1907 Order in Council contain, among others, the following provisions:The Executive Council shall consist of the Chief Secretary, the Treasurer, and the Attorney-General, with precedence in the order in which they are mentioned. The Governor shall preside at meetings of the Council. The Legislative Council shall consist of the Governor as President, the Chief Secretary, the Treasurer, the Attorney-General, as ex officio members. Unofficial members, at present three in number, shall also be appointed. The method of despatching the business of the Legislative Council and the framing of Ordinances is laid down. The Instructions further prescribe the formalities to be adopted for suspending a Public Officer, and urge the Governor to promote religion and education among the Natives. The method of dealing with the conimutation or carrying into effect of sentences of death is dealt with, and instructions laid down for the preparation of an annual Blue Book.

On the basis of the Orders in Council and other documents outlined above, the administration of the Protectorate has gradually been built up until at present it consists of the following depart. ments :--

The Secretariat and Native Affairs.

Printing.

District Administration.

Treasury.

Customs and Immigration.

Audit.

Marine Transpuri.

Judicial and Legal.

Lands and Survey.

Police, Prisons and Lunatic Asylum.

Medical.

Transport.

Military.

Post Office.

Agricultural.

Public Works.

Geological.

The functions of most of these departments are sufficiently indicated by their titles, and the Police and Military will form the subjects of later chapters. A few remarks may, however, be devoted to some of the more important of those which are controlled by specific legislation or otherwise.

\section{The Secretariat and Native Affairs.}

The Chief Secretary is the channel of communication between the Governor on the one hand, and Hearls of Departments and the general public on the other. $\mathrm{He}$ is, in effect, the head of the Civil Service. The policy of the Government is defined and controlled 
in the Secretariat. The First Assistant Secretary is specially charged with the supervision of all matters in which natives are particularly concerned.

\section{District Administration.}

The duties of the District Staff are incapable of exact definition. The Protectorate is divided into Districts by Proclamations under the Order in Council of 1902, and in June, 1921, it was divided into three Provinces, each in charge of a Provincial Commissioner. Residents of Districts carry out instructions issued to them by Provincial Commissioners, who, in their turn receive instructions from the Secretariat on matters of policy. Residents also carry out the requests of Heads of Departments in connection with departmental affairs. Their chief duties, however, lie, as is only natural, in the direction of native affairs, and in the performance of these functions a considerable amount of responsibility is delegated to Chiefs and Headmen in those districts where the Native Administration Ordinance of 1912 is in force. The principal Ordinances governing these matters are :-

The District Administration (Native) Ordinance, 1912.( $\left.{ }^{1}\right)$

The Hut or Poll Tax Ordinance, 1921.

The Employment of Natives Ordinance, 1909.( $\left.{ }^{1}\right)$

The following is an outline of the method of administering the first named Ordinance :-

Each Principal Headman is responsible for the good order of the administrative section of which he is in charge, the maintenance of discipline, the reporting of crime and the apprehension of criminals, sanitation, controlling the movement of cattle, reporting outbreaks of epidemic disease and for other matters in the interest of law and order and of the welfare of the native population. The Resident uses the Principal Headman in all ordinary matters as a medium of communication with the natives of his section. He gives his orders to the Principal Headman, whose duty it is to see that they are explained to and carried out by such of his people as may be concerned. He uses the Principal Headman for securing the attendance at the Boma of natives wanted in connection with deceased estates, remittances, \&c., for recruiting labour for Government purposes, for accelerating the collection of hut tax, and numerous other matters of purely district administration. This system obviates the constant presence of police in the villages for such purposes, and leaves them free to attend to their proper police duties. The employment of police in matters which have no connection with ordinary police administration gives them opportunities for extortion and oppression which would not occur in the exercise of their proper functions. The constant performance of extraneous. and trivial duties also tends to render the police careless and to lessen their sense of the responsibility of their position as officers of the law. The Resident is careful to indicate by his attitude. towards the Principal Headmen and by his dealings with them

(1) Note.-It is proposed to repeal and re-enact these Ordinances. 
the fact that they are the chiefs of their respective sections and occupy a position of honour, and are entitled to the respect and obedience of their people. Each Principal Headman is assisted in the performance of his duties by two Councillors.

The Principal Headmen have at present no judicial powers. They are at liberty to hear petty native civil cases if the parties concerned prefer to take such matters to their Principal Headman instead of to the Magistrate. The natives usually elect to take all their disputes to the Magistrate.

The Resident holds District and Section Councils periodicaliy as occasion may require. Such Councils are attended by the Principal Headmen, their Councillors and the more important village headmen. They are also invariably attended by a large concourse of natives. Opportunity is taken at such Councils to explain new laws and regulations and to give orders or instructions which require universal attention, and to deal with important matters which need discussion with all the headmen collectively.

This system of administration is giving excellent results and is acceptable to the natives. It is to be preferred to the old system in which the police were used for all purposes. It restores and regulates the power and authority of the Chiefs, who under the old system had become merely nominal chiefs with no real part in the affairs of their country.

\section{CUstoms and ImMigRa'ion.}

The functions of this Department are defined in the Customs Ordinance, 1906, and amending Ordinances of 1914 and 1919, and the Customs (Railways) Ordinance, 1915. Immigration is controlled by the Immigration Restriction Ordinance, 1913.

\section{Judictal and Lfgal.}

The High Court Practice and Procedure Ordinance, 1906, regulates the administration of justice in the High Court, and the Subordinate Courts Ordinance, 1906, as amended in 1915, and 1921, controls the functions of Residents in their capacity as Magistrates. Appeals lie from Sub-District Courts to District Courts and from District Courts to the High Court. From the High Court there is a right of appeal to the Eastern Africa Court of Appeal as provided in the Appeal Ordinance, 1911, as amended in 1921, and the Eastern African Court of Appeal Order in Council, 1921, and thence to the Privy Council. In District Courts, sentences of more than 6 months or fines exceeding $£ 20$ may not be imposed by District Magistrates unless confirmed by the High Court, nor may they try civil cases where the amount in dispute exceeds $£ 250$. They may not pass sentence of death or imprisonment for a term exceeding 7 years. In District Native Courts the Magistrate tries purely native cases, and may pass any lawful sentence, subject in the case of sentences of imprisonment for more than 6 months or of 12 lashes, to confirmation by the High Court. Procedure in cases of murder, manslaughter and other serious crimes is as follows. The 
Magistrate, after trial, but before giving judgment, forwards the record to the Attorney-General. The latter may either have the case transferred to the High Court or retain it in the Magistrate's Court, giving such directions as he may think necessary. When the Attorney-General is satisfied as to the conduct of the proceedings and the finding that should be brought in, he forwards the proceedings to the High Court. The Judge then issues the necessary instructions to the Magistrate, who in cases where the accused is found guilty, passes a sentence which is subject to confirmation by the High Court. Murder trials are conducted with assessors, from two to four in number, who should, if possible be Europeans. It will be seen from the foregoing that ample provision is made for the proper application of the law and the prevention of miscarriage of justice.

Officials of the High Court also deal with the estates of deceased Europeans, and the registration of Companies, Banking, Trade Marks, \&c.

\section{Lands and SURveY.}

The activities of the Lands Department are controlled by the Mining Ordinance, 1906, as amended in 1914 and 1921, the Mining Regulation (Oil) Ordinance, 1910, and the Crown Lands Ordinance, 1912, as amended in 1920. The Lands Officer is also Registrar under the Land Registration Ordinance, 1916, and the Trustees Incorporation Ordinance, 1921.

\section{Post Office.}

The Postal Department is run in accordance with the Post Office Ordinance, 1916, as amended in 1917, and the Post Office Savings Bank Ordinance, 1910, as amended in 1921.

\section{AGRICULTURF.}

The principal Ordinances affecting the working of the Department of Agriculture are the Forests Ordinance, 1911, the Agricultural Statistics Ordinance, 1917, and the Agricultural Pests Ordinance, 1918, although there are many Ordinances in force regulating the duties of the public in connection with various agricultural and veterinary questions.

\section{COAT OF ARMS.}

The original coat of arms of the Protectorate consisted in its main features of a shield poised on a map of Africa, supported on either side by a negro carrying respectively a pick and a shovel. The crest was a coffee tree in full bearing, and the motto was "light in darkness." Later on the coat of arms was changed to a lion emerging from Lake Nyasa, and by Royal Warrant of the 11th of May, 1914, the following Armorial Ensign was assigned to the Protectorate :-Argent on a rock issuant from the base a Leopard statant proper on a Chief wavy Sable the Rising Sun Or, with the Motto "Lux in tenebris." 


\section{CHAPTER VI.}

\section{THE SOUTHERN PROVINCE.}

The Southern Province, under a Provincial Commissioner with his headquarters at Blantyre, comprises the Lower Shire, Ruo, West Shire, Mlange, Blantyre, Chiradzulu, Zomba and Liwonde Districts. It includes most of the private estates and the bulk of the European and Asiatic population, but less than one quarter of the natives.

\section{Lower Shire District.}

The area of the district is, approximately, 443 square miles and it is divided into seven administrative sections, each under a principal headman. The area of each section, is approximately, as follows in square miles :-

Sec. A, 231 ; Sec. B, 31 ; Sec. C, 42 ; Sec. D, 30 ; Sec. E. 44 ; Sec. F, 32 ; and Sec. G. 31 .

The boundaries of the district are as follows:-Commencing at a beacon on the right bank of the Shire river, at Mzimu (Marka), the boundary is carried due west $13 \frac{1}{2}$ miles ; thence it is carried in a N.-N.-W. direction for a distance of approximately $1 \frac{1}{2}$ miles to the Zambesi-Shire watershed; thence it is carried along this Zambesi-Shire watershed in a northerly direction through the Kafalantengo hills, Kafuta hill, Mwanambidzi hill, Mlaka hill, Mlanga hill and Chirunda hill to a point 1 mile (about) north-west of this Chirunda hill which is in latitude $16^{\circ} 41^{\prime}$ south (the distance the boundary is carried along this watershed, measuring along the sinuosities, is approximately 46 miles); thence it is carried along this latitude $16^{\circ} 41^{\prime}$ east for a distance of approximately 23 miles to the right bank of the Shire river (this point is about Ntonda village at Nyamatute river); thence down the Shire river in the centre of the navigable channel to the point of commencement.

Malawe hills rise from the plains about $2 \frac{1}{2}$ miles to the east of Port Herald, the highest point (3,190 feet) being about 6 miles therefrom. The range lies in a direction west by south from $10^{\circ}$ to $30^{\circ}$ and the height is from 2,600 to 3,190 feet. The eastern front of the hills is very abrupt, and is heavily timbered with small trees; in the gullies mbila and mbawa trees are plentiful. The sides to the north and west fall abruptly 500 to 800 feet when a broken plateau of from 1,800 to 2,500 feet extends to the north for about 10 miles and to the west for about 5 miles, the highest hills in this plateau being Mwanambidzi and Mlaka.

Lulwe hills are situated on the south-western corner of the district, and rise to a height of 2,588 feet. The peak is in British territory but the plateau, about 1,600 feet, extends several miles into Portuguese territory to the south and west.

Mwanambere hill, south-west of Malawe, is about 2,500 feet, and is well timbered on the eastern side with mahogany. 
Mbungwe hill, Kafuta hill, Matope hill and Kafalantengo hill to the south of Mwanambere run due east and west, and attain a height of from 2,500 to 2,700 feet. Mbila and mahogany trees are plentiful on the slopes of these hills.

Mpofu hill, about 18 miles north-west of Malawe, is about 1,500 feet, and Chirunda, 1,311 feet, Nyantoko, 1,194 feet, and Mlanga complete the most prominent hills.

Unless hills are landmarks they are not named by the natives. The names of the smaller hills are only known by natives living within a few miles of them.

The hills consist mainly of gneiss, composed of alternating folia of quartz, felspar, hornblende or biotite, together with occasionally garnet and graphite. In the gneisses there are several beds of crystalline limestone, which in places swell out to a considerable thickness. These gneisses have been formed by metamorphic action on a series of beds which were originally of sedimentary origin.

Associated with these original rocks were basic intrusions of igneous rocks which are now converted into amphibolites. In a few places in the district there may still be seen small patches of the original unaltered shaly sedimentary beds which have escaped the metamorphosing action that transformed the other beds into gneisses. During the metamorphosing processes the folia of the gneiss were interlaminated with pegmatic veins, some of which may be termed aplites. They consist mainly of quartz and also contain crystals of plagioclase, a mineral which contains a certain percentage of lime. The decomposition by weathering of such a bed gives rise to a limey looking outcrop which however has been burnt for lime without success. At some time, probably towards the close of the metamorphosing action, granite was intruded into and among: the gneisses, and owing to its greater hardness and resistance to weathering agencies it now forms the summits of many of the most prominent peaks in the southern district.

There are several deposits of limestone in the hilly part of the district, notably in the valleys of the Nyachirenda and Nyachiperi rivers and at Mkuche to the north of Mlawi hill. No extensive. use is now made of this lime (which is of good quality) but as there is a growing demand for lime for manurial purposes it is expected that burning on a larger scale will result. As the deposits are chiefly on the hills and beyond reach of wheeled vehicles, the transport of the lime to the railway presents some difficulty.

The western half of the district is a plateau varying in height. from 1,000 to 2,000 feet, from which all the hills previously mentioned rise ; the plateau is really a series of small hills and is covered with. timber, principally Mbila (a very hard dark timber used for boat: making by Europeans and Indians). Mahogany is found in stream. beds.

The eastern half is a plain of from $2 \frac{1}{2}$ to 7 miles wide, is heavily timbered with the exception of the Ndindi marsh and the places. cleared for native gardens; a number of the largest trees are never felled in the gardens. This plain is at an altitude of 150 to 200 feet. 
above the sea and it is considered unhealthy for Europeans owing to the excessive heat experienced between October and March. The hottest month (dry heat) is November, when the temperature has been known to reach $120^{\circ} \mathrm{F}$. in the shade. From the end of December till March the temperature seldom exceeds $100^{\circ}$ in the shade, but as that is the rainy season and the heat is moist, the climate is more trying to Europeans than when the temperature is higher but dry.

The Shire river is the eastern boundary of the district. Its width varies from 40 yards between high banks to 70 yards in low lying country; the depth between high banks in the dry season is from 6 to 12 feet, and in low country 6 inches to 2 feet. The rise in the river depends on the rainfall and sometimes reaches 20 feet. There is also a rise at times due to the Zambesi being in flood earlier than the Shire, thus banking up the water, and periodically flooding the Ndindi marsh which, in 1918, was covered with about 8 feet of water causing the loss of all the crops and some loss of life. There was a similar flood in 1920, which destroyed the cotton crop on the marsh.

The Shire river was formerly the highway into Nyasaland, and it maintained a navigable level as far as Katungas, in the West Shire district, during the greater part of the year. Since 1903, however, either the level of the river has been dropping or its sandy bottom has been silting up, and now it cannot be regarded as a navigable river. For about 4 months of the year (January till the end of April), stern wheel steamers are able to reach Port Herald, about 110 miles by river below Katungas.

The Tengasi river rises in Mlaka hills and flows north, entering the Shire river above Chiromo, the principal tributaries being the Dzenji, Kasuka, Mwabvi and Dandi rivers, draining the range of hills from Mlaka hill to Chirunda hill, and the Mwanantu, Mapofu, Masamva, and Matope rivers draining the range from Mlaka hill to Mpofu hill. There is water in the upper reaches of the Tengasi river from December till July; from July to December it can be obtained from all these rivers by digging.

The Nyamatute river drains the eastern slope of the Mapofu hills, and flows into the Shire river at Ntondo village about 21 miles from Port Herald. It carries no water except during the rains.

The Nyamyala river drains the eastern slope of Mlaka hills and part of the Juepe hills, and flows into the Shire at Tangani village about 14 miles from Port Herald. The Kandi river is a tributary of the Nyamyala river, and joins it about 1 mile from the Shire. There are several pools of water, well known to natives, to be found all the year. The Nyamyala crosses the railway at 15 miles and the Nkandi at 14 miles from Port Herald.

The Panga river drains the east and south of the Juepe hills and the north of the Mwanambidzi hills, and flows into the Shire at 7 miles from Port Herald, crossing the railway at $7 \frac{1}{4}$ miles. Water is found all the year in the Juepe hills, but further down is only to be found during the rains. 
The Nyamazere river, with its tributary the Nyakamwa, drains the northern and western slopes of the Malawe hills and the southern slope of the Mwanambidzi hills, and flows into the Ndindi marsh, forming a boundary between principal headmen Chataika and Chipwembwe. This is a running stream all the year round, down to the foot of the hills, but it is dry on the plain except in the rainy season.

The Ngoni and Chimara streams drain the eastern slope of Malawe hills, and have water in the rainy season only. They flow into the Ndindi marsh.

The Malindi river drains the southern and south-western slopes of Malawe hills and the northern slope of Mwanambere hills, and flows into Ndindi marsh. It carries water all the year down to the foot of the hills. In times of heavy rain it spreads over the plain, and on more than one occasion it has damaged the railway.

The Nyachipere river drains the Mwanambere hills, Mbungwi hills, Kafuta hills and Kafalantengo hills on their northern slopes ; its tributaries are the Nyakatola, Nyambidzi, Chikokola and Magoma on left bank. It flows into the Ndindi marsh, and is the boundary between principal headmen Ngabu and Chimombo. It carries water all the year close to the hills.

The Nyachirenda river drains the southern slopes of the Nsampa hills and the northern slopes of the Lulwe hills and flows into Ndindi marsh. It carries water all the year, for some distance from the hills. There are important outcrops of lime in the bed of this stream.

The Ntundu river drains the Iulwe hills to south and west; it flows into the Nyachirenda river near Ndamera village, and carries water all the year.

The Ndindi marsh, to the south of Port Herald, is 5 to 8 miles wide and about 15 miles long. It is separated from the Shire river by a bank from half-a-mile to 2 miles wide, intersected by natural ditches which drain the marsh into the Shire river as the latter falls. The marsh can be crossed only in canoes during the rains, from December to April.

The entire district with the exception of the Ndindi marsh is heavily timbered, but the forests are easily penetrated. Timber in the plains is generally thorny and useless for manufacture, but the timber in the hills and higher ground is hard wood and useful for house and boat building. Mahogany is found in river and stream valleys in the higher portions of the district, but valuable timber is gradually being destroyed by grass fires. Palm trees, which are a feature of the Shire valley in other parts of the country, are only represented here by a few scattered clumps of Borassus. The Hyphaene palm of which there are large forests in the Ruo district is absent from this district, as also is the Raffia palm.

Towards the end of 1918,14 plots of 500 acres each were marked off in the Ndindi marsh and were leased to various Europeans for cotton planting. The first crop was destroyed by 
a flood and the second was a failure owing to drought, so the venture cannot be considered a success. The cotton expert who recently visited the locality is stated to have regarded the land as unsuitable for cotton planting on a large scale even with irrigation. The natives have, however, grown considerable quantities of cotton on the marsh on selected patches, and will, no doubt, continue to do so when prices on the home markets improve. The marsh would be an ideal place for rice growing by natives, but only very small quantities are produced at present. The plains are subject to periodical droughts which render systematic cultivation risky. There is a sisal fibre plantation, of close on 1,000 acres, 4 miles above Port Herald, which is approaching the productive stage. A rubber plantation at Nyatando has been abandoned.

The District Administration (Native) Ordinance, 1912, was applied to this district in 1913 and gradually brought into full operation. Experience has proved that it is an ideal form of government for natives under present conditions, and that it is greatly appreciated by them. All crime is investigated by the headmen, and criminals are brought by them to the district native courts where one headman or more usually sits to assist the magistrate. A district council is held once a month, at which all matters relating to the administration of the district, such as the collection of taxes, the repair of roads, grass fires, food supplies and crops are discussed, and petty civil and domestic cases are generally settled at the council meetings. The district is divided into seven administrative sections, each under a principal headman, appointed by the Governor, with due regard to hereditary claims and to the wishes of the natives of the section. Each principal headman is assisted by two councillors who are important sub-headmen in the section, and he is permitted to employ a messenger. On rare occasions one or more of the district police is placed at his disposal to assist in carrying out the instructions of the Government, conveyed through the District Resident. The sections, with names of principal headmen, population, \&c., are as follows :-

\begin{tabular}{|c|c|c|c|c|c|}
\hline Sec. & Principal Headman. & $\begin{array}{c}\text { Area. } \\
\text { Sq. Miles. }\end{array}$ & $\begin{array}{l}\text { No. of } \\
\text { Villages. }\end{array}$ & $\begin{array}{l}\text { No. of } \\
\text { Huts. }\end{array}$ & Population. \\
\hline $\mathrm{A}$ & Tengani & 231 & 54 & 2,209 & 7,941 \\
\hline $\mathrm{B}$ & Chataika .. & 31 & 25 & 855 & 2,000 \\
\hline C & Chipwembwe & 42 & 53 & 1,894 & 6,087 \\
\hline D & Ngabu & 30 & 33 & 1,563 & 5,182 \\
\hline $\mathrm{E}$ & Chimombo .. & 44 & 58 & 2,966 & 8,400 \\
\hline $\mathrm{F}$ & Ndamera .. & 32 & 50 & 1,819 & 6,409 \\
\hline \multirow[t]{2}{*}{ G } & Nachikadza & 33 & 50 & 1,407 & 4,627 \\
\hline & & 443 & 323 & 12,713 & 40,646 \\
\hline
\end{tabular}


The food crops grown by natives are, mentioned in order of importance, as follows :-Machewere, a kind of millet, whose plant, however, resembles a bulrush. It is extensively planted in the drier parts of the plain and it is to some extent drought resisting. The small, canary-seed-like grain is said to be very nourishing as food. A Portuguese priest who visited the Zambezi about 1572 mentions it (Meixoira). Maize is grown on the "dimba" land along the river, on the Ndindi marsh and on the hills. Mapira (Kaffir corn) is sown at the same time as machewere and generally mixed with the latter. It is also drought resisting but takes longer than machewere to come to maturity. Sweet potatoes are grown in large quantities on the marshy lands and on the hills. They are relied upon when other crops fail. Beans of various kinds are grown in considerable quantities, on damp soil. The Nandolo bean (dhal), which is a perennial and is drought resisting, is grown chiefly on the hills. Attempts are being made to increase the cultivation of this crop. Cassava is not extensively grown, although it resists drought. Small patches are grown on the hills and its cultivation on the plains is being encouraged. Maere (three fingered millet) is grown in small patches. The grain is used for making beer. Various kinds of pumpkin, cucumber and a semiwild water melon are grown among grain crops. Groundnuts used to be cultivated in considerable quantities for sale, but the output has fallen off in the last few years owing to the Indian traders having given up purchasing the commodity. This is not seriously regarded as a food crop.

Fishes of various kinds are found in the Shire river and in lagoons and are caught by nets and in traps. The supply, however, is diminishing owing to the river getting so low each year that practically all the fish which congregate in the pools are caught. The best eating fish is Mpende (a perch) which is got up to 3 or 4 l lbs. in weight. The fish that affords the best sport for rod fishing is the "tiger" fish which comes up from the sea to spawn and is not found above the Murchison falls on the Shire or the Zoa falls on the Ruo. It is a very strong and game fish, rivalling even the salmon, but as it has very long teeth with cutting edges, steel wire traces are required to land it. The largest specimen caught with rod and line so far weighed 13 pounds.

The main road of the district runs from the boundary of the Ruo district at Ntondo village to the Portuguese boundary at Nyatando, about 38 miles. This is the old Chiromo-Sena road. There is also, in the dry season a road from Port Herald to Marka (16 miles) and from Nyatando to Marka (5 miles). Two roads connect Port Herald with the hills, one by the Ngoni valley and one following the Nyamadzeri valley. The latter from where it crosses the river and begins to climb, to the hill Residency, is 6 miles long and has an average gradient of 1 in 7 . District paths connect all villages on the hills and the plain. There are no bridges except one across a "donga" on Mr. Body's estate at Panga. All the roads in the district are merely cleared tracks, and are unsuitable for wheeled traffic except light motor cars or bicycles, and small bullock carts, and in the wet season only the Sena road can be used 
for wheeled vehicles. Bush cars can be used for short distances on the hill roads but owing to the very broken nature of the country travelling there is mostly done on foot. All roads are kept in repair by the principal headmen.

The Central African Railway enters the district at the Portuguese boundary near Nyatando and joins with the Shire Highlands Railway at Port Herald. The latter railway leaves the district at the boundary of the Ruo district at 22 miles. There is thus a railway line running from end to end of the district, a distance of 38 miles.

Game is not plentiful in this district but the following animals are found in limited numbers:-Eland, waterbuck, kudu, klipspringer, reedbuck, bush buck, hartebeest and nswala (impala), also various species of the smaller antelope. The Inyala is not found here although it is known to exist opposite Chiromo, only a few miles from the boundary of this district. The hippopotamus is now seldom seen in the rivers but formerly it was fairly common. Warthogs are rare, but bushpigs are plentiful and destructive to crops, especially on the hills. Elephants have been known to pass through the northern part of the district, and the same is true of buffalo, but neither animal can be said to frequent this locality. Carnivora are relatively plentiful and comprise lions, leopards, hyænas, jackals, \&c. Lions have at times done considerable damage to cattle and other live stock. Hunting dogs have been seen on Mlawi hill but as they are wandering animals they probably left the district very soon.

The district is rich in bird life. All the varieties of wild geese and ducks known to exist in the Protectorate are found, also the two varieties of guinea fowl (crested and common) and two francolins. Quail have been seen, but not in large numbers. Marabou storks nest in the Port Herald township and egrets are found on the Ndindi marsh. Marabou and egrets are killed in large numbers in Portuguese territory and are decreasing rapidly. In a few years, if the slaughter goes on, they will become extinct in this part of the country.

The only township in the district is Port Herald, which is so called after H.M.S. "Herald," one of the two British gunboats stationed on the Zambesi and Shire from about 1890 till 1902. The station contained the office of the District Resident and some Indian trading house, and was a place of call for river steamers but it was of no importance till the construction of the Shire Highlands Railway commenced there in 1903, when it was formed into a township and rapidly grew in size. With the opening of the Central African Railway to the Zambesi in 1915, Port Herald ceased to be a railway terminus and the staffs of the transport companies were consequently reduced, the opening of Blantyre as a Customs clearing station in the same year helping towards that end. Since 1915 Port Herald has been the headquarters of the Customs Department.

The European population of the township at present is 19, including 6 ladies. The only other European settlement in the 
district is the South African General Mission at Chididi, about 6 miles from Port Herald, on the hills, where there are 2 male and 3 lady missionaries.

The British Cotton Growing Association has its headquarters at Port Herald, and there are branch establishments of the African Lakes Corporation and A. J. Storey. There are also several Indian trading stores.

The following tribes inhabit the district, the numbers shown being the result of the census taken last April :-

Amang'anja $(27,066)$ were the original settlers in the Shire valley, as far as can be ascertained. All the principal headmen, councillors and village headmen of consequence belong to this tribe.

Chikunda. This is not a tribe. The word means the same as "askari," and they were employed in slave raiding by a half caste Portuguese called Matekenya. They began to settle in this district about 40 years ago, and belong to various Zambesi tribes.

Achipeta (26) are said to have come from Lilongwe long ago.

Amuenye. (60) have settled in the district within the last 20 years. They came from Sena. This tribe practices certain Mahomedan rites such as circumcision, the bleeding of animals and abstention from eating the flesh of any animal of the pig tribe. They are supposed to be descended from the Arabs found by the Portuguese at Sena when they came there in 1572. "Some 20 peaceful Arab traders" lived in Sena and the Portuguese proceeded to torture and kill most of them on the advice of a priest called Monclaro, who accused them of bewitching the horses and cattle, which as a matter of fact were dying of tsetse fly bite. The name is derived from a Portuguese word "Monhe", which means Arab, and is supposed to be a corruption of the Indian word "Bunya." The natives apply the same name to the Indian Mahomedan traders. The men of this tribe are workers in iron, copper and brass and the women manufacture cooking pots. In appearance they differ considerably from the purely African tribes.

Atonga (4,684). This tribe came from Makombe's country south of the Zambesi. They have no connection with the Atonga of West Nyasa.

Azimba $(3,249)$ came from Ntoko in Southern Rhodesia. They were originally hunters and killed elephants with axes. They settled in this district a long time ago.

Asena. (4,281) from south of the Zambesi. The men of the tribe are silversmiths and goldsmiths.

Aphodzo and Arambara $(1,275)$ came from Morambala and are regarded as one tribe. They live on the banks of the rivers and they hunt hippopotami and crocodiles.

Anyungui, from Tete, one village only in section $\mathrm{C}$.

Yan (5) one family settled permanently in the district. 
The native population of the district is 40,646 (19,170 males and 21,476 females), which is equal to $91 \cdot 7$ to the square mile. The European population numbered 35 when the census was taken in April, 1,921 (25 males and 10 females) and the Indian population 50 (43 males and 7 females), making a grand total of 40,731 , or 91.94 to the square mile. The European population is continually fluctuating. Of the natives there were 83 professing Christians, 8 Mahomedans and 40,555 pagans.

The chief superstitution among the natives is the belief that the spirits of the dead can influence nature for the good or ill of the living, and those spirits are propitiated by making sacrifices (nsembe) to them, generally of native beer. This belief is specially strong as regards Mbona, who is considered to be the "patron saint" of the district, with control of the rainfall, and consequently the food supply. Mbona lives in Mlawi hill, which is considered sacred to him, but his "temple" is a hut in a thick clump of forest known as Kuluvi, in section C, almost at the foot of Mlawi. A woman lives in this hut who is known as Mbona's wife. Offerings must be made in this hut only and must consist of blue or black cloth. The persons making the offering, or anyone who approaches the hut, must be clothed in blue or black. Europeans are not encouraged to visit this "temple," and very few have done so.

There are several versions of the history of Mbona which differ in many particulars, but the following notes were communicated by Ngabu and Chipwembwe (principal headmen), who are Mbona's "High priests," and who received the tradition from their fathers. It is impossible to ascertain, even approximately, when the events occurred. Mbona probably is not credited with possessing any special powers himself, but he intercedes with "Mlungu" on behalf of the Amang'anja people, when he is pleased, and leaves them to suffer from droughts and floods when they have neglected or offended him :-

"Mbona carne from Malawe, Kukambiritiya,(1) near the Achipeta country. His father's name was Chingale and his mother's name Chimbe. He had four wives called Sawawa, Samisanje, Chungwe and Tiza. Mbona came down to this country on account of a 'Mlandu' regarding an accusation brought against someone of being a witch, to whom a headman named Msumpi ordered 'mwabvi' to be given. The accused drank the mwabvi and did not die, so the headman ordered a feast to be given to celebrate the event, and Mbona refused to take part in it as he objected to the ordeal trial. He told the people that he had power from 'Mlungu' to tell when people were guilty and that poison was unnecessary. They wanted to kill him, so he ran away and came towards this country, and across the Shire into what is now Portuguese territory. He wanted to make a village at Zambawe in that country, and planted rice there which the pecple still grow every year. There is a peculiarity

$\left({ }^{1}\right)$ Note.-C $f$. Kapirimtiya on pp. 43 and 48. 
about this rice that it cannot be removed from the locality in which it was first planted by Mbona.

"People have gone there to buy it, but have always forgotten to take it with them when they left. Mbona left Zambawe as he heard that his pursuers from his own country were close by, and he recrossed the river, but was overtaken by them at Ndione forest, in Chipwembwe's section, on the Ndindi marsh. They killed him there, but before he died he asked that his body should be buried in Ndione, but his head taken to Kuluvi forest near Mbango's village, and Mbango, who was one of his slaves, was to look after the place. The latter appointed Mbukwa to be the headman in Kuluvi forest. Mbona had a brother called Kupatikana, who wanted to succeed him and take his name, but Mbona told him in a dream that he did not want him to do so in case he might also be killed, so Mbona had no successor, but Kupatikana remained here and made sacrifices (Nsembe) to Mbona every year. After he died Ngabu (Mbona's son) and Chipwembwe (Mbona's brother) made sacrifices and continue to do so to this day, or rather their descendants do. The principal chief, Tengani, agreed to this arrangement, but he is not related to Mbona. When there is no rain Nsembe is made to Mbona, who intercedes with 'Mlungu,' and rain comes. This 'nsembe' is always made at Kuluvi, where his head is buried."

The South African General Mission was established at Iulwe hill in the southern part of the district (section F.) in 1901, but that station is now unoccupied, and the mission is situated at Chididi about 2 miles from the hill residency, to the west of Port Herald. Village schools, in charge of native teachers, are scattered throughout the district. A branch of the Marist Fathers' Mission which was established in the Protectorate in 1901 is now being formed at Port Herald.

\section{Ruo District.}

The Ruo district is about 1,773 square miles in extent, and is wholly situated within the basin of the Shire river. It is bounded on the north and east by the West Shire, Blantyre and Mlange districts; on the south-east by the Ruo river which forms the Anglo-Portuguese boundary; on the south it bounds the Lower Shire district in a straight line drawn due west from a point on the right bank of the Shire river 10 miles distant in a straight line from the junction of the rivers Shire and Ruo (i.e., Chiromo) to the Anglo-Portuguese boundary; on the west by the Portuguese prazo Goma.

For the purpose of Native Administration the district is divided into four sections under a similar number of Principal Headmen, viz., Tengani, Ngabu, Makwira and Mlolo, who carry out the duties prescribed under the District Administration (Native) Ordinance, 1912. Each Principal Headman is assisted by a number of representative Village Headmen. District and Sectional Councils are held periodically, under the presidency of the Resident, for the purpose of assisting in the management of the affairs of the district and of the respective sections. 
There are extensive alluvial plains lying on both sides of the Shire between that river and the parallel hill ranges. These plains do not vary in altitude to any extent, but in width they range from 4 to 20 miles between the river and the hill ranges, the variation being due to the winding nature of the river.

The district is practically enclosed by three distinct hill-ranges running parallel to the Shire. On the east side is the Cholo range which forms the western edge of the Shire Highlands plateau, and which culminates at its northern end in Mount Cholo with an altitude of 4,000 feet.

The average altitude of the plateau is from 2,000 to 3,000 feet above the sea level. The range on its western face is of a precipitous nature, but eastwards it falls with a gentle undulating slope to the Nswadzi and Tuchila rivers. The Cholo range is generally well wooded except where the ground has been cultivated by natives or Europeans; the trees on these ranges and generally over the Shire Highlands rarely exceed 18 inches in diameter, their growth being hampered by grass fires and overcrowding. In common with the rest of the country the Cholo range is also covered with a dense growth of reedy grass which, towards the end of the wet season, attains a height of from 4 feet to 8 feet. On the west of the Shire there are two hill ranges, the Matunda range to the south and the Marangwe range to the north. The former runs in a northerly direction, and is a continuation of the Port Herald (Lower Shire) range. It is about 15 miles in length. The Marangwe range commences about 15 miles north of the Matunda range, and also runs north and south. Both these ranges rise with a gentle slope and are more or less flat topped. They have a scanty covering of soil but are clothed with scrubby forests, the Marangwe in particular being covered with thorn trees and prickly vines which are almost impenetrable.

About 50 miles of the Shire river are within the Ruo district, which it practically bisects. The navigability of the Shire depends so much on the rainfall in the Lake Nyasa basin that is difficult to lay down precisely what its state from that point of view is at any time of the year. Formerly, in a year having a normal rainfall the river was navigable right through the district for vessels of light draught for 9 or 10 months in the year, but in recent years, owing to the fall in the level of Lake Nyasa, such navigation has only been possible for a short period when the river is in flood. Since the extension of the Shire Highlands Railway to Blantyre, steamer traffic between Chiromo and Chikwawa has been discontinued and only a very few cargo steamers come up each year even as far as Chiromo. There is still, however, a considerable barge traffic between Chikwawa and Port Herald, the principal cargo being cotton. The depth of the river varies very considerably, from 1 foot in the dry season to as high as 20 feet when it overflows its banks in times of heavy flood.

In exceptionally wet seasons the river floods its banks and the elephant marsh becomes a swamp with numerous lakes and pools instead of the almost entirely dry plain which it is in the dry weather. 
The banks of the Shire are flat and open, but are covered with high reeds except where these have been cleared to make room for native rillages or gardens. The banks are not thickly forested anywhere in the district.

The next river in importance is the Ruo, which is the largest tributary of the Shire ; it rises in the southern part of Mlanje and receives by far the greater part of the drainage of this mountain range. The Ruo forms the boundary of the district (and also the Anglo-Portuguese boundary) for a distance of 32 miles, following a south-westerly course till it joins the Shire at Chiromo; it is navigable in the rainy season to a point some 8 miles above Chiromo. Above that point it is rocky, and much broken by rapids, and at Zoa, 25 miles above Chiromo, the river falls over a precipice about 180 feet in height. The Ruo has a swift current except for the last 8 miles of its course; its average width throughout its navigable reach, which varies in depth as does the Shire, is some 300 feet. Except for these last 8 miles it runs between steep and sometimes precipitous banks, the southern end of the Cholo range falling abruptly to the river; these banks are heavily wooded with fine trees and thick undergrowth.

Of the tributaries which join the Ruo the most important is the Tuchila, which forms the boundary between the Ruo and Mlanje districts for the last 5 miles of its course. Five miles from its mouth it is joined by the Nswadzi, a mountain stream which, rising in Cholo mountain, brings a considerable volume of water to the Tuchila throughout the year : the Nswadzi forms the boundary between the Ruo and Blantyre districts throughout its course of some 25 miles, and receives the water of various small tributaries, including (from the west) the Natanda, Nandolo and Namanjasi. Other tributaries of the Ruo are the Zimbili and Chinyenyedi, the Limbi running in at Zoa, and the Tekerani and Lifuluni. Of the tributaries of the Shire there are only two in the district which throughout the year carry water over their whole length from the hills-the Maperera and Nkate, two short streams rising in Cholo mountain, the Maperera forms the northern boundary of the district east of the Shire. All the other streams which flow westward from the Cholo range lose themselves in the Elephant marsh and all but the Limpangwi, Levunzu, Chizimbe, Masenjere and Tangasi are dry on the surface within 2 miles of the foot of the hills as early in the year as July.

In the western district there is not one stream in which there is running water in the dry weather. The Mwanza and Tangasi are traceable as dry sandy nullahs from the hills to the river; the numerous other streams which rise in the western hills carry no surface water in the dry weather, though water can be obtained by digging in the sandy beds of most of them; they lose themselves in the Mbengo plain, which in the rains become a swamp, draining itself into the Shire through reed grown channels such as the Chimbia, Nazombe, Nkwete and Namikungulu. Similarly the Cherobondo drains the swamp west of Pokera. 
The plains of the Ruo district are formed of various strata of decomposed rock, varying from a few inches to some feet in thickness, while mica andmicaceous silt is impregnated with the various alluvial strata; in places the alluvial soil is destitute of stratification.

The geographical construction of the hill ranges may be described generally as being perfect, all ranges and spurs run east and west with hardly any exception. On the north-east face of the range (Cholo) lying to the east of the district large sheets of basaltic rock are to be seen, and in the beds of the streams cracks or splits may be noted in these basaltic rocks filled with various mineral rock, the rock system being igneous. The southeast side of the range is metamorphic, and is composed of clay, slate, gneiss, schists, serpentine, \&c. This range is well watered, and is covered generally with a deep deposit of soil, chiefly of a red clayey nature, but many varieties are to be met with, varying from dark loam to light sandy soil. Iron deposits are common. On the western boundary of the district the hill range lying to the south is metamorphic, the various hill tops, spurs and ridges being capped with basalt, which is much weather worn. Round boulders, small and large, are met with. Both metallic and hematite iron is found at the north-east base of the hill, and is still being smelted by natives, and used for making spears, knives and hoes. This range has been proved to be auriferous and to bear various other minerals, but not in paying quantities. The range lying to the north on the same side of the district is carboniferous. These ranges are scantily covered with soil.

The chief native food crop of the district is maize, though in the western portion millet is the crop more generally grown. Subsidiary foodstuffs such as kaffir corn, potatoes, beans, pumpkins, \&c., are also grown.

The Shire and Ruo rivers abound in fish, the principal species being chambo, ncheni (tiger fish), k'ombe, nyanda, ndimbandiani, nkolokolo, mlamba, mphuta, simbo.

The district contains an abundance of palm trees of two species, viz., the Palmyra (Borassus flabellifer) and Fan Palm (Hyphone crinita). The wine obtained from the latter makes an excellent substitute for hops in bread. Between the left bank of the Shire, starting at about 22 miles from Chiromo, and the Cholo hills there is a large forest of these trees known as Mazongoza.

Excluding the Cholo area the rainfall is about the lowest in the Protectorate, 25 to 28 inches being about the average. The rainy season commences about the end of November and lasts until April, the heaviest fall being in January. Excellent bird shooting is to be had both on the Ruo and Shire rivers, where teal, snipe and various duck, geese, \&c., are to be found. There are also large numbers of pelicans, egrets, storks, various herons, \&c., indigenous to the river.

The district had formerly a great reputation as a game district, and even now almost every species is to be found, including elephant and buffaloes, but in smaller quantities than formerly. 
The climate of the greater portion of the district is tropical in the extreme, the only cool months on the plain being from about the middle of May to the middle of August. In the hottest weather, which usually occurs just before the rains set in, a shade temperature of from 105 to 112 is quite normal in the heat of the day.

The climate in the Cholo area is entirely different, approximating to that of Blantyre, both as regards temperature and rainfall throughout the year. In the plain cotton is extensively planted by Europeans, Asiatics and natives, with varying success. The soil is eminently suitable, and in normal years some excellent crops have been obtained. In other years crops have been wholly or partially ruined by flood or drought. The crop can therefore only be regarded as a very uncertain one.

Rice, which is not one of the local natives' staple foods, is not extensively cultivated and is often disastrously affected by flood or drought.

The only crop other than cotton which is planted on the low levels is sisal, it is to be found exclusively between Sankulani and Chiromo on European Estates.

In the Cholo area the only crop of importance is tobacco, which is grown very successfully by European planters.

Wheat is also grown in small quantities with encouraging results. Cattle and small stock thrive in all parts of the district. In July, 1921, a census of cattle was taken, the figures were as follows:-Owned by Europeans, 1,133; owned by Asiatics, 445 ; owned by Natives, 28 ; total, 1,606.

The numbers of small stock are approximately as follows:Sheep, 1,000 ; Goats, 2,600 ; Pigs, 1,900.

The main roads, none of which are macadamized, are as follows :

(l). Chiromo to Nyaphambere (Lower Shire border). Distance $8 \frac{1}{2}$ miles. This is a good road in the dry season, but is flooded in parts during the rains.

(2). Chiromo to Maperera, 42 miles. This route lies through the Elephant marsh and forms part of the Chiromo-Chikwawa. road. There is a branch road from Chikonje (36 miles peg on the Shire Highlands Railway), which joins this road at Mlolo, about 9 miles from Chiromo. In the dry season the road is a fairly good one, but the surface in places is very hard as the the result of flood-water standing on it during the rains.

(3). Nswadzi to Kangoma, $8 \frac{1}{2}$ miles. This road is the last portion of the main Limbe-Cholo road and run from the Nswadzi river (Blantyre border) to a point about $2 \frac{1}{2}$ miles beyond Malamulo Mission. It is a good earth road.

The district roads are as follows :-

(1). Chiromo to Maperera, along the right bank of the Shire river, 40 miles.

(2). Chiromo to Maperera, along the left bank of the Shire river, $42 \frac{1}{2}$ miles. 
These two roads are essentially dry-weather routes and in the rains are for the most part flooded.

(3). Chiromo to Sankulani. This road runs from Chiromo to. Sankulani railway station, a distance of 11 miles. It is a good road throughout the year.

The headquarters of the district are at Chiromo, at the junction of the Shire and Ruo rivers. It was formerly the chief port of entry of the Protectorate and the headquarters of the Shire Highlands Railway, but since the removal of the railway headquarters. to Limbe, the European and Indian population has gradually decreased and the Resident is now the only permanent European inhabitant of Chiromo, which was abolished as a township in 1915. Several Indian traders still have stores at Chiromo which remains. an important centre for native trade.

The Amang'anja and the so-called Achikunda are the principal native tribes in the district. The Amang'anja, who are largely in the majority here, from long years of peace have their own tribal characteristics and traditions far better preserved than have their hunted and enslaved fellow tribesmen of the hills and lake: yet if either tribe ever gives up its own ways in favour of those of the other, Chikunda ideas will probably prevail. In one small point connected with their marriage customs a tendency in this direction is already observable, as mentioned in the following notes on local marriage customs.

The Chikunda bridegroom pays, on marriage, a present known as the "mpete" (ring) to the bride's father. This varies considerably, the lowest amount now commonly paid being $£ 1$, and the highest $£ 4$ or $£ 5$. He then takes his woman away to his own village : should she disagree with her husband and leave him her parents. will probably tell her to return; if she does not do so, they must refund the "mpete" present. The husband will usually claim for clothing and feeding expenses as well. but this was hardly ever allowed by native custom, such expenditure being reasonably regarded as payment for services rendered.

The Mang'anja bridegroom builds a hut for his bride at her village and lives there thenceforth. "Ankoswe" or marriage brokers conduct the marriage ceremony: no payments pass and should the chiefs, parents and the Ankoswe agree that her husband treats her ill or is otherwise undesirable, they can tell him to go, thus putting an end to the marriage: the husband having paid nothing has no redress by Mang'anja custom. This arrangement is not found to be invariably satisfactory and sometimes results. in an appeal to the Resident's Court by a rejected husband. There is also a tendency now observable among the Amang'anja to imitatethe Chikunda custom of the "mpete" present and thereby strengthen the husband's position.

Before the days of European influence here, a man caught in adultery with a Chief's wife would have been killed and probably the woman would have been killed also as an exemplary measure. A stranger in a village, caught in adultery with the wife of a member 
of the community, would also probably have been killed, though the woman would probably have suffered nothing more than a beating. These are neither of them fair instances as the stranger was as far below the protection of village law as the Chief was above its restrainst. Adultery cases in which members of the same community were concerned were settled by payment. The aggrieved party submitted a definite claim to a Court consisting of the Chief and the "Akuru" (the old men of the village) who, after proof of the offence, reduced the sum claimed as seemed fair to them, giving consideration to such circumstances as absence of the husband and the woman's character and share of initiative in the offence : any discipline to be meted out to the woman was a matter entirely in her husband's hands.

Under modern conditions payment of damages to the aggrieved husband is the usual penalty though in serious cases the matter is treated as a criminal offence and imprisonment is ordered by the magistrate.

The customs relating to births and deaths are those obtaining among natives throughout the Protectorate.

The census taken in April, 1921, shewed the native population as follows :-The figures relating to tribes include sub-tribes.

Anyanja, 20,947 ; Achikunda, 12,246 ; Anguru, 5,217 ; Angoni, 676; Yao, 405; other tribes, 11. Total, 39,502. As pointed out above the Anyanja were the original inhabitants of the district and the influx of Achikunda dates back to about 1863 .

The immigration of the Anguru in considerable numbers is recent, dating back only to 1912 .

They are an undoubted asset to the labour supply, being excellent workers in strong comparison to the Anyanja and Achikunda, who are extremely lazy peoples.

The Angoni also are recent immigrants, mostly from Portuguese territory: they came as workers on European estates in the Cholo area and have now become permanent settlers.

The same applies to the Yaos with the exception that they came from other districts in the Protectorate. The language most extensively in use is Chinyanja, which is understood by all natives in the district except the more recent Anguru immigrants. The tribes other than the Anyanja have preserved their own languages for use amongst themselves but these are of very subsidiary importance taking the district as a whole.

As regards religions, by far the greatest number are pagans, the figures derived from the census taken in April,1921, being as follows:-

Pagans, 37,167 ; Christians, 2,154; Mohamedans, 181.

The numbers of Europeans and Asiatics recorded at the Census were :-Europeans, males, 39 ; females, 10. Total 49 . Asiatics, males, 25 ; females, 3 . Total 28.

All the adult Europeans are engaged in agricultural or missionary work, the latter being carried out by the Seventh Day Adventist, Nyasa Industrial Mission and the Marist Fathers. The adult Asiatics are engaged exclusively in native store trade and agriculture. 


\section{West Shire District}

The district is bounded on the north by a southerly tributary of the Lisungwe river, from its source on the Anglo-Portugues, boundary at Beacon No. 27 downstream, for a distance measured in a straight line of $3 \frac{1}{4}$ miles more or less; thence east to the source of the Fumfuli stream; thence along the Fumfuli stream downstream to its confluence with the Mwendang'ombe river; thence along the Mwendang'ombe river downstream to its confluence with the Lisungwe river; thence along the Lisungwe river downstream for a distance measured in a straight line of 7 miles more or less; thence in a straight line in a south-easterly direction for a distance of $10 \frac{1}{2}$ miles or until it reaches the right bank of the Shire river at the commencement of the Pamfunda rapid (the second rapid downstream from Matope).

The eastern boundary begins at the commencement of the Pamfunda rapid; from this it follows a straight line drawn due east for a distance of 3 miles; thence it follows a line drawn southwards at an average distance of 3 miles from the left bank of the Shire river until it meets the Maperera stream.

The district is bounded on the south by the right bank of the Maperera stream from a point 3 miles upstream from the Shire river downstream to its confluence with the Shire river; thence along the right bank of the Shire river downstream to its confluence with the Nwanza river: thence by the left bank of the Mwanza river upstream for a distance measured in a straight line of 3 miles; thence in a southerly direction parallel to, but distant 3 miles from, the Shire river until the Nkombedzi wa fodia stream is reached : thence in a westerly direction to Beacon No. 43 (Valeta hill) on the Anglo-Portuguese boundary.

The western boundary follows the Anglo-Portuguese boundary in a northerly direction from Beacon No. 43 to Beacon No. 27.

The area of the district is $2,174 \cdot 12$ square miles.

It consists of two divisions; the Neno division and the Chikwawa division. It is divided into 12 sections, the areas and population of which are given below :-

\begin{tabular}{lr|r|r|r}
\hline & Section. & Area. & Population. & $\begin{array}{c}\text { No. of } \\
\text { Villages. }\end{array}$ \\
\cline { 2 - 5 } Neno. & A. & $219 \cdot 69$ & 1,783 & 19 \\
& I. & $92 \cdot 32$ & 1,074 & 11 \\
& C. & $102 \cdot 17$ & 1,593 & 18 \\
& D. & $39 \cdot 20$ & 702 & 8 \\
& E. & $221 \cdot 64$ & 1,665 & 22 \\
& F. & $104 \cdot 68$ & 834 & 7 \\
& G. & $75 \cdot 47$ & 1,625 & 19 \\
\hline \multirow{2}{*}{ Totals : Neno } & $855 \cdot 17$ & 9,276 & 104 \\
\hline
\end{tabular}




\begin{tabular}{rr|r|r|r}
\hline & Section. & Area. & Population. & $\begin{array}{c}\text { No. of } \\
\text { Villages. }\end{array}$ \\
\cline { 2 - 5 } Chikwawa & H. & $684 \cdot 35$ & 3,276 & 45 \\
& I. & $292 \cdot 47$ & 2,883 & 22 \\
& J. & $17 \cdot 31$ & 1,495 & 12 \\
K. & $68 \cdot 22$ & 1,891 & 14 \\
L. & $256 \cdot 60$ & 1,896 & 16 \\
\cline { 2 - 4 } Totals : Chikwawa & $1,318 \cdot 95$ & 11,441 & 109 \\
\cline { 2 - 4 } Totals for district & $2,174 \cdot 12$ & 20,717 & 213 \\
\hline
\end{tabular}

The principal tribes represented are :-

\begin{tabular}{|c|c|c|c|}
\hline Mang'anja & 10,300 & Makololo & 446 \\
\hline Angoni & 3,802 & Yao & 441 \\
\hline Ambo & 2,458 & Chipeta & 369 \\
\hline Chikunda & 1,852 & Other tribes & 354 \\
\hline Makanga & 695 & Total & 0,717 \\
\hline
\end{tabular}

Each section is under a principal headman appointed under the District Administration (Native) Ordinance, 1912; their names are as follows:-

\begin{tabular}{cl} 
Section. & \multicolumn{1}{c}{ Name. } \\
A. & Simon Likongwe. \\
B. & George Chekucheku. \\
C. & Dambe Achanza. \\
D. & Chikalema Liwambano. \\
E. & Masache Abanda. \\
F. & Kanduku Ameseko. \\
G. & Ntache Angondo. \\
H. & Beleu Apiri. \\
I. & Ndaeni Amputi. \\
J. & Daniel Apiri. \\
K. & Katunga Apiri. \\
L. & John Apiri.
\end{tabular}

Each principal headman has the assistance of two councillors, these, as a rule, being the two foremost village headmen in his section; district and section councils are held from time to time under the presidency of the District Resident, at which matters of general interest to natives are discussed, and new Regulations or Ordinances affecting native affairs are explained.

The headquarters of the district are at Neno in the northern part of the district; at Chikwawa on the Shire river, in the southern part, there is a sub-station in charge of a native Capitao, where a corporal and four privates of the Civil Police are stationed, which is visited periodically by the District Resident. The 
headquarters used to be at Chikwawa, but were moved to the more healthy northern part in 1906, when the closing of the river to navigation no longer necessitated the continual presence of the Resident at Chikwawa.

The northern part of the district consists of three distinct levels; the valley of the Shire and Lisungwe from which the land rises abruptly to the Neno plateau; and beyond this towards the Portuguese border the Kirk range of hills, to the top plateau of which the ascent is no less steep. The first is about 1,000 feet above sea level; the country round Neno is about 3,000 feet, while the Kirk range reaches an elevation of some 5,000 feet. To the east, west and south of Neno off the plateau the country is very broken, and travelling is in consequence very difficult and tiring. From Neno southwards the country falls towards Dzobwe and Tambani hills down the Mwanza and Wankurumadzi valleys to an elevation of about 2,500 feet by Dzobwe; from here it falls more gradually to Chikwawa, where the elevation is only some 300 feet.

The whole of the district except the high plateau of the Kirk hills is very well wooded; it has not been so denuded of its timber as other districts by native methods of cultivation, this being partly due to the richness of the soil in the habitable parts and in part to the more intensive methods adopted. Mbawa trees of a good size are fairly plentiful, especially on the Mwanza.

There are four rivers of consequence in the district. The Shire flows along the eastern border ; this river, which until about 1900 was navigable for steamers up to Chikwawa where rapids make further progress impossible, has now so fallen and is so overgrown that it is only with difficulty that barges and canoes can traverse it; in the wet season, however, it is liable to sudden floods with great resulting damage to the crops planted near its banks. The Lisungwe river rises in the north of the district and flow sinto the Shire about 8 miles below the crossing on the Blantyre road; it flows rapidly all the year round.

The Wankurumadzi and Mwanza rivers both rise in the Kirk range to the north and west of Neno, and descend rapidly to the plains, the former joining the Shire about 16 miles above Chikwawa ; the latter keeping closer to the Portuguese border and flowing into the Shire some 12 miles below Chikwawa. The Wankurumadzi flows all the year round, but the Mwanza after it reaches the plains dries up before the rains, and water can only be obtained from pools and holes dug in its bed.

Practically the whole of the population of the district is grouped along these four rivers; they are the only ones from which water can be obtained throughout the year, natives in other parts having to rely on wells and springs; there are several quite waterless areas of a large size, more especially the two which lie between the Lisungwe and the Wankurumadzi, and the latter and the lower Nwanza.

The climate at Neno is cool and pleasant ; the temperature seldom rises above $95^{\circ}$, the mean maximum temperature for the 
hot months being only $83^{\circ}$. Chikwawa's climate is that of the lower Shire, very hot and unpleasant from October to April, and cooler during the rest of the year. The average maximum temperature is probably about $85^{\circ}$ in the cold weather and $95^{\circ}$ to $100^{\circ}$ in the hot. The rainfall at Neno for the past 15 years averages 46.82 inches per year, the extremes being $36 \cdot 24$ and $63 \cdot 89$. At Chikwawa the average fall is 31.81 inches.

The climate and soil on the Mwanza between Dzobwe and Tambani hills has been found very suitable for tobacco planting, some of the best tobacco grown in the Protectorate coming from this locality. Cotton is grown with good success when the rains are favourable both at Chikwawa and on the Lisungwe; in both places a large number of natives grow cotton for their own profit, and there are several European plantations.

A small quantity of rice is grown at Chikwawa and on the Lisungwe, and also in the hills round Neno.

Coffee used to be extensively cultivated near Neno, but all the plantations have now been abandoned when, on the breaking of the boom, this crop ceased for various reasons to be profitable.

Rubber also has been tried quite extensively but with no success.

Lime of good quality is found near Neno hill ; gold is present in the Lisungwe river bed but not in sufficient quantity to allow of its being profitably worked; and coal and oil have been located at Sumbu near Chikwawa; a plant for boring for the latter was erected some years ago but has now been abandoned.

The staple food of the natives in the district is maize flour: this is supplemented, particularly in the Chikwawa division, by "mapira" and "machewere"; two crops a year are grown at Chikwawa, one in the wet season, and one in "madimba" by the river in the dry. A little rice is grown in some parts. For relish natives rely chiefly on beans, sweet potatoes and cassava, and, at Chikwawa, to a certain extent on fish. European potatoes of fair quality are also to be had round Neno.

There are about 350 head of cattle owned by natives in the district, nearly all by the Angoni round Neno ; native owned sheep number about 1,000 and goats 2,000, while there are some 2,500 pigs chiefly in the Chikwawa division.

Most of the game, including the protected Inyala, to be found in the Protectorate is present in the district; buffalo are fairly common, and elephants do a great deal of harm each year to the native gardens at Chikwawa.

There are no main roads in the district. District roads suitable for motor cycle traffic are the following :-

Neno to Shire ferry on Blantyre road (long road)-28 miles. It is quite good and well graded; there is no bridge over the Lisungwe and help is needed here to carry the cycle over.

Neno to Mwanza-30 miles. This road follows the Neno-Ferry road for the first 18 miles, and then branches off to cross the valley 
of the Wankurumadzi, where also there is no bridge and where help is needed.

Neno to Chikwawa-65 miles-via Mwanza and Ngadziwe.

Neno to Mbanga-6 miles.

Chikwawa to Mikolongo-31 miles.

Chikwawa to Maperera-8 miles.

There are also the following other district roads which, however, are quite unsuitable for wheeled traffic, owing to the steep and broken nature of the country they pass over :-

Neno to Shire ferry on the Blantyre road (short road)-16 miles.

Neno to Tambo Rest House-10 miles. hilly.

Neno to Mwanza (short road)-20 miles. This road is very

Tambani to Mikolongo, down the Mwanza-32 miles.

There are brick rest houses at the Shire ferry on the Blantyre road, and on Tambo hill in the Kirk range.

The European population of the district is about 30 .

Large European plantations for tobacco are situated on the upper Mwanza near Dzobwe and Tambani hills, and also at Sangadzi on the long road to the ferry. Round Chikwawa and on the lower Nwanza there are several large cotton plantations, the British Central Africa Co. in particular having large estates there, and a good plant for ginning cotton. There are one or two Indians owning stores in the district, all of them at Chikwawa.

Four Missions are working in the district; the Marist Fathers, the Seventh Day Adventists, the Church of Scotland, and the Zambesi Industrial Mission. Only the first two have headquarter stations in the district; the Marist Fathers near Neno on the Wankurumadzi and at Chikwawa ; and the Seventh Day Adventists at Matandani 6 miles to the north of Neno.

The native population of the district is small for its area, only 9.53 to the square mile; this is due to the general poverty of the soil away from the four rivers mentioned above, and to lack of water apart from them. There are large tracts quite uninhabited, and the population is fairly thick in the localities indicated.

The northern population consists mostly of Angoni and Ambo ; though there are also a few Achewa and some Yao. The Ambo are grouped almost entirely in the Kirk hills to the west of the Wankurumadzi. They are industrious and have some idea of agriculture, and they make good carriers. The Angoni are also good carriers and good herdsmen, but wasteful agriculturalists.

The Chikwawa division is populated almost entirely by Mang'anja; these people are not over industrious ; they make a fair success of their own cotton gardens, but are unsatisfactory labourers on European plantations.

The Chikunda and Makanga tribes are represented in the district at Chikwawa and round Dzobwe hill. 


\section{Mlanje District.}

The area of Mlanje district is 1,674 square miles, with a total native population of 64,143 ; it is divided into the following six sections :--

No. 1.-Mlanje mountain.

Subdivision 2.-Likabula, with boundaries as follows:The Mlanje-Cholo road, from the Tuchila crossing to its junction with the Blantyre road, thence along the Blantyre road to its junction with the old Zomba road, thence to the Ruo river at its junction with the Tuchila, thence along the Tuchila river to the Cholo road.

Subdivision 3.-Lower Tuchila. It is bounded by the Mlanje-Cholo road, Mlanje-Blantyre road, and the Tuchila river.

Subdivision 4.-Upper Tuchila. The boundaries are the Mlanje-Blantyre road, Mlanje-Blantyre compass boundary, Namadzi river; thence along the old Zomba road to Lukulezi, thence along the main Fort Anderson road to its junction with the Blantyre road.

Subdivisions 5 and 6 are bounded by the Palombi and Sombani rivers, and Portuguese territory.

Subdivision 1 consists of the main bulk of Mlanje mountain. Mlanje is not strictly speaking a solitary mountain, but rather a short, isolated range, rising very abruptly from the plains beneath and having its steepest side facing westward towards British territory. On the eastern or Portuguese side the ascent is comparatively gradual, and the scenery in consequence is less rugged and imposing than on the British front, where the scarp of the mountain falls in many places almost sheer to the plain, and is set off by several magnificent peaks or buttresses of which the great naked precipice of Chambi is perhaps the most conspicuous. At its northern extremity the range is flanked by the hill (sometimes called by the natives Mwananyani) on which Fort Lister once stood, and beyond that by the detached cone of Machesa, while still further to the north a number of isolated and broken peaks stud the flat country towards Lake Shirwa.

A remarkable pyramidal cliff of bare stone is conspicuous to the south and east of Chambi behind the Estate of Lauderdale, and is known to the natives as Manga. It has every appearance of having formed part of volcanic crater.

Further to the south-east again the range is terminated in Portuguese territory by the fine hill called Manene, opposite to which, on the left bank of the Ruo, stands the peak of Machinjiri, a detached cone, having much the same situation relatively to the bulk of the range as Machesa has upon the north side. There are several paths leading from the plain to the plateau of Mlanje. One of these at the Fort Lister end is almost exclusively used for the purpose of transporting timber to Zomba from the 
cedar forests which are found on the mountain. Another patha private one-runs from the Church of Scotland Mission up the Likabula valley, while a third starts from Fort Anderson, and a fourth from near Mr. Brown's Thornwood Estate. The three last named all converge upon what is known as the Luchenya plateau, lying at a height of about 6,000 feet above sea level. The Mission path and the one from Fort Anderson are both exceedingly steep and rough, but owing to their directness comparatively short, so that a good climber could reach the plateau by them in about 2 hours. The path from the Thornwood end is much easier but also very much longer. It was made to enable invalids to be carried up the plateau and for driving cattle to the upland pastures, and the gradient has been chosen accordingly. A machilla team would, however, take fully 7 or 8 hours to make the ascent by this route from Fort Anderson. Mlanje mountain contains the source of practically every river and stream in the district. The Malosa, which forms part of the AngloPortuguese boundary, rises at the back of the range near Fort Lister, and flowing round the eastern flank joins the Ruo a few miles east of Thornwood. From that point the united streams bear the name of the Ruo, which then constitutes the international frontier up to its junction with the Shire at Chiromo.

Among other streams issuing from Mount Mlanje, to name only the most considerable, are the Luchenya, Linji, Likabula, Tuchila, Palombe and Sombani. Besides these, countless minor rivulets and tributaries take their rise in the different parts of the hills, and during the rains (which are heavier in Mlanje than anywhere else in Nyasaland) the whole face of the mountain is covered with a perfect network of torrents, which can be seen from a great distance, glittering among the trees and rocks everywhere. Owing to the tremendous impetus with which all this accumulated water dashes down the sides of Mlanje, there is much difficulty in keeping the roads and bridges round the foot of the range in practicable condition. The actual erosion of soil and rock is also considerable, and large slabs of stone and earth are constantly torn up and washed away during every wet season. The formation of Mlanje mountain is that of a basal terrace from 5,000 to 7,000 feet high, covered at the top with undulating grassy downs or natural meadows, from which again the bulk of the mountain ascends to a total altitude of nearly 10,000 feet above the sea. The meadows or downs are broken up by ravines into several distinct areas, of which the best known is the already mentioned Luchenya plateau. This beautiful upland lies at a height of from 5,500 to 6,500 feet above sea level, and occupies perhaps 10 square miles in extent. It is traversed or rather bounded by the deep gorges of the Luchenya and Likabula rivers, and, like all the high plateaux of Nyasaland, is covered with rich natural grass, comparatively short, giving in fact, when viewed from a little distance, almost the effect of English meadow land, though in reality it grows from 10 to 18 inches long, in rough tussocks. The Luchenya plateau is frequently visited by Europeans 
in the hot dry season from August to November, and there are several cottages there, including the Government cottage $(5,700$ feet), Mission cottage (6,200 feet), Mandala (5,800 feet), Brown's $(5,750$ feet $), \& c$.

The air on the plateau is remarkably pure and bracing, the water supply good and abundant, and the pasture is excellent for cattle and all domestic animals. The mountain is distinguished by being the natural habitat of several unique animal and vegetable types which are not found elsewhere, e.g., the Mlanje thrush (turdus Manjensis) and the Manje cedar (Widdringtonia Whytei).

Subdivision 2.-Consists of the valleys of the Upper Ruo and of the Likabula with its numerous tributaries. The Ruo in this part of its course is a most picturesque river, dashing boldly down the slopes of Mlanje through masses of rocks and sweeping in broad reaches through the plains beyond. Even in the dry season it is a considerable stream, but during the rains it becomes greatly swollen, and in places extends to a breadth of 200 yards or even more. The whole of this subdivision is well watered, exceedingly fertile, and inhabited by a dense native population. It is bisected by the main road from Fort Anderson to Chiromo and bounded on the north by the Fort Anderson-Cholo road, while native paths traverse it in every direction. The principal villages in the subdivision are those of Mabuka, Duswa, Naluso, Bondo, Chipoka and others.

Subdivision 3.-Is the area contained between the Fort Anderson-Blantyre and Fort Anderson-Cholo roads. It is bounded on its western side by the lower Tuchila, a considerable stream, but narrower and far more sluggish than the Ruo. Like the preceding subdivision this one is very fertile and supports a large native population, including the villages of Tiramanja, Mohomadi and Matipwiri and many of Chikumbu's outlying villages.

Subdivision 4.-Contains the valley of the Upper Tuchila from Kada's (near Lukulezi) to the Tuchila crossing on the Fort Anderson-Blantyre road. The general configuration of the land in this subdivision is that of an extensive flat plain which stretches almost without any variation of level from the banks of the Tuchila to the very edge of Mlanje Mountain.

The banks of the Tuchila itself are fertile and crowded with villages except in the neighbourhood called Tamanda (the pools), a well known hunting ground lying between the villages of Chiuta and Kada. These Tamanda plains are much overgrown with mimosa forests and with a thorny scrub. The principal villages in the subdivision are those of Nkando, Chiuta and Kada, all on the Tuchila. In the wet season the Tamanda plains are inundated for a considerable distance and form an extensive swamp, which would be a serious obstable to the construction, otherwise perfectly feasible, of a direct road from Fort Anderson to Zomba.

Subdivisions Nos. $5 \& 6$.-Include all that part of the Shirwa littoral which falls within the boundaries of the Mlanje district, together with the valleys of the Palombe and Sombani rivers. 
This country forms a great level plain, unbroken except by isolated hills, which are most numerous on the eastern side, where they arise in clusters, including such considerable peaks as Machemba and Mauze. These detached hills appear to be a sort of interrupted continuation of the Mlanje range, and stretch almost the whole way from Fort Lister to Shirwa. Elsewhere the land is perfectly level, very hot and dry. The banks of the Palombe and Sombani are, however, fertile, and there is a considerable native population there and also between the Sombani and Portuguese territory on the east.

Numbers of Anguru and other natives frequent the shores of Lake Shirwa for the purpose of catching fish, but have their permanent homes elsewhere. The largest villages in these two subdivisions are those of Dyanyama and Chimombo on the Palombe, and of Mtemanyama, on the Sombani, besides Kumba, Nyaserera and others near Lukulezi. The road from Lukulezi to Zomba, which forms the southern boundary of these subdivisions, is exceedingly difficult to keep in repair, owing to the nature of the soil which, in the wet season is merely a mass of mud, and in the dry weather cracks into flakes and lumps under the heat of the sun.

There is also a considerable swamp on both sides of the road immediately beyond Fort Lister. The marshy nature of the soil during the rains and its tendency to become friable in hot weather is characteristic of the whole country lying about the shores of Shirwa. In particular, the immense treeless plain or dambo which stretches between the lake and the Sombani and Palombe rivers is particularly difficult to traverse at any time from August to October or November, being then completely parched and full of cracks; moreover, although shade trecs are absent, there is an abundance of low scrub covered with thorns which are shed freely upon the surface of the ground in such numbers as positively to lame native carriers and others who travel with bare feet.

It is worth mentioning that near Mtemanyama's village on the Sombani some iine park-like forest with open glades is to be found which used to harbour a good herd of game which is now shot out.

The immediate vicinity of Lake Shirwa is interesting by reason of the extraordinary abundance of aquatic bird life, but is otherwise dreary, being low-lying, stagnant and full of reeds.

The lower reaches of the Palombe and Sombani have few tributaries, but towards their sources they are fed by a great multitude of rivulets, flowing from the northern and western flanks of Mlanje mountain.

Manje, unlike the majority of districts, has no chiefs of any importance or power. The District Native Administration Ordinance is not in force, and the district is governed by the Resident, without the assistance of local chiefs.

The staple foods of the population are maize, mapira, cassava, mawere (millet), and nandolo, nkunguzu, ngunde, mbweso, mseula, mzama and other beans, pumpkins, gourds, cucumbers. Fish is obtained in large quantities from Lake Shirwa and the Ruo river. 
The main roads are from the Ruo in the south to Luchenza station, a distance of 30 miles, the greater part of which is macadamized, the second branches off the Mlanje-Luchenza road to Blantyre (which is not macadamized), 9 miles from Fort Anderson, and is 35 miles in extent.

The district roads are from Fort Anderson to Mlanje road station, a distance of 25 miles; from Fort Anderson to Palombe via the Upper Tuchila bridge, 31 miles; and from the main Luchenza road (12 miles from the Residency) to the Lukulezi road, 15 miles. None of these roads is macadamized, and they are in consequence very difficult for motor transport during the rains.

With the advance of civilization game has almost disappeared from the district. A few sable and eland are found near Palombe. Hartebeeste, gnu, zebra, warthog, buffalo, \&c., have all disappeared. A few bush buck and klipspringer are to be found on the top and lower slopes of Mlanje mountain; the grey duiker and oribi are occasionally seen on the plains; the blue duiker is still found in very small numbers in the thick wooded slopes of the mountain. Lions are seldom seen; leopards are numerous on the northern and eastern slopes of the mountain, also on Machesa and near the old Fort Lister.

There are no townships in the district.

The first Government Station was opened by Mr. Bell in 1892, but was abandoned in 1898, and the present Fort Anderson $\left({ }^{1}\right)$ built instead by Mr. G. C. L. Ray at an elevation of 2,200 feet above sea level on the site of Chikumbu's old village. Owing to the heavy rainfall, which averages 100 inches per annum, and the proximity of the mountain it is very hot and damp, and infested with mosquitoes during the rains. The gardens, which have been planted by various residents, are among the most beautiful in the country, and there is a golf course.

The principal language spoken in the district is Chinyanja, but Anguru, Yao and Swahili are also spoken.

There are 4,047 Christians, 2,892 Mahommedans, and 57,204 Pagans in the district.

It cannot be said that there are any European or Asiatic settlements. Planters are scattered throughout the country, and Banyan stores at intervals along the main and district roads.

Excellent tea is grown on the lower slopes of the mountain, from the Ruo in the south to Chitakali in the north, a distance of 20 miles, beyond which point the rainfall is insufficient.

Tobacco is grown all over the district, with the exception of the slopes of the mountain.

Cotton of very good quality is grown in the north and northeastern sections of the district.

The following native crops are annually cultivated:Chimanga (maize), two kinds of millet, viz., mapira and mawere several kinds of beans, pumpkins, gourds, cucumbers, a small amount of mustard and ginger, chillies, peas, native and European 



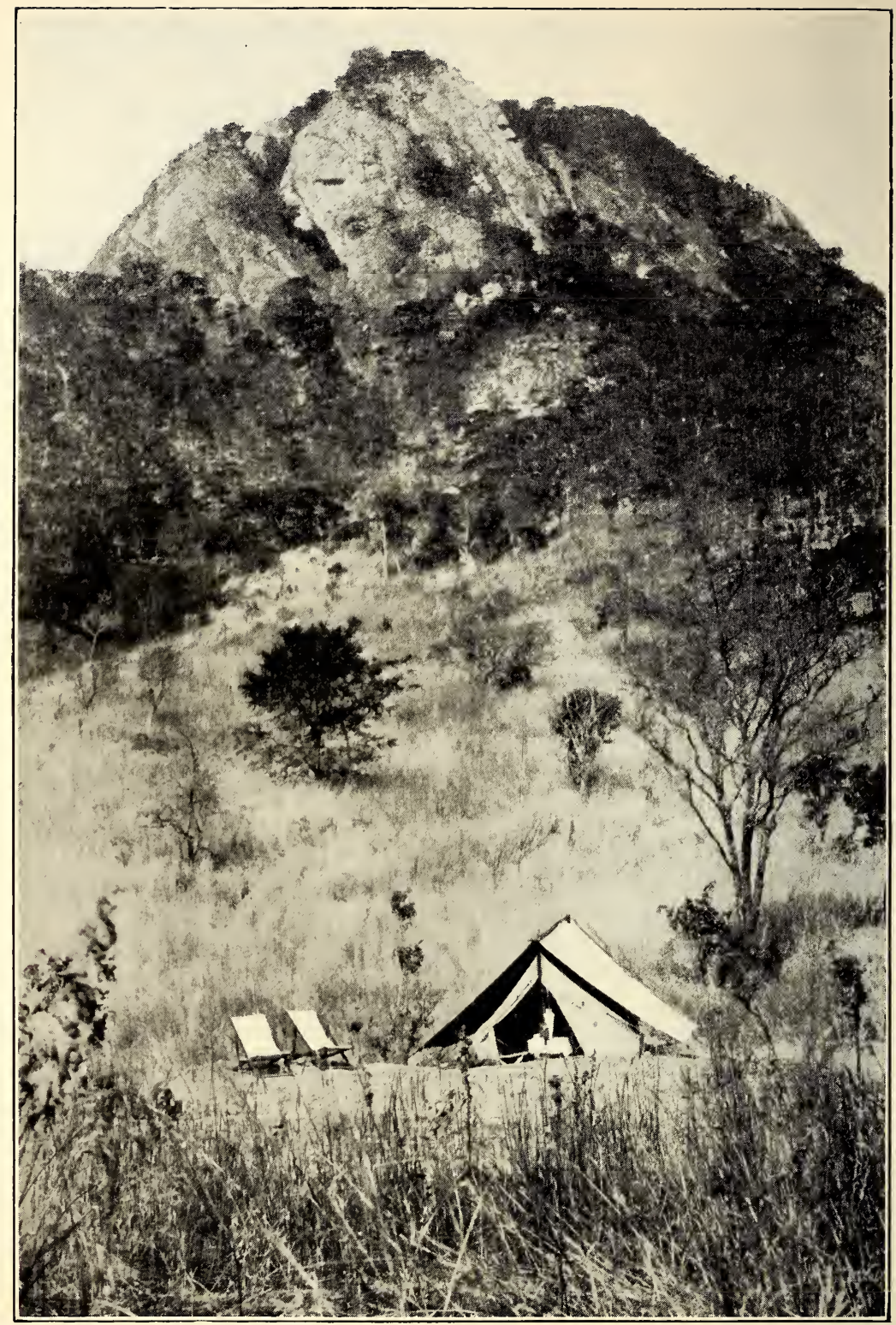

Photo by Lt.-Col. H. B. Smeeton.

NDIRANDE MOUNTAIN. 
potatoes, and cassava. Lemon, mango and guava trees were distributed among the chiefs in 1909, consequently most of the principal villages have large groves, which form a valuable addition to their usual food; bananas and pineapples are common throughout the district. Oranges and naartjes do exceedingly well: also avocado pears. Excellent apples can be and are cultivated on the plateau, at an elevation of 6,000 feet, where there are six cottages usually inhabited during the hot months of the year.

\section{Blantyre District.}

The area of the Blantyre district is about 1,334 square miles, and it is divided into the following sections:-

1. Central Division.-Boundaries: On the north the south boundary of B. \& E.A. Lunzu Estate and the Ngumbe to its junction with the Likubula; on the west the main ridge of Michiru mountain and the Mitsidi Estate; eastern boundary and southern boundary to the point where it almost touches the Mudi before that stream turns sharply to the south; the Mudi to its junction with the Naperi ; on the south the Naperi upstream to the point where it meets the west boundary of the Soche Native Reserve ; the western and southern boundary of the Soche Native Reserve to the Blantyre-Cholo road northwards to its entry into the Limbe Estate and the Lunzu to the point of commencement.

2. Northern Division.-Bounded by the Blantyre-Zomba and Blantyre-Neno roads from the points where they leave the Central Division and by the district boundary with the Zomba, Upper Shire, West Shire and Chiradzulu districts.

3. Likubula Division.-Bounded by the Neno and Katunga's roads from the points where they leave the Central Division and by the district's western boundary.

4. West Cholo Division.-Bounded by the Katunga's road and the Cholo road (to the Nswadzi bridge on the old Chiromo tract) from the points where they leave the Central Division and by the district's southern boundary.

5. East Cholo Division.-Bounded by the Cholo road from the points where it leaves the Central Division to the Nswadzi bridge, by the Nswadzi, Tuchila and Luchenza rivers to the pointwhere the latter leaves the Central Division.

Blantyre is situated in the Shire Highlands, about 3,000 feet in height. The bulk of the district consists of a broken plateau, draining on the north, west and south-west into the Shire river, which sweeps completely round these sides of the district; on the north-east into the Namadzi river, which flows into Lake Shirwa, and on the south-east into the Tuchila, a large tributary of the Ruo, which again is a tributary of the Shire, and joins it at Chiromo in the Ruo district. There is very little forest in the district except on some of the hills and near the rivers, and firewood is becoming scarcer every year. The soil on the whole is fertile, and in places rich. 
The climate is comparatively healthy and probably cooler than any other station in Nyasaland, the coolest time of the year being from May to July, and the hottest from November to January. The meteorological reports show in the last three years a maximum temperature registered $96^{\circ}$ and lowest $50^{\circ}$.

The rainfall is variable, 29.94 inches falling in the year 1919 and 43.91 inches in 1920 .

The soil on the whole appears to be fertile, and good for the cultivation of cotton, tobacco, tea, maize and millet crops.

The hills around Blantyre and the Midima range are the principal hills in the broken plateau which forms the bulk of the Blantyre district, and slopes down towards the Tuchila plain on the one hand and the Shire valley on the other. Streams drain down either into the Shire river, which runs round the district from the north to the south-west, or into the Namadzi (northeastern boundary of the district), which empties itself into Lake Shirwa, or the Tuchila, which rises in Mlanje mt., forms the southeastern boundary of the district, and runs into the Ruo. To the north is a flat plain broken by occasional hills bordering the Shire river. It lies about 1,500 feet lower than the average level of the rest of the district.

Through the 60 miles of the Murchison cataracts, the Shire runs between broken limestone hills in contrast to the flat alluvial plains which border it elsewhere.

Ndirande mountain, three miles from Blantyre to the north-east, consists of a small plateau to the south and a bare rocky ridge to the north, the plateau being about 4,000 feet and the ridge 1,304 feet higher. It is about $1 \frac{1}{2}$ miles long and half-a-mile wide.

Michiru mountain at its nearest point is less than 3 miles north-west of Blantyre, and is a well-wooded mass of land with many points, nearly 5,000 feet high. Its top is a small plateau, covered with dense forest.

2 miles from Blantyre to the north is Nyambadwe, a small conical hill of 4,028 feet.

To the south, 25 miles distant, is Cholo mountain, a large well-wooded hill of the same type as Michiru.

There are no navigable rivers in the district. The left bank of the Shire forms the district boundary for a short distance. The principle streams are:-The Tuchila and its tributaries, the Luchenya, Nswadzi, the Likabula, and its tributaries, the Mudi Naperi, Namadzi and their numerous small tributaries; but only the above-mentioned carry water on the surface all the year. From many apparently dry streams water can be obtained by digging in the beds. In the wet and cold weather the water in these streams is excellent for drinking. The banks are usually high and heavily wooded.

On the Mlanje road there is a wire foot-bridge over the Tuchila, and the Mudi is bridged in three places near Blantyre. 
Drifts have been made over all the streams on the principle roads, but these are usually carried away directly the heavy rains begin.

There is no heavy forest in the district, except the small patches on the hills mentioned above and near streams. The country, however, is lightly-wooded everywhere except where natives have made their gardens within the last twenty years.

In the wet and cold weather the country is covered by a coarse grass, varying from 4 to 8 feet in height, which is fired about August, and makes no great growth again until well on in December.

The Mvuu marsh, in the northern part of the district, is crossed by the Blantyre-Matope road; it is muddy for wheeled traffic in the wet weather, but from August to the breaking of the rains the "marsh" is a dry plain with one or two water holes, notably the Ivuu hole which lies a few miles from the road, about 7 miles from Matope, and contains water throughout the year.

The Yaos are the most warlike of the local tribes; at present they are a quiet and law abiding people, and unless the rapid strides that Mohammedanism is making among them contain the germ of a very distant danger they are not likely to depart from their present peaceful and agricultural mode of life.

The Anguru (including some Alolo) are numerically the most important tribe of the district; on the Portuguese occupying their country they crossed to British territory, and have been settling here in large numbers ever since. Their principal characteristics then appeared to be timidity, and a tendency to thieving. They hare settled down with surprising rapidity, and, though they more often learn the Chinyanja language than the Yao, they imitate the Yao very closely in the merging of tribal distinctions, which is one of the most noticeable of native tendencies; they will doubtless. approximate more and more to the Yao standard. Conversions to the elementary Mohammedanism, prevalent among the Yao population, are increasing among the Anguru and their old timidity and dishonesty are disappearing amongst the older settlers.

The Manganja (including the Achikunda and Ambo) have always been an unwarlike people. Under settled Government they differ from the Yao, principally in their lack of enterprise.

The so-called Angoni, settled in the Blantyre district, are partly freed slaves of mixed races and partly Achipeta, who have settled in the district of recent years. They resemble the Manganja, except that they show somewhat greater industry. Bvumbwe, of Mipezo, is the only chief of undoubted Angoni extraction who now lives in the district.

The influence of the chiefs has been declining since the advent of the British Government. Four headmen attend court alternately for a week to sit as assessors.

Except that the Manganja predominate in the district of Chola no locality is peculiar to any one tribe. 
The District Native Administration Ordinance has not yet been applied to the Blantyre District, owing to the large number of private estates on which natives reside. The district is divided into divisions and sections as follows :-

Central Division.

Section. Chief.

Territory.

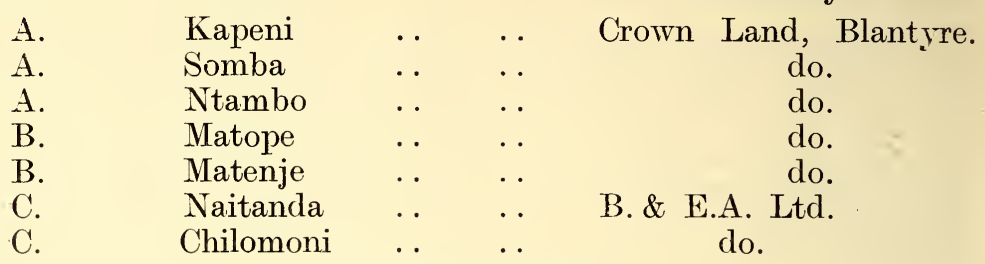

Likubula Division.

$\begin{array}{llllcc}\text { D. } & \text { Kantunkule } & \ldots & \ldots & \text { Crown Land, Likubula. } \\ \text { D. } & \text { Mbendera } & \ldots & \ldots & & \text { do. } \\ \text { D. } & \text { Kundembwe } & . & \ldots & & \text { do. }\end{array}$

Northern Division.

\begin{tabular}{|c|c|c|c|c|}
\hline E. & Karonga & . & \multirow{2}{*}{\multicolumn{2}{|c|}{ Crown Land. }} \\
\hline E. & Chigaru & .. & & \\
\hline F. & Machinjera & .. & \multicolumn{2}{|c|}{ B. \& E.A. Ltd. } \\
\hline I. & Chitera & .. & \multicolumn{2}{|c|}{ B.C.A. Coy. } \\
\hline & WEST & Сноцо & Division. & \multirow{4}{*}{$\begin{array}{c}\text { Estates, } \\
\text { do. } \\
\text { do. }\end{array}$} \\
\hline $\mathrm{G}$ & Chimombo & . & \multirow[t]{2}{*}{ Private } & \\
\hline G. & Kabambe & . & & \\
\hline & Pondamali & . & . & \\
\hline & \multicolumn{2}{|c|}{ EASt CHoLO } & Division. & \\
\hline & Vumbwe & . & \multirow[t]{2}{*}{ B.C.A. } & Coy., Cholo. \\
\hline $\mathrm{H}$ & Ntenje & . & & do. \\
\hline & Mlambuzi & & & \\
\hline
\end{tabular}

The following are the paramount chiefs of the district:Kapeni, of the Yao tribe, central division.

Chimombo, of the Mang'anja tribe, West Cholo division. Ntenje, of the Yao tribe, East Cholo division.

The following list shows the principal crops grown in the district by natives as well as by Europeans:-

Maize, cassava, millet (red), millet (white).

Beans (various kinds), sweet potatoes, English potatoes, ground nuts.

Peas, sugar cane, bananas, mangoes.

There is very little fish to be obtained in the district, but a certain quantity is to be found in the Nswadzi and Tuchila rivers during the rainy season.

Game is getting scarcer every year owing to the increase of plantations under European cultivation, and the game has moved away to more unfrequented parts, but most of the buck and antelope 
species are to still be found, chiefly in the north-west part of the district at Matope, and the western outskirts towards the Shire river.

Blantyre is the oldest settlement in the country, if we except the abortive attempt of the Universities Mission to Central Africa to found a station at Magomero in 1862, and the settlement at Cape Maclear. which was abandoned by the Livingstonia Mission in 1880. The Church of Scotland Mission established its headquarters at Mandala, 2 miles from Blantyre, in 1876. The residence of the head of the Mission is said to be the oldest European dwelling in Central Africa between the Zambesi and Khartoum.

In 1883 Captain Foot, R.N., the first consular representative of Great Britain in the sphere of influence north of the Zambesi after Livingstone, took up his post at Blantyre.

Blantyre was declared a township in 1895 and was enlarged in 1903. It forms the terminus of the Shire Highlands railway, and contains the High Court of Nyasaland and the Lands Office, and is the headquarters of the Provincial Commissioner of the Southern Province. It may also properly be regarded as the commercial centre of the Protectorate, more especially if we associate with it the township of Limbe, some 5 miles distant.-

Blantyre contains also the Queen Victoria Memorial Hall, at which most of the social functions are held, and which also forms the meeting place of the Nyasaland Chamber of Agriculture and Commerce. A well-stocked subscription library with magazine rooms is also housed in the hall. There is a flourishing sports club in the town, which, besides a playing field for cricket, hockey and football, maintains a golf course and tennis courts. There are several hotels in the town, whose charges are moderate.

Limbe was declared a township in 1909, and is the headquarters of the railway, the Imperial Tobacco Company and the British Central Africa Company. A hotel adjoins the station, and a golf course has recently been opened.

Cholo, 28 miles from Blantyre, is now a Government station and the centre of a flourishing planting community. The Imperial Tobacco Company have erected a factory there, and a club has recently been formed. The place will in all probability develop into a township.

There were, at the census of 1921, 542 Europeans in the Blantyre district, over one-third of the total in the Protectorate, as well as 280 Asiatics, or just a half of the total. During the three years $1918-20$ the European birth rate was 31.5 per 1,000 , and the death rate $9 \cdot 5$ per 1,000 .

The native population in 1921 was 94,685 , principally composed of 33,236 Anguru, 24,546 Wayao, 18,565 Anyanja, and 14,641 Angoni.

The principal roads in the district are the Blantyre-Cholo road, which accommodates some 25 estates; and the CholoKonjeni road, which is a continuation of the former through about 12 more estates. The total length of this road is about 40 miles, At about 30 miles from Blantyre a road branches off to Luchenza, running for just over 10 miles through 8 estates. The Blantyre Natope road is 33 miles in length and serves about 20 estates. 
The main macadam road from Blantyre to Zomba runs through the district for about 26 miles, and is joined a few miles outside the town by the road from Limbe. The road runs by or near some 20 estates in the Blantyre district. From Blantyre to Chikwawa on the Shire river, a distance of about 28 miles, there are about 11 estates. The road to Mlanje runs through about 20 miles of the district, and provides means of communication for some 15 estates. The road to Neno runs for the first 26 miles through Blantyre district until it reaches the Shire. There are various other roads intersecting the district, and the large estates have private roads joining up the sectional areas with each other and the estate headquarters. With the exception of the BlantyreZomba, Blantyre-Limbe and Blantyre-Cholo roads, heavy rains may render the roads impassable for motor traffic for a few days.

\section{Chiradzulu District.}

The district of Chiradzulu comprises an area of approximately 470 square miles. It is bounded on the north by the Namadzi river from the point where it is crossed by the Blantyre-Zomba road as far as the boundary of the Mlanje district; on the east by the Mlanje boundary proceeding south to the Tuchila river, and thence by the Tuchila to its confluence with the Luchenza river; on the south by the Luchenza to its source in Pingwe hill, thence in a direct line to the source of the Lunzu river, and thence by the Lunzu as far as the Blantyre-Zomba road; and on the west by the Blantyre-Zomba road from the crossing of the Lunzu as far as the crossing of the Namadzi.

Chiradzulu mountain gives its name to the district, its summit being 5,500 feet above sea level. To the south lie the hills of Zedi, Pingwe, Bangwe and Malabvi, with the Midima hills further east. The district is moderately well watered by streams, but owing to deforestation, which has become so marked within the past ten years, the smaller streams are void of surface water for a portion of the year. For its size the district probably produces more foodstuffs than any other, and has been termed the granary of the Shire highlands. The soil is exceedingly rich, and large annual crops of maize, beans, millet and cassava are raised by the natives. The soil is also admirably suited to the cultivation of tobacco, and the European planters in the Midima area enjoy a particularly long season, it being possible to plant out tobacco seedlings as late as the month of March in most years. Many of the natives cultivate small areas of tobacco with some success.

There is a good district road from Zedi hill, on the BlantyreZomba road, which runs 9 miles to Chiradzulu station and thence 8 miles to Namaka, where it again meets the main road. Six miles from Zedi this road is met by another district road, 9 miles in length, which connects with the Limbe-Mlanje main road.

There is no game in any part of the district.

A sub-station of the Blantyre district was first established at Chiradzulu in the year 1910, and Chiradzulu was proclaimed a 



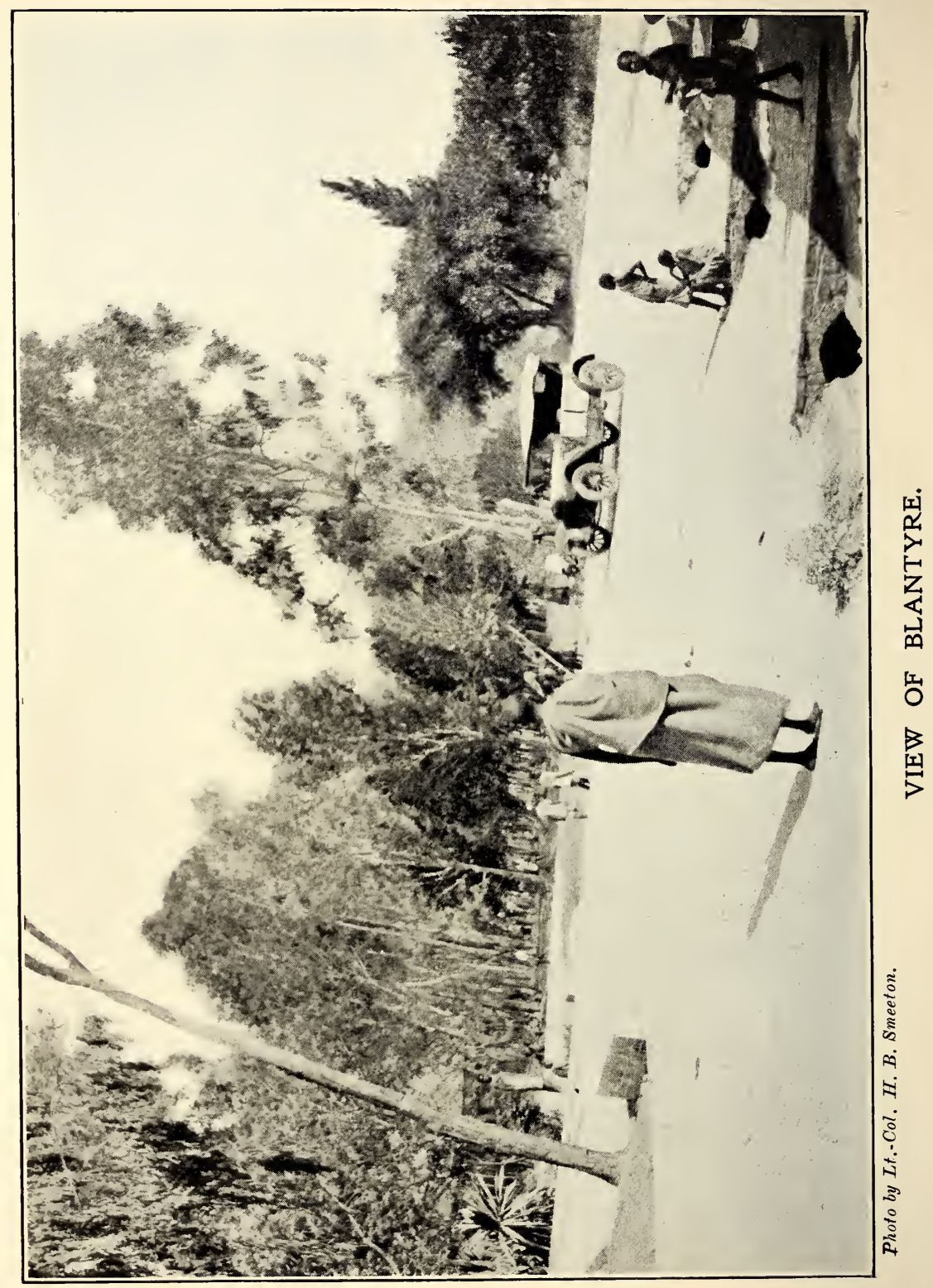


separate district in June, 1921. European settlement is confined to the large Magomero estates in the northern part of the district, with other estates bordering the Blantyre-Zomba road, and to the Midima area in the south, where there are a number of planters. At the time of the 1921 census there were 66 Europeans and 21 Indians in the district. No other district in the country is so densely populated, the last census figures reading 29,194 male and 31,407 female natives, and there is therefore no further land arailable for Europeans. The number of native-owned cattle has now increased to 700 head, for which there is insufficient grazing land, and there are also large numbers of sheep and goats, but the quantity of pigs is comparatively small.

For administrative purposes the district is divided into six sections, of which the principal chiefs are Mpama, Malika, Likoswe, Kadewere, Chiniko and Mkalo, but it cannot be said that any one of these exercises any extensive influence over his people. Association with and employment by Europeans has tended to lessen the native's respect for his chief or headman, and has made him more independent, particularly in a district where the natives have no lack of money. Profit or gain, which latter word he has adopted in his own vernacular, appeals more to the Chiradzulu native than regular work at a fixed rate of pay, and there are many more merchants than labourers in the district.

The district holds approximately 19,000 Yaos, 11,000 Anyanja, 4,000 Angoni, and 26,000 Anguru, but a large number of the so-called Yaos and Anyanja are of mixed stock, and many are Anguru who prefer to hide their parentage. Of this population 3,000 profess Christianity, 5,000 Mahommedanism, and the remainder are Pagans. The Yaos migrated to Chiradzulu from Mangoche about 1860 as a result of Angoni raids, and the present chief Mpama is a direct descendant of the chief of that name who was at the head of the Yaos who so migrated. Chief Malika is a descendant of the Malika who accompanied Mpama. The number of pure Yaos to-day must be very small, and it is the exception rather than the rule to meet with a Yao native who speaks his language well, this being particularly noticeable among the younger generation. This lack of knowledge of his own tongue is to some extent due to the fact that European employers only endeavour to speak Chinyanja, but the intermarriage of the Yaos with natives of other tribes is the greater cause, and it is regrettable that Chiyao, perhaps the finest of all Central African languages, should show such marked signs of falling into disuse. The southern portion of the district around the Tuchila and Luchenza rivers was originally inhabited by Anyanja natives, but now the majority of the people are Anguru. The great immigration of the Anguru from Portuguese territory commenced about 1901 and has continued steadily ever since. These natives have intermarried freely with Anyanja, Yaos, or half-bred Yaos, and this influx of Anguru is mainly responsible for the very mixed race which now inhabits the Chiradzulu district. 


\section{Zomba District.}

The area of the Zomba district is about 1,975 square miles, and it is divided into the following administrative sections :-

A. Section-Malemia.

B. , Kawinga.

C. " Mwambo.

D. , Chikowi.

E. , Mlumbe.

F. , Kumtumanji.

G. ", Mkumbila (Mchisi island).

The boundaries of the Zomba district, including Chikala. are as follows:-

North.-From the point at which the hoed path from Kawinga's village meets the Nsuka stream, along the right bank of the Nsuka stream to its confluence with the Nyenyezi, thence along the right bank of the Nyenyezi to the Anglo-Portuguese houndary between beacons 12 and 13 S.E. of Ipani hill.

East.-By the Anglo-Portuguese boundary and by the east bank of Lake Shirwa (including all islands in the said lake north of the embouchure of the Palombe river).

South.-Left bank of the Palombe river from its entrance into Lake Shirwa to its confluence with Namadzi river, thence by the left bank of the Namadzi to its source on the water parting between Shire river and Lake Shirwa, thence along this water parting to the source of the Lintipi river.

West.-From the source of the Lintipi near Misenga hill, along the Shire-Lake Shirwa water-parting to where the road from Chiwalo's village meets the hoed road from Kawinga's village near the source of the Mpira stream.

The Zomba district excluding the Chikala area slopes gradually from the bracing plateau of Zomba and Malosa (highest point above sea level 6,647 feet) to the level of Lake Shirwa (about 1,700 feet above sea level with brackish water), and is well watered by the streams which flow along this watershed. The granite rock which forms its main structure is easily decomposed, and forms the heavy red soil which gives such a characteristic colour to the roads and clearings of this part of the Shire Highlands. Most of this part of the district is well-wooded ; the best timber trees are found in the alluvial soil of the river beds.

The most important streams flow all the year round. There are, however, large streams which only run in the wet season, as for example the Naminga, Nambadzi, Ngande, Mikoko, Mpwiri, and the Songwe. All these streams are situated north of the Sumulu stream. From this stream to the extreme north end of the district there is no running water in the dry season; water is then obtained from water holes or from shallow wells. 



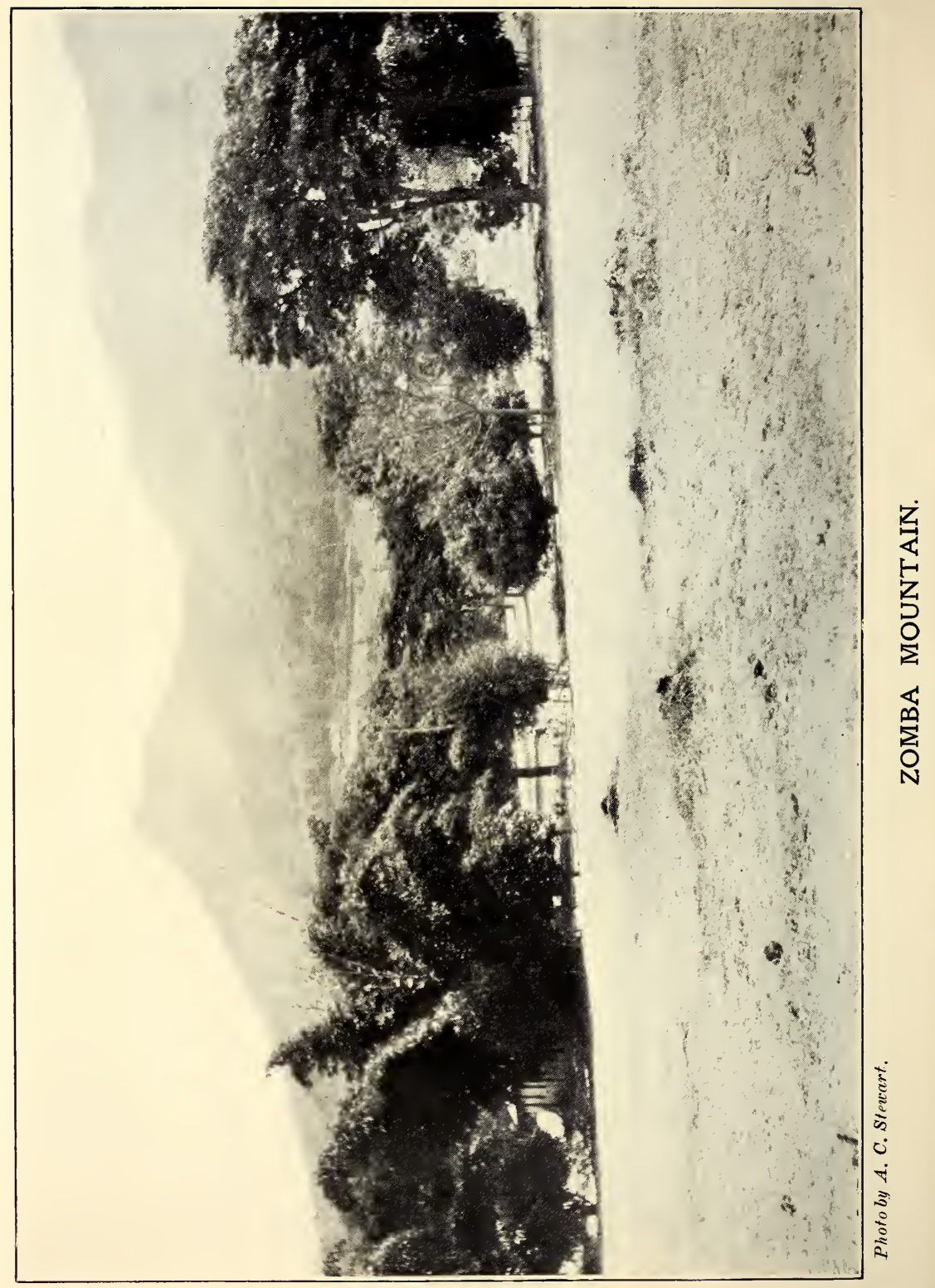


The main streams in the district are :-

1. Likangala.-Rises in hilly country in the western part of the district, and flows through the district into Lake Shirwa on the east, with many villages on its banks.

2. Palombe.-Rises south of the Zomba district, of which it forms the south-east boundary. Flows into Lake Shirwa.

3. Nambadzi.-Rises in south-west boundary of the district and forms the southern boundary thereof. Flows into the Palombe.

4. Ntondwe.-Rises in Mount Ntondwe on the western boundary and flows into the Namiwawa.

5. Namiwawa.-Rises by the Ntonia hills and flows into the Palombe.

6. Domasi.-Rises between the Zomba and Malosa plateaux and flows into Lake Shirwa.

7. Naisi and Songani.-These rivers rise on the Zomba plateau and flow into Lake Shirwa.

8. Other important rivers are the Likwenu, Lintipi and the Namitembo.

The mean temperature for 1920 was $68^{\circ} \mathrm{F}$., ranging from $97^{\circ} \mathrm{F}$. in October to $42^{\circ} \mathrm{F}$. in June ; in 1919 the mean temperature was $69^{\circ} \mathrm{F}$., ranging from $97^{\circ} \mathrm{F}$. in November to $45^{\circ}$ in August. In 1920 the total rainfall at Zomba was 65.77 inches, of which 21.78 inches fell in March; the total rainfall in 1919 was $43 \cdot 29$ inches.

The Zomba district contains one of the most thickly-settled planting sections in the Protectorate, and owes its popularity to the fertility of the soil, the congenial climate at elevations above 2,000 feet, and the good roads connecting the district with the townships of Zomba and Blantyre.

In 19204,158 acres were planted with tobacco and 2,822 with cotton by Europeans. Both of these crops do well, but at elevations above 2,500 the cultivation of cotton is speculative owing to the temperature being too low at the critical period in the setting of the bolls.

Excellent yields of maize, beans, and other food crops are grown by both Europeans and natives. Small acreages of tobacco and cotton are planted by natives.

The following are the names of the paramount chiefs and their principal headmen :-
A.
Malemia.-Kuminama.
B. KaWINGA.
1. Mbeta.
2. Mbela.
3. Chamba.
4. Mposa.
5. Chikweo.
6. Nyambi.
C. Mwambo.-Kimu and Chawesa.
D. CHIкоwI.-Lambulira.
E. Mlumbe.-Namonde.
F. Kumtumanji.-Kanda.
G. Mkumbila. 
The system of government through native chiefs is as follows :-

While each paramount chief is responsible to the Government for the section under him, yet he is not allowed to interfere with natives on private land without first approaching the owner of that land.

The District Administration Ordinance has not yet been applied to the Zomba district in view of the large number of European settlements.

Hence the Government works through the chiefs who are recognised as its mouthpiece. The chief is the medium by which the instructions of the Government are conveyed to his leading headmen, and by them to the village headmen.

The following are the native products of the district which provide the staple food :-maize, beans, ground nuts, millet, cassava, bananas, fish, pineapples, mangoes, sweet potatoes and ordinary potatoes.

The main roads which traverse the Zomba district are :-

(1). Zomba-Namadzi, 16 miles, Blantyre main road.

(2). Zomba-Likwenu, 19 miles, Liwonde main road.

(3). Zomba-Namiwawa, 9 miles, Mlanje road.

All the above roads are kept in repair by the Public Works Department, and are suitable for motor traffic the whole year round.

In addition to these there are district roads :-

1. Zomba-Lake Shirua road--Turning off to the right this road leaves the Zomba-Liwonde road 2 miles from Zomba.

For a distance of 10 miles this road passes between eight estates, all of which can be reached by car.

2. Zomba-Namitembo road.-Leaves the Blantyre main road one quarter of a mile above Likangala bridge. During the rainy season this road is dangerous for motor traffic owing to the wellknown hair-pin bends.

3. Zomba-Chikala road.-Turning to the right this road leaves the Zomba-Liwonde road at Mtwiche's village, 15 miles from Zomba. It is from this point the road becomes a district road. This road is largely used by planters proceeding to and from Portuguese East Africa. The most important bridges crossed are those over the Lifani and Lingoni rivers.

4. Chikala to Madziabango, 21 miles.

5. Chikala to Chiuta, 46 miles.

6. Chikala to South Nyasa boundary, 32 miles.

With the exception of baboons on the slopes of the mountain, bushbuck on the plateau, and an occasional leopard or lion, there is very little game of any kind in the near vicinity of the Zomba township. A good deal still exists, however, in the Chikala area, but even here, where game used to be found in large herds, it is now more scattered, and this is largely due to the fact that the ZombaMalakotera military road passed right through this game country.

Buffalo, gnu, zebra, eland, kudu, sable, hartebeest and waterbuck, however, are still to be seen, while leopards and hyenas and the smaller buck, such as duiker, oribi, and reedbuck, may be found all over this area. 
Occasionally elephant and rhinoceros may be tracked on the Masanje, and there are a number of hippopotami in Lake Chiuta and the Chi Nyasa pool. Warthog and bushpig are fairly plentiful in certain parts of the district.

Zomba was, early in the history of the Protectorate, chosen as the site for the administrative headquarters of the country, and even before that time had been occupied by planters, notably the Buchanan brothers, who started coffee planting in the eighties. It was in 1887 that Consul Hawes commissioned one of the Buchanans to build the Old Residency, a fine double-storied house, which was for long the finest European dwelling in East Africa north of the Zambesi. The place at first served as residence and office, and continued to be the official house of the Commissioner until the present Government House was built in 1901. Zomba may boast of being the first town in East Africa to be lighted by electricity, the experimental installation at Government House having been extended to all the dwellings in 1903-4. The present Government offices were first built in 1904 and, having been partially destroyed by fire on the 17th of February, 1919, have since been rebuilt.

The boundaries of the Zomba township were first defined in Gazette dated 30th September, 1900, when the appointment of a Town Council also took place. The boundaries referred to were amended by Proclamation No. 4 of 1911.

The township is situated at the foot of the Zomba plateau, with an excellent supply of water and electric lighting. It forms the headquarters of the Government, and contains the residence of His Excellency the Governor as well as most of the principal departments. There is a good hospital for Europeans and one for natives. There are two churches, one belonging to the Church of England and the other to the Church of Scotland.

The David Livingstone Lodge of Freemasons in 1921 completed a temple situated in the township area. Zomba is well supplied with means of recreation in that it possesses a gymkhana club which provides for the following :--

(a) Tennis courts (5).

(b) Hockey, football and cricket ground.

(c) Badminton court.

(d) Golf links (9 holes).

The club was started 25 years ago. With the extensive additions and alterations now nearing completion the club buildings will contain reading, smoking and billiard rooms, palm court, concert and ball room. The membership of the club is 280 . The library consists of 4,000 volumes and also provides for all principal newspapers, magazines and weeklies.

The inter-town sports between Blantyre and Zomba generally take place in August, when the various silver trophies are competed for, including the Boyd-Wallace cup, known as the Championship cup, which is held by the club scoring the largest number of points in the following games:-Cricket, hockey, football, shooting, athletics, billiards, golf and tennis. 
The following show in round figures the numbers of the various tribes inhabiting the Zomba district:-

40,000 Yaos, 31,000 Anyanja, 21,000 Anguru, 1,600 Angoni, 5,000 Apotola, 700 Akokola.

There are 4,000 Christians and 20,000 natives who profess to be Mohammedans.

At the last census (April, 1921) there were 231 Europeans (157 males and 74 females) in the district, and 72 Asiatics, mostly Indian traders.

Of the Europeans 171 (115 males and 56 females) reside in the Zomba township. The remainder are resident in the district, and are engaged in the planting of tobacco and cotton.

\section{Liwonde District.}

The area of the district is approximately 1,400 square miles. It is bounded on the north by an imaginary line running due east and west, and cutting the Upper Shire at a point one mile below its exit from the south end of Lake Pamalombe; on the east by the Zomba range and by the line of water-parting between the watersheds of the Upper Shire and Lake Shirwa; on the west by a line drawn in a south-south-westerly direction through Zirimbuzi hill to the most easterly point of the Lisungwe river; on the south from the most easterly point of the Lisungwe river, down stream, for a distance, measured in a straight line, of 7 miles more or less, thence in a straight line in a south-easterly direction for a distance of $10 \frac{1}{2}$ miles, or until it reaches the right bank of the Shire river at the commencement of the Pamfunda rapid (the second rapid downstream from Matope) ; thence the right bank of the Shire river upstream to a point 1 mile north of Matope, thence in an easterly direction until it meets the Blantyre-Mpimbi road, thence by the Blantyre-Mpimbi road until it is crossed by the Lintipi river, thence along the Lintipi river upstream to its source on the Shire river-Lake Shirwa water-parting.

The district is divided into four administrative sections.

Section No. 1 (north-eastern). This section comprises that part of the district which lies to the north of the Liwonde-Zomba road and to the east of the Shire river.

The principal rivers of this section are the Likwenu, Mwalasi and Namandauji, all of which flow into the Shire. The Likwenu drains the Mongorwe range and the northern slopes of Zomba mountain, where it takes its source. The Mwalasi and Namandauji have their sources in the low hills (called Makongwa), which form the water-parting dividing the Chikala district from the Liwonde district. All these rivers have numerous tributariesnone of them are navigable-which are dry in the dry season except near their sources. The eastern portion of this section is elevated throughout, and the drainage is entirely from east to west into the Shire river.

The only range of importance in this section is the Mongorwe range, which runs at an altitude of some 2,000 feet. Njunguni 
is a prominent hill, and lies $\mathbf{l}$ mile north of Likwenu river and 2 miles east of the Shire. There is no water on this hill, except in pools in the rainy season.

The Nyapyulo hills, two breast-like hills, are also a prominent landmark, and are situated between the Mwalasi and Nambere rivers near their junction.

Section No. 2 (north-western). This section comprises that part of the district which lies north of the Liwonde-Ncheu road, and west of the Shire river. The Liwawasi (a tributary of the Rivi-Rivi), the Chiranga and the Nkasi are the only rivers of importance in this section. The Chiranga rises in Ulongwe and flows in a south-easterly direction, joining the Shire at Msali. The Nkasi has its source in the South Nyasa district near Piriulongwe and flows in a southerly direction as far as Ulongwe, and then in an easterly direction to the Shire. There are no mountains in this section.

Section No. 3 (south-western). This section comprises that part of the district which lies south of the Liwonde-Ncheu road and west of the Shire.

The only river of importance is the Liwawasi (mentioned above). The Chimwalire is worth mentioning. It is a small stream, some 12 or 15 miles in length, but it always affords a supply of water, and has in consequence a considerable population on its banks.

There are no mountains of any importance in this section, although Chinkumbi is a prominent hill.

Section No. 4 (south-eastern). This section comprises that part of the district which lies south of the Liwonde-Zomba road and east of the Shire.

The only river of importance is the Lisanjala, which drains the western slopes of the Zomba range and the eastern slopes of Chinduzi hill. It has many small tributaries. It is a large torrent in the rainy season, and has water even in the dry season.

With the exception of the Zomba range, which forms the eastern boundary of this section, the only hill of importance is Chinduzi, which has an elevation of 2,000 feet, the peak being 2,504 feet.

The district is governed under the District Administration (Native) Ordinance, and each of the four sections is under the control of a principal headman appointed by His Excellency the Governor. Each principal headman is assisted by two councillors, also appointed by His Excellency the Governor. The village headmen are responsible for the good behaviour, etc., of their village to the principal headman of their section, who in turn is responsible to the resident for his section.

The principal headmen are as follows :-

No. 1 section

No. 2 section

No. 3 section

No. 4 section

$\begin{array}{ll}\ldots & \ldots \\ . & \ldots \\ \ldots & \ldots \\ . & .\end{array}$

P.H. Namputu.

P.H. Chingwalugwalu.

P.H. Kungwalu.

P.H. Mpilisi. 
The rainfall is from 30 to 40 inches per annum. The rainy season is from November to March inclusive, the heaviest falls occuring during December, January and February. With the exception of the small hilly portion of the district in section No. 4, the district is very hot during the hot season, the temperature rising to $105^{\circ}$ in the shade.

Cotton thrives in almost any part of the district, and is cultivated by both Europeans and natives. The chief enemy to cotton is the boll-worm, which is very destructive if it once finds entry.

Tobacco has been successfully cultivated in the district (the higher parts only) during the last two years. As a whole the district would appear to be too low-lying to be suitable to tobacco.

Fibre. The fibre plant grows well in the district, and should thrive in most parts. When some economical method of extracting the fibre has been discovered it should form a remunerative product.

Maize is the chief native food crop, and it thrives well in any part of the district, except when the rainfall is unusually low.

Ground nuts, sweet potatoes, and beans also do very well.

Fish is obtainable from the Shire river all the year round, and the natives are very fond of it. The fish, however, has a very muddy taste, and is not palatable to Europeans.

The main roads in the district are the following :-

Liwonde-Zomba road: Section 1, Liwonde-Likwenu, length 15 miles. The road from Zomba enters the Liwonde district at Likwenu, where there is good water and a rest house. It is a good camping place at an altitude of 2,500 feet. The road from here to a point $9 \frac{3}{4}$ miles from Liwonde is undulating. From the $9 \frac{3}{4}$ mile point there is an abrupt fall of 300 feet in three-quarters of a mile. Thence to a point 7 miles from Liwonde the road is fairly level, while the last 7 miles into Liwonde forms a gradual descent. The whole of the road from Liwonde to Likwenu is an excellent one for any sort of traffic, up to 4 ton lorries.

Water can be obtained at the following places :-

\begin{tabular}{llrccc} 
Hot spring .. &. & 1 & \multicolumn{2}{c}{ mile from } & Liwonde. \\
Mombe stream &. & 7 & miles &, &, \\
Chitokoto stream &. & 9 &, &, &, \\
Likwenu river &. & 15 &, &, &,
\end{tabular}

Liwonde-Fort Johnston road: Section 2, Liwonde-Mpale, length 23 miles. This road is level throughout, and is an excellent one for all sorts of traffic, up to 4 ton lorries.

Water can be obtained at the following places:-

\begin{tabular}{|c|c|c|c|c|c|}
\hline Chiranga river & & 3 & miles & from & Liwonde. \\
\hline Nkon & & $9 \frac{1}{2}$ & ", & ", & ," \\
\hline illage & & 14 & ," & & ", \\
\hline river & & 15 & ," & & ," \\
\hline Mpale river & & 23 & , & , & , \\
\hline
\end{tabular}

Between the Nkasi river and the Mpale river there is no water to be found. 
Liwonde-Ncheu road: Section 3, Liwonde-Balaka, length 27 miles. In the dry season this road is fairly good throughout for all traffic up to 4 ton lorries. The road is undulating throughout, and in the wet season gets rather badly cut up by motor traffic. In the wet season motor traffic up to 2 tons only is allowed on the road.

Water can be obtained at the following places:-

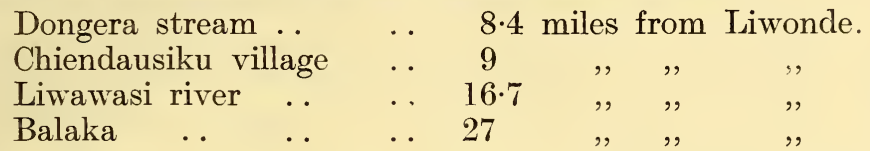

In addition to main roads there are two district roads.

Liwonde-Mpimbi road, length 17 miles. This road is quite level and follows the course of the Shire more or less the whole way. Chinduzi estate (B.C.A. Coy.) is traversed by the road at a distance of 10 miles from Liwonde. Water can be obtained at any point from the Shire.

The road is a poor one during the rains, as the country drains from east to west across the road, and it is flooded in many places during the wet weather.

In the dry season it is a good road for machila or cycle.

This road forms part of the old main road direct to Blantyre.

Liwonde-Mvera road, length 22 miles. From Liwonde to Litete the road is suitable for pedal cycles and machilas. From Litete to Mvera there is a good native path, which is intersected by numerous streams, not provided with bridges. Water can be obtained from the Shire at any point.

The following species of game are found in the district:antelope, kudu, zebra, duiker, sable, nswala, hartebeeste, bushbuck, waterbuck, reedbuck and eland, as well as warthog and bush pig.

The following carnivora occur:-Lion, leopard, civet cat, hyena, jackal and wild dog. buffalo.

Big game is represented by elephant, hippopotamus and

Antelope of all the above mentioned species are to be found in the district, especially in the vicinity of the Shire river.

Warthog and bush pig abound.

Lion and leopard are much in evidence, also hyena and jackal. Wild dog are also very numerous and often drive the game away from their usual feeding places. Every year natives are occasionally taken by lions

Elephant cannot be said to have their permanent habitat in the district, but roving herds visit it.

There are still a number of hippopotami in the Shire river. C'rocodiles also infest the Shire. Buffalo are occasionally found on the east bank of the Shire river, about 12 miles north of Liwonde.

Most of the different varieties of game birds are to be found in the district. 
Guinea fowl abound, and two kinds of francolin are common ; quail are met with occasionally. Knob-nose geese and three specimen of duck are generally to be found on or near the Shire.

Up to the year 1919 the European settlement in the district was very small, apart from missionaries; the only planting being carried on was by the B.C.A. Company, who had two European agents working their estates. Since 1919, however, 15 new estates have been opened up by Europeans in the district. These estates are each of about 1,000 acres, their crops being cotton and tobacco. The B.C.A. Company have also opened up more of their land, and now there are six agents on different B.C.A. estates in the district.

The Asiatic population is small, there being only 3 Indians in the district, all of whom are engaged in native trading in small stores in various parts of the district.

The principal tribe in the district is the Yao. The census taken in April, 1921, revealed the following numbers in the district :-

$\begin{array}{lllr}\text { Yao .. } & . & . & 14,401 \\ \text { Angoni } & . & . . & 7,113 \\ \text { Anyanja } & . & . . & 3,562 \\ \text { Makololo } & . & . & 1,773 \\ \text { Anguru } & . & . & 902 \\ \text { Atonga } & . & . & 235\end{array}$

The Yao population is chiefly Mohammedan, and mosques are to be found attached to most groups of Yao villages. The Yao, on the whole, however, is not a very strict Mohammedan, and most of the mosques are not much used except during the Fast of Ramazan.

\section{South Nyasa District.}

The area of the district is about 2,782 square miles, and it is divided into the following administrative sections :-

Section boundary No. 1. Starting from Mpinganjila's village ; thence in a mortherly direction along the Shire river to its source at Lake Nyasa ; thence along the lake shore to Matuwi's village ; thence in a south-westerly direction to Mselema's village on the Sangasi river; thence following that river, upstream, to Mwawa's village; thence crossing that river and taking in part of the Nasenga river so as to include Mpinganjila.

Section boundary No. 2. Starting from Mausu's village; thence along the lake shore to Cape McClear; thence following the lake shore down the south-west arm to the mouth of the Gubudira river; thence up the Gubudira river to where it crosses the Fort Johnston-Ganya road; thence along the road to the Sangasi river ; thence down the Sangasi river to Mselema's village ; thence in a straight line in an easterly direction to Mausu's village.

Section boundary No. 3. Starting from Changamire's village for a distance of about 2 miles in a north-easterly direction to a point on the boundary of Division No. 1 ; then following the 
Nasenga river in a westerly direction to a point where the said river takes a southerly direction, then leaving this river and following the boundary of Division No. 1 to Mwawa's village; thence following the Ganya road to where it joins the Gubudira river; thence in a straight line to the Liwonde boundary close to Tambala's village; and thence eastwards following the said boundary to Mvera on the Shire river and thence along this river back to Changamire's village.

Section boundary No. 4. Starting from Fort Johnston along the Namwera road to the Portuguese boundary; thence southwards along the boundary to the Nyenyezi river; thence along the left bank of the Nyenyezi river to its source; thence in a straight line to the Sonje hill ; thence following the Chikala boundary to the Masanje river and along this river to Lake Pamalombe.

Section boundary No. 5. Starting from Mterera's village along the Namwera road to the Portuguese boundary road; and thence following that in a north-westerly direction to Kwisimba's village; and thence in a westerly direction to Kaluwa's village; and thence due south along the ridge of hills back to Mterera's village.

Section boundary No. 6. Starting from Fort Johnston along the lake shore to Chiponda's village ; thence eastwards to Kaluwa's village; thence along the western boundary of division No. 5 ; thence along the Namwera road to Fort Johnston.

Section boundary No. 7. Starting from Chikulo's village on the lake shore in a northerly direction to the Lupuchi river; and thence southwards along the Portuguese boundary road to a point nearest Liwiga's village; and thence westwards to the point of commencement.

The district itself is bounded on the north by the shores of Lake Nyasa; on the west by a straight line from Piriwisa to where the Gubudira river crosses the Fort Johnston-Ganya road near Songa village; thence by the Gubudira river to the lake; on the east by the Anglo-Portuguese boundary to where it touches the south-eastern shore of Lake Nyasa; and on the south by the Liwonde boundary to Sonje hill, and thence along the Chikala boundary to the Portuguese boundary.

The principal feature of the eastern division of this district is the triple range of hills running in a northerly direction almost parallel with the eastern shore of Lake Pamalombe, culminating at Fort Mangoche, 5,450 feet above the level of the sea, and continuing along the eastern shore of Lake Nyasa to and beyond the most northerly point of the eastern boundary of the district. The Anglo-Portuguese boundary practically runs in a straight line along this range of hills. Mangoche is about 18 miles from Fort Johnston by road, or 14 miles in a direct line. Fort Johnston, the capital of the district, is situated on the left bank of the Upper Shire river, about 6 miles south of its exit from Lake Nyasa.

West of the waterway dividing this district is another prominent range of hills running nearly parallel to the western shore 
of Lake Pamalombe, the Upper Shire river and Lake Nyasa as far as Livingstonia, the most northerly point of the west side of the district. This range extends as far back as Pirilongwe mountain (about 3,500 feet above the level of the sea) approximately 20 miles west of Fort Johnston. This mountain is the principal feature of this hilly part of the country and, being situated in the centre of the western division of the district, affords an excellent landmark from most points of view. Travelling is difficult in the hills on account of the extreme irregularity of the country. Westward of this range a large plain extends to the Livelezi river. Owing to the scarcity of water during the dry season this plain is very thinly populated.

The South Nyasa district is well wooded, the hills are all covered with fairly tall but slender trees and the plains with a somewhat larger kind of forest. During the wet season, when the grass grows to a height of between 6 and 12 feet, one can only travel through the forest by keeping to the native paths which lead from village to village.

Lake Pamalombe formed part of lake Nyasa at one time. The soil of the whole of the basin between the two ranges of hills alluded to is of a sandy nature, but on the shores of the lake and on the banks of the river it is very rich alluvial soil. In the hilly parts of the district and under the hills the soil is of a clayish nature generally. Under the west side of Pirilongwe clumps of virgin forest may still be found, but most of the soil on the plain between the mountain and the Livelezi river is of that black variety commonly called " cotton soil."

During the last few years the lake level has fallen considerably, and consequently the Shire to the south of Fort Johnston is no longer navigable.

The only other rivers in the district that need mention are the following :-

The Tamankokwe, which rises near Pirilongwe and flows in an easterly direction into the Upper Shire, about 2 miles above Fort Johnston; the Nasenga, which flows through the hills running parallel with the western shore of Lake Pamalombe into the lake; the Sangasi, which flows in a northerly direction into the southwest arm of Lake Nyasa, rising near Pirilongwe; and the Bwanji, which rises in the Upper Shire district and runs in a northerly direction and practically midway between the Sangasi and the Livelezi into the same arm of the lake. All these rivers are full of water during the rainy season, but during the dry season lose themselves in the sand of the plains. In the eastern division of the district the Mandimba river rises near Mangoche and flows eastwards into Portuguese territory; the Lingamadzi also rises near Mangoche and flows into Lake Pamalombe.

The Upper Shire river is crossed by means of canoes and small boats; the other rivers are all fordable.

Lake Pamalombe is 15 miles long and 10 miles wide. It has now become a marsh, and is no longer navigable. 
On the lake shore and on the banks of the Upper Shire water is, of course, plentiful throughout the year. The smaller rivers also have sufficient water all the year to supply the needs of the villages along their banks. In the dry season when running water is not found in the plains sufficient for drinking purposes, it can nearly always be found by digging a shallow hole in the bed of a stream. That part of the district known as the Chipata and Kola district, lying between the Pirilongwe range and the Livelezi river, is the only part where water is very scarce and unfit for drinking purposes.

The average annual rainfall for Fort Johnston is 28 inches, and the average mean temperature $76^{\circ}$. The rainfall in the higher parts of the district is naturally considerably in excess of this.

The climate on the plains and at Fort Johnston itself is very hot and trying, but on the hills, especially round Mangoche, it is much cooler and is similar to that of the Shire Highlands near Zomba and Blantyre.

On the plains there are several European planters who have flourishing cotton plantations. The natives living in the villages along the Shire river also grow cotton of good quality. There is good cotton land in the west of this district, near the south-west arm of the lake. Along the eastern shore of the lake a good deal of rice is grown by the natives. In the hills, both to the east and west, tobacco has been successfully grown by Europeans, and there are a number of Europeans engaged in this industry round Namwera. The principal cereals grown by the natives are maize, millet and rice. The women also grow large quantities of ground nuts, cassava, beans and sweet potatoes. All the larger villages have extensive groves of bananas and pawpaws round them. Potatoes and onions are aîso grown in fair quantities by the villagers in the Namwera and Mangoche districts.

There are a few herds of cattle round Fort Johnston, mostly owned by Europeans. The natives in the Fort Maguire district have a large number of cattle, sheep and goats. There are also a few cattle near Namwera and Mangoche.

All the rest of the district is infested by tsetse fly and has been denuded of stock by this pest.

The system of government in force in the district is "government of natives through their chiefs."

There is a district resident magistrate with an assistant stationed in Fort Johnston, who is responsible for the administration of the whole district.

The district is divided into seven sections, and each section is under a principal headman, who has councillors and village headmen to assist him in looking after the affairs of his section. The principal headman is directly responsible to the resident.

The sections are divided in such a manner as to coincide as nearly as possible with areas occupied by the different sections of tribes. Thus in the section of which Mponda is the principal 
headman are included nearly all the villages, which in the past acknowledged Mponda as paramount chief, and so on.

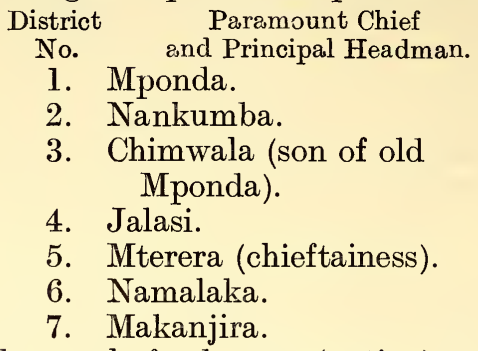

The staple food crops (native) are :--Maize, millet, rice, beans, cassava, sweet potatoes and ground nuts. The natives also make a kind of beer from maize, of which they are very fond.

There is a large native fishing industry at the south end of the lake. The fish are caught in seine nets and in fish traps (baskets). They are then cured in a primitive manner (chiefly dried in the sun) and taken to the native markets in Zomba and Blantyre, where they are sold at 1d. each. The local price is three fish for $1 \mathrm{~d}$.

In addition to three European stores there are native markets at Fort Johnston and Namwera's (Mangoche) at which native grown vegetables, eggs, fowls, sheep and goats are sold. The local price for eggs is $1 \mathrm{~s}$. for 36 , fowls $6 \mathrm{~d}$. each, sheep 7s. $6 \mathrm{~d}$. to $10 \mathrm{~s}$. each. Fowls and eggs are fairly plentiful. The native is rapidly learning to appreciate the benefits of a market and to realise the advantage of a central spot for exchange of goods, and a considerable amount of bartering is seen every day.

The following is a list of the hoed roads in the district :-

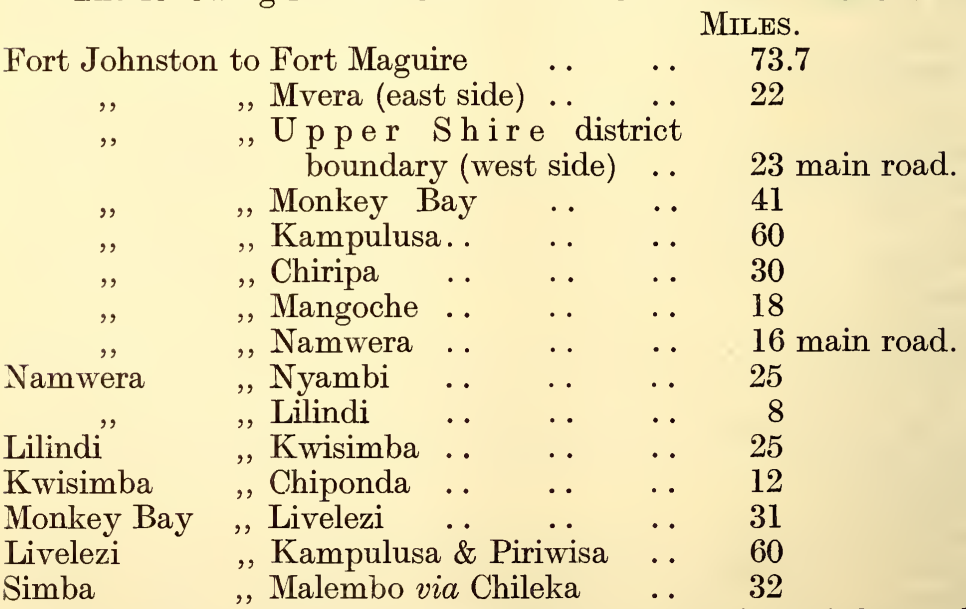

All these roads are from 12 to 15 feet wide and kept clean throughout the year. The following is a more minute description of the principal ones.

The Fort Maguire road is level to a little way past Chilinda's (approximately 60 miles), thence to Fort Maguire (Matola's) it is 
slightly undulating. The road runs parallel with the lake, and at a distance varying from a quarter to half a mile until reaching Chilinda's. At this point the lake shore runs in a west-north-west direction, while the road continues north-north-west and meets the lake again at Matola's. The surrounding country consists of palm and thin forest. Ndoka's (25 miles), Saidi Mzungu (37.8), and Chilinda's (58), form convenient camping grounds. A cycle can be used the whole way except for half a mile of very thick sand near Kadango's village (31 miles), and another stretch of threequarters of a mile between Saidi Mzungu and Lipongo. Some of the larger of the streams are bridged.

There is a good motor road to Namwera, east of Fort Johnston, where there is a Government Rest House. People wishing to go to Fort Mangoche follow this road to Namwera and then take a rough road up the hills to the Fort.

The road to Liwonde (west side) is well made, level, and excellent for motor or ordinary cycle.

The road to Monkey Bay runs parallel with the lake shore at a distance from it varying from half to one mile. The surface is for the most part good, and, notwithstanding one or two sandy places, a cycle, either motor or otherwise, can be ridden as far as Mbwadzulo's village, a distance of 34.3 miles from Fort Johnston; from this point, however, into Monkey Bay (41.1 miles) the sand is too loose to permit of any riding. The journey can be comfortably made in two stages by camping at Chiwalo's (26.8) miles where there is a huge tree giving splendid shade. During the heavy rains a large part of this road is under water. The Tamankokwe is the only large river to be crossed.

The road from Monkey Bay runs across the Livingstonia peninsular, striking the south-west arm of Lake Nyasa at Kasanga's village, and then running parallel with the lake. The Sangasi and Bwanji have to be crossed, but both are dry for the greater part of the year. The Sangasi is $1 \frac{1}{4}$ miles from Kasanga's village, and the Bwanji 20.4 . Between the two rivers mentioned there is a smaller stream called the Nangolokola, running nearly the whole year, but always easily fordable.

For travelling direct from Fort Johnston to the south-west arm of the lake, a road has been made ( 7 miles in length), leaving the Monkey Bay road just after the 33rd mile post, joining the old road again at Kasanga's. This reduces the distance again by 7 miles, and avoids the sand and hills near Monkey Bay.

The remaining roads are hilly and rather rough, and only to be recommended for walking or machila. In addition to the roads tabulated above there are many smaller paths of 6 to 8 feet wide, especially in the western part of the district, connecting village to village.

Some years ago big game was very numerous in this district, but there is now very little game left, and what there is is very scattered. In the Fort Maguire area there are always elephant to be found, but there are no large tuskers left in the herds. The natives in Portuguese East Africa are allowed to hunt elephant 
if they bring in the tusks to the official in charge of the district. It is owing to this that there are no good tuskers left in these herds, which often stray over the border only a few miles inland from Fort Maguire. There is another herd of elephant, which mostly remains in the thick bush round Pirilongwe.

In the hills to the north-east a few kudu and an occasional eland can be found. Eland, kudu, waterbuck, bushbuck, nswala, klipspringer and duiker can be found in the peninsular between the two arms of the lake, but they are not numerous, and shooting in this district means hard work for the sportsman.

Hippopotomi are to be found in the river and along the lake shore, but they are very wary, and it is difficult to get a shot at them. Lion and leopard are numerous, and the former account for a certain number of natives every year; they are especialy numerous along the eastern shore of the lake.

Natives are now and then carried off by crocodiles when bathing or fetching water from the river.

Before the British took the country the eastern and central parts of the district were occupied by several powerful Yao chiefs. Makanjira ruled that part of the district which lies between Fort Maguire and Malindi on the east side of the lake ; Jalasi over that section which lies between the Shire and the lakes Amaramba and Chiuta to the east of the boundary of Portuguese East Africa, and his own village was on Mangoche mountain. Mponda ruled all that part of the district which lies to the west of the Shire as far as Pirilongwe and up to Malembo on the south-west arm of the lake. The western part of the district was held by Chikusis Angoni. All the three Yao chiefs resisted the British when they first came, and it was due to this fact that the three forts, viz., Maguire, Mangoche and Johnston were established. Fort Maguire was established to subdue Makanjira and to prevent the traffic in slaves across the lake. The fort was placed on a rocky ridge overlooking the lake where it is narrowest opposite Rifu point. This was the principal crossing place for bringing over slaves who had been bought from the Angoni living on the highlands west of the Lake. The natives once attacked the fort but were driven off by the garrison composed of Sikhs. It was named after Captain Maguire, who was killed in the fighting there. Fort Maguire is now deserted and is no longer of any military use. Makanjira's old village was built on a sand spit, which had a deep lagoon on one side and the lake on the other, and he had made the place almost impregnable against native attack by building a strong stockade from the lagoon to the lake.

Fort Mangoche is situated on a small plateau near the top of Mangoche mountain not far from the site of Jalasi's old village; this fort is still used sometimes by the King's African Rifles as a training camp. It was of some importance during the war, as it commands the main roads from the northern part of Portuguese Territory to Zomba and Fort Johnston. Fort Johnston, the only township in the district, is the headquarters for the district. There is a European and a native hospital at Fort Johnston. 


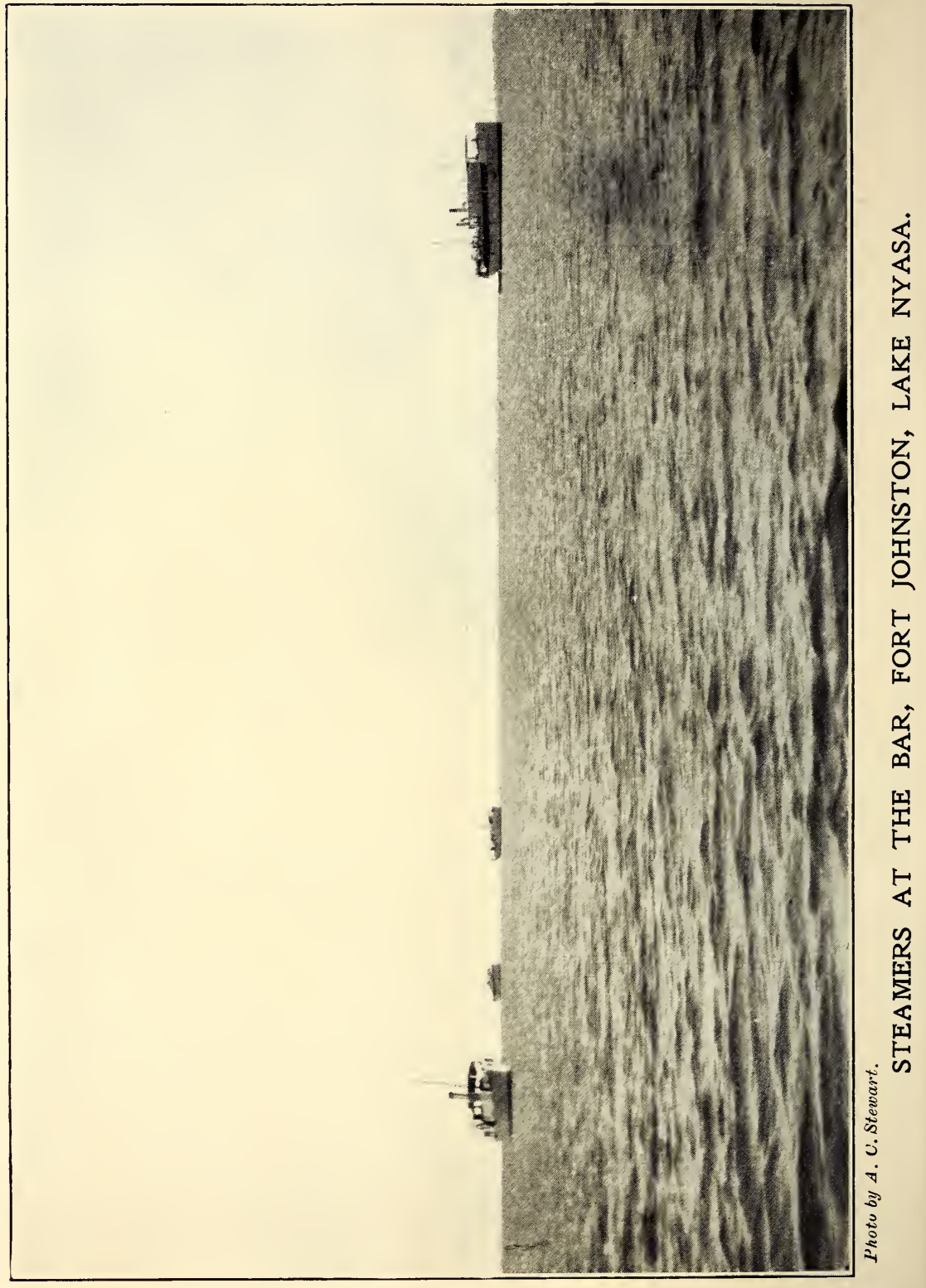


The marine transport department and engineering shops are also there, the latter under the charge of the engineer-commander, who is assisted by two engineers and a shipwright. The senior naval officer and his second-in-command live on the lake shore near the mouth of the Shire, 6 miles from the fort, where there is anchorage for the lake steamers.

There is a telegraph office belonging to the A.T.T. Company.

All the large trading companies have stores, and the African Lakes Corporation also have an engineering shop. A good hotel exists at Fort Johnston.

The Government and the African Lakes Corporation each have small river steamers, which ply between Fort Johnston and the lake. On the lake itself there are seven steamers. Three are owned by the Government, two by the African Lakes Corporation, and two by the Universities Mission. The largest of these is the Government gunboat Gwendolen of about 350 tons.

Fort Johnston was founded in 1891 by Sir Harry Johnston, after whom it is named. The first boma was built at a place about 2 miles further up the river from the present town, but it proved to be so unhealthy, owing to the swamps by which it was surrounded, that it was moved, in 1897 , to the present site.

There were several reasons for building a station at this place. First, it was necessary to check the raiding which took place between Jalasi and Mponda's people. Secondly, it was the most suitable place for the headquarters of the marine department, as the river was then navigable, and the large steamers could come down as far as the town, and the smaller river steamers could go as far as Matope, which is only 30 miles from Blantyre.

Owing to the continual fall of the lake level the river below Fort Johnston is now no longer navigable, and has become blocked up with mud and weeds. As soon as the railway reaches the lake no doubt Fort Johnston township will be moved to a site near railhead.

There are five tribes represented in this district, viz.: Yao, Anguru, Anyanja, Abisa and Asenga. The Yaos are the predominating tribe. They are physically strong and well made and well disposed. They are not naturally fond of agriculture, but make excellent artisans, soldiers, police and servants.

These Yaos may be sub-divided into three distinct classes :Masaninga Yaos, living in the north-eastern part of the district round Fort Maguire; Achisi Yaos, in the east; and Machinga Yaas, occupying the country on the west between the lake and river and a line drawn from Pirilongwe due south to the southern boundary and north-east to Monkey Bay. The tribal mark of all these is the same : two short cuts on each side of the face between the eye and ear. They are not indigenous inhabitants, but have come in as a conquering people from the east, driving out the Anyanja in places and in others settling amongst them.

The Anyanja are an inferior tribe both physically and intellectually to the Yao. They are found mixed up with the Yaos all along the west bank of the river and lake shore, and round Livingstonia and 
the south-west arm of the lake. The Anyanja are the original inhabitants of the whole of the south end of the lake. Before mixing with the Yaos they had no tribal marks on the face. Now, however, they are using the same marks as the Yaos.

The Abisa, who have settled near Livingstonia on the south west arm of the lake, are few in number. They migrated here from the regions round Bangweolo, North-Eastern Rhodesia, some twenty years ago, and are apparently allied to the Awemba tribe. The Asenga likewise, from Luangwa, are evidently of the same branch as the Abisa, their language being closely related and their tribal marks identical. These marks consist of groups of small round dots on the forehead, over each eyebrow, in the centre and on each side of the face.

Yao and Chinyanja are the two languages spoken in this district.

The following is an approximate census of the district:-

$\begin{array}{lcccr}\text { Yaos .. } & . & . & . . & 64,667 \\ \text { Anguru } & . & . & . & 600 \\ \text { Anyania } & . . & . & . . & 13,129 \\ \text { Abisa .. } & . . & . & . . & 804 \\ \text { Asenga } & . & . . & . . & 473 \\ & & \text { Total } & . & \underline{79,673} \\ & & & & \end{array}$

Religions :-

$\begin{array}{lrrrr}\text { Mohammedans } & \ldots & . & 11,112 \\ \text { Christians } & . & . & . & 2,969 \\ \text { Pagans } & . & . & . . & 65,592\end{array}$

The various initiation ceremonies practised by these tribes are still maintained, though slight modifications have been introduced (in particular amongst the Yaos) under the influence of Mohammedanism.

Notwithstanding the constant efforts which are being made to stamp out the "ula" or "chisango," that is, the casting of lots in the event of a death in a village to find out who is the cause, and the drinking of "mwabvi" poison by the accused it is still prevalent with all the tribes.

Another old custom which is now rapidly falling out of fashion is the use of the pelepele (a large disc of lead or wood worn in the upper lip by women). The chipini (a disc of bamboo or lead worn in the nose), also the wearing of several small discs in the ear (a custom brought in from the coast) is becoming very fashionable amongst the Yao women.

A small spear knife in the belt is generally the only weapon now carried by natives when travelling.

The natives are for the most part heathens. If a census were taken by asking each person what his religion is at least two-thirds of the Yao and Anyan'a population would proclaim themselves Mohammedan, but at least half of the number so professing only do so because they consider it will give them a better social 
standing in their villages, and are neither in heart nor in practice Mohammedans. Nevertheless, Mohammedanism is rapidly growing and beginning to compete seriously with Christianity.

There are three missions in the district, viz.:-

The Universities Mission to Central Africa, with two stations, Mpondas and Malindi, and 44 out schools. The Dutch Reformed Mission in the west, with one station at Malembo and 28 schools; and the Baptist Industrial Mission with no school. The U.M.C.A. have also a steamer which is used as a school, and in which they visit the villages along the lake shore. A large amount of medical work is done for the native both at Mpondas and Malindi.

The bar at the mouth of the river is now difficult to cross, and only very shallow draught vessels can reach the lake.

Raiding by natives has, of course, ceased long ago. For these reasons Fort Johnston will most likely be deserted as soon as the railway reaches the lake, and a new town will be built on the lake shore near railhead.

Since the war a good number of Europeans, mostly British, have taken up land in the district for tobacco and cotton planting. The majority of planters have settled near Namweras and Mangoche. These are all planting tobacco. Three or four have taken up land on the plain for cotton, and a few others have tobacco plantations in the direction of Pirilongwe, south-west of Fort Johnston.

No Asiatic has taken up land for planting, but there are a number of British Indians engaged in trade. These are all small traders and cater for the native market only.

List of planters :-

To the east, Namwera and Mangoche division, 17 planters with estates. estates.

To the west, Pirilongwe (Mpali) division, 9 planters with

On the plains, 4 planters with estates.

Indians owning stores in Fort Johnston

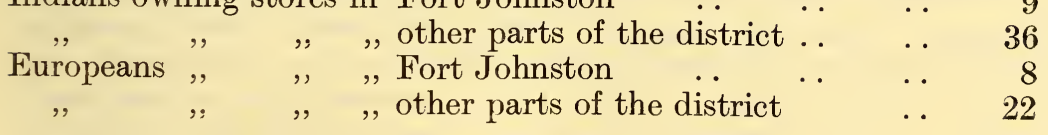




\section{CHAPTER VII.}

\section{THE CENTRAL PROVINCE.}

The Central Province consists of the Ncheu, Dedza, Lilongwe, Fort Manning, Dowa, and Kota-Kota districts. There are a certain number of European planters, and this number will doubtless increase as the communications of the Protectorate develop. Almost two-thirds of the native population of Nyasaland live in the Province, whose area is just over one-fourth of the whole country. The Provincial Commissioner is at present stationed at Lilongwe.

\section{Ncheu District.}

The area of the district is 950 square miles.

The district is divided into eight administrative sections, each under the control of a principal headman.

The boundaries of the district are as follows:-

On the north by a line starting from Beacon No. 9 on the Anglo-Portuguese frontier and running to the nearest point on the Biritsi stream (a distance of about 600 yards); thence along the Biritsi stream to its junction with the Livelezi river; thence along the Livelezi river to its junction with the Dombole stream at Mluma hill; thence along a line drawn in a south-easterly direction to the confluence of the Ngoni stream with the Bwanji river, and thence by a line running due east to Mvera 1 mile south of Lake Pamalombe.

On the east by a line drawn through Zirimbuzi hill on the north and running in a south-westerly direction to a point on the Lisungwe river near its junction with the Mwendang'ombe river.

On the south, from the junction of the Mwendang'ombe and Lisungwe rivers the boundary follows the former river upstream to its junction with the Fumfuli (Fimfi) stream; thence to the source of the Fumfuli ; thence to the nearest point on the headwaters of the Lisungwe river and thence along the Lisungwe river upstream to Beacon No. 27 on the Anglo-Portuguese frontier.

On the west by the Anglo-Portuguese frontier from Beacon No. 27 to Beacon No. 9.

The district may be divided into two portions. The western highland portion consists of the Kirk range, which forms the western border of the district from north to south. The general altitude of this range is about 4,500 feet, with occasional prominent peaks of from 6,000 to 6,600 feet above sea level. The eastern lowland portion is a part of the Shire valley, and gives altitudes of from 2,000 to 3,000 feet. Altitudes of from 3,500 to 3,800 feet are obtained along the foothills of the Kirk range.

The principal rivers of the district are the Livelezi, which flows northwards into Lake Nyasa, the Rivirivi and Lisungwe, 
which flow into the Shire river. All these rivers have a number of tributaries which drain the eastern slopes of the Kirk range. The district is well watered with the exception of an arid area between the Kapene and Lipangwe rivers. The district with the exception of the Kirk range is on the whole well covered with timber. The more valuable timber is found along the waterways.

No part of the district can be said to have a really bad climate. Malaria is more prevalent in the low country, particularly along the larger rivers and in swampy parts. The hot months are also somewhat trying on the lower levels, although the night temperature is not usually excessively warm. The climate and temperature of the worst parts of the disirict are pleasant and tolerable compared with such conditions on the Shire river or the shores of Lake Nyasa. The climate of the Highlands is excellent and in the cold season bracing.

The principal products cultivated in the district are cotton and tobacco. Coffee is produced with some success by the Zambesi Industrial Mission at an altitude of 3,000 feet. The lowest levels are the most suitable for cotton cultivation. A great proportion of the low country is suitable for this crop, and also for tobacco, but the latter crop must be confined to parts which have an adequate water supply for nurseries. The higher levels (up to 3,000 feet) are also to a large extent suitable for tobacco. Wheat is grown in the dry season under irrigation; chillies thrive well.

Cattle can be kept at altitudes of 3,000 feet or more. Below 3,000 there is always a grave risk of tsetse fly. Sheep, goats and pigs thrive in all parts of the district.

The best cattle-land is the Kirk range, but in many parts of this plateau the grazing area is limited by the close proximity of the Portuguese border. Cattle ranching on a large scale would in most parts necessitate the acquisition of grazing rights in Portuguese territory.

The District Administration (Native) Ordinance was introduced in the district in the year 1913.

There is no paramount chief. The names of the eight principai headmen are as follows :-

1. Kwataine.

2. Pfuko.

3. Mpando.

4. Chauya Salima.

5. Mberengwa.

6. Yohane Champiti.

7. Njeromole.

8. Zitonga (pending confirmation of appointment).

Each principal headman is responsible for the good order of the administrative section of which he is in charge, the maintenance of discipline, the reporting of crime and the apprehension of criminals, sanitation, controlling the movement of cattle, reporting outbreaks of epidemic disease, and for other matters in the interest of law and order and of the welfare of the native population. The resident 
uses the principal headman in all ordinary matters as a medium of communication with the natives of his section. He gives his orders to the principal headman, whose duty it is to see that they are explained to and carried out by such of his people as may be concerned. He uses the principal headman for securing the attendance at the boma of natives wanted in connection with deceased estates, remittances, etc., for recruiting labour for Government purposes, for accelerating the collection of hut tax and numerous other matters of purely district administration. This system obviates the constant presence of police in the villages for such purposes, and leaves them free to attend to their proper police duties. The employment of police in matters which have no connection with ordinary police administration gives them opportunities for extortion and oppression, which would not occur in the exercise of their proper functions. The constant performance of extraneous and trivial duties also tends to render the police careless and to lessen their sense of the responsibility of their position as officers of the law. The resident is careful to indicate by his attitude towards the principal headmen and by his dealings with them the fact that they are the chiefs of their respective sections and occupy a position of honour and are entitled to the respect and obedience of their people. Each principal headman is assisted in the performance of his duties by two councillors.

The principal headmen have at present no judicial powers. They are at liberty to hear petty native civil cases if the parties concerned prefer to take such matters to their principal headman instead of to the magistrate. The natives usually elect to take all their disputes to the magistrates.

The resident holds district and section councils periodically as occasion may require. Such councils are attended by the principal headmen, their councillors and the more important village headmen. They are also invariably attended by a large concourse of natives. Opportunity is taken at such councils to explain new laws and regulations and to give orders or instructions which require universal attention and to deal with important matters which need discussion with all the headmen collectively.

This system of administration is giving excellent results and is acceptable to the natives. It is to be preferred to the old system in which the police were used for all purposes. It restores and regulates the power and authority of the chiefs, who under the old system had become merely nominal chiefs with no real part in the affairs of their country.

The staple food of the Angoni is maize, which they cultivate extensively for their own consumption and also for sale. They also grow "mawere" (a small grain like millet), which they use almost entirely for making beer. Other crops cultivated by the natives are sweet potatoes, pumpkins, beans and peas of various kinds, ground nuts and cassava, which give them variety in their diet. Bananas and pawpaws are the only fruits generally cultivated, but of recent years occasional natives have taken to growing mangoes, peaches and pineapples to a limited extent. 
The natives are well provided with goats and sheep. They also own considerable herds of cattle. Pigs are fairly numerous, and fowls universal. Ducks are kept in some villages. Prices have risen considerably since the War and are now as follows :cattle, $£ 4$ to $£ 6$; sheep, 8 s. to $12 \mathrm{~s}$.; goats, $6 \mathrm{~s}$. to $10 \mathrm{~s}$., according to size and sex; fowls, $6 \mathrm{~d}$. each; eggs $\frac{1}{4} \mathrm{~d}$. each.

Zomba-Dedza main trunk road.-This road enters the district at the village of Kalambo on the east and leaves the district at Mlangeni, where it enters Portuguese territory. The length of the section traversing the district is 37 miles. This road is suitable for light motor transport and is even used for heavy lorries during the dry months. The road surface is of earth, and the bridges and culverts are stoutly built of timber on dry stone abutments. From Mangeni the road proceeds through Portuguese territory to Dedza, entering the Dedza district at a point about 4 miles south of Dedza station.

Ncheu-Blantyre road.-This road was constructed as a main road direct to Blantyre as it saves a distance of 40 miles compared with the route via Zomba. It was, however, never made suitable for motor traffic, and is only fit for bicycles and machilas. It lacks bridges over many of the streams. It is seldom used for passenger traffic, but forms a convenient route for the thousands of carriers and other natives who pass between Ncheu and Blantyre during the year. This road, which crosses the Shire river at Matope, enters the district on the south-east at Nziza, and joins the Zomba-Dedza road at Bemvu, 5 miles south-east of Ncheu station. The length of the section within the district is about 30 miles. The total length of the road from Blantyre to Bemvu is 75 miles.

The following branch roads are maintained by Government :--

Kambironjo road.-This road leaves the Zomba-Dedza road at Chipula village, 7 miles north of Ncheu, and proceeds in a south-westerly direction to the Indian settlement of Kambironjo. It affords communication with the Portuguese administrative station of Mtengo-wa-mbalame. The length of the road is 5 miles. Though rather narrow it can be used by motor cars.

Gowa road.-This is a branch road to Gowa Mission station. Length, 7 miles. It leaves the Zomba-Dedza road at a point 1 mile north of Ncheu station. Suitable for motor cycles. It passes by Dombole Mission station at a point $2 \frac{1}{2}$ miles from Ncheu.

Chiole road.-Length, $1 \frac{1}{2}$ miles. This road leaves the ZombaDedza road at the same point as the Gowa road, and proceeds in a north-easterly direction to Chiole Mission station. Suitable for motor cycles.

Dzunje road.-Length, 6 miles. This road leaves the ZombaDedza road at a point 9 miles east of Ncheu station, and proceeds in a northerly direction to Dzunje estate. Suitable for motor cycles.

Nearly all the native villages are connected by hoed paths which are kept cleared by the villagers.

Although not so plentiful as in former years there is still a considerable quantity of game in the district. The following 
species are to be found in the district :-Eland, kudu, hartebeeste, waterbuck, sable-antelope, reedbuck, duiker, oribi, klipspringer, warthog, bushpig, bushbuck and zebra. Elephant and buffalo are occasionally observed, but only wander into the district at very infrequent periods. The carnivora are well represented ; lions, leopards, hyenas, wild dogs and jackals are still fairly numerous.

There are no townships in the district.

The only Government station in the district is Ncheu, which was established in 1902 as a sub-station of the Upper Shire district, and which became the headquarters of the Upper Shire district, in 1908. Since the partition of the Upper Shire district it has now become the headquarters of the Ncheu district.

Before the War there were few settlers in the district. In 1914 the white population numbered about 20 persons, who were nearly all connected with mission work. Since the War there has been a considerable influx of settlers, who have leased land and planted cotton or tobacco. The white population is double what it was in 1914. The acreage held by Europeans in 1914 was 16,821 acres. Since then 11,220 acres have been acquired by settlers on lease, making a total of 28,041 acres held by Europeans at the present time. The cessation of demand in the home markets for such economic products placed the planters temporarily in a serious financial position and discouraged further settlement. It has been shown, however, that such crops can be profitably cultivated in the district.

The Asiatic population, which never exceeded half-a-dozen, remains fairly stationary. These Indians are engaged entirely in native trade, with the exception of one who owns a plantation. The number of Indian trading stores has decreased somewhat since the War. This was partly due to inability at one time to obtain supplies of trade goods, but mainly to the fact that trade goods have reached such a prohibitive price that the natives purchase as little as possible.

\section{Dedza District.}

The area of Dedza district is about 1,200 square miles, and it is bounded by Ncheu on the south, South Nyasa on the east, Dowa and Lilongwe on the north, and Portuguese territory on the west.

The district consists of three portions :-

1. The lake plain.

2. The escarpment and mountain portion along it.

3. The portion of the Angoni plateau to the north-west which runs through Lilongwe to Momberas.

The chief mountains are Dedza and Changoni (about 2,000 feet), Mbonduni, Chirenje and Mpunzi.

From the escarpment range the district slopes to the northwest and is watered by the Lintipe river, which rises on the slopes of Dedza mountain, and its tributaries of Diampwe and those rising on the Portuguese border. 
The district is well watered throughout and very fertile. Wheat is grown at the higher levels, tobacco on the upper Lintipe, and cotton on the Lake plain.

Every variation of climate and rainfall is to be found at different altitudes.

There is no good anchorage along the lake shore, but rice is shipped from Chipola's by the smaller steamer.

The District Administration Native Ordinances was introduced in 1915.

\begin{tabular}{cl} 
Sections. & \multicolumn{1}{c}{ Principal Headmen. } \\
1. & Pemba (Angoni). \\
2. & Kapuka (Chipeta). \\
3. & Tambala (Yao). \\
4. & Kasambu (Angoni). \\
5. & Pemba (Yao). \\
6. & Kachindamoto (Angoni). \\
7. & Masasa (Angoni). \\
8. & Ndindi (Yac).
\end{tabular}

The Zomba-Mzimba trunk road enters the district about 2 miles from Dedza boma, having passed through Portuguese territory for about 24 miles after leaving Ncheu district at Mlangeni.

There is also a motor road from Dedza to Bembeche on the edge of the escarpment down which to the lake shore there is a steep track, impossible for vehicles.

There is a road to Nkhoma, passing the Milanda gap east of Chayoni mountain and crossing the Lintipe by a drift, which is passable for motors in the dry weather, and a similar road from Nkhoma to Mpunzi through the Lintipe plain.

Elephant, buffalo, eland, sable, and all the game indigenous to Nyasaland are to be found except puku and inyala, but game is not very plentiful. Tsetse fly are prevalent between the escarpment and lake shore.

Dedza was founded as a Government station in about 1900 , and was the original headquarters for all Central Angoniland. It is the only European settlement in the district.

There are four mission stations in the district. Mpunzi, of the Dutch Reformed Church Mission, and Bembeche, Mua and Ntaka-taka, of the White Fathers.

Tobacco is grown on several estates in the centre of the district and cotton below the escarpments.

Dedza, Dowa, Lilongwe and Fort Manning were all originally included in the district of Central Angoniland.

The original Chipeta (Achewa) inhabitants were largely dispossessed by Angoni and Yaos, and the population is now very mixed.

Tambala, a Yao chief from the east coast, owing to continual raiding, was driven out, but was reinstated in 1910 .

The Dedza Angoni are related to the Ncheu Angoni, who came in round the south of the lake and were at continual warfare with the northern Angoni under Chiwere (Dowa) and the Yaos under Tambala. Kachindamoto of Ntaka-taka is the leading Angoni chief. 


\section{Lilongwe District.}

The area of the Lilongwe district is 2,212 square miles.

The boundaries are as follows:-

North. Domira Bay-Fort Jameson telegraph line from the Bua river crossing to point of intersection with Nambuma stream.

East. Centre of Nanbuma stream, from its point of intersection with the Domira Bay-Fort Jameson telegraph line to its second crossing of the Dowa-Kongoni road, thence the north side of the Dowa-Kongoni road to the Lombadzi river crossing, thence the centre of the Lombadzi river to the Dowa-Nkhoma district road crossing, thence the west side of the Dowa-Nkhoma district road to its nearest point to the Katete stream in the Chirenji-Nkhoma pass, thence the centre of the Katete stream to its confluence with the Lintipe river.

South. Centre of the Lintipe river from its confluence with the Katete stream to its confluence with the Diampwe river, thence the centre of the Diampwe river upstream to its source on the Anglo-Portuguese boundary.

West. The Anglo-Portuguese boundary (watershed on the Dzalanyama mountains) northward as far as the source of the Namitete stream, thence a line drawn along the east bank of the Namitete stream to its confluence with the Bua river, thence the east bank of the Bua river to its crossing at the Domira Bay-Fort Jameson telegraph line.

For administrative purposes the district is divided into five sections with boundaries as follows:-

Section 1. Main road to Dowa from Lilongwe station to the Lombadzi river. Lombadzi river downstream to its crossing at the Dowa-Nkhoma district road. Dowa-Nkhoma district road to its crossing of the Lilongwe river. Lilongwe river upstream to Lilongwe station.

Section 2. Northern boundary of district to the Lombadzi river. Dowa main road from Lombadzi river to Lilongwe station. Old road from Lilongwe station to Bua river at Kongoni. Bua river to the Dowa-Domira Bay telegraph line.

Section 3. Old road from Lilongwe station to Bua river. Namitete stream from its source to confluence with Bua river. Likuni stream from its source to its confluence with the Lilongwe river. Lilongwe river downstream to Lilongwe station.

Section 4. Likuni stream from its source to its confluence with Lilongwe river. Lilongwe river to Lilongwe station. Dedza main road from Lilongwe station to district boundary. District boundary to Anglo-Portuguese (district) boundary. AngloPortuguese boundary to source of Likuni stream.

Section 5. Lilongwe river from Lilongwe station to DowaNkhoma district road. District boundary to Lintipe. District 
boundary as far as the Dedza main road. Dedza main road to Lilongwe station.

Practically the whole of the district may be described as an undulating plain at an average altitude of 3,000 feet above sea level. The south-east portion is characterised by a number of small rocky hills or kopjes, which rise abruptly from the general level of the country and are not connected with any definite range of hills. The following are the most conspicuous :-Ngala, Bunda, Malingunde, Kachawa and Mchesi and Zanzi rocks. The extreme south-west part contains the Dzalanyama mountains, the watershed of which forms the Anglo-Portuguese boundary. This region may be described as mountainous, the principal peaks being Kasitu 7,000 feet, Kadedwa 6,800 feet, Kampambe 5,500 feet, and Dzipungu. The only rivers of any importance are the Lilongwe and the Bua, which forms the western boundary for some 20 miles. The Lilongwe river rises in the Dzalanyama mountains and flows through the middle of the district in a north and north-east direction. It has numerous tributaries, of which the Katete, Likuni and Lingadzi are the most important in this district, and contains an abundant supply of water throughout the year. All the many smaller streams or dambos which feed these rivers dry up almost entirely in the dry season and water has to be obtained by digging wells. The Bua is one of the biggest rivers in the Protectorate, but only touches this district on the western border, where it consists of a series of swamps, which can only be crossed at certain points, even in the dry season. In general, the district can be called well wooded. From the Dzalanyama range a vast belt of forest extends as far as Bunda hill; large and numerous dambos or plains are, however, interspersed in the forests, which are composed mainly of trees which do not produce useful timber, thorn trees, such as mitete and misangu, mombo, used by natives for making bark cloth, chiumbu, msumwa, nchere, ditimbe, kadale and balitsa. There is a certain amount of mlombwa and a tree known as msambamfumu which yields a fair timber of a pronounced reddish colour. The dambos and much of the forest country are covered with a dense growth of the chipeta grass which renders travelling off the beaten tracks practically impossible for a great part of the year. The climate is fairly temperate, owing to the altitude, and the temperature rarely exceeds $90^{\circ}$ in the shade, often falling to freezing point on the grass in some localities during June and July in the early mornings. The rainfall over a period of fourteen years averages 33.69 inches, varying from a minimum of 21.92 inches to $56 \cdot 31$, the latter however, being quite exceptional. All the usual native food crops flourish well with the exception of rice, and it has been found that tobacco can be grown with success. Cotton has been tried at various times, but it is thought that the country on the whole is too windswept and exposed for the successful cultivation of this crop. Wheat can be grown under irrigation in some parts of the district, but the rainfall is not sufficient for the more tropical crops such as rubber and tea. 
The District Native Administration Ordinance was introduced into the district in May, 1913. For the purposes of this ordinance the district is divided into five sections, each in charge of a principal headman and two councillors. The names of the principal headmen are as follows :-

Section 1. Principal headman, Chimdidi.

Section 2. Principal headman, Matanda.

Section 3. Principal headman, Masumba.

Section 4. Principal headman, Masula.

Section 5. Principal headman, Mazengera.

The principal headmen are responsible for the order and good government of their respective sections, upkeep of district and village roads, and all the other duties defined by the District Native Administration Ordinance. District councils are held at least every alternate month, often at more frequent intervals, and sectional councils at frequent intervals. The principal headmen have limited powers of jurisdiction in civil cases and to a certain extent in minor criminal cases. For the purposes of hut-tax collection the principal headmen are advised to encourage all taxpayers to come in to the station, but with a view to checking the more distant parts of the district and saving many natives a considerable journey permanent camps are formed at least twice a month during the season in alternate sections (in most cases at the village of the principal headman), and tax collection is carried on at these sectional headquarters under the supervision of the resident or assistant resident. Native courts for the settlement of minor civil cases. are also held at these camps, but the bulk of the judicial work is done at Lilongwe, where the court sits three times a week all through the year.

The staple foods are naize, millet and mawere, a small grain grown chiefly for making into beer, cassava, sweet potatoes, beans, peas, ground nuts, pumpkins, mushrooms, locusts and white ants. (termites), which are caught when emerging in their winged state from the antheaps and eaten in the form of a paste as a relish. A certain kind of large caterpillar is also much sought after at certain seasons. Fish are caught in the larger rivers, such as the Lilongwe and Bua in the dry season, the chief varieties are mpende, mlambe, sanjika, chambo and kambuzi. There are a fair number of native cattle, sheep and pigs in most of the villages, and goats are very plentiful and form the chief asset of the Chipeta portion of the population. Fowls are also kept in large numbers and can always be obtained.

The Lilongwe section of the main road from Zomba to Fort Jameson begins at the Diampwe river, distance to Lilongwe station 20 miles. There are two fairly large bridges on this section, viz., at the Natenji and Nanjiri streams. The second section extends from Lilongwe station to the district boundary at the Namitete river, a distance of 30 miles. The Namitete is spanned by a pole bridge which is maintained by Lilongwe station.

The Lilongwe river at the station is crossed by a new brick bridge of seven spans, one of the largest road bridges in the country. 
The whole of this road is fit for light motor traffic throughout the year. The main road to Dowa extends from Lilongwe station to the Lombadzi river, $16 \frac{1}{2}$ miles. There are three bridges on this section, at the Lingadzi, Dothe and Mchenzi streams, and a great number of culverts which require constant attention.

Lilongwe to Bua river at Kongoni, 40 miles. This is the old Fort Jameson road and is in fairly good condition, having no large bridges.

Iilongwe to Malingunde via Likuni, 17 miles, only fit for motor bicycle traffic. Malingunde to Nkhoma across country, about 26 miles.

Lilongwe to Masulas along right bank of Lilongwe river, 16 miles.

Old Dowa-Kongoni road from second crossing of Nambuma stream to Kongoni, about 30 miles. The villages of the principal headmen are connected with the main roads by hoed tracks suitable for motor bicycle traffic, and there are numbers of similar tracks connecting most of the important villages. It is possible to travel almost anywhere in the district by light-weight motor-bicycle during the dry season.

All the species of big game known in the Protectorate with the exception of gnu, inyala and nswala (mpaliah) are to be found in this district. Elephant are numerous at certain seasons, and do considerable damage to native gardens and occasionally even kill natives ; eland are more numerous than in most districts, sable, roan, hartebeest and reedbuck are also common. Herds of buffalo live in certain localities and hippopotami are to be found in the Bua and Lilongwe rivers. The smaller game, such as duiker and oribi, are very plentiful. Of the beasts of prey, lions and leopards are common and occasionally destructive to cattle and other livestock, and also claim a certain number of human victims every year. The spotted hyena, hunting dog (lycaon pictus), and the serval and the smaller felines are all fairly common and the cheetah is occasionally found. There is a variety of game birds including at least twelve different species of geese and duck, i.e., spurwing, Egyptian and knobnose geese, the so-called dwarf goose (nettapus auritus), two species of treeduck, the African teal, the red-billed pintail, black duck, yellow-bill, pochard and stiff-tailed duck; the common guinea fowl, two species of francolin, the black-bellied bustard, and two species of quail.

The Central Angoniland Game reserve extends in this district from the Dedza boundary as far as Lilongwe station on the west side of the Zomba-Fort Jameson main road, the Dzalanyama range as far as the source of the Katete stream, the Katete stream to its confluence with the Lilongwe river, and the Lilongwe river to its crossing by the Fort Jameson main road being the other boundaries. It has been observed that big game are no more abundant in this area than in any other part of the north-west portion of the district.

No tsetse fly have as yet been discovered in the Lilongwe district. 
Lilongwe is the central district of a group which used to be known as Central Angoniland, and which included Dedza, Lilongwe, Dowa and the Fort Manning division. In the early days of the Protectorate this country was administered from Dedza with a sub-boma at Chuwamba on the Nkhoma-Dowa road; the headquarters were afterwards at Dowa for a short time and finally at Lilongwe which was established by the late Mr. H. C. McDonald, C.M.G., in 1903. Later, Dedza was made into a separate district and then Dowa (in 1914), and now the districts are all separate, but form with Ncheu and part of Marimba the Central Province.

The relative numbers of the various tribes are as follows :-

$\begin{array}{lllr}\text { Achewa } & . & \ldots & 92,458 \\ \text { Achipeta } & . & . & 4,073 \\ \text { Angoni } & . & . & 11,544\end{array}$

There are also in the extreme south-west a few villages of Azimba, who have immigrated within recent years from Portuguese Zambezia. Amongst the Achipeta and Angoni, spirit worship is still the chief form of religion. There only exists among these races a small difference in the personality of the spirits, i.e., the Achipeta worship the spirits of their dead uncles and grandmothers, which personages are looked on even in life as their household gods. The Angoni worship chiefly the spirit of their deceased fathers. There is also some vague conception of a Great Spirit and of other lesser spirits which control the rains, etc. In continued droughts prayers are made to the rain spirit, generally from the top of the highest hill in the neighbourhood. There is general belief in the transmigration of souls, and a lion which becomes a man-eater is thought to be possessed by the spirit of some man who wishes to injure the people. The whole belief in ufiti (witchcraft) and the practices of the ula (lot), leading to the various ordeals (l) by mwabri poison given to the suspected persons or, by proxy, to their dogs, fowls, etc., (2) by boiling water, are common to all tribes and are too well known to need mention.

The language spoken all over the district is Chichewa, a branch of Chinyanja, differing in many details and the use of peculiar words, but on the whole the same language as that spoken by the aboriginal Amanganja wherever found in the Protectorate. Chingoni is really known only by a few of the older natives and is rapidly dying out for general use.

Lilongwe station was established in 1903 ; it consists of the Government buildings, viz., offices, residency (a new residency has just been completed), assistant resident's house, dispensary, resthouse, police lines, prison and stores. The European quarter, also on the left bank of the Lilongwe river, contains stores and dwelling houses of the African Lakes Corporation, Ltd., Kubula Stores and London and Blantyre Supply Co. The Asiatic quarter is on the right bank of the river and contains some eight stores belonging to various Indian traders. 
There are two mission stations in the district, The Dutch Reformed Church Mission at Malingunde, 17 miles from Lilongwe, and the White Fathers at Likuni, 5 miles. There are also two European plantations at Mbabzi, about 8 miles from. Lilongwe on the old Fort Jameson road, the chief crop grown being tobacco. An experimental plot of cotton was planted on one of these estates.

The European and Asiatic population as ascertained at the General Census in April, 1921, was as follows :-

Europeans.

Asiatics.

$\begin{array}{lccc}\text { M. } & \text { F. } & \text { M. } & \text { F. } \\ 13 & 9 & 1 & -\end{array}$

\section{Fort Manning District.}

Fort Manning district, 1,892 square miles in area, is divided into three sections, whose boundaries are defined as follows:Sections "A" and "B" by Proclamation No. 15 of 1914, and section "C" by Proclamation No. 7 of 1921, published in the Government Gazettes. Looking at a map, therefore, the sections appear from north to south in the order "C," "A " and "B."

The district is bounded on the north by the Rusa river from its junction with the River Bua upstream to its junction with the Livelezi river; from this point the northern boundary is an imaginary line drawn from the junction of the Rusa and Livelezi rivers to Nauzi hill on the Rhodesian boundary in a west-north-west direction.

On the west by the Rhodesian boundary.

On the south by the Rhodesian and Portuguese boundaries.

On the east by the Mtete river to its junction with the Bua, and thence the Bua river downstream to its junction with the Rusa at Kasera's, the point of commencement.

The district forms part of the Central Angoniland plateau, and the altitude averages well over 3,000 feet, the highest peak reached in the Mchinji hills being 6,200 feet above sea level; the whole extent of the Rhodesian boundary is particularly hilly, Fort Manning station itself being at a height of 4,000 feet. The climate is quite suitable for Europeans, and the maximum temperature seldom reaches $95^{\circ}$.

The country north of the African Trans-continental Telegraph line is of lower altitude, and tsetse fly is met with. A very large area of country in this part of the district lying between the rivers Bua and Livelezi is uninhabited, and "dambos" are larger and more often seen than elsewhere.

The whole country is well watered by the Bua and its tributaries; this river is the longest and most important river of Central Angoniland and rises close to the Rhodesian boundary, a few miles west of the Mchinji hills and not very far from Fort Manning station. After flowing eastwards in a semicircle for about 35 miles it turns 
to the north, and enters Lake Nyasa above Kota-Kota. The Livelezi, Rusa, Mtete, and Likase are also important rivers. The smaller streams are usually dry from June till October, and natives have to dig several feet to obtain water.

The soil is sandy and of a reddish and blackish colour, the last named being generally considered the most fertile.

The average rainfall is 30 inches per annum.

Wheat has been tried with success by both Europeans and natives, but owing to the distance from the towns and the cost of transport it is not grown to any large extent. It seems to do best when grown in dambos or under irrigation; wheat sown during the rainy season does not appear to be very satisfactory.

Tobacco has been tried with success by Europeans, and a small tobacco patch often forms part of a native garden. Cereal crops do very well.

Although on the whole well wooded, the district has been denuded in parts of its timber supply by the usual wasteful methods of native agriculture.

The District Administration Native Ordinance was first applied to the district by Proclamation No. 14 of 1914 . Under this Ordinance the district is divided into three administrative sections as stated above. Each section is presided over by a principal headman, who is appointed and paid by Government and is responsible for the good order of his section. He has specified duties to perform, in which he is assisted by two councillors.

The following are the principal headmen of the district.

$\begin{array}{cl}\text { Section. } & \text { Principal Headman. } \\ \text { A. } & \text { Zulu. } \\ \text { B. } & \text { Mlonyeni. } \\ \text { C. } & \text { Mkanda. }\end{array}$

The staple food crops are :-maize (chimanga) and millet (mapira and mawere).

Native beans (nyemba), ground nuts (ntedza) and sweet potatoes (mbatata) supplement the food supply to some extent. area.

Cattle, sheep, goats and pigs are kept, except in the "fly"

Fish caught in the Bua, Rusa and Mtete, known to the natives as "mlamba" and "matemba," are not suitable for Europeans.

The main trunk road from Zomba to Fort Jameson runs through the district for a distance of 42 miles. Commencing at a bridge over the Mtete river, which at that point forms the Lilongwe-Fort Manning inter-district boundary, it passes through several "dambos," until the river Bua is crossed by pontoon ferry at Likasi, a distance of 15 miles; thence through several more "dambos," until Fort Manning is reached, a distance of 21 miles. The river Bua is crossed again $\frac{1}{2}$ mile beyond the Boma, and runs through the White 
Father's Mission at Kachebere for another $3 \frac{1}{2}$ miles to a bridge 2 miles beyond the mission which forms the boundary between the district and Northern Rhodesia.

From Fort Manning to Kongoni on the Bua, a distance of 26 miles, runs the old Fort Jameson-Dowa road, which follows the present main road to Lilongwe for a distance of 12 miles.

Another district road runs from Fort Manning to Chimimbe hill, a distance of 21 miles, on the southern boundary between the district and Rhodesia.

From Fort Manning to Mchinji Mission a road 7 miles long runs on the slopes of the Mchinji hills due northwards.

From the Bua near Sante's village on the Kota-Kota-Fort Manning boundary a district road extends to the Rhodesian boundary, a distance of 41 miles. This is the old main road from Kota-Kota to Fort Jameson and is level until the Mchinji hills are reached.

The district is well supplied with game of almost every species to be found in Nyasaland, including elephant, hippopotamus, rhinoceros, buffalo, eland, sable, roan, hartebeest, zebra, waterbuck, puku, etc. Every year elephants do great damage to native gardens. Lions and leopards are found everywhere and seem to be increasing in numbers. The game are believed to be the cause of the spread of the "fly" from the north, but this has not been definitely established.

Fort Manning station was originally a military post and was named after Lieutenant-Colonel Manning, afterwards Governor of the Protectorate, who, with a force of Protectorate troops, was instrumental in suppressing the Angoni under Chief Mpeseni. Fort Manning became an outpost of the British Central Africa Regiment, now the King's African Rifles. In 1911 the civil administration took over the station, and Mr. A. J. Brackenbury was the first assistant resident to take charge, the country from the telegraph line to the Portuguese border being named Fort Manning subdistrict, with administrative headquarters at Lilongwe.

So far as recorded history relates the Achewa or Achipeta tribes are the indigenous inhabitants of the district-it is known that they were living here long before the Angoni invasion took place-the Achewa, who lived on the lake shore of Central Angoniland, ascended the plateau owing to the necessity of finding new homes for their expanding numbers; those who did so changing their name to "Achipeta." The word "Chipeta" means long grass, which they found growing all over the plateau; the Achewa or Achipeta are, therefore, natives of one stock, and are probably descended from the Amalawi race.

The Achewa speak a language known as Chichewa, whilst the Angoni once sroke a language known as Chiwazi, which, by intermixture with Chichewa, has ceased to exist. The Angoni intermarried with the people they conquered; Chichewa is for all practical purposes synonymous with Chinyanja, the "lingua franca" of the country. 
The inhabitants of the district, to whichever tribe they belong, are fast becoming one by intermarriage: the lighter Zulu colour can sometimes be seen, more especially amongst the Angoni chiefs., This tribe has to a large extent lost its previous warlike characteristics, although on ceremonial occasions the Angoni still don their old war dresses, usually consisting of a huge kilt of animals' tails and head-dress of zebra mane or black cock's feathers. They wear frills round the ankles, and the large shields which they carry complete a very warlike appearance.

Their tribal marks are usually a hole pierced in the lobe of the ear into which a quill is inserted.

Marriage amongst them is a question of purchase, the intending husband giving from five to ten goats or sheep if he is poor and five to ten head of cattle if he is well to do to the father of his future wife. When married the wife lives in her husband's village.

The law of succession amongst them is from father to son, usually the eldest son of the first wife.

The principal Angoni dances are Ng'oma, Chipe, Mzangaza, and Nsindo."

The Achewa and Achipeta are a timid and gentle race, and perhaps this is not to be wondered at, as they were subjected to continual Angoni raids for so many years. They are physically quite strong, and large numbers engage in carrier transport every year or work on "down" country plantations so as to earn money to pay their taxes, whilst others go farther afield to the mines of Southern Rhodesia. The total lack of European plantations in the district precludes them from earning money near their homes.

They have no tribal mar:s of their own but copy those of the Yao.

The Achewa marriage usually consists of a present given by the man to the brother of his intended wife, consisting of a few goats or fowls and some beads. This is given before the man may even know the name of the girl that he is to marry. He then builds a hut for her in her father's village, and when it is built they become man and wife, but not before.

An Achewa is succeeded by his nephew, always a sister's son. Chitoto.

Their principal dances are Gulutu, Kacheche and

The census returns of 1921 show a total native population of 18,630 for the district, composed of 12,626 Achewa, 3,480 Angoni, 2,474 Achipeta and 50 belonging to other tribes.

It is computed that the native Christians number 2,127, Mohammedans 10, and Pagans 16,493.

Spirit worship exists amongst the tribes inhabiting the district, e.g., the Achipeta worship the spirits of their dead uncle and grandmother, whilst the Angoni worship the spirit of their deceased father.

Totemism is customary amongst them. Every man has a clan name apart from any individual name which he may bear; this name is usually that of some animal or plant ; anyone bearing that name may not destroy, eat or kill the animal whose clan 
name he bears nor may he wear its skin. The law of exogamy which arises out of this system and which is a part of it forbids two persons of the same clan name to marry; this system which has grown up with mystic rites for long ages is in all probability a survival of the native way of preventing the evils of intermarriage amongst relations. This rule of taboo, however, is ignored amongst the Achewa.

There are two Missionary settlements in the district:-

(1). The White Fathers, who established a mission at Kachebere in the year 1903. (Kachebere is 4 miles west of Fort Manning on the main road to Fort Jameson.)

(2). The Dutch Reformed Church Mission started work in the district in 1901, but did not establish a permanent station until 1916, when they obtained a lease of 100 acres of land at Mchinji, about 7 miles north of Fort Manning, on the slopes of the Mchinji hills.

There are no European plantations or Asiatic settlements in the district. A few Indians have native stores, but there are no resident Asiatics.

Fort Manning ceased to be a sub-district, and became a full district by Proclamation No. II. of 1921 under the British Central Africa Order in Council, 1902 ; a new section north of the telegraph line and formerly administered from Ngara being added to the existing sub-district, and forming with it the district of Fort Manning.

\section{Dowa District.}

Area 2,710 square miles, with a population of 94,102 , consisting of 43,242 males and 50,860 females.

The district is divided into four administrative sections under principal headmen, assisted by councillors and village headmen.

On the east the district is bounded by Lake Nyasa, from the southern boundary of the Kota Kota district to a point about $1 \frac{1}{4}$ miles north of the mouth of the Lintipe river at Mtonda's village, where the old hoed road which divides the villages of Chief Pemba from those of Chief Maganga reaches the western shore of the lake, and includes all the islands of Lake Nyasa lying between a line drawn due east from the mouth of the Chirua river and a line drawn from the point $1 \frac{1}{4}$ miles north of the mouth of the Lintipe river to the point where the Anglo-Portuguese boundary reaches the eastern shore of the lake.

On the south the boundary runs by the said old hoed road in a north-westerly direction for a distance of about 7 miles until it reaches the Lintipe river, thence by the middle of the Lintipe river upstream to its confluence with the Katete stream.

On the west by the eastern boundary of the Lilongwe district.

On the north by the southern boundary of the Kota Kota district from the confluence of the Bua river and the Rusa stream to Lake Nyasa. 
The district may be divided into three parts :-

1. The eastern or low-lying country between the lake and the foothills. This stretches from the lower Chirua to the lower Lintipe rivers, and in from the lake to the foothills, and has a length of about 45 miles and an average width of from 10 to 25 miles. The whole of this section is very flat, and rises but a few feet above lake level. The whole of it is well wooded, with well-grown timber in marked contrast to the denuded state of the high-lying plateau country. At the southern end at Rifu a few small hills rise suddenly from the plain to the height of 300 feet, forming a conspicuous landmark; the most northerly hill projects into the lake, and its water-worn sides to the height of 30 feet above present lake level indicate how greatly the lake has fallen.

There is a small bay at Rifu, but the anchorage is not good, the bay being exposed to the prevalent south-east winds. Opposite Maganga's village occur the two small cone-shaped Malile islands. Northward, opposite Domira bay, Banje island is situated, a conical rock, small and uninhabited.

Domira is a large well-sheltered bay, with good anchorage. Owing to the swampy nature of most of this section during the rains and the absence of water in the dry season the villages are confined for the most part to the lake shore or the banks of the rivers.

2. The central plateau lies between the upper Chirua and Lintipe rivers, rising by a series of hills to more undulating country, broken by a series of higher hills. The following rivers flow through it from west to east, the Lintipe coming in from the Dedza district at Nkhoma hill, and entering the lake at Chitije. About 20 miles north of the Lintipe flows the Lilongwe river, which, after passing through the Lilongwe district, enters this district at its junction with the Lombadzi stream, and after flowing for some 25 miles joins the Lintipe at Nangoa. The Lingadzi river flows through the central part of the district after rising near Chiponda, and enters the lake not far from the northern boundary.

Between the Lilongwe and Lintipe rivers lies a long range of hills forming the watershed between these rivers. At the western end of this range lies Nkhoma mountain, a large rugged hill with high peaksat its western and southern ends. To the east of Nkhoma lie the high hills of Tuma, which stretch away to the east until they form the point near Nangoa where the Lintipe and Lilongwe rivers join.

The whole of this country is very rough and broken, intersected with many small streams. Northward towards the Lingadzi and beyond again to the Chirua the country is a series of steep, bare hills, covered with grass but denuded of timber. The most important of these hills are :-Kasu hill near Mvera; Kongwe mountain, a few miles north of the Government station at Dowa; Chisuni, 6 miles south of Dowa; Sachi hill, slightly to the south of Dowa ; and Chiponde hill, near the Lungudzi stream to the west. 
3. The third division consists of the western plain lying between the western foothills from the Lungudzi to the Bua river. The whole of this plain is well wooded and is very fertile, but during the dry season water is scarce and bad.

The climate of the eastern portion is hot and unhealthy, and the whole division, with the exception of a small area in the immediate neighbourhood of Domira Bay, is infected with tsetse fly, while the northern part to the Chirua was originally scheduled off as infected with sleeping sickness. Much of the soil is fertile and cotton has been successfully grown; while along the lake shore there is a considerable industry in native grown rice.

The climate of the central plateau and western plain is cool and healthy, these districts lying at an elevation of from 3,000 feet to 4,500 feet at the Government station. Native foodstuffs, maize, millet, beans, and ground nuts are grown in large quantities, while wheat has been successfully introduced, being grown under irrigation by the Dutch Reformed Mission and to a certain extent by native cultivators on the damp dambo.

With a view to enlisting the services of the chiefs in the government of the district, the District Native Administration Native Ordinance was applied in June, 1919. With this object the district was divided into four administrative divisions:- No. 1 of which Chiwere is the principal headman, and which consists of two-thirds of the whole district. He is assisted by seven Indunas or councillors, Mponera, Mkukula, Msakambewa, Chimbalanga, Chiponda, Mtalimanja and Nguluwe. Division 2, a small division on the lake shore of which Makanjira is the principal headman, assisted as councillors by Kumbemba and Kalaunda, the latter being a woman. Division 3, another small lake division of which Maganga is the principal headman, having as councillors Chizui and Mlima. Division 4, into which has been absorbed a portion of the former Ngara sub-division of Marimba, including the original Ngara boma, of which Dzoole is principal headman, with Kayembe, Kayembe Kasilika, and Dzoole as councillors.

The staple food crop of the district is maize, though a considerable quantity of millet is also grown. Beans, peas, and ground nuts are also produced in considerable quantities, while the nativegrown rice crops average 100 tons. Fishing is carried on successfully in the lake shore villages, and the natives own large herds of cattle and very large numbers of goats. The annual count at the close of the year 1920-21, gave the following figures:-cattle, 14,216 ; sheep, 6,207; goats, 34,739; pigs, 205.

A main road runs from the Lilongwe border at the Lombadzi river to the Government station at Dowa, a distance of 14 miles, and thence, more as a district road to Ngara, 33 miles, continuing northward to the Kota Kota boundary. An equally good road connects Domira Bay with the station, a distance of 44 miles, and a waggon road runs from Dowa to the Dutch Reformed Church Mission's head station at Nkhoma, 44 miles. Another road connects the station with Fort Manning, running through the district to its border at the Nambuma stream. Inter-village roads are hoed 
under the supervision of the headmen of the respective villages, while a short district road connects Dowa with Nchisi in the Kota Kota district.

While little or no game is found in the central part of the district, it is still plentiful near the lake, along the Lingadzi and Chirua rivers, and particularly so on the western boundary along the Bua and in the neighbourhood of Ngara. Elephant are found along the Bua and on the plain near the lake, buffalo are on the Lingadzi and near the lake, rhinoceros live near the Bua, hippopotomi are found both in the Bua and lake and do considerable damage to native crops. Kudu are scarce. Sable, roan, eland, zebra, hartebeest, waterbuck, bushbuck, reedbuck are all found both along the Bua and also in the neighbourhood of the lake. Jions are numerous and are to be found in all parts of the district, and the same remark applies to leopards. Oribi and steinbuck, wart hog, and bush pig are also to be found in most parts of the district.

Duck of various species and geese are numerous on the Bua, as well as along the lake shore and in the marshes bordering the lake. Francolin and guinea fowl, while not plentiful, are to be met with in most parts of the district.

There are four tribes inhabiting the district, the Ngoni, which is the principal tribe and numbers 55,842, scattered throughout the district, the Chipeta, numbering 30,787 , who are mainly found in the western parts, the Yao, numbering 4,209, and the Myanja, numbering 3,264, who live in the lake regions.

The Angoni have lost their distinctive language and speak the language of the Achewa, the latter together with the Chipeta, Yao and Anyanja retaining their own languages.

Considerable areas of land have been alienated for European settlement, a total of 20,184 acres being held in freehold. Of this total 3,454 acres are held by the Dutch Reformed Church Mission, who have four stations in the district, Nkhoma, the principal station, Mvera, Kongwe and Maganga. A considerable industry has been started by this mission in the making of basket work chairs, tables, etc., while weaving has also been started at Mvera, and tanning and bootmaking at Kongwe.

No land has been taken up by Asiatics for agricultural purposes, the Banyan community confines itself to trading, holding 23 stores in various parts of the district for native trade.

\section{Kota-Kota District.}

Kota-Kota is situated on the western shore of Lake Nyasa between the parallels of latitude of $12^{\circ} 5^{\prime}$ south and $13^{\circ} 25^{\prime}$ south, has an area of about 2,411 square miles, and is, for the purpose of administration, under the District Administration (Native) Ordinance, divided into seven sections. It is a port of call for the Government steamer H.M.S. Guendolen, the African Lakes Corporation steamer Queen Victoria, and the Universities Mission to Central Africa steamer Chauncey Maples. Each of these ships calls once a month. 
The district is bounded on the north by the Dwangwa river, on the south by the Chirua stream from its mouth on the western shore of the lake, up stream to its source, thence in a westerly direction south of the Chinji hill to the source of the Kasangadzi stream, down stream to a point near Dzoole some 4 miles more or less east of the Dowa-Ngara main road. On the west by the Kasangadzi stream down stream in a straight line to the confluence of the Kasangadzi stream and the Bua river, from the north side of the Bua river at a point where the Chimpoyo stream enters, and north to its source, and thence from the source of the Liwala stream to its confluence with the Dwangwa river. On the east by the western shore of Lake Nyasa, including Likoma, and Chisumulu islands, and the islands of the lake lying between a line drawn due east from the mouth of the Dwangwa river, and a line drawn due east from the mouth of the Chirua river.

The principal rivers are the Bua, Dwangwa, Kaombe, Chirua and Lifuliza. These rivers are more or less perennial, but in an abnormally dry season the Chirua is the only one which continues to flow. Although the Bua and Dwangwa dry up in places they are always left with extensive pools.

The district is divided into two distinct geographical areas; the lake shore and the undulating plateau to the west, which is part of the great Angoni plateau beyond the Nchisi-Chipata range of hills. The lake shore strip extends from Lake Nyasa to the base of the Nchisi-Chipata hills, varving in extent according to the coast line. It is for the most part swampy and wooded with small trees and palms, and in the rainy season, when most of the rivers overflow their banks, it is almost impassable in many places.

The climate along the lake shore is usually very hot, especially during the months from October to February, but at other times a cooling south wind prevails.

The temperature of the hill country is much cooler, in fact during the dry season it may be regarded as quite cold in the mornings and evenings.

Large quantities of rice are grown along the lake shore every year, of which between 200 and 300 tons are purchased by the Government. Cassava can be found growing practically everywhere, and seems to thrive in the poorest soil, while in the hills, maize, wheat, potatoes and vegetables do well.

The staple food crops of the natives on or near the lake shore consist of rice and cassava, supplemented by an ample supply of fish which is always procurable. There is a considerable fishing industry. The hill people who are unable to grow rice or catch fish live mainly on maize and millet, with the addition of cassava, potatoes and other vegetables. In the hills round Nchisi wheat is grown to advantage.

Of the numerous roads leading from Kota-Kota five can be regarded as main roads :-

(1). Kota-Kota to Ngara, 57 miles, and thence to Fort Jameson, 60 miles. The first 40 miles of this road is through the 
hills, and necessitates a steady climb of about 1,500 feet through well wooded country, after which comes an undulating country more sparsely wooded and with tall stout grass.

(2). Kota-Kota to Nchisi, 46 miles, and thence to Dowa, 21 miles. From Kota-Kota to Sani hill the country is quite flat, but after that there is a steady climb over steep and difficult hills, with many rivers which in the wet season are often flooded and present difficulties in crossing.

(3). Kota-Kota to Kasungu via Ndondo, 60 miles. This road is only slightly divergent from the Ngara road, and passes through hills of which Ndondo is the highest. It forms part of the old slave track from the interior to the coast.

(4). Kota-Kota to the Bua river, 12 miles. This road runs within a few miles of and parallel to the lake shore to the north.

(5). Kota-Kota to the Chia river, 15 miles. This road runs southwards at a distance of a few miles from the lake shore. There are also numerous district inter-village roads which are cleaned every year and which connect with the main roads.

Game in large numbers and many varieties is distributed throughout the district, and include elephant, rhinoceros, buffalo, hippopotamus, eland, roan antelope, sable antelope, kudu, zebra, hartebeeste, waterbuck, puku, reedbuck, bushbuck, impala, wart hog, bush pig, and numerous varieties of small buck. Lions and leopards are particularly numerous, and occasionally the cheetah or hunting leopard is seen.

Kota-Kota, the headquarters of the district, was an emporium of the Arab slave trade at the time when it was visited by Livingstone in 1863.

The Jumbe or Sultan of Kota-Kota was the representative of the Sultan of Zanzibar, but was practically independent, and in 1889 the Jumbe, Tawakali Sudi, made a treaty with Sir Harry Johnston, and placed his country under British protection in return for a subsidy of $£ 200$ a year. In 1893 an expedition was sent to assist the Jumbe against Chiwaula, a Yao sub-chief who objected to Jumbe's British alliance, and shortly afterwards a Government station was established at Kota-Kota, the present offices occupying the site of the original camp.

The native town of 3,000 or 4,000 huts extends along the old harbour, and there is a fine avenue joining the market place, near which are the mosque, the Jumbe's grave, and chief's house, with the Government office. Cocoanuts, mangoes, cashew, and other trees from Zanzibar were planted by the Arabs, and the rice industry introduced.

In the town there is a settlement of the Universities Mission, and stores of European and Indian traders. For some years before the introduction into Nyasaland of motor transport Kota-Kota was the port for Fort Jameson.

With the exception of a station of the Dutch Reformed Mission at Chintembwe, south of the Nchisi mountain, there are no other European settlements in the district. 
The District (Native) Administration Ordinance was introduced in 1913, and by it the district is divided into seven sections, one of which comprises the islands of Likoma and Chisumulu.

The sections are administered through the following tribal chiefs who have been appointed principal headmen, with the exception of the islands where the Priest-in-Charge of the Universities Mission at Likoma acts in this capacity.

Msusa as successor of the Jumbe as representative of the Sultan of Zanzibar at Kota-Kota is regarded as premier chief of the district. $\mathrm{He}$ is of mixed Nyamwezi-Yao descent.

Mwadzamu, principal headman of section 2, is the only other chief of importance residing on the lake shore. He is of mixed Yao-Mchewa descent.

Kasakula, of section 3, is an Mchewa whose sphere of influence is round the Lifuliza river to the north-east of Nchisi.

Jere, of section 4 , is a grandson of the old Ngoni chief Mombera; his country is to the south of Nchisi.

Kalumo, of section 5, is an Mchewa, and his district lies between the Nchisi range and the watershed of the Kasangadzi and Nkalalu rivers.

Kwenda Kwina, of section 6 , is an Ngoni whose country lies round the Chafumbi stream to the north-west of the Nchisi range.

There is a small European settlement at Kota-Kota comprised of the Resident, the Assistant Resident, the Medical Officer, members of the Universities Mission and agents of the African Lakes Corporation and Kubula Stores.

There are a few Asiatic traders with stores in Kota-Kota itself and in other parts of the district. 


\section{CHAPTER VIII.}

\section{THE NORTHERN PROVINCE.}

The Northern Province, with a Provincial Commissioner stationed at Nkata Bay, comprises the West Nyasa, the Momberas, and the North Nyasa districts. Arrangements are, however, being made to create a new district for this province, to be composed of a part of the existing Momberas and the Kasungu area of the Kota-Kota district in the Central Province. This province contains but few Europeans, although it comprises almost a third of the Protectorate, and provides a home for rather more than one-sixth of the natives.

\section{Kasungu Section.}

The area of the Kasungu section is about 1,500 square miles.

It forms one section under Chief Mwasi, with Chiefs Chiloa and Chulu as councillors in charge of their own sub-sections.

It is bounded by Rhodesia on the west, Fort Manning and Dowa districts on the south, Kota-Kota district on the east and Momberas on the north.

The section consists of a level plain, and is part of the great western Nyasaland plateau which lies between the LuangwaNyasa watershed and the hills along the Lake escarpment.

The chief hills are Kasungu and Ngombe Rume, which rise abruptly from the level plain.

Between the Rusa and Bua rivers, which form the southern boundary, and the Dwangwa, which forms the northern, there are no permanent rivers of any size, and the bulk of the water is obtained from wells or dambo pools. Owing to the lack of water the greater part of the district is thinly populated, over half the population living within 20 miles of Kasungu mountain.

No economic crops are grown for sale, but tobacco would probably do well over a great part of the area if water was available.

The climate is hot and dry in the hot weather and is never really cold.

The rainfall averages barely 30 inches, and falls almost entirely in December, January and February.

The grass is very tall and dense, and many parts are hardly traversable until it is burnt.

The District Administration (Native) Ordinance is in force and was introduced in 1916.

The principal headman is Chief Mwasi.

The Zomba-Mzimba trunk road runs north and south through the district to the east of Kasungu mountain. The Bua river is crossed by a ferry, but cars have been got across by a drift in the dry season. 
From Kasungu there is a district road through Old Fort Alston to Fort Jameson and through Ndondo pass to Kota-Kota.

Game is plentiful throughout the section, especially elephant, eland, roan, buffalo, zebra and waterbuck. But with the exception of inyala most of the game indigenous to Nyasaland can be found. Tsetse fly are prevalent in the western and northern part of the section.

The only station in the section is Kasungu Mission, a station of the Free Church of Scotland Mission, about 3 miles south-east of Kasungu mountain, and close to the head villages of Chiefs Mwasi and Chiloa.

Fort Alston, about 14 miles to the west of Kasungu, was the first Government station, but owing to the poor water supply it was moved to the foot of Ngara mountain. On the re-division of the Marimba district this was closed.

This section formed part of the Ngara sub-district of the Marimba district, which had its headquarters at Kota-Kota, Fort Alston being about half way between Fort Jameson and Kota-Kota, through which all the Fort Jameson traffic used to pass.

When Livingstone first visited this country, in September, 1863, Mwasi was already recognised as chief of all the neighbouring country, known from the hill as Kasungu.

According to native tradition, however, Chulu was the original chief, and Mwasi, who came from further south, obtained his position by his ability in fighting the Angoni, Chulu resigning the chieftainship in his favour.

The natives of the section are all of Achewa-a branch of the Manganja-stock.

In 1895 an expedition had to be sent from Kota-Kota against Mwasi, with whom Saidi Mzungu had taken shelter after the defeat of Makanjira at Fort Maguire, and who had attacked villages under British protection and closed the road to NorthEastern Rhodesia. The expedition, under Lieut. Alston and Mr. Swann, was successful ; Saidi Mzungu was captured and Fort Alston established as a military post, and the whole Kasungu area taken under charge of Kota-Kota, Mpezeni agreeing to recognise the Protectorate.

\section{Mombera District.}

The Mombera district is bounded on the north by the North Nyasa district, on the east by the West Nyasa district, on the south by the Kota-Kota district, and on the west by Northern Rhodesia. It is divided from the West Nyasa district by the Vipya mountains (highest peaks about 7,000 feet above sea level).

The country generally is undulating and covered with small trees, and is about 4,000 feet above sea level, except the country south of the Chimaliro hills to the Dwangwa river, which varies 
from 1,600 to 3,500 feet above sea level. Here and there are isolated hills, the most prominent of which is Hora, which rises to a height of about 1,200 feet above the plateau and is situated 17 miles north of Mzimba, the headquarters of the district.

The two principal rivers are the Rukuru and its tributary the Kasitu, the former of which rises at Perekezi hill on the western side of the Vipya mountains; thence it flows in a southerly direction, and, making a large bend, eventually flows north and north-east through a gorge into Lake Nyasa. This river above its confluence with the Runyina dries up in the cold season, with the exception of some pools, but water can be obtained in most parts by digging a foot or two into the sand of the river bed. Below Mount Njakwa there is a good flow of water supplied from the Runvina river, which rises at the south end of the Nyika plateau and has a strong flow of clear water the whole year. The Rukuru valley appears at one time to have been a lake, as it is very sandy and shells can be found there. The Kasitu river rises at Wozi hill on the western slopes of the Vipya mountains and, flowing in a northerly direction, joins the Rukuru about a mile below Mount Njakwa. This river flows all the year, but there is not much water in the dry season. The only other streams that do not dry up in the dry season north of the Chimaliro hills are the Lunyangwa, which flows into the Kasitu, near Bunganya hill, and the Mzimba, which joins the Rukuru west of Mount Sorora.

South of the Chimaliro hills there is a good supply of water in the eastern portion, the best of which is the Lupachi stream, which rises at Ngombe Chinda, the south-eastern corner of the Vipya range, and flows, with a fall of about 2,000 feet, into the Dwangwa river, 7 miles from Lake Nyasa. A tributary of the Lupachi-the Pwazi-also has a constant flow of water, and runs in a deep valley north of Mpalapala hill. Besides these there is the Livelezi, west of the Lupachi, which has a fair supply of water all the year. West of the Livelezi there is no water to be found in the dry season, except in a few shallow wells.

The only swamp worth mentioning is on the Rukuru, north of Kaharai hill, which is visited at times by elephants, and contains a large number of duck and other waterfowl.

The best timber is found in the Rukuru valley. The forests of small trees, with which the district is covered-with the exception of the north-eastern part, where trees are scarce-are practically useless excent for firewood.

The rainfall at Mzimba is between 30 and 35 inches annually, but varies in different parts of the district, the Rukuru valley and the valleys near the Vipya mountains having a larger fall. The rains, as a rule, begin towards the end of November and continue until April. There is usually a fortnight's drought in January. In the dry season water is very scarce, the people in many cases having to walk some miles from their villages to obtain water, which is taken from holes dug in the sandy river beds. 
Owing to the raiding of the Angoni in former years, the population of the district consists of-besides the AngoniAwemba, Akamanga, Sukuma, Safwa, Wankonde and Wapoka from the north, Atonga from the east, Senga, Bisa and Achewa from the west and south, and finally the Batumbuka-the original inhabitants of the country.

The area of the district is 4,300 square miles, and the population in round numbers 112,700 , or 26.2 to the square mile. Before the district was actively administered the people lived in large villages for fear of being raided by their neighbours, but during the last 15 years they have scattered all over the district, building small villages adjacent to patches of fertile soil, which is found chiefly near the banks of the streams.

Crops grown by the natives are maize, beans and millet, also some peas and, in some instances, cassava. Owing to a large proportion of the food supply, whether the crops have been abundant or not, being used in the manufacture of native beer, etc., there is usually a scarcity of food in February and March, and it is then difficult to obtain food for carriers, etc.

The only method of cultivation is with the hoe, of which a fair number are made in the district, there being a considerable iron deposit in the valley of the Rukuru river.

The only religion of the people is a belief in a Supreme Being and in the spirits of their ancestors. They are intensely superstitious.

The Angoni were formerly very large owners of cattle till rinderpest decimated their herds, some twenty-five years ago. Since then, however, there has been a steady increase, the number at present being about 29,000 head ; in addition, there are roughly 7,000 sheep and 12,000 goats.

Besides the Government headquarters at Mzimba, the Livingstonia Mission has stations at Loudon 19 miles south and Ekwendeni about 50 miles north-east of Mzimba. Formerly this mission had stations at Njuyu and Hora, but these were abandoned, the native population having moved to more fertile parts of the country. A large number of schools have been established in the district, and it is the exception to find an important village without one. The African Lakes Corporation have a station at Ekwendeni and a dozen native stores spread over the district. The Kubula Stores have eight native stores and there are two native stores run by an Indian and one store by a native. One Indian has a small plantation at the northern end of the district.

The greater part of the district is quite unsuitable for European cultivation, the soil being generally poor and the cost of transport prohibitive, but it is considered that wheat growing and cattle ranching might be successfully tried on the Vipya range.

The principal roads in the district are :-(1) The main road from Zomba to Karonga, which traverses the district for about 140 miles; (2) the road to Nkata Bay, which branches off the main road 42 miles north of Mzimba, and, passing through Ekwendeni, reaches the West Nyasa district border 24 miles from the main 
road ; (3) the road to Manda on the western boundary of the district (about 35 miles), which branches off the main road near Hora mountain, 18 miles north of Mzimba ; (4) the road from Loudon to the North Rhodesian border (about 16 miles), which branches off the main road 18 miles south of Mzimba, and goes to Lundazi (25 miles from Loudon).

These roads are 10 feet wide, and in the dry season, when the damage caused by the rains has been repaired, are suitable for motor-cycle traffic. In the rains, however, parts of the road and a number of small bridges are liable to be washed away, and the roads become overgrown with small bush.

A weekly mail is received from Zomba on Friday, and mails. from Karonga and Chintechi on Saturday. Outward mails leave Mzimba for Zomba on Monday morning, and for Chintechi and Karonga on Saturday morning. Parcel mails are brought by the Government steamer every four weeks, and are forwarded, via Chintechi, on arrival. The District Administration (Native) Ordinance was introduced in December, 1915 and, under it, the district is now divided into nine sections under the following principal headmen :-

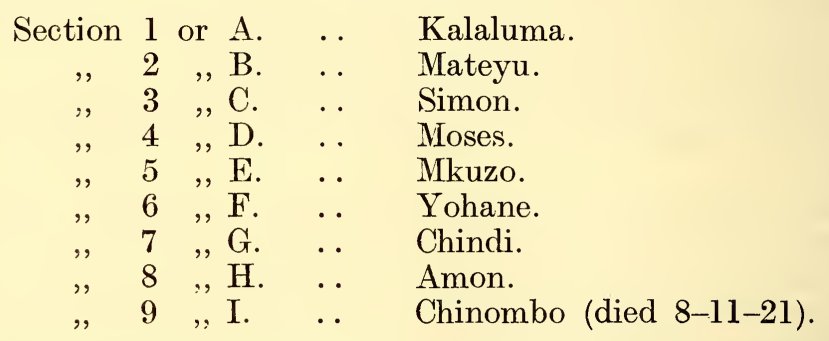

Each principal headman is assisted by two councillors.

\section{The West Nyasa District.}

The West Nyasa District consists of a long, wild, broken stretch of country lying between the north Ngoniland plateau and Lake Nyasa, in area some 2,609 square miles, and with a coast line of 140 miles and a breadth of 15 to 40 miles. It is bounded in the west, on the Ngoniland side, by the Vipya range; on the east by the lake itself. In the north it is divided from the North Nyasa district by the Rukuru river, and on the south from the Kota-Kota district by the Dwangwa river.

With the exception of a narrow strip of land along the lake shore, the country is broken and mountainous, rising gradually to the Vipya range, a rolling grassland well watered but said to be unsuitable for grazing.

A number of peaks in the district attain to more than 6,000 feet, notably, Usumara in the north and Kaningina and Cheoli in the west, with Kwandama to the south-west.

The whole of the district is well watered, the chief river being the Luweya, which, rising at the back of Kwandama, wanders 
through the middle of the district, and, with its tributaries, drains more than half it. The Kawia and Duambazi are also useful streams. Hot springs are to be found at Chiwe in the southern portion, and in the vicinity of the Limpasa. There are no navigable rivers.

There are two district roads, one of about 45 miles from Chintechi to Mzimba, which passes through some very rough country until the Vipya is reached. This is not at present suitable for wheeled traffic.

The other road runs from Bandawe to Nkata Bay, a distance (if 30 miles, and there joins with a rough road leading to Ekwendeni, an additional 40 miles. Owing to the broken nature of the country and the late rains this track is scarcely ever suitable for wheeled traffic.

There is anchorage for steamers at Nkata Bay, Bana, and Ruarwe and at Chintechi, the present Government headquarters, weather permitting. The Government steamer calls regularly once a month.

The food of the West Nyasa native is mainly cassava and is always plentiful. This is supplemented by a small quantity of rice, maize, potatoes and beans. Fish is generally plentiful, but scarce at certain seasons. The local natives are expert fishermen. During the month of September the lake fish ascend the Luweya river for spawning.

There are approximately 4,000 head of cattle in the district, and they appear generally to do fairly well, but owing to the nature of the country grazing ground is scarce, and this no doubt retards their increase.

Tsetse fly (glossina morsitans) is found in great numbers between Bana and the Kota-Kota boundary. It has also been found in the Henga valley, and its presence is suspected in the vicinity of the Duambazi, Limpasa and Luweya, though there have apparently been no authenticated captures.

Wild game is fairly abundant, and the animals common to the Protectorate are found in different parts of the district, notably in the southern section in the country around the Dwangwa, where reedbuck, waterbuck, hartebeest, sable, zebra and eland are plentifui. Buffalo are also met with in the Henga, Duambazi and Limpasa valleys. Roan and eland are also plentiful on the Vipya. The Henga valley contains most animals common to the Protectorate. In addition the more rare bluebuck and red duiker are sometimes found.

The hippopotamus, once very plentiful, is found occasionally in inland pools and is still fairly numerous at and around the Bana swamps. The Mtonga, who has the name for being a skilled and plucky hunter, used to hunt these amphibians with a harpoon. Flephant occasionally come down the Duambazi and Limpasa, and are frequently met with near the southern boundary of the Dwangwa.

The usual gamebirds and wildfowl appear in due season, partridge and guineafowl being common everywhere. The crested 
variety of the latter is also known. Cranes, storks, duck and geese are common in the swamps.

The district is as a whole well wooded and there is no lack of wood for domestic purposes and house building. Well grown Mlombwa and Mbawa are found in the ravines of the hill country, as well as other of the useful timbers. The country in many parts is thick with rubber vine.

The average rainfall for the last ten years recorded at Chintechi was 72 inches. Rain falls most of the year in the country between Bandawe and Nkata Bay. The rainfall at Chombe and Vizara, the African Lakes rubber plantations, is still heavier, and probably records as much as 100 inches. The record fall recorded by the Government at Chintechi was 90.30 inches, in the year 1916-17.

Tobacco, cotton, rubber and coffee have all been tried with varying success. Tea and wheat could possibly be successfully grown. The native rice crop averages approximately 80 tons per year, but this amount could be greatly extended.

The administration of the West Nyasa district was finally taken over in 1897, when the first resident magistrate was stationed at Nkata. Before that time, in 1881, the Livingstonia Mission occupied and built their mission station at Bandawe. In 1901, owing to local and truculent disturbances by the Atonga, a substation for the Government was started at Chintechi.

In 1900-1901 the African Lakes obtained the large rubber property of Vizara and Chombe, some 9 miles west of Nkata Bay. The heavy rainfall and the indigenous vine encouraged the venture, so that the introduction of Para and other varieties has been for many years successful. Lately the universal trade depression has caused a temporary check.

The present European population consists of ten males and three females. There are no Asiatics. The corrected numbers of the last census show a total native population of 53,367 ; of these 23,158 were males and 30,209 females.

A long line of mission schools has been opened up by the Livingstonia Mission, with its headquarters at Bandawe, for the welfare of native education. The upper portion of the district being overseered by the Ekwendeni and Livingstonia Mission in North Nyasa. At Bandawe there is a Medical Missionary in charge with a trained nurse. Here, in addition to schools and church, there are a small native hospital and dispensary. In spite of these attractions the Atonga is fond of change and will readily turn aside to a new creed or sect.

This district has been in consequence the scene of several religious disturbances in connection with the Kenanites, Watch Tower, and Church of Christ.

The local native of the present generation is conceited and truculent, undisciplined and fond of intrigue, but a useful and hardworking native when away from his own country. As an instance of this he has done good work in many parts of Africa as a soldier with the King's African Rifles. He likewise emigrates in great numbers every year to South Africa and Rhodesia, where 
he is in great request both as an ordinary labourer as well as in positions of trust in mines, offices, hotels, \&c. Many of those who have left the district have no intention of returning to Nyasaland. He is, besides, a fearless hunter and at his own trades shows a good deal of intelligence, being an expert worker at the weaving of nets and the manufacture of pottery and canoes.

For purposes of Government the district was divided in 1917 into eight different sections under principal headmen and councillors :-

\begin{tabular}{|c|c|c|c|c|c|}
\hline Section & $1 \mathrm{~A}$. & . . & Principal & headman, & 1 \\
\hline ", & 2 B. & .. & $"$ & , & Mbwana. \\
\hline ," & $3 \mathrm{C}$. & $\cdots$ & ", & ", & Mkumbira. \\
\hline " & $4 \mathrm{D}$. & . & ", & , & Chigoo. \\
\hline ," & $5 \mathrm{E}$ & $\cdots$ & " & , & Kabundu \\
\hline " & & $\cdots$ & $"$ & " & Gulu. \\
\hline ", & 7 & $\cdots$ & " & ", & Maleng \\
\hline :" & $8 \mathrm{H}$ & $\cdots$ & " & ", & Kanyend \\
\hline
\end{tabular}

It is perhaps early yet to say whether this form of administration is a success, but at present these principal headmen do not appear to obtain the respect and obedience accorded to their old chiefs. Half-yearly councils are held at headquarters, when all the headmen appear and discuss any new or old regulations or vital matters connected with the district. Sectional councils are held as opportunity occurs. There does not appear to have ever been a paramount chief, though there were one or two with outstanding names and influence, most of whom with the exception of Fuka and Chiweyu, who are both very old, are now dead.

The early history of the Atonga is surrounded in mist. They are said to have treked from somewhere in the north and to have split up at a certain unknown rocky pass. From there some reached the Dwangwa and some Usisya, while others who afterwards became the more dominant Atonga were embodied in the Ngoni, but broke away and eventually settled at Bandawe, when they found that the Ngoni, fearing their increasing numbers and strength, had made a plot to annihilate the whole tribe. Later they appear to have more or less successfully protected themselves against the Ngoni, but to have always been more or less known for their quarrelsome nature among themselves.

The Atonga is now the dominant tribe of the district. Ahewa in the south are very few in numbers, as also are the Wahenga in the north, so that to all intents and purposes they may be looked upon as one and the same people.

\section{North Nyasa District.}

This, the most northerly district of the Protectorate, is also the largest in area $(4,334$ square miles). It is bounded on the north by the River Songwe and Tanganyika territory : on the west by Northern Rhodesia (the water-parting between tho water- 
shed of Lake Nyasa and the watershed of the Zambesi River): on the south by the Mombera and West Nyasa districts, approximately latitude $11^{\circ}$ south and the South Rukuru river: and on the east by the western shore of Lake Nyasa.

Topographically, the district is divided roughly into three sections : a strip of low-lying country about 10 miles wide along the lake shore from Songwe to Florence Bay, where Mount Waller comes right down to the water's edge ; a plateau in the south central portion, called the Nyika plateau with an altitude of from 6,000 to 8,000 feet above sea level ; and in the north the Misuku hills merging westwards into the great Tanganyika plateau. Thus, practically the whole area is mountainous; there are nine peaks. attaining a height of over 8,000 feet.

The more important mountains seen from the lake steamers travelling northwards are Mount Waller (4,613 feet) not unlike Table Mountain, overlooking Florence Bay; Nyamkhowa $(7,060$ feet), followed by undulating hill-tops to Kawozya (7,352 feet) and Mpanda (6,676 feet), near Karonga and easily recognisable by its twin peaks. The highest peaks of the plateau are not seen from the lake, since they lie farther back.

The whole district is well-watered; the principal rivers are the Songwe, flowing almost due west to east down from the Tanganika plateau along the northern boundary: the Lufira, a smaller river, almost parallel a few miles south: the North Rukuru, which rises in the heart of the Nyika plateau, flows south for about 10 miles, then turning sharply to the north traverses the back of the plateau and breaking through the Mpata gorge finally debouches into the lake a mile and a half north of Karonga: the Wovwe, coming down from the Nyika across the Vua flats: the South Rukuru, the last 40 miles of which form the southern boundary of the district: the Rumpi, flowing down from the Nyika in a south-easterly direction into the lake behind Mount Waller : and the Runyina, a tributary of the South Rukuru, flowing from north to south from the south-western corner of the Nyika plateau. There are two large swamps which are almost impassable at the end of the wet season, one a few miles inland from Deep Bay and the other the Vwaza marsh in the extreme south-west corner.

With the exception of the higher parts of the plateau and a few big open plains at Lake level, the whole district is also wellwooded. Sound timber is plentiful, notably "mbawa," "mlombwa," and "mwina "; natives come in from other districts to cut canoes from the abundant supply of suitable trees, e.g., in addition to those mentioned, "mpapa," "msyepa," "mvivi," and many others. These trees are, of course, also good for general building purposes and carpentry. For domestic uses, natives on the lake shore especially plant trees for shade and to obtain bark cloth (e.g., from the banyan, " chiombo," etc.), string, fruit, etc., they also grow a small bush "chopwa" from which string is made for fishing nets, "koinje," which yields a fibre for net making,. "masira," a very light wood for floats for fishing nets, and "dinde". and "mtetezia." from which a fish poison is made. 
The universal cultivation of the banana tree is notorious: it might almost be called the eponymous characteristic of the Wankonde. (Nkonde literally means " bananas.")

Geologically the formation of the district is mainly metamorphic; in minerals it is undoubtedly very rich, but little skilled prospecting has been done so far. The mineral rights are reserved by the British South Africa Company. The country rock is mainly quartzite interspersed with crystalline, talcous, and chloritic schist belts running almost due north and south; in the belts there are occasional outcrops of serpentine rocks. Lime outcrops occur along the North Rukuru river northwards as far as Songwe, and shew the three varieties argillaceous, crystalline, and Iceland spar. At Mpata lime is burnt by natives and used for general building purposes. Almandite (iron-aluminium) garnets are frequently found in gneissoid rocks ; in certain localities, ilmenite, hematite, and limonite iron ores are fairly common. Mica, especially the ordinary muscovite, is plentiful. Indications of gold are common. The carboniferous formations have been favourably reported upon, in particular those at Mount Waller and Nkana. In the 'eighties the late Professor Drummond found very interesting fossils at Mpata.

The average annual rainfall at Karonga during the last ten years has been $41 \cdot 2$ inches ; this, of course, is no criterion of the amount received in or near the mountains, and it may be regarded as almost the minimum for the district. The average mean temperature is $74^{\circ}$; seldom rising above $95^{\circ}$ even in the hottest weather, the heat on the lake shore is very trying on account of its excessive humidity; in the hills the climate is ideal.

Slight earthquakes are a common occurence; more severe shocks have been experienced on 28th February, 1909, 14th December, 1910, and on 1st May, 1919, all of which had a duration of about fifteen seconds, followed by a succession of lesser shocks.

For purposes of native administration, in 1913 the district was sub-divided into eight sections, each under the supervision of a principal headman, assisted by two councillors and a number of village headmen. The distribution of principal headmen and sections is as follows :-

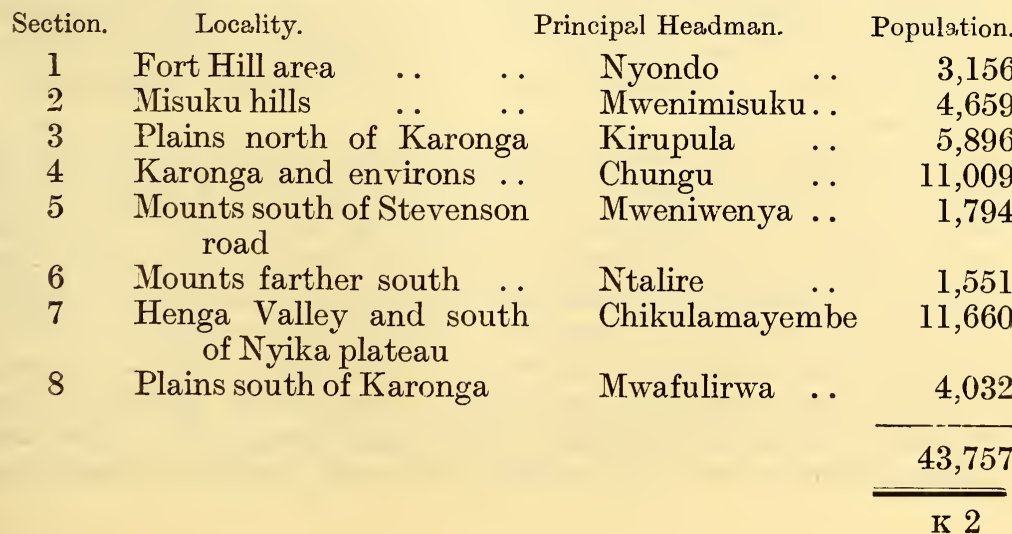


Independently of the District Administration (Native) Ordinance, Chungu and Chikulamayembe are chiefs of paramount power in the archaic sense; the former has real influence over all the Wankonde tribe and its ramifications far across Songwe into Tanganyika territory, while the latter enjoys similar prestige among all the Wahenga and kindred tribes.

The Ordinance was applied to this district largely with a view to securing improvement in native sanitation as a means of reducing ankylostomiasis, which was and still is prevalent; recently the system has been found useful in enforcing prophylactic measures against plague.

Probably as a result of the frequent raids by other tribes, a tendency towards dispersal of villages arose; villages of any size only remained on naturally advantageous sites where it was possible to build stockades for safety; more commonly, hamlets of two or three huts were resorted to in secluded places in the folds of the hills. After the settlement of the country this segre.. gation was continued on account of the freedom it afforded from any disciplinary control. To counteract this, and for greater general administrative facility, huts were compulsorily concentrated into villages of not fewer than 20 huts, and advancement towards a corporate village life was encouraged. Periodically councils are held, at which the principal headmen, their councillors, and village headmen attend, under the presidency and direction of the Resident; topics of local interest are discussed, and any new legislation affecting natives is carefully explained. The inauguration of these councils was readily understood, especially by the Wankonde, who were already accustomed to them under their own paramount chief. Although the annual remuneration of the headmen is small, it is found they perform their prescribed duties none the less conscientiously, and considerable progress is being made towards achievement of the many desirable objects at which the Ordinance aims.

The main roads of the district are suitable for motor cycle and sidecar traffic during the dry season, with the exception of part of the Stevenson road which is very hilly and stony, and the marshy country near Deep Bay. In the mountains the most primitive forms of travel are still necessarily prevalent; the employment of ox wagons by the Livingstonia Mission up from Florence Bay to Livingstonia is an exceptional indication of progress.

The best known road, though not the best in quality, is the Stevenson road; begun at the instigation of the late Mr. James Stevenson about 1880 the road was intended to be the main trade route to the interior, connecting Lakes Nyasa and Tanganyika; owing to various misfortunes the project failed, but the name survives in memory of a great aspiration. From Karonga the road runs due west for 12 miles to Mpata, whence a steep climb leads up on to the Tanganyika plateau; after crossing the Lufira (33 miles) and the Chambo (36 miles) and passing Mweniwanda (42 miles), the road improves steadily as 
far as Fort Hill (51 miles); at Nyala, 7 miles farther on, the road enters Rhodesian territory, but returns again into Nyasaland for a few miles to Nyimbo (69 miles), whence it finally leaves the Protectorate for Fife (102 miles) and Abercorn, on Lake Tanganyika.

There is a main road from Karonga northwards to the ferry across the Songwe at Kalongolera (19 miles) into Tanganyika territory; at lake level during the rains large stretches are under water, and in the dry season from Kaporo onwards soft sand makes walking very arduous.

Southwards from Karonga the main road passes through Kayuni (10 miles), Mlali (17 miles), Ngara (25 miles), Vua (27 miles) and Hara (45 miles) to Florence Bay (56 miles); since the abandonment of Deep Bay as a Government station a direct route to the south has been cut from Mdoka to Mwakanyamali, leaving Deep Bay a few miles to the east. A branch road, used by the European cotton estates for ox waggons runs inland from Ngara viâ Nyungwe, to Mwafulirwa (19 miles). From Florence Bay to Livingstonia (13 miles) - a skilfully engineered road winds up a spur of the mountain; a gentle, steady gradient is main tained; on this section ox wagons are used throughout the year. From Livingstonia the road descends in a south-easterly direction along the beautiful Henga valley, passing Chidiwo (10 miles), Muhuju (25 miles), Salimo (32 miles) to Mount Njakwa (41 miles); after crossing the South Rukuru river, the southern boundary (110 miles from Karonga), the road continues south through Ekwendeni to Mzimba. From Salimo there is a district road across the mountains to Chikulamayembe and over to Hewe on the Rhodesian border. District roads also connect Karonga with Iwenimisuku, viâ Mwaulambo, and with Mweniwenya and Ntalire.

Game is plentiful in all parts of the district except the mountainous Nyika plateau. In addition to a herd of some 150 rogues in the vicinity of Vua, elephants are usually to be found in the south-west and the northern corners of the district, but they do not nowadays carry nıuch ivory. Rhinoceros are said to have been found in the south-western area, but they are very rare. Buffalo are common near Fort Hill and on Mwanda in the south. Eland, sable, roan, hartebeest, waterbuck, reedbuck, bushbuck, duiker, warthog and wild pig are still common in appropriate localities; kudu a few miles south of Karonga are numerous as ever. Lions are ubiquitous; there is almost incessantly a man-eater at large in some parts of the district-in 1919 the Henga valley was particularly unfortunate in this respect, one old male accounting for something over 100 natives. Leopards are scattered throughout the district; hippopotami are common on the lake shore; crocodiles infest the larger rivers.

There are in the district over 23,000 head of cattle, mostly owned by the Wankonde, 1,000 goats, and 600 sheep. Despite endemic east coast fever, intermittent demodectic mange, and threats of trypanosomiasis and rinderpest, the cattle seem to thrive remarkably well. In 1917 an invasion of rinderpest similar 
to that of 1896 threatened the northern frontier of the Protectorate, but was averted by the prompt and drastic measures adopted; as a result, a triple line of defence is still maintained, i.e., north of the Songwe cattle have been inoculated, and there is what may be termed an "immune belt" immediately south of the river; all cattle have been moved back to form a " cattle free belt " about 10 miles across; and south of that again all cattle are registered and movements carefully controlled, so as to obtain speedy information of any unusual sickness.

The principal native food crops are maize, millet, "malesi," sweet potatoes, cassava, several kinds of beans, rice on the lake shore, and peas in the Misuku hills; the cultivation of wheat and European potatoes is being gradually introduced; the staple food of the Wankonde is bananas and milk. Lake fish are plentiful; the best varieties are the rock fish from Deep Bay, and " msipa," a kind of whitebait; small inedible fish are found in the larger rivers.

A consular post was established at Deep Bay in 1886 which was not finally abolished until 1900. In 1895, a Government station was built at Karonga-the original house with walls 3 feet thick is still in use. Another station was built at Fort Hill against Awemba raids, and was not closed down until 1903. From 1903 steady peaceful development, unbroken by inter-tribal warfare, was maintained until the outbreak of the War in 1914.

There are over thirty different tribes in the district; these may be resolved into two main divisions, those of the southern half being comprised within the generic term Tumbuka and in the northern half of the district the Wankonde.

In the north-western corner of the district there are a few Awemba, Amambwe, and kindred tribes indigenous on the Tanganyika plateau.

After the hanging of Mlozi, in 1895, what real Arabs there were left the district, with the exception of one, Hamedi, who, with a few ruga-ruga, remained behind and founded a village, which still survives as a somewhat cosmopolitan centre of Mohammedanism near Karonga.

Tumbuka tribes are represented locally by the Akamanga, Wahenga, Afulirwa, Apoka, Anyika, Ahewa, and some Asisya. They have assumed names either from their leader or chief, or from the locality to which they have been driven by raids of the Angoni from the south or the Awemba from the north ; all are of a mongrel type, probably formed by association of refugees from many tribes during the period of universal raiding. Their history is obscure ; the salient feature is that for many years there has been a paramount chief always called Chikulamayembe (the present chief assumed office in 1907); the founder of the dynasty appears to have been an immigrant from the east side of the lake. The name literally means "vendor of hoes"; it is a pleasing fancy to imagine he may have been a hawker who eventually became a merchant prince ; at all events, the original Chikulamayembe is still remeinbered for his liberality and enlightenment. 
Despite their hard life in the past, these tribes are an industrious agricultural people ; some are proficient workers in iron. Generally, however, their manners and customs are akin to those of the tribes to the south of them.

The Wankonde people in this district include, among others, the Wankana, Wasukwa, Awandia, Alambia, and the Awanyamwanga.

Internal evidence afforded by their language, many of their primitive customs that have survived to this day, the recollection of the proper names of the successive holders of the chieftainship) (Chungu), their conservative spirit, and many other characteristics indicate they are a very ancient tribe of remarkable homogeneity; they are quite probably the "oldest inhabitants" of the Protectorate, being found here long before the Yao, Angoni, and other immigrants.

Under a selected leader, always called Chungu (lit. "great man "), the Wankonde appear to have inhabited this country as far back as can be traced with any degree of historical accuracy; by their own account they originated in the adjacent Ukinga mountains at the north end of the lake, and, travelling south across the Songwe, settled in the rich fertile plains about Karonga; others went up into the hills westward and adopted local names, e.g., Wankana, Wasukwa. The whole tribe is governed by the paramount chief Chungu, with the aid of a cabinet of advisers, "makambara." The present Chungu (Mwangarawa, son of Malema) lives on the Rukuru, 7 miles west of Karonga; he assumed office in 1903. A timid but very conservative people, they never ran before their many oppressors like other local tribes; they consider themselves a warlike tribe; of good and often handsome physique, they seem to lack endurance.

Perhaps the most striking characteristics of the Wankonde on first acquaintance are their nudity, their banana groves, and their cattle; they are reputed to be the blackest of all African natives.

Adult males wear no clothing except " manyeta," copper or brass waist belt, in appearance a large metal ring brightly polished by wear, with a skin or small piece of cloth suspended in front, leaving the buttocks bare; as a concession to our ideas of decency, when working for Europeans as carriers, etc., they fashion cunning kilts of banana leaves, which are often quite artistic; thus the banana provides them with raiment as well as food.

The women are similarly nude; their one dress is a strip of barkcloth wound round the waist as a belt and passed between the legs and tied in front, leaving the ends hanging loose to the ground; occasionally a small apron of beadwork is worn by the more wealthy.

Both sexes tattoo themselves, especially on the chest and abdomen, and many of the designs are quite attractive.

Cattle are not as in many tribes an attribute of chieftainship : they are the life and soul of the whole people. They not only provide the milk, which is drunk curdled as a staple diet, but 
they are also invariably paid as dowry to secure a bride. The animals are well tended and are often very attached to their owners ; in this connection they have a curious custom: when a calf is born the herdsmen wears the placenta round his neck as a charm, with the result that the mother cow follows him wherever he goes. Cattle and herdsmen sleep together in long, rectangular kraals. The ears of the cows are cut and notched in varying fashion to indicate ownership. Milking is invariably done by men only: women are not allowed to have anything to do with cattle. The practice of stringing a bell on the cow's neck is common-a herd in the hills at evening often recalls memories of Swiss pastoral life.

They are a polygamous people; early marriage is favoured, and many of their marriage customs, copied by other tribes in certain respects, are most interesting.

When a youth wishes to marry, and has found the bride of his choice (generally a young girl barely arrived at puberty) he first of all presents her with a token of betrothal ; he then reports the matter to his father or elder brother. A messenger is sent to the relatives of the prospective bride, and if they agree to the match marriage gifts are sent; these may consist of hoes, beads, salt, brass wires, and nowadays money, but cattle are a sine qua non; the cattle, which vary in number according to the social position and wealth of the girl's family, are not in any sense purchase money, but are in the nature of dowry, and form a security for the good behaviour of the parties when married; that is, in the event of divorce or misconduct the cattle and their subsequent progeny have to be repaid either all or part, according to the culpability of the parties.

If the wife dies before her husband the cattle are kept for the children; they are only returned to the husband if there are no children and his father-in-law has no other bride to offer him. If the wife dies as a result of childbirth the cattle are all retained by her relatives, possibly as compensation.

If the husband dies first his brother or eldest nephew succeeds him and marries the widow; if she refuses, the cattle have to be returned, save a portion kept for the children, if any.

If a husband treats his wife well it is common for his father-inlaw to give him another daughter to wife, with the result that a man may marry two sisters contemporaneously. The wife goes to live in the village of the husband. Marriage outside the tribe is rare; marriage between cousins is scrupulously avoided.

Adultery with a chief's wife was formerly always punished with death, both parties being burnt to death; in other cases the offence was met by payment of cattle as damages.

The birth of twins is regarded with horror; the parents are segregated for a month or more, and the man hides lest his enemies kill him; if a succession of a man's children die he is expected to commit suicide.

Post-mortem examination of the dead is common; an elder of the village determines from the appearance of the viscera whether 
death was due to witchcraft; being thus closely connected with their own superstitious beliefs post-mortem examination performed by an European doctor is rather resented.

Another curious superstition, in which they believe most firmly, is that certain human beings have power over lions and other carnivora and can make them do their bidding; in 1920 even an otherwise enlightened principal headman asked for protection from an old man who he asserted was responsible for the depredations of a man-eater on the Stevenson road.

Belief in rainmakers is still very strong; in Karonga there is a sacred tree whose services were often invoked for making rain.

Even this wholly inadequate account of the Wankonde would be incomplete without special mention of their peculiar huts. The type of hut they construct is round, but the sides taper outwards, with the result the hut presents a funnel-shaped appearance; the space between the reeds is not mudded in the ordinary manner, but is filled in with symmetrical little blocks of dried clay; the whole design and general effect is most pleasing.

It is not possible to do justice to the many other peculiar customs of the Wankonde in a brief account of this nature; their differences from and resemblances to other tribes are apparently inexhaustible; owing to the most conservative spirit of the tribe, they have been less affected by the advance of civilisation than probably any other tribe in the Protectorate; anthropologically they are an ideal field for almost original research.

Practically the whole of the district is owned by the British South Africa Company; the land was originally purchased by the representatives of the African Lakes Corporation from native chiefs, and subsequently transferred to the late Cecil Rhodes in payment of money he had lent the corporation in their early financial difficulties.

The African Lakes Corporation reserved 6,000 acres at Karonga and smaller estates at Vua and Nkana.

For mission purposes Rhodes gave the Livingstonia Mission some 25 square miles, but little of this has been taken up.

Government obtained plots of 1,000 acres at Karonga, Kambwe, Songwe, and Fort Hill, and a plot of 2,000 acres at Deep Bay.

The 1921 census returned the European population of the district as follows :-

\begin{tabular}{|c|c|c|c|}
\hline Locality. & M. & F. & Total \\
\hline Karonga & 9 & 5 & 14 \\
\hline Vua and Deep Bay & 5 & 1 & 6 \\
\hline Livingstonia .. & 8 & 8 & 16 \\
\hline \multirow[t]{2}{*}{ Wanda } & 1 & - & 1 \\
\hline & 23 & 14 & 37 \\
\hline
\end{tabular}

There are no Asiatics in the district. 
Karonga. This is the Government headquarters of the district; the choice of its site was originally determined by the conflict with the Arabs under Mlozi, and has since been retained on account of its being in the centre of the most densely-populated part of the district. In addition to the Government staff, comprising a resident, assistant resident, medical officer, and stock inspector, there are two Europeans employed at the agency of the African Lakes Corporation, Limited, and in connection with their cotton and rubber estates in the vicinity, an European clerkin-charge at the office of the African Transcontinental Telegraph Company and an engineer. The large mission station is at present unoccupied, but it is to be reoccupied under European supervision next year. The station is very unhealthy during the greater part of the year, since it is surrounded by flat marshy country; proximity to the hills and healthy country is its great redeeming feature.

Kambwe. Prior to 1903 there was water in the Kambwe Lagoon, $3 \frac{1}{2}$ miles north of Karonga, and vessels were able to lie at anchor with safety; after the establishment of order in 1895 a considerable trade in ivory and rubber sprang up, and there was a flourishing little township of over 20 Europeans at Kambwe ; latterly, however, the prosperity of the transport service to the interior and trade by barter waned, and in 1904 Kambwe was abandoned.

Vua. At Vua and in the neighbourhood there are three large European cotton estates dating from 1909; a ginnery started in 1911 at Ngara continues operations on the lake shore.

Deep Bay. There are two other European cotton estates near Deep Bay opened in 1919.

Livingstonia. The Overtoun Institution, established in 1894 at Kondowe, subsequently renamed Livingstonia, about 3,000 feet above the lake, is the headquarters of the Mission of the United Free Church of Scotland; it forms the centre of higher education and selected pupils from other stations are sent there for training.

There is a junior school, a normal department for the training of teachers, a technical school, a course for evangelists, and also courses in arts, theology, elementary medicine, commercial work and telegraphy. On the industrial side apprentices are trained in agriculture, building, carpentry and printing.

A water supply has been brought by gravitation to the station from the hills behind. An electric installation has been completed, supplying power to the workshops and mill and light for the schools and other buildings. The whole station, with its many and varied activities, is a noble example of the possibilities of native development under European guidance and control. 


\section{CHAPTER IX.}

\section{AGRICULTURE AND LIVE STOCK.}

It is as an agricultural country that Nyasaland must progress, if it is to prosper at all. No precious metals have been discovered in paying quantities ; there are no mines or fisheries of commercial importance ; industries, other than those connected with agriculture are of little actual significance, and are not susceptible of any material advance in the existing conditions of the country. With the opening of direct railway communication with the East Coast of Africa at the Port of Beira, and the prospect of a line to connect the Shire Highlands Railway with Lake Nyasa, there is every reason to believe that the agricultural outlook for Nyasaland is a bright one. A description of the most important of the agricultural products of the country is given below, but a few remarks on the subject generally may not be out of place by way of introduction. The most important factor in connection with tropical agriculture is the native labour supply. The wages paid to native field labourers -six or seven shillings a month and food-seem ridiculously low to the European mind; but the cost of labour is not an absolute factor ; it can only be judged in relation to the return obtained for the expenditure. In countries where civilisation is more advanced, or nature less prodigal of her gifts, than is the case in Central Africa, practically everybody has to work incessantly to gain the means of livelihood. In Nyasaland, the average native labourer has for his object the performance of as little work as possible. The only compulsion is that of paying his hut or poll tax of 6s. a year, and the need for the scanty clothing with which he adorns himself. Natives whose aspirations soar to a higher level are not content with the wages obtainable in Nyasaland: they emigrate to Rhodesia and South Africa for employment in the mines and other industries, in which they can obtain far higher rates of pay than they receive at home. This emigration will doubtless increase now that the railway to Beira is opened although, as a matter of fact, natives in the remote parts of the Protectorate have not a great deal farther to walk in going to Salisbury than in going to the Shire Highlands.

This natural disinclination on the part of natives to steady and protracted labour received a great encouragement during the period of prosperity which outstripped the war and the armistice and lasted until 1920. During 1919 and 1920 there was a rush of new settlers to Nyasaland, many of whom had little experience 
of natives or of tropical agriculture, and, in the feverish competition for labour that ensued, wages were raised to unprecedented figures, while at the same time the tasks were successively reduced until in some cases they scarcely exceeded two hours work a day. The natives entered with zest into this scramble, and played off one employer against another with a great deal if ingenuity. The stagnation of trade and commerce that set in in 1920, with its inevitable re-action upon agriculture, brought about a saner feeling, and it is now fully recognised by the agricultural community that one of the most pressing needs of the industry is for concerted action to ensure such remuneration to labour as will induce it to remain in Nyasaland, combined with the fixing of tasks that will make such labour profitable to the employer. This, combined with co-operation for the purchase of machinery and other products necessary to the planter, as well as for the disposal of his crops, should go far towards lessening the cost of production and putting agriculture on a satisfactory basis. Another point needing careful attention is the question of the increased use of agricultural machinery and implements. At present the amount of land that can be cultivated is limited by the quantity of labour available. It is estimated that in the height of the cultivating season one native labourer an acre is needed on the average, and the total man power available for all purposes in the Protectorate is only about a quarter of a million. A British farmer will no doubt learn with surprise that it takes on the average one labourer to cultivate an acre of land, and the need for increasing the use of mechanical appliances is apparent.

There is no doubt that much of the firancial stringency felt during 1921, when planters experienced considerable difficulty in disposing of their crops, owing to the general stagnation of trade, was due to the fact that many settlers, attracted by the profitable returns received from agriculture during 1919, started operations with insufficient capital. Agriculture in any country is a precarious industry; in the tropics it is especially so. It is therefore absolutely necessary that a man intending to devote himself to the cultivation of tropical products should be provided with sufficient capital to take up land, erect the necessary buildings, maintain himself until his first crops have been sold, and generally to tide himself over the vicissitudes he may expect to encounter until he is securely established. It is sound policy for a new-comer to study the methods that the experience of the older settlers has proved to be successful, and to be content with small beginnings. A planter with no previous experience of tropical agriculture and native labour, would be well advised to make arrangements to live and work on one of the established plantations, and thus to conserve his capital until he has acquired sufficient experience to enable him to expend it to the best advantage. If he will do this, and if he is prepared to work industriously, there is no reason why a man with a capital of from $£ 2,000$ to $£ 3,000$ should not make a very successful living in Nyasaland. 


\section{Cotton.}

The following table shows the quantities of ginned cotton exported during the last ten years, together with the acreages under European cultivation :-

$\begin{array}{cccc}\text { Year. } & \text { Acreage. } & \text { Crop in lbs. } & \text { Valued at } £ . ~ \\ 1911-12 & 23,332 & 1,356,904 & 44,099 \\ 1912-13 & 23,755 & 3,237,555 & 80,939 \\ 1913-14 & 25,697 & 2,401,142 & 65,486 \\ 1914-15 & 24,006 & 2,648,508 & 72,068 \\ 1915-16 & 29,578 & 3,065,248 & 68,586 \\ 1916-17 & 27,342 & 3,462,478 & 127,131 \\ 1917-18 & 28,372 & 866,510 & 39,948 \\ 1918-19 & 18,141 & 2,670,834 & 156,031 \\ 1919-20 & 12,658 & 930,048 & 55,475 \\ 1920 * & 18,274 & 913,718 & 86,483 \\ & * & \end{array}$

Of the above quantities of cotton exported the native gown cotton, as to which reliable statistics of acreage are unavailable, amounted to the following tonnage of seed cotton. (It must be remembered that seed cotton reduces in weight to something less than one third when ginned.)

$\begin{array}{cc}\text { Year. } & \text { Tonnage of Seed Cotton. } \\ 1911 & 962 \\ 1912 & 744 \\ 1913 & 1,198 \\ 1914 & 867 \\ 1915 & 816 \\ 1916 & 1,085 \\ 1917 & 1,070 \\ 1918 & 365 \\ 1919 & 300 \\ 1920 & 288\end{array}$

Cotton cultivation was introduced into Nyasaland about the year 1900, and, although the crop gained such popularity that in a few years it headed the list of exports in value, it has of recent years taken second place to tobacco. With the decline in prices of the latter commodity, however, and the restriction in demand following on the rapid development of tobacco cultivation in America and elsewhere at the time when prices were so favourable, there is no reason why cotton should not be restored to its former favour in Nyasaland. There is a strong movement on foot for the development of cotton growing within the British Empire, for America uses yearly a greater and greater proportion of the cotton it grows, and the question of meeting the needs of the cotton mills of Manchester has become one of increasing urgency. The demand for this product is likely to exceed the supply for many years to come, as the areas where soil and climate are alike favourable to the cultivation of cotton are limited in extent, and those places, 
like Nyasaland, which are suited to its growth are in a commanding position. In the early years Egyptian cotton was tried in the Protectorate. The experiments met with moderate success in the low country; but in the Shire Highlands the results were disastrous. The variety now grown in the Highlands is Upland, and Nyasaland cotton of this kind compares very favourably with American Upland cotton, more especially since in recent years the ravages of the boll-worm in America have led to a partial discarding in that country of the long staple varieties in favour of shorter-stapled, earlier maturing types. Of recent years ginneries have been erected even in the more remote parts of the Protectorate ; but still more are required if cotton cultivation is to be made a success. The heavy cost of transport of unginned cotton renders it an unprofitable crop in outlying districts when prices are low, and the native growers are easily discouraged if a season's crop proves unremunerative, and are quickly disposed either to abandon the industry altogether, or to limit their efforts to growing merely sufficient to provide the means to pay their taxes. Taking into account this lack of enterprise on the part of natives, it would be an unwise policy to attempt to foster the native cotton industry too rapidly, so that the available means of transport and facilities for ginning proved inadequate to enable the crops to be disposed of with facility. A serious set-back to the enthusiasm displayed by natives for this product would inevitably take much time and trouble to repair.

The importation of cotton seed is forbidden except under special permit, in order to check the introduction of cotton pests and diseases. Cotton is a plant that requires continuous selection to adopt it to the climatic conditions of the country into which it is introduced. In the strains of Upland now cultivated are individual plants admirably adapted to the conditions at present prevailing in the Protectorate, and good results may be expected from careful selection with a view to increasing the quality and length of the staple.

Native Cotton. The native cotton industry is firmly controlled by Government. Cotton seed is distributed by the Department of Agriculture, and it is an offence under the Cotton Rules, 1920, for any unauthorised person to distribute seed to natives. Cotton grown on Crown Lands may not be purchased without a licence. The present method is for native grown cotton to be sold by auction at places notified beforehand. If no licensed buyer bids what the official in charge of the market considers to be a fair price, Government may exercise its right to buy in the cotton on behalf of the native grower. Buyers must pay the purchase money to the official in charge at the time of sale, and the latter hands over to each native the value of his crop. Bonuses. are sometimes given to natives producing cotton of exceptionally good quality. There is room for a great expansion in the native cotton industry, but the native must first of all develop his character in the direction of patient industry and determination. 



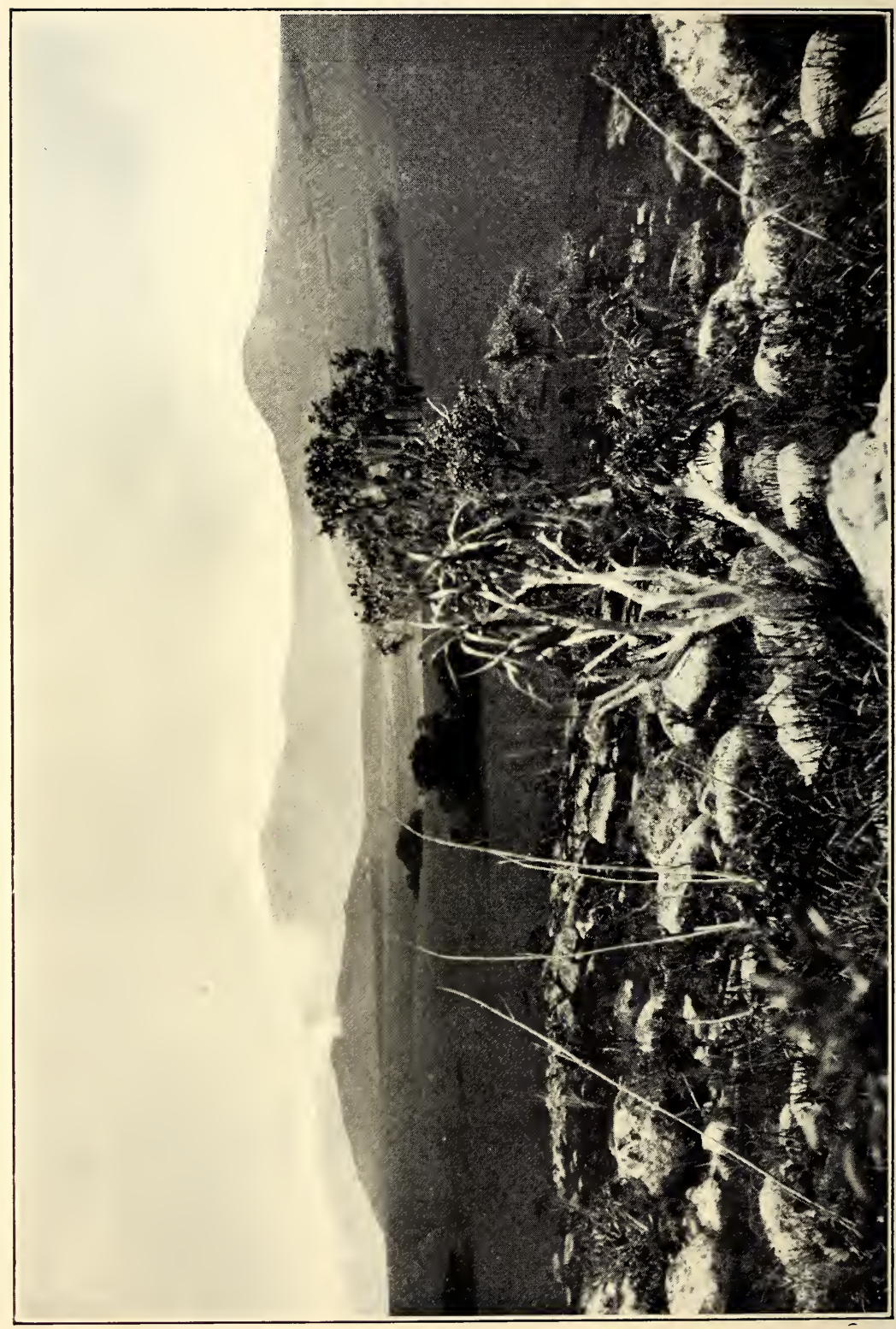

岕 


\section{Tobacco.}

Tobacco first figured among the exports of Nyasaland in 1893, and the statistics relating to this crop for the last 10 years are as under:-

$\begin{array}{cccc}\text { Year. } & \text { Acreage. } & \text { Exports in lbs. } & \text { Value. } \\ 1911-12 & 4,507 & 2,146,615 & 53,690 \\ 1912-13 & 7,411 & 2,262,545 & 56,599 \\ 1913-14 & 10,499 & 3,763,014 & 94,168 \\ 1914-15 & 9,042 & 3,308,948 & 82,735 \\ 1915-16 & 7,484 & 3,706,203 & 92,657 \\ 1916-17 & 9,386 & 4,304,124 & 112,321 \\ 1917-18 & 9,516 & 2,025,332 & 67,539 \\ 1918-19 & 6,027 & 5,805,396 & 279,511 \\ 1919-20 & 9,818 & 4,340,381 & 271,396 \\ 1920-21 & 14,218 & 4,963,130 & 481,519\end{array}$

While the culture of bright tobacco is a comparatively new industry in Nyasaland, it has become a permanent one and, since the Protectorate receives the benefit of the Imperial Preference of $1 \mathrm{~s}$. $4 \mathrm{~d}$. per pound, there is no reason why the industry should not become a very flourishing one provided every endeavour is made to produce the types required by the English manufacturers, and no effort is made to force on the market trashy rubbish which is not wanted at any price. While a Preference of 1s. $4 \mathrm{~d}$. per pound is received, it is well to bear in mind that Nyasaland tobacco. is a new growth, and that the manufacturer will not use it unless. his trade will take it, and the only way to persuade the smoker to use Nyasaland tobacco is to give him the very best that can be produced in the country.

The term "Bright Tobacco" must not be read to mean white, thin tobacco, without any oil in it, as there are various shades. of "Bright," such as "Bright Red" and "Bright Yellow." A good many planters have the idea that any tobacco that has the least amount of body or oil in it is unsuitable for cigarettes ; this is a serious mistake, as the lack of body in tobacco seriously affects the flavour and burning qualities.

\section{Tea.}

Tea is grown on the south-eastern slopes of Mlanje mountain, where the rainfall is very high. A considerable amount is consumed locally, and the following table shows the acreage devoted to this product and the results of its cultivation :-

$\begin{array}{cccr}\text { Year. } & \text { Acreage. } & \text { Exports in lbs. } & \text { Value. } \\ 1911-12 & 2,593 & 43,876 & 1,097 \\ 1912-13 & 2,812 & 67,726 & 1,693 \\ 1913-14 & 2,870 & 116,074 & 2,902 \\ 1914-15 & 3,338 & 166,248 & 4,156 \\ 1915-16 & 4,141 & 288,341 & 8,585 \\ 1916-17 & 4,228 & 420,685 & 14,023 \\ 1917-18 & 4,523 & 155,338 & 5,179 \\ 1918-19 & 4,433 & 700,455 & 27,985 \\ 1919-20 & 4,840 & 801,899 & 33,479 \\ 1920-21 & 4,285 & 496,836 & 22,505\end{array}$


Tea was first introduced into Nyasaland in the early nineties by the Church of Scotland Mission, but not till many years after the importation of the seed was any serious effort made to plant areas as a business concern. About the year 1902 the first real start was made. Steady progress has been made by a few enter. prising planters, and if the high expectations entertained by them have not yet materialised, hopes are still held that the Nyasaland product will come into its own, in face of the recent very low prices for this tea on the home market.

It still seems an undecided question as to the real jat(variety) of the tea; but those men who have seen the cifferent types of trees in other countries, and who have been in a position to learn, describe the variety as a mixed one, learing more strongly to the China jat than to any other. Be this as it may, the tree grows well here, and with ordinary care and normal seasons, the seed is easily raised, and when the plants are strong enoughsay 18 months from the time the seed was put into the nursery -planting out into the field can be done very successfully at the arrival of the proper planting season, usually from the month of December to the month of April.

The majority of the tea seed ripens from early in February to early in May, although occasional handfuls may be found on pruned trees at other times of the year. The seed will open and fall to the ground if left long enough, but for successful rearing of plants, it is by far the better way to pluck the seeds, care being taken that they are ripe, and as they do not all ripen on the bush at the same time, the pluckers should be sent round at intervals of a week or more. Very great care should be exercised in the choice of trees to be left for seed. Only strong, healthy ones which pluck well, should be selected, and these should be left unpruned.

\section{Coffee.}

Coffee was the first crop to be cultivated by Europeans in the Protectorate, and in early years the prospects of this industry appeared so bright that the coffee tree was adopted for the armorial bearings of Nyasaland. Prices were high, as much as 114 s. a cwt. being realised for some lots in 1896 and 1897. The high water mark of cultivation was reached in 1901, when nearly 17,000 acres were under coffee. In 1900 over 2,000,000 pounds were exported. Serious crop failures, coupled with a decline in the price of coffee, led to its cultivation being abandoned to a great extent. Sufficient is still grown to meet local requirements, and it is of excellent quality. In 1920 only 64,000 pounds were exported, as against 178,000 pounds in the previous year. Coffee planting is, however, a very speculative business in Nyasaland, owing to the irregularity of the setting in of the rains. With little rain in October or November the crop is always a relative failure. It succeeds, however, in very wet seasons, and for this reason is useful as a secondary crop in suitable localities with a light soil. 


\section{Capsicums and Chillies.}

Chillie cultivation is remunerative as a secondary crop, and several varieties are grown in Nyasaland. "Nyasaland Chillie," with a pod reaching $\frac{3}{4}$ inch in length, is the type in greatest demand, as it retains its vermilion colour during a long voyage. A light soil is the most suitable, and the plants should be transferred from the nursery when they are about 3 inches high. They should be replanted every two years. Chillies are picked by children, and they can be profitably cultivated on cotton estates where picking takes place in the early mornings, when it is too damp to pick cotton. During the War there was an increased demand for chillies for use in the manufacture of "tear shells," and the amount exported rose to 150,000 pounds in 1916-17. In normal years about 20,000 pounds are exported. The value at present at the place of export is $2 d$. a pound for ordinary capsicums and $8 d$. a pound for chillies.

Capsicums cost less for picking than chillies and can be dried in tobacco barns.

\section{Fibres.}

Fibre cultivation is receiving a good deal of attention at present, and several large estates have been devoted to the production of this product. There are many indigenous fibres in Nyasaland, including Bowstring hemp (Sanseviera), Denje (Sida rhombifolia), Nzongwe (Triumfetta rhomboidea), and Buaze (Securidaca longipedunculata).

Sanseviera is valuable, but is too slow in growth to attract the planter, and is not very prevalent in its wild state. Buaze, which is strong and fine, resembles flax. It is, however, a difficult plant to cultivate, and the fibre is surrounded with almost insoluble gum. Denje is a finer fibre and is also more amenable to cultivation. Well-prepared Denje is quite equal to the best jute and does not require expensive machinery for its preparation.

Ramie (Boehmeria nivea) requires a rich loamy soil and irrigation during the dry season, and is a very exhausting crop. Experimental trials of this plant have not proved satisfactory.

Sisal hemp (Agave rigida var. sisalana) and Mauritius hemp (Furcroea gigantea) are the most suitable fibres for cultivation in Nyasaland. Both plants are very hardy and grow well in loose sand throughout the Protectorate. In heavy and moist soils the plant grows luxuriantly, but the fibre itself is not so good. The Lower Shire and Lake districts should prove most suitable for Sisal and Mauritius hemps.

Mauritius hemp is valued at present for export at $£ 15$ a ton. and Sisal hemp at £18. In 1918-19 460,000 pounds of fibre were exported, in 1919594,000 pounds, and in 1920290,000 pounds. 


\section{Ground Nuts.}

Ground nut or Monkey nut (Arachis hypogoea) is a minor agricultural product that might receive more attention than it does at present. It is a plant that comes from South America, and is easily cultivated. Dry, sandy soil suits it best. A good crop runs to about 50 bushels of unshelled nuts an acre. Heavy soil is distinctly unfavourable to the growth of ground nuts. The plant is grown by the natives for food, but from the European point of view it is the oil they contain that constitutes their commercial value. The yield of oil is from 40 to 45 per cent., and it is used extensively as a substitute for olive oil. It can also be used in soap manufacture, for lubricating and lighting purposes, and in cloth dressing. The nuts are also of value as food, being richer in flesh-forming constituents than other vegetable products. The leaves form an excellent fodder for cattle and increase the milk supply. Fifteen years ago the annual export reached half a million pounds, but although it reached 150,000 pounds in 1919 , the export trade to-day is practically negligible. Most of the ground nuts exported from Africa are shipped to Marseilles, where they are ground up and the oil extracted. The residue is made into cattle cake.

Ground nut meal, cooked into a porridge with separated inilk, forms an excellent food for calves of three weeks old and over.

\section{Rubber.}

Rubber is another product that, like coffee, has not fulfilled its early promise in Nyasaland, chiefly because the climate of the Highlands is too cold and the rainfall insufficient. There was a good deal of activity in planting rubber trees (Ceara) about 15 years ago, but the plantations have been a failure. Para rubber planted at Vizara in the West Nyasa district has given more promise of success. Rubber is also obtained from the indigenous Landolphia vines, which are found by the side of streams throughout the country. The total export is only 120,000 pounds a year, and it is doubtful whether Europeans will plant up any more land with this product.

\section{Wheat.}

A little wheat is grown in various parts of the country for local consumption, chiefly at Missions situated at higher elevations. It thrives well under suitable conditions.

\section{Maize.}

Maize is grown almost everywhere by the natives, and during the War a good deal was cultivated on European estates to aid the food supplies for the military forces. Now that railway communication is open to Beira there is no reason why attention should not be devoted to the cultivation of maize for export. It 
is a product for which there is a big demand; its cultivation is well understood by natives; and it has proved itself a valuable commercial crop in Rhodesia. The possibility of producing power alcohol from maize is another factor which may lead to an increasing interest on the part of Eurojeans.

\section{Rice.}

Rice is cultivated by natives in the Lake districts and, to a slight extent, on the Lower river and Lake Shirwa. About 1,200 to 1,500 tons are grown annually, and Government accepts rice in lieu of money for hut tax, using the produce to feed its labour in the Shire Highlands. The rice grown in Nyasaland is of excellent quality, but it is merely husked and not polished, as is the case with rice sent to Europe from the east. As a matter of fact, this leaves it more nutritious, as the polishing process remores a great deal of the food-forming constituents.

\section{Soya and Veivet Beans.}

The Soya bean (Glycine hispida) and the Velvet bean (Mucona lyonii) will not repay cultivation for export. Their great use in Nyasaland is as rotation crops with cotton to replenish the nitrogen in the soil. Soya beans are edible, moreover, and can be grown as native foodstuff, especially on the Lower river, where its drought-resisting qualities make it specially suitable for cultivation for this purpose.

Velvet beans form one of the best crops for use as green manure. The plant is robust, and is not attacked by field insects.

\section{General.}

The extension of the railway to Beira on the one hand and to Lake Nyasa on the other calınot but have an extranrdinary effect on the agricultural development of the Protertorate There is no doubt that agriculture had reached the limits with which existing transport difficulties could deal adequately. The congestion at ports of exit after a good season sufficiently demonstrated this fact. Increase of transport facilities, whether by road or rail, must undoubtedly lead to the opening of thousands of acres of rich cotton and tobacco land in the northern areas. North Nyasa district, in particular, is capable of enormous development, and so are many parts of Angoniland.

It cannot be too strongly impressed on planters that cheap native labour is not always efficient labour; that even the element of cheapness will rapidly disappear as Nyasaland becomes more and more linked up with the southern portion of the continent by railway; and that with the wider development of the country native labour will prove insufficient for the needs of agriculture.

Farming implements must be brought into greater use, and more dependence placed on cattle in fly-free areas. Machinery cannot be economically employed in opening up new estates, but 
it should be used as extensively as circumstances permit in actual cultivation. It is impossible to get the deep, fine cultivation of the soil that is necessary if the only instrument used is the native hoe. Moreover, the same surface soil is used year after year, unless a system of deep ploughing is adopted. There is no doubt that cultivation is too extensive at present. Estates are too large and gardens are opened, sown repeatedly with the same crop until the soil is exhausted, and then abandoned. Agriculture in Nyasaland must follow the course which history shows it to have followed elsewhere.

As land and labour become dearer, intensive agriculture on smaller estates, with proper rotation of crops and the use of implements, must take the place of the present wasteful methods.

Nyasaland in the past has followed the practice prevalent in most parts of Africa of abiding too closely by one crop. Apart from the evil of soil exhaustion it is a bad practice financially, as a sudden fall in prices is apt to leave a planter in a precarious position. It will, of course, be necessary to select a main crop, cotton, tobacco, or fibre. But both for good farming and for a stand-by, maize, chillies, beans or some such crop should always be cultivated in addition.

\section{Live Stock.}

Cattle, sheep, goats and pigs are reared by the natives in various parts of the Protectorate.

In the northern districts North Nyasa, Momberas, West Nyasa, Kota Kota and in Southern Angoniland, including the districts of Dowa, Lilongwe, Dedza and Ncheu, cattle are reared by natives, the greatest numbers being kept by the natives of North Nyasa and Momberas. In the north we have the Wankonde tribe, a pastoral race who excel in the care of their cattle, which are small, compact, humped beasts with short horns. Our northern border divides the area occupied by this tribe, this being mainly in the Rungwe district of Tanganyika territory. To the south of North Nyasa we have the Momberas district occupied by the Angoni tribe, whose methods of cattle husbandry are much less advanced than those of the Wankonde tribe, but who own large numbers of eattle, mainly of the long-horned Africander type or crosses of these with the Wankonde type. In the Momberas district there have been very considerable extensions in recent years of the tsetse fly belts, and a consequent reduction in the available grazing areas, and as a result of this the numbers of cattle have not increased in the normal proportion one should expect. The disease "East Coast Fever" is endemic in both the North Nyasa and the Momberas district, and losses from this among the calves have an adverse effect on normal increases in the herds. In both these districts there are, however, a few large areas of country suitable for ranching under European supervision. These are areas not suitable for growing the staple crops of the country, and are not at all ever likely to be occupied by natives, the country being unsuitable owing to 



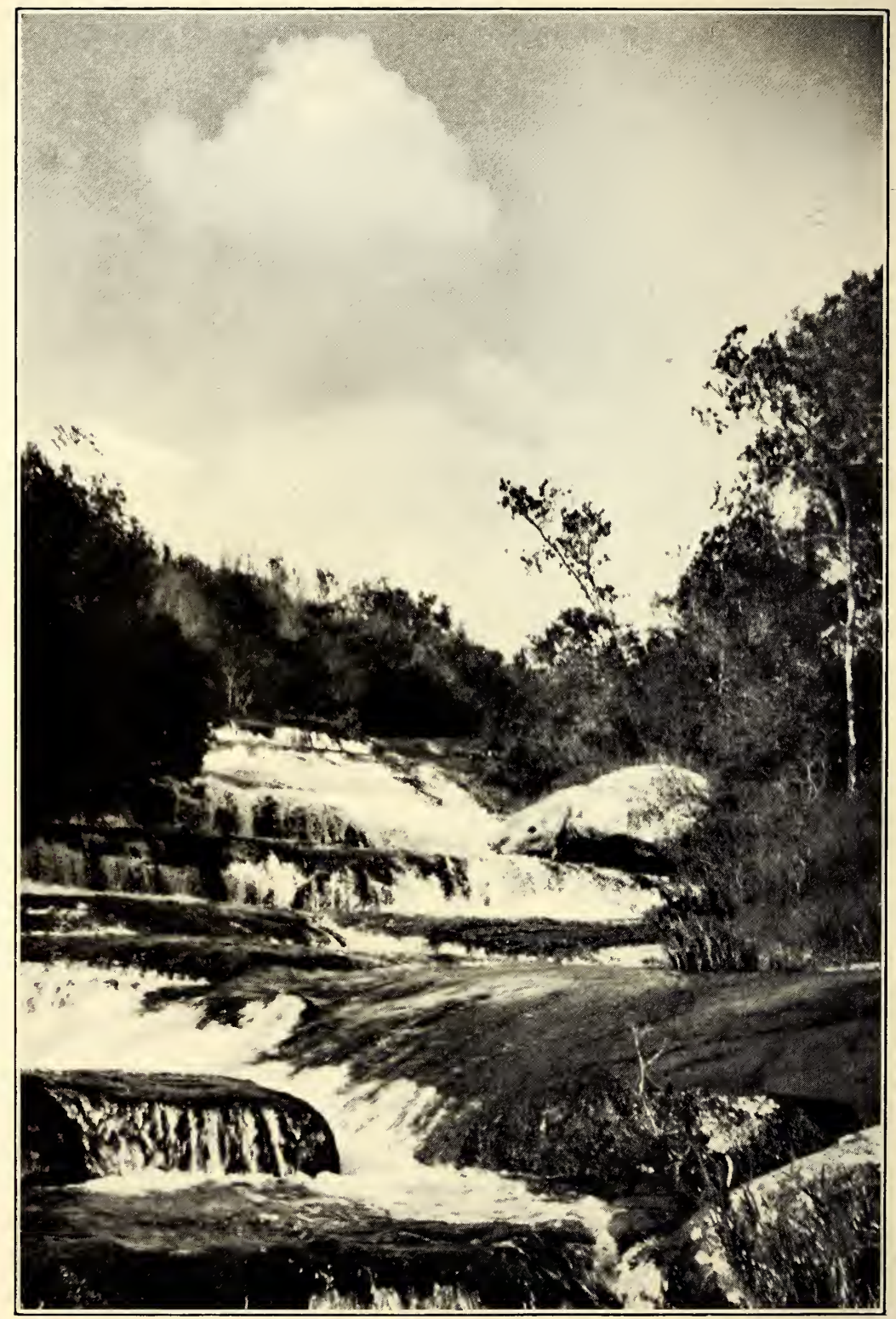

Photo by Capt. N. Farmer.

VIEW ON ZOMBA MOUNTAIN. 
various reasons such as altitude, lack of sufficient timber to allow of the usual methods of native cultivation being followed, \&c. The Nyika plateau in North Nyasa and the Vipya in Momberas are the most important of such areas.

In all the districts of Nyasaland there are vast tracts of country suitable for cattle raising which cannot be used for this purpose owing to the presence of the dreaded tsetse fly, which spreads the disease trypanosomiasis.

In Nomberas, and particularly Southern Angoniland, sheep and goats are reared by the natives in large numbers, and there is certainly scope in the Dedza, Ncheu and Neno districts, for sheep raising, for the production of wool, being carried out by Europeans, if this be on a large scale and under modern methods. It would, of course, be necessary to import wool producing varieties of sheep to form the nucleus of a flock as the rative sheep do not produce wool.

In the Shire Highlands land is too valuable to raise live stock of any kind, but there is a demand for animals for food, work oxen and dairy purposes.

On the lower river in the Ruo and Lower shire districts cattle do very well owing to the excellent grazing available along the Shire river throughout the year, but the area for grazing is not very extensive, as it is practically confined to the bank of the river, at any rate during the dry season.

At the present time the only available market for live stock is within the Protectorate, but if the supply exceeds the demand in the future the extension of the railway to the coast should reopen up a market for the export of our live stock at remunerative prices. The old routes to Southern Rhodesia for the export of cattle have long since been closed by the extension of the tsetse fly over the country through which the cattle could pass to this market.

Both private persons and the Government have imported breeding animals for the improvement of our live-stock. Bulls of the Shorthorn, Aberdeen Angus, Ayrshire and Sussex breeds have been imported from England, and Africander and Hereford graded animals from the Zambesi as well as Zebu Bulls from India.

The breeds which have given the best results so far in crossing with our native stock are, in the order mentioned, Indian Zebu, Aberdeen Angus and Sussex. The Shorthorn and Hereford crosses are not such a success, as they do not thrive under local conditions.

The native cattle of the country are born with a high degree of resistance to the local enzootic diseases.

Nyasaland, as is the case with the rest of Africa, is burdened with the whole gamut of tick-borne diseases, East Coast fever, red water, gallsickness, heartwater, \&c., as well as trypanosomiasis.

In some of our districts, notably North Nyasa and Momberas, cattle have a high degree of resistance to all of these tick-borne liseases, and the losses are, therefore, not heavy, but the crosses of imported stock with the native animals have not the same degree of resistance, and greater losses have thus to be expected 
with these. In so far as diseases are concerned Nyasaland is not in any worse position than the most favourable parts of the Union of South Africa or Rhodesia, in fact, in many respects, notably in the absence of the diseases anthrax, tuberculosis, blackquarter, pleuro-pneumonia and rinderpest this territory may be considered particularly free from serious epizootic disease.

The prices of cattle and other live stock vary very considerably in different parts of the Protectorate. Trained work oxen in the Southern Province cost $£ 10$ to $£ 15$ each, and untrained oxen may be purchased according to age and district for from $£ 5$ to $£ 10$. In the areas of European settlement cattle are much more expensive than in the districts which are at present practically native reserves, such as North and West Nyasa, Momberas and the districts of Southern Angoniland. The further north one goes the cheaper cattle may be purchased, but to bring them to the south of the Protectorate is a risky proceeding, owing to the danger of animals becoming infected with trypanosoniasis by passing through tsetse fly belts en route. Unless great care be taken to follow the proper routes a large percentage of any herd taken through such an area become infected with this disease.

In the more northern districts cattle may still be purchased cheaply. Bulls for from $£ 1$ to $£ 2$ and cows from $£ 210$ s. to $£ 310$ s., but in the districts further south the effect of military purchases during the War has been to give the native owners an exaggerated idea of the value of live stock, and prices are thus quite twice those above mentioned.

The demand for animals suitable for transport and agricultural work is sufficient to maintain the market price of cattle in the Shire Highlands apart altogether from the increased demand for animals for slaughter by butchers, and the greater demand for milking animals owing to the increases in the numbers of European and Indian settlers.

The enzootic diseases of the country can for the greater part be combated by universal dipping of live stock, except for trypanosomiasis, and it is, therefore, possible for the nlajority if settlers taking up land to maintain a dairy herd, and also oxen for work purposes, except in actual tsetse fly belts.

The effect of settlement by the opening up and clearing of indigenous forest and cultivation of the land is to prevent the spread of, or to clear infected country of tsetse fly, and is, therefore, to be encouraged as a means of clearing the territory of these pests to both man and beast.

The native sheep and goats can and do exist and even do well in tsetse fly belts, they being apparently quite immune to natural infection by trypanosomes. Imported sheep have never been given a fair trial, although the conditions in several areas, if they are treated properly, are quite favourable for sheep raising on a large scale.

Crosses with merinos and the indigenous sheep have been prolific, and a great improvement on the native animal both for the quality of the meat and also on account of wool production. 
Pigs are only plentiful in Angoniland. There have been outbreaks periodically of swine fever in the Fort Manning district among native pigs, but in the southern districts imported pigs and their offspring have done particularly well when reared under modern hygienic conditions. Pigs have been much more commonly reared by planters in recent years, as the tendency with hard times is gradually to adopt more and more the methods of mixed farming. Any notable advances in the live stock industry of Nyasaland have to a great extent been hampered by the various successive booms, coffee, tea, cotton and tobacco, which have offered far more attractive profits to the planters who settled in Nyasaland. The majority of persons who have been attracted to the country have been drawn by one or other of these booms, and live stock have only been considered as first a means of obtaining milk, and then later, as labour became more scarce, and consequently more expensive, for work purposes.

A few donkeys and mules are used by some planters with light cultivators and for working maize mills, but these are not very common, although there is no doubt of their economic value as compared with man power. Both donkeys and mules will be used much more in Nyasaland when it is possible to bring them in from the coast by railway, and at a price which will allow of them being used in competition with native labour.

Very few horses have ever been imported owing to the cost of bringing them into the country via the River Zambesi. Horses have, however, lived for years in certain parts of Nyasaland. In considering the importation of horses or mules preference should be given to animals immunised against "South African Horse Sickness." Both the known "tick fevers" of the horse occur in Nyasaland.

The importance of fostering our live stock production is a much more serious matter at the present time owing to the neressity of lessening the cost of production by utilising to the utmost extent oxen for transport as well as all agricultural work.

The plough and the harrow, with other implements available for the modern agriculturist, must take the place of the primitive hoe, and the only econonical method of working these implements is by using oxen, mules and donkeys to the utmost extent to replace the native labourer.

There is no cheaper method of transporting produce than the ox wagon, and while cattle can be kept free from serious losses from the more common epizootic diseases, by universal dipping and the control of movements of animals, it will be possible for the majority of settlers in Nyasaland to use animals for transport and agricultural work as well as for the production of meat and dairy products.

In 1920 the following live stock were owned in the Protectorate:Cattle. Mules and Sheep. Goats. Pigs.

$\begin{array}{lllrrrr}\text { European owned } & . & 14,000 & 280 & 1,700 & 540 & 850 \\ \text { Native owned } & . & 70,000 & - & 37,000 & 143,000 & 18.000\end{array}$




\section{CHAPTER X.}

\section{TRADE, COMMERCE AND FINANCE.}

In 1891 the imports into Nyasaland, excluding specie and Government stores, were valued at about $£ 33,000$. The settlement of the Protectorate led to a steady increase in the volume of trade, and by the year 1896-97 the figures reached $£ 70,655$. The following tables show the values of the imports for home consumption as they lay at the port of shipment, as well as the exports of local produce, for the past 20 years. The figures do not include specie, Government stores and railway material :--

$\begin{array}{ccc} & \text { Imports. } & \text { Exports. } \\ 1901-02 & \mathfrak{f} & \mathfrak{1} \\ 1902-03 & 116,751 & 21,739 \\ 1903-04 & 134,606 & 34,766 \\ 1904-05 & 169,309 & 27,409 \\ 1905-06 & 135,928 & 46,453 \\ 1906-07 & 177,485 & 56,785 \\ 1907-08 & 192,258 & 49,138 \\ 1908-09 & 125,242 & 54,371 \\ 1909-10 & 124,687 & 81,791 \\ 1910-11 & 106,167 & 97,502 \\ 1911-12 & 193,488 & 148,150 \\ 1912-13 & 229,787 & 151,460 \\ 1913-14 & 267,669 & 174,521 \\ 1914-15 & 179,527 & 200,422 \\ 1915-16 & 171,634 & 182,283 \\ 1916-17 & 216,601 & 198,006 \\ 1917-18 & 356,115 & 289,268 \\ 1918-19 & 323,261 & 144,747 \\ 1919-20 & 648,975 & 504,740 \\ 1920-21 & 569,884 & 429,086 \\ 11110 & 519,949 & 651,217\end{array}$

It will be seen that the opening of the Shire Highlands Railway in 1908 was soon reflected in an increase of trade, and that the completion of the Central Africa Railway in 1915 was also closely followed by an upward movement in the figures.

In a newly opened country like Nyasaland the imports are necessarily of a more or less fixed type, and consist principally of provisions, native clothing, and building and agricultural material. Since, moreover, such imports are not presented to the country, they must be paid for by exports, at any rate such part of them as do not represent capital transferred to the Protectorate in the hope of its producing annual profits either at the time or later. It is, then, to the exports that we must look to gain a proper idea of the progress and vicissitudes of Nyasaland. 
It is interesting to notice the figures for 1891. In that year the exports were valued at $£ 6,965$, made up as follows:--

\begin{tabular}{|c|c|}
\hline Ivory & \\
\hline Coffee & \\
\hline Oil sceds & \\
\hline Stropanthus & \\
\hline Rhinoceros horns & \\
\hline Hippo teeth .. & \\
\hline Beeswax & \\
\hline India rubber. & \\
\hline
\end{tabular}

It will be observed that coffee alone represents the definite results of European agriculture. By 1893 a considerable advance was shown, and again the list is given in full on account of its historic interest:-

Lbs.

\begin{tabular}{|c|c|c|c|}
\hline Ivory & & & 42,495 \\
\hline Hippo teeth & & & 2,252 \\
\hline Rhinoceros $\mathrm{h}$ & orns & . & 332 \\
\hline Beeswax & $\bullet$ & .. & 5,228 \\
\hline Oil seeds & • & $\cdots$ & 87,055 \\
\hline Rubber.. & . & . & 539 \\
\hline Coffee .. & . & . & 93,118 \\
\hline Stropanthus & . & . & 2.311 \\
\hline Tobacco & . & . & 40 \\
\hline Cotton ... & .. & . & 400 \\
\hline Sundries & . & & \\
\hline
\end{tabular}

$£$

18.252

146

20

174

182

34

2,997

280

2

1

52

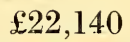

It is often stated that cotton first figured in the list of exports in the year 1902-3, but the above table shows that a sample had been sent home 10 years earlier. In 1895-6 cotton samples were valued at $4 \frac{1}{2} \mathrm{~d}$. a pound, at Kew, and, of course, when the country was first occupied by Great Britain cotton of good quality was heing cultivated by the natives in rather widely separated patches throughout Central Africa. In fact it was the cotton fields of the Zambesi and Shire that particularly attracted the attention of Livingstone. Tobacco also makes its first appearance in the year 1893. Those who are concerned about the destruction of the African elephant will no doubt be surprised to note the enormous quantities of ivory exported during the early years, and to these figures must be added the ivory taken out by slave and ivory traders without the formality of passing it through the Customs.

Coffee continued to engage the almost undivided attention of the early planters, of whom there were about 100 in the middle nineties. In 1896-7 coffee accounted for $£ 16,427$ out of a total export value of $£ 23,299$; and in the following year it provided $£ 22,402$ out of $£ 27,436$. In $1899-1900$ coffee reached its zenith, $2,148,160$ pounds, valued locally at $£ 62,245$, being exported in that year. Cotton and tobacco did not attain those figures until 1912-13. 
The following tables show the acreage devoted to the cultivation of various products, the quantities exported, the values at the port of shipment from the Protectorate, and the total value of the crops over a series of years. In many cases the exports are the result of the previous year's cultivation :-

\section{Coffee.}

Year.

1893-94

1894-95

1895-96

1896-97

$1897-98$

1898-99

1899-00

1900-01

1901-02

1902-03

1903-04

1904-05

1905-06

1906-07

1907-08

1908-09

1909-10

1910-11

1911-12

$1912-13$

1913-14

1914-15

1915-16

1916-17

1917-18

1918-19

1919-20

1920
Acreage.

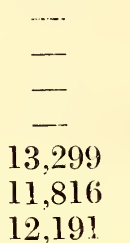

16,917

10,713

11,287

8,867

4,880

5,273

5,565

6,134

6,037

5,629

4,339

3,735

2,600

1,976

1,559

1,331

1,460

1,237

1,194

492
Quantity in lbs.

93,118

165,320

322,000

762,382

861,034

809,758

$2,148,160$

1,248,402

699,030

$1,007,092$

714,743

$1,303,655$

773,919

454,111

780,133

934,896

748,410

334,161

786.304

194,704

192,076

99,477

106,081

131,390

2,774

188,865

112,055

64.362
Value.

6d. \& 7d.

5d. \& 6d.

5 d. \& 6 d.

5d. \& 6 d.

5d. \& $7 \mathrm{~d}$.

5d. \& $7 d$.

5d. \& 7d.

5d. \& 6d.

5 d. \& 6d.

$6 d$.

$5 d$.

$5 d$.

$5 d$.

$5 d$.

$5 d$.

$5 d$.

$5 \mathrm{~d}$.

$5 d$.

$6 d$.

6 d.

$6 \mathrm{~d}$.

$6 d$.

$6 d$.

$6 d$.

$6 d$.

$6 d$.

$6 \mathrm{~d}$.

$6 d$.
Total.

2,997

4,133

7,136

16,426

22,412

23,756

62,245

26,576

14,751

25,177

17,869

27,159

16,123

9,461

16,253

19,472

15,574

6,962

16,381

4,868

4,802

2,487

2,562

3,285

70

4,722

2,801

1,609

\section{Cotton.}

Year. European acreage. Total exports in lbs.

Value.

Total.

$\begin{array}{rr}1901-02 & 60 \\ 1902-03 & 580 \\ 1903-04 & 7,000 \\ 1904-05 & 21,900 \\ 1905-06 & 10,012 \\ 1906-07 & 7,017 \\ 1907-08 & 8,659 \\ 1908-09 & 8,975 \\ 1909-10 & 12,000\end{array}$

692
56.886
285,185
776,640
526,119
403,486
756,120
858,926

Experimental parcels.

$5 \mathrm{~d}$.

3

$5 d$.

1.777

$5 d$.

5,914

$5 d$.

16,179

$7 d$.

15,345

$7 d$.

13,999

6d. to $1 /-$

28,355

6d. to $1 /--$

26,209 
Cotton-iontinued.

Year. European acreage. Total exports in lbs.

Value.

Total.

\begin{tabular}{|c|c|c|c|c|}
\hline $1910-11$ & 12,752 & $1,736,999$ & $6 d$. to $1 /-$ & 58,687 \\
\hline $1911-12$ & 23,332 & $1,359,904$ & $6 \mathrm{~d} . \& 10 \mathrm{~d}$. & 44,099 \\
\hline $1912-13$ & 23,755 & $3,237,555$ & $6 d$. to $1 /-$ & 80,93 \\
\hline $1913-14$ & 25,697 & $2,401,142$ & $6 d$. to $1 /-$ & 65,48 \\
\hline $1914-15$ & 24,006 & $2,648,508$ & $5 \mathrm{~d}$ & 72,06 \\
\hline $1915-16$ & 29,578 & $3,065,248$ & Sd. & 68,58 \\
\hline $1916-17$ & 27,342 & $3,462,478$ & $8 d . \& 10 d$. & 127,131 \\
\hline 1917-18 & 28,372 & 866,510 & 10 d. \& $1 /-$ & 339,94 \\
\hline $1918-19$ & 18,141 & $2,670,834$ & $1 / 2$ & 156,03 \\
\hline $1919-20$ & 12,658 & 930,048 & $1 / 4,1 / 2,2 /-$ & 55,47 \\
\hline 1920 & 18,274 & 913,718 & $1 / 4$ to $2 / \ldots$ & 86,48 \\
\hline
\end{tabular}

Native grown cotton began to form part of the quantity shown in the exports column from about the year 1903. The extraordinary increase in acreage in 1904-05 was due to the reckless opening up of unsuitable land with untried varieties by inexperienced planters. The lesson was soon learnt, however, and the 1911-12 crop, when next the area under cotton exceeded 20,000 acres, was five times as valuable as the crop from the 1904-0こ acreage.

\section{Tobacco.}

\begin{tabular}{|c|c|c|c|c|}
\hline Year. & Acreage. & Exports in lbs. & Value. & Total. \\
\hline 1898-99 & - & 2,240 & $5 \mathrm{~d}$. & 47 \\
\hline 1899--00 & 69 & 4,480 & $4 d$ & 113 \\
\hline $1900-01$ & 24 & 1,482 & $4 \mathrm{~d}$. & 0 \\
\hline $1901-02$ & 88 & 14,369 & $7 \mathrm{~d}$ & 41 \\
\hline $1902-03$ & 441 & 17,604 & $4 \mathrm{~d}$. & 29 \\
\hline $1903-04$ & 944 & 28,914 & $4 d$. & 48 \\
\hline $1904-05$ & 421 & 56,826 & $4 d$. & 947 \\
\hline $1905-06$ & 955 & 199,020 & $4 d$ & 3,317 \\
\hline $1906-07$ & 2,330 & 413,316 & $4 \mathrm{~d}$. & 6,889 \\
\hline $1907-08$ & 1,843 & 554,395 & $4 \mathrm{~d}$. & 9,23 \\
\hline $1908-09$ & 2,386 & 570,102 & $6 d$. & 14,25 \\
\hline $1909-10$ & 2,386 & $1,084,757$ & $6 d$. & 27,12 \\
\hline $1910-11$ & 3,274 & $1,704,637$ & 6d. \& 1/-. & 42,62 \\
\hline $1911-12$ & 4,507 & $2,146,615$ & 6d. \& $1 /-$ & 53,69 \\
\hline $1912-13$ & 7,411 & $2,262,545$ & $6 d . \& 1 /-$ & 56,59 \\
\hline $1913-14$ & 10,499 & $3,763,014$ & 6d. \& $1 /-$ & 94,16 \\
\hline $1914-15$ & 9,042 & $3,308,948$ & $6 d . \& 1 /-$ & 82,73 \\
\hline 1915--16 & 7,484 & $3,706,203$ & 6d. \& 1/- & 92,657 \\
\hline $1916-17$ & 9,386 & $4,304,124$ & 6d. \& 8d. & 112,32 \\
\hline 1917-18 & 9,516 & $2,025,332$ & 8d. \& $1 /-$ & 67,53 \\
\hline 1918-19 & 6,027 & $5,805,396$ & 10d. \& $1 /-$ & 279,51 \\
\hline 1919-20 & 9,818 & $4,340,381$ & $1 /-, 1 / 6,2 /-$ & 271,39 \\
\hline 1.920 & 14,218 & $4,963,130$ & $2 / 3,2 /-, 1 / 6$ & 481,51 \\
\hline
\end{tabular}

It is worthy of note that the exports of cotton and tobacco in 1907-08, the year of the opening of the Shire Highlands Railway, were valued at about $£ 23,000$. Three years later they were valued at over $£ 100,000$. 


\begin{tabular}{|c|c|c|c|}
\hline \multicolumn{4}{|c|}{ Rubber. } \\
\hline Year. & Exports in lbs. & Value. & Total. \\
\hline 1897-08 & 21,416 & $1 /-$ & 1,059 \\
\hline 1898-99 & 91,264 & $2 / 3$ & 10,267 \\
\hline $1899-00$ & 118,720 & $2 / 3$ & 13,356 \\
\hline $1900-01$ & 85,904 & $2 / 3$ & 9,669 \\
\hline 1901-02 & 14,393 & $2 / 3$ & 1,619 \\
\hline $1902-03$ & 11,723 & $2 /-$ & 1,172 \\
\hline $1903-04$ & 4,262 & $2 /-$ & 426 \\
\hline 1904-05 & 17,664 & $2 / 6$ & 2,208 \\
\hline $1905-06$ & 17,280 & $2 / 6$ & 2,160 \\
\hline 1.906-07 & 16,403 & $4 / 3$ & 3,486 \\
\hline 1907-08 & 15,533 & $4 / 3$ & 3,301 . \\
\hline $1908-09$ & 15,414 & $4 /-$ & 3,083 \\
\hline $1909-10$ & 27,144 & $3 /-$ & 4,261 \\
\hline $1910-11$ & 59,472 & $3 / 6 \& 5 /-$ & 10,659 \\
\hline $1911-12$ & 47,709 & $3 / 6 \& 5 /-$ & 9,154 \\
\hline $1912-13$ & 61,112 & $3 /-\& 4 / 6$ & 11,003 \\
\hline $1913-14$ & 65,083 & $3 /-$ & 9,598 \\
\hline 1914-15 & 36,707 & $1 / 6$ & 3,423 \\
\hline $1915-16$ & 46,002 & $1 / 8 \& 1 / 6$ & 3,801 \\
\hline $1916-17$ & 69,851 & $1 / 8 \& 1 / 9$ & 6,041 \\
\hline 1917--18 & 61,336 & $1 / 7 \& 1 / 9$ & 5,342 \\
\hline 19$] 8-19$ & 35,300 & $1 / 4 \& 1 / 6$ & 2,639 \\
\hline $1919-20$ & 119,854 & $1 / 4 \& 1 / 6$ & 8,988 \\
\hline 1920 & 128,253 & $1 / 6 \& 1 / 4$ & 9,619 \\
\hline
\end{tabular}

There is no export duty on rubber at present, although prior to 1913 there was a duty of $4 \mathrm{~d}$. a pound on uncultivated rubber. At present there is a Forest Due of $2 \mathrm{~d}$. a pound on wild rubber, however. Most of the exports shown in the above tables in recent years are cultivated rubber. Prices to-day are too low to encourage extensive tapping in the plantations.

\section{Tea.}

$\begin{array}{cccrr}\text { Year. } & \text { Acreage } & \text { Exports in lbs. } & \text { Value. } & \text { Total. } \\ 1908-09 & 598 & 23,948 & 6 \mathrm{~d} . & 599 \\ 1909-10 & 518 & 36,281 & 6 \mathrm{~d} . & 907 \\ 1910-11 & 1,190 & 42,042 & 6 \mathrm{~d} . & 1,051 \\ 1911-12 & 2,593 & 43,876 & 6 \mathrm{~d} . & 1,097 \\ 1912-13 & 2,812 & 67,726 & 6 \mathrm{~d} . & 1,693 \\ 1913-14 & 2,870 & 116,074 & 6 \mathrm{~d} . & 2,902 \\ 1914-15 & 3,338 & 166,248 & 6 \mathrm{~d} . & 4,156 \\ 1915-16 & 4,141 & 288,341 & 8 \mathrm{~d} . & 8,585 \\ 1916-17 & 4,228 & 420,685 & 8 \mathrm{~d} . & 14,023 \\ 1917-18 & 4,523 & 155,338 & 8 \mathrm{~d} . & 5,179 \\ 1918-19 & 4,433 & 700,455 & 9 d . \text { and } 1 /- & 27,985 \\ 1919-20 & 4,840 & 801,899 & 9 d ., 10 \mathrm{~d} . \& 1 /- & 33,479 \\ 1920 & 4,285 & 496,836 & 1 /- \text { to } 7 \mathrm{~d} . & 22,505\end{array}$

The tea industry has suffered from low prices of late years as compared with other products, but there is a considerable local demand at a price which helps in some measure to compensate for the losses encountered on the home market. 


\section{Total Trade.}

The following schedules show in total the import and export trade of the Protectorate from 1909-10 to 1920-21, classified under the various headings. Government stores and specie are excluded.

\section{IMPORTS.}

\begin{tabular}{|c|c|c|c|c|c|c|}
\hline Year. & & $\begin{array}{l}\text { Food, } \\
\text { Drink } \\
\text { and } \\
\text { Tobacco. }\end{array}$ & $\begin{array}{c}\text { Raw } \\
\text { Materials. }\end{array}$ & $\begin{array}{l}\text { Manu- } \\
\text { factured } \\
\text { Articles. }\end{array}$ & $\begin{array}{l}\text { Miscel- } \\
\text { laneous } \\
\text { and Un- } \\
\text { classified. }\end{array}$ & Totals. \\
\hline $\begin{array}{l}1909-1910 \\
1910-1911 \\
1911-1912 \\
1912-1913 \\
1913-1914 \\
1914-1915 \\
1915-1916 \\
1916-1917 \\
1917-1918 \\
1918-1919 \\
1919-1920 \\
1920-1921\end{array}$ & $\begin{array}{l}\ldots \\
\ldots \\
\ldots \\
\ldots \\
\ldots \\
\ldots \\
\ldots \\
\ldots \\
\ldots \\
\ldots \\
\ldots\end{array}$ & $\begin{array}{c}£ \\
16,524 \\
19,674 \\
28,619 \\
31,849 \\
23,784 \\
20,363 \\
39,426 \\
44,133 \\
48,835 \\
85,554 \\
79,844 \\
91,264\end{array}$ & \begin{tabular}{r}
\multicolumn{1}{c}{$£$} \\
- \\
656 \\
953 \\
2,053 \\
3,674 \\
3,964 \\
5,792 \\
5,169 \\
6,004 \\
29,341 \\
22,233
\end{tabular} & $\begin{array}{c}£ \\
85,887 \\
166,603 \\
195,877 \\
230,808 \\
148,035 \\
110,653 \\
140,685 \\
260,719 \\
217,815 \\
486,027 \\
377,562 \\
313,167\end{array}$ & 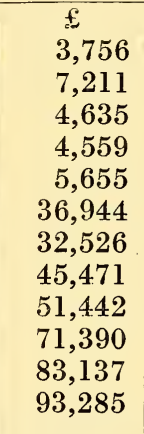 & $\begin{array}{c}£ \\
106,167 \\
193,488 \\
229,787 \\
267,669 \\
179,527 \\
171,634 \\
216,601 \\
356,115 \\
323,261 \\
648,975 \\
569,884 \\
519,949\end{array}$ \\
\hline $1920-1921$ & & 529,869 & 79,839 & $2,733,838$ & 439,511 & $3,783,057$ \\
\hline
\end{tabular}

EXPORTS.

\begin{tabular}{|c|c|c|c|c|c|c|}
\hline \multicolumn{3}{|c|}{ Year. } & \begin{tabular}{|c|} 
Food, Drink \\
and \\
Tobacco. \\
$£$ \\
49,688
\end{tabular} & 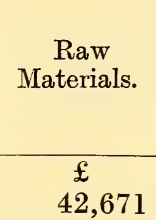 & 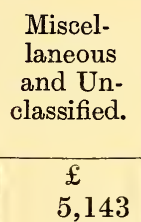 & 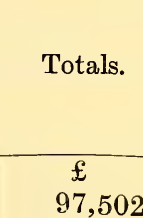 \\
\hline $\begin{array}{l}1909-1910 \\
1910-1911 \\
1911-1912 \\
1912-1913 \\
1913-1914 \\
1914-1915 \\
1915-1916 \\
1916-1917 \\
1917-1918 \\
1918-1919 \\
1919-1920 \\
1920-1921\end{array}$ & $\begin{array}{l}\ldots \\
\ldots \\
\ldots \\
\ldots \\
\ldots \\
\ldots \\
\ldots \\
\ldots \\
\ldots \\
\ldots\end{array}$ & $\begin{array}{l}\ldots \\
\ldots \\
\cdots \\
\ldots \\
\ldots \\
\ldots \\
\ldots \\
\ldots \\
\ldots \\
\cdots\end{array}$ & \begin{tabular}{|r|}
$f$ \\
49,688 \\
61,298 \\
75,706 \\
67,481 \\
102,096 \\
89,889 \\
106,155 \\
133,059 \\
75,022 \\
315,683 \\
308,901 \\
484,302 \\
\end{tabular} & $\begin{array}{r}£ \\
42,671 \\
48,450 \\
72,834 \\
105,457 \\
87,443 \\
86,949 \\
81,326 \\
143,318 \\
52,704 \\
172,849 \\
81,181 \\
114,655\end{array}$ & \begin{tabular}{r}
\multicolumn{1}{c}{$£$} \\
5,143 \\
2,402 \\
2,920 \\
1,583 \\
10,883 \\
5,445 \\
10,525 \\
12,891 \\
17,021 \\
16,208 \\
39,004 \\
52,260
\end{tabular} & $\begin{array}{c}£ \\
97,502 \\
148,150 \\
151,460 \\
174,521 \\
200,422 \\
182,283 \\
198,006 \\
289,268 \\
144,747 \\
504,740 \\
429,086 \\
651,217\end{array}$ \\
\hline $1920-1921$ & & & $1,869,280$ & $1,125,837$ & 176,285 & $3,171,402$ \\
\hline
\end{tabular}


Figures for transit trade, which are additional to the figures quoted above, are as follows :-

TRANSIT IMPORTS.

\begin{tabular}{|c|c|c|c|c|c|c|}
\hline Year. & & $\begin{array}{c}\text { Food, } \\
\text { Drink } \\
\text { and } \\
\text { Tobacco. }\end{array}$ & $\begin{array}{c}\text { Raw } \\
\text { Materials. }\end{array}$ & $\begin{array}{l}\text { Manu- } \\
\text { factured } \\
\text { Articles. }\end{array}$ & $\begin{array}{l}\text { Miscel- } \\
\text { laneous } \\
\text { and Un- } \\
\text { classified. }\end{array}$ & Totals. \\
\hline $\begin{array}{l}1909-1910 \ldots \\
1910-1911 \ldots \\
1911-1912 \ldots \\
1912-1913 \ldots \\
1913-1914 \ldots \\
1914-1915 \ldots \\
1915-1916 \ldots \\
1916-1917 \ldots \\
1917-1918 \ldots \\
1918-1919 \ldots \\
1919-1920 \ldots \\
1920-1921 \ldots\end{array}$ & $\begin{array}{l}\ldots \\
\ldots \\
\ldots \\
\ldots \\
\ldots \\
\ldots \\
\ldots \\
\ldots \\
\ldots \\
\ldots \\
\ldots\end{array}$ & $\begin{array}{c}£ \\
1,241 \\
3,048 \\
2,038 \\
2,798 \\
2,090 \\
1,875 \\
2,640 \\
2,410 \\
1,910 \\
1,149 \\
2,634 \\
8,859\end{array}$ & $\begin{array}{r}\text { £ } \\
3,417 \\
4,167 \\
-\quad \\
25 \\
57 \\
37 \\
24 \\
108 \\
537 \\
1,282 \\
937 \\
2,163\end{array}$ & \begin{tabular}{r}
\multicolumn{1}{c}{$\mathcal{L}$} \\
8,039 \\
18,194 \\
19,143 \\
25,097 \\
15,619 \\
15,715 \\
7,184 \\
12,770 \\
19,435 \\
24,926 \\
30,910 \\
32,320
\end{tabular} & \begin{tabular}{r|}
\multicolumn{1}{|c|}{$£$} \\
2,416 \\
5,681 \\
2,466 \\
372 \\
1,323 \\
2,332 \\
853 \\
1,164 \\
832 \\
1,449 \\
2,252 \\
2,826 \\
\end{tabular} & 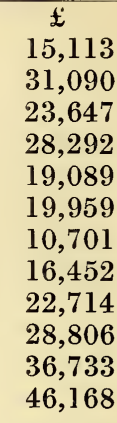 \\
\hline 1 & & 32,692 & 12,754 & 229,352 & 23,966 & 298,764 \\
\hline
\end{tabular}

TRANSIT EXPORTS.

\begin{tabular}{|c|c|c|c|c|c|}
\hline \multicolumn{2}{|l|}{ Year. } & $\begin{array}{c}\text { Food, Drink } \\
\text { and } \\
\text { Tobacco. }\end{array}$ & $\begin{array}{c}\text { Raw } \\
\text { Materials. }\end{array}$ & $\begin{array}{c}\text { Miscel- } \\
\text { laneous } \\
\text { and } \\
\text { Unclassified. }\end{array}$ & Totals. \\
\hline $\begin{array}{l}1909-1910 \\
1910-1911 \\
1911-1912 \\
1912-1913 \\
1913-1914 \\
1914-1915 \\
1915-1916 \\
1916-1917 \\
1917-1918 \\
1918-1919 \\
1919-1920 \\
1920-1921\end{array}$ & $\begin{array}{l}\ldots \\
\ldots \\
\ldots \\
\ldots \\
\ldots \\
\ldots \\
\ldots \\
\ldots \\
\ldots \\
\ldots\end{array}$ & \begin{tabular}{r}
\multicolumn{1}{c}{$£$} \\
-649 \\
2,179 \\
1,776 \\
3,314 \\
1,814 \\
5,677 \\
6,182 \\
5,366 \\
16,800 \\
40,248 \\
87,913
\end{tabular} & \begin{tabular}{r}
\multicolumn{1}{c}{$£$} \\
4,145 \\
4,891 \\
18,083 \\
15,173 \\
11,880 \\
9,225 \\
8,531 \\
5,957 \\
6,675 \\
3,828 \\
14,137 \\
10,450
\end{tabular} & $\begin{array}{c}£ \\
1,102 \\
15,077 \\
- \\
160 \\
537 \\
372 \\
549 \\
345 \\
- \\
- \\
603 \\
573\end{array}$ & $\begin{array}{c}£ \\
5,247 \\
20,617 \\
20,262 \\
17,109 \\
15,731 \\
11,411 \\
14,757 \\
12,484 \\
12,041 \\
20,628 \\
54,988 \\
98,936\end{array}$ \\
\hline $1920-1921$ & & 171,918 & 112,975 & 19,318 & 304,211 \\
\hline
\end{tabular}




\section{APPENDIX I.}

\section{CUSTOMS TARIFF。}

\section{A.-Imports.}

1. Save as hereinafter provided a duty of 15 per cent. ad valorem shall be charged on all goods imported into the Protectorate.

The words ad valorem shall mean the value of the goods at the place where such goods are purchased as shown on the genuine invoice produced to and accepted by the Comptroller of Customs, together with all charges on such goods up to the port or place from which they are shipped to the Protectorate. Such invoice shall be the genuine invoice of the manufacturer or supplier from whom the goods are purchased.

The Comptroller of Customs may allow trade discounts recognized in the particular trade and shown on the invoice to be deducted from the value for duty, but no further deduction may be allowed on account of any cash or special or sample discount or of any arrangements concerning the export or the exclusive right of sale of the goods or any consideration by which a reduction in value results.

The Comptroller of Customs may allow the cost of outside packages used for exportation of goods including the cost of zinc linings, tarred papers and materials (if any) in which the goods are packed for export to be deducted from the value for duty if shewn on the invoice, but the cost of packing, inside packages, wrappers and ordinary outside casings in which goods are normally sold for home consumption is to be included in the value for duty.

2. There shall be paid on the following goods the duties specified, that is to say :-

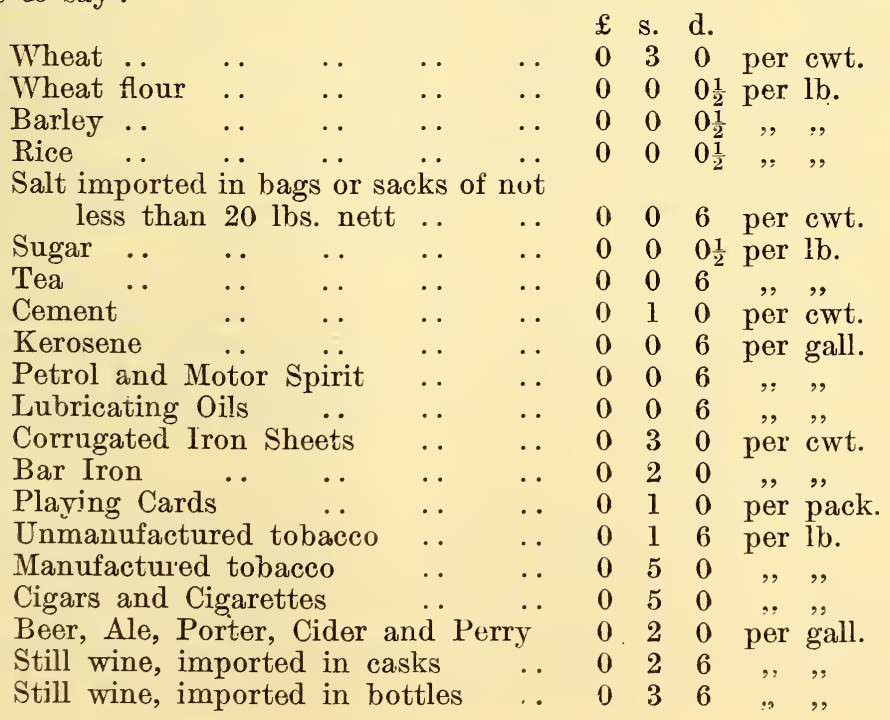




\section{A. -Imports--continued.}

Other wines, excluding cordials and $£ \mathrm{~s}, \mathrm{~d}$.

$\begin{array}{lllllllll}\text { syrups } & \ldots & \ldots & \ldots & \ldots & 0 & 5 & 0 & \text { per gall. }\end{array}$

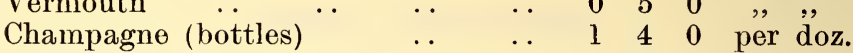

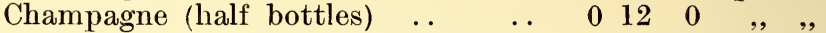

Spirits per proof gallon as ascertained

$\begin{array}{cccccc}\text { by Sikes' hydrometer } & . & \ldots & 1 & 5 & 0 \\ \text { Scents and perfumed spirits } & \ldots & & 25 \% & \text { ad val. }\end{array}$

(a) The duty on whisky, brandy, rum and gin shall be calculated on the proof strength as shewn by Sikes' hydrometer at as low a temperature as possible. When such spirits are mixed with colouring, sweetening or other matter in solution tending to conceal the actual strength, an addition of 5 per cent. shall be made to the apparent strength as shewn by the hydrometer in lieu of the test for obscuration.

(b) The strength of all liqueurs and other spirits so mixed or sweetened that they cannot be tested with the Sikes' hydrometer shall be assumed to be proof strength and duty shall be charged on the proof gallon accordingly, provided that Imperial Customs Certificates as to strength may be accepted.

(c) Six reputed quart bottles or twelve reputed pints shall be assumed to contain one liquid gallon.

(d) On preparations containing alcohol so mixed with wood naphtha or methylic alcohol as to make them totally unfit for use as a potable spirit there shall be paid import duty at the rate of 15 per cent. ad valorem.

3. The following goods shall be exempt from import duty:-

(1). Goods imported by and for the use of the Government of the Protectorate, and all goods imported by the Governor for his private use.

(2). Current coin of the realm.

(3). Agricultural and industrial power machinery, farming implements and all apparatus and plant usually and principally omployed in farming operations.

(4). Materials for making roads, bridges, railways, tramways and telegraphs, also railway rolling stock.

(5). Coal and undressed timber fit only for firewood.

(6). Trees, plants and seeds intended for cultivation, the importation of which is not expressly prohibited.

(7). Manures, insecticides and disinfectants.

(8). Unmanufactured tobacco leaf imported solely for the purpose of re-handling and packing for export from the Protectorate.

(9). Drugs of the British Pharmacopœia surgical instruments, dressings and appliances imported by Medical and Dental practitioners; Hospitals and Missions.

(10). Quinine.

(11). Horses, mules, donkeys and other live stock.

(12). Printed matter, which term shall include books; newspapers, periodicals, music, catalogues and price lists, but not stationery.

(13). Personal baggage of passengers which is in actual use at the time of importation, including clothes which have been worn, 
a reasonable quantity of jewellery which is in use by the passenger and which is not being imported except for his own use, bedding and articles of the toilet and medicines which are in actual use by the passenger, and scientific instruments intended for the private or professional use of the passenger and not intended for trading purposes. New and unworn wearing apparel or any goods which are being imported by a passenger for the use of or on account of other persons, and any form of alcohol, firearm, or weapon of any description, save as hereinafter provided, and any medicines or provisions beyond what the Comptroller of Customs shall consider to be a reasonable amount, shall not be deemed to be the personal baggage of passengers.

(14). Naval, military and civil service uniforms imported by Officers in the Protectorate services, including the necessary arms, badges and accoutrements.

(15). Camp kit, one pair of field glasses, one revolver or other pistol permitted by the Army Regulations, with 100 rounds of ammunition for same, one .303 rifle and 200 rounds of sporting ammunition imported by Military and Police Officers stationed in the Protectorate. The luggage, equipment and stores of the Inspector-General, King's African Rifles, and of his Staff Officer when they are travelling on duty.

(16). Samples which the Comptroller of Customs shall decide to be of no commercial value.

(17). Cups, medals and other trophies bona fide imported for presentation as prizes at exhibitions, shows or other public competitions.

(18). Gunny bags, gunny cloth, sacking and hooping, and other materials to be used for packing produce of the Protectorate.

(19). Goods imported by and for the use of Consular Officers of the United States of America, Mexico, Cuba and the Argentine Republic.

(20). Tombstones and ornaments for graves, memorial windows, tablets and brasses, and wine bona fide imported for church or religious purposes.

(21). Boats, yachts and vessels or parts of such.

(22). Native foodstuffs grown or raised in adjacent territory.

(23). Scientific apparatus imported by persons who have satisfied the Governor that such apparatus is intended solely for purposes connected with the gratuitous collection and preparation by them of specimens for a public isstitution or for other research work.

(24). Cinematograph films and lantern slides hired for the purposes of display, provided that the importer satisfies the Comptroller of Customs that such filns shall be re-exported within three months of the importation thereof or for such other period as the Governor may, in special cases, direct.

(25). Vehicles, including motor lorries, which are proved to the satisfaction of the Comptroller of Customs to be constructed and adapted for use and intended to be used solely for the conveyance of goods, and chassis, component parts and accessories which are so proved to be imported solely for any such vehicles.

4. Where the import duty amounts to less than 3d., a sum of 3d. shall be charged, and where such duty exceeds 3 d. or any multiple thereof an additional $3 \mathrm{~d}$. shall be charged in lieu of such excess; 
provided that in the case of goods imported by post the minimum duty shall be 3d., and thereafter duty shall be calculated to the nearest penny.

5. A rebate of the full import duty on all goods lawfully re-imported into the Protectorate shall be allowed upon the following conditions:-

(1). That a certificate containing a full description of the articles to be re-imported be obtained from a Customs Officer at the time of exportation, which certificate must be produced on re-importation.

(2). That the articles re-imported are those actually described in the certificate and are re-imported within twelve mouths from the date of exportation.

\section{B. - Exports.}

1. A duty of 1s. 6 d. per lb. shall be charged on all ivory.

2. A duty of 1 d. per lb. shall be charged on hippopotamus teeth and rhinoceros horns. gold coin.

3. A duty of 1s. per ounce shall be charged on gold other than

4. A duty of 1d. per lb. shall be charged on beeswax.

\section{APPENDIX II.}

Road and River Duties, Wharfage Dues, Registration Fees, Re-importation Certificates and other Charges.

1. In respect of all imports and exports and all goods in transit through the Protectorate there shall be charged road, river, wharfage and registration dues at the rate of 1 per cent. ad valorem save as: hereinafter provided.

For the purposes of this Schedule ad valorem shall be (1) in the case of goods imported for consumption in the Protectorate, of goods. in transit through the Protectorate by way of imports into adjacent territories, and goods re-exported the value as defined by para. 1 of Appendix I.A ; (2) in the case of exports the product of the Protectorate and of goods from adjacent territories in transit through it for export, the value shall be assessed on the prevailing market price of the article at the time of export in the country of destination, less cost of freight and other charges of transport thereto, so far as the same can be ascertained. And for the foregoing purpose the Governor in Council may appoint a Committee consisting of the Comptroller of Customs and traders or others to determine, quarterly or at such shorter intervals as may be expedient, the values for such articles. at the port or place of export in the Protectorate, and the charge of 1 per cent. hereby imposed shall be levied and taken on the values so determined. The Comptroller of Customs shall be Chairman of the Committee and where there is equality of voting shall have a casting vote.

2. No such dues shall be charged in respect of :-

(1). Goods imported by and for the use of the Government of the Protectorate and all goods imported by the Governor for his. private use. in transit.

(2). Current coin of the realm and current coin of any nationality 
(3). Live stock.

(4). Printed matter as defined in Appendix I.A. para. 3 (12).

(5). Goods imported by and for the use of Consular Officers of the United States of America, Mexico, Cuba and the Argentine Republic.

(6). Cinematograph films as defined in Appendix I.A. para. 3 (24).

(7). Personal baggage of soldiers of the King's African Rifles.

(8). Native foodstuffs.

(9). All articles lawfully re-imported into the Protectorate upon the same conditions as those set out in Appendix I. in respect of import duty under the like circumstances.

(10). The luggage, equipment and stores of the InspectorGeneral of the King's African Rifles and of his Staff Officer when they are travelling on duty.

(11). Disinfectants, manures and insecticides.

(12). Goods exported by post.

3. A fee of 2s. $6 \mathrm{~d}$. shall be charged for each Re-importation Certificate.

4. In addition to the ordinary import duty the following charges are prescribed:-

(1). On each licence to import firearms and ammunition, $10 \mathrm{~s}$.

(2). On each permit to remove alcoholic liquors from bond or King's Warehouse :-For each consignment, 2s. 6d.

5. Rent in King's Warehouses :-

For each package, per week or part thereof, $6 \mathrm{~d}$.

\section{APPENDIX III.}

\section{PRÉCIS OF INFORMATION.}

King's Warehouses are established at Blantyre and Port Herald for the reception of goods seized by the Customs, unclaimed or abandoned goods, and merchandise deposited by an importer pending the payment of Customs charges. Bonded stores, the property of merchants who have deposited security with the Customs for the duties payable on goods removed to such stores, have been opened at Blantyre and Port Herald.

The importation of any of the following goods is prohibited, whether for home use or consumption or in course of transit, that is to say :---

(a) False or counterfeit coin, or coin not of the established standard in weight of fineness, or counterfeit bank-notes, postal orders or money orders, bonds and the like.

(b) Indecent or obscene prints, paintings, photographs, books, cards, lithographs, or other engravings, or any other indecent or obscene articles.

(c) Provisions which are unfit for human food.

(d) Any seeds or plants, the importation of which is prohibited by or under any law in force or hereafter enacted.

(e) Cattle, sheep, or other animals the importation of which is for the time being prohibited by or under a law now in force or hereafter enacted. 
( $f$ ) Any goods, the importation of which is for the time being prohibited by any proclamation made by the Governor for the protection of the public health or other purposes of public policy.

$(g)$ Articles of foreign manufacture bearing the name, address, or trade-mark of any manufacturer of, or a dealer in such articles resident in the United Kingdom or in any British possession or Protectorate, or in Cyprus, or bearing the name of any place in the United Kingdom or any British possession or Protectorate, or in Cyprus, and calculated to impart to them a special character of British manufacture.

(h) Artillery of all kinds, apparatus for the discharge of all kinds or explosive or gas-diffusing projectiles, flame-throwers, bombs, grenades, machine guns, rifles, guns or other firearms of any kind whatsoever, and the component parts of and ammunition for any of the foregoing.

Provided the Governor may by licence authorize any person to import, whether for home use or in course of transit, any specified arms or ammunition. Such licence shall be in the form and be granted on payment of the fee, for the time being, and under the conditions and limitations which the Governor may prescribe, and may be revoked, varied, or suspended by the Governor whenever he may think fit.

Licences will not be granted by the Governor authorizing the importation of $\cdot 303$ rifles or anmunition for the same, except in accordance with item A. 3 (15) of the Tariff.

Any person importing goods in breach of these regulations or being in any way concerned in such importation, shall be liable to imprisonment for any term not exceeding three months, or to a fine not exceeding $£ 50$, or to both, and the goods in respect of which the offence was committed may be forfeited.

All vessels arriving within the limits of any port in the Protectorate must come up quickly to the proper place of mooring or unlading, without touching at any other place, and shall not remove from that place except to some other place of mooring or unlading.

Any Officer of the Customs may board any ship arriving at any place within the Protectorate and stay on board until all cargo has been discharged, or the ship has been cleared and has departed from the limits of the port. No goods are to be landed except with the authority or in the presence of a Customs Officer.

The master of every ship must within 24 hours of his arrival make a report in the proper form to the Officers of the Customs. Such report must contain a full description of all cargo laden on board the vessel. The Importer or his agent shall immediately upon the entry of any goods intended for home consumption pay the duties leviable upon such goods.

Immediately on arrival at any port in the Protectorate of any ship all alcoholic liquors upon which duty is not paid must be declared and shall be placed under seal by the Customs, until the vessel has again passed out of the Protectorate waters.

If entry is not made and goods not landed from a ship within fourteen days after the arrival of such ship, the goods may be removed to a King's Warehouse, and if the duties are not paid within one month afterwards the goods may be sold and the proceeds thereof applied as directed by the Customs Ordinance, 1906. Perishable goods may 
be sold immediately. The ship may be detained for expenses of guarding the cargo beyond fourteen days after arrival. All expenses incurred in connection with the checking or examination of goods must be borne by the importer.

Any warehouse goods not cleared within one year may be sold or destroyed. No compensation shall be made to any importer for damage which goods may receive while in any warehouse.

A person shall be deemed guilty of smuggling who smuggles or imports into, or exports from any place any goods with intent to avoid payment of any Customs duty, or any goods the importation or exportation whereof (as the case may be) into or from such place is prohibited, or who attempts to smuggle, import or export anv such goods, or who aids or abets any other person in the commission of any such offence.

A person convicted of smuggling shall be liable to imprisonment for any term not exceeding three months, or to a fine not exceeding $£ 100$, or to both; and any goods smuggled shall be declared forfeited to His Majesty, together with any ship, boat, cask, case, carriage, wagon or other receptacle wholly or partly belonging to the offender and containing such goods, or used in the commission of the offence.

Any person who shall bribe or attempt to bribe any Customs Officer to do anything contrary to the Customs Ordinance, 1906, or to refrain from doing anything ordered to be done by or under that Ordinance shall be guilty of an offence and upon conviction liable to a fine not exceeding $£ 100$, or three months' imprisonment or both.

The full Customs laws are contained in the Consolidating Customs Ordinance, No. 8 of 1906, and in notices and rules subsequently published in the Government Gazette.

The provisions of the Customs Ordinance governing the manner in which goods may be imported or exported, and the powers and duties of Customs Officers, and the penalties attached to the nonobservance of any of the provisions of the Ordinance shall apply, mutatis mutandis to the importation or exportation of goods by railway. 


\section{Taxation.}

In 1893 the only taxes imposed on Europeans in Nyasaland were the following :-

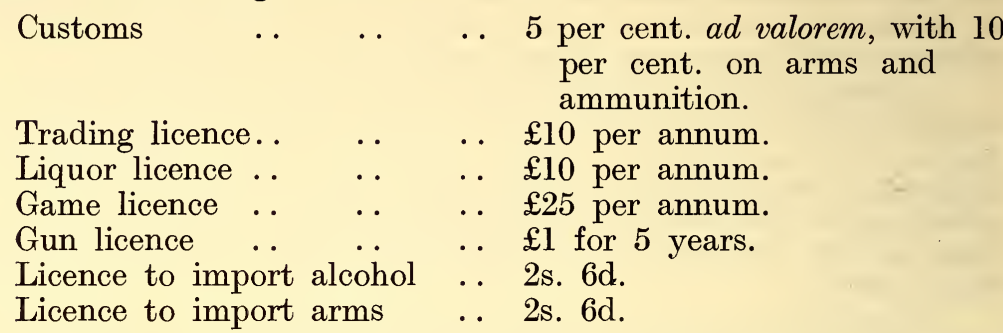

In 1891-92 a hut tax at a uniform rate of $3 \mathrm{~s}$. had been imposed in those districts fully under the protection of the administration, as it was felt that the natives might justly be expected to pay something towards the expenses incurred in keeping law and order and protecting them from the attacks of their enemies. In the Hut Tax Regulations of 1901 the tax was fixed at a maximum of $12 \mathrm{~s}$., with a labour rebate of half the amount of the tax. In 1902-03 the tax was fixed at $6 \mathrm{~s}$. with a $3 \mathrm{~s}$. rebate, and the maximum rate under the Regulations was never imposed. The Hut Tax Ordinance of 1911 retained the maximum of $12 \mathrm{~s}$., but the actual rate imposed remained at $6 \mathrm{~s}$. and, in addition to the labour rebate, a produce rebate was introduced for natives growing for sale 120 pounds of rice, 100 pounds of tobacco, or 36 to 56 pounds of cotton according to the district.

In 1912-13 the rate was raised to $8 \mathrm{~s}$. with a $4 \mathrm{~s}$. rebate, and in 1920-21 a flat rate of $6 \mathrm{~s}$. was imposed, which was continued by the Hut and Poll Tax Ordinance, 1921, in order to remove certain irregularities which had arisen in connection with the labour rebate and had caused some dissatisfaction. The Ordinance gives powers to the Governor, however, to receive taxes in kind, and at present rice is so received in Lake districts at the rate of 120 pounds of rice to a tax. By the 1921 Ordinance a poll tax of equivalent amount is payable where a native is not liable for hut tax.

When the rebate system was in force the number of taxes paid at the higher rate varied from about 8 per cent. to 16 per cent. of the total.

In 1903 the Import Duties were increased from 5 per cent. to 10 per cent. ad valorem, with specific charges on wines and spirits, and little change was made until March, 1921, when the duty was levied on the values at the port of entry instead of on the port of shipment as hitherto. The change was only temporary, however, pending a revision of the Berlin Convention, and on the 1st of October, 1921, a new tariff was introduced containing many specific duties and raising the ad valorem duty on other articles to 15 per cent. on the value at port of shipment. 
In 1912-13 a Land Tax of $\frac{1}{2} \mathrm{~d}$. an acre was introduced, which brings in about $£ 9,000$ a year. The rest of the revenue continued to be made up from various rents, fees, licences and stamp duties, until the Income Tax Ordinance, 1921, levied an income tax for the financial year 1921-22 and successive years, assessable in each year on the income for the previous calendar year. This income tax had been under consideration for some little time, but owing to delay in creating the necessary machinery, a temporary expedient was adopted for the year 1920-21 in the shape of an export duty of $2 \mathrm{~d}$. a pound on the cotton and tobacco and $\frac{1}{4} \mathrm{~d}$. a pound on tea. The imposition of these duties synchronised with a sudden fall in the home prices of the products named and a yet more unfortunate state of the market which prevented the crops from being sold on their arrival in the United Kingdom. These factors combined to produce an opposition to the export duties which would probably not have arisen otherwise.

\section{Finance.}

In the early years of the Protectorate the British South Africa Company paid an annual subsidy of about $£ 8,000$ to $£ 10,000$ towards the expenditure on military and police which were maintained partly for the benefit of North Eastern Rhodesia. The last payment was made in the year 1910-11. Grants-in-Aid were also paid by the Imperial Treasury down to 1912-13 and again in 1916-17. Since then the Protectorate has been self-supporting except in the matter of assistance to the extent of $£ 100,000$ rendered by the Imperial Government in meeting the TransZambesia Railway Guarantee for 1921-22. This amount stands as a loan to the Protectorate, and is to be liquidated by a charge of 7 per cent. per annum by way of interest and sinking fund. The following tables show the total revenue and expenditure of Nyasaland in each of the years from 1900-01 to 1920-21. The revenue figures include the British South Africa Company's subsidy, but exclude the Imperial grants-in-aid.

$\begin{array}{crccr}\text { Year. } & \text { Revenue. } & \text { B.S.A. Co. Subsidy. } & \begin{array}{c}\text { Imperi»l } \\ \text { Grant-in-Aid. }\end{array} & \begin{array}{r}\text { Expenditure } \\ 1900-01\end{array} \\ 49,212 & -- & - & 78,366 \\ 1901-02 & 51,704 & - & - & 107,439 \\ 1902-03 & 67,477 & - & - & 107,257 \\ 1903-04 & 75,895 & 10,435 & 48,000 & 102,526 \\ 1904-05 & 67,553 & 5,350 & 36,800 & 122,771 \\ 1905-06 & 76,738 & 7,350 & 32,000 & 108,682 \\ 1906-07 & 82,106 & 7,350 & 37,000 & 111,564 \\ 1907-08 & 75,197 & 8,000 & 25,000 & 105,587 \\ 1908-09 & 80,534 & 10,000 & 15,000 & 103,032 \\ 1909-10 & 76,647 & 8,000 & 30,000 & 108,728 \\ 1910-11 & 94,980 & 8,000 & 31,500 & 112,369 \\ 1911-12 & 97,356 & - & 31,500 & 118,070\end{array}$


Year

$\begin{array}{ll}1912-13 & 128,272 \\ 1913-14 & 124,849 \\ 1914-15 & 118,523 \\ 1915-16 & 137,911 \\ 1916-17 & 148,284 \\ 1917-18 & 144,240 \\ 1918-19 & 187,645 \\ 1919-20 & 186,927 \\ 1920-21 & 267,970 \\ 1921-22 & * 283,758 \\ 1922-23 & * 284,926\end{array}$

Imperial

B.S.A. Co. Subsidy. Grant-in-Aid. Exrenditure.

$\begin{array}{ccc}- & 5,000 & 116,360 \\ - & - & 135,105 \\ - & - & 143,161 \\ - & 10,150 & 125,666 \\ - & - & 128,272 \\ - & - & 143,640 \\ - & - & 150,198 \\ - & \dagger 100,000 & * 379,589 \\ - & * \dagger 86,000 & * 372,000\end{array}$

The earliest loan transaction in the affairs of the Protectorate was that for the redemption at the rate of $10 \mathrm{~s}$. an acre of 361,800 acres of land which had been granted to the British Central Africa Company as a subsidy in connection with the construction of the Shire Highlands Railway. The loan was raised on the terms of $3 \frac{1}{2}$ per cent. interest and 1 per cent. towards sinking fund, and was advanced in the following instalments as the land was gradually redeemed :-

$\begin{array}{rllr}1912-13 & \ldots & \ldots & £ 50,000 \\ 1914-15 & \ldots & \ldots & 65,000 \\ 1915-16 & \ldots & \ldots & 50,000 \\ 1918-19 & \ldots & \ldots & 15,800 \\ & & & £ 180,800\end{array}$

On the 31st of March, 1921, the position as regards this loan was as follows:-The debt had been reduced to $£ 169,846$, and the annuity for repayment and interest stood at $£ 8,371$.

In 1914 an Imperial loan was raised for the development of the East African dependencies and a sum of $£ 803,000$ was allotted to Nyasaland for the purposes of improving roads, constructing a dockyard at the south end of Lake Nyasa, and a railway to connect the Shire Highlands Railway with the Lake. Owing to the War the scheme was delayed and the following sums only have been advanced:-

$£ 12,000$ in March, 1915, and $£ 28,000$ in March, 1920, making a total of $£ 40,000$. The first $£ 12,000$ bears interest at 4 per cent., and is to be repaid by a sinking fund annuity for 37 years dating from lst April, 1918.

On the 31 st of March, 1921; the original $£ 12,000$ was reduced to $£ 11,541$, and the annual charge for interest and sinking fund stood at $£ 627$.

The cost of the local campaign stands debited by the War Office against Nyasaland to an amount which stood at $£ 3,294,000$

* Estimated.

$\dagger$ Loan on account of Trans-Zambesia Railway Guarantee. 
at the end of the financial year 1920-21, but the final incidence of the cost of the German East Africa Campaign has not yet been settled.

In addition to the loans described above, the Nyasaland Government guarantees the interest on the Central Africa Railway until the year 1923 , the estimated liability being $£ 20,000$ in 1921-22. It also guarantees the interest on the 6 per cent. debentures of the Trans-Zambesia Railway, the maximum annual liability on this account being $£ 86,000$.

By Orders in Council of 1894 and 1920 the currency of the Nyasaland Protectorate is declared to be English gold, silver and bronze. No local paper money is in circulation, and English treasury notes, Bank of England notes, and South African bank notes, although used to some extent, are not legal tender. The export of coin is at present prohibited, so that the use of some form of paper money is practically compulsory for people leaving the Protectorate, and facilities to that end are granted by the local banks.

Before the country came under British rule there was no form of currency in use, and all trade was carried on by barter. Payment of labourers was made in kind, chiefly in calico. In the earliest years of the Protectorate, rupees only were available. In 1894, English silver was obtained, and by adopting the device of fixing the exchange rate for rupees at $18 \frac{1}{2}$ to the pound, Government soon drove them out of circulation and they disappeared. In 1894 shillings and sixpences were hardly seen beyond Blantyre. By 1897 they were in full use everywhere except in the extreme north of the Protectorate, and even there the natives early learned to prefer payment in money, as they realised that by no other means could savings be stored safely and easily. Pennies were introduced soon after silver, but an attempt made a few years ago to introduce farthings met with failure. It has long been illegal to pay natives except in coin.

Banking facilities are provided by the National Bank of South Africa and the Standard Bank of South Africa, with branches at most of the important centres. Banking operations are controlled by the Banking Ordinance of 1902. Both Government and the principal missions provide savings bank facilities for natives. 


\section{CHAPTER XI.}

\section{LANDS, MINES AND FORESTS.}

In 1921, a Commission appointed by the Governor to enquire into and report upon certain matters connected with the occupation of land, presented its final report which is at present under consideration. The terms of reference on which the Commission reported were :-

1. The existing laws and policy with regard to the tenure of land by non-natives, and whether any amendment therein is desirable to better assure the position of present holders and the introduction of other and desirable settlers with adequate financial support, for the greater development of the resources of the Protectorate.

2. The areas which it may be desirable to set aside for nonnative settlement having regard to head 3 of the enquiry.

3 . The creation of reserves and the settlement of natives thereon and of native locations in or near townships.

4. The individual holding of land by natives as apart from communal occupation, both within and without native reserves, and what is desirable in respect of the reservation of crown rights thereon.

5. The cultivation by natives of industrial and economic crops (as apart from their ordinary food supply) on crown lands generally, not in individual occupation, and the conditions under which such cultivation should be permitted.

6 . The status of natives on private estates.

7. Any other matter which may be considered relevant to the questions involved in the foregoing references.

From the evidence laid before it the Commission found that the total area of the Protectorate to be 25,161,924 acres, of which $3,705,255$ acres are held in freehold by private owners under a form of grant known as a Certificate of Claim which arose in the following manner. In 1892 the Commissioner, Sir Harry Johnston, held an enquiry into the ownership of land by Europeans. Lengthy occupation combined with considerable cultivation or the erection of buildings was recognised as constituting a good claim even if unsupported by properly executed documents. In cases where land had been purchased from chiefs who did not repudiate the bargain, provided an authentic deed of sale was produced, the grant was confirmed, subject to the original price being raised to what was considered a fair value. Threepence an acre was the maximum in the Blantyre and Mlanje districts; in remote places the value was as low as a halfpenny an acre.

The sites of existing native villages were exempted from all these grants, and Government reserved to itself, when issuing 
the certificates of claim, the right to make roads, railways and canals over the property without compensation, the control over running water, and where mining rights were included, a royalty on the produce of the mines. In many cases mining rights only were at issue, and these rights were confirmed if the chiefs admitted having made the grant. Strictly speaking, of course, the chiefs had no power to dispose of the tribal lands, but their assumption of the right was tacitly accepted by the people, and by the Government.

The principal owners of land under these certificates are :-

The British South Africa Company 2,731,663 acres (practically all North Nyasa district)

The British Central Africa Company

The A.I. Bruce Trust .. ..

Blantyre and East Africa, Ltd. ..

United Free Church of Scotland ..

African Lakes Corporation .. ..

350,841

169,448

91,415

59,206

49,658

Zambesi Industrial Mission ..

.

31,025

The British South Africa Company hold mining rights over the greater part of Central Angoniland as well as over their freehold land in North Nvasa.

When all the land claims had been settled, the Commissioner concluded treaties on behalf of the Crown with all the chiefs in the Protectorate securing to Government control over all the remainder of the land, which henceforth became known as Crown Land.

Since that date Government has granted about 140,000 acres in freehold, and 120,000 under lease, as well as some hundreds of small trading plots, none of them exceeding an acre in extent, on yearly tenancy. The Lands Commission estimated that of the unalienated Crown Lands some 6,000,000 acres are cultivable.

The rents of Crown Lands leased for agricultural purposes was formerly 1s. 6d. an acre in the Shire Highlands, and 1s. an acre elsewhere. Lately, however, they have been slightly increased, the usual charge being $2 \mathrm{~s}$. an acre in the Lower Shire, Ruo, Mlanje, Ncheu, Liwonde, South Nyasa and Zomba districts, and ls. to $1 \mathrm{~s}$. 6d. an acre in other districts. But little land remains for disposal in Zomba district and none in Blantyre.

The grant of Crown Lands is governed by the Crown Lands Ordinance, 1912, as amended in 1920. An applicant selects the plot of land he desires to lease, fills in the particulars on a form obtainable from the Lands Officer, Blantyre, or from any Resident, and returns the form to the Resident of the districts in which the land is situated, together with a fee of $£ 2$. If the application is finally approved by the Governor the lease is usually put up to auction with the upset rental fixed at the rates quoted above. No one but the original applicant is allowed to bid at the auction unless he has first obtained, through the Lands Officer, the permission of the Governor. Agricultural leases are not granted for 
more than 21 years, except for slow-growing crops such as tea and rubber, when the period is 99 years. Rent is liable to re-assessment every 7 years in the former, and every 33 years in the latter case. Freehold is no longer granted. Survey fees and the first half year's rent are pavable in advance.

Survey fees are charged under the Land Surveyors Ordinance, 1912 , and vary trom a mininum of $£ 7$ for areas less than 125 acres, to $£ 3310$ s. for areas from 950 acres up to but not including 1,000 acres, $£ 46$ for 2,000 , and $£ 75$ for 5,000 acres. Government itself provides the survey, plans and deeds. The documents of title are registered under the Land Registration Ordinance, 1916, and the charges amount to about £2. Fees for preparing deeds are fixed by the Schedule to the High Court Practice and Procedure Ordinance, 1906, as amended in 1920. The minimum fee is $£ 3$ for rentals not exceeding $£ 10$; for rentals between $£ 10$ and $£ 100$, the fee is $\mathfrak{f} 5$. Stamp duties are charged under the Stamps Ordinance, 1912, and for a lease between 7 and 21 years amount to $10 \mathrm{~s}$. for each $£ 25$ of the annual rental.

It is probable that much of the procedure with regard to granting leases, and the length and conditions of leases, will be modified as a result of the recommendations of the Lands Commission.

Legislation dealing with mines consists of the Mining Ordinance, 1906, as amended in 1914 and 1921, the Mining Regulation (Oil) Ordinance, 1910, and the Oil Rules of 1910. There are Rules under the Mining Ordinances dated 1911, 1912, 1914, 1915, and 1916, and Safe Mining Rules were promulgated in 1906. But, as a matter of fact, very little mining has been undertaken in the Protectorate, nor is it likely that any immediate developments will be made in this direction. As stated above the British South Africa Company own the sole mining rights over enormous areas in Nyasaland. A Prospecting Licence costs $\mathfrak{f l}$ and applications should be addressed to the Lands Officer, Blantyre, who is also Director of Mines.

\section{FORES'TRY.}

\section{The Main Types of Tree Growth.}

Throughout the uninhabited parts of the Protectorate there still exist large tracts of natural forests composed chiefly of small broad-leaved trees and scrub of little commercial value except as poles and fuel. But around European settlements, and in localities more densely populated by natives, extensive tracts of country have been cleared of forest vegetation for agriculture and for native food gardens.

Throughout the elevated tracts of country between 2,000 and 4,000 feet above sea level, which constitute the bulk of the Protectorate, the character of the tree growth is very similar; that is to say, away from the banks of the streams the trees are mostly small with stems ranging from 4 inches to about 12 inches diameter at breast-height. Valuable timber yielding trees of 



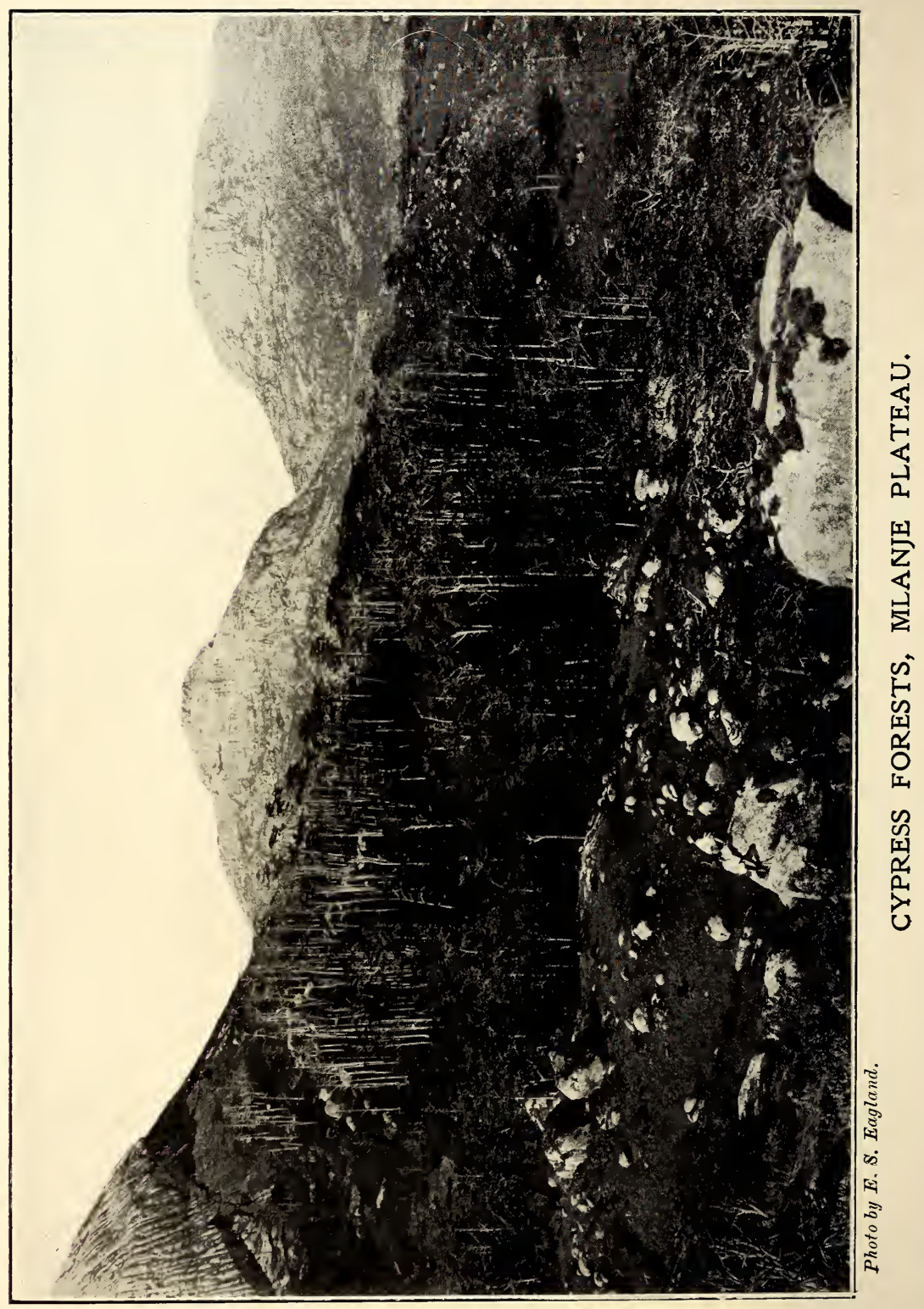


fairly large dimensions, such as mbawa, mwenya, kweranyani and mwabvi are confined chiefly to damp ravines on mountain and hill slopes and to the banks of streanis on the plains. In the hills and hilly country generally the trees are more or less evergreen, the dominant kinds being several species of Brachystegia (bark-cloth trees) and Uapaca kirkiana (msulku). At the lower elevations several kinds of trees which are evergreen in the hills are leafless for various periods during the dry season, due to the drier conditions prevailing throughout most of the low country.

Occasionally at the lower altitudes patches of pure Acacia woods are net with, and, in the Shire valley at an altitude of about 1,500 feet, some fairly large stretches of almost pure Sanya (Copaifera mopana) forests are met with on sandy soils.

The ivory palm (Hyphaene crinata) is fairly abundant on the sandy flats at the south end of Lake Nyasa, and in the Shire valley between Chiromo and Chikwawa. The Borassus palm is also occasionally met with in small numbers in the Shire valley. Other palms indigenous to Nyasaland found scattered throughout the country are the Raphia palm (Raphia vinifera) and the wild date palm (Phoenix sp.).

The oil palm (Elaeis guineensis) is occasionally found in North-West Nyasaland, but probably this has been introduced from the Congo. Cocoanut palms, introduced from the east coast of Africa, are also found growing at one or two places on Lake Nyasa.

In most districts at all elevations up to about 3,500 feet, small thickets of a very useful bamboo-a species of Oxytenanthera -are frequently met with.

The only tracts of really heary timber-forest are the small patches of Mlanje cypress (Widdringtonia Whytei) which are confined to the valleys and ravines on the higher slopes and plateaux of the Mlanje mountain between 4,000 and 7,000 feet above sea level, or about 1,700 to 4,700 feet above the surrounding plains at the base of the mountain. The aggregate area of the cypress woods at Mlanje amounts to approximately a little over 2,000 acres, about a third of which is inaccessible at present.

The Mlanje cypress is not found in any other part of Nyasaland, and the only other region in which it is known to exist naturally is the Chirinda mountain in the Melsetter district of Southern Rhodesia, where a few small patches of this tree are found between 5,000 and 7,000 feet elevation.

Podocarpus milanjianus, a tree belonging to the Yew family, and said to be identical with the "Yellow-wood" of South Africa, and which is also found at the higher elevations in Kenya Colony and Uganda, is found sparsely scattered throughout the cypress and other woods on the Mlanje mountain. But the trees are usually of small dimensions, rarely exceeding about a foot in diameter at breast-height.

The only other coniferous tree found in Nyasaland is Juniperus procera, commonly known as the East Africa Pencil 
Cedar. This tree is confined to the Nyika plateau in the North Nyasa district at an elevation of about 7,000 feet, and is apparently very scarce, as only a few specimens have been seen so far. In Kenya Colony there are extensive forests of this tree, and it is also found in Abyssinia.

Although the existing natural bush forests throughout the country are of little commercial value except for the supply of firewood, as valuable timber yielding trees of sawable dimensions are rarely found away from the banks of streams, they are of great importance in a hot country with a long dry season, such as Nyasaland, owing to the marked effect they exert in mitigating extremes of climate, in preventing soil erosion, and in acting as a protective covering to the moisture in the ground, thereby conserving and regulating the water supply and thus rendering the flow of water in streams and rivers more continuous during the dry season. If the forest regetation, especially on the hills and along the banks of streams, is destroyed, the country generally will undoubtedly get drier, though the annual rainfall may remain about the same as before the damage was done. The reason for this is that in a hot country with a well marked dry season like Nyasaland, once the forest covering is removed from the land the surface soil invariably gets hardened by the sun and is consequently unable to absorb anything like the same quantity of moisture that can be taken in by the more open and porous soil in a well-stocked forest. During a downpour of rain most of the water that falls on bare or open land rushes off to the nearest watercourse carrying with it particles of the surface soil, whereas on tree clothed land the impetus of the downpour is checked first. by the crowns of the trees and then by the undergrowth, so that there is comparatively little run-off and most of the water gradually percolates to various depths according to the nature of the soil.

The effect wooded areas exercise in increasing the relative humidity of the atmosphere in their neighbourhood is also very marked, this being due to the enormous quantities of moisture transpired from the leaves of the trees. A high relative humidity retards to a great extent the evaporation from the surface soil and tends to the formation of mist and dew, which are of the greatest importance to plant growth in localities with a meagre. rainfall.

The most important timber yielding trees in Nyasaland are :Mkungusa or Mlanje cypress (Widdringtonia whytei), Mbawa or African mahogany (Khaya senegalensis var. nyasica), Mwenya. (Adina microcephala), Kweranyani (Piptadenia buchanani) and Mlombwa (Pterocarpus angolensis).

Mlanje cypress.-Owing to its general utility this timber claims first attention. The tree frequently attains fine dimensions, and, in pockets of good deep soil, trees with clean stems up to about 50 feet, and measuring 4 to 5 feet in diameter at breast-height, are occasionally met with. Generally, however, the 
average diameter is about 30 inches, and the boles are usually clear of branches up to 30 or 35 feet. The wood, which is of a pale reddish colour and very durable, is easily worked, and resists the attacks of white ants (termites). It is extensively used by the Public Works Department for general building purposes.

Mbawa.-A fine tree confined chiefly to the vicinity of streams, though in the Mlanje wet zone large Mbawa trees are sometimes found at a good distance away from any stream. Attains very large dimensions in the more suitable situations, such as in good deep soil on the banks of streams, specimens measuring 20 to 25 feet in girth at breast-height and 70 to 80 feet in height to the first branch having been recorded. An excellent wood for furniture and general cabinet making and suitable for house building when cheaper wood is not available.

Mwenya.-This is a lofty tree rarely found away from the banks of streams. Fairly common, between 2,000 and 3,000 feet, and occasionally met with at higher elevations. The wood is hard and durable, and very suitable for heavy beams where great strength and durability are required. An excellent timber for bridge construction.

Kweranyani.-A tall tree with boles usually measuring a little over 2 feet in diameter at breast-height. Frequent on the banks of streams on the lower slopes of Zomba and Mlanje mountains and occasionally found in other parts of the country on the banks of streams above 1,500 feet. Timber suitable for general building purposes.

Mombwa.-This is a small tree with a stem rarely exceeding about 15 inches in diameter at breast-height. The dark heartwood is moderately hard and very durable, and is used for furniture, building, bridge planking and other purposes.

Other trees known to yield good timber, which, however, is not obtainable in any great quantity in any particular locality, the trees being sparsely scattered throughout the country, are :-

Mwabvi (Erythrophloeum guineense).-A fairly large tree, the timber of which is hard and very durable. Like Mwenya, the wood is used for heavy beams where great strength and durability are required. Said to be suitable for wheelwrights' work.

Mkongomwa (Afzelia cuanzensis).-A large spreading tree with a bole of only moderate length, but usually of fairly large girth. A low country tree, met with up to an elevation of about 2,000 feet. Reddish hard timber, useful for a variety of purposes, such as furniture making, waggon building, naves for wheels, and constructional work.

Msopa (Bridelia micrantha).-A moderate-sized tree which yields a good, easily worked timber, suitable for general building purposes and furniture. 
Mpindimbi (Vitex shirensis).-Small to moderate-sized tree, yielding a fine teak-like wood suitable for a variety of purposes.

Lifefe (Apodytes dimidiata).-A moderate sized tree, occasionally met with at elevations from 2,000 to 5,000 feet. This tree is also found in various parts of South Africa, where the timber is highly prized for felloes.

Chikwani (Albizzia fastigiata).- Usually a small tree, but occasionally moderate-sized specimens are met with in the Mlanje wet zone. The heartwood of this tree is said to be very suitable for naves for wheels.

Ntanga-tanga (Albizzia sp.).-A useful building timber.

Napini (Terminalia sericea).-A small to moderate-sized tree with a wide distribution, being found at all elevations up to about 3,000 feet. Timber hard and very durable in the ground; an excellent wood for bridge work and for beams and supports where strength and durability are required.

Sanya (Copaifera mopani).-Usually a small tree, fairly abundant in certain localities up to about 1,500 feet. The heartwood, which is almost black, is very hard and durable.

Mwanga (Afrormosia angolensis).-A small tree yielding a hard and very durable timber suitable for a variety of purposes, including wheelwrights' work.

Msewa (Lonchocarpus stuhlmannii).-A small tree, producing a strong durable timber.

Msuku (Uapaca kirkiana).-A small tree very common throughout the country. The timber, which is of a reddish colour, is useful for ordinary building purposes.

There are several other kinds of trees, mostly of small dimensions, which produce useful timber, but being so very scattered and scarce, they are of little value to timber users.

Rubber yielding plants are represented by several species of Landolphia, the two of most importance being Landolphia kirkii and Landolphia parvifolia, both of which are fairly abundant in certain parts of the West Nyasa district.

The genus Strophanthus is represented by at least three species, namely, Strophanthus kombe, Strophanthus ecaudatus, and Strophanthus courmontii. Of these the most important is Strophanthus kombe which produces the best seed, small quantities of which are yearly exported to England for medicinal purposes, being used chiefly for the treatment of cardiac affections. The Kombe vine is rarely found at a higher altitude than 1,500 feet; it is fairly plentiful in the Chikwawa locality, but extremely rare in other parts of Nyasaland.

Of the great variety of fibre-yielding plants found throughout Nyasaland, the following are known to yield fibre of good quality :Khonje (Sansevieria spp.). Khwisa (Hibiscus spp.), Buazi (Securidaca 
longipedunculata), Denje (Sida rhombifolia), Nsonongwe ('Triumfetta rhomboedia) and Lichopwa (Pouzolzia hypoleuca).

A useful fibre is also obtained from the bark of the Baobab tree which is fairly common at the lower elevations.

Bark-cloth, a fabric which is still extensively used by natives in some of the more out-lying parts of Angoniland as a substitute for calico, is made by beating out the fibrous bark of two of the commonest trees in Nyasaland, namely, Mombo and Nchenga (two species of Brachystegia). Most of the luzi or bark-rope, which is so extensively used by natives for binding purposes in hut building, is also obtained from the bark of these two trees.

Several species of Acacia yield a useful mucilage gum, and an astringent gum (African kino) is obtained from the Mlombwa (Pterocarpus angolensis).

The bark and seed pods of some of the Acacias are excellent tanning materials, notably the bark and pods of Acacia arabica (Mtete) and Acacia benthami (Chisio), which contain a high percentage of tannin.

The genus Indigofera, represented by about a score of species, is extremely common. Of the various species met with throughout the country the most valuable is Indigofera arrecta which is said to be the richest yielder of indigo dye.

Of the better kinds of indigenous timber trees, the Mlanje cypress and the Mbawa are not only the two of most importance, but they are also the most suitable for plantation work when the object in view is the production of timber of first class quality. Mbawa requires a rich, deep, loamy soil in which it does well up to an elevation of about 3,500 feet, Mlanje cypress, on the other hand, when grown for timber, should be planted at elevations above 3,500 feet. There is, fortunately, no difficulty in obtaining ample supplies of seed of these two trees, as they both seed freely.

For fuel plantations at the lower elevations where white ants are troublesome, two of the most suitable native trees are Nsangusangu (Prosopis kirkii) and Ntondo (Cordyla africanum), both of which make comparatively rapid growth, yield good fuel, and do not appear to be attacked by white ants. These two trees also produce seed in abundance every year.

Of the various exotic trees which succeed in Nyasaland none has been planted more extensively than Eucalyptus, certain species of which appear to thrive at all elevations when planted in good deep soil where sufficient subsoil moisture is available for their requirements during the dry season. As the greatest enemy of the Eucalyptus in this country is the white ant, land selected for gum plantations should be as free as possible from this pest.

The most suitable gums for timber and fuel plantations in Nyasaland have so far proved to be Eucalyptus saligna, Eucalyptus 
rostrata, Eucalyptus tereticornis, Eucalyptus punctata, and Eucalyptus paniculata, all of which, besides yielding good fuel, are said to produce timber of excellent quality suitable for a great variety of purposes. Fresh seed of all these species collected from trees at Zomba can be obtained in quantity from the Forestry Department.

Eucalyptus seed sown any time between the beginning of June and the end of August, according to elevation, will produce plants a suitable size and strong enough to put out in the plantation during the following rainy season. The seed should be sown broadcast on the surface of well-prepared nursery beds, covered with a sprinkling of fine soil, and firmly clapped down with the back of a spade. Besides the usual form of grass shading, which is erected over the seed bed at a height of about 3 feet, a thin layer of grass should be placed on the surface of the bed to prevent the tiny seeds being washed off the bed or too deeply into the soil when the beds are being watered, and to retard evaporation and so keep the soil sufficiently moist during the germinating period; but this layer of grass must be removed as soon as the seed has germinated. Under favourable conditions, Eucalyptus seed usually germinates in about seven days. The seed-beds must never be allowed to become dry ; but, at the same time, they should not be watered too much, only kept moist. When the seedlings are about an inch high, they should be pricked out or transplanted into shaded beds in the nursery, in lines 6 or 8 inches apart, the distance between the seedlings in each line being about 2 inches. A good width for nursery beds is 3 feet, and between each bed there should be a path 2 feet broad. When the seedlings have been transplanted into shaded beds, they should be kept well watered, and, in order to get strong and sturdy plants, the grass shading should be gradually removed as soon as the transplanted seedlings have become well established in the bed, which will be when they have reached a height of 3 to 4 inches. After that, except for daily watering during dry weather and the usual weeding, the plants will require little attention till they are ready to plant out in the field.

The transplanting of the seedlings from the seed-bed into other beds in the nursery is a most important operation, and should never be neglected, as it acts as a check on the early development of long taproots, and encourages the growth of healthy fibrous roots, which are what the plant really wants to enable it to absorb nourishment from the soil. Young trees with a good fibrous root-system have a better chance when planted out in the field, and establish themselves much more easily than plants with strong taproots, but little or no fibrous roots.

Instead of transplanting into nursery beds, another method is to transplant the seedlings into small bamboo baskets 3 to 4 inches in diameter and about 9 inches deep filled with soil, one seedling being planted in each basket. When plants which have 
been grown in baskets are being planted out in the field, all that is required to be done is to break open the bottom of the basket in order to enable the roots to push through into the ground, the basket being planted with the young tree. In hot, arid localities this method gives the best results, as the roots of the young trees are not disturbed or injured in any way during the process of planting out, and there is no check in the growth of the plants.

When selecting sites for tree planting, it must be remembered that, owing to the long dry season which the trees have to contend with, the most satisfactory results are obtained when the trees are planted in good deep soil where sufficient sub-soil moisture is available for their requirements during the dry season. In temperate zones with a well distributed rainfall and a high relative humidity of the atmosphere throughout the year, economic tree planting is practicable even on shallow soils, but in a hot country with a long dry season, such as Nyasaland, the presence of sufficient depth of soil to maintain sub-soil moisture during the dry season is of vital importance.

The ground to be planted with gums or other kinds of trees should be well prepared beforehand by deep hoeing or by ploughing where practicable. If the young gums in the nursery are a foot or more in height they should be cut back to 4 or 6 inches from the ground two or three days before planting out in the plantation (cypress and other coniferous plants must not be cut back, as they do not coppice like gums and other broad-leaved species). This pruning reduces transpiration from the plants and enables them to recover and establish themselves in their new site much more easily than tall unpruned plants carrying a lot of foliage, which require more moisture to keep them alive until their roots are well established and able to absorb sufficient water from the soil.

Plant out in dull weather during the rains, and, when planting, see that the roots of the young trees are not doubled up or twisted, but go straight down into the hole or pit made for their reception, and that the soil is firmly pressed down amongst the roots. A large percentage of the failures in a new planting is the result of careless planting, the roots having been doubled up or the young trees not planted firmly enough.

Five by five feet is a very suitable planting distance for gums; but where white ants are troublesome, closer planting is advisable, so as to allow for thinning out by the ants.

Another tree, which is now being extensively planted by the Forestry Department, and by tobacco growers and tea planters, is Cedrela toona, which yields a light cedar wood of the best quality, and which is said to be one of the most valuable timber trees known. This tree makes rapid growth in Nyasaland, and has proved very suitable for planting on land badly infested by white ants, as the young trees are rarely attacked by these pests. 
Cedrela plants are raised in the nursery in much the same way as eucalyptus. Fresh seed is now being obtained in quantity from trees in the Arboretum at Zomba. The seed commences to ripen about the end of November, and must be sown almost as soon as it is harvested, as it does not retain its vitality for any length of time.

As Cedrela toona has a pronounced tendency to start branching close to the ground at an early age, a certain amount of pruning is necessary, even in close plantings, during the first two or three years.

Another ant-resistant tree which is being planted in fuel plantations is Cassia siamea. This is a small tree which yields good fuel at an early age, and which has done well at all elevations from the coast up to 4,000 feet in Tanganyika territory.

Other exotic timber trees which have made satisfactory growth at Zomba are :-

Acrocarpus fraxinifolius.-A tall tree introduced from India, where the timber is said to be largely used for tea chests and for ordinary building purposes.

Araucaria cunninghamii, "Moreton Bay Pine."-Not a true pine, but yields a pine-like timber.

Araucaria excelsa, "Norfolk Island Pine."-A lofty tree, which reaches a height of 200 feet in its native habitat. Yields a useful softwood.

Callitris calcarata, "Australian Black Cypress."-A small tree yielding strong, durable timber.

Callitris robusta, "Australian White Cypress."-Small tree, the timber of which is often highly ornamental and durable against both decay and attacks of white ants.

Casuarina equisetifoloa, "She Oak."-This is the pine-like tree that has been so largely planted on the sands at Chinde. The timber, which is hard and very durable, makes excellent fuel, giving great heat and leaving little ashes. This and Casuarina glauca are being planted in fuel plantations at Fort Johnston by the Forestry Department.

Casuarina glauca, "Swamp Oak."-Of the various species of Casuarina which have been tried by the Forestry Department, this and Casuarina equisetifolia have proved the most suitable for cultivation in this country. Timber red, finely marked, hard and tough. Makes good fuel.

Cedrela odorata, "West Indian Cedar."-This and Cedrela toona are not true Cedars, but belong to the same family as the Mbawa. The older trees of Cedrela odorata flower regularly every year at Zomba, but rarely produce any seed, whereas Cedrela toona seeds freely every year.

Cupressus arizonica, "Arizona Cypress."

", lusitanica, "Goa Cypress."

" macrocarpa, "Monterey Cypress."

" torulosa, "Himalayan Cypress."

" sempervirens, "Horizontal Cypress." 
All the above Cupressus yield valuable timber. They are excellent trees for wind-breaks and make splendid hedges when kept properly trimmed.

Grevillea robusta, "Silky Oak."-Does well in deep rich soils, but its growth in light dry soils is seldom satisfactory. The timber is useful for furniture and general indoor work.

Jacaranda mimosifolia. "Jacaranda."-This tree yields the valuable scented Palixander wood of Brazil. It has been planted to some extent in fuel plantations where white ants are troublesome as it is rery ant-resistant.

Juniperus virginiana. "Pencil Cedar."-A tree of rather slow growth, but very hardy and succeeds on almost any kind of soil of fair depth.

Melia azederach. "Syringa" or "Pride of India."-A medium-sized tree which yields a useful soft timber of a reddish colour.

Tectona grandis. "Teak."-In deep, moist, alluvial soil this valuable timber tree has. made quite good growth in the Arboretum at Zomba.

The Forestry Department has several other kinds of timber trees under trial at Zomba, some of which look very promising.

Black Wattle does fairly well on Zomba Plateau, but at lower elevations it is not a success.

Several species of the true Pine (Pinus) have been tried on Zomba Plateau, but without success. The seeds were sound enough, as the plants came up well, but the young pines refused to grow beyond about a foot high.

The carelessness of natives has resulted in much of the Protectorate becoming deforested, and the question of afforestation is receiving the careful consideration of the Government. Re-afforestation clauses are now inserted in Government leases and steps are being taken to check the harmful grass fires and to encourage forestry work in the villages.

Particulars regarding royalties and other matters concerning timber and firewood on Crown Lands may be obtained from the Chief Forest Officer, Zomba. 


\section{CHAPTER XII.}

\section{ANIMAL AND BIRD LIFE.}

Game is still fairly plentiful in Nyasaland, except in the districts that have been thickly populated by Europeans. In the chapters on the Provinces will be found notes on the prevalence of game in the various districts. Under the Fire-arms and Ammunition Ordinance 1908, the importation of firearms and ammunition is regulated. A permit to import firearms and ammunition costs $10 \mathrm{~s}$., and a licence to carry a breach-loading rifle costs 10s. for each gun. Such licence expires on the 31st of March in each year. The sale, assignment or transfer of arms and ammunition within the Protectorate is prohibited except under permit to be obtained from the Resident of the district. A fee is charged of $6 \mathrm{~d}$. to the seller and 2s. 6d. to the purchaser. All possessors of arms and ammunition are required to make a return of such arms and amimunition to the nearest Resident on the 1st of April in each year, stating full particulars of each weapon.

Most visitors to and residents in Nyasaland indulge in game shooting as opportunity occurs and it will probably be convenient to them to have the Game Ordinance reprinted here in full, (See Appendix to this cliapter.)

The best season for shooting is from August to the beginning of the rains in about November, as during this period the long grass is burnt, and scarcity of water keeps the game from scattering.

This is not the place to give a scientific description of the fauna of Nyasaland, but the following notes on the principal animals and birds to be met with in the Protectorate will doubtless be of use to sportsmen. Fish are plentiful in parts of the country, the most important from the fisherman's point of view being the "Tiger" fish of the Lower Shire and Ruo rivers. Many years ago an attempt was inade to introduce trout into the mountain streams and a hatchery was constructed on Zomba plateau. Although trout thus bred have lived and spawned, it cannot be said that trout fishing as a sport has yet been firmly established.

\section{Big Game.}

Elephant (Elephas africanus). The forehead of the African Flephant slopes more than that of the Indian. He has only four toe-nails on the forefoot, whereas the Indian Elephant has five.

Food. Maize, millet, pumpkins and bananas from native plantations; shoots and leaves of the castor oil plant, bamboo, Namalenga thorn and other trees; the fruit of the Masuku and Kaffir orange. They are still found in fair numbers in the districts 



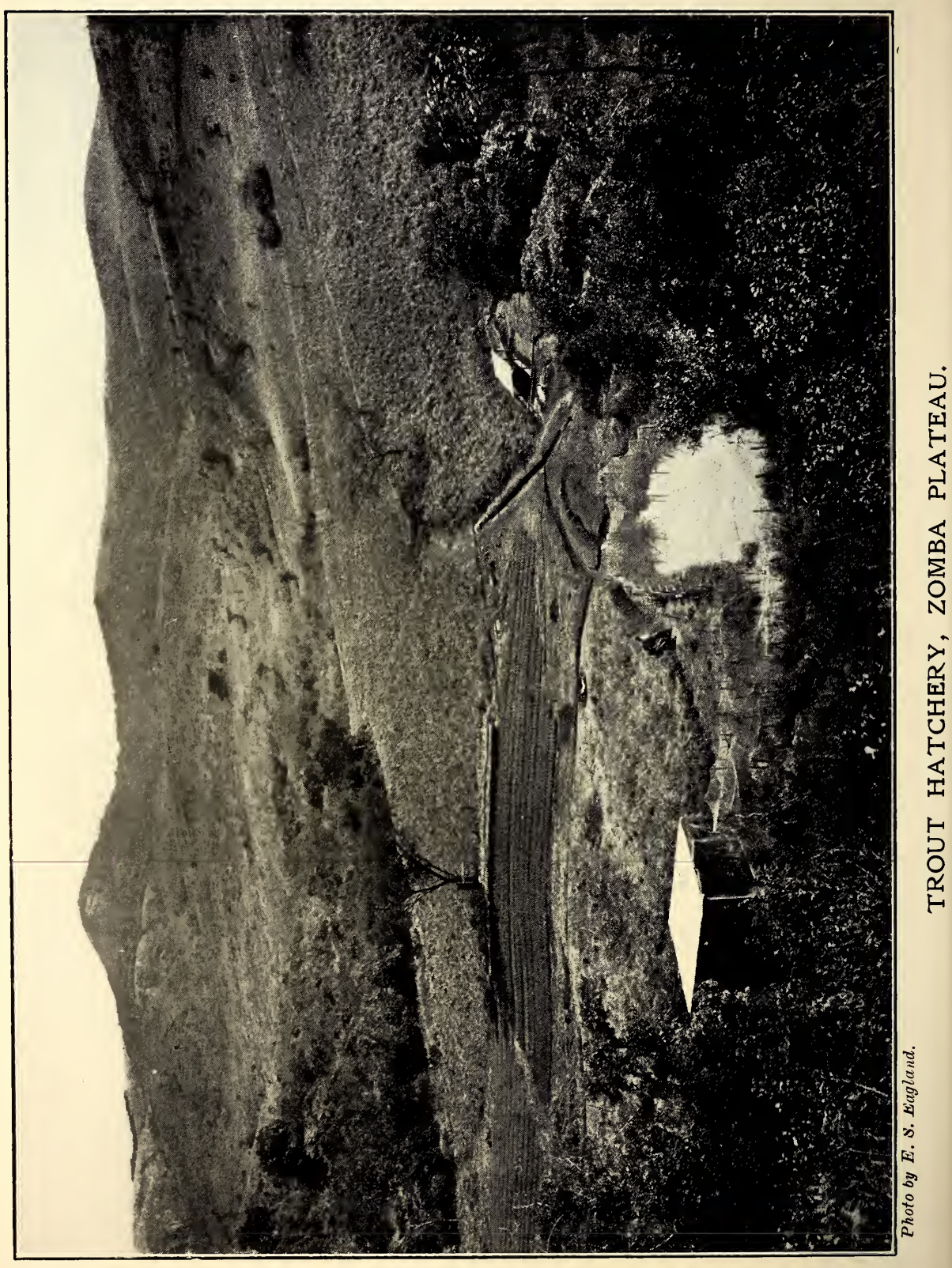


north of Dedza, where they do enormous damage to native gardens, villages and to growing trees, and there are a few herds in the South Nyasa district. Big tuskers are now rare.

Native names:--

$$
\begin{aligned}
& \text { Chinyanja and Chichewa .. Njobvu. }
\end{aligned}
$$

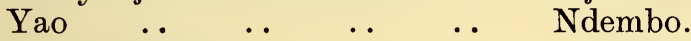

RHINoceros (Rhinoceros bicornis) is the black Rhino and has a pointed prehensile lip. the Mtete.

Food. Chiefly the leaves and bark of thorny trees such as

Rhino are not common, but they are still to be found in the Kota-Kota and Ngara districts and near the Nyika plateau. They have a fierce temper and need to be hunted with caution.

Native names :-

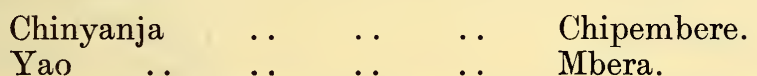

Hippopotamus (Hippopotamus amphibius). Has four toes rather pointed and with nails. Feeds at night. Very rarely leaves the water in the daytime.

Food. Grass, maize, rice and other crops.

Is still fairly plentiful in the larger rivers and in the lake, specimens weighing three tons having been secured.

The flesh is much prized by the non-Mohammedan natives, and the skin is used for making whips.

Native names:-

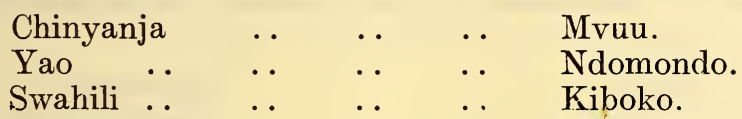

Buffalo (Bos caffer). Has larger and more massive horns than other African buffalo.

Food. Senjere reeds, Bango reed, shoots and grass.

Buffalo are still to be found on the lake shore in the Dowa and Kota-Kota districts, and in the Ngara district. They are only found in very thick country and never near human habitation. A buffalo when wounded is a dangerous beast to follow The calves are born during March and April.

Native names:-

$$
\begin{aligned}
& \begin{array}{lllll}
\text { Chinyanja } & \text {. } & \text {.. } & \text {. } & \text { Njati. }
\end{array}
\end{aligned}
$$

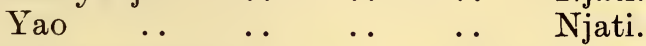

Eland (Taurotragus oryx). The Nyasaland type is " Livingstonianus." The bull has an enormous dewlap, and when old is of a slaty blue colour. The horns of the female are more slender and often longer than those of the bulls. In both sexes the body is marked by fine vertical lines.

Food. Maize, grass, castor oil shrub, the leaves, bark and fruit of the Mai (Kaffir orange), also a plant with a large pale blue flower which grows in wooded country. 
Eland are still to be found in large numbers in the districts to the north of Dedza. They are nearly always in herds, sometimes numbering well over 100 in a herd. They do not mind the neighbourhood of villages and cause much damage to the maize fields into which they come at night to feed.

Native names :-

$\begin{array}{lllll}\text { Chinyanja } & . & \ldots & \ldots & \text { Nchefu. } \\ \text { Yao .. } & . & \ldots & . . & \text { Mbunju. }\end{array}$

GNU (Connochaetes taurinus). The variety known as the Nyasaland Gnu.

Food. Grass.

Is found in large herds and prefers uninhabited country where there are no villages. Is only found in the South Nyasa and Zomba districts near the Portuguese boundary.

Native names:-

$$
\begin{aligned}
& \begin{array}{lllll}
\text { Chinyanja } & \ldots & \ldots & \ldots & \text { Tsindi. }
\end{array}
\end{aligned}
$$

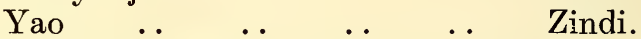

SABLE (Hippotragus niger). One of the handsoniest of Antelopes; both males and females have long scimitar shapedhorns. The males are much darker in colour than the females. Old bulls are almost entirely black. Is found in herds of from five to thirty or more. Likes broken country and is often found on high hills but comes down to the dambos in the mornings and evenings.

Food. Grass and Bwazi leaves.

Is still fairly common in the districts north of Dedza but they are also to be occasionally met with in the Shire valley.

Native names :-

$$
\begin{aligned}
& \begin{array}{lllll}
\text { Chinyanja } & \ldots & \ldots & \ldots & \text { Mpalapala. }
\end{array}
\end{aligned}
$$

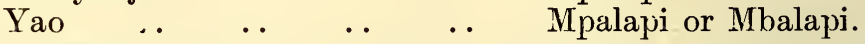

ROAN (Hippotragus equinus). Considerably larger than the sable but has shorter and thicker horns. Colour, reddish roan.

Is a rather clumsy looking animal. Has very long ears with a small tuft on the ends. Both sexes have horns. The horns of the male are heavier. Is found in small herds. Likes wooded country with small open dambos.

Food. Grass and leaves of certain shrubs.

Is common in the districts north of Lilongwe; is not known south of Dedza.

Native names :--

$$
\begin{array}{lllll}
\text { Chinyanja } & \ldots & \ldots & \ldots & \text { Chilembwe. } \\
\text { Yao } & \text {. . } & \ldots & \ldots & \text { Mlembwe. }
\end{array}
$$

KUDU (Strepsiceros kudu). Adult males have magnificent spiral horns; females are hornless. Are found in small herds. Sometimes two or three males are found together with no females. Are very shy and difficult to find as they always keep on the edge of thick bush. They are hardly ever seen in the open. Are very fond of feeding in old gardens. They like hilly and stony country. 
They reach a height of 5 feet at the shoulder, and have a fringe of long hair on the throat.

Food. Leaves of Castor oil plants, fresh leaves of the Mapira (Millet) which sprout after the Millet has been cut. Grass and certain small shoots under trees. Kudu are to be found in nearly every district in the Protectorate.

Native names :-

$$
\begin{aligned}
& \begin{array}{lllll}
\text { Chinyanja } & \ldots & \ldots & \ldots & \text { Ngoma. }
\end{array} \\
& \text { Yao } \quad \text {. }
\end{aligned}
$$

Waterbuck (Cobus ellipsiprymnus). Common Waterbuck. Has a white band on the rump. Females are hornless. The males have a strong musky smell. The flesh is uneatable by Europeans, but the hides are useful for leather. Are found in small herds in the open. Always near water. One of the commonest antelopes in the Protectorate.

Food. Grass.

Native names :-

$\begin{array}{lllll}\text { Chinyanja } & \ldots & \ldots & \ldots & \begin{array}{l}\text { Nakodzwe. } \\ \text { Chichewa }\end{array} \\ \text { Yao } & \ldots & \ldots & \ldots & \begin{array}{l}\text { Vulavula. } \\ \text { Ndogolo. }\end{array}\end{array}$

Hartebeest (Lichensteins) (Bubalis lichensteini). Both males and females have horns. Are found in small herds. Graze in the open dambos, but move into the bush during the heat of the day; move very fast when galloping. Are still numerous in the districts north of Dedza. It is about 50 inches high at the shoulder and weighs about $300 \mathrm{lbs}$. The general colour is tawny yellow.

Native names :-

$$
\begin{array}{lllll}
\text { Chinyanja } & \ldots & \ldots & \ldots & \text { Ngondo. } \\
\text { Yao .. } & \ldots & \ldots & \ldots & \text { Nkhose. }
\end{array}
$$

InYaLA (Tragalaphus angasi). Very rare. It is always found near water and very thick bush. Only comes out on the edge of the bush very early in the morning and just at sunset, and is very local. It stands about 40 inches high at the shoulder and weighs to 300 pounds. The hair is long and coarse.

Food. Grass and shoots of plants in the bush. Is only found in one or two places in the Ruo and West Shire district.

$$
\text { Native name. . } \quad \ldots \quad \text {. } \quad \ldots \quad \text { Nyala. }
$$

Bushвuck (Tragelaphus scriptus). Lesser Bushbuck. Females are hornless. Old males are very dark in colour. Usually one male with two or three females, found always near thick bush or dense reeds. Often found on the tops of high hills where there are clumps of thick bush. It is very shy and wary.

Food. Grass, Bwazi leaves and wild bean.

To be met with in moist districts.

Native names:-

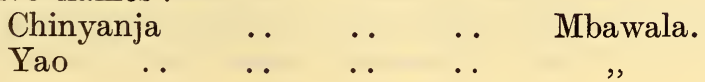


Impala (Aepyceros melampus). Variety Johnstonii. Females hornless ; go in herds ; found on the banks of large rivers or lakes where the ground is dry and hard. Likes open forest with short grass. Is very local, when running off they often make high leaps and bounds. The horns are fairly long, with a graceful double curve.

Food. Pods and leaves of Chitimbe thorn, grass.

Is still fairly common in the Upper Shire valley.

Native names :-

$\begin{array}{lllll}\text { Chinyanja } & \ldots & \ldots & \ldots & \text { Nswala. } \\ \text { Yao .. } & \ldots & \ldots & \ldots & \text { Swala. }\end{array}$

PuKu (Cobus vardoni). Females hornless. Found in herds of about 30 to 50 , with one or more males in each herd. They are an exceedingly local animal. They are always found near a river from which they never wander far, likes open dambos with light forest near.

Food. Grass.

In Nyasaland they are only to be found on the Bua river and in the Karonga district.

Native names :-

$$
\begin{array}{lllll}
\text { Chinyanja } & \ldots & \ldots & \ldots & \text { Nseuli. } \\
\text { Yao .. } & \text {. } & \ldots & \ldots & \text { Seula. }
\end{array}
$$

ReedBuck (Cervicapia arundinum). Common Reed Buck. Females hornless. Generally found in small herds in open dambos. They give a loud whistle when they are disturbed or see anyone, and this often causes the hunter to lose his chance with bigger game, as the noise gives the alarm to all buck within hearing. It is inferior in size to the waterbucks and of lighter build.

Food. Grass.

Is still common in the districts north of the Shire.

Native names:-

$$
\begin{array}{lllll}
\text { Chinyanja } & \ldots & \ldots & \ldots & \text { Mpoyo. } \\
\text { Yao .. } & \ldots & \ldots & \ldots & \text { Ndope. }
\end{array}
$$

ORIBI (Oribia scoparia), (Cape Oribi). Larger and redder in colour than the duiker. Generally found in pairs. Always in open dambos, which it seldom leaves. It is about 24 inches high and is excellent for eating. The horns are comparatively smooth and slender.

Food. Grass.

It is found in numbers in flat country all over the Protectorate, but is seldom seen in the hills.

Native names:-

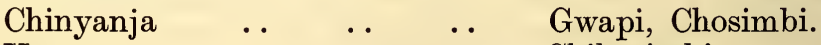

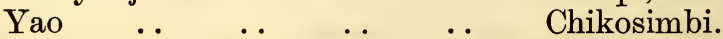

DuIKer (Cephalophus grimmi). Common Duiker. Smaller than the oribi, standing only 20 inches high at the shoulder, and is more greyish in colour. Generally found singly and always in 
forest. Feed in early morning and late evening, and seldom leaves cover. Females are hornless and the males have only short straight horns. Can live in waterless regions.

Food. Grass, the shoots of a plant with a blue flower which grows in the bush, pods of Chitimbe thorn, Bwazi leaves.

Are to be found in nearly every district.

Native names:-

Chinyanja $\quad$. $\quad$. $\quad$. $\quad$ Hisa (Gwapi sometimes).

Yao $\quad . . \quad \ldots \quad \ldots \quad$.. Isia.

RED DUIKer. Stands higher, is redder in colour, and is more graceful than the common duiker. Habits and distribution same as common duiker. Is much rarer.

Native names same as for common duiker.

KLIPSPRINGER (Oreotragus saltator). It can be distinguished by its peculiar hair and hoofs. The hair is very brittle and the hoofs are small, rounded, and like rubber, giving it a very firm grip on rocks. Is said never to drink. Usually found in pairs and always on rocky hills. The horns are only a few inches long, and the animal is extremely agile.

Food. Grass, and also chews aloes for moisture.

Is widely distributed and found in all districts where there are large and rocky hills.

Native names:-

$$
\begin{aligned}
& \begin{array}{lllll}
\text { Chinyanja } & \ldots & \ldots & \ldots & \text { Chinkoma. }
\end{array}
\end{aligned}
$$

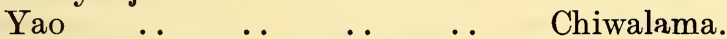

Sharpes Steinbuck (Raphiceros sharpei). Females are hornless. Is very much smaller than a duiker. They lie very close and bolt off like rabbits, never stopping to have another look. Usually found in wooded country and often in scrub near hills.

Food. Grass and leaves of bushes.

Native names :-

$$
\begin{aligned}
& \begin{array}{lllll}
\text { Chinyanja } & \ldots & \ldots & \ldots & \text { Kasenga. }
\end{array}
\end{aligned}
$$

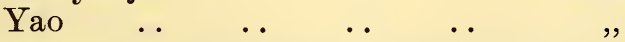

ZEBRA (Equus burchelli). Likes broken country where the grass in the small dambos is thick and luscious. But is also found in flat country where there are good bamboos and good grazing. Nyasaland zebra are very distinctly and beautifully marked.

Food. Grass and bamboo shoots.

Common in the districts north of Lilongwe.

Native names:-

$$
\begin{aligned}
& \begin{array}{lllll}
\text { Chinyanja } & \text {. } & \text {.. } & \text {.. } & \text { Mbidzi. }
\end{array}
\end{aligned}
$$

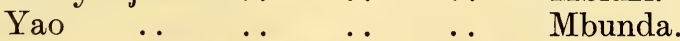

WarT Hog (Phocochoerus aethiopicus). Is very common. Is generally found in twos and threes. When disturbed they trot off with their tails stuck straight up in the air. The young are striped. Males have longer tusks than the females. The upper 
tusks are very long and curved. It often kneels on the forelegs when digging for roots, sleeps in holes made by antbears, which it enlarges.

Food. Roots of several kinds of grass and bulbs.

Found in most districts.

Native names :-

$\begin{array}{lllll}\text { Chinyanja } & \ldots & \ldots & \ldots & \text { Kapulika (Njiri). }\end{array}$

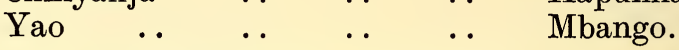

Bush Pig (Potamochaerus chaeropotamus). Cape Bush pig. Found in small herds. Is reddish in colour. Generally found in the bush, but is occasionally seen in the open. They cause much destruction, as they come down into the natives gardens to feed at night. Owing to its nocturnal habits it is not seen so often as the Wart Hog. Tusks are quite small.

Food. Shoots of bamboos, maize, millet, etc., etc.

Native names :-

$$
\begin{aligned}
& \begin{array}{lllll}
\text { Chinyanja } & \ldots & \ldots & \ldots & \text { Nguruwe. }
\end{array} \\
& \text { Yao } \quad \text {. }
\end{aligned}
$$

Potamochaerus Johnstonit. Is a smaller species of bush pig. Is rather rare. Habits are the same as the Bush pig.

LIoN (Felis leo). They generally keep in pairs, sometimes a lion and two lionesses. Very rarely they are seen in troops of six or more. Lion wanders about in search of game, sometimes going great distances at night. They are particularly fond of buffalo and eland and will occasionally follow a herd of these for some days. They are also very fond of zebra. Lions often go into kraals at night to kill cattle. In districts where there is little game they often take to man-killing. They are to be found in all parts of the Protectorate but as they are such nocturnal animals they are not often seen.

Native names :-

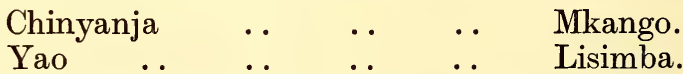

Leopard (Felis pardus). Food. Prey on all the smaller buck, but sometimes will attack larger animals such as hartebeeste or zebra. Also comes often into villages and takes goats and sheep. It will sometimes attack man and is very dangerous when wounded. Is easily caught in traps. Is common to most districts.

Native names :-

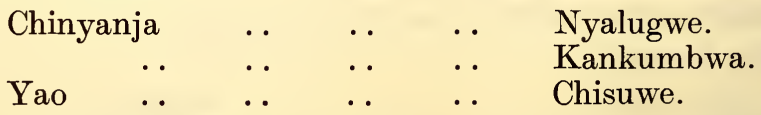

Cheetah (Cynaelurus jubatus). Is longer in the leg than a leopard, is very rare in the Protectorate.

OTTER, large clawless (Lutra capensis). Lighter coloured than the smaller kind.

Food. Fish. 
Lives in rivers and lakes but prefers marshes.

Native names :-

$$
\begin{aligned}
& \text { Chinyanja } \quad \text {.. } \quad \text {.. } \quad \text {.. Katumbu. }
\end{aligned}
$$

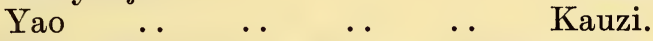

OTtER, small (Lutra maculicollis). Darker colour than the large kind, and has spots on the neck.

Native names same as above.

Spotted Hyena (Hyaena crocuta). Very common, feeds on any dead animal, seldom attacks anything else; sometimes has been known to bite a piece out of sleeping natives at night; has very powerful jaws.

Native names :-

$$
\begin{array}{lllll}
\text { Chinyanja } & \ldots & \ldots & \ldots & \text { Fisi. } \\
\text { Yao .. } & \ldots & \ldots & \text {.. } & \text { Litunu. }
\end{array}
$$

BRown Hyena (Hyaena brunnea). Larger than the spotted hyena, will hunt small game. Is much rarer than the spotted species.

Native names same as above.

Honting Dog. (Lycaeon pictus). Not so large as a hyena and has black and white markings Hunts in packs and is exceedingly bold. A pack will soon clear a place of game. If animals suddenly become wild and begin to desert a place where they are usually found it generally means that a pack of wild dogs is hunting there.

Native names:-

$$
\begin{aligned}
& \begin{array}{lllll}
\text { Chinyanja } & \ldots & \ldots & \ldots & \text { Mbulu. }
\end{array}
\end{aligned}
$$

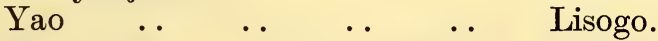

Civet Cat (Viverra civetta). Catches field mice and rats, also eats wild fruits. Lives in caves or thick reed beds. Is nocturnal.

Native names :-

$$
\begin{aligned}
& \begin{array}{lllll}
\text { Chinyanja } & \text {. } & \text {. } & \text {.. } & \text { Fungwe. }
\end{array}
\end{aligned}
$$

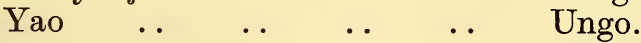

JACKAL, striped (Canis adustus). Found almost everywhere and is very bold. Is not often seen as it is nocturnal. Has a white stripe on its sides.

Food. Wild fruits, meat and offal and takes chickens from villages.

Native names:-

$$
\begin{aligned}
& \begin{array}{lllll}
\text { Chinyanja } & \ldots & \ldots & \ldots & \text { Nkhandwe. }
\end{array}
\end{aligned}
$$

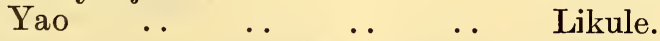

Hyena, black backed (Canis mesomelas). Habits and food same as above.

Serval (Felis serval). Has handsome spotted skin. Tail rather short. Lives in hollow trees and in holes.

Food. Kills guinea fowl, francolin, and steals poultry. Habits nocturnal. 
Native names :-

$$
\begin{aligned}
& \begin{array}{lllll}
\text { Chinyanja } & \text {. } & \text {. } & \text {.. } & \text { Njusi. }
\end{array}
\end{aligned}
$$

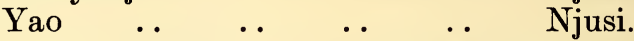

WiLd CAT (Felis caffra). Food, habitat and habits same as above.

Native names:-

$\begin{array}{lllll}\text { Chinyanja } & \ldots & . . & \ldots & \text { Vumbwe. } \\ \text { Yao .. } & . & . & \ldots & \text { Chiulu. }\end{array}$

Rusty Spotted Genet (Genetta rubiginosa). Food: mice. Smaller than a wild cat. Makes a delightful pet. Habitat and habits same as wild cat.

Native names:

Chinyanja $\quad$.. $\quad$.. $\quad$ Simba, Mwiri.

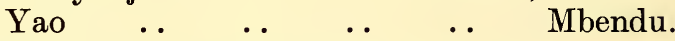

Honey BADGer (Mellivora ratel). Food: honey and ants. Lives in antbear holes. Nocturnal.

Native names:-

$$
\begin{array}{lllll}
\text { Chinyanja } & \text {.. } & \text {. } & \text {.. } & \text { Chuuli. } \\
\text { Yao . } & \text {. } & \text {.. } & \text {. } & \text { Tsapitenyi. }
\end{array}
$$

Slender Mongoose (Herpestes gracilis). Food: birds and mice. Takes poultry by night.

Native names :-

$$
\begin{aligned}
& \begin{array}{lllll}
\text { Chinyanja } & \ldots & \ldots & \ldots & \text { Nyenga. }
\end{array} \\
& \text { Yao } \quad \text {. }
\end{aligned}
$$

Marsh Mongoose (Herpestes galera). Food: small fish. Lives near water.

Native names:-

$$
\begin{array}{lllll}
\text { Chinyanja } & \ldots & \ldots & \ldots & \text { Kaka. } \\
\text { Yao .. } & \text {. } & \text {. } & \text {.. } & \text { Likaka. }
\end{array}
$$

Red Mongoose. Food: mice and locusts. Habitat and habits same as above.

BANDed Mongoose (Crossarchus fasciatus). Food: snakes, mice, ants, etc. Smaller than the slender mongoose. They live in colonies in holes; not often seen as they are nocturnal.

Native names:-

$$
\begin{aligned}
& \begin{array}{lllll}
\text { Chinyanja } & \ldots & \ldots & \text {. } & \text { Msulu. }
\end{array}
\end{aligned}
$$

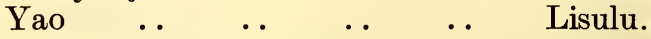

ZorILLE (Ictidonyx zorilla). Food: termites, mice, and rats, etc. Lives in holes. Black and white markings. Has a strong smell.

Native names :-

$\begin{array}{llll}\text { Chinyanja } & \ldots & \ldots & \text { Kanyimbe. }\end{array}$

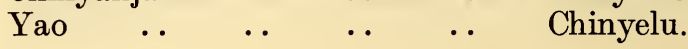


Stoat. Food: guinea fowl and chickens.

Native names :-

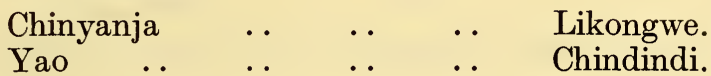

GIANT RAT. Food: bango reeds and senjere grass. Lives near water. Natives are very fond of the flesh of this animal.

Native names :-

$$
\begin{aligned}
& \begin{array}{lllll}
\text { Chinyanja } & \ldots & \ldots & \ldots & \text { Nchenzi. }
\end{array}
\end{aligned}
$$

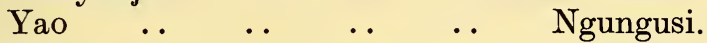

Porcupine (Hystrix afræaustralis). Food: roots. Not often seen as it is nocturnal. Lives in holes.

Native names :-

$$
\begin{array}{lllll}
\text { Chinyanja } & . & \ldots & \ldots & \text { Nyungu. } \\
\text { Yao .. } & \ldots & \ldots & \ldots & \text { Ndinu. }
\end{array}
$$

AntBear (Orycteropus afer). Is often met very early in the morning on native paths. Food: termites and ants.

Burrows into ant hills and hard earth.

Native names :-

$$
\begin{array}{lllll}
\text { Chinyanja } & \ldots & \ldots & \ldots & \text { Unungu. } \\
\text { Yao } & . . & \ldots & . . & \text { Mbawe. }
\end{array}
$$

BABOON.

Native names :-

$$
\begin{aligned}
& \begin{array}{lllll}
\text { Chinyanja } & \ldots & \ldots & \ldots & \text { Nyani. }
\end{array}
\end{aligned}
$$

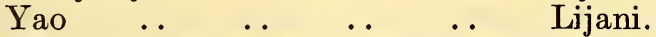

Live in troops and do much damage to native gardens.

Monkey (Cercopithecus pygerythrus). Food: wild fruits, maize, etc. Lives in troops and always where there are large trees.

Native names :-

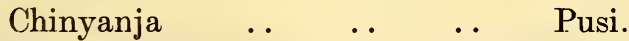

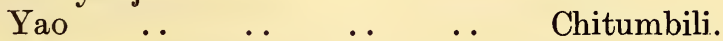

Monkey (Cercopithecus). Not so common as the above. Live in tall trees near water. Lives in troops.

Food: fruit.

Native names:-

$\begin{array}{lllll}\text { Chinyanja } & \text {. } & \ldots & \ldots & \text { Mchima. }\end{array}$

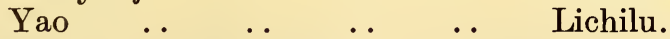

Galago (Galago crassicaudita). Lives in trees and caves. Do not live in troops. Habits, nocturnal.

Food: leaves and insects, also gum found on trees. 
Native names:-

$\begin{array}{lllll}\text { Chinyanja } & \ldots & \ldots & \ldots & \text { Changa. }\end{array}$

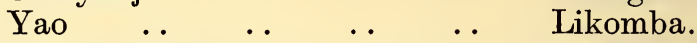

Bush BaBy. Food and habits are the same as above but it lives in families.

Native names :-

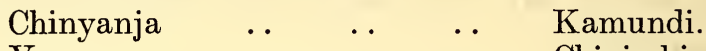

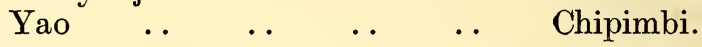

Hyrax. Lives on hills in holes in the rocks.

Native names:-

$$
\begin{array}{lllll}
\text { Chinyanja } & \ldots & \ldots & \ldots & \text { Mbira. } \\
\text { Yao .. } & . & \ldots & \ldots & \text { Njechele. }
\end{array}
$$

HARE. A little larger than a rabbit.

Native names:-

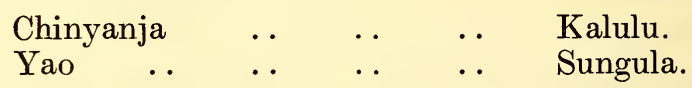

HaRe. A larger kind than the above is found on the top of mountains.

SqUIRREL. Small and reddish in colour.

Native names :-

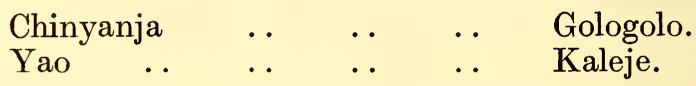

\section{Domestic Animals.}

Natives appear to make no effort to domesticate any of the animals or birds they see around them, and the domesticated animals of Nyasaland are all of foreign origin. Chickens and ducks are the only birds commonly seen in native villages.

The native dog, a terribly mongrel looking animal with a long tail, came originally from Arabia and India, while the native cat was probably introduced from India by Arabs or Portuguese. The native fowl came into Africa many centuries ago from India by way of Persia and Egypt.

The Muscovy duck was introduced from Brazil by the Portuguese, who also brought pigs into the country.

Cattle, goats, and sheep were first made known to Africa by early immigrants from Asia into the north of Africa. The Portuguese introduced the turkey to East Africa and the same people together with the Arabs are responsible for the presence of the pigeon.

\section{Birds.}

In marked contrast to the political diversity of Africa is the homogeneity of the Ethiopian faunal region, which includes the whole of the continent lying to the south of the Sahara. There are, indeed, in Nyasaland but few birds which are not represented 
by more or less closely-allied in Senegal, the Cape, and Abyssinia. The peculiar interest of the Protectorate arises from its position on the borders of the East African and South African subregions. Between these the Zambesi is taken as the boundary; arbitrarily perhaps, but one finds in fact that where a species differs in its eastern and southern forms it is generally the former which is met with in Nyasaland. Our knowledge of the birds of Nyasaland may be said to begin with the year 1891, when, acting under Sir Harry Johnston, Mr. Alexander Whyte made his first collections at Mlanje, Zomba, and Mpimbi. His activities continued till 1897, and included a very successful ornithological exploration of the Nyika plateau and Masuku range in the winter of 1896 . Other general collections were made under the directions of Sir Alfred Sharpe and Sir William Manning, while Mr. Richard Crawshay on the Nyika, Mr. A. B. Percival at Chiromo and Dr. Percy Rendall at Fort Johnston added important contributions from those localities. All this work was done in the last decade of the nineteenth century, and little that is new has been published since, though some collections must have been made.

In the 10 years referred to, 28 species of birds previously unknown to science were discovered in Nyasaland, comprising 2 Francolins, 1 Parrot, 3 Barbets, 5 Bulbuls, 1 Shrike, 1 Oriole, 3 Flycatchers, 1 Finch, 3 Weavers, 1 Weaver-finch and 7 Thrushes and Warblers. Of these species no fewer than 25 stand to the credit of Wr. Whyte, and one each to Sir Alfred Sharpe, Sir William Manning and Mr. Richard Crawshay. With one exception-a parrot from Liwonde-all the discoveries were made on the high plateaus of Zomba, Mlanje, Chiradzulu, and North Nyasa, most of the new birds being denizens of mountain forests. Many of them have since been shown to have also an extra-limital distribution, but there remain as peculiar to Nyasaland 11 species, namely :-

Crawshay's Francolin (Francolinus crawshayi) from the Nyika ; Bertrand's Bush Shrike (Chlorophoneus bertrandi), the Mlanje Bulbul (Phyllastrephus milanjensis), the Green-headed Oriole (Oriolus chlorocephalus), the Mlanje Thrush (Turdus milanjensis), the Mlanje Alethe (Alethe anomala), the Yellow-breasted Bush Warbler (Apalis flavigularis), the Nyasa Reed Warbler (Bradypterus nyasae), all of which were first found at Mlanje; Whyte's Crombec (Sylvietta whytei) and the Lesser Thick-billed Weaver-finch (Pyrenestes minor), both discovered at Zomba, and Sharpe's Weaver (Othyphantes sharpei), the type-locality of which is unfortunately unrecorded. It may be that having regard to the present swing of the pendulum against the naming of forms which are merely sub-specific, some of the above will later have to be "lumped" with others known from districts outside the Protectorate. If one had to select the most strikingly distinct of the new species, the choice of the writer of these notes* would fall on the Green-headed Oriole, which is also one of the largest and most beautifully-coloured of the discoveries. 
The list of known Nyasaland birds at present stands at 451, representing 61 families, as follows :-

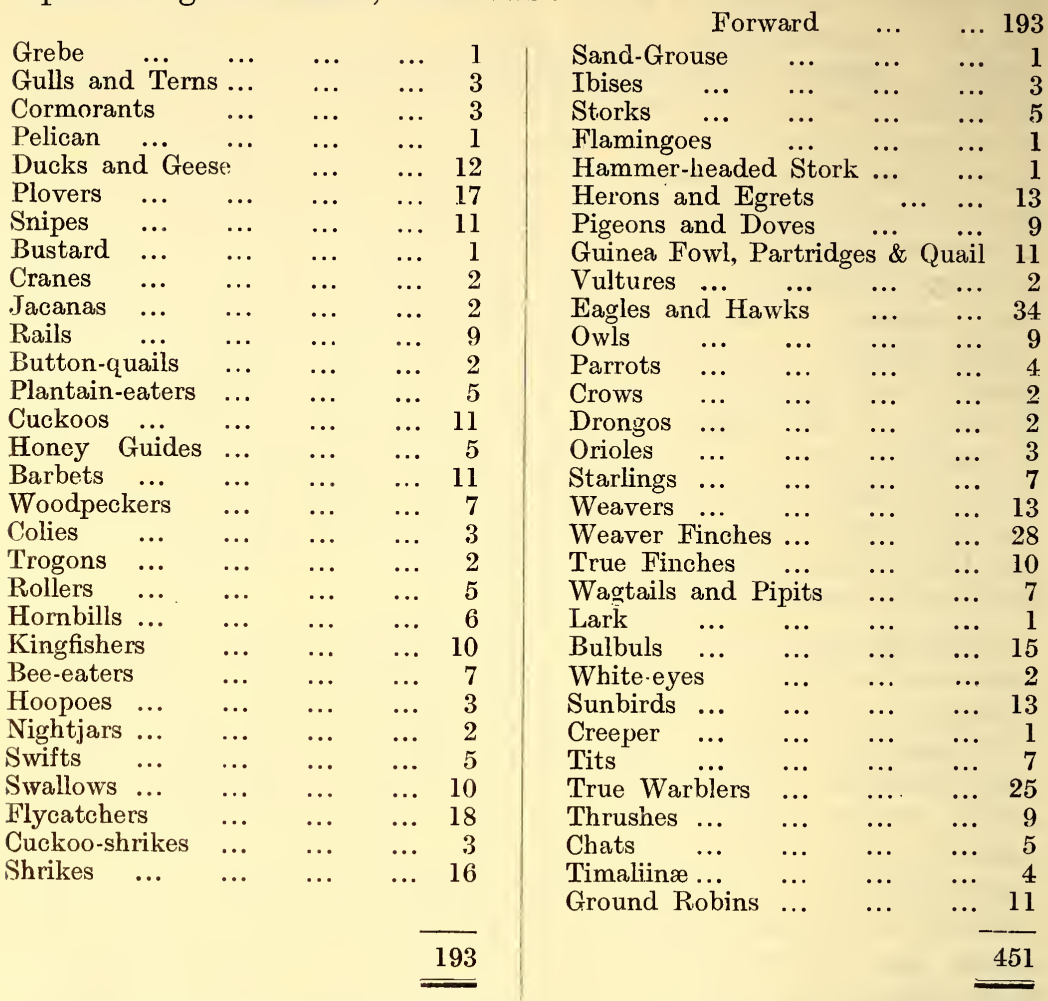

The foregoing list is in the main as it would have stood in the year 1900, but it contains some species not observed until quite recently, a circumstance from which it may be inferred that there are still additions to be made and that the actual number of resident and visiting species is nearer 500. Of quite recent additions, not recorded by the earlier workers, may be mentioned the Double-barred Sand Grouse (Pterocles bicinctus), obtained by Mr. Rodney Wood at Chiromo in 1916, and the following species recorded by the present writer in 1921 :-Grey-rumped Swallow (Hirundo griseopyga) from Tete river, East African Rock Martin (Riparia rufigula) from Blantyre, South African Sand Martin (Riparia paludicola) from Chiromo, Indian Swift (Apus affinis) from Lake Nyasa, the Warblers Calamonastes stierlingi, Eremomela flaviventris, and Euprinodes neglecta, the two first from Blantyre and the last from Chiromo, and the large African Cormorant Phalacrocorax lugubris from Lake Nyasa; it is curious that the last, a common lake bird, should hitherto have escaped notice.

Most of our birds are residents and breed within the Protectorate. Migrants from Europe which visit us during the northern winter include the Pelican, 13 kinds of Plover and Snipe, the 
Corn Crake, Flamingo, Osprey, Roller, Bee-eater, Swift, Swallow, Flycatcher, Yellow and Blue-headed Wagtails, Reed Warbler, Garden Warbler, and Nightingale. The last mentioned bird was noted by Whyte at Zomba in January. There can be little doubt that such birds as the Willow-warbler, Chiffchaff, Wheatear, and Whinchat also visit us, but they have not yet been recorded. A certain number of species found in Nyasaland may be termed infra-African migrants, having regular migrations within the continent. Of these the African Hoopoes, Cuckoos, Bee-eaters and the long-tailed Paradise Flycatcher are most conspicuous examples; they reach us in the spring and breed in Nyasaland, but the direction and extent of their winter travels is unknown.

It need hardly be said that the bird life of the Lakes Nyasa and Pamalombe and of the Shire and Ruo valleys differs from that found on the higher levels of the Shire Highlands and Angoniland : the former area exhibits a wealth of water-birds unknown in the Highlands while to a less extent the land-inhabiting species also differ, those of most brilliant colouring usually inhabiting the lower, more tropical country. There are, however, many species common to both areas and it is only when we come to the forested belts on the mountains, as on Mlanje and Zomba plateaus, Chiradzulu, and partly on Mikalongwe, Soche, Ndirande and other hills in the south and on the Vipya and Nyika in the north, that we meet a really distinctive bird-fauna quite unlike anything elsewhere in the country and having affinities rather with West Africa and the great forests of the Congo. Forest Bulbuls, Trogons, Plantain-eaters of the genera Turacus and Gallirex, and bush-haunting Thrushes, Warblers, and Flycatchers characterise these dense patches; to such an extent that in really thick mountain bush one hardly finds a single species that is also met with in the open : this provides an additional if merely sentimental argument for the preservation of what is left us of the primeval forests of the Protectorate.

To enumerate the birds of beautiful colouring found within Nyasaland would exhaust available space: one may perhaps single out the Lilac-breasted Roller (Coracias caudatus) with its long tail and brilliant plumage of light and dark blue, the magnificent Emerald Cuckoo (Metallococcyx smaragdineus) with feathers of burnished copper, and the little blue Malachite Kingfisher (Corythornis cyanostigma); but every Bee-eater, Starling, Plantaineater and Trogon is superbly coloured, and among the males of the sunbirds are some only surpassed in their gorgeous iridescence by the humming-birds of the American region.

Of game birds the Ducks, Francolin (Spur-fowl) and Guineafowl are widely distributed and afford good sport, while Blackchested Quail (Coturnix delegorguei) visit us annually from the north for a month after Christmas. True snipe of three species are to be found in suitable localities; these are the migrant Double Snipe (Gallinago media) and Ethiopian Snipe (Gallinago nigripennis) and the resident but less sporting Painted Snipe (Rostratula bengalensis). Lake Shirwa is still the centre for all water 
birds, but is rapidly being depleted of its feathered inhabitants owing to proximity to Zomba with its numerous sportsmen and shooting-boys. There is no close season.

Numbers of our birds build nests of strange and beautiful forms. Beneath the grass-woven nest of Smith's Weaver there hangs down an entrance tube which may be as much as 2 feet long; the little warbler Cisticola semitorques sews its nest between green leaves like a tailor-bird; the Palm Swift's home is a pad of feathers stuck on the midrib of a swaying Borassus frond, with the single white egg fastened firmly to the nest by means of a glutinous secretion; while most conspicuous of all is the huge domed stick-built house of the Hammerheaded Stork (Scopus umbretta) placed in the lowest fork of some riverside tree. This is the one bird which the native here, as elsewhere all over Africa, treats with superstitious veneration; the man who meddles with the Nanchengwa can never settle anywhere but must move from place to place, like the wandering Jew, all his days.

Of song birds in the true sense there are not many; among the best are the common Pied Wagtail (Motacilla vidua) so often seen about houses all over the country, and the rarer Ground-robin (Erythropygia brunneiceps), a bird of the bush. But of course almost every bird has its own call or series of calls, and all of them are pleasant-sounding to the lover of birds.

It is commonly said that in the tropics birds nest all the year through, but this is true in Nyasaland only to a very limited extent. There are occupied nests of one sort or another to be found in any month of the year, and some few families, Doves and Sunbirds in particular, do seem to breed at all times. Ducks nest in September on Lake Nyasa and the Bua; and towards the end of the rains, say February-March, in the lower country about Chiromo and Port Herald, probably also at that season on Lake Shirwa when they get a chance. Small warblers of the genera Cisticola, Prinia, and Heliolais nest when the December rains have brought the undergrowth high enough to afford concealment. Most of the 28 species of Weaver-finches (including those birds whose males don bright garments of scarlet and yellow, and sometimes long tails, as in the genera Vidua and Coliuspasser) wait for the ripening of the long grass, and nest from January to April. There is one ground-building species, the Rock Bunting (Fringillaria tahapisi) which only nests during the rainless winter months from May to August.

But for most other birds, that is to say for the vast majority of species on our list, the nesting time falls in September, October and November, the months of spring in the Southern Hemisphere. It can only be the increasing warmth of the days that gives the birds their cue, for the general rains are still far ahead when mating commences.

The end of September, especially after a light shower or two such as often occur at that time, is quite the best time for birdobservation in the Highlands. The earth is still black and buint from the fires that yearly sweep the country at the winter's end, 
and the acacias, and other tall deciduous trees stand leafless and bare. Only the bursting leaf-fronds of the smaller growth, coloured in all shades of green and red, give a hint of the season. Every movement of a bird is detected at once when there is so little cover, and it is a marvellous variety which unfolds itself to the interested observer. The black Drongo with deeply forked tail sits motionless near his shallow saucer nest in some high horizontal fork, till a blue Swainson's Kingfisher darting past leads him quite needlessly to a short and fruitless chase. From the top of a mass of grey rocks on a little kopje sings ceaselessly the Ground-Robin, always in full chorus at sunrise and sunset. Her ground-built, rock-sheltered nest is somewhere close at hand In a dense thicket which the fire has left unscarred in the stream-bed, a pair of Robin Chats (Cossypha) call loudly and sweetly as they fetch materials for their cup of rootlets and moss in a ledge of the bank; and thence proceeds to the single clear flute-note of the Organ shrike (Laniarius). In the bare tree tops flit little companies of Flycatchers (Batis) and treeloving Warblers of the genera Sylvietta and Eremomela; the Sylvietta distinguishable by the apparent absence of any tail, the other by a loud ringing call which it seems impossible should proceed from so tiny a creature.

Every bird is vocal, from the Emerald Dove with its series of melancholy yearning notes to the cheerful ubiquitous Bulbu!. Sunbirds, black or with iridescent gloss on head and neck, flutter and poise before budding tufts of mistletoe, or hurry to and from their lichened purse-like nests swinging free in air from some lofty twig. From somewhere in the distance, faint but insistent, comes through the trees the monotonous nesting-call of the Hoopoe, now double, now treble; the call which has given that strange crested wanderer a name that varies little in all languages and centuries; it was Upupa to the Latins and it is Mpupupu to the Anyanja. As one walks on, there may rise suddenly, trailing behind him a pair of white wing-streamers, enormously long, a male Standard-wing Nightjar, and one knows that somewhere within a hundred yards, on a patch of black burnt soil, his plumeless mate will be hatching her beautiful pair of marbled eggs. Far above, the short harsh croak of the great Thick-billed Raven (Corvultur) is heard from the mountain side. A pair of Augur Buzzards circle in the cloudless blue above the peak, soaring with clanging cries, while tumultuous flights of sharp-winged Equatorial Swifts wheel to and fro before their nesting places in the topmost cornice of some precipitous grey krantz. 


\section{APPENDIX.}

\section{The Game Ordinance.}

\section{1." \\ 1. This Ordinance may be cited as "The Game Ordinance,}

Interpretation of terms.

2. In this Ordinance-

"Hunt, kill or capture" means shooting at, wounding, killing or capturing by any method and includes molesting.

"Game" means any animal mentioned in any of the Schedules.

"Animal," save as herein expressly provided, means mammals and birds other than domesticated, but does not include reptiles, amphibia, fishes and invertebrate animals.

"Resident in the Protectorate" means any person whether nonnative or native who has satisfied the District Resident of the district in which he resides that he is a bona fide resident in the Protectorate.

\section{General Provisions.}

Animals not to be hunted, de., without special licence, Schedule I.

3. No person, unless he is authorized by a special licence in that behalf, shall hunt, kill or capture any of the animals mentioned in Schedule I.

Schedule II.

4. Save as in this Ordinance otherwise expressly provided no person unless he is authorized by a special licence in that behalf, shall hunt, kill or capture any animal of the kinds mentioned in Schedule II. if the animal be $(a)$ immature or $(b)$ a female accompanied by its young.

\section{Schedule III.}

5. No person, unless he is authorized under this Ordinance, shall hunt, kill or capture any animal mentioned in Schedule III.

\section{Power to vary Schedules.}

6. (1) The Governor may, if he thinks fit, by Proclamation remove any animal from any of the Schedules, or declare that the name of any species, variety, or sex of animal not mentioned in any Schedule hereto, shall be added to a particular Schedule, or that the name of any species or variety of animal mentioned or included in one Schedule shall be transferred to another Schedule, and, if he thinks fit, apply such Proclamation to the whole of the Protectorate, or to any district or other area.

(2) The Governor may, if he thinks fit, by Proclamation alter the number of the animals of any species mentioned in any of the Schedules which may be hunted, killed or captured under a licence. 
Prohibition against the export of trophies for sale.

7. (1) Save as hereinafter provided no person shall export or shall attempt to export for sale any head, horn, bone, skin, feather or flesh or any other part of any animal mentioned in any of the Schedules, unless the animal has been kept in a domesticated state.

(2) Any District Resident or Customs Officer may lawfully detain any of the things mentioned in the preceding sub-section which it is sought to export until he shall be satisfied by the person seeking to export the same that such thing is not intended for sale.

(3) Nothing in this section contained shall be deemed to prevent the export for sale of elephant ivory or hippopotamus tusks which has or have been lawfully obtained.

Prohibition against unlawful possession, \&c., of trophies.

8. No person shall possess, store, pack, convey or export or attempt to export any animal or any head, horn, bone, skin, feather or flesh or any other part of any animal which has been killed, captured or obtained in contravention of this Ordinance or of "The Game Regulations, 1902," unless such animal or such head, horn, bone, skin, feather, flesh or other part of an animal has been sold by order of the Governor or of a Court.

\section{Penalty for offence against Sections 7 and 8.}

9. Any person who shall export or shall attempt to export for sale any part of any animal in contravention of Section 7 or shall be in possession of or shall store, pack, convey or export or attempt to export any animal or any part of any animal in contravention of Section 8 of this Ordinance shall be guilty of an offence and on conviction shall be liable to a fine not exceeding $£ 20$ and in default of payment to imprisonment for a term not exceeding two months and the animal or the part thereof in respect of which the offence shall have been committed shall be forfeited unless the Governor shall otherwise order.

Animals killed by accident, \&c., or found dead the property of the Government.

10. (1) When any animal mentioned in any of the Schedules hereto is killed by accident or when the carcase or remains of any animal shall be found the head, horns, tusks, skin or feathers of such animal shall belong to the Government.

Provided that the Governor may waive the right of the Government in this respect in any case as he may deem fit; and provided that the Governor may direct the payment to any person or persons so killing or finding of compensation sufficient to cover the cost of the transport of any ivory to the nearest Government station, and may direct rewards to be paid to the finder of any ivory.

(2) Any person removing the head, horns, tusks, skin or feathers of any animal killed by accident or forming part of the carcase or remains of any animal found dead with the intention of converting the same to his own use or of depriving the Government of the same shall be guilty of an offence against this Ordinance.

(3) Nothing in this section shall be deemed to prohibit the removal of any part of any animal lawfully killed under the provisions of this Ordinance by the person killing the same or by his servants or agent, or to make it an offence for any person to remove any part of any 
carcase or remains of any animal if such person is the holder of a licence which would authorize him to kill an animal of the same species, sex and variety.

Provided, however, that in such case the animal shall count towards the number of animals which such person is entitled to kill under his licence.

Possession, sale, \&c., of immature ivory.

11. (1) No person shall possess, sell, transfer, export or attempt to sell, transfer or export any ivory which has been obtained in contravention of this Ordinance or of "The Game Regulations, 1902 ," or any elephant tusk weighing less than $11 \mathrm{lbs}$., or any piece of ivory which formed part of a tusk under $11 \mathrm{lbs}$, in weight.

Provided that the Governor or any person authorized by the Governor in that behalf may possess, sell or transfer within the Protectorate or may export any ivory belonging to the Government or forfeited under the provisions of this Ordinance or of any law repealed by this Ordinance.

Marking of ivory sold under reservation.

(2) All such ivory possessed, sold, transferred or exported under the provisions of the last preceding sub-section shall be distinctively marked with such mark and in such manner as the Governor by Notice published in the Gazette may appoint.

Saving to purchaser.

(3) The purchaser or transferee of any ivory so sold or transferred under the provisions of sub-section (1) of this section shall lawfully possess such ivory and may lawfully export the same.

\section{Penalty for offence against preceding section.}

12. (1) Any person who shall possess, sell, transfer, export or attempt to sell, transfer or export any ivory in contravention of the preceding section shall be guilty of an offence, and shall be liable to a fine not cxceeding $£ 100$ or to imprisonment for a term not exceeding six months or to both fine and imprisonment, and the ivory shall be forfeited unless the Governor shall otherwise order.

\section{Onus of proof.}

(2) Whenever a person shall be charged with the offence of being in possession of or selling or transferring or exporting or attempting to sell, transfer or export any ivory obtained in contravention of this Ordinance or of "The Game Regulations, 1902," it shall be sufficient if the summons or charge shall allege that the ivory was obtained in contravention of the law, without specifying the law, and the onus shall then be on the person accused to produce satisfactory proof that the ivory was lawfully obtained.

Provided, however, that if the person accused shall fail to produce such proof but there shall not be sufficient evidence to prove that such person knew or ought to have known that the ivory was obtained in contravention of the law, the ivory shall be forfeited, but the person accused shall not be liable to either a fine or imprisonment.

\section{Restriction on killing fish.}

13. No person shall use any poison, or, without written permission from the Governor first obtained, any dynamite or other explosive for the killing or taking of any fish. 
Power to prohibit destructive methods of capture.

14. Where it appears to the Governor that any method used for killing or capturing animals is unduly destructive, he may, by Proclamation, prohibit such method or prescribe the conditions under which any methor may be used, and if any person uses any method so prohibited, or uses any method otherwise than according to the conditions so prescribed, he shall be liable to the same penalties as are provided in Section 35 of this Ordinance.

\section{Gaye Reserves.}

Game reserves. Power to vary game reserves.

15. (1) The area described in schedule IV. hereto is hereby declared to be a game reserve. The Governor in Council, with the approval of the Secretary of State, may by Proclamation declare any other portion of the Protectorate to be a game reserve, and may define or alter the limits of any game reserve, and this Ordinance shall apply to every such game reserve.

Power to abolish game reserve.

(2) The Governor in Council, with the approval of the Secretary of State, may by Proclamation abolish any game reserve.

Prohibition of hunting, \&:., any animal in a game reserve.

(3) Save as provided in Section 20 of this Ordinance any person who hunts, kills or captures any animal in a game reserve, or is found within a game reserve under circumstances shewing that he was unlawfully in pursuit of any animal, shall be guilty of an offence against this Ordinance.

\section{Game Licences.}

Licences and by whom issued.

16. (1) The following licences may be granted by the District Resident of a district or by such other person as may be authorized by the Governor in that behalf, that is to say :--.

(a) A visitor's licence. (Licence A).

Fees.

(b) A Protectorate licence.- (Licence B).

(2) The following fees shall be paid for licences:--For a visitor's

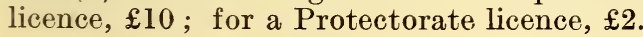

(3) Every visitor's licence and Protectorate licence shall expire on the 3lst day of March next following the date of issue.

(4) Every licence shall bear the name in full of the person to whom it is granted, the date of issue, the period of its duration, and the signature of the person granting the same.

(5) A licence granted under this Ordinance is not transferable.

(6) The holder of a licence shall on demand being made by a Magistrate or other officer authorized in that behalf, produce his licence to such Magistrate or officer, and any licence holder who fails, without reasonable cause to produce his licence shall be guilty of an rffence against this Ordinance.

(7) A visitor's licence shall not be granted unless and until the applicant has deposited with the officer issuing the licence a sum of £.0 sterling or has given such adequate security for the payment of a like sum as in the circumstances the officer issuing the licence shall deem fit. The deposit so made or the security so given may be forfeited 
on conviction of the licensee of a breach of this Ordinance, without prejudice to any other penalties to which the licensee may be liable under the remaining provisions of this Ordinance.

\section{To whom Protectorate licence may be granted.}

17. A Protectorate licence shall not be granted except to a person resident in the Protectorate or to an officer in the public service of the Protectorate.

Animals which may be hunted under visitor's or Protectorate licence.

18. A visitor's licence, and a Protectorate licence respectively shall authorize the holder to hunt, kill or capture animals of any of the species mentioned in Schedule III., but not more than the number of each species fixed by that Schedule:

Provided that the Governor may in any particular case allow a larger number of animals to be hunted, killed or captured, the extent of such permission to be endorsed on the licence by the Government Secretary.

\section{Protection of crops.}

19. (1) Any landbolder, or his servant, finding an animal mentioned in the Schedules spoiling his crops or doing damage to his holding may kill the same without a licence if such act is necessary for the protection of his crops or holding :

Provided that whenever an elephant is killed under the provisions of this section, the tusks shall be the property of the Government and shall be dealt with as the Governor may direct.

(2) Every such killing shall be at once reported by the landholder to the District Resident of the district.

Special licence issued for scientific or administrative reasons.

20. (1) When it appears proper to the Governor for scientific or administrative reasons, he may grant a special licence (Licence $\mathrm{H}$ ) to any person, to hunt, kill or capture animals of any one or more species mentioned in any of the Schedules or to hunt, kill or capture in a game reserve specified beasts or birds of prey or other animals whose presence is detrimental to the purposes of the game reserve; or for scientific reasons to kill or capture as the case may be, any animal or animals in a game reserve.

(2) A special licence shall be subject to such conditions as to fees and security (if any), number, sex and age of specimens, district and seasons for hunting, and other matters as the Governor may prescribe.

Revocation of special licences.

(3) The Governor may revoke any special licence issued by him when he is satisfied that the holder has been guilty of a breach of any of the provisions of this Ordinance or of the conditions of his licence or has connived with any other person in any such breach, or that in any matters in relation thereto he has acted otherwise than in good faith.

(4) Save as aforesaid, the holder of such special licence shall be subject to the provisions of this Ordinance.

Additional licence to kill elephants.

21. (1) No person, unless he is authorized by an additional licence in that behalf, shall hunt, kill or capture any male elephant or elephants.

(2) A District Resident may on the application of the holder of a visitor's or a Protectorate licence grant an additional licence authorizing such person to hunt, kill or capture either one or more male elephants 
(not more than four in all) as the applicant may require and as shall be specified in such licence. Such licence shall not authorize the holder to hunt, kill or capture any elephant having tusks weighing less than $11 \mathrm{lbs}$. each.

(3) There shall be paid for each additional licence the following fees:For a licence to hunt, kill or capture one elephant $£ 10$. (Licence C).

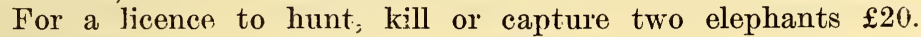
(Licence D).

For a licence to hunt, kill or capture three elephants $£ 40$. (Licence E).

For a licence to hunt, kill or capture four elephants $£ 60$. (Licence F).

(4) Every additional licence granted under this section shall expire on the 31st March next following the date of issue and only one such licence shall be granted to such person during the currency of any such visitor's or Protectorate licence:

Provided, however, if such person shall have taken out an additional licence to hunt, kill or capture any less number of elephants than four, he may be granted a further licence or licences to hunt, kill or capture an additional elephant or elephants but so that the total number to be killed or captured under all licences he may hold does not exceed four, and the fees paid are on the scale laid down in this section, namely for the second elephant an additional $£ 10$ and for the third and fourth an additional $£ 20$ each, and provided further that he shall first surrender the additional licence he already holds.

Refunds applicable to holder of Protectorate licence.

(5) (a) In the case of the holder of a Protectorate licence a refund of the full amount paid in respect of an additional licence shall be made if no elephant be wounded, killed or captured and refunds shall be made in the following circumstances to the extent hereinafter specified, that is to say:-If the holder of such licence or licences authorizing the licensee to hunt, kill or capture in all two elephants wounds, kills or captures one elephant only $£ 10$ shall be refunded.

(b) If the holder of such licence or licences authorizing the licensee to hunt, kill or capture in all three elephants wounds, kills or captures one elephant only, $£ 30$ shall be refunded, and if the licensee wounds, kills or captures two elephants $£ 20$ shall be refunded.

(c) If the holder of such licence or licences authorizing the licensee to hunt, kill or capture in a'l fou: elephants wounds kills or captures one elephant only, $£ 50$ shall be refunded, and if the licensee wounds, kills or captures two elephants $£ 40$ shail be refunded and if the licensee wounds, kills or captures three elephants $£ 20$ shall be refunded.

(d) In all cases where an application is made for a refund under this sub-section the burden shall lie upon the applicant to prove to the satisfaction of a District Resident that he is entitled to such refund, and the application therefor shall be made on or before the 30th day of April following the date of expiry of such licence or licences.

Provided always that a District Resident mav in his discretion waive payment of the licence fee in this section referred to and in lieu of paymient thereof may require the applicant to enter into a bond or make a deposit of cash for or of the same amount as the fee chargeable upon such licence and upon entering into such bond or making such deposit the applicant shall be entitled to hunt, kill or capture the number of elephants to which such bond or deposit extends 
(6) In every case in which a bond has been entered into or a deposit made under the preceding sub-section the Protectorate licence shall be endorsed by the District Resident to the effect that such bond has been entered into or such deposit made.

(7) Every holder of a Protectorate licence whose licence has been endorsed as aforesaid shall without delay upon wounding, killing or capturing an elephant or elephants present his licence for further endorsement thereon by a District Resident of the district in which the elephant or elephants were wounded, killed or captured of the fact of his having wounded, killed or captured an elephant or elephants and the number so wounded, killed or captured, and shall thereupon take out the necessary additional licence.

(8) Where a bond or deposit has been accepted as aforesaid in lieu of payment in cash the amount of the liability of the holder of a Protectorate licence under such bond or deposit shall be determined in accordance with the provisions regulating refunds in this section contained :

Provided that every person whose bond or deposit is accepted as aforesaid in lieu of payment shall be subject save as aforesaid to all the provisions of this Ordinance.

Refunds applicable to holder of visitor's licence.

(9) (a) In the case of the holder of a visitor's licence refunds shall be made in the following circumstances and to the extent hereinafter specified :- -If the holder of such licence or licences authorizing the licensee to hunt, kill or capture in all three elephants wounds, kills or captures two elephants or less $£ 20$ shall be refunded.

(b) If the holder of such licence or licences authorizing the licensee to hunt, kill or capture in all four elephants wounds, kills or captures two elephants or less $£ 40$ shall be refunded, and if the licensee wounds, kills or captures three elephants $£ 20$ shall be refunded.

Original licence to be endorsed.

22. Every person who shall obtain an additional licence under the last preceding section shall produce to the officer granting the saine his visitor's or Protectorate licence, and such officer shall endorse thereon the fact that such additional licence has been granted, and the extent of the licence.

Penalties.

23. The holder of an additional licence issued under Section 21 who shall hunt, kill or capture any elephant in excess of the number authorized by such additional licence shall be guilty of an offence against this Ordinance.

Forms of licences.

24. (1) The Governor may by Rule prescribe the forms of licences issued under the provisions of this Ordinance.

Game Register.

(2) Every licence holder shall keep a register of the animals killed or captured by him in the form specified in Schedule V.

Production of register for inspection.

(3) Any person authorized to grant licences or any Magistrate may at any time call upon any licence holder to produce his register for inspection.

(4) Every holder of a licence must within 15 days after his licence has expired produce or send to the District Resident of the district 
in which he resides the register of the animals killed or captured by him under his licence.

(5) Every person holding a licence shall before leaving the Protectorate submit his licence and register to the Comptroller of Customs.

Fuilure to keep or prociuce a register an offence.

(6) If any holder of a licence fails to keep his register truly or to produce his licence or register as required by this section he shall be guilty of an offence against this Ordinance.

Extension of period of licence.

(7) Where the holder of a Protectorate licence or of a visitor's licence is unable to make any use of his licence during the year for which it is issued he may on application to the Governor have his licence endorsed to that effect, and thereupon such licence shall remain in force until the 31st day of March next following the date of such endorsement. Such application may be made at any time within four years from the expiration of the year for which the licence was originally granted. If no use is made of the licence during the period for which the licence has been renewed the licensee may from time to time have the licence further endorsed so as further to extend the period for which it is available.

Provided always that no such renewal shall be granted after five years from the original date of issue of the unused licence.

Refusal of licence.

25. The Governor mav at his discretion direct that a licence under this Ordinance shall be refused to any applicant.

\section{Lost licences.}

26. Any person whose licence has been lost or destroyed may obtain a fresh licence for the remainder of the term of the licence lost or destroyed on payment of a fee of $5 \mathrm{~s}$.

\section{Licence does not authorize trespass.}

27. No licence granted under this Ordinance shall entitle the holder to hunt, kill or capture any animal on private land or to trespass on private land without the consent of the owner or occupier.

Hunting, \&ic., animals beyond limit allowed, an offence.

28. Any person who after having killed or captured animals to the number and of the species authorized by his licence, proceeds to hunt, kill or capture any animals which he is not authorized to kill or capture shall he guilty of a breach of this Ordinance.

\section{Restrictions on Kiling Game by Natives.}

\section{Native licences.}

29. 'The District Resident of a district may, at his discretion, grant licences (Licence $G$ ) to natives to hunt, kill or capture any of the animals mentioned in Schedule III., but not more than the number of each species fixed by that Schedule within the said district on payment of a fee of $\mathfrak{E l}$.

\section{District Resident may authorize natives to kill game.}

30. (1) When the members of any native tribe or the native inhabitants of any village appear to be dependent on the flesh of wild animals for their subsistence, or when it is shewn that any wild animals are causing damage to any native or to the lands or property of any native, the I)istrict Resident of the district may, with the 
approval of the Governor, by order addressed to the chief of the tribe or headman of the village, authorize the tribesmen or inhabitants, as the case may be, to kill animals within such area, and subject to such conditions as to mode of hunting, number, species, and sex of animals, and otherwise as may be prescribed by the order.

Provision re licences.

(2) The provisions of this Ordinance with respoct to the keeping of registers shall not apply-

(1) To native licensees under Section 29 who are unable to read or write :-

Provided that every such native licensee shall be required to make a report to the District Resident, containing the number and species of game killed or captured under his licence.

(2) To a member of a tribe or a native inhabitant of a village to which an order under Section 30 (1) applies:-

Provided that any such member or native may in the case of

a tribe through the chief or in the case of a village through the headman be required to make a report containing particulars of the number of game killed or captured under any such order.

Other provisions to apply.

(3) Save as aforesaid, the general provisions of this Ordinance shall apply to every native who is authorized under this section, and a breach of any order shall be an offence against this Ordinance.

\section{Rewards for Killing Felide.}

Rewards for killing felidce.

31. The Governor in Council may from time to time by notice in the Gazette offer rewards for the killing of felidx or other carnivora or other animals dangerous to life or destructive to property subject to such conditions as may be prescribed in such notice.

\section{Procedure and Penalties.}

Powers to Magistrates or Policcmen to arrest without warrant.

32. (1) Any Magistrate or Policeman who sees or finds any person committing an offence or has reason to suspect any person of having committed or of being engaged in committing an offence against this Ordinance may, without warrant stop and detain such person and if the Magistrate or Policeman does not know and cannot satisfactorily obtain his name and address or if the Magistrate or Policeman has reason to believe that unless such person is arrested there may be difficulty in afterwards finding him or making him answerable to justice then such Magistrate or Policeman may without warrant apprehend him.

(2) A person apprehended under this section shall be taken with all practicable speed before a Magistrate and shall not be detained without a warrant longer than is necessary for that purpose.

Power to search and seize, \&c.

33. Whenever any Magistrate or Policeman thinks it expedient for the purposes of verifying the register of a licence holder, or suspects that any person has been guilty of an offence against this Ordinance, or of committing a breach of the conditions of his licence, he may inspect and search, or authorize any subordinate officer to inspect 
and search, any baggage, package, wagon, tent, building or caravan belonging to or under the control of such person or his agent, and if the Magistrate or Policeman finds any animal or any head, horn, tusk, skin, feather or other remains of any animal appearing to have been killed, captured, obtained or dealt with or to be possessed in contravention of this Ordinance he shall seize and take the same before a Magistrate to be dealt with according to law.

Power to enter upon land for purposes of the Ordinance.

34. Any Magistrate or Policeman may enter upon any land for the purpose of this Ordinance or for the purpose of preventing or detecting offences against this Ordinance.

\section{Penalties.}

35. (1) Any person who hunts, kills or captures any animal in contravention of this Ordinance or otherwise commits any offence against this Ordinance for and in respect of which no penalty is specially provided or commits a breach of this Ordinance or of the conditions of his licence shall on conviction be liable to a fine not exceeding $£ 50$ or to imprisonment for a term not exceeding two months or to both fine and imprisonment.

(2) In all cases of conviction any aninial or any head, horn, tusk, skin, feather or other remains of any animal obtained or possessed in contravention of this Ordinance or of the conditions of a licence shall be forfeited unless the Governor shall otherwise order. If the person convicted is the holder of a licence his licence may be revoked by the Court.

Payment of informers.

36. Where in any proceeding under this Ordinance any fine is imposed, the Court may award any sum or sums not exceeding half the total fine to any informer or informers.

\section{Power to make Rules.}

37. The Governor in Council may make and when made shall publish in the Gazette Rules for the better carrying into effect of the provisions of this Ordinance. Such Rules may provide penalties not exceeding those set forth in Section 35 of this Ordinance.

Power to suspend Ordinance.

38. The Governor in Council may suspend the operation of this Ordinance or parts thereof, either as to the whole Protectorate or certain districts or portions of districts.

Repeals.

REPEAL.

39. "The Game Regulations, 1902," are hereby repealed; provided as follows :-

Savings.

(1) Where any legal proceedings have been begun under the said repealed Regulations the same shall be continued as if this Ordinance had not been enacted.

(2) Any person who has before the commencement of this Ordinance committed an offence against the said repealed Regulations or committed any breach of the provisions of the said Regulations or of the conditions of any licence granted thereunder, which offence or breach cannot be punished under this Ordinance, shall be proceeded against and punished as if this Ordinance had not been cnacted. 


\section{SCHEDULE I.}

Animals not to be hunted, killed or captured by any person exrept under special licence :-

Elephant (female or young)

Rhinoceros

Giraffe

Mountain Zebra

White Tailed Gnu

Inyala (Tragelaphus Anyasi)

Secretary Bird

Owl

Rhinoceros Bird

Common Stork

Vulture

Whiteheaded Fish Eagle (Haliætus Vocifẻr)

Hoopoe

Heron

Wattled Starling or Lesser Locust Bird (Dilophus Carunculatus)
Marabout

Bee-eater

Raven

Blue Jay

Kingfisher

Hornbill

Oriole

Sunbird

Trogon

Glossy Starling

Emerald Cuckoo (Chrysococeyx)

Turaco

Shrike

Woodpecker

Buzzard Eagle (Asturinula

Monogrammica)

Any animal within a game reserve.

\section{SCHEDULE II.}

Animals the females of which are not to be hunted, killed or captured when accompanied by their young, and the young of which are not to be captured, except under special licence.

1. Hippopotamus

2. Zebra (other than Mountain Zebra)

3. Chevrotain (Dorcatherium)

4. All Antelopes and Gazelles mentioned in any Schedule.

\section{SCHEDULE III.}

Animals a limited number of which may be hunted, killed or captured under a visitor's or Protectorate licence :-

1. Buffalo $\quad$.

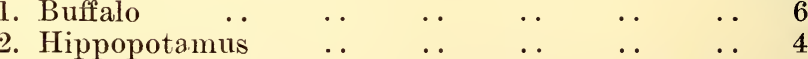

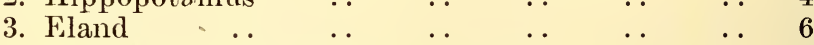

4. Gnu, Wildebeest (except white-tailed species) $\quad$. 6

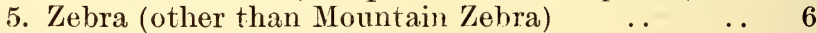

6. Antelopes and Gazelles :-

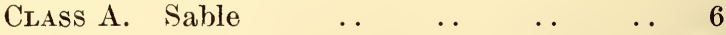

$\begin{array}{lllllll}\text { Roall } & \ldots & \ldots & \ldots & \ldots & \ldots & 6\end{array}$

$\begin{array}{lllllll}\text { Kudu } & \text {. } & \ldots & \ldots & \ldots & \ldots & 6\end{array}$

Class B. Any other species in all .. $\quad$. 30

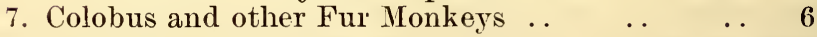

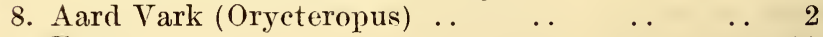

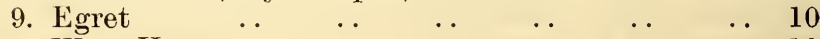

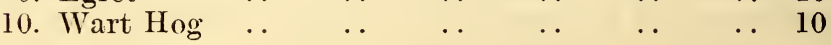




\section{SCHEDULE IV.}

\section{GAME RESERVE.}

\section{(The Central Angoniland Game Reserve.)}

Commencing at the point on the Dedza-Lilongwe road where this road is crossed by the Tete river (a tributary of the Lintipe river) the boundary shall be carried along the Tete river, up stream, to its source on the Anglo-Portuguese watershed, thence it shall be carried along the Anglo-Portuguese boundary in a westerly and northerly direction until it reaches the source of the Katete river (a tributary of the Lilongwe river) near Kazuzu peak on the Dzalanyama range of hills ; thence it shall be carried along the Katete river, down stream, to its confluence with the Lilongwe river; thence it shall be carried along the Lilongwe river, down stream, until the Dedza-Lilongwe road is reached; thence it shall be carried along this Dedza-Lilongwe road in a south-easterly direction to the point of commencement.

SCHEDULE V.

GAME REGISTER.

\begin{tabular}{l|l|l|l|l|l}
\hline Species. & Number. & Sex. & Locality. & Date. & Remarks. \\
\hline & & & & & \\
\hline & & & & & \\
& & & & \\
\hline
\end{tabular}

I declare that the above is a true record of all animals killed by me in the Nyasaland Protectorate under the licence granted me on the

(Signed) 19 .

Signature of Examining Officer. 


\section{CHAPTER XIII.}

\section{CLIMATE AND HEALTH.}

The Climate of the various districts is described in the chapters on the three provinces, and little need be said here on the subject. There are two distinct climates in the Protectorate, prevailing respectively in the low-lying areas round the Shire river and the Lakes, and the rest of the country which lies at a much higher elevation. In the hot season, before the rains break, the temperature in the low-lying districts sometimes reaches $120^{\circ}$ in the shade, and the rainfall does not as a rule exceed 35 inches in the year. In the Highlands the temperature varies between a maximum of about $97^{\circ}$ to a minimum of about $40^{\circ}$ in the coldest months. On the Nyika plateau in North Nyasa, and in some other elevated localities the temperature falls much below $40^{\circ}$, and frost is not infrequently experienced at night during the cold season.

The rainy season usually extends from the end of November to the end of March, with the heaviest rainfall in January and February. Different years, however, vary very considerably in this respect. The hottest seasons are those just preceding and following the rains. The cool season lasts from about May to September, but even then it is quite warm when the sun is up.

The tables on next page give the results of meteorological observations for two years selected at random, 1912 and 1918.

Nyasaland cannot be said to be altogether a healthy country for Europeans, although the effects of the climate lie in the direction of an almost unnoticeable sapping of vitality rather than in the production of actual ill-health. The average European not only feels the need of alcoholic stimulant, but experience shows that he cannot maintain his efficiency without recuperating his health every few years in a temperate climate. The most usual illnesses in the Protectorate are malaria, catarrhal troubles and bowel complaints.

As regards malaria it is now definitely established that it can only be contracted as the result of bites of infected mosquitoes. Mosquito nets and mosquito boots should, therefore, be used throughout the year, even when no mosquitoes appear to be in evidence. As far as possible houses should be mosquito-proofed, and every care exercised to destroy all breeding places for mosquitoes. Quinine should be taken regularly either in doses of 5 grains daily, or 15 grains on two successive days once a week, and should be commenced immediately the passenger reaches the coast. Natives, especially children, are reservoirs of malaria, and native children should not be allowed to live in the compounds of European houses. When travelling, camp should not be pitched in the vicinity of native villages. The site should be selected with care at least half-a-mile from any village or stagnant water, and in this matter the traveller should not rely on the judgment of native servants. 



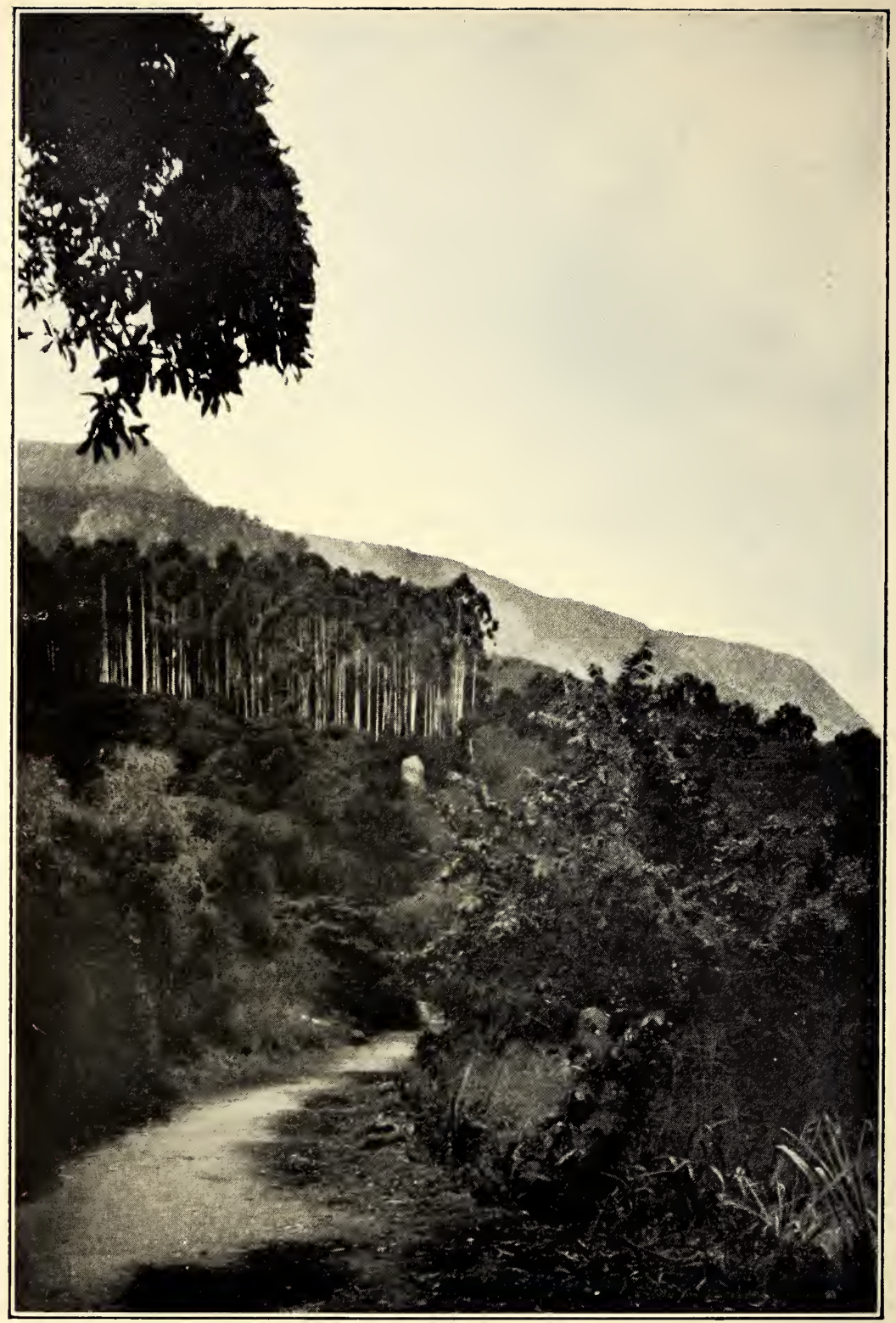

Photo by Capt. N. Farmer. IN ZOMBA TOWNSHIP. 


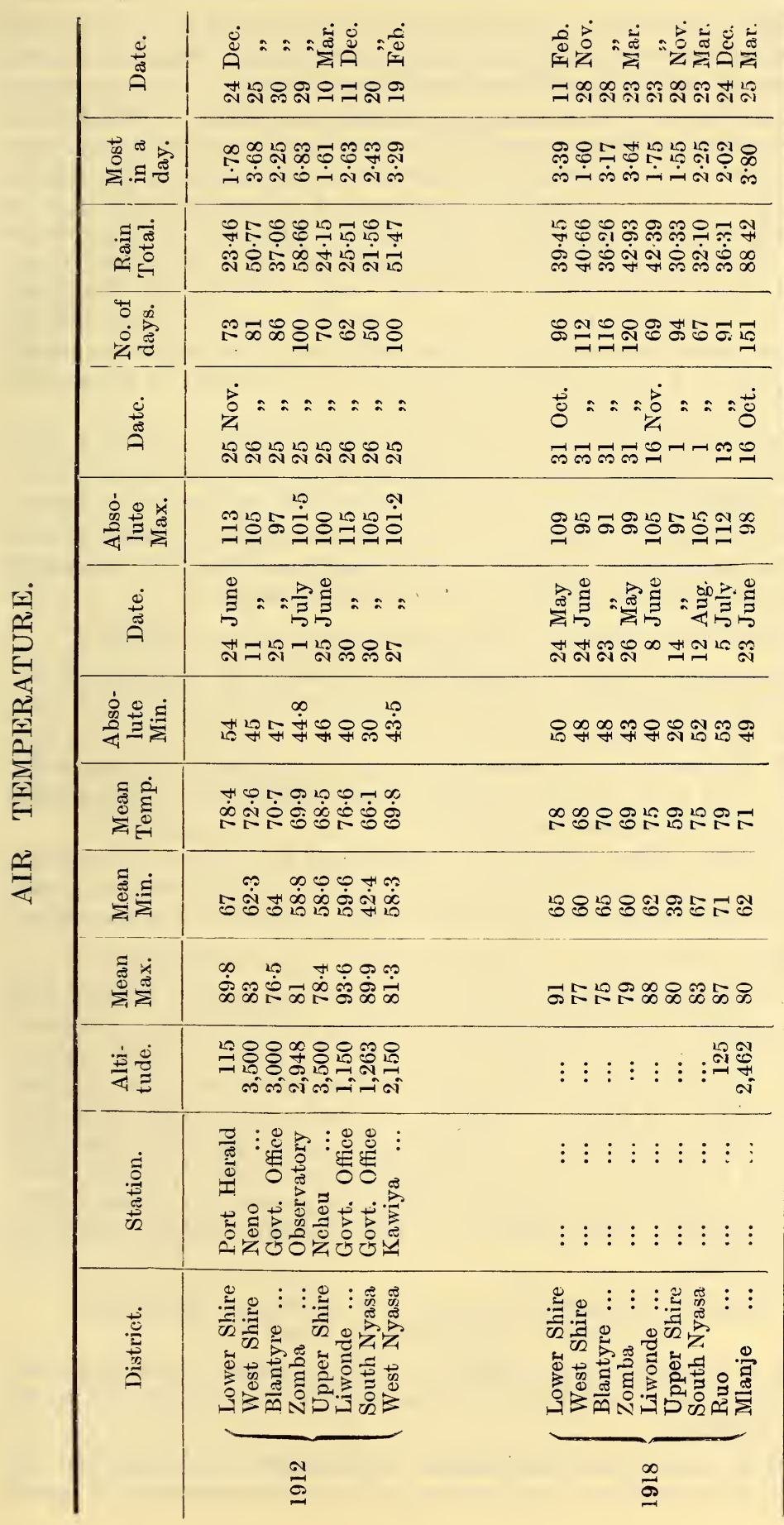


Blackwater fever is a form of fever that hardly ever occurs except in those who have previously suffered from frequent attacks of malaria, which have been inefficiently treated. In such cases a single dose of quinine may precipitate an attack. Blackwater fever was at one time very fatal, but a better acquaintance with the disease and its treatment have removed much of its terror, although it is still the most dangerous of all tropical ailments in the Protectorate. In 1895-6 there were 16 deaths from blackwater fever alone, in a European population of 275 ; in recent years deaths from this cause have been very considerably reduced. Since it is essential that treatment should commence immediately the symptoms are recognised, the following notes have been prepared by the Principal Medical Officer for the benefit of those who live far from a medical practitioner.

This information is intended for the guidance of those who reside in outlying parts of the Protectorate, and who are in consequence unable to procure at short notice the services of a doctor.

The directions which follow are therefore to be regarded merely as in the nature of " first aid" ; a medical man should be consulted as soon as possible in every case of blackwater fever.

\section{How is an attack of Blackwater Fever to be recognized?}

The patient has previously had attacks of malarial fever, more or less frequent, for which he has been in the habit of taking quinine in a haphazard manner.

He notices in one of these attacks of fever that he is unusually restless, and that there is perhaps some slight pain or uneasiness over the liver and in the loins.

In many cases, though not in all, there is " bilious" vomiting. The temperature goes up, it may be to $104^{\circ}$ or $105^{\circ}$, and he passes water which varies in colour from a light claret to a dark porter.

\section{How is the patient to know that the urine is Blackwater?}

It has frequently bappened that a person having passed very high-coloured urine and looked at it in a bad light, in a darkened room or at night, has become alarmed and mistaken it for " blackwater." A rough and ready test is to place the urine in an untinted glass bottle, and having corked it, to shake the bottle vigorously so as to produce a froth. If this froth is of a pinkish colour (not greenish) the urine is most probably " blackwater." In all cases of doubt a sample of the urine should be placed in a clean bottle, and forwarded without delay to the nearest medical man for examination.

\section{Should the patient be moved to a doctor, or should the} the latter be summoned to attend him?

It is generally undesirable to move a patient suffering from blackwater fever, but it may be permissible in the first 24 hours of the illness :-

(a) If there are considerable advantages to be gained by removing the patient, e.g., a change from circumstances of great 
discomfort to comparative comfort; or if the patient is very distressed and anxious to be moved; or if the move will result in his being seen by a doctor much sooner than if he stays where he is.

(b) If the journey can be performed by boat, train, or otherwise, without more than a minimum of jolting or shaking, the patient remaining throughout in a recumbent position.

(c) If the distance is only a few miles.

In every case, whenever possible. the medical man should go to the patient rather than that the sick person should be carried to the doctor.

\section{How is the patient to be treated before he can be seen by a doctor?}

Absolute rest in bed is the first point to attend to ; the patient must on no account suddenly sit up or get out of bed. He should pass his urine and empty his bowels in the recumbent position.

If the bowels have not already acted freely, Epsom or Glauber's salts (the magnesium or sodium sulphate) should be given. If constipation has been marked, 3 to 5 grains of calomel may be given in place of the salts. If there is any tendency to vomiting, calomel is to be given in preference to salts, as it is more likely to be retained. If only tabloids of calomel are available these should be crushed and given in the form of powder.

Stimulants should not be given to the patient in the absence of a doctor, unless the patient feels faint, or appears breathless, and the pulse is 120 or more to the minute. Good brandy or whisky are the best stimulants, and when given should be well diluted with water, or with soda or sparklet water.

All nourishment must be fluid and should not be given in concentrated form. The patient may drink freely of water, or soda, or thin barley water. At regular intervals of an hour or two he should be given small quantities of milk, diluted with plain or soda or sparklet water, or with barley water. If milk is not digested but is repeatedly vomited in curdled lumps, plain chicken soup, with all the fat carefully removed, may be given instead.

If vomiting is so severe that nothing can be retained, the stomach should be given a rest, and saline enemata, consisting of a teaspoonful of common salt dissolved in a pint of warm water, should be given every two or three hours. When the vomiting has subsided, fluid nourishment should again be administered by mouth.

When the urine has cleared and the temperature fallen to normal, the patient is not to consider himself out of danger, as any slight exertion may bring about heart failure. He should remain in bed till strong enough to lie in a chair, in a reclining position.

\section{Symptoms which are of serious import during an attack of Blackwater.}

These are:-(a) Much restlessness, followed by collapse, the patient appearing to be in a dazed condition. (b) Breathlessness and sighing respiration, with quick and feeble pulse. In this condition the patient must be kept absolutely quiet and no movement of any kind is to be permitted; a teaspoonful of brandy or whisky 
diluted in half a wine glass of water may be given every half hour for an hour or two. (c) Persistent vomiting, accompanied by hiccup : this is very exhausting to the patient, wearing out his strength : relief will in most cases follow the giving of saline enemata as mentioned above. (d) Sudden fall in the quantity of urine excreted, so that only a very little or none at all is passed: In this condition the best that can be done is to continue giving fluids by the mouth in order to flush out the kidneys ; if fluids cannot be retained by the stomach, saline enemata should be given in the manner described.

\section{How can Blackwater Fever be avoided?}

Although there is still some difference of opinion on the subject we may for all practical purposes assume that if we avoid getting attacks of malarial fever we shall equally avoid blackwater.

Protection from the bites of mosquitoes by using mosquito nets at all times, and the prophylactic use of quinine, are the two principal means of avoiding malarial infection. Should infection nevertheless occur, as it sometimes will, every attack of malaria must be very thoroughly treated with quinine, so as completely to clear the system of the poison.

Experience has shown that blackwater fever occurs mainly in those who lightly regard their attacks of malaria and take quinine, either not at all, or at most in an irregular, haphazard manner. The ideal way to take quinine is in solution; if for any reason this is found inconvenient then tabloids of the bihydrochloride of quinine are to be preferred to the sulphate, as these contain a larger quantity of the alkaloid, are more soluble, and are less likely to upset digestion.

Not less important than the measures to be taken to decrease mosquitoes and to avoid being bitten by them is the need for scrupulous cleanliness in the house, kitchen and compound. Most bowel complaints and attacks of typhoid may be traced to food contaminated by flies or to the use of unboiled and unfiltered water. Boiling of all drinking water is essential. As regards typhoid or enteric fever the intending visitor or settler would be well advised to undergo anti-typhoid innoculation before leaving for Nyasaland.

For the general preservation of health the following precautions are advisable. Clothes should be changed as soon as possible when wet through with rain, and the greatest care exercised to avoid sitting in a draught or in the cool air after becoming heated with exercise in the evening. The head should always be effectively protected even on days when the sun is hidden by clouds. Sun helmets are most commonly used for this purpose, and are undoubtedly preferable to any other form of hat except perhaps a very broad-brimmed double terai. Spirits should never be taken during the heat of the day, and it is as well to avoid heavy meals. Moist, damp heat is as dangerous as the direct rays of the sun, and as likely to cause sun fever, so that prolonged or violent exertion in the open should be equally avoided 
in both kinds of weather. Anyone intending to visit or settle in Nyasaland should take the precaution of being re-vaccinated if more than seven years have elapsed since the last occasion on which he was vaccinated.

European children appear to do very well during the first few years, but after that period they become pale and listless compared with children at home, and experience shows that they should be sent home as soon as possible after the age of five. In the Highlands they may maintain tolerably good health after that age, but parents accept a grave responsibility for the child's welfare by allowing a child to grow up in the climate of Nyasaland. There are reasons other than those mainly concerned with health why the adolescence of European children should take place in a temperate climate, and under European influences. Children should be kept indoors or under shade during the heat of the day, even when the weather is dull. European women appear to stand the climate better on the whole than men, probably owing to the more careful life they lead.

Except in large centres Europeans in Nyasaland will be obliged to attend to the ailments of their native labourers and of villagers who naturally look to them for treatment, and the following notes have been prepared by the Medical Department for guidance in such cases. The treatment is equally adapted for European patients, but in all cases of serious illness of whatever kind an endeavour should be made to obtain the services of a doctor where a European patient is concerned.

\section{Notes on the Treatment of Common Ailments among Natives.}

\section{BRONCHITIS.}

Symptoms.-In very mild cases, only the symptoms of an ordinary bad cold may be present; but if the bronchial tubes are affected there is a rise of temperature, greater frequency of the pulse, and some difficulty of breathing. In bronchitis of the larger tubes the cough is very frequent and loud, and the expectoration varies from a glairy grey-white mucus to a mucopurulent secretion.

Treatment.-If necessary the patient should be propped up in bed to allow of easier breathing.

The following mixture may be given :-

Carbonate of ammonia . . . . 40 grains

Wine of ipecacuanha or tincture of

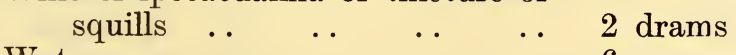

$\begin{array}{llllll}\text { Water } & \ldots & \ldots & \ldots & \ldots & 6 \text { ounces }\end{array}$

Dose :-A tablespoonful in water, every 4 hours.

Burns and Scalds.

Treatment.-The surface should be cleansed with warm boracic lotion, and cotton wool soaked in the warm lotion should be placed 
in contact with the burned part, and the whole covered with a layer of cotton wool. At subsequent dressings any loose dead and charred fragments of skin may be removed with scissors.

Picric acid solution, 1 part in 100 water, is recommended as the best routine antiseptic dressing for burns and scalds, and if available this solution may be used in place of boracic lotion.

\section{Chicken Pox.}

Severe cases of this disease need to be distinguished from small-pox. The eruption is accompanied by slight fever, and papules appear on the first day upon the trunk and slightly upon the forehead. They become vesicles in a few hours. The fever declines upon the second day, and the vesicles dry up, leaving in some cases a slight cicatrix about the fifth day. It usually occurs as an epidemic.

Treatment.-The patient should be isolated, and generally no other treatment is required.

\section{Conjunctivitis.}

The following is a good routine lotion for sore eyes :-

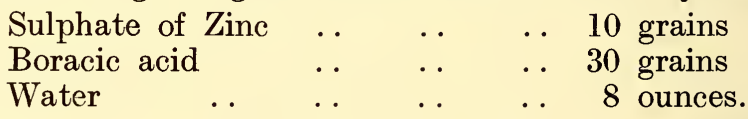

Constipation.

For the acute form the handiest medicines are Epsom salts ( 2 to 4 drams), and castor oil.

It should be borne in mind, however, that if constipation is attended with much pain, distention of the abdomen, and vomiting, purgatives should not be given as these symptons point to obstruction of the bowels, and medical aid should be sought.

\section{DIARRHGA.}

The following mixture may be given :-

Subnitrate of bismuth $\quad$. $\quad$.. 2 2 drams

Tincture of opium .. $\quad$. $\quad$.. $\quad 1 \frac{1}{2}$ drams

Tincture of catechu or tincture of

$\begin{array}{llllll}\text { kino } & \text {. } & \text {. } & \text {. . } & \text {. } & 1 \text { ounce }\end{array}$

$\begin{array}{llllll}\text { Water } & \ldots & \ldots & \ldots & \ldots & \text {. } \\ & \text { ounces }\end{array}$

Shake the bottle well and give a tablespoonful in water every 3 or 4 hours.

Or the following, in more obstinate cases :-

Tincture of opium $\quad . \quad$. $\quad$.. $\quad 1 \frac{1}{2}$ drams

Dilute sulphuric acid $\quad . \quad \quad \ldots \quad 3$ drams

$\begin{array}{llllll}\text { Water } \quad . . & \ldots & \ldots & \ldots & 6 & \text { ounces }\end{array}$

Dose :-A tablespoonful in water every 4 hours, if necessary.

Dysentery.

The best routine treatment is to give Epsom salts in one dram doses 4 to 6 times a day until the stools are free of mucus and blood. 
Particular attention must be paid to diet and only light, nourishing food given.

If there is an outbreak of dysentery on a plantation all the cases should if possible be isolated and their stools buried, to prevent flies from spreading the disease.

\section{DysPePsIA.}

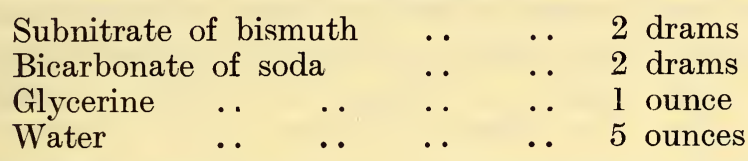

Shake the bottle and give a tablespoonful in water three times a day before meals.

\section{Headache.}

Antipyrine, phenacetin or aspirin may be given in 10 grain doses, to be repeated after 4 hours, if necessary.

It should be remembered that frequently when a native complains of headache he means he has fever. His temperature should therefore be taken, and if feverish he should be given 10 grains of quinine three times a day.

\section{INFLUENZA.}

Symptoms.-These usually begin with shivering and fever, intense headache, nausea and vomiting, and severe pain in the back and limbs. The temperature rises as high as $103^{\circ}$ or $104^{\circ}$. The chief complication to be feared is pneumonia.

Treatment.-This should be commenced with an aperient such as Epsom salts, and the patient must be at once isolated and kept in bed. The intense headache and pains in the back and limbs may be relieved by 5 grains of antipyrine or 10 grains of aspirin, to be repeated after 4 hours if necessary. The routine treatment may consist of giving 5 grains of quinine 3 times a day. If pneumonia supervenes, see under pneumonia. The diet should be light and nourishing. The patient should not resume work until he has completely recovered his strength.

\section{MaLaRia.}

Treatment should be commenced with an aperient, and 10 grains of quinine in solution should be given thrice daily. Headache may be relieved by 5 grains antipyrine, or 10 grains phenacetin.

\section{Measles.}

Symptoms. - These begin with malaise and fever. The eruption appears on the chest, arms and face, becomes more diffuse and fades away in about ten days followed by a branny desquamation. The symptoms are accompanied by more or less catarrh of the respiratory mucous membranes, with sneezing, cough and mucous expectoration.

Treatment.-The patient should be isolated, kept warm, and given a cough mixture (as under bronchitis) if this is necessary. 


\section{Pleurisy.}

Symptoms.-There is a feeling of chillness followed by fever, with sharp pricking pains in the side; but sometimes there is only sudden sharp pain without warning or fever. The pain is generally at the side and base of the chest. The breathing is shallow and rapid owing to deep inspiration causing severe pain. Pneumonia may co-exist with the pleurisy-pleuro-pneumonia.

Treatment.-The painful spot should be blistered with repeated paintings with tincture or liniment of iodine. A sharp saline purge is useful. The following mixture should be given :-

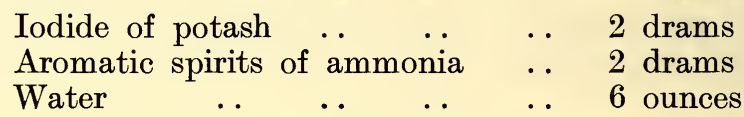

Dose :-A tablespoonful in water thrice daily.

\section{Pneumonia.}

Symptoms.-These usually commence with shivering, the temperature rising in a few hours to $104^{\circ}$ or $105^{\circ}$. The pulse is quick and the breathing markedly hurried. Pain is very frequently complained of in the side, and there is usually a short husky cough accompanied by the expectoration of tenacious rusty-coloured sputum, which is characteristic. Sometimes it is less viscid and like prune juice.

Treatment.-Externally, iodine liniment or tincture may be used, several coats being painted on the chest. The following mixture should be given :-

$$
\begin{aligned}
& \text { Carbonate of ammonia } \quad \ldots \quad \ldots \quad 40 \text { grains } \\
& \text { Tincture of squills .. } \quad \text {.. } \quad \text {.. } 2 \text { 2 drams }
\end{aligned}
$$

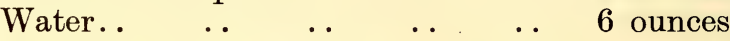

Dose :-A tablespoonful in water every 4 hours.

If the temperature is high it may be reduced by giving 10 grains of quinine thrice daily, or 5 grains phenacetin every 4 hours till three doses have been given. If the pulse becomes weak alcohol is urgently needed.

\section{Rheumatism, Muscular.}

This is a frequent complaint and is best relieved by giving 10 grains aspirin three times a day.

\section{RINGWORM.}

Chrysarobin ointment is a good routine application; failing this ammoniated mercurial ointment may be used.

\section{SCABIES.}

Sulphur ointment should be used after the affected parts have been well washed with soap and water. If this ointment is not available a substitute may be made with sulphur and ground nut oil. 


\section{SNAKE BITE.}

A cord should at once be applied to the limb above the bite and firm pressure exercised by inserting a small stick under the cord and rotating it so as to compress the blood vessel. Then make a cross incision with a sharp knife over the part bitten and allow the wound to bleed freely. Crystals of permanganate of potash or of carbolic acid may then be rubbed into the wound. Stimulation with alcohol is necessary should there be any symptoms of collapse.

\section{ULCER.}

Ulcers are of various kinds and no hard and fast rule can therefore be laid down for treatment. The commonest form of ulcers met with in natives are of the indolent or callous type, showing little tendency to heal. Such ulcers may be stimulated with copper sulphate, lunar caustic or a solution of corrosive sublimate. Lint soaked in antiseptic lotion should be applied after the ulcer has been dusted with iodoform or some other dusting powder. In some cases healing will only be expedited by scraping the edges of the ulcer.

WoRMs.

Only three kinds of worms may here be considered.

\section{ANKYLOSTOMES OR HoOKWORMS.}

Symptoms.-One of the earliest symptoms of ankylostomiasis is pain or uneasiness in the pit of the stomach, and there is a progressive anaemia associated with dyspeptic trouble. As the anaemia advances the face becomes puffy and the feet and ankles may be swollen. There is disinclination for work, breathlessness, palpitation, giddiness and liability to fainting.

Treatment.-Preventive measures consist in the adoption of trench latrines for the use of workers and in seeing that they are properly used, as it is by the agency of exposed human excreta that the disease is acquired and spread.

A dose of castor oil should be given in the evening, and next morning, after the bowels have acted, a dose of 30 grains of thymol or beta-naphthol, the dose to be twice repeated after intervals of two hours, followed by a dose of 5 grains of calomel to expel the killed worms. During this period the patient must abstain from food.

\section{ROUND WoRMS.}

Treatment.-Give the patient a dose of castor oil in the evening. Next morning, after the bowels have acted, give 5 grains of santonine mixed in a teaspoonful of castor oil, and if purging does not again follow give another dose of castor oil to expel the killed "worms.

\section{TAPE WORMS.}

Treatment.-The patient should be prepared by giving him only light liquid food during the day and early next morning a 
dose of 4 drams of Epsom salts should be given, followed two hours later by a dose of 1 dram of the liquid extract of malefern (ext. filicis liquidum). Five hours later a dose of castor oil should be given to expel the killed worm.

\section{WoUnds.}

In accidental incised wounds apply oil of turpentine. This causes some smarting but effectually destroys all organisms, checks bleeding, and promotes healthy healing. A safe and efficient sterilizer of wounds is peroxide of hydrogen.

Punctured and lacerated wounds should be sterilized by thorough irrigation with carbolic lotion of the strength of 1 in 40 .

Poisoned wounds such as dog, leopard, lion or crocodile bites should be thoroughly irrigated with carbolic, boracic, or perchloride of mercury lotions. Small wounds should be swabbed with pure carbolic acid and dressed with a warm boric compress.

The death rate in the Protectorate has decreased from about 7 per cent. to 10 per cent. 25 years ago, to well under 2 per cent. during the past 10 years. And it should be remembered that in the early days there were in the country few but men in the prime of life, whereas now there are many older men as well as women and young children. The decline in mortality is partly due to a better knowledge of tropical complaints and to improved treatment ; and partly to the increasing numbers of European women, with a consequently more careful attention to domestic life, comfort, and cleanliness.

European hospitals are maintained by Government at Zomba, Blantyre, and Fort Johnston, with Medical Officers and Nurses in attendance. Medical officers are also stationed at Port Herald, Mlanje, Dedza, Kota-Kota, and Karonga. There are in addition several medical missionaries in various parts of the Protectorate.

Native hospitals are provided by Government at Port Herald, Manje, Blantyre, Zomba, Fort Johnston, and Karonga, and Indian Sub-Assistant Surgeons are posted at the following stations:Chikwawa, Zomba, Lilongwe and Mzimba.

Dispensaries for dealing with native out-patients have been provided at stations where Medical Officers and Sub-Assistant Surgeons are posted, and, Venereal Disease hospitals have been opened or are in course of erection for the treatment of natives at Port Herald, Mlanje, Blantyre, Zomba, Fort Johnston, KotaKota and Karonga. Missions also provide medical facilities for natives, as do some of the larger European estates.

The natives at present suffer considerably from. venereal diseases, especially since the war, and small-pox occurs in epidemic form from time to time in various parts. Plague appeared in the north of the Protectorate in 1916, but so far it has been kept in check and very few deaths have occurred from this cause. Sleeping Sickness has existed in the Kota-Kota and Dowa districts for some years, although it has never assumed serious proportions, and there has been no noticeable spread of the disease. 


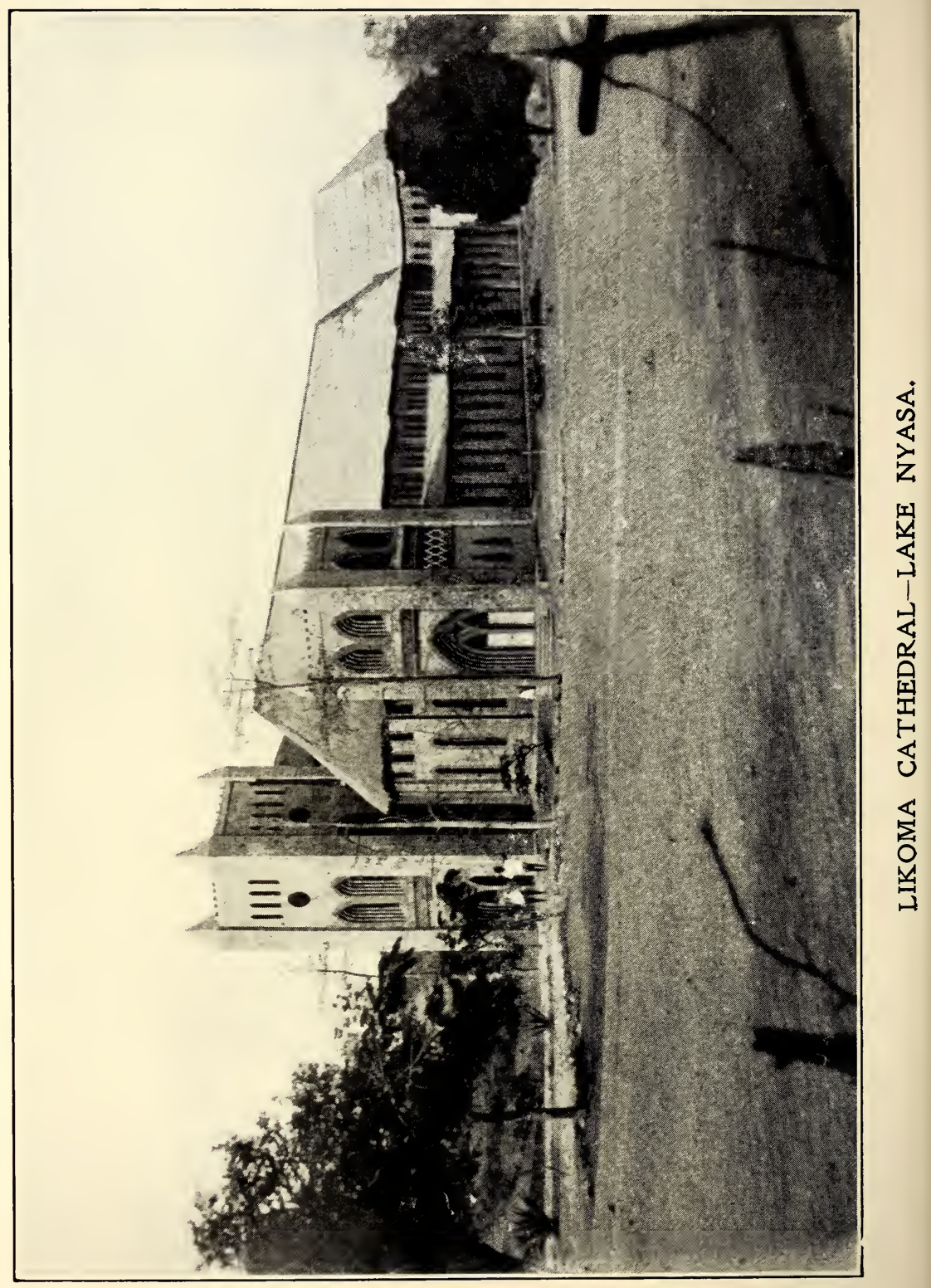




\section{CHAPTER XIV.}

\section{MISSIONS AND EDUCATION.}

The part played by the various Missions in opening up and developing Nyasaland has, perhaps, been under-rated in recent years. The life work and romantic death of Livingstone undoubtedly sent a thrill through the churches in England, and awakened a vivid interest in the natives of Central Africa. Even while Livingstone was still exploring the Shire Highlands and Lake Nyasa, the Universities of Oxford and Cambridge took active steps in the matter of evangelizing the country and the ill-fated mission under Bishop Mackenzie started work at Chiradzulu, where they attempted to protect the Anyanja from the aggressions of the Yao. Dr. James Stewart of Lovedale was the next to take up Livingstone's task, both as explorer and missionary, and it is due to his inspiration that the Livingstonia Mission of the Free Church of Scotland in 1875 and the Church of Scotland Mission the following year commenced operations in the Protectorate. A brief account of each of the Missions now working in Nyasaland is here set out.

\section{The Universities to Central Africa.}

The Universities Mission was founded in answer to an appeal made by Dr. Livingstone to the University of Cambridge on December 4th, 1857. Cambridge accepted the appeal and other Universities joined. Oxford, London and Durham have steadily supported and shared the work; Dublin took part for a time but more recently has developed missionary work on its own account elsewhere. It is hoped that as years go on the newer Universities will also take it up, and a first meeting with such an end in view was held at Sheffield in 1920 .

The first missionary chosen to begin the work was C. F. Mackenzie of Caius College, Cambridge, who was consecrated as "Missionary Bishop to the tribes round Lake Nyasa and along the Shire River" on the 1st of January, 1861. The Bishop with a party of 3 priests and 3 laymen attempted at once to reach the diocese by the Zambesi route; they got to Magomero and some work of much promise was begun, but before the end of the year slave-raiding and tribal war generally made any settled work impossible. Early in the next year, 1862, the Bishop went to Chiromo to meet some new workers; various accidents happened, including a canoe upset and the loss of all medicines. Shortly after, the Bishop got fever and died on January 31st. The work of that year (the first organised missionary work in this country), is here only represented by the graves at Magomero and Chiromo, but the first native Christians of Nyasaland date from it. One child who died was certainly baptized and another (Anne Daoma) who was first taught by Bishop Mackenzie is still alive and is working 
as a Christian teacher in Cape Town. A memorial church dedicated to St. Paul was built at Chiromo in 1907, and in 1921 it was re-erected at Blantyre, since the township of Chiromo has ceased to exist. The grave of Bishop Mackenzie near the junction of the Ruo and Shire rivers is well kept and cared for.

The next Bishop was Dr. Tozer, and he came to the conclusion after trying the Zambesi entrance again and spending some time at Morambala, that his best chance of getting through to the main diocese and the lake was by the caravan route from Zanzibar. He moved to Zanzibar accordingly as a temporary measure in order to do this. It did not, however, work out as soon as was expected and this stage of the work took some years during which much missionary work grew up, at Zanzibar itself, chiefly among released slaves, and more generally on the coast opposite. In 1875 Bishop Steere, who had succeeded Bishop Tozer, got to Mwembe, Mataka's village, a place then and since in direct connection with Lake Nyasa ; in 1876 Chauncy Maples, afterwards Bishop, and the Rev. W. P. Johnson, afterwards and still Archdeacon, joined the Mission for this work. Mr. Johnson was at Mwembe for some time between 1876 and 1880 , and in 1881 at last reached the lake with Charles Janson, who, however, died almost immediately at Chia. It is interesting to note that Maendaenda the Chia Chief of those days was still chief there in 1921. Since then, work on the lake has gone steadily forward and practically the whole east coast is occupied. In 1885, the steamer Charles Janson, in memory of the above priest was built on the Shire and began work on the lake. During this period Likoma island was occupied and became as it remains the headquarters of the Mission. Work was also begun at KotaKota. Bishop Smythies who succeeded Bishop Steere visited the lake, and the diocese generally, five times, but the work was practically under the direction of Maples who had become Archdeacon. In 1890 the Bishop came to the conclusion that it was impossible for the same man to be responsible both for the original work in Nyasaland, now in order again, and for the new work, now of much importance, that had grown up in and near Zanzibar. The diocese was therefore divided, Bishop Smythies remaining at Zanzibar, which now became a separate diocese, and Dr. Hornby being consecrated for Nyasaland. In 1893 Fr. A. G. B. Glossop, now Archdeacon, joined the staff.

The next stage began with great difficulties. Dr. Hornby broke down in health almost at once and had to resign. Archdeacon Maples, who was consecrated to succeed him, was drowned on his way from the Bar to Kota-Kota before he had really taken up his work as bishop. Several other members of the staff died about the same time. Dr. Hine was consecrated as the new bishop and at last the work went forward steadily, the principal extension being in the Yao hills between Mwembe and the lake. In 1901 he was transferred to Zanzibar and Dr. Trower was consecrated to succeed him in Nyasaland on January 25th, 1902. He remained till 1909 and developed the diocese into practically its present condition. His first work was to consecrate a new and much larger 
steamer given in memory of Bishop Maples and called after him. $\mathrm{He}$ also built the great cathedral at Likoma. Besides this he initiated much extension both at the north of the lake, along the shore (then in German East Africa, now the Tanganyika Territory), and in the south round Fort Johnston and along the Shire river, thus completing at last the original objective of the Mission. In 1910 Bishop Trower was transferred to North-west Australia and the present bishop, Bishop Fisher, was appointed. The work of the last ten years has been much interrupted by the War, but has nevertheless steadily increased. The cathedral at Likoma was consecrated on November 14th, 1911, and a large college for training teachers has been built on the island.

The Mission has never undertaken industrial work in a commercial sense, but a good deal of training is given to Africans in building, carpentry and printing. Several African printers trained at Likoma are now in Government service both at Zomba and at Livingstone. Medical and hospital work has always been a chief feature and the Mission has been singularly fortunate in its workers. At the present time in addition to the Medical Officer, there are 11 trained nurses on the staff, many of whom have given up important appointments in large English hospitals to undertake work here. A large staff of trained teachers also carry on educational work among women and girls.

It is a definite part of the Mission ideal to train African clergy to carry on the work, but it is recognised that a very full training is needed, 15 years is the minimum, and that for the present it is only exceptional men who are likely to be fit for it. Such men have been found and there are at present 7 in full orders and 2 deacons. Two of the priests, Fr. Augustine Ambali and Fr. Yohannah Abdallah, are becoming well known to many residents outside the Mission.

The present staff of the diocese is 66 ; a bishop, 26 priests, 13 laymen, 11 nurses and 13 teachers. There are 13 principal stations, 8 of them in the Protectorate, one in the Tanganyika Territory, and 4 in Portuguese East Africa. From these as a base 229 out-stations are worked and supervised, being in charge of resident African teachers. The latest record of numbers (December, 1921 ) is 30,404 adherents, of whom 19,727 are baptized and 12,444 are communicants. There are 11,669 children at school and 110 teachers at college. The in-patients at Mission hospitals during the year 1921 were 948 and the out-patient attendances 97,926.

\section{The Livingstonia Mission of the United Free Church of Scotland.}

This Mission was the proposal of the late Rev. Dr. Stewart, of Lovedale, and in 1875 the first expedition came out from Scotland under the leadership of Mr. E. D. Young, R.N., with Dr. Robert Laws as medical missionary, and 5 artisans. They brought with them the Ilala as the first steamer to be placed on Lake Nyasa. The Ilala is still running on the Chinde river. 
The first settlement of the Mission was at Cape Maclear, but the site proved unhealthy, and, except for its harbour, was otherwise unsuitable. In 1881 the European staff moved to Bandawe, which has since become the centre of a large missionary district.

In 1894 the headquarters of the Mission was fixed at Livingstonia, near Mount Waller, and about 5 miles due west of the lake shore of Nyasa, but at an altitude of nearly 3,000 feet above it. There the work of the Overtoun Institution is being developed as the centre of the higher educational work of the Mission. Selected pupils from the other stations and from other missions are sent for training.

There is a junior school, a normal department for the training of teachers, a technical school, a course for evangelists, and also course in arts, theology, elementary medicine, commercial work and telegraphy. On the industrial side, apprentices are trained in agriculture, building (including stone quarrying and hewing as well as brickwork), in carpentry and printing. A water supply has been brought by gravitation to the station from the hills behind. An electric installation has been completed, supplying power to the workshops, and light for the schools and other buildings.

At the Overtoun Institution there is a well equipped modern hospital for natives and in connection with it there is accommodation for European patients under the care of doctor and nurse. Native patients come from far away places for treatment.

There are European stations at Bandawe and Karonga on the lake shore and (not counting 4 stations in Northern Rhodesia) at Ekwendeni and Loudon in Mombera district, and at Kasungu. At all these stations a small amount of industrial work is carried on, but the chief work is medical, education and evangelistic. There is normally a doctor at each station with a small hospital for native patients. The schools in 1920 numbered 446 , teachers 853 , scholars 25,722 , and $£ 32919$ s. 4 d. was paid in fees, which, except for advanced teaching are nominal.

Within the Mission there are 34 native congregations of the Church of Central Africa. Presbyterian, and a membership of 7,663 , and catechumens numbering 5,036.

\section{The Church of Scotland Mission.}

The Church of Scotland Mission in Nyasaland was founded in the year 1876 by the settlement of the first missionary party at Blantyre on the 23rd October of that year. The site and the sphere of the Mission had already been fixed by Mr. Henry Henderson, who in the previous year had come out from Scotland with the pioneer party of the Livingstonia Mission for that purpose. Mr. Henderson, who had had large pioneering experiences in Australia, after examining the country round the shore of 
Lake Nyasa, resolved to explore the Shire Highlands as more likely to afford the kind of site he was in search of. He was guided in this largely by Livingstone's expressed favour for these high lands as a suitable site for "a mission and a colony." Accordingly, after exploring the districts round Zomba and Chiradzulu he fixed at last on the present site of Blantyre as possessing all the requisites for healthy European settlement.

The Mission was planned at the outset as a religious, educational, medical and industrial agency. The first party consisted of a doctor and five artisans. A minister was not appointed till two years later.

The country was in a very disturbed state owing to the absence of any large chief paramount over the others, and to the raids of the Angoni from the West side of the Shire river. The slave trade was rampant-yearly batches of slaves were sent from the district to the coast at Quelimane and Angoche. Not a few slave refugees sought shelter in the Mission under the aegis of the white men. This naturally led to difficulties with the neighbouring chiefs who were concerned with the slave traffic, and to complications caused by the position of these refugees under the care of the Mission. These ceased when the Rev. David Clement Scott took over the headship of the Mission in 1881. He put the Mission on a new basis, and so may be considered as the real founder of Blantyre as it now is. He has left two monuments to his memory-the Blantyre Church and the Dictionary of the Mang'anja Language.

In 1878 a small branch of the Mission was opened at Zomba under Mr. John Buchanan, then a member of the Mission Staff, but the Zomba Mission as it stands to-day was not opened till 1895, by the late Dr. Henry E. Scott. In the meantime, the Mission at Domasi was founded in 1884, and in 1889 a beginning was made at Mlanje. In 1893 a branch of the Mission, under native agency, was begun in Angoniland at Panthumbi.

The lines on which the Mission was at first founded as a religious, medical, educational and industrial agency have been followed ever since. Latterly, the industrial training and the higher educational training have been centralized in the Henry Henderson Institute at Blantyre, and now natives are there trained as ministers, teachers, hospital attendants, clerks, printers. gardeners, carpenters and sewing machinists, while women are trained in sewing, laundry work and house craft.

Schools have been opened in the districts round each of the head stations above mentioned to the number of 215 , with 7,794 pupils on the roll. Native churches have been established in close connection with the educational work. These number 43 , with communicants and catechumens to the number of 10,989. Five native ministers have been ordained by the Presbytery of Blantyre. A movement is on foot for the union of this Presbytery with that of Livingstonia to form the Synod of the Church of Central Africa Presbyterian. 


\section{The Dutch Reformed Church Mission.}

This Mission was started in 1889. It is supported by the Dutch Reformed Church of the Cape Province of South Africa. It now has stations and outschools in the Fort Johnston, Ncheu, Dedza, Dowa, Kota-Kota, Fort Manning and Lilongwe districts. Its stations number 10, its outschools nearly 600 . Its European staff consists of 16 ordained missionaries and 9 laymen, with 17 lady workers engaged in the work of its girls homes, nursing or teaching. This does not include the wives of the ordained missionaries or laymen. Its Christians and the members of its Baptism classes number together over 15,000 .

Its head station is at Nkhoma in the Dowa district, where its Training School and Mission Hospital are situated, and its printing work is done.

In addition to its Church and School work, it is developing industrial work in several lines, such as basket and chair making, bootmaking and mending, \&c. The Mission is arranging to extend its agricultural training as well.

\section{The Zambesi Industrial Mission.}

The Zambesi Industrial Mission commenced its operations in the Shire Highlands in 1892 . It carries on its educational and spiritual work on similar lines to other Missions working in the Protectorate. It seeks, however, by means of its industries and trading to make its work self-supporting, and in this it has hitherto been largely successful.

Its industries are chiefly planting, coffee being the main product, the crop of 1921 being about 44 tons. A good quantity of this is usually sold in the country. Tinsmithing, blacksmithing and carpentry are carried on at the head stations. A number of bricklayers are taught in the Mission's building operations.

The Mission has 4 stations in charge of Europeans, the staff at present being 13 . There are 89 outschools in charge of native teachers supervised by Europeans. The Higher Training school for Teachers is at present located at Dombole.

Two hospitals are in operation, one in each of the districts, and medical work is carried on at all the stations.

Continuous employment is given to about 500 natives on a daily average.

\section{The South African General Mission.}

The South Africa General Mission was founded at Lulwe in the Lower Shire at the extreme south-west end of the Protectorate in 1900. Another station was afterwards founded in 1909 at Chididi about 8 miles west of Port Herald.

The Mission is interdenominational, and has an English Home Council, an American Home Council, and an Executive Council in 
Cape Town. The Mission has stations throughout South Africa, Southern and North-western Rhodesia, in Angola (Portuguese West Africa), and are opening up 2 stations in Portuguese East Africa.

The South Africa General Mission has 46 stations and over 100 Europeans on the staff, and numerous sub-stations and schools. The European staff in Nyasaland numbers 10, and there are many well trained native workers and numerous schools.

At Chididi there is a Training Institute for the training of native teachers and evangelists, also a higher training school for the training of the young girls, who will become the wives of the teachers and evangelists, \&c. Technical training is also given in carpentry, gardening, building, brick and tile making, sawing, basket and mat making, and boot repairing, and for the girls sewing, grain planting, and pot making, \&c. The object is to keep them in touch with village life.

There are 2 dispensaries and several trained nurses.

\section{The Nyasa Industrial Baptist Mission.}

This was started in 1892, and in 1894 was taken over and reorganized by a Baptist Council at Rev. C. H. Spurgeon's Tabernacle, London. Its first station, Likubula, is situated about 3 miles north-west of Blantyre, and includes schools and workshops where boot making and mending are taught, together with plantation work.

In 1897 a station was opened at Cholo, where a training institute has been established for the training of teachers and evangelists. A printing press is also in use.

In 1905 a station was opened at Kapopo, in North-west Rhodesia.

In 1919 a station was opened at Nkate, near Makwira's, for the better supervision of our river work and village schools.

\section{The White Fathers.}

(Société des Missionnaires d'Afrique, Pères Blancs.)

The White Fathers started work in Nyasaland in 1889, on the Upper Shire, at Mponda, but owing to many difficulties they withdrew after 18 months. Work was subsequently resumed in 1902. Its object is the bettering of the natives by Christian education and industrial training. Special attention is given to agriculture and European methods of cultivating wheat, vegetables and fruit trees. The Mission embraces a department for the treatment of sick natives.

The staff consists of a bishop, 20 fathers, (6 lay brothers and 5 sisters, and has stations at Ntakataka, Mua, Bembeche, Likuni and Kachebere in Angoniland. 


\section{The Baptist Industrial Mission of Scotland.}

The Baptist Industrial Mission of Scotland has been established over a quarter of a century.

The Gowa Estate was purchased from the Government by Sir Adam Nimmo and Professor Coats, and a board of trustees formed in Scotland to carry out the object of the Mission.

Industrial work was begun on the plantation to give employment to the otherwise unemployed native. Joiners' shops were opened and joiners trained to make good doors, windows and suitable furniture for the Mission and others. A large number have been taught brickmaking and building and every thing has been done with a view to raise the dignity of labour and make a useful citizen of the Angoni.

The Mission has over 30 schools under the charge of mission trained boys. These schools are visited from time to time by the Europeans. Medical work is carried on at Gowa and Dzunje. A trained midwife has given valuable aid to the women of the district. Teachers are supplied with medicine and dressings to give away at the villages. All medicine is given free.

There are 3 Churches, Gowa, Dzunje and Zamimba.

\section{The Montfort's Marist Fathers Mission.}

The Montfort's Marist Fathers were founded in the 18th century in France. They started work at Nzama near Ncheu in 1901. The present staff consists of 23 ordained priests, 3 lay brothers and 12 sisters. They have 9 main stations, i.e., Nguludi, Nzama, Neno, Utale, Nankunda, Blantyre, Chikawwa, Limbe, Port Herald; also 17 secondary stations and 287 out-schools. There is a boarding school for half-caste children at Nzama (for boys), and another one at Nguludi (for girls). There is a training school for teachers at Nguludi, and a seminary was started about 2 years ago for training future native priests ; moreover, a boarding school for white children has recently been opened at Limbe.

Native patients are looked after in 3 small hospitals ; 6 dressing stations attend the out-patients; 4 Medical Sisters visit villages as often as possible.

An Orphanage has been started lately at Nzama.

The industrial work provides employment for the natives in carpentry, building, sawing, etc.

Education in Nyasaland is conducted by these various Missions. Many of the scholars receive employment in the Government Departments, and with the commercial and other firms established in the country. In 1907-08 Government commenced an annual 



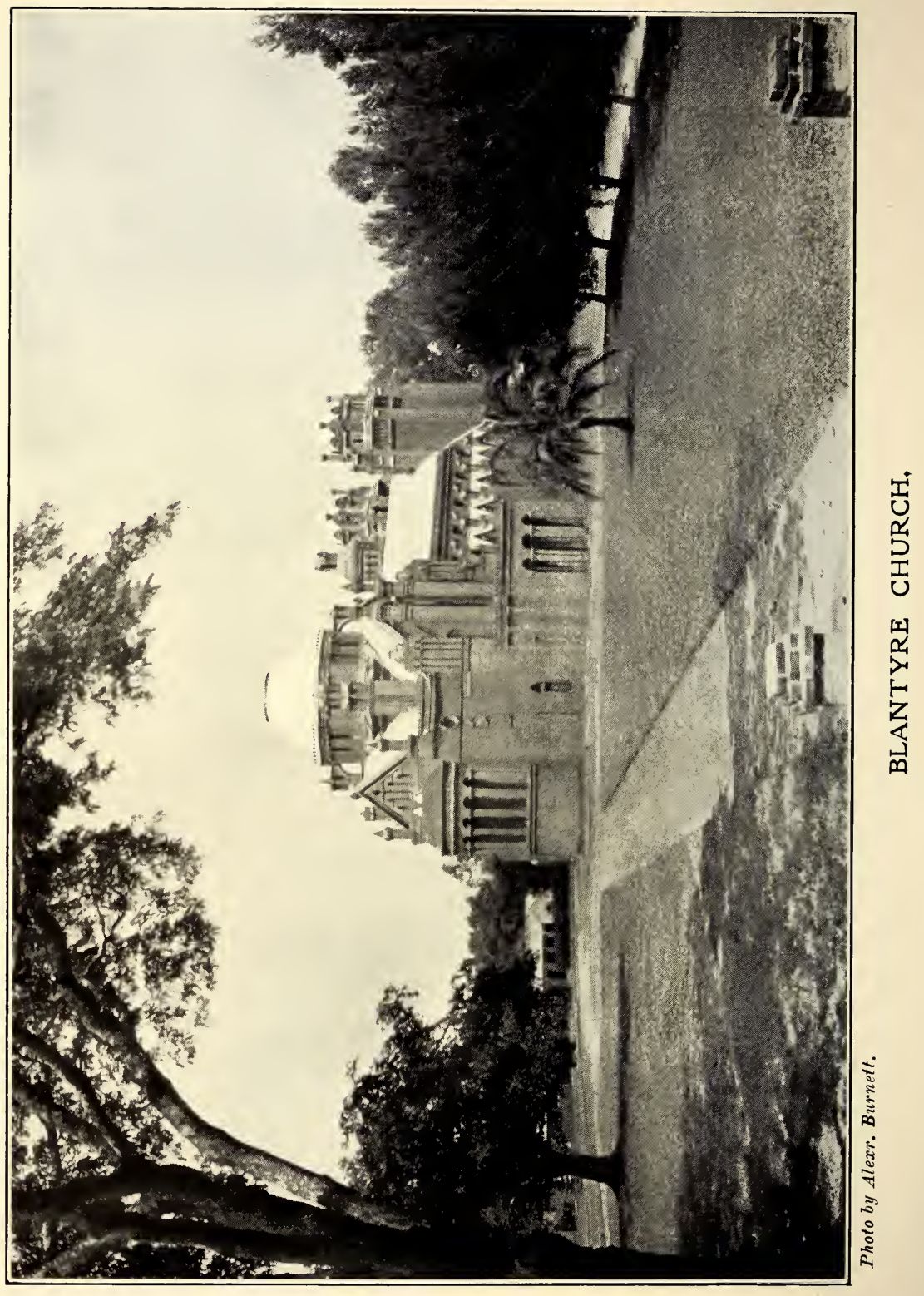


grant of $£ 1,000$ towards education, which is divided between the Missions subscribing to the Education Code. The Universities Mission has never availed itself of this grant, as it holds strict riews on the question of secular education and state control.

In 1920-21 the annual grant was increased to $£ 2,000$ and Government at present has under consideration the whole question of the education of natives.

The Census of 1921 showed 103,000 Christian natives, and in 1920 the number of Mission schools was 2,030 with 68,330 boys and 49,308 girls on the rolls and an average of 41,441 boys and 29,477 girls in attendance.

There are but few European children of school age in Nyasaland, but in 1921, the Marist Fathers opened a boarding school at Limbe which promises to be well patronised. 


\section{CHAPTER XV.}

\section{COMMUNICATIONS, POSTS AND TELEGRAPHS.}

On the 14th of May, 1858, Livingstone in the Pearl stood in for the West Luabo or Hoskins branch of the Zambesi mouth. He had been appointed a consular representative for the territories north of the Zambesi, and sent out at the head of a Government expedition for the purpose of exploring the Zambesi and Shire Rivers, and reporting on the slave trade. In the Pearl he carried a small steamer or launch, the Ma-Robert, in sections. The Kongoni mouth was, however, discovered, and found to be more advantageous for the purpose. The Ma-Robert was thus the earliest steamer to be used on the Zambesi and Lower Shire.

The vessel was soon found to be too small and otherwise unsuitable for the purpose, and Livingstone applied to the Government for a larger one, at the same time making arrangements to purchase a steamer privately. The Government paddlewheel steamer, the Pioneer, arrived in 1861, but it was too deep in the water, drawing 5 or 6 feet. It was, therefore, necessary for Livingstone to leave it on the Lower Shire while he proceeded up stream in a four-oared boat which had to be carried by porters past the Murchison Cataracts. On the 31st of January, 1862, H.M.S. Gorgon reached the Luabo mouth with Livingstone's own ship, the Lady Nyasa, in sections. The Pioneer was unable, owing to its deep draught and difficulties with sand-banks, to carry the Lady Nyasa, and it was therefore fitted together at Chupanga on the Zambesi, a task which was completed in June, 1862. On the 10th of April, 1863, Livingstone reached the Murchison Cataracts and took the vessel to pieces with a view to carrying it over a road he had made for nearly $\mathbf{4 0}$ miles past the Cataracts. Livingstone received notice of the recall of his expedition on the 2nd of July, and his scheme of placing the Lady Nyasa on the Lake was thereby frustrated. He left the Zambesi with his two ships on the 14th of February, 1864, and no further attempt to place steam vessels on the Zambesi and Shire was made for some few years. 
Eventually, the African Lakes Company introduced another Lady Nyasa on these rivers, followed shortly by the James Stephenson. In the early days of European settlement a traveller to Nyasaland left Quelimane by canoe or houseboat and proceeded up the Quaqua river as far as it was navigable at that time. Then followed a walk of 6 miles across to the Zambesi, near where Mopea now stands. Next came a journey of three weeks by houseboat to Katunga's, a period reduced to 6 days when the Lady Nyasa started running. From Katunga to Blantyre was a 2 days' uphill walk. Sometimes the Zambesi was entered direct by way of Inhamissengo at the mouth of the southern or main outflow.

Ocean communication to Quelimane in the old days was chiefly undertaken by the German East Africa Line which ran from Naples in 24 days. Other lines were unsatisfactory as they sent very small steamers and were constantly changing their time tables. In 1889 the Chinde mouth of the Zambesi (the only one now used) was discovered, and the question raised by Livingstone of the control of the Portuguese over the waters of the Zambesi arose in a more acute form. In 1890 negotiations were opened between the British and Portuguese Governments as to their respective spheres of influence in East and Central Africa, and on the 14th of November, an agreement was signed recording a "modus vivendi " with regard, among other things, to the navigation of the Zambesi and Shire Rivers. On the 18th of the same month a decree was promulgated at Lisbon granting the freedom of navigation of the above named rivers to the vessels of all nations. On the 11th of June, 1891, a treaty was signed between the two Governments and ratified on the 3rd of July confirming and amplifying these arrangements.

The Union and Castle Lines, quite unwarrantably as the event showed, feared Chinde Bar and soon ceased to run to that port. The position would have proved serious had not the Rennie Line been more enterprising and put the Induna on the trip between Durban and Chinde. The German East Africa Line followed suit, and the Union Castle Line, finding that their fears were unfounded, resumed their calls at Chinde, both companies running to a more or less fixed schedule. All danger to the ocean going vessels was finally removed when the German Line built the tenders Adjutant and Cadett for the transhipment of passengers and cargo over Chinde Bar.

Immediately after the outbreak of war in 1914 the steamers of the Union Castle and German East Africa Lines ceased to call at Chinde, and it is unlikely that ocean going vessels will ever again make use of this port. Passengers and cargo for Chinde are now carried to and fro from Beira and Lourenco Marques by the small coasting steamers of the Union Castle Company, the Ellerman Line, the Emprezo Nacional Ultramarino, the Companhia National de Naregacao, the Sena Sugar Estates, and the German East Africa 
Line. These small vessels connect with ocean liners at Beira and other East Coast ports. Beira lies about one day's sailing south of Chinde.

The journey from Beira to England by the all-sea route, whether north via the Suez Canal and Marseilles, or south via Durban and Cape Town, occupies about 40 days. The overland route via Bulawayo and Cape Town and thence by mail steamer takes about 26 days.

Chinde is situated on a sandspit at the mouth of the river of the same name which forms one of the outlets of the Zambesi. On the 1st of January, 1892, the Portuguese Government granted the lease for 99 years of a plot of land at the mouth of the Chinde river to be used for the purpose of landing, storing, and transhipping goods for and from the British sphere. The original area of the plot was 10 hectares (about 25 acres) in extent, with a river frontage of 420 yards. Erosion has caused the entire disappearance of this plot, but compensating grants have been made from time to time and the Inner Concession, as it is called, now consists of 50 acres of land having a river frontage of 500 yards. In conformity with the terms of the lease it is enclosed by a 12 foot fence, except on the water front. The total length of this fence is about a mile. Inside the Concession are situated the offices and dwellings of the Vice-Consul and Agent and the Postmaster, as well as the offices and workshops of the sub-lessees.

On the lst of January, 1896, the Portuguese granted the lease of a further 150 acres, known as the Outer or Extra Concession, which is used as a residential quarter by members of the British community at Chinde. It adjoins the Inner Concession and lies between its south-eastern boundary and the Indian Ocean. Both the Concessions remain under the sovereignty of Portugal, and are subject to the laws in force in the Province of Moçambique, except in so far as they are modified by the Anglo-Portuguese 'Treaty of 1891, and the terms of the leases. The Vice-Consul and Agent is in charge of the Concessions and is responsible for its due administration under the terms of the leases, and he also acts as intermediary between the British residents and the local authorities when necessary.

The cost of administration amounting to about $£ 1,600$ a year is defrayed by the Nyasaland Protectorate, which also receives the rents and other fees totalling about $£ 2,000$. A Concession rate is levied for the upkeep of the roads therein. Mails to and from Nyasaland were formerly dealt with by the Postal Agency at Chinde, but the opening of the Trans-Zambesia Railway put an end to this arrangement. The telegraphic communications at Chinde are somewhat unreliable. Messages are sent over the Portuguese Government line either by way of Quelimane and the Eastern Telegraph Company's cable system, or by way of Tete and the 



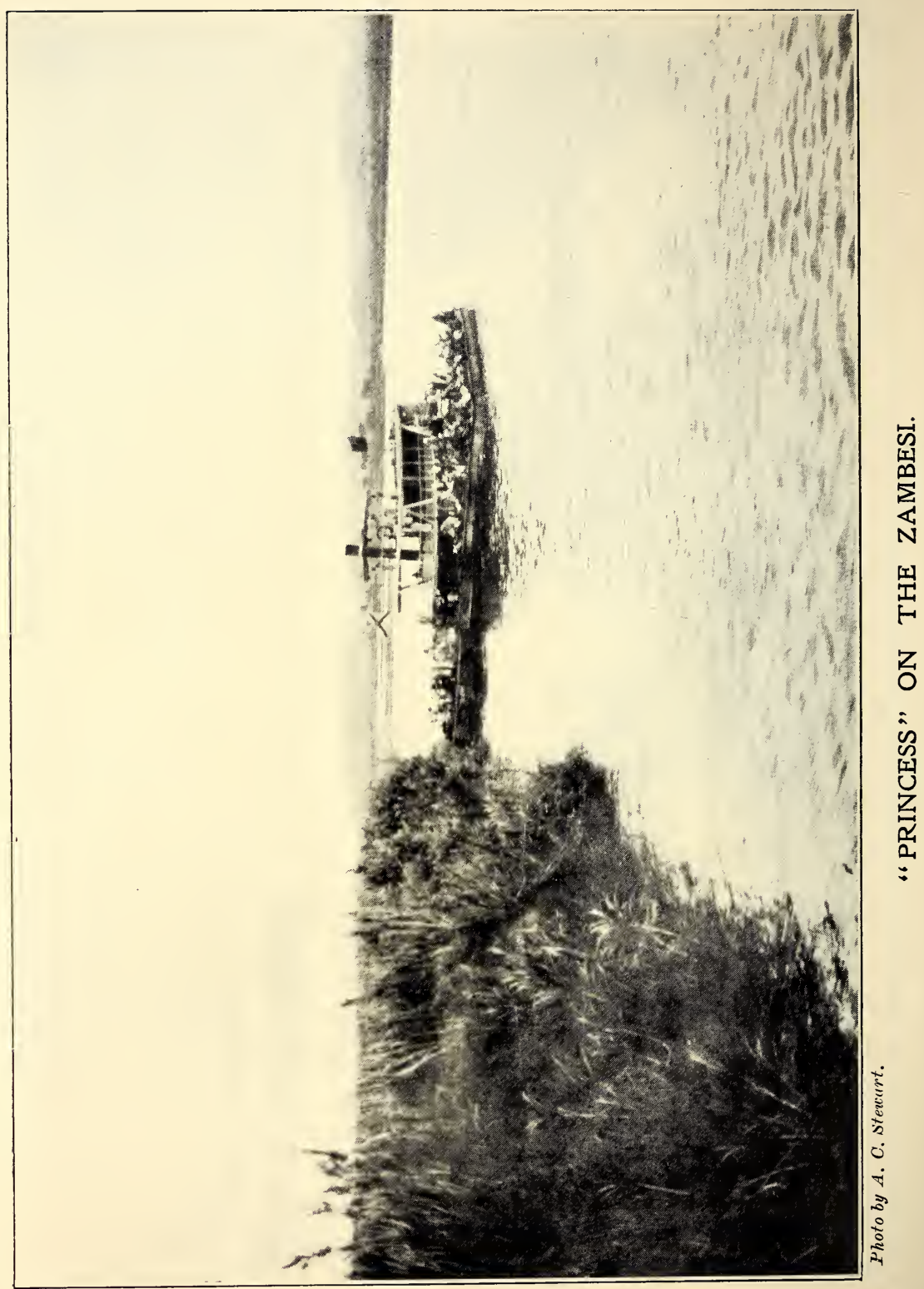


African Transcontinental Company's system, north to Nyasaland and south to Rhodesia and the Union of South Africa.

It is for the future to show whether the traffic at Chinde and on the Zambesi will entirely disappear with the opening of railway communication between Beira and the interior.*

From Chinde, cargo and passengers for Nyasaland are carried to Chindio on the Zambesi, the terminus of the Central Africa Railway. During the wet season, when the river is in flood, a certain number of steamers come up the Shire as far as Port Herald, the terminus of the Shire Highlands Railway. In early years they used to reach Katunga's about 110 miles above Port Herald, but by 1902 the outflow from the lake had diminished and the river had silted up to the extent that in that year steamers could only reach Villa Bocage on the Zambesi, 90 miles below Port Herald. Since that time the Shire has gradually ceased to be a navigable river, although from January till April in a normal year steamers can usually reach Port Herald. It is probable that even this degree of navigability will tend to disappear, although the matter is not so important now that railway communication is available to replace river traffic.

The first steamer put on the river by the African Lakes Corporation was the paddle-wheel Lady Nyasa. The parts were brought out from home and she was built in Quelimane in 1879. For some months she plied on the Quaqua river, until during that wet season the Zambesi overflowed its banks and the Lady Nyasa steamed over the flooded land into the Zambesi. This boat was sunk by the natives in 1884 after the Makololo chief, Chiputula, had been killed by the ex-missionary. Fenwick, but was floated again only to be finally lost in Chinde Harbour in 1896. In 1887 the same Company introduced the James Stephenson, the first stern-wheeler to be used in this part of Africa. Her frames and plates were landed at the Kongoni mouth of the Zambesi, where she was built and fitted for service. This vessel became historical as the subject of international correspondence owing to the action of the Portuguese in capturing it and imprisoning the captain and others on two occasions in 1890. The correspondence is set out in Africa No. 7 (1891). Other steamers, including Portuguese gun-boats, followed in rapid succession so that by 1896 there were 17 British steamers p)lying on the Zambesi and Shire. In 1890 the Imperial Government placed the gun-boats the Herald, Mosquito, and Redbreast, on the river. They patrolled the Zambesi and Shire for many years and were withdrawn in 1902.

Transport problems by land were not long in receiving attention and in 1895 the African Lakes Corporation sent out a survey party to report on the best route for a railway between Blantyre and Chiromo, while the British and Portuguese Governments surveyed a route from Quelimane to the junction of the Tuchila and Ruo rivers. In 1897 a Government survey was undertaken of a railway route

* Serious damage to Chinde and the river steamer, accompanied by loss of life, resulted from a cyclone on the 24th February, 1922. 
from Chiromo to Blantyre and thence to Mpimbi on the Upper Shire. No actual steps were taken to construct a line in the Protectorate until December, 1902, when a contract was signed between the Crown Agents for the Colonies and the Shire Highlands Railway Company for the construction and equipment of a line of railway from Chiromo to Blantyre. Owing to transport difficulties on the Shire a line was first constructed from Port Herald to Chiromo.

The Shire Highlands Railway runs from Blantyre to Port Herald, a distance of 113 miles, and the Central Africa Railway continues the line for 61 miles to Chindio on the Zambesi. The former was opened for traffic on the 31st of March, 1908, and the latter in May, 1915. Early in 1922, the Trans-Zambesia Railway was opened which connected Chindio with Beira and thus provided through railway communication between Blantyre and the East Coast of Africa and linked up the Nyasaland railways with the South African system. It is hoped that the projected railway from Luchenza on the Shire Highlands Railway to the south end of Lake Nyasa will soon be an accomplished fact. This railway will open up large tracts of fertile country at present lying idle owing to the lack of transport facilities.

Railways in Nyasaland are controlled by the Railway Ordinance, 1907, and rules made thereunder, notably those of the 31st of October, 1912, amended as regards rates in 1920 and 1921.

The first steamer to be placed on Lake Nyasa was the Ilala, which was brought out by the pioneers of the Livingstonia Mission. Her frames and plates were landed and bolted together at the Kongoni mouth of the Zambesi and she steamed up the Zambesi and Shire rivers to a point near Chirala, above Chikwawa. There she was taken into sections and carried overland to the Upper Shire where she was finally rivetted up and fitted out for transport on Lake Nyasa into which she steamed on the 12th of October, 1875. The Ilala afterwards became the property of the African Lakes Corporation and did good service for many years on the lake. The Universities Mission later on imported the Charles Janson and the Chauncey Maples (214 tons), which was built up on the Shire in 1885, and the African Lakes Corporation in 1902 a second steamer, the Domira. In 1892 the Admiralty placed on the lake the gunboat Pioneer and on the Upper Shire the Dove and Adventure. These were taken over by the local administration in 1896 . In 1897 the African Lakes Corporation launched the Queen Victoria (195 tons), which was followed in 1898 by the Government vessel Gwendolen (350 tons). In 1892 the German Anti-Slavery Society placed the Hermann von Weissmann (90 tons) on the lake to aid in suppressing the slave trade. This vessel afterwards became the property of the German Government, and was captured during the War and re-named King George. The ships at present running regularly on Lake Nyasa are the Gwendolen, Queen Victoria, and Chauncey Maples. The Pioneer, Domira and Charles Janson make occasional trips. 
Cargo and passenger rates by the African Lakes Corporation steamers on Lake Nyasa are as follows. The average speed of the vessels is about 6 miles an hour.

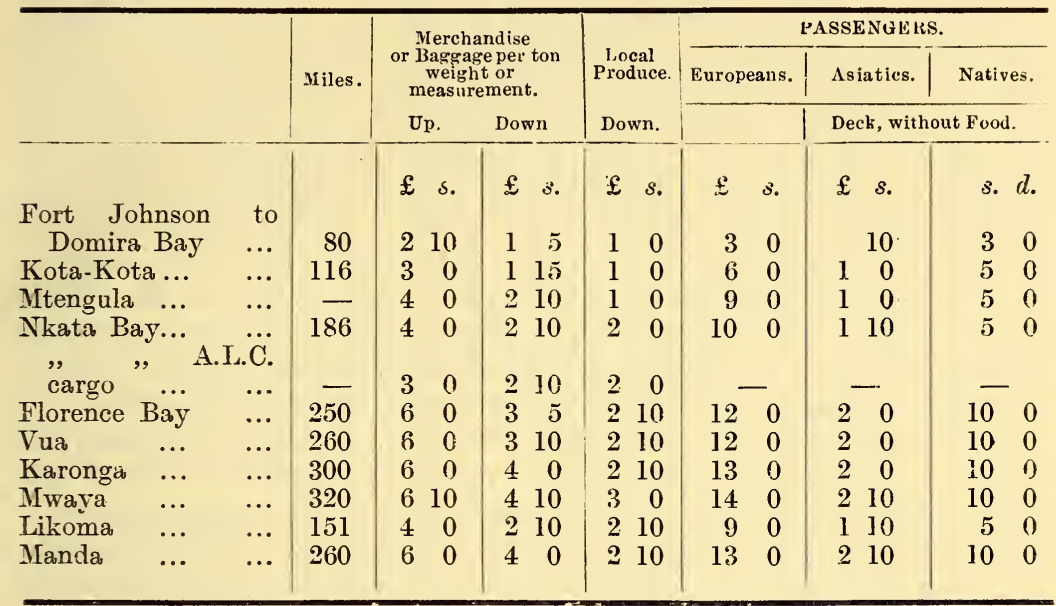

10 per cent. reduction on return tickets taken out by Europeans.

Besides railways, other means of dealing with overland transport, so as to obviate the necessity of human porterage were the subject of experiment in early days. For example, in 1897-8 the African Lakes Corporation imported a steam traction engine which was unsuccessful as it could not negotiate the hills. By 1902, however, they had three traction engines and a pair of steam wagons, all using wood fuel. The traction engines did excellent work between Blantyre and Matope on the Upper Shire, so long as the river remained navigable for the steamers Monteith and Livingstone plying between Fort Johnston, Liwonde, and Matope. They also ran for a time between Blantyre and Katunga, but on both routes the traffic ceased when the low state of the river caused the steamers to discontinue their sailings.

An interesting experiment, not directly connected with Nyasaland, was also made by the same company with ten camels imported from India in 1904, to assist in transport between Tete and Cachomba where the rapids prevented their stern wheel steamers from plying. The camels did not acclimatise very well and they all died after serving their purpose for a time. The British Central Africa Company also laid a mono-rail near Matope but it does not appear that the experiment encouraged any extension of the system.

Petrol driven motor vehicles, first introduced in 1907, received a remarkable impetus during the war and the Protectorate is now extremely well provided in this respect. Motor cycles, in particular. are a very popular means of locomotion and a large proportion of the adult male European population own one or more of these vehicles. 
Descriptions of the principal roads will be found in the chapters describing the various provinces and districts, but some mention may conveniently be made here.

There is a good macadam road 14 miles in length from Mlanje to Luchenza, the proposed starting point for the line to connect the Shire Highlands Railway system with Lake Nyasa. Beyond this there is a good earth road, available for motor traffic in the dry season, extending to the Portuguese border. The principal macadam road in the Protectorate is that joining Zomba with Limbe (40 miles) and Blantyre (45 miles). From Zomba to Fort Johnston (86 miles) runs a good earth road which will stand a maximum load of 3 tons at a slow speed in the dry season, but is only capable of bearing $35 \mathrm{cwt}$. loads on pneumatic tyred vehicles during the rains. An earth road 232 miles in length connerts Zomba with Fort Manning on the North Eastern Rhodesian border. It runs through Liwonde (33 miles), Ncheu (79 miles), Dedza (120 miles), and Lilongwe (169 miles). As far as Dedza the road will stand a four-ton load in the dry season, but in the rains pneumatic tyred vehicles only are allowed with a one-ton load. Beyond Dedza the road becomes very difficult in the wet season and is sometimes impassable for motor vehicles. There is a rest house at Lilongwe where passengers may break their journey for the night. Branching off from this trunk road are several branches, notably from Lilongwe to Mzimba (167 miles), passing through Dowa (24 miles) and Ngara (64 miles). The Ngara-Mzimba section is seldom used, as passengers usually reach the remote districts via the lake. Besides the principal roads mentioned above the following are worthy of note :-

\begin{tabular}{|c|c|c|c|c|c|}
\hline Chiromo to Katunga & & & & & miles. \\
\hline Katunga to Blantyre & & & & 2 & , \\
\hline Blantyre to Upper Shire fer & rry for & Neno & & 2 & \\
\hline Upper Shire ferry to Neno &.. & .. & . & 1 & \\
\hline Blantyre to Mpimbi .. & . & . & & 4 & \\
\hline Blantyre to Cholo & & & & 4 & \\
\hline Cholo to Luchenza & . & . & & 1 & \\
\hline Blantyre to Mlanje & $\cdots$ & • & & 4 & \\
\hline Blantyre to Chiradzulu & . & & & $1 \varepsilon$ & \\
\hline Zomba to Chikala & . & . & & 2 & \\
\hline Zomba to Lake Shirwa & . & • & & $1^{\prime}$ & $"$ \\
\hline Zomba to Mpimbi .. & . & $\ldots$ & . & 2 & ," \\
\hline Fort Johnston to Namwera & & 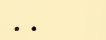 & & 2 & \\
\hline Namweras to Mangoche & $\ldots$ & & & & \\
\hline Domira Bay to Dowa & $\cdots$ & $\cdot$ & & 4 & , \\
\hline Dowa to Ngara & & & & 4( & \\
\hline Kota-Kota to Ngara .. & & & & 5 & \\
\hline Chinteche to Mzimba & . & & & 5 & \\
\hline
\end{tabular}

The culverts and bridges on these roads, with the exception of that from Cholo to Luchenza, are constructed of rough timber, and the surface of the roads are of earth only, Although they are reliable in the dry season, they are sometimes difficult for motor 
traffic in the rains. In order to avoid the devious route from Blantyre to Ncheu through Zomba and Liwonde a saving of 40 miles is to be effected by the construction of a road from Blantyre due north through Matope and Rivi-Rivi. This will facilitate motor transport from Fort Jameson to Blantyre. Although mechanical transport is rapidly coming into use, ox-wagons, even if slow, provide the cheapest means of transport in areas free from tsetse fly. They are accordingly much used on large estates, in the Shire Highlands, especially on roads converging on Limbe, Luchenza and Blantyre, and between Fort Jameson and Dedza.

The control of roads and motor traffic is maintained by the Public Roads Ordinance and its amending Ordinance, both of 1913, and by the Motor Traffic Ordinance, 1920, as amended in 1921. The use of solid tyred motor vehicles on the Zomba-Fort Johnston and Liwonde-Fort Jameson roads is forbidden between November 30th and April 1st. Materials for road and bridge building are exempt from import duties.

Telephonic communication has not made the advance that might have been expected. In 1898 three telephones were in use in Blantyre, and a scheme was under consideration for connecting Blantyre with Zomba by telephone. At present the only township enjoying a telephone system is Zomba, where a beginning was made in about 1900 . The offices there are all connected by a system which extends to the Camp and the National Bank Buildings. There is also a Government telephone line from Fort Johnston to the Bar, a distance of about 5 miles, and the Livingstonia Mission in North Nyasa is connected by telephone with Florence Bay on the Lake some 14 miles away.

The Postal Service prior to the founding of the Protectorate was an informal one, mails being delivered at Quelimane or Chinde as occasion served. The organisation of a proper service was energetically undertaken, and by 1895 there were 18 post offices in existence in Nyasaland and North-eastern Rhodesia, the number of letters dealt with, including local correspondence, being about 130,000. In 1892-3 the expenditure and recejpts amounted to $£ 714$ and $£ 396$ respectively. By 1895 the business had increased 50 per cent., and in the following year a further increase of 30 per cent. resulted. In the latter year nearly 100,000 letter packets were dealt with as external correspondence only. By 1904-5 the total volume of business dealt with had reached half a million packets, and the million mark was touched in 1907-8. At present the numbers are about double the latter figure.

In 1894 the Protectorate first issued its own postage stamps, and in 1903 the letter mails from the United Kingdom began to come overland from Cape Town to Delagoa Bay. In January, 1910, this route was abandoned and a direct exchange of mails was introduced via Salisbury and Chinde. The mails now come by rail from Beira to Limbe and the river route from Chinde is no longer used. A convention for the direct exchange of mails 
between Nyasaland and Portuguese East Africa was arranged in October, 1920.

In 1921 the number of post offices transacting public business in the Protectorate was 25. The mails to and from the United Kingdom are despatched weekly, being carried between Cape Town and England by the mail steamers of the Union Castle Line. The following table sets out the inland mail service :-

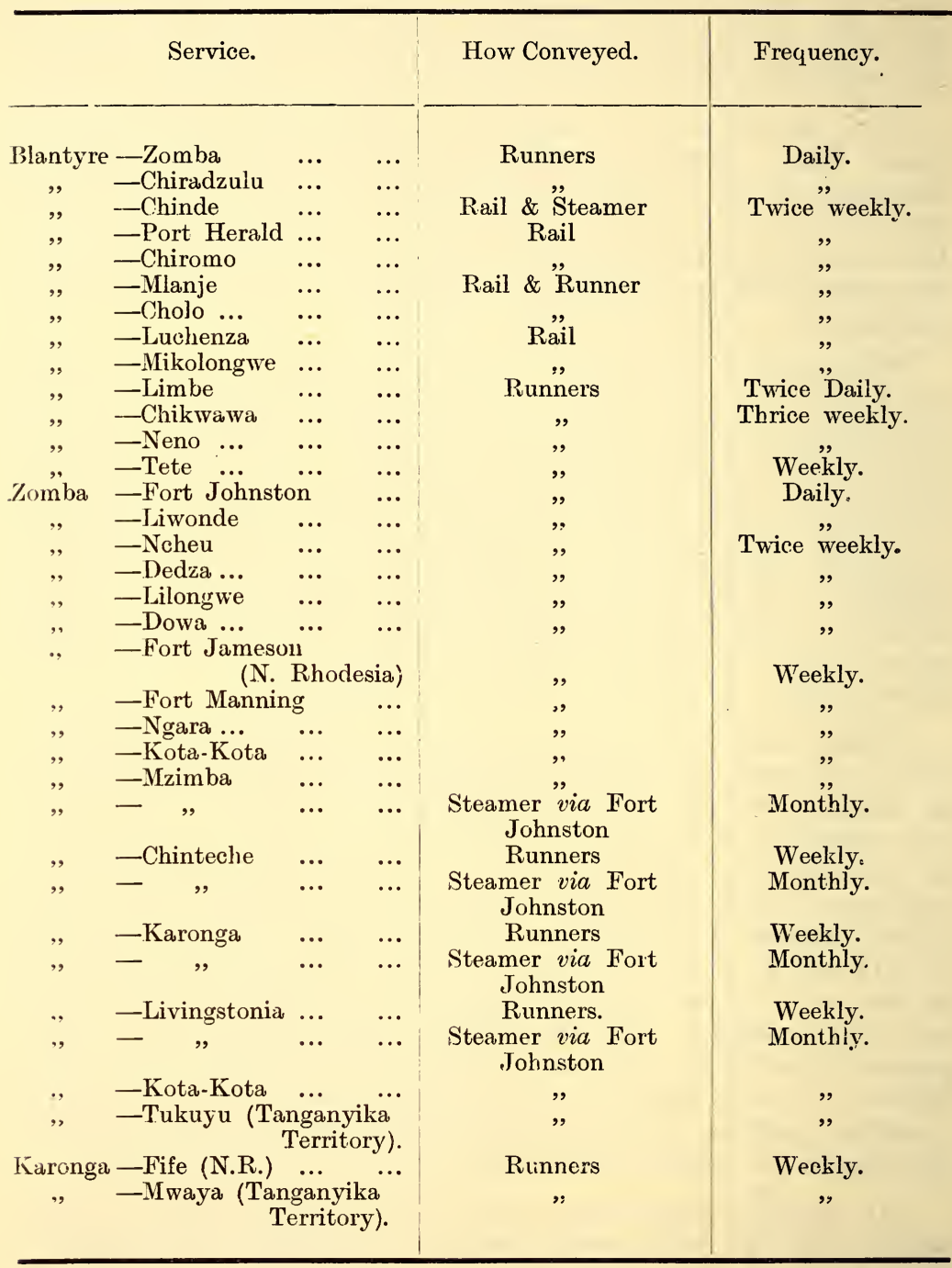

The daily mails from Blantyre to Zomba and vice versa are despatched at 4 p.m., and are ready for delivery at 8 a.m. the following morning. Heavy newspaper and parcel mails from Overseas are transported by motor wagon. 
The postal rates at present in force in Nyasaland for internal correspondence and parcels are shown in the schedules set out hereunder.

\section{INLAND TARIFFS.}

\section{Rates of Postage.}

\begin{tabular}{l|l|}
\hline Description. & Rate \\
\hline
\end{tabular}

LETTERS.

Not exceeding ... 1 oz. $\quad \ldots$. For every additional oz. ...

Post-CARDS (each) ...

Newspapers.

Not exceeding $\ldots 4$ ozs. $\quad \ldots$

Each additional ... 2 ozs. $\quad \ldots$

\section{Printed Papers.}

Not exceeding

Exceeding 1 oz. but not exceeding 2 ozs.

For every additional $\ddot{2}$ oz. $\dddot{\text { or }}$ fraction thereof up to a limit of 2 lbs.

\section{Sample Packets.}

Not exceeding ... 4 ozs. ...

Each additional ... 2 ozs. $\quad \ldots$.

\section{Parcels,}

Not exceeding $\ldots 2$ lbs. ...

Exceeding 2 lbs. but not exceed. ing 5 lbs. $\quad \ldots \quad \ldots \quad \ldots$

Exceeding $\check{~}$ lbs. but not exceeding 8 lbs. $\quad \ldots \quad \ldots \quad \ldots$

Exceeding 8 lbs. but not exceeding $11 \mathrm{lbs}$.
Dimensions may not exceed 24 by

2d. 12 by 12 ins.
ld. No limit as to weight.

1d. May not exceed $5 \frac{1}{2}$ by $3 \frac{1}{2}$ ins., nor be less than 4 by $2 \frac{3}{4}$ ins.

$\frac{1}{2}$ d. May not exceed 24 by 12 by 12 ins. $\frac{1}{2} \mathrm{~d}$. nor $7 \mathrm{lbs}$. in weight. Packets containing newspapers can be sent at the rate of $\frac{1}{2} \mathrm{~d}$. for each newspaper not exceeding 4 ozs. in weight.

$\frac{1}{2} \mathrm{~d}$. May not exceed $2 \mathrm{lbs}$, in weight nor 24 by 12 by 12 ins. in size. If in

1d. the form of a roll, the limits of size are 30 ins. long by 4 ins. in diameter.

$\frac{1}{2} \mathrm{~d}$.

1d. Samples may not exceed 2 lbs. in $\frac{1}{2} \mathrm{~d}$. weight nor 24 by 12 by 12 ins. in size : or, in the case of a roll, 12 ins. in length by 6 ins. in diameter.

1/- The limit of weight is $11 \mathrm{lbs}$. Greatest length, $3 \mathrm{ft}$. 6 ins., or greatest length

$2 /-\quad$ and girth combined $6 \mathrm{ft}$.

3/- Prohibition-Letters.

Fee for registration of any article above described

... $\quad \ldots 4$ d.

, , acknowledgment of delivery of a registered article

If demanded at time of posting $\quad \ldots \quad \ldots \quad \ldots \quad \ldots 4 \mathrm{~d}$.

If demanded subsequently $\quad \ldots \quad \ldots \quad \ldots \quad \ldots \quad \ldots \quad 6 \mathrm{~d}$.

", enquiry re disposal of unregistered article... $\quad \ldots \quad \ldots \quad 4 \mathrm{~d}$. 
The telegraph service in the Protectorate is conducted by the African Trans-Continental Telegraph Company, whose line runs from Umtali, in Southern Rhodesia, to Tete in Portuguese East Africa, where the Zambesi river is crossed; from Tete to Chikwawa, crossing the Shire river, thence to Blantyre and Zomba and on to Karonga at the north end of Lake Nyasa. From Karonga the line traverses the Tanganyika plateau, passing through the northern districts of North-eastern Rhodesia to Lake Tanganyika. There are branch lines running from Ntakataka to Dedza, also from Domira Bay to Fort Jameson and Karonga to the Songwe, where it joins the Tanganyika Territory Telegraph line for that Territory and Kenya, Uganda, \&c. A branch line also runs from Luchenza (Shire Highlands Railway Telegraphs) to Mlanje.

The Shire Highlands Railway Company own a telegraph line along the line of railway between Chindio and Blantyre.

A Portuguese line connects Quelimane and Chinde with the Shire Highlands railway line at Chiromo.

The following tables give the tariffs and distances between offices:-

To and from any station within the Nyasaland Protectorate or Fort Jameson, Kasama and Abercorn in Northern Rhodesia. Ordinary Telegrams, 3d. per word. Minimum charge 10 words 2s. 6d. Cypher Messages, $4 \frac{1}{2} \mathrm{~d}$. per word. Minimum charge 3s. 9d.

Southern and Northern Rhodesia, Union of South Africa,

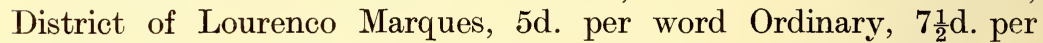
word Cypher. Minimum 12 words 5s. and 7s. 6d. respectively.

Beira Railway Company's Offices $5 \frac{1}{2} \mathrm{~d}$. per word Ordinary, $8 \frac{1}{2} \mathrm{~d}$. per word Cypher. Minimum 12 words.

Zambesia and Districts of Tete, Quelimane, Chinde, Mozam-

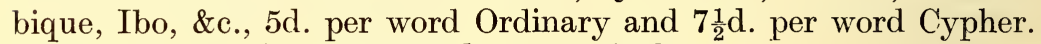
Minimum 4s. 2d. and 6s. 3d. respectively.

Tanganyika Territory, $5 \frac{1}{2} \mathrm{~d}$. per word Ordinary and $8 \mathrm{~d}$. per word Cypher. Minimum 5s. 6d. and 8s. respectively.

Kenya and Uganda, $11 \frac{1}{2} \mathrm{~d}$. per word Ordinary and 1s. $3 \frac{1}{2} \mathrm{~d}$. Cypher. Minimum 11s. 6d. and 15s. 6d. respectively.

Cablegrams to Europe 2s. 5d. per word. The rates to all other parts of the world mav be obtained on application to any Telegraph Office. Telegrams are accepted for delivery in the United Kingdom, to be forwarded by post from Cape Town, on payment of ordinary rates to Union of South Africa plus 2d. postage. Such telegrams should be clearly and fully addressed to ensure delivery by ordinary post.

"Post Cape Town" must be inserted at the end of the address.

Tables of Distances Between Sections.

Main Line.

Miles. Poles. Miles. Poles.

Umtali to Blantyre Section :-

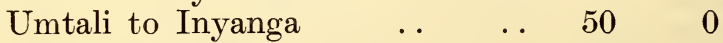

Inyanga to Tete . . $\quad \ldots . \quad \ldots \quad 199 \quad 0$

$\begin{array}{lllll}\text { Tete to Chikwawa. . } & \text {. } & \text {. . } & 92 & 0\end{array}$

$\begin{array}{lllll}\text { Chikwawa to Blantyre } & \ldots & \ldots & 26 & 10\end{array}$ 
Main Line.

Miles. Poles. Miles. Poles.

Blantyre to Karonga Section :-

$\begin{array}{lllll}\text { Blantyre to Zomba } & \text {. } & \ldots & 47 & 10\end{array}$

Zomba to Fort Johnston $\quad$. . $77 \quad 77 \quad 10$

Fort Johnston to Domira Bay .. $95 \quad 5$

Domira Bay to Kota-Kota . . $50 \quad 0$

$\begin{array}{lllll}\text { Kota-Kota to Nkata } & \text {. } & \text {. . } & 102 & 0\end{array}$

$\begin{array}{lllll}\text { Nkata to Florence Bay } & \text {. . } & \text {. . } & 70 & 17\end{array}$

$\begin{array}{llll}\text { Florence Bay to Karonga } & \text {. } & 59 & 17\end{array}$

Karonga to Ujiji Section :-

$\begin{array}{llllll}\text { Karonga to Fife } & \ldots & \ldots & \ldots & 93 & 10\end{array}$

Fife to Abercorn .. $\quad$.. $\quad$.. $105 \quad 5$

Abercorn to Bismarkburg $\quad$.. 37370

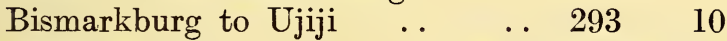

$\frac{529}{1,399}-\frac{10}{19}$

Branch Lines :-

Domira Bay to Fort Jameson .. $128 \quad 5$

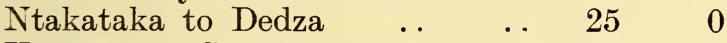

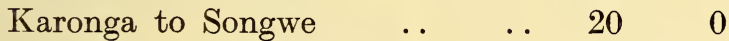

$\begin{array}{lllll}\text { Luchenza to Mlanje } & \text {. } & \ldots & 15 & 0\end{array}$

$\begin{array}{lllll}\text { Fort Johnston to Bar } & \text {. . } & \text {. } & 6 & 0\end{array}$

$\begin{array}{lllll}\text { Blantyre to Limbe } & \ldots & \ldots & 6 & 15\end{array}$ 


\section{CHAPTER XVI.}

\section{THE KING'S AFRICAN RIFLES.}

The King's African Rifles is a Force maintained in the Protectorates of Uganda and Nyasaland, the Colony of Kenya, and in Tanganyika Territory; the 1/1st, 2/1st and 2nd Battalions being raised in Nyasaland. The Force consists of African Ranks, officered by Officers seconded from British Regiments.

The native, of the tribes from which the African native soldier is recruited, makes an exceptionally good soldier; the several expeditions and campaigns have proved him to be courageous and steady in action, an untiring marcher, cheery and goodtempered under all circumstances.

He places implicit confidence in his Officers and becomes much attached to them, quick to learn and simple in ideas he is very amenable to discipline, he is, however, somewhat credulous and liable to pick up the qualities, good or bad, of those he comes in contact with. Keen to learn, he picks up drill readily and takes pride in turning out well on parade and on guard ; with a naturally good eye he shoots well and takes great care of his arms and equipment. During training his intelligence developes rapidly, and good specialists such as Machine Gunners, Signallers, etc., can be trained.

When first raised, Sikh N.C.O.'s were used as Instructors, but the entire instruction from a recruit to a trained soldier is now carried out by British Officers and Non-Commissioned Officers.

The tribes from which the soldiers are recruited are, mainly :-

1. Yao.

2. Atonga.

3. Anyanja.

4. Angoni.

5. Anguru.

The first levies were raised from the Atonga, with whose assistance the slave-trading Yaos were suppressed; the latter, together with Anyanja, enlisting under the name of "Yao," formed a further field for recruiting. Together they served with great success in the local operations in British Central Africa and in the expeditions in Ashanti, Gambia and Somaliland. In recent years Angoni, Anguru and Awemba (from North-east Rhodesia) have all been enlisted and found to make good soldiers. Under the name of "Yao" many Anyanja have enlisted, and the large percentage of these promoted to the rank of N.C.O. is proof of their worth.

An unmixed Angoni Company was tried with complete success by the 1st Battalion in the Nandi Expedition of 1905 .

In 1905, the 2nd Battalion raised an Angoni and Awemba Company which had not been tested on service, but they appeared to be in every way up to the standard of the Yaos and Atonga, 
Though now only distantly connected with the Zulus of South Africa, the Angoni appear to retain many of the traditions of training and discipline of the former race.

\section{Record of Service of the King's African Rifles.}

1899. - The 1st Battalion (with Sikhs) was actively employed in co-operation with the Portuguese Expeditionary Force sent against the Yao Chief Mataka. A detachment was furnished on the requisition of the Government of North Eastern Rhodesia, to assist in the punitive measures taken against the chief Kazembe. These men marched 1,000 miles in two months.

A second Battalion of the Central Africa Regiment was raised for garrison duty at Mauritius. It was afterwards temporarily transferred to the Somaliland Protectorate.

1900.-A part of the 1st Battalion and Sikh Contingent from Nyasaland, and half the 2nd Battalion from Somaliland, were employed in the Ashanti Campaign under General Willeocks.

1901. - The other half of the 2nd Battalion went to Gambia and took part in the Expedition under Colonel H. E. J. Brake.

The designation of these Battalions was now changed from "Central Africa Regiment" to the 1st and 2nd Battalions of the King's African Rifles; the 1st being stationed in Nyasaland and the 2nd being kept as the Reserve Battalion of the East Africa Protectorate.

1902.-Both Battalions, with the exception of a portion of the 1st, left to garrison Nyasaland, served in Somaliland in Campaigns against the Mullah from 1902-04. By their uniform good conduct and gallantry in the field, they added considerably to the good reputation they had already earned. The 2 nd Battalion was present at the action of Erigo on 6th October, 1902. The greater part of the Battalion which was overwhelmed at Gumburru in April, 1903, after inflicting heavy losses on the enemy, was composed of men of the 2nd Battalion, seven officers of the Battalion including Colonel Plunket, being killed.

A small detachment formed part of Major Gough's force at Daratoleh on 23rd April, 1903.

Both Battalions were present at Jidbali, 10th January, 1904, when a loss of 1,000 was inflicted on the Mullah's followers.

1904.- On the termination of the Somaliland campaign the 1st Battalion returned to Nyasaland, the 2nd proceeded to East Africa, and after three months in garrison at Nairobi, followed the 1st to Nyasaland.

1905.-A further re-organisation took place in 1905 (April). The two Battalions with a Depôt Company in Nyasaland were made interchangeable, serving alternately in Nyasaland and British East Africa for periods of three years, the Battalion for the time being in Fast Africa being a reserve Battalion for the Protectorate.

The 1st Battalion proceeded to East Africa and took part in the Nandi Expedition, 1905. 
1906.-Two Companies of the 1st Battalion were sent from East Africa to garrison Zanzibar.

1908. - The 1st Battalion returned to Nyasaland from East Africa in July, being relieved there by the 2nd Battalion.

In December a detachment of officers and men of the 1st Battalion proceeded to Somaliland.

A Reserve was raised at the beginning of the year, composed of men who had previously served with the King's African Rifles. These Reservists, on being called out for service, responded with great promptness, and a number of them accompanied the troops to Somaliland.

1909.--Part of the 1st Battalion was still serving in Somaliland.

1910._2nd Battalion (four Companies) was stationed in East Africa.

1st Battalion (four Companies) was stationed in Nyasaland.

1911. - The 2nd Battalion returned to Nyasaland from East Africa, and was disbanded on reduction of establishment.

The lst Battalion consisted of four single Companies of 100 each-two Companies were sent to East Africa to replace the 2nd King's African Rifles, one of which was sent to Zanzibar.

1912.-The lst King's African Rifles was increased to six Companies, a third Company being sent to East Africa; one Company was employed on the Turkhana and Marquet patrols : the other two Companies, including that from Zanzibar, were sent to Jubaland.

1913.-A fourth Company, lst King's African Rifles, was sent to British East Africa, and all took part in the Merehan Somali Expedition in Jubaland.

1914. - The strength of the 1st King's African Rifles was again reorganized to four Companies (100) which were in East Africa and four Companies (75) in Nyasaland. Early in 1914, one Company in East Africa was relieved by one Company from Nyasaland. From the outbreak of war with Germany in 1914. the whole strength of the 1st King's African Rifles was actively engaged, together with the King's African Rifles Reserve, who answered the call at once.

1915.- Substantial increases in the two halves of the 1st King's African Rifles were made by recruiting.

1916. - In April, the 2nd King's African Rifles was re-formed out of the men of the lst King's African Rifles serving in East Africa. The 2nd King's African Rifles was formed into two Battalions in April, 1916, the 3rd Battalion being formed in November, 1916. The ]st King's African Rifles was formed into two Battalions.

1917.-The 3rd and 4th Battalions and Depôt, 1st King's African Rifles were formed. 4th Battalion and Depôt, 2nd King's African Rifles were formed. Recruiting and training depôts were also formed in Nyasaland. 
The whole of the 1st King's African Rifles were employed on the Nyasaland front and the 2nd King's African Rifles on the East Äfrican front.

The first three Battalions of each Regiment were actively engaged in the campaign in German East Africa and Portuguese East Africa until the Armistice on November 11th, 1918. After the Armistice recruiting ceased and disbandment was commenced at once.

1919.-In March. the 1st King's African Rifles was reduced to $2 \frac{1}{2}$ Battalions and the 2nd King's African Rifles to two Battalions. A further Battalion of each Regiment was disbanded in October, 1919.

In October, 1919, the stations were :-1st Battalion, 1st King's African Rifles (two double Companies and Depôt Company) in Nyasaland; Headquarters, Zomba : 2/1st King's African Rifles (four double Companies) ; Headquarters, Massoko : and 2nd King's African Rifles (four double Companies); Headquarters, Tabora, in Tanganyika Territory.

1920.-The stations were not altered. One double Company, 2nd King's African Rifles proceeded to Somaliland and took part in the expedition against the Mullah and then returned to Tabora, Tanganyika Territory.

1921. - The stations were the same as in 1920, reliefs for the 2/1st King's African Rifles and 2nd King's African Rifles being carried out by the Depôt Company, 1/1st King's African Rifles in Nyasaland. During 1921, the 2/1st King's African Rifles was reduced by two Companies and the 2nd King's African Rifles by one Company. 


\section{CHAPTER XVII.}

\section{THE DEFENCE FORCE.}

The Volunteer movement was initiated in the year 1900, with the object of providing a reserve force of trained marksmen for service in case of emergency. It was officially recognised as a Government institution in 1901. Rules were drawn up and sent out by the Colonial Defence Committee and duly published in the "Nyasaland Gazette." An Organising Secretary was appointed, local rules were made, and, by the beginning of 1902, the Corps was organised and armed with Martini-Enfield rifles issued by Government.

In 1907-8 the Corps was re-armed with the short magazine Lee-Enfield rifle.

As the result of the experience gained, it was found necessary to amend the rules originally published, and in November, 1908, the Legislative Council passed a Volunteer Ordinance, placing the movement on a proper and liberal basis, by which Members obtained the free issue of a Government rifle, 200 rounds of ammunition per annum for practice purposes, and could earn 30s. per head capitation grant on passing the Government efficiency tests.

With a view to further increasing the efficiency of the Corps, an Officer of the Regular Army was appointed as Staff Officer to the Volunteers in 1913. In 1914, a new set of rules was drawn up by which the musketry course was revised and a system of compulsory parades was instituted.

On the outbreak of the Great War the Volunteers were called out by proclamation in the "Nyasaland Gazette." A party of 50 men after undergoing 10 days special training left Zomba on the 27th August and reached Karonga on the 5th September, where they joined the Nyasaland Field Force.

At that time a German column had invaded the Protectorate from the north and on the 9th September an engagement took place at Kasoa, a few miles north of Karonga, in which the Germans were defeated with heavy loss and driven back into their own territory. The Volunteers took part in this action and their casualties amounted to three men killed and three wounded. Owing to the completeness of the German defeat no further attempt was made to invade the Protectorate from that direction.

After the affair at Kasoa, the Volunteers continued to act with the King's African Rifles to protect the northern frontier, and early in 1915, a small reinforcement proceeded into training camp at Vua, 20 miles south of Karonga.

When the advance took place in May, 1916, the Volunteers ceased to operate in the field as a separate unit and the members either joined the King's African Rifles as Officers or were employed 
on duties such as with the Carrier Transport, Intelligence, etc., where their knowledge of the natives and local conditions could be employed to the best advantage. In these duties they performed invaluable service which was acknowledged from time to time by the Officers in command of the Nyasaland Field Force.

During the later stages of the War the Volunteer Reserve became practically a recruiting depôt for the provision of European personnel for the Nyasaland Field Force.

In February, 1915, the Volunteer Reserve assisted in quelling the native rising which broke out in Nyasaland under the leadership of John Chilembwe.

Since the War the Volunteer Reserve has reverted to the same footing as in 1914.

There are at present eight Sections, viz. :-at Fort Johnston, Zomba, Magomero, Limbe, Blantyre, Mikaiongwe, Mianje and Port Herald. Applications for membership should be made to the Secretary at either of these centres who will afford further particulars.

On enrolment, members must take the oath of allegiance and they are required to appear for military service within the Protectorate when called out by the Governor.

There are a number of shooting trophies open to competition amongst members and in 1906 Sir W. H. Manning, K.C.M.G., C.B., presented a challenge cup for competition between teams representing Nyasaland, Uganda and Kenya. 


\section{CHAPTER XVIII.}

\section{THE POLICE AND PRISONS.}

In the early days of the Protectorate the functions of the police and the military forces were scarcely separable. Zanzibar natives were at first tried, but difficulties in the way of obtaining recruits, combined with the expense of maintaining them and certain defects in their character, led to the abandonment of the experiment. The Makua of Mocambique, in those early days, enlisted in the police force, and Atonga were freely employed. This latter tribe was loyal to the British from the first, and has always supplied good police and soldiers. Later on the Yao and other tribes began to provide recruits.

The Residents of districts have always combined administrative with magisterial duties, and as the country developed, the use of native police in a dual capacity was found to lead to abuses and difficulties, as natives are very act to presume on their official positions. The question of reorganization was, however, put on one side at the outbreak of war, and it was not until 1920 that a beginning was made with a separate police force under European officers. The question had become more acute with the spread of crime which resulted from the war.

In July, 1920, a Chief Commissioner of Police was appointed, who immediately reported on the question and submitted a scheme for a police force. The new organization was limited in the first place to the Zomba, Blantyre, Mlanje, and South Nyasa districts, but it is hoped to extend it in due course to the whole Protectorate. Each of these districts is in charge of a Superintendent of Police, and at Headquarters in Zomba there are a Depôt Superintendent, a Controller, and a Superintendent in charge of Criminal Investigation and the Finger Print Bureau. The whole force is under the control of the Chief Commissioner, who is also Chief Inspector of Prisons, and as such he controls the prisons also. The Central Prison, Zomba, is in charge of a Superintendent, with an Assistant Superintendent under him. In the four districts mentioned above, the prisons are under the Superintendents of Police, but in all other districts the police and prisons remain under the control of the Residents, subject to the general supervision of the Chief Commissioner.

In 1921, the Nyasaland Police Ordinance was passed, which repeals the old Civil Police Discipline Ordinance and forms the constitution of the reorganized system. A Prisons Ordinance is being drafted, and it will in all probability have been promulgated by the time this book is printed.

The most important crimes with which the police have to deal are burglary, larceny in its various forms, assaults of various degrees, and murder. Burglary and larceny constitute at least 50 per cent. of the crime in the districts with which the new force is directly concerned, and already there has been a marked decrease 
in these forms of crime. Assaults of various degrees comprise about another 25 per cent. of the crimes dealt with, and are usually the results of native beer drinking. Murder cases are comparatively rare, considering the backward state of the people of the country.

The following is a brief account of the reorganization of the police force.

During 1920, it was definitely decided to reorganize the Civil Police of the Protectorate and to place them under a separate department controlled by Police Officers. To begin with, authority was sanctioned to carry out the reorganization in the four principal districts in the Southern Province, and to comprise Zomba, Blantyre, Manje and Fort Johnston Districts.

The new force is known as the Nyasaland Police, and the Headquarters are at Zomba.

The European staff consists of a Chief Commissioner, Controller, and 6 Superintendents as under :-

The Chief Commissioner, who is also Chief Inspector of Prisons, is directly responsible to the Governor through the Chief Secretary for the control of all police and prisons in the Protectorate.

Controller.-This Officer is graded as a Superintendent, and is responsible to the Chief Commissioner for all stores and financial matters concerning police and prisons of the Protectorate.

Depot Superintendent.-This Officer is in charge of the Depôt at Headquarters, and is responsible to the Chief Commissioner for the enlistment, training and drafting of recruits, also the discharge of all native members of the new force. He also assists at Headquarters.

District Superintendents.-A Superintendent is placed in charge of each district, and is responsible to the Chief Commissioner for the control and policing of his own particular district. He is also in charge of the local prison under the direction of the Chief Inspector.

Assistant Superintendent $i / c \quad$ C.I. Department. - When appointed this Officer will take charge of the C.I. Department and Finger Print Bureau with his office at Headquarters; he will visit the districts at intervals and give assistance to District Officers in the investigation of any serious crimes as requested.

All Officers are appointed by the Secretary of State for the Colonies under the Colonial Regulations. Preference is given to Officers who have had previous police experience in Africa.

The office of Controller is a special appointment as distinct from District Superintendents, although he is graded as a Superintendent.

Native Ranks.-The men are selected from ex-soldiers or policemen of the following tribes :-

Yao, Anyanja and kindred tribes, Angoni, Awemba, Atonga, Achikunda and a few natives from Tanganyika Territory.

Men must be $5 \mathrm{ft}$. 6 ins. in height (with exception of Atonga of whom a few are accepted who are not up to this standard), 
medically fit, of good physique and character. The period of service is for two years on first attestation and one year for each re-attestation. Service in any part of the Protectorate as ordered.

Men of the Civil Police who have been transferred to the new force are gradually being brought into the depôt for a special course of training.

On the reorganisation of a district, a certain number of the police are retained by the Resident for the Messenger Service, and the remainder are given the option of transferring to the new force or taking their discharge ; if they wish to transfer they are required to re-attest for one year from date of transfer.

At District Headquarters the Officer is assisted by a native clerk, and also an interpreter who acts as a charge office sergeant. At present these men are selected from the Native Civil Service, and are paid according to their grade, but it is hoped at a future date to be able to appoint charge office sergeants who will be properly attested members of the force.

In sub-districts where there is no Police Officer, the Resident has charge of the police and is assisted by a specially trained native clerk who keeps all the police records, takes statements and generally supervises the Charge Office.

In districts not affected by the new scheme the Residents remain in direct command of their police as before, but the Chief Commissioner supervises the expenditure over all votes, issues of supplies and stores relating to the police and prison forces, and inspects in any district where he is able to do so.

The new scheme of reorganisation has only been in operation for just over a year and so far it has proved satisfactory; this is mainly due to the assistance rendered to Police Officers by Residents, which has resulted in the close co-operation of the two departments. 


\section{CHAPTER XIX.}

\section{NYASALAND AND THE GREAT WAR.}

With the declaration of War against Germany in August, 1914, Nyasaland became at once involved on her northern and eastern borders contiguous to what was German East Africa, now Tanganyika Territory.

The military forces of the Protectorate consisted of the 1st Battalion of the King's African Rifles, at an established strength of 300 , with a further 300 in the Reserve; but at the time they were considerably below these figures. The European Volunteer Force numbered about 200, scattered over the whole Protectorate, and while reorganisation was then under consideration, little had been done to train and equip the Volunteers as a fighting unit. On the other hand German East Africa, approximately ten times the size of Nyasaland, possessed well organised and efficiently equipped military and police forces. On Lake Nyasa all the steam vessels with the exception of the German gunboat, Hermann von Weissmann, were controlled by the Nyasaland Government.

All troops were immediately mobilised-men on leave recalled and reservists ordered to report with the colours. A staff was formed of military and civil officers, retired military officers were posted to the King's African Rifles, and the small force of about 400 rifles, under the command of Captain C. W. Barton, D.S.O., marched out from Zomba and reached Fort Johnston, at the south end of Lake Nyasa, on the 9th of August.

On the 8th of that month, the Gwendolen, a 350 ton Government steamer, armed with two 3-pounder Hotchkiss guns and a Nordenfeldt quickfirer proceeded northwards under Commander E. L. Rhoades to search for the Hermann von Weissmann, reported to be undergoing repairs at Sphinxhaven. At dawn on August the 13th, the Weissmann was surprised and captured, together with the Captain, Chief Engineer, and four Indian artificers. It was found impossible to float her, but she was disabled and disarmed as she remained on the stocks. Nyasaland thus gained a gratifying initial success and the command of the lake, which received recognition from Viscount Harcourt, then Secretary of State for the Colonies, in his much appreciated telegram, "Well done, Nyasaland!"

The Gwendolen returned to Fort Johnston, and on the 16th and 17th of August the military forces embarked in her, the Chauncey Maples, Queen Victoria, Pioneer, and Adventure for the north end of the lake and disembarked at, Vua, about 30 miles south of Karonga. By the 22nd of the month the forces had concentrated at Karonga, some 15 miles south of the Songwe river, the boundary between Nyasaland and German East Africa. In the meantime, on the 20th, an enemy patrol had crossed the river and engaged a police patrol. Between 
that date and the 8th of September, various reconnaissances were made towards the border, the Germans having an advanced position at Kapora, about 5 miles within British territory, and there were some patrol encounters.

Early in September, the force under Captain Barton was strengthened by men from the Volunteer Reserve, and on the 8th of the month he moved out of Karonga, leaving a small garrison in charge, with the intention of driving the Germans back over the Songwe. It so happened, however, that the enemy had made a simultaneous decision to advance and attack Karonga, which they did with a force of about 400 rifles with 2 light field guns and 3 maxims. On the 9 th of September, at about 7 a.m., a company of the King's African Rifles engaged on the north bank of the Lufira, a company of the enemy which retired, and an hour later the sound of firing was heard from the direction of Karonga. Scouts also reported that the main body of the enemy had passed by the British forces during the night in two columns marching southwards. A double company of the King's African Rifles with one maxim, commanded by Captain A. H. Griffiths, immediately set off to the relief of Karonga, followed by the remainder of the force with the transport. Karonga with its small garrison held out bravely against a heavy fire, and at 11 a.m. Captain Griffiths arrived on the scene, completely surprised the enemy, put them to flight and captured a field gun and 2 maxims. At 11 o'clock the main force encountered and routed a half-company of the enemy, and two hours later, while crossing the Kasoa stream, came in contact with the main body of the enemy retiring from Karonga. After a sharp action lasting two hours the German force was defeated and retired in disorder towards the border, having lost 2 field guns, 2 maxims and a stand, and a quantity of rifles, ammunition, and stores. The casualties on the British side were 3 officers, 2 European volunteers, and 8 native troops killed; and 3 officers, 4 volunteers, and 42 natives wounded. The enemy left on the field 7 Europeans and 51 natives killed, while 2 wounded and 1 unwounded officers were taken prisoners with 96 wounded and unwounded native soldiers. Reliable reports were received later that the casualties on the German side had been greater as several wounded had been removed.

Captain Barton was among the wounded, and handed over the command to Captain H. W. Stevens, who was relieved in December by Lieutenant-Colonel G. M. P. Hawthorn.

Although it was anticipated that the Germans would return with larger forces to wipe out the defeat, the engagements on the 9th September were in a measure decisive in maintaining the integrity of the Nyasaland border until, in 1915, reinforcements from South Africa and Rhodesia arrived under General Northey's command and a general advance into German territory from the south-west was organised in connection with the operations from British East Africa.

In January, 1915, the position in the Protectorate was further complicated by a native rising that occurred in the southern area 
district. This cannot be attributed to disloyalty or disaffection on the part of the mass of the native population, but was promoted by a native religious sect professing Ethiopianism. It was marked by the brutal murder of three Europeans at Magomero, between Zomba and Blantyre, and was intended to synchronize with similar action on the part of the adherents of this sect in other parts of the Protectorate. Considerable numbers of natives were involved but the prompt action of the King's African Rifles recruits in training at Zom ba, and the concentration of the Europeans averted the serious spreading of the trouble so that the troops immediately despatched from Karonga who arrived at Zomba on the 29th of January, found little more to do than round up detached bodies of rebels. Mention may, however, be made of the brilliant march of these troops under Captain H. G. Collins from Fort Johnston to Zomba, dragging a 7 pounder gun over up-hill country, a distance of 86 miles in 47 hours.

During March, a naval detachment under the command of Lieutenant-Commander G. H. Dennistoun, R.N., arrived with 6-pounder Hotchkiss guns and assumed charge of the lake flotilla. News had been received that the Germans were endeavouring to repair the Hermann von Weissmann, and on the 24th of May, a combined naval and military contingent left Fort Johnston. The British landed a few miles south of Sphinxhaven at about 3 a.m. on the 30th of May, and the enemy's position was assaulted by the troops under Captain Collins, aided by a bombardment from the guns of the Gwendolen, and captured at 11 a.m. The Weissmann was completely disabled by means of dynamite charges, and the force re-embarked at 2.30 p.m., the last section being hampered by the fire of the enemy who had returned to the scene.

During 1915, although patrol encounters were frequent on and about the Songwe, there were no operations of any importance. It had been decided not to imperil the small Protectorate forces by assuming an offensive, but the defence of the Protectorate was well maintained. Although strengthened, the enemy devoted his attention chiefly to attacks on the North Rhodesian boundary where he was opposed by Rhodesian and Belgian forces.

These were supplemented later by the South African Imperial Service contingent some 1,200 strong, and in January, 1916, General Northey arrived and took over the combined forces on the Rhodesian and Nyasaland frontiers. The whole force became known thenceforth as the Nyasaland-Rhodesia Field Force.

General Northey's first task was to rearrange the forces on the border, convert the garrisons between Lakes Nyasa and Tanganyika into mobile columns, and organize the supply and transport services for an advance to be made into German East Africa in co-operation with operations on the north. The advance commenced on the 25th May when the enemy was attacked along the whole line and by the end of July had been completely driven from the New Langenburg and Bismarksburg districts. Many prisoners and much material were captured, and 20,000 square miles of German East Africa occupied. During August and September the British forces 
wheeled to the east and drove the re-inforced enemy eastwards from the Iringa, Ubena, and Songea districts. The next five months witnessed severe fighting on a front some 200 miles long, between Songea and Iringa.

It is impossible in this narrative, which must necessarily be brief, to attempt a detailed account of all the engagements and incidents of the campaign-many of them brilliant and reflecting the greatest credit on the troops engaged, both white and black. Special difficulties were created when General Wahle, defeated at Tabora by the British and Belgian forces in his endeavour to join up with the main German force under Von Lettow, then driven south of Morogoro into the basin of the Rufiji and its tributaries, sought to cut his way through the rear of General Northey's line, or later when Wintgens and Kraut doubled back near Gumbiro through a too extended line, the former proceeding north near the lake shore, the latter south across the Rovuma. General Northey's front, weakened by the deflection of troops in pursuit of these parties, was still able, however, to maintain its position, and by the end of 1917, in co-operation with troops operating from the eastern side, was able to driveVon Lettow and the whole of his force across the Rovuma near Ngomano into Portuguese East Africa.

From this time the pursuit was steadily maintained--Von Lettow being driven gradually south till, in August, 1918, he reached Namacurra close to Quelimane. Throughout the chase the advantage was entirely with him; he moved through a fertile country which he devastated, while following a line as far as possible from the bases in Nyasaland and the coast from which the British forces had to be supplied, sometimes upwards of two hundred miles distant. In August he turned rapidly west towards the Nyasaland frontier, and, checked near Regone, proceeded north through German East. Africa, round the north end of the Lake and entered Northern Rhodesia near Fife. Although closely followed and engaged on several occasions he was able to reach the Chambesi river south-east. of Kasama where he was found when the Armistice was declared in November. On the 13th of November he surrendered with his whole force. In June, 1918, the command of the NyasalandRhodesia Field Force had passed to Brigadier-General Hawthorn on Major-General Northey's appointment to be Governor of British East Africa, now Kenya Colony.

From this brief outline of the part played by Nyasalandfirst in defence of her own borders and subsequently in the general operations for the reduction of German East Africa-it will be seen that she was actively engaged throughout the whole period of the war. That campaign has been adversely criticised by many, and while it has to be admitted that Von Lettow and the German forces were not disposed of with that expedition that was anticipated and to be desired, it did accomplish its main purpose, and German East Africa, 384,000 square miles of territory or very nearly twice the size of the German States in Europe, was conquered and brought under our sway by the end of 1917. The critics of the conduct of the campaign cannot be those who had practical 
experience on the spot or they would appreciate better the difficulties which had to be contended with and the arduous nature of the services rendered by the troops engaged-this requires a knowledge of tropical African bush and climate. It is estimated that after crossing the Rovuma into Portuguese East Africa, Von Lettow was pursued for upwards of 1,500 miles with the advantage on his side throughout in obtaining food supplies. With his very mobile force of thoroughly hardened men he could move rapidly, choosing his own line, and that as far as possible from the British bases, and new lines of communications, often extending to 200 miles, had frequently to be opened up for the supply of the troops pursuing him. Between May, 1916, and December, 1917, the small force under General Northey was able to clear the enemy out of some 80,000 square miles of his territory.

The transport difficulties connected with the maintenance of a force operating from Nyasaland require some notice. Beira, on the east coast of Portuguese East Africa, is the nearest ocean port. Thence transhipment of men and stores is undertaken by coasting steamers for 150 miles to Chinde at the mouth of the Zambesi, whence the journey up the river is effected by shallow draught stern wheel steamers towing barges for 120 miles to Chindio, the southern terminus of the Nyasaland railway system. A journey of 170 miles by rail and 125 by road ensues before the south end of Lake Nyasa is reached. Carriage on this waterway extending, as bases varied, up to 350 miles, then brought men and stores to the lines of communication from the lake shore which supplied the columns operating in the field often 200 miles in length. While mechanical transport over very imperfect roads, often mere tracks through the bush, was as fully resorted to as possible, it was on human carriage that the troops in the various columns had chiefly to depend.

Nyasaland made a splendid effort in its contribution of man power. From a native adult male population capable of physical labour estimated at 250,000, there were recruited for service with the King's African Rifles 18,920, and as carriers and non-combatants 191,200 rendered service, or reckoning those who served on two or more occasions, 257,250 . Thus practically every adult male native must have helped in some way or other during the campaign, and it must be further remembered that the native food supply for a population of upwards of a million had to be maintained. Valuable assistance was rendered by the native chiefs, whose loyalty was most marked throughout the campaign. The casualties among men of Nyasaland during the campaign were 1,741 combatants killed or died of wounds and sickness, and 2,195 wounded ; 2,611 carriers killed or died, and 749 other non-combatants.

A word of special praise must be accorded to the Tenga-Tenga or native carriers. General Northey in his farewell message said: "I would award the palm of merit to the Tenga-Tenga." They suffered all the hardships of unusual exposure to wind and rain, cold and heat, mountain heights and low lying swamps, and they had none of the compensating excitments of active warfare, although 
often exposed to the fire of the enemy. Nor could they have had any enthusiasm for a cause which they could but imperfectly understand. It was a case of rendering very devoted service to a Government they loyally respected.

Of the European population some 254 were called up or volunteered as combatants or non-combatants -54 per cent. of the adult male population. In addition, the industrial, commercial and official life of the community had to be maintained, and officials had to be lent for services directly connected with the campaign and the civil administration of occupied enemy territory. Mention may also be made of the fact that the contributions to war charities averaged $£ 20$ a head for the European population, men, women and children.

Nyasaland occupied a unique position during the War. Of all the overseas dominions it bore longest the strain of actual warfare on and near its borders. Immediately War was declared the Protectorate had to enter at once into hostilities in circumstances admittedly more difficult and precarious than any other colony had to face, and from that time it maintained an incessant campaign until three days after the conclusion of the armistice which brought fighting to an end on every other front in the world. Between the date of the armistice and the time when news of it could be conveyed to the German Commander an engagement actually took place between the enemy's rear-guard and Brigadier-General Hawthorn's troops, so that to the Nyasaland-Rhodesia Field Force probably belongs the distinction of having fired the very last shot in the War. 


\section{CHAPTER XX.}

\section{MISCELLANEOUS INFORMATION AND ADVICE.}

Those who intend to visit or settle in Nyasaland are often hampered by lack of knowledge of just those little difficulties and requirements which soon become so familiar to the settler that they forget to mention them to friends or acquaintances who may intend to follow their example in coming to the Protectorate, and a few hints may therefore be acceptable.

There are many steamship lines plying between England and South Africa, and it is advisable to make enquiries of some travel agency, such as Thomas Cook \& Sons, as to relative fares, accommodation, sailing dates, etc. For a first tour in the country, the average man will have a considerable quantity of baggage and would be well advised to make the trip by the all sea route, if possible, via Cape Town and Durban, in order to avoid the heavy charges for baggage on the train journey between Cape Town and Beira. A passenger should keep an eye on his baggage during the whole voyage, and take especial care to see that it is duly placed in the steamer whenever he trans-ships. No notice should be taken of the officials of steamship companies and others who request him not to bother, and assure him that it will be all right. Baggage accidentally left behind at any port may probably never be seen again, will certainly take many months before it reaches the passenger, and most likely pilferage will have taken place in the meantime.

Heavy and bulky packages should be avoided as far as possible. Clothes and similar articles should be packed in tin cases or uniform boxes about 26 inches by 13 inches by 10 inches in size, and they will be protected from the rough handling they are sure to receive if enclosed in skeleton cases of wood.

Bedding and blankets and such articles can be conveniently packed in rot-proof canvas bags provided with a hasp and padlock. Unless baggage is labelled "cabin " or "wanted on the voyage," the passenger will not be able to gain access to it on the voyage. Methodical travellers adopt the convenient expedient of numbering each piece of baggage, and preparing a list showing exactly what each contains. By this means a desperate search for some particular article suddenly needed is avoided, and time and temper are saved.

Safety bicycles are not much used by Europeans in Nyasaland, but are very useful in remote districts. Nearly every adult male in the Protectorate is a motor-cyclist, and the settler would be well advised to bring with him a motor-cycle, well packed in a stout wooden case. Cycles and motor-cycles can often be obtained second-hand in the country, or can be purchased new at a price which leaves the merchant with a moderate profit.

There are no horses in Nyasaland, and saddlery and riding kit would, therefore, be useless. Most kinds of sport are carried 
on, however, and equipment for various games such as tennis, 'golf, cricket, football and hockey will be useful. Fishing tackle 'should not be specially purchased, but if already in the passenger's possession, it might be included with his baggage. A camera and photographic material will always come in handy, and collector's equipment for those interested in natural history.

Lending libraries and magazine rooms exist in Zomba and Blantyre, but it is advisable for those who will reside in out-districts to arrange for a supply of reading matter to be sent out to them regularly, either by friends or by firms like W. H. Smith \& Sons or Alfred Wilson, who specialise in this business.

Although almost any article required can be purchased in the country, it is noticeable that cheaj) and bulky articles of common use are very expensive to purchase locally. Rather than lay out much money on provisions and wines, it would be well to bring out crockery, cutlery, table and bed linen, glass-ware and cooking utensils. Fnamel saucepans and kettles are not recommerided, aluminium or cast iron being preferable. Oil lamps and candlesticks will be required, except for those who intend to live in Zomba, which is lighted by electricity. A filter is essential, Pasteur ('hamberland and Doulton being good types to purchase.

An iron bed with spring mattress should be brought out, although wooden bedsteads can be obtained locally. Pictures, ornaments, curtains, and any odds and ends calculated to promote comfort will be appreciated by the passenger who has the foresight to bring them with him. A mosquito net is, of course, essentia!. It should be rectangular in shape and not of bell pattern, and should have small meshes. There should be a hem of calico about a foot wide to be tucked in under the mattress. A white net is preferable, as any mosquitoes that may have penetrated inside the net are more visible. At night, the ends of the net should be tucked in under the mattress, and not allowed to hang loose on the floor. A useful type of bath is the one with a lid which locks down and a wicker basket inside, as it can be used for packing baggage.

Mosquitoes are most active about sunset, and bite particularly on the ankles. Mosquito boots should, therefore, be brought out and worn regularly at night.

Timned food should be avoided as far as possible in the tropics, and care must be taken that all drinking water is boiled and filtered as well, if possible. A dirty filter is worse than none at all, and all " candles" and fittings should be thoroughly scrubbed and boiled once a week and the filter re-assembled by the European himself, who should at once discard any worn or loose part, and any "candle" that has the least suspicion of a crack in it. Water that has been filtered but not boiled is unreliable.

Cane easy chairs are obtainable locally from some of the Missions, but a couple of Edgington's canvas deck chairs will be useful, both on the voyage out and in the Protectorate.

The question of clothing is a difficult one on which to advise. A great number of Europeans engaged in sedentary occupations wear ordinary clothing, such as they would wear at home, throughout 
the year. Those who spend their time mostly in the open adopt a more unconventional attire, including khaki shorts which can be made locally. A passenger should not lay in too big a stock of clothing as he can always obtain by post the type he decides to wear when he has made himself acquainted with local conditions. Tennis clothes and soft collars should be brought, as well as evening dress clothes and a dark blue serge suit. Khaki and white drill suits can be made in the country. A waterproof and stont boots for the rainy season will be needed. A sun helmet, white or khaki, is essential.

Most people will indulge in a little shooting, and a tent is desirable for the purpose. Edgington's No. 2 is convenient. Faddy camp furniture is to be avoided. A good folding washstand with enamelled iron basin and jug, a camp table and chair, a small canteen with cups, saucers, plates, \&c., a folding camp-bed with solid mosquito curtain rods, a water bottle and a waterproof ground-sheet, make up a useful outfit. A $\cdot 256$ sporting pattern and a $\cdot 350$ rifle, together with a cheap shot gun are the weapons recommended. A 380 colt revolver will be useful. The importation of $\mathbf{3 0 3}$ rifles and ammunition is prohibited.

It is useful to know some Chinyanja on arrival in the country, and Hetherwick's Manual of Chinyanja may usefully be studied in leisure moments on the voyage out.

It was usually possible for a passenger to engage a native servant at Chinde, and this proved a great convenience during the journey from Chinde to Blantyre. It may not be so easy to do so now that the usual mode of entry into the Protectorate is by the railway from Beira.

It will be necessary to engage a cook, whose wages will be about $£ 1$ a month, a houseboy at from 10 s. to $£ 1$ according to his experience, and a kitchen and pantry boy at about 6s. a month. It may be necessary to pay each servant $6 \mathrm{~d}$. a week food money in addition to his wages. As the household is developed, a second houseboy at $8 \mathrm{~s}$. to $10 \mathrm{~s}$. may be required, and a laundry boy at about los. a month. Outdoor servants such as wood boys and garden boys cost about $6 \mathrm{~s}$. a month. Ladies in townships usually travel about in garettas or small rickshaws mounted on a pair of motor-cycle wheels. One native is required for the shafts and one or two to push behind. Garettas are not easy to obtain at present, but in normal times they can be bought second-hand. A good one now costs at least $£ 20$.

The new arrival should be careful when engaging servants, as there are many bad characters among them. No native should be employed who cannot produce a satisfactory employment register, and in any case of doubt it is advisable to consult the nearest Resident Magistrate. Europeans are apt to be over trusting in the matter of native servants, but as a class they need to be carefully watched.

In conclusion it should be pointed out most strongly that there is no casual employment for Europeans in Nyasaland, and no one should come to the Protectorate in the hope of finding work. 


\section{CHAPTER XXI.}

\section{BIBLIOGRAPHY.}

\section{Official Publications-Local.}

The Nyasaland Government Gazette, published monthly.

The Annual Blue Book.

Reports of various departments, issued as Gazette Supplements. The Consolidated and Annual volumes of Ordinances.

The Consolidated and Annual volumes of Pules, Notices and Proclamations.

The Volume of Orders of the King in Council.

Notes for Intending Settlers.

The Report of the Lands Commission, 1921.

The Report on the Census of 1921.

(The above publications may be obtained from the Government Printer, Zomba.)

\section{Official Publications-Parliamentary.}

African Protectorates administered by the Foreign Office, Cd. 1635, 1903; Cd. 3731, 1904; Cd. 4449-28, 1909.

Anglo-German Boundaries, C. 6043, 6046, 1890 ; C. 7203, $1.893-4$.

Anglo-Portuguese Boundaries, Cd. 6147, 1912-13; Cmd. $1,000,1920$.

Anglo-Portuguese Convention and Sphere of Influence, etc., (. $6212,6370,6375,6495,1890-91 ; \quad$ (. 7032, 1893; (\%7971, $1896:$ C. $8434,1897$.

Annua! Reports, 1895-1920.

Annual Statistical Abstracts of British Colonial Possessions.

B!ackwater Fever, Reports on, Cd. 6514, 1912-13; Cd. 7211, 1914; Cd. 7792, 1914-16.

British Central Africa, Report on first three years administration, C. $7504,1894$.

Chinde, Report on Journey from Chinde to Tete, Cd. $7049-1,1914$.

Cotton Cuitivation in the British Empire, Cd. 2020, 1904; (d. 3997, 1908 : Cd. 5215, 1910.

(cutton, Empire, Growing Committee, Report, Cmd. 523, 1920.

Education System, Cd. 2378, 1905

Entomological Conference, 1920, Report, Cmd. 835, 1920.

Forestry Conference, 1920, Report, Cmd. 865, 1920.

Labour, Recruitment for Transvaal, Cd. 1531, 1903, Cd. 1950, 1904 ; Cd. 3993, 1908.

Land in Crown Colonies, etc., H.C. 68, 1912-13.

Malaria Investigation, Cd. 1598, 1903.

Mineral Survey Reports, Cd. 3916, 1908 ; Cd, 4908, 1909 ; Cd. $5900,1911$. 
Slave Raiding, C. 6699,1892 ; C. $7031,1893-4$.

Slavery and Slave Trade, C. 9502, 1899; Cd. 1389, 1903.

Slave Trade Conference, Brussels, C. 6049, 6049, 6049-1, 1890 : C. 6557,1892 ; C. 7594,1895 ; Cmd. 477, 1919.

Slave Trade Suppression, Treaties, etr., C. 5901, 1890 ; C. 6592, C. 6702,1892 .

Slave Traders, Report of Operations against in British Central Africa, C. 7925, 1896.

Sleeping Sickness, Cd. 3778, 3854, 1908; Cd. 5856, 1911 ; Cd. 7349, 7350, 1914.

Surreys, etc., Cd. 6007-30, 1912-13 ; Cd. 7050-16, 1914; Cd. 7622-19, 1914-15.

Veterinary Departments, Staffing Report, Cmd. 922, 1920.

Wild Animals Preservation, Cd. 101, 1900; Cd. 3189 1906 ; Cd. 4472, 1909; Cd. 5136, 1910; Cd. 5775, 1911 ; Cd. $6671,1913$.

\section{General Works.}

Buchanan (JoHN)

CADDick (HFLeN)

Coillakd (F.).

CRoss (Dr. KeRR)

DUFF (Sir H. L.)

Elmslie (Dr. W. L.) . .

FotheringhaM

(I. Monteith)

Hertslett (Sir E.) . .

Johnston (Sir H. H.)

Keane (A. H.)

Keltie (J. Scott)

Livingstone (David). .

LuCas "Sir C. P.)" $\quad$.

LUGARD (Sir F. J).) . .
"The Shire Highlands as Mission and Colony."

"A White woman in Central Africa," London, 1910.

"On the threshold of Central Africa," London, 1897.

"Health in Africa."

"Nyasaland under the Foreign Office," 2nd edit., London, 1906.

"Among the Wild Angoni," Edinburgh, 1899.

"Adventures in Nyasaland," London.

"Map of Africa by Treaty," 2nd edit., London, 1897.

"Commercial Treaties."

"British Central Africa," London, 1897.

"Livingstone and the Exploration of Central Africa."

"History of a Slave."

"History of Colonisation in Africa," Cambridge, 1899.

"Africa, vol. II.," 2nd edit., London, 1908.

"The Partition of Africa," 2nd edit., London, 1895.

"Journals."

"Zambesi and its Tributaries."

"Historical Geography of British Colonies," vol IV., Oxford, 1897.

"The Rise of our East Africa Empire," London, 1893. 
MACDONALD

(Rev. A. DuFF)

MoCall (J. S. J.) ․

Moore (J. E. S.) ․

"Oxford Survey of the British Empire, vol. III.," London, 1914. RANKIN (D. J.) ․

Sharpe (Sir Alfred)..

SWANN (A. J.)

Vyvyan (C. B.) ..
"Africana," London.

"Handbook on Cotton and Tobacco Cultivation," Zomba, 1920.

"The Tanganyika Problem," London, 1903.

"The Zambesi Basin and Nyasaland," London, 1893.

"The Backbone of Africa," London, 1920.

"The Geography and Economic Development of British Central Africa," Geographical Journal, January, 1912.

"Fighting the Slave Hunters in Central Africa."

"Precis of Information concerning the British Central Africa Protectorate," London, 1901.

\section{Works on Languages and Tribes.}

(a) GENERAL.

Johnston (Sir H. H.)

Molema (S. M.). . . .

"Comparative Study of Bantu Languages," Oxford, 1919.

"The Bantu, Past and Present, Edinburgh," 1920.

(b) CHINYANJA.

BARnes (Rev. H.) _ " Nyanja - English vocabulary " (S.P.C.K.), London, 1902.

Caldwell (R.) ․ "Chinyanja Simplified" (Z.I.M.), London, 1896.

DUfF (Sir H. L.) . "Nkani za dziko la Amang'anja," 2nd edit., Zomba, 1913.

HETHERWICK

(Rev. Ir. A.)

"Practical Manual of the Chinyanja Language" (S.P.C.K.), London, 1901 (and later editions).

Laws (Rev. Dr. R.) .. "Table of Concords of the Chinyanja Language," Edinburgh, 1885.

Chinyanja Exercise Book (Likoma Dialect, S.P.C.K.), London, 1898.

Vocabulary of English-Chinyanja as spoken at Likoma (S.P.C.K.), London, 1895.

Sсотт (Rev. D. C.) . "A Cyclopoedic Dictionary of the Mang'anja Language," Edinburgh, 1892 . 


\section{(c) CHIPETA.}

Rebuan (Rev. J.) . "Dictionary of the Kiniassa Language" (Church Missionary Society), 1877.

(d) CHITUMBUKA.

Elmsuie (Dr. W. L.) . " "Notes on the Tumbuka Language," Aberdeen, 1891.

(e) CHIYAO.

HeTHeRWick

(Rev. Dr. A.)

"Introductory Handbook of the Yao Language " (S.P C.K.), 2nd edit., London, 1902.

Sanderson (Dr. M.) . " "Yao Grammar," Zomba, 1916.

"Chiikala Cha Wayao" (History of the Yaos) by Yohanna B. Abdallah, with notes and translation by M. Sanderson, Zomba, 1919 .

(f) KI-SWAHELI.

MADAN (A. C.) . "Steere's Handbook of the Swaheli Language," (S.P.C.K.), 9th edit., London, 1913.

"English-Swaheli Dictionary," Oxford, 1894. 
Business or Pleasure.

The economy of the New-Hudson is worthy of consideration. Hard wearing qualities, low consumption, low upkeep, increase the value per pound sterling of the initial cost.
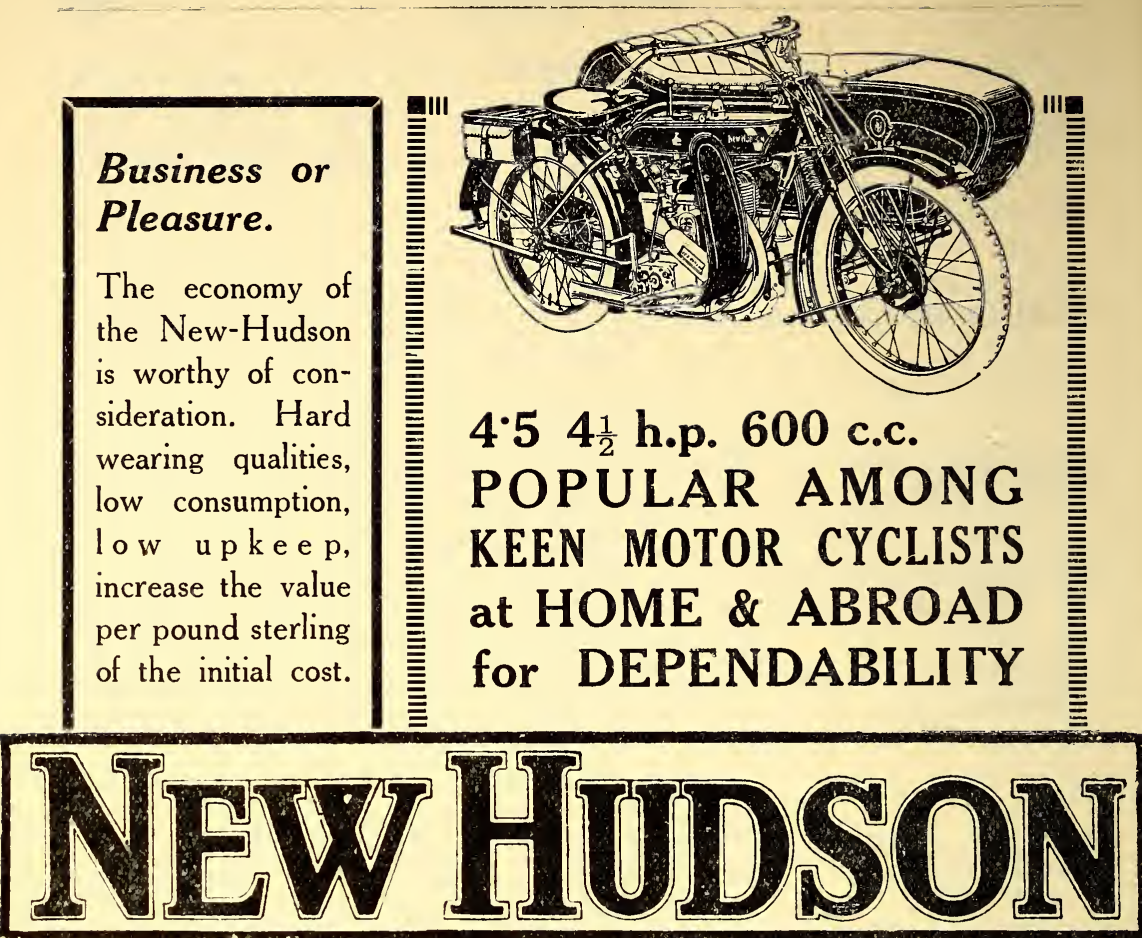

All Chain Drive, Patent Shock Absorber, Large Tyres, Special Spring Saddle, High Ground Clearance, Solid Steel forgings to frame and chassis, four point attachments to side car, high carbon steel tubing, comfort \& weather protection for rider and passenger, these set the seal on world-wide public approval.

The machine that wins through is the machine for you.

Write for 1923

- Catalogues.-

BICYCLES 22 Models MOTOR CYCLES LIGHT WEIGHTS MEDIUM WEIGHTS HEAVY WEIGHTS 


\section{INDEX.}

NOTE.-Numbers in italics relate to principal or descriptive references.

A

\begin{tabular}{|c|c|c|c|c|c|c|}
\hline Abercorn & & & & $\cdots$ & $\ldots$ & 149. \\
\hline Abisa Tribe & $\ldots$ & $\ldots$ & $\ldots$ & $\ldots$ & $\ldots$ & $10,113,114,141$. \\
\hline Abyssinia... & $\ldots$ & $\ldots$ & $\ldots$ & $\ldots$ & $\ldots$ & 1,209 \\
\hline Acacia Tree & $\ldots$ & $\ldots$ & $\cdots$ & $\ldots$ & $\ldots$ & $189-9 \%$ \\
\hline Achewa Tribe & $\ldots$ & ... & ... & $\ldots$ & $\ldots$ & $\begin{array}{l}28,33,34,43,85,121,126,129, \\
130,137,139,141 .\end{array}$ \\
\hline Achikunda Trib & & & & & & $31,72,79,80,82,85,93,265$. \\
\hline Achipeta Tribe & & ... & ... & $\ldots$ & ... & $\begin{array}{l}28,32,33,34,36,38,43,72,73, \\
\quad 82,93,121,124,126,129,130 \\
134 .\end{array}$ \\
\hline
\end{tabular}

Achisa Tribe, see Yaos.

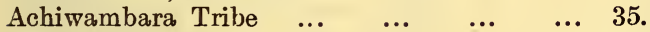

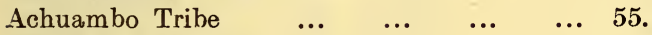

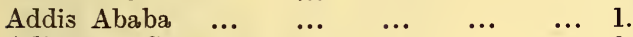

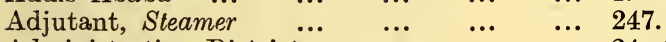

Administrative Districts $\quad \ldots . \quad \ldots . \quad \ldots \quad 24,62$.

Adventure, Steamer $\quad \ldots \quad \ldots . \quad \ldots \quad \ldots \quad 250,267$.

Africa (Acquisition of $\dddot{\mathrm{L}}$ and) $\dddot{\mathrm{O}}$. in $\dddot{\mathrm{C}}$., 1898

Africa O. in C., 1889-93 $\ldots . \quad \ldots \quad \ldots .58,59$.

Africa Protectorates (Capital Sentences)

O. in C., $1898 \quad \ldots \quad$... $\quad \ldots \quad$.. 59.

African Lakes Corporation $\quad \ldots \quad \ldots . \quad \ldots \quad 12,13,14,15,17,18,19,24,72$,

$113,126,134,137,141,144$,

$153,154,247,249,250,251$.

African Transcontinental Telegraph Co. ... 3, 113, 127, 154, 249, 256-5\%.

Afulirwa Tribe $\quad \ldots \quad \ldots \quad \ldots \quad \ldots \quad \ldots \quad 38,39,150$.

Agriculture $\quad \ldots \quad \ldots \quad \ldots \quad \ldots \quad \ldots \quad \ldots \quad 24,25,64,70,77,78,84,85$,

$90,92,94,96,99,104,106$, $109,115,117-8,120-1,123$, $128,133,141,155-64$.

Ahewa Tribe

$\begin{array}{llllll}\text { Akamanga Tribe } & \ldots & \ldots & \ldots & \ldots & 38,141,150 .\end{array}$

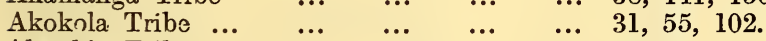

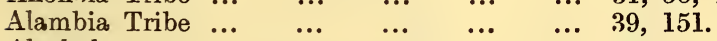

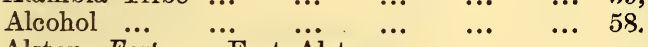

Alston, Fort, see Fort Alston.

Alston, Lieut. $\quad \ldots . \quad \ldots \quad \ldots \quad \ldots . \quad \ldots \quad 139$.

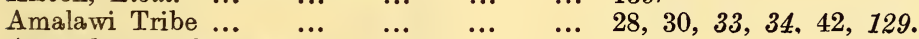

Amambwe Tribe $\quad \ldots \quad \ldots . \quad \ldots . \quad \ldots .6150$.

Amang'anja, see Anyanja.

Amanyawa Tribe $\quad \ldots . \quad \ldots . \quad \ldots \quad \ldots \quad 55$.

$\begin{array}{llllll}\text { Amarata Tribe } \ldots & \ldots & \ldots & \ldots & \ldots & 55 . \\ & \ldots & \ldots & \ldots & \ldots & 55,56 .\end{array}$

Amaravi, see Amalawi.

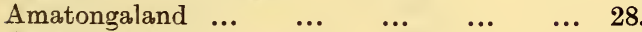

$\begin{array}{llllll}\text { Amatetwa Tribe } & \ldots & \ldots & \ldots & \ldots & 28 .\end{array}$

Ambo Tribe $\quad \ldots \quad \ldots \quad \ldots \quad \ldots \quad \ldots \quad \ldots \quad 28,33,38,42,82,85,93$.

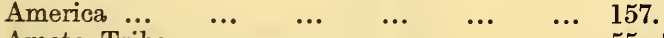

Ameto Tribe $\quad \ldots \quad \ldots \quad \ldots \quad \ldots \quad \ldots \quad \ldots \quad 55,56$.

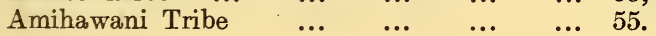




\section{Amon}

Ampotola Tribe

Amwenye Tribe

Andradite

Anglo-Portuguese Boundary

Anglo-Portuguese Convention

Angoche ..

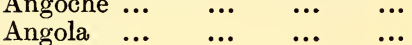

Angoni Tribe
Anglo-German Convention

$\begin{array}{lllll}\ldots & \ldots & \ldots & \ldots & 142 .\end{array}$

... 28, 42, 55, 102.

... 72 .

... 5 .

... 1,17

... $1,3,70,71,74,81,83,86,87,98$, $107,112,116,117,120,122$, $123,127,129,131,252$.

$1,16,17,247,248$.

$\begin{array}{lll}\ldots & \ldots & 1,16, \\ \ldots & \ldots & 241 .\end{array}$

$\ldots \quad \ldots 9,15$.

... $9,10,11,12,13,18,19,22,23$, $28-30,33-39,42,47,49-54$, $80,82,85,93,95,97,102,106$, $112,121,126,129,130,134$, $137,139,141,145,150,151$, 164, 241, 244, 258, 265.

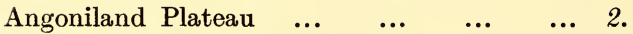

Anguru Tribe $\quad \ldots \quad \ldots \quad \ldots \quad \ldots \quad \ldots \quad 21,23,30,34,35,42,45,46,47$, $55-57,80,89,90,93,95,97$, $102,106,113,114,258$.

Anikuku Tribe $\ldots \quad \ldots \quad \ldots \quad \ldots \quad \ldots \quad \ldots \quad 53$.

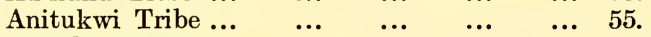

$\begin{array}{llllll}\text { Ankylostomiasis } & \ldots & \ldots & \ldots & \ldots & 148 .\end{array}$

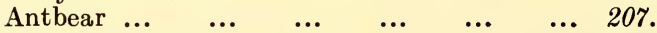

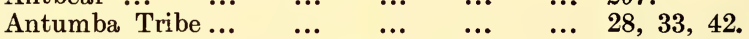

Anyanja Tribe ...

Anyika Tribe

Anyungwi Tribe

Aphodzo Tribe ...

Appeals ...

Apoka Tribe

Apples $\quad \ldots \quad \cdots$

Arabia $\quad \cdots \quad \cdots$

Arabs

Arambara Tribe...

Armorial Ensign

Asbestos

Asena Tribe

Asenga Tribe

Ashanti ... ...

Asia $\quad \ldots \quad \ldots$

Asisya Tribe

Assessors ...

Atakwani Tribe

Atonga Tribe

Atonga (Zambesi) Tribe

Attorney-General

Augustine Ambali

Avocado Pears ...

Awandia Tribe ...

Awanyamwanga Tribe

Awemba Tribe ...

Azimba Tribe
$10,12,18,28,31-34,36-38$, $42-46,56,72,73,78,80,82$, $85,93,95,97,102,106,110$, $113,114,126,134,237,258$, 265.

38,150 .

... 72 .

... 72 .

... $58,59,63,64$.

... $38,141,150$.

... 91 .

... 8, 41, 208.

... $10,13,14,15,17,19,20,21,22$, $23,27,34,36,39,48,72,136$, $150,154,208$.

72.

... 64 .

... 5 .

... $31,42,72$.

... $113,114,141$.

... 258.

... 38,150 .

... 64 .

... 31,55 .

... 13, 17, 20, 21, 28, 29, 39, 42,

$31,72$.

... 61,64 .

... 239 .

... 91 .

... $39,151$.

... $39,151$.

... $22,27,39,114,141,150,258,265$.

... $31,72,126$.
... $8,40,41,208$. $106,141,144-45,258,264,265$. 
Babisa Tribes, see Abisa Tribes.

Baboons ... $\quad \ldots \quad \ldots \quad \ldots$

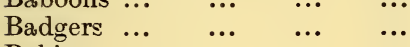

$\begin{array}{llll}\text { Bahia } & \ldots & \ldots & \cdots\end{array}$

$\begin{array}{llll}\text { Bakonjo Tribe } & \ldots & \ldots & \cdots \\ \text { Balakas } & \ldots & \ldots & \ldots\end{array}$

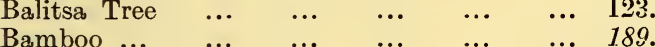

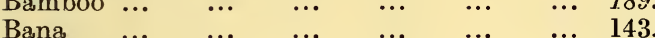

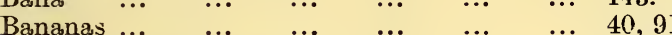

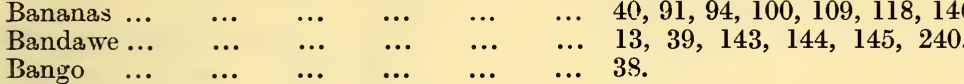

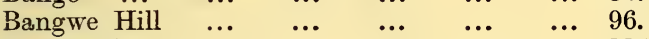

$\begin{array}{lllllll}\text { Bangweolo } & \ldots & \ldots & \ldots & \ldots & \ldots & \\ \text { Banian } & \ldots & \ldots & \ldots & \ldots & 114 .\end{array}$

Banian Traders ... $\quad \ldots \quad \ldots \quad \ldots \quad \ldots \quad 44,72,85,90,102,106,115,120$

Banji Island $\quad \ldots \quad \ldots \quad \ldots \quad \ldots \quad \ldots \quad \ldots \quad 132$.

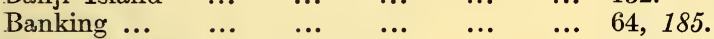

Bantu Races $\quad \ldots . \quad \ldots . \quad \ldots . \quad \ldots . \quad \ldots \quad 8,39,40-42$.

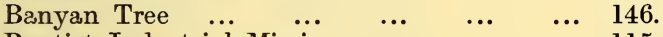

Baptist Industrial Mission $\quad \ldots \quad \ldots \quad \ldots \quad 115,244$.

$\begin{array}{lllllll}\text { Barbets } \ldots & \ldots & \ldots & \ldots & \ldots & \ldots & 209-13 .\end{array}$

$\begin{array}{lllllll}\text { Barotseland } & \ldots & \ldots & \ldots & \ldots & \ldots & 209-1 \\ & \ldots & \ldots & \ldots & \ldots & \ldots & 12 .\end{array}$

Barton, Capt. $C . W . \quad \ldots \quad \ldots \quad \ldots \quad \ldots \quad \ldots \quad 267,268$.

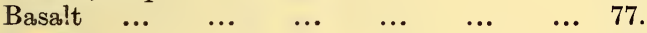

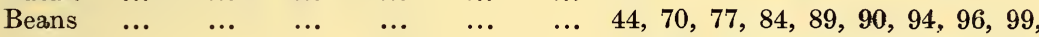
$100,104,109,110,118,124$, $128,133,143,150$.

$\begin{array}{llll}\text { Bee Eaters } & \ldots & \ldots & \ldots \\ \text { Beer } \quad \ldots & \ldots & \ldots & \ldots\end{array}$

Beira

Belcher, Mr. C. F.

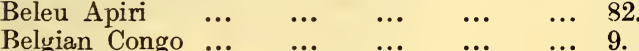

Bell, $M r$.

Bembeche

Bemru

Berlin Conference, $188 \check{0}$

Berlin Convention

Biotite

Birds

Biritsi River

Bismarksburg ...

Blackwater Fever

Blantyre ...

$\cdots$

$\cdots$

... $\quad \ldots \quad 90$.

... 90 . 121

... $121,243$.

... 119

... 58 .

... 182.

.. 5,66 .

... $71,77,105,125,134,140,143-4$ 208-213.

116.

.. 269.

.. 226-31.

$10,12,16,20,25,31,32,34$, $36-38,43,45,65,71,74-6$, $78,90,91-96,99,102,105$, $109,110,113,119,186,187$, $236,238,240,241,244,247$, $249,251,253,254,256,263$, 264.

Blantyre Mission

Blantyre and East Africa, Limited.

Bleek, Wilhelm ...

Pluebook

Bluebuck

Blue Duiker

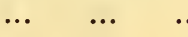

.. $\quad 24,37,38,43,240-41$.

... 91 .

... 40 .

61.

.. 143.

... 90 . 


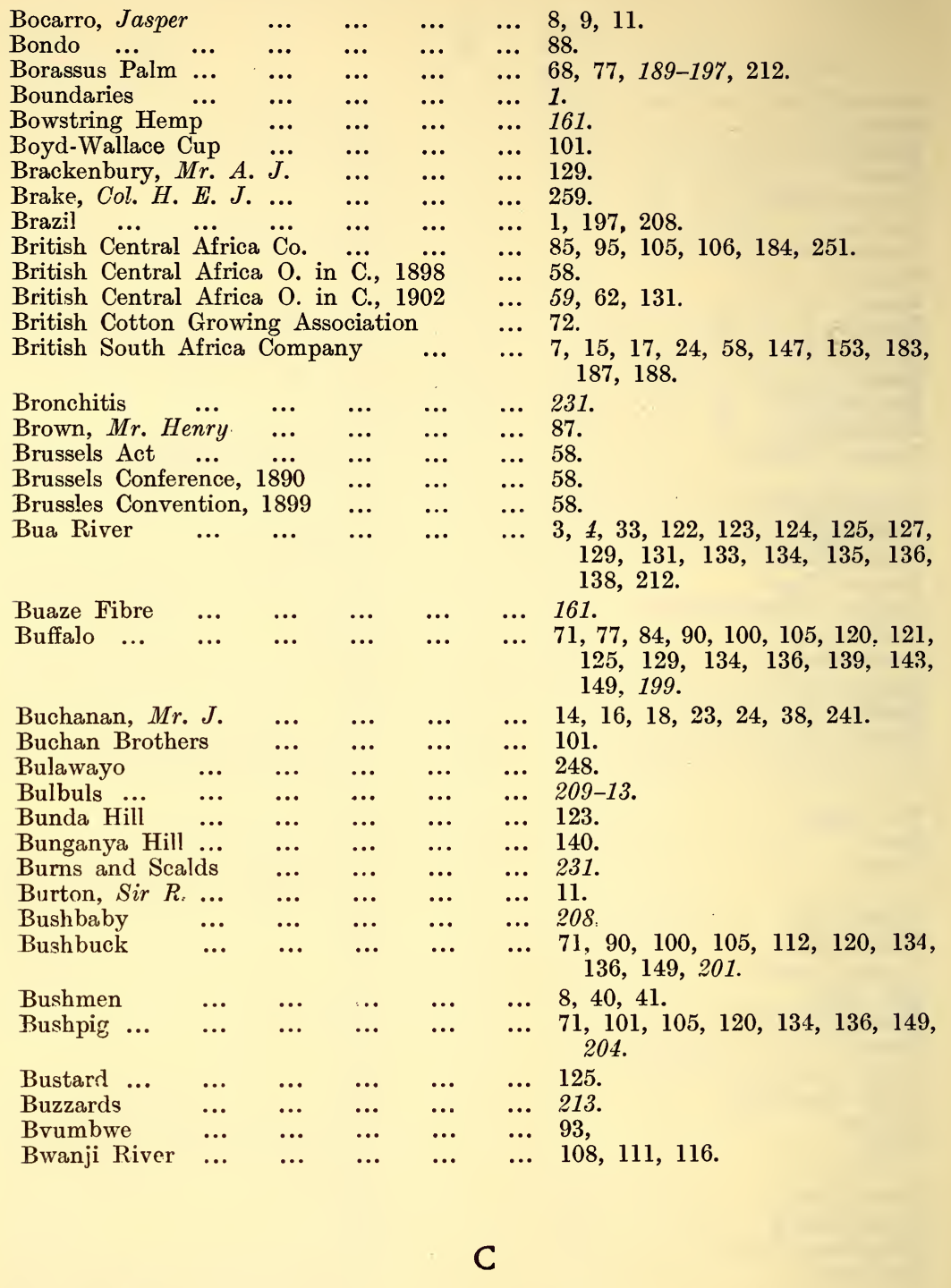

$\begin{array}{lllllll}\text { Cachomba } & \ldots & \ldots & \ldots & \ldots & \ldots & 251 .\end{array}$

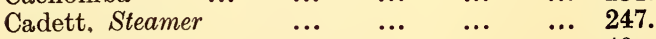

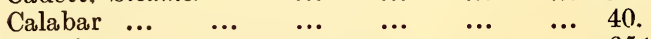

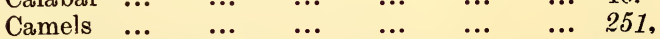

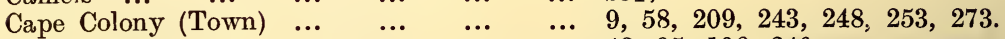

Cape Maclear $\quad \ldots \quad \ldots \quad \ldots \quad \ldots \quad \ldots \quad \ldots \quad 43,95,106,240$.

$\begin{array}{lllllll}\text { Cape York } & \ldots & \ldots & \ldots & \ldots & \ldots & 1 .\end{array}$

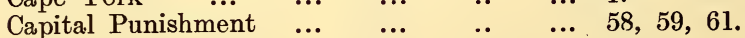

$\begin{array}{lllllll}\text { Capsicums } & \ldots & \ldots & \ldots & . . & \ldots & 161 .\end{array}$

Cardoso, Candido da Costa $\quad \ldots . \quad \ldots . \quad \ldots .9$.

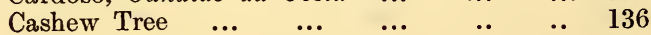


Cassava

Cassia Tree

Cat

Cattle

Cedars

Cement

Centra] Africa Railway

Central Angoniland

Central Prison ...

Central Province

Chad, Lake, see Lake Chad.

Chafumba River

Chaka

․ $\quad \cdots \quad$.

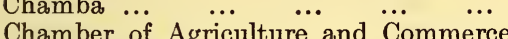

Chambo River

Chambezi River

Chambj Hill ...

Chanda Hill $\ldots$...

Changamire $\quad \ldots \quad \ldots$.

Chanưoni Mountain $\quad . . \quad$..

Chaniiri (God) ... $\quad \ldots$.

Charles Janson, Steamer

Chataik'...

Chauncey Maples, Steamer

Chauya Salima...

Chayoni Mountain

Cheetah

Cheoli Mountain

Cherobondo River

Che-Somba

Chia Tribe

Chia River

Chibisa .

Chichewa

Chicken Pox

Chididi

Chidiwo ...

Chief Secretary ${ }^{\cdots}$

Chiendausiku ...

Chiffchaffs

Chifise

Chigaru $\cdots$...

$\ldots \quad \ldots$

$\begin{array}{lll}\text { Chigoo } & \ldots & \ldots \\ \text { Chikala } & \ldots & \ldots\end{array}$

Chikalema Liwämbano

Chikoja

... $\quad \cdots$

Chikonje..

Chikowe ...

Chikulamayembe

Chikulo ...

Chikumbu

Chikuse

Chikwani $\dddot{T}$ ree
$44,57,70,84,90,94,96,100$, $109,110,118,124,135,141$, $143,150$.

\section{6.}

... 208 .

... 44, 78, 84, 97, 109, 117, 119, 124,

$128,133,141,143,149,151$, 164-6\%, 208. 195-9\%.

... 7

... 4, 25, 71, 168, 185, 249, 250

... $22,32,33,34,43,121,125,126$. $127,129$.

... 264.

... 116-13\%.

137.

... 9,28 .

... 99 .

... 95 .

... 77, 124

... 148.

... 270.

... 86 .

... 32 .

... 106, 107 .

... 120 .

... 43 .

... 14, 17, 238, 250 .

... 68,69 .

... 134, 239, 250, 267.

... 117 .

... 99.

... 121 .

... 125, 136, 204.

... 142 .

... 76 .

... 35 .

... 238 .

... 136 .

... 32 .

... 126, 129 .

... 232 .

... $30,33,36,38,42$.

... $72,74,242-3$.

... 149 .

... 61 .

... 105 .

... 211.

... 19,30 .

... 36,94 .

... 145 .

... 21, 30, 33, 36, 45, 98-102, 107.

... 82 .

... 35 .

... 68 。

... 78 .

... 35, 98, 99 .

... $39,147,148,149,150$.

... 107, 110 .

... 18, 36, 38, 88, 90 .

... 18, 22, 30, 37, 38, 112.

... 192 . 


\section{Chikwawa}

Chikweo

$\begin{array}{lllllll}\text { Chileka } & \ldots & \ldots & \ldots & \ldots & \ldots & \ldots \\ \end{array}$

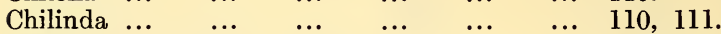

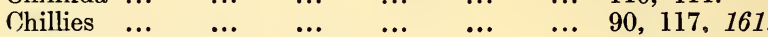

$\begin{array}{llllllll}\text { Chiloa } & \ldots & \ldots & \ldots & \ldots & \ldots & \ldots & 138,139 .\end{array}$

$\begin{array}{lllllll}\text { Chilomoni } & \ldots & \ldots & \ldots & \ldots & \ldots & 94\end{array}$

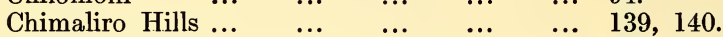

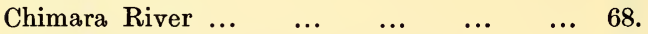

$\begin{array}{lllllll}\text { Chimbalanga } & \ldots & \ldots & \ldots & \ldots & \ldots & 133 .\end{array}$

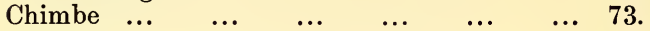

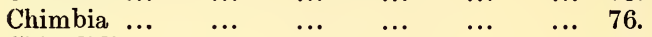

$\begin{array}{lllllll}\text { Chimdidi ... } & \ldots & \ldots & \ldots & \ldots & \ldots & 124 .\end{array}$

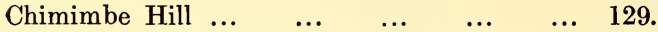

Chimombo

Chimpoyo River

Chimwala

Chimwalire River

Chinde

Chindi $\quad \ldots \quad \ldots$

Chindio $\ldots . .$.

Chinduzi Hill ...

Chingale ... ...

Chingoni ... ...

Chingwarungwaru

Chiniko ... ...

Chinji Hill Hill...

Chinombo ...

Chinsumpi (God)

Chinteche

Chintembwe

Chinyanja

Chinyasa Pool ...

Chinyenyende River

Chiole Mission ...

Chiombe Tree ...

Chipata ...

Chipe Dance

Chipironi

Chipoka ...

Chipola ...

Chiponda

Chipula ..

Chiputula

Chipwembwe

Chiradzulu

Chiradzulu Mountain

Chirala

Chiranga River ...

Chirenje Mountain

Chiripa ...

Chiromo ...

Chirua River

Chirunda Hill
$3,75,78,81,82,83,84,85,96$, $192,236,244,250,256$.

... $68,69,89,94$.

... 135 .

... 30, 35, 36, 93.

... 110 .

... 103

... 12, 15, 247, 248-49, 253, 256, $271,275$.

142.

$\ldots 4,25,249,250,256,271$,

... 103, 105 .

... 73 .

... 126 .

... 33, 103.

... 97 .

... 135 .

... 103.

... 142 .

... 43 .

... 3, 43, 142-145.

... 136 .

$\ldots .41,42,47,80,90,93,97,114$, $126,129,275$.

... 101

... 76 .

... 119

... 146.

... $109,135$.

... 130 .

... 36 .

... 36,38 .

... 121 .

... 107, 110, 132, 133 .

... 119 .

... 12, 32, 249.

... $68,69,73,74$.

... $10,19,31,32,34,35,37,45$, $91,96-7,209,237,24$ ]. 2.

... 2 .

... 250 .

... 103,104 .

... 120, 122.

... 110 .

$\ldots 4,8,12,16,17,18,25,31,67$, $71,74,75,76,77,78,79,87$, $88,89,209,212,237,249$, 256.

$131,132,133,134,135$.

$65,66,67$. 
Chisiombe

$\begin{array}{llllll}\cdots & \ldots & \ldots & \ldots & \ldots & 3 .\end{array}$

$\begin{array}{lllllll}\text { Chisio Tree } & \ldots & \ldots & \ldots & \ldots & \ldots & 193 .\end{array}$

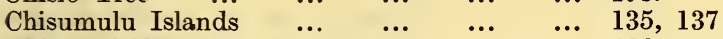

$\begin{array}{lllllll}\text { Chisuni Hill } & \ldots & \ldots & \ldots & \ldots & \ldots & 132 .\end{array}$

$\begin{array}{lllllll}\text { Chitakali ... } & \ldots & \ldots & \ldots & \ldots & \ldots & 90 .\end{array}$

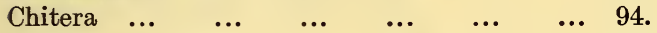

$\begin{array}{llllllll}\text { Chitije } & \ldots & \ldots & \ldots & \ldots & \ldots & \ldots & 91 .\end{array}$

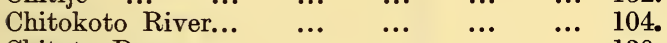

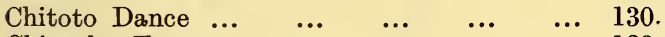

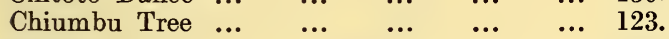

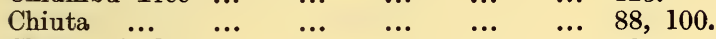

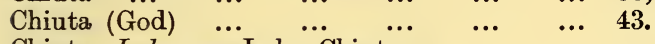

Chiuta, Lake, see Lake Chiuta.

Chiwalo ...

$\begin{array}{lllllll}\text { Chiwanga... } & \ldots & \ldots & \ldots & \ldots & \ldots & 98,111 .\end{array}$

$\begin{array}{llllllll}\text { Chiwaula } & \ldots & \ldots & \ldots & \ldots & \ldots & 21,136 .\end{array}$

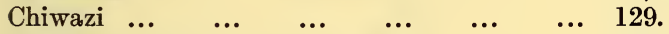

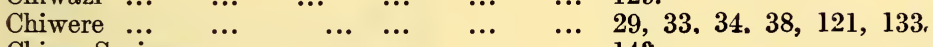

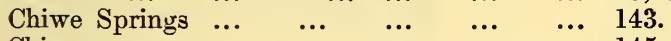

Chiweyu ... $\quad \ldots . \quad \ldots \quad \ldots . \quad \ldots \quad \ldots \quad 145$.

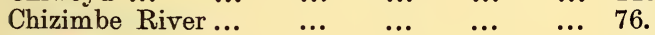

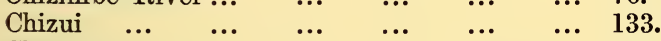

$\begin{array}{lllllll}\text { Chizumulu } & \ldots & \ldots & \ldots & \ldots & \ldots & 133 .\end{array}$

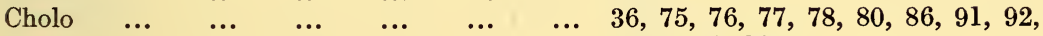

$\begin{array}{llllll}\text { Choma Mountain } \quad \ldots & \ldots & \ldots & \ldots & 29 .\end{array}$

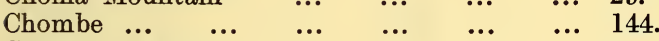

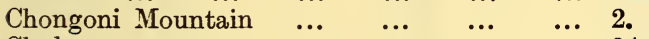

Chulu

$\begin{array}{llllll}\text { Chungu } & \ldots & \ldots & \ldots & \ldots & \ldots \\ & \ldots & \ldots & \ldots & \ldots\end{array}$

... 34, 138, 139.

$\begin{array}{lllllll}\text { Chungwe ... } & \ldots & \ldots & \ldots & \ldots & \ldots & 39, \\ & & \ldots & \ldots & \ldots & 73 .\end{array}$

$\begin{array}{lllllll}\text { Chupanga } & \ldots & \ldots & \ldots & \ldots & \ldots & \ldots \\ \end{array}$

Church of Central Africa Presbyterian ... 240, 241.

Church of Christ $\quad \ldots \quad \ldots . . . \quad \ldots \quad \ldots \quad 144$.

$\begin{array}{llllll}\text { Church of England } \quad \ldots & \ldots & \ldots & \ldots & 144 .\end{array}$

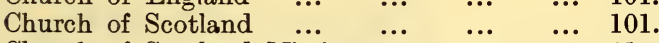

Church of Scotland Mission $\ldots . . \ldots \quad \ldots \quad 11,12,87,95,160,240-41$.

$\begin{array}{lllllll}\text { Chuwamba } & \ldots & \ldots & \ldots & \ldots & \ldots & 126 .\end{array}$

$\begin{array}{lllllll}\text { Civet Cat } & \ldots & \ldots & \ldots & \ldots & \ldots & 126 . \\ & \ldots & \ldots & \ldots & \ldots & \ldots & 105,205 .\end{array}$

Civil Police, see Police.

Civil Service $\quad \ldots \quad \ldots \quad \ldots \quad \ldots \quad \ldots \quad 24,60$.

$\begin{array}{lllllll}\text { Clay } \quad \ldots & \ldots & \ldots & \ldots & \ldots & \ldots & 77 .\end{array}$

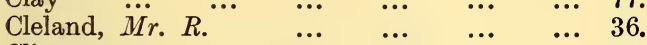

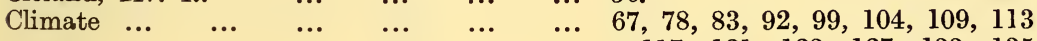

$117,121,123,127,133,135$, $138,147,226$.

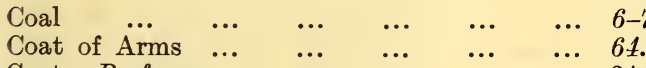

Coats, Professor $\quad \ldots . \quad \ldots \quad \ldots . \quad \ldots \quad 244$.

$\begin{array}{lllllll}\text { Cocoanuts } & \ldots & \ldots & \ldots & \ldots & \ldots & \ldots \\ \end{array}$

$\begin{array}{llllllll}\text { Coffee } \quad \ldots & \ldots & \ldots & \ldots & \ldots & \ldots & 136,189 \\ & & \ldots & \ldots & \ldots & \ldots & 24,84,\end{array}$

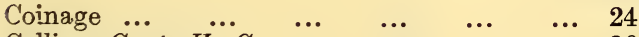

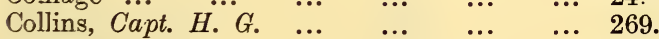

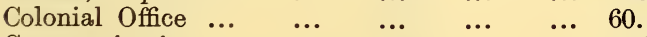

$\begin{array}{llllll}\text { Communications... } & \ldots & \ldots & \ldots & \ldots & 246-5 \%\end{array}$

$\begin{array}{lllllll}\text { Companies } & \ldots & \ldots & \ldots & \ldots & \ldots & 64 .\end{array}$

Companhia Nacional de Navegacao ... $\quad \ldots .624$.

$\begin{array}{llllllll}\text { Congo } & \ldots & \ldots & \ldots & \ldots & \ldots & \ldots & 8,9,211 .\end{array}$

$\begin{array}{lllllll}\text { Conjunctivitis } & \ldots & \ldots & \ldots & \ldots & \ldots & 232 .\end{array}$

$\begin{array}{lllllll}\text { Constipation } & \ldots & \ldots & \ldots & \ldots & \ldots & 232 .\end{array}$

$\begin{array}{lllllll}\text { Constitution } & \ldots & \ldots & \ldots & \ldots & \ldots & \ldots \\ \text { Contund }\end{array}$

$\begin{array}{lllllll}\text { Cormorants } & \ldots & \ldots & \ldots & \ldots & \ldots & 210 .\end{array}$ 
Corn Crake Corundum

Cotton

Court Fees

Courts of Justice

Coutinho, Lieut....

Cranes

Crawshay, $M r . \dddot{R}$.

Crimea

Crocodiles

Crown Lands ...

Cuckoos ..

Cucumbers

Currency ...

Customs and Excise

Cypresses

Cyprus $\begin{array}{llllll}\ldots & \ldots & \ldots & \ldots & \ldots & 211 \\ \ldots & \ldots & \ldots & \ldots & \ldots & 7 . \\ \ldots & \ldots & \ldots & \ldots & \ldots & 24\end{array}$

.. 59 . $117,120-1,123,127,133,144$, $154,157-8,169,170-1$.

$\begin{array}{lllll}\ldots & \ldots & \ldots & \ldots & 59 . \\ \ldots & \ldots & \ldots & \ldots & 24,58,59,63-64,95 . \\ \ldots & \ldots & \ldots & \ldots & 16 . \\ \ldots & \ldots & \ldots & \ldots & 144 . \\ \ldots & \ldots & \ldots & \ldots & 14,209 . \\ \ldots & \ldots & \ldots & \ldots & 1 . \\ \ldots & \ldots & \ldots & \ldots & 72,105,112,149 . \\ \ldots & \ldots & \ldots & \ldots & 59,60,64,186-88 . \\ \ldots & \ldots & \ldots & \ldots & 211 . \\ \ldots & \ldots & \ldots & \ldots & 70,89,90 . \\ \ldots & \ldots & \ldots & \ldots & 185 . \\ \ldots & \ldots & \ldots & \ldots & 24,58,63,71,168-182 . \\ \ldots & \ldots & \ldots & \ldots & 189-196 . \\ \ldots & \ldots & \ldots & \ldots & 1 .\end{array}$

D

\begin{tabular}{|c|c|c|c|c|c|}
\hline Dambe Achanga & $\cdots$ & $\cdots$ & $\cdots$ & .. & 82. \\
\hline Dances $\ldots \quad \ldots$ & ... & ... & ... & ... & 130. \\
\hline Dandi River $\quad \ldots$ & $\ldots$ & $\ldots$ & $\ldots$ & $\ldots$ & 67. \\
\hline Daniel Apiri $\quad \ldots$ & $\ldots$ & $\ldots$ & ... & $\ldots$ & 82. \\
\hline Decken, Von der & $\ldots$ & $\ldots$ & ... & ... & 11. \\
\hline Dedza $\quad \ldots$ & $\cdots$ & $\ldots$ & ... & .. & $\begin{array}{r}7,30,34,35,45,116,119,120-21 \\
125,126,132,164,236,242,256 .\end{array}$ \\
\hline Dedza Mountain & $\cdots$ & $\cdots$ & $\cdots$ & ... & \\
\hline Deep Bay & $\ldots$ & $\ldots$ & $\ldots$ & $\ldots$ & $146,148,149,150,153,154$ \\
\hline Defence Force ... & $\ldots$ & $\ldots$ & ... & $\ldots$ & $262-63$. \\
\hline Deforestation $\quad \ldots$ & $\ldots$ & $\ldots$ & ... & ... & $57,83,96,128,131,188-97$. \\
\hline Delagoa Bay ... & ... & $\ldots$ & ... & ... & 28,253 . \\
\hline Demodectic Mange & $\ldots$ & $\ldots$ & $\ldots$ & $\ldots$ & 149. \\
\hline Denje Fibre $\quad \ldots$ & $\ldots$ & $\ldots$ & $\ldots$ & $\ldots$ & $161,193$. \\
\hline Dennistoun, Lieut.-C & m. $G$. & $H$. & ... & ... & 269. \\
\hline $\begin{array}{l}\text { Deportation } \quad \ldots \\
\text { Dialects, see Langu }\end{array}$ & es. & ... & ... & ... & 59. \\
\hline Diampwe River & $\ldots$ & ... & $\cdots$ & ... & $120,122,124$. \\
\hline Diarr & $\ldots$ & $\ldots$ & $\ldots$ & $\ldots$ & 232. \\
\hline Dinde Tree & $\ldots$ & $\ldots$ & $\ldots$ & $\ldots$ & 146. \\
\hline Dingiswayo & $\ldots$ & $\ldots$ & $\ldots$ & $\ldots$ & 28. \\
\hline District Ädministra & & $\ldots$ & ... & ... & $\begin{array}{l}61,62-63,69,74,82,94,97,100 \\
103,109,117-18,121,124,128 \\
131,133,137,138,142,145, \\
147,148 .\end{array}$ \\
\hline \multicolumn{6}{|c|}{$\begin{array}{l}\text { District Courts, see Courts of Justice. } \\
\text { Districts, see Administrative Districts. }\end{array}$} \\
\hline Ditimbe Tree $\quad .$. & $\ldots$ & $\ldots$ & $\ldots$ & $\ldots$ & 123. \\
\hline Dogs $\quad \ldots$ & $\ldots$ & $\ldots$ & $\ldots$ & $\ldots$ & 208. \\
\hline Domasi $\ldots$ & & & & & 21,35 . \\
\hline Domasi Mission & $\ldots$ & $\ldots$ & $\ldots$ & $\ldots$ & 241. \\
\hline Domasi River ... & $\ldots$ & $\ldots$ & $\ldots$ & $\ldots$ & 99. \\
\hline Dombole Mission & $\ldots$ & .. & . & ... & $119,242$. \\
\hline Dombole River ... & ... & $\ldots$ & $\ldots$ & $\cdots$ & 116. \\
\hline Domestic Animals & ... & $\ldots$ & $\ldots$ & .. & 208. \\
\hline Bay & ... & ... & ... & ... & $3,35,36,46,122,132,133,256$ \\
\hline a, Steamer & ... & ... & $\ldots$ & & $18,19,20,250$ \\
\hline Domwe Mountain & $\ldots$ & ... & $\ldots$ & $\ldots$ & $30,33,42$. \\
\hline
\end{tabular}


$\begin{array}{lllllll}\text { Dongera River } & \ldots & \ldots & \ldots & \ldots & \ldots & 105 .\end{array}$

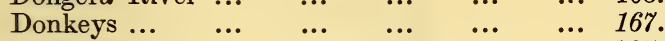

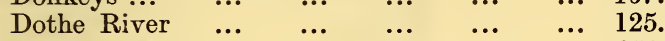

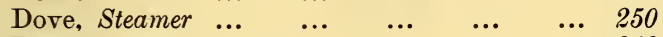

$\begin{array}{llllllll}\text { Doves } & \ldots & \ldots & \ldots & \ldots & \ldots & \ldots & 212 .\end{array}$

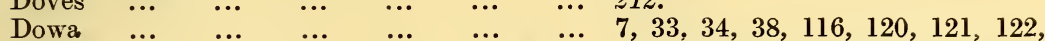

$125,126,129,131-34,135,136$, $138,164,242$.

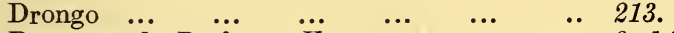

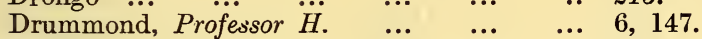

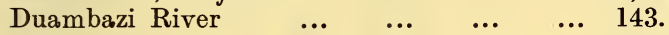

Ducks

... $71,77,106,119,125,134,140$, $144,208,211$.

Duiker

Duncan, Mr. J...

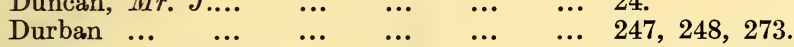

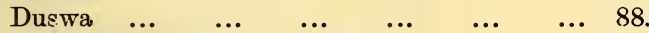

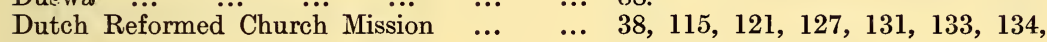
$136,242$.

Dwangwa River...

$\begin{array}{lllllll}\text { Dyanyama } & \ldots & \ldots & \ldots & \ldots & \ldots & 89 .\end{array}$

$\begin{array}{lllllll}\text { Dysentery } & \ldots & \ldots & \ldots & \ldots & \ldots & 232 .\end{array}$

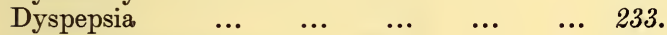

$\begin{array}{llllll}\text { Dzalanyama Mountains } & \ldots & \ldots & \ldots & 122,123,125 .\end{array}$

$\begin{array}{lllllll}\text { Dzenji River } & \ldots & \ldots & \ldots & \ldots & \ldots & 67 .\end{array}$

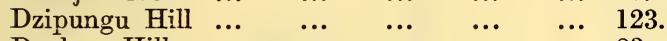

$\begin{array}{lllllll}\text { Dzobwe Hill } & \ldots & \ldots & \ldots & \ldots & \ldots & 83,84,85 .\end{array}$

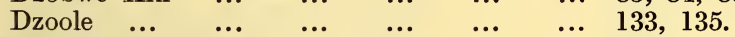

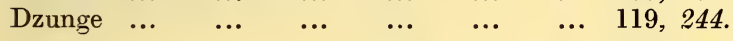

East Coast Fever

Eastern Africa Court of Äppeal O. in. C., 192

$149,161-6 \%$.

Education

Edward, Lake, see Lake Edward.

$\begin{array}{lllll}\text { Eggs } & \ldots & \ldots & \ldots & \ldots \\ \text { Egrets } & \ldots & \ldots & \ldots & \ldots\end{array}$

$\begin{array}{llllll}\ldots & \ldots & \ldots & \ldots & \ldots & 71,77 .\end{array}$

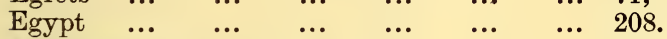

$\begin{array}{lllllll}\text { Egyptians } & \ldots & \ldots & \ldots & \ldots & \ldots & \\ & \ldots & \ldots & \ldots & \ldots & \ldots & 40 .\end{array}$

Ekwendeni $\quad \ldots \quad \ldots \quad \ldots \quad \ldots \quad \ldots \quad 141,143,144,149,240$.

Eland $\quad \ldots \quad \ldots \quad \ldots \quad \ldots \quad \ldots \quad \ldots \quad \ldots \quad 71,90,100,105,112,120,121$, $125,129,134,136,139,143$, $149,199$.

$\begin{array}{lllllll}\text { Electric Light } & \ldots & \ldots & \ldots & \ldots & \ldots & 101,154\end{array}$

$\begin{array}{llllll}\text { Elephant Marsh } & \ldots & \ldots & \ldots & \ldots & 101,154 . \\ & \ldots & \ldots & \ldots & \ldots & 75,76,78 .\end{array}$

Elephants

Elgon Mountain...

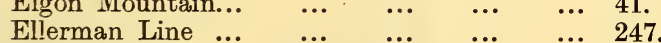

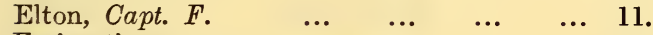

$\begin{array}{lllllll}\text { Emigration } & \ldots & \ldots & \ldots & \ldots & \ldots & 54 .\end{array}$

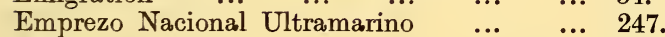

England $\ldots \quad \ldots \quad \ldots \quad \ldots \quad \ldots \quad \ldots \quad \ldots \quad 165,192,248,254$.

$\begin{array}{llllllll}\text { Erigo } & \ldots & \ldots & \ldots & \ldots & \ldots & \ldots & 259 .\end{array}$

$\begin{array}{lllllll}\text { Ethiopianism } & \ldots & \ldots & \ldots & \ldots & \ldots & \ldots \\ \end{array}$

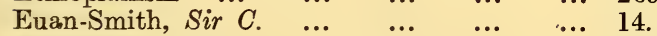

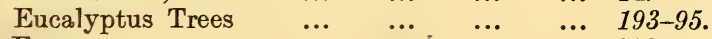

Europe $\ldots \quad \ldots \quad \ldots \quad \ldots, \quad \ldots \quad \ldots \quad 210$. 


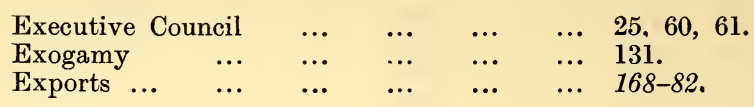

F

Fan Palm

\begin{tabular}{|c|c|c|c|}
\hline Fan Palm & & & \\
\hline Faulkner, & Cap & tain & $\ldots$ \\
\hline Felspar & & & $\ldots$ \\
\hline Fenwick, & $M r$. & $G$ & \\
\hline Fibre & $\cdots$ & & $\cdots$ \\
\hline Fife & $\cdots$ & 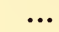 & $\ldots$ \\
\hline $\begin{array}{l}\text { Fiji } \\
\text { Finance }\end{array}$ & $\ldots$ & . & $\ldots$ \\
\hline $\begin{array}{l}\text { Finance } \\
\text { Finches }\end{array}$ & & $\cdots$ & $\cdots$ \\
\hline $\begin{array}{l}\text { Finches } \\
\text { First Assi }\end{array}$ & istant & $\ddot{\mathrm{Sec}}$ & ary \\
\hline Fish & $\ldots$ & & $\ldots$ \\
\hline
\end{tabular}

Fisher, Bishop ...

Flamingo

Florence Bay $\cdots, \quad \cdots$

Flycatchers

Foot, Captain, $\ddot{R} . N$.

Forbes, Major W. P. ...

Foreign Jurisdiction Act, 1890

Foreign Office

Forestry

Fort Alston

Fort Anderson

Fort Hill

Fort Jameson

Fort Johnston

Fort Lister

$\begin{array}{lllll}\text { Fort Maguire } & \ldots & \ldots & \ldots & \ldots \\ \text { Fort Mangoche } & \ldots & \ldots & \ldots & \ldots\end{array}$

Fort Manning

Fossils

Fotheringham, $\dddot{M} r$. L. $\dddot{M}$. $\quad \ldots$

Fowls

$\begin{array}{lllll}\text { France } & \cdots & \cdots & \cdots & \cdots\end{array}$

$\begin{array}{lllll} & \ldots & \ldots & \ldots & \ldots\end{array}$

$\begin{array}{llll}\cdots & \ldots & \ldots & \ldots\end{array}$

Free Church of Scotland Mission

Freemasons $\ldots, \quad \ldots \quad \ldots$

Friendly Islands... $\quad \ldots \quad \ldots$

$\begin{array}{llll}\text { Fuka } & \ldots & \ldots & \ldots\end{array}$

Funeral River ...

$\cdots \quad \cdots$

... 5,66 .
... 77

... 11,43 .

... $12,32,249$

... $69,104,161,192-93$.

... $149,270$.

... 1 .

... $168-85$.

... 209-13.

... 62 .

... 70,77, 84, 89, 94, 100, 104, 110, $124,128,133,135,143,150$, 1.98 .

... 239 .

... 211.

... $3,146,148,149,253$.

... 209-13.

... 12,95 .

... 17 .

... 59 .

.. $\quad 15,17,20,60$.

... $66,68,75,92,98,108,117,123$, $128,131,140,144,146,188-9 \%$. 139.

$20,86-90$.

$22,147,149,150,153$.

... $23,29,122,124,125,128,129$,

$131,135,136,139,256$.

$3,18,19,22,45,46,48,104$, $106-13,209,236,239,242$, $251,253,263,267,269$.

$20,86,87,89,90$.

... 3, 21, 109, 110, 111, 112, 113, 139.

$\ldots \quad 22,107,108,109,110,111,112$, 115.

$7,23,33,116,121,126,127-31$, $133,138,167,242$.

... $6,147$.

... $13,14,19$.

... 31, 110, 119, 124, 208.

... 9, 244.

... 71, 106, 125, 134, 209-13.

... 139, 239-40.

... 101 .

... 1.

... 145

... 81,116

... 49, 50, 152 .

G

$\begin{array}{llllllll}\text { Galago } & \ldots & \ldots & \ldots & \ldots & \ldots & \ldots & 20 \%\end{array}$

$\begin{array}{llllllll}\text { Galena } & \ldots & \ldots & \ldots & \ldots & \ldots & \ldots & 20 \% \\ & \ldots & \ldots & \ldots & \ldots & \ldots & 7 .\end{array}$

$\begin{array}{llllllll}\text { Gambia } & \ldots & \ldots & \ldots & \ldots & \ldots & \ldots & \ldots \\ \end{array}$ 
Game

Game Ordinance

$\begin{array}{llllllll}\text { Ganya } & \ldots & \ldots & \ldots & \ldots & \ldots & \ldots & 106,107 . \\ \text { Garnet } & \ldots & \ldots & \ldots & \ldots & \ldots & \ldots & 5,66,147 .\end{array}$

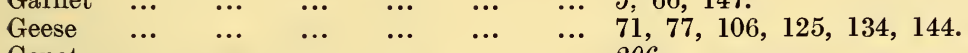

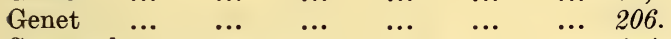

$\begin{array}{lllllll}\text { Geography } & \ldots & \ldots & \ldots & \ldots & \ldots & 206 . \\ & \ldots & \ldots & \ldots & \ldots & \ldots & 1-4 .\end{array}$

Geology $\quad \ldots \quad \ldots \quad \ldots \quad \ldots \quad \ldots \quad \ldots \quad 4-7,66,77,147$.

George Chekucheku $\quad \ldots \quad$... $\quad \ldots \quad$.. 82 .

German East Africa, see Tanganyika Territory.

German East Africa Line $\quad \ldots \quad$... $\quad \ldots \quad 247$.

Germans ... $\quad \ldots \quad \ldots \quad \ldots \quad \ldots \quad \ldots \quad \ldots \quad 11,15$.

$\begin{array}{lllllll}\text { Germany } \ldots & \ldots & \ldots & \ldots & \ldots & \ldots & 1 .\end{array}$

Ginger $\quad \ldots \quad \ldots \quad \ldots \quad \ldots \quad \ldots \quad \ldots . \quad \ldots \quad 90$.

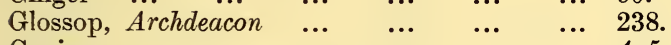

$\begin{array}{llllllll}\text { Gneiss } & \ldots & \ldots & \ldots & \ldots & \ldots & \ldots & \ldots \\ & \cdots & & & \ldots & \ldots & \ldots & \end{array}$

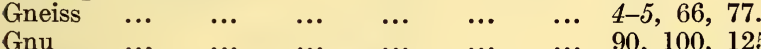

$\begin{array}{llllllll}\text { Gouts } & \ldots & \ldots & \ldots & \ldots & \ldots & \ldots & 90,100,125,200 \text {. }\end{array}$

Gold

Goman

Gorgon, H.M.S.

Gough, Major

Gourds

Governor ...

Government House

Government Offices

Gowa

Granite $\ldots \quad \ldots \quad \ldots$.

Graphite ... $\quad \ldots \quad \quad$..

Griffiths, Captain $A . \ddot{H}$.

Groundnuts

Ground-robin

Guavas ... $\quad \ldots \quad$...

Gubudira River

Guinea-fowl

$\begin{array}{lll}\text { Gulu } & \ldots & \\ \text { Gulutu Dance }\end{array}$

Gumbiro ...

Gumburru $\quad \cdots \quad \cdots$

Gum Trees $\quad \ldots . \quad \ldots$

Gunboats, see Steamers.

Gwaza

Gwendolen, H.M.S. $\quad \ldots$ $119,124,128,133,141,149$, 164-6\%, 208.

$134,136,139,143,149,198-$ 213.

$\ldots \quad 7,8,77,84,147$.

246.

... 259.

... 89,90 .

$\ldots .60,61,69,101,103,187,263$.

... 101 .

... 101 .

… $119,244$.

... 66 .

... 5,66 .

... 90 .

... 268 .

... $70,94,100,104,109,110,118$, $124,128,133,162$.

... 212-13.

... 90 .

... 106, 107.

... 71, 106, 125, 134, 143, 211 .

... 145 .

... 130.

... 270 .

... 259.

... 194-96.

... 36,37 .

... 113, 134, 250, 267, 269.

$\mathrm{H}$

\begin{tabular}{|c|c|c|c|c|c|c|}
\hline Hamedi ... & $\cdots$ & & & $\ldots$ & $\ldots$ & 150. \\
\hline Hamitic Races & $\ldots$ & $\ldots$ & $\ldots$ & $\ldots$ & $\ldots$ & 40. \\
\hline Hara & $\ldots$ & $\ldots$ & $\ldots$ & $\ldots$ & $\ldots$ & 149. \\
\hline Harcourt, Visco & ount & ... & $\ldots$ & $\ldots$ & $\ldots$ & 267. \\
\hline Hare $\quad \ldots$ & $\ldots$ & ... & $\ldots$ & $\ldots$ & $\ldots$ & 208. \\
\hline Harris Peaks & $\ldots$ & $\ldots$ & $\ldots$ & $\ldots$ & $\ldots$ & 2. \\
\hline Hartebeeste & ... & ... & $\ldots$ & ... & $\ldots$ & $\begin{array}{l}71,90,100,105,120,125,129, \\
134,136,143,149,201\end{array}$ \\
\hline Hawes, Consul & ... & ... & ... & $\cdots$ & & $14,101$. \\
\hline
\end{tabular}


Hawthorne, General G. M. P.

Headache

Health

Hematite

Henderson, $M r, \ddot{H}, \quad \cdots \quad \cdots \quad \cdots$

Henga Valley $\ldots$... $\quad \ldots \quad \ldots, \quad \cdots$

Henry Henderson Institute ....

Herald, H.M.S. $\quad \ldots \quad \ldots . \quad \ldots$

Hermann von Weissmann, Steamer ...

Herons $\ldots \quad \ldots \quad \ldots \quad \ldots \quad \ldots$

Hetherwick, Rev. Dr. A. $\quad \ldots \quad$...

Hewe … … $\ldots$ Courts of Justice.

Hine, Bishop

Hippopotamus $\cdots \quad \cdots \quad \cdots$

History $\ldots \quad \ldots \quad \ldots \quad \ldots$

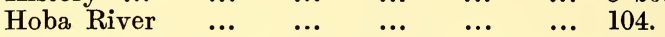

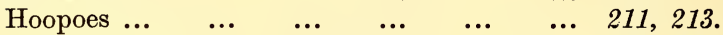

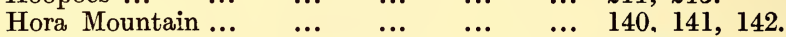

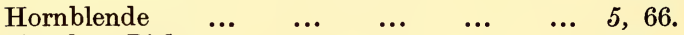

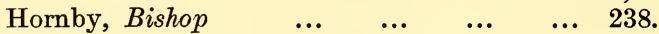

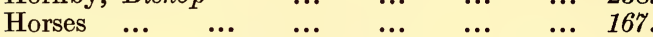

Hospitals $\begin{array}{lllll}\cdots & \cdots & \ldots & \ldots & \ldots \\ & & \end{array}$

Hotels

Hotels $\ldots$.

Hottentots
Hunting Dogs

Hut Tax

Hyenas ...

Hyphæne $\dddot{P}_{\text {alm }} .$.

Hyrax
... 268, 270, 272 .

33.

$\therefore 5$

... $37,240$.

... $38,143,147,149$.

... 241 .

... 17, 71, 249.

... $20,250,267,269$.

... 77.

... $11,16,37,38,275$.

... 149 .

... 101, 112, 144, 236, 239, 240, $241,242,243,244$.

... 95, 113 .

... 40,41 .

... $71,125,205$.

$\ldots \quad 24,124,155,182$.

... 71, 100, 105, 120, 125, 205.

... 68, 77, 189-197.

... 208 .

Ilala, Steamer $\quad \ldots \quad \ldots \quad \ldots \quad \ldots$

... 13, 17, 239, 250 .

Ilmenite $\ldots \quad \ldots \quad \ldots \quad \ldots \quad \ldots$

... 5 .

$\begin{array}{lllllll}\text { Immigration } & \ldots & \ldots & \ldots & \ldots & \ldots & 5 .\end{array}$

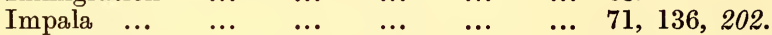

Imperial Tobacco Co. ... $\quad \ldots \quad \ldots \quad \ldots \quad \ldots 95$.

Imports $\ldots \quad \ldots \quad \ldots \quad \ldots \quad \ldots$

$\begin{array}{lllllll}\text { Income Tax } & \ldots & \ldots & \ldots & \ldots & \ldots & 183 .\end{array}$

India $\quad \ldots \quad \ldots \quad \ldots \quad \ldots \quad \ldots \quad \ldots \quad \ldots \quad 165,208,251$.

Indian Ocean $\quad . . \quad \ldots \quad \ldots \quad \ldots \quad \ldots \quad \ldots \quad 3,10$.

Indian Traders, see Banian Traders.

247.

$\begin{array}{lllllll}\text { Influenza } & \ldots & \ldots & \ldots & \ldots & \ldots & 233 .\end{array}$

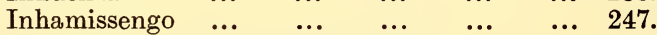

Initiation Ceremony, see Unyago.

... $71,84,121,125,139,201$.

$\begin{array}{lllllll}\text { Ipani Hill } & \ldots & \ldots & \ldots & \ldots & \ldots & \\ & \ldots & \ldots & \ldots & \ldots & \ldots & 98,\end{array}$

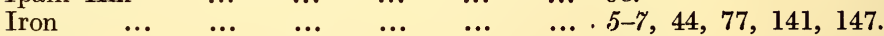

$\begin{array}{llllllll}\text { Iringa } & \ldots & \ldots & \ldots & \ldots & \ldots & \ldots & 5 \\ & \ldots & \ldots & \ldots & \ldots & \ldots & \ldots & 270\end{array}$

$\begin{array}{llllllll}\text { Ivory } & \ldots & \ldots & \ldots & \ldots & \ldots & \ldots & 270 .\end{array}$

$\begin{array}{llllll}\text { Jacaranda Tree } \ldots & \ldots & \ldots & \ldots & \ldots & 197 .\end{array}$

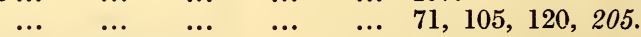

$\begin{array}{llllllll}\text { Jalasi } & \ldots & \ldots & \ldots & \ldots & \ldots & \ldots & \ldots \\ \end{array}$

James Stephenson, Steamer $\ldots . \quad \ldots \quad \ldots \quad$ 15, 247, 249. 


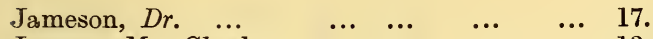

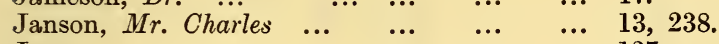

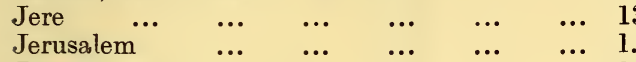

$\begin{array}{llllllll}\text { Jesuits } & \ldots & \ldots & \ldots & \ldots & \ldots & \ldots & 8,9 .\end{array}$

$\begin{array}{llllllll}\text { Jibdali } & \ldots & \ldots & \ldots & \ldots & \ldots & \ldots & 8, \\ & \ldots & \ldots & \ldots & \ldots & \ldots & 259 .\end{array}$

$\begin{array}{llllllll}\text { Jinja } & \ldots & \ldots & \ldots & \ldots & \ldots & \ldots & \ldots \\ & & \ldots & \ldots & \end{array}$

$\begin{array}{lllllll}\text { John Apiri } & \ldots & \ldots & \ldots & \ldots & \ldots & \ldots \\ & \ldots & \ldots & \ldots & \ldots & 82 .\end{array}$

John Chilembe ... $\quad \ldots . \quad \ldots \quad \ldots . \quad \ldots \quad 263$.

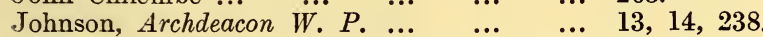

Johnston, Sir H. H.

Jubaland

Judge

Juepe Hills

... 15, 16, 17, 113, 136, 186, 209.

... 260 .

Jumbe

... 64

... 67.

... $15,17,20,21,34,136,137$.

K

\begin{tabular}{|c|c|c|c|c|c|c|}
\hline Kabambe... & $\cdots$ & $\cdots$ & $\cdots$ & $\cdots$ & $\cdots$ & 94. \\
\hline Kabuma ... & $\cdots$ & $\ldots$ & $\ldots$ & $\ldots$ & $\cdots$ & 33. \\
\hline Kabunduli & ... & $\cdots$ & $\cdots$ & $\cdots$ & ... & 145. \\
\hline Kachawa Hill & $\cdots$ & $\cdots$ & $\cdots$ & .. & $\cdots$ & 123. \\
\hline Kachebere Mis & ssion & $\cdots$ & $\cdots$ & $\cdots$ & $\cdots$ & $129,131,243$. \\
\hline Kacheche Dan & & $\cdots$ & $\cdots$ & ... & $\cdots$ & 130. \\
\hline $\begin{array}{l}\text { Kachindamoto } \\
\text { Kachulu }\end{array}$ & $\cdots$ & $\cdots$ & $\cdots$ & .. & $\cdots$ & 30,121 . \\
\hline $\begin{array}{l}\text { Kachulu ... } \\
\text { Kada }\end{array}$ & $\cdots$ & $\cdots$ & $\cdots$ & $\cdots$ & $\cdots$ & 46. \\
\hline $\begin{array}{l}\text { Kada } \quad \ldots \\
\text { Kadale }\end{array}$ & $\cdots$ & $\cdots$ & $\cdots$ & $\cdots$ & ... & 88. \\
\hline Kadale Tree & $\cdots$ & $\cdots$ & $\cdots$ & $\cdots$ & $\cdots$ & 123. \\
\hline $\begin{array}{l}\text { Kadango .... } \\
\text { Kadedwa Hill }\end{array}$ & $\cdots$ & $\cdots$ & $\cdots$ & ... & $\cdots$ & 111. \\
\hline Kadedwa Hill & $\cdots$ & $\cdots$ & $\cdots$ & ... & $\cdots$ & 123. \\
\hline Kadewere & $\cdots$ & $\cdots$ & $\cdots$ & $\cdots$ & .. & 97. \\
\hline Kaduyu ... & & $\cdots$ & $\cdots$ & .. & $\cdots$ & 34. \\
\hline Kafalantengo I & Hills & $\cdots$ & ... & ... & $\ldots$ & $65,66,68$. \\
\hline Kaffir Corn & ... & $\cdots$ & $\ldots$ & ... & $\ldots$ & $44,57,70,77$ \\
\hline $\begin{array}{l}\text { Kafuta Hill } \\
\text { Kahari Hill }\end{array}$ & $\cdots$ & $\cdots$ & ... & ... & $\cdots$ & $65,66,68$ \\
\hline Kahari Hill & ... & $\cdots$ & $\cdots$ & ... & $\ldots$ & 140. \\
\hline Kalaluma & ... & $\ldots$ & ... & ... & $\cdots$ & 142. \\
\hline Kalambo & $\cdots$ & $\cdots$ & ... & ... & $\cdots$ & 119. \\
\hline Kalaunda & $\cdots$ & $\cdots$ & $\cdots$ & $\cdots$ & ... & 133. \\
\hline Kalimakudzuru & u $\ldots$ & $\ldots$ & $\cdots$ & $\ldots$ & $\ldots$ & 30,33 . \\
\hline Kalindankoo & $\ldots$ & $\ldots$ & $\ldots$ & $\ldots$ & $\ldots$ & 38. \\
\hline Kalonyolera & $\cdots$ & $\ldots$ & ... & ... & $\ldots$ & 149. \\
\hline Kalumo ... & $\cdots$ & $\cdots$ & ... & $\cdots$ & $\ldots$ & 137. \\
\hline Kaluwa $\ldots$ & $\cdots$ & $\ldots$ & $\ldots$ & $\ldots$ & $\ldots$ & 107. \\
\hline Kambironja & $\cdots$ & $\ldots$ & $\ldots$ & $\ldots$ & $\ldots$ & 119. \\
\hline Kambuzi Fish & $\ldots$ & $\cdots$ & $\ldots$ & ... & $\ldots$ & 124. \\
\hline Kambwe ... & $\cdots$ & $\ldots$ & $\ldots$ & $\cdots$ & $\ldots$ & 153,154 . \\
\hline Kampambe Hi & ill... & $\ldots$ & $\ldots$ & $\cdots$ & $\cdots$ & 123. \\
\hline $\begin{array}{l}\text { Kampulusa } \\
\text { Kanda }\end{array}$ & $\cdots$ & $\cdots$ & $\cdots$ & $\cdots$ & $\cdots$ & 110. \\
\hline $\begin{array}{l}\text { Kanda } \ldots \\
\text { Kandi River }\end{array}$ & $\cdots$ & $\cdots$ & $\cdots$ & $\cdots$ & $\cdots$ & 99. \\
\hline $\begin{array}{l}\text { Kandi River } \\
\text { Kanduku Ama }\end{array}$ & $\ldots$ & $\cdots$ & $\cdots$ & $\cdots$ & $\cdots$ & 67. \\
\hline $\begin{array}{l}\text { Kanduku Ama } \\
\text { Kangoma... }\end{array}$ & seko & $\cdots$ & $\cdots$ & $\cdots$ & $\cdots$ & 82. \\
\hline $\begin{array}{l}\text { Kangoma.... } \\
\text { Kaniangere }\end{array}$ & $\cdots$ & $\cdots$ & $\cdots$ & .. & $\cdots$ & 78. \\
\hline $\begin{array}{l}\text { Kaniangere } \\
\text { Kaningina Mou }\end{array}$ & $\ldots$ & $\cdots$ & $\cdots$ & $\cdots$ & $\ldots$ & 33. \\
\hline $\begin{array}{l}\text { Kaningina Mol } \\
\text { Kankomba }\end{array}$ & untain & $\cdots$ & $\cdots$ & $\cdots$ & $\cdots$ & 142 . \\
\hline $\begin{array}{l}\text { Kankomba } \\
\text { Kanono .... }\end{array}$ & $\cdots$ & $\cdots$ & $\cdots$ & $\cdots$ & $\cdots$ & $\begin{array}{l}32 . \\
37\end{array}$ \\
\hline Kantunkule & $\cdots$ & $\begin{array}{l}\cdots \\
\ldots\end{array}$ & $\cdots$ & $\cdots$ & $\cdots$ & $\begin{array}{l}37 . \\
94 .\end{array}$ \\
\hline Kanyenda & ... & $\cdots$ & $\cdots$ & $\cdots$ & $\begin{array}{l}\cdots \\
\cdots\end{array}$ & 34,145 . \\
\hline Kaolin & $\ldots$ & $\ldots$ & $\ldots$ & $\ldots$ & & 7. \\
\hline Kaombe River & r... & $\ldots$ & $\ldots$ & $\ldots$ & $\ldots$ & 135. \\
\hline Kapene River & $\ldots$ & ... & $\ldots$ & $\ldots$ & $\cdots$ & 117. \\
\hline
\end{tabular}




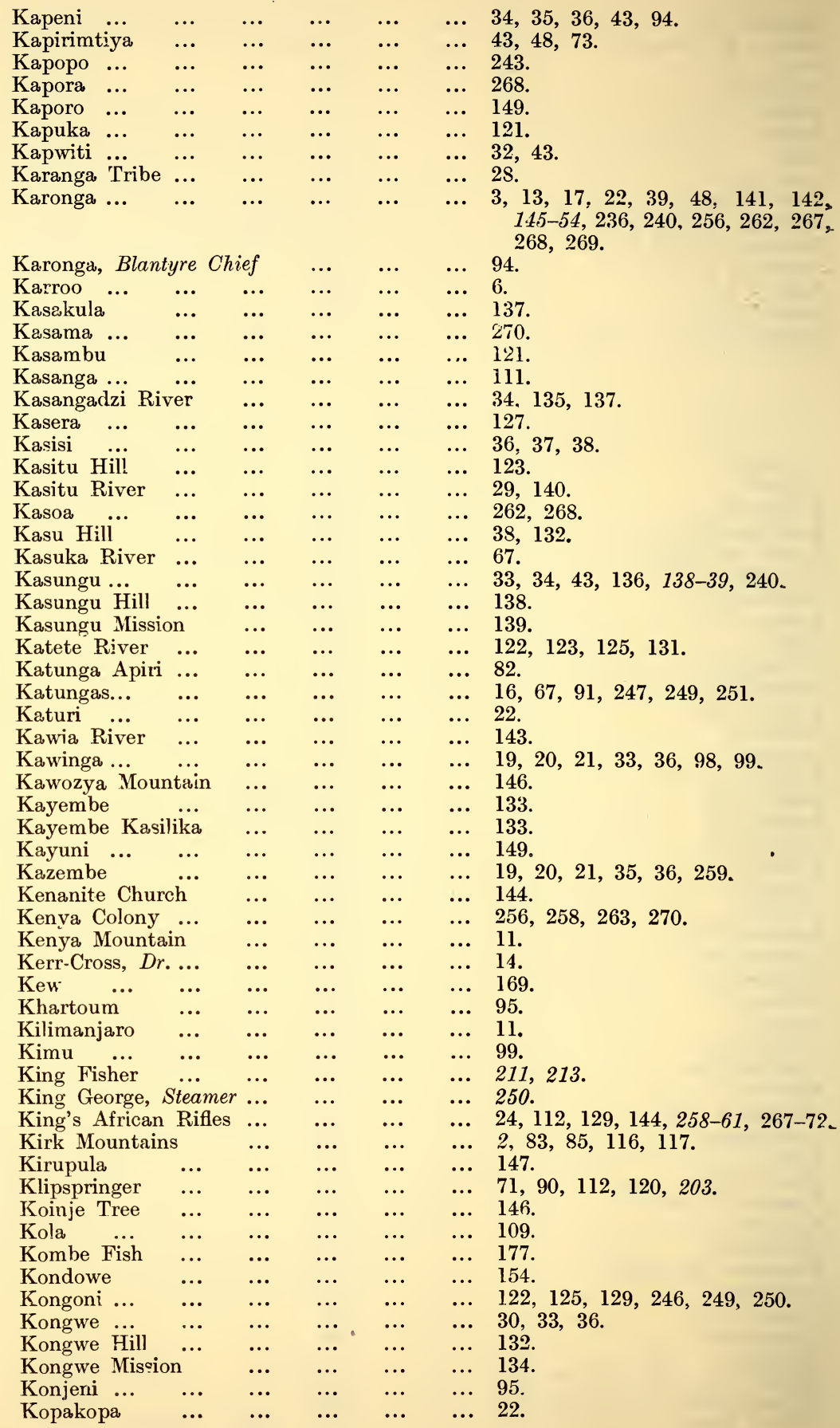


Kota-Kota

Kraut

Kubula Stores

Kudu

Kukambiritiya ...

Kuluundu

Kuluvi

Kumba $\cdots$..

Kumbemba

Kuminama

Kumisesa.

Kumpama

Kumtiramanji

Kumtumanji ...

Kundembwe

Kungwalu

Kupatikana

Kwandama Mountain ...

Kwataine..

Kwenda Kwina

Kweranyani Tree

Kwisimba

$3,7,15,17,21,22,29,33,34$, $38,48,116,128,129,131,133$, $134-37,138,139,142,164$, $236,238,242$.

$$
\begin{array}{lll}
\ldots & \ldots & 270 . \\
\ldots & \ldots & 126,141 . \\
\ldots & \ldots & 71,100,105,112,120,134,136, \\
& \multicolumn{2}{l}{149,200 .} \\
\ldots & \ldots & 73 . \\
\ldots & \ldots & 21,36,46 . \\
\ldots & \ldots & 73,74 . \\
\ldots & \ldots & 89 . \\
\ldots & \ldots & 133 . \\
\ldots & \ldots & 99 . \\
\ldots & \ldots & 35 . \\
\ldots & \ldots & 34,35,43,94 . \\
\ldots & \ldots & 22,34,35 . \\
\ldots & \ldots & 98,99 . \\
\ldots & \ldots & 94 . \\
\ldots & \ldots & 103 . \\
\ldots & \ldots & 74 . \\
\ldots & \ldots & 142 . \\
\ldots & \ldots & 117 . \\
\ldots & \ldots & 137 . \\
\ldots & \ldots & 189-97 . \\
\ldots & \ldots & 107,110 .
\end{array}
$$

Labour

Lacerda, $\dddot{D}$ r. Francisco

Lady Nyasa, Steamer ...

Lake Arambara

Lake Chad

Lake Chiuta $\cdots$

Lake Edward $\ldots$.

Lake Ireru

Lake Nyasa
Lake Pamalombe

Lake Shirwa

\section{Lake Tanganyika}

Lake Victoria Nyanza

\section{Lakes}

Lambulira

Land Claims

Land Leases and Sales

Land Tax

Lands and Mines

Languages

Laterite ...

Laws, Rev. Dr. $\dddot{R}$.

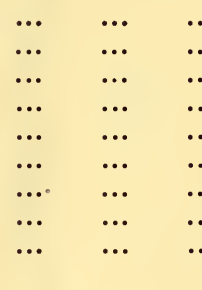

... 58, 155-67.

... 9,38 .

... 12, 246, 247, 249.

... 112.

... 41 .

$\ldots .1,2,3,31,101,112$.

... 41 .

... 9 .

... $1,2-3,4,6,8,9,10,11,12,13$. $14,15,16,17,19,20,22,23$, $25,28,29,30,35,36,39,42$, $43,45,48,75,106,108,11]$, $113,116,117,128,131,134$, $135,138,140,142,146,148$, $155,163,184,210,211,237$, $240,241,250,267,269,271$. ... 3, 4, 30, 102, 107, 108, 116, 211. ... $1,2,3,9,10,21,23,28,31,35$, $43,86,88,89,91,92,98,99$, $100,102,163,211,212$.

$9,11,13,15,17,29,148,149$, $256,269$.

$9,11,29,41$.

... $2-3$.

... 99 .

$\ldots \quad 24,153,186-88$.

... $58,59,64,95,134,153,186-88$.

... 183.

... 186-8S.

... $41,42,55,56,80,90,93,97,114$. $126,129,134$.

6 . 6 .

... 11, 13, 239 . 


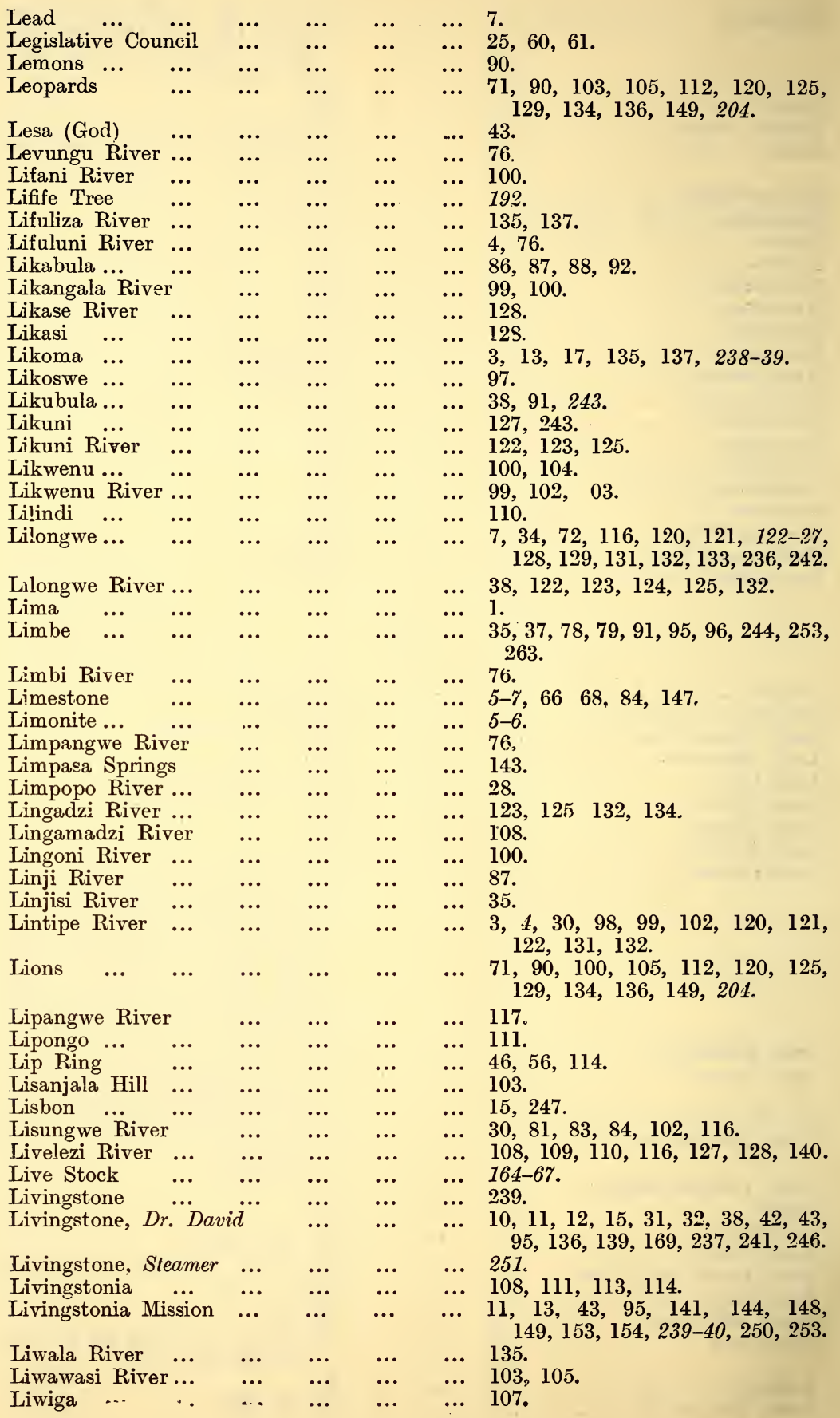


Liwonde ...

Liwonde, Chief ... Loangweni

Loans

Locusts ...

Lombadzi River

Lomwe Tribe ...

Loudon ... ...

Lourenco Marques

Lower Shire

Luabo

Luangwa River...

Luchenya Plateau

Luchenya River...

Luchenza

Luchenza River

Lufira River

Lugard, Sir $F$. ...

Lujenda River ...

Lukulezi ... ...

Lulwe ... ...

Lulwe Hills ...

Lundazi River ...

Lundu

Lungudzi River

Lunyangwa River

Lupachi River ...

Lupuchi River ...

Luweya River ...
$7,10,33,36,45,46,100,102-6$, 107, 111, 187, 209, 251.

20,33 .

... 23.

... 184-\$5.

... 124.

... 122, 125, 132, 133.

... 55,56 .

... $141,142,240$

... 247 .

... $4,7,10,28,31,32,34,36,42,43$, $65-74,84,163,165,187,242$. 246.

$\ldots 9,10,13,29,34,42,114,138$.

... 87 .

... 87,92 .

$\ldots \quad 25,90,95,250,256$.

... $91,96,97$.

... $146,148,268$.

... 14 .

... $2,3,9,35$.

... $86,88,89,90$.

... 242.

... $65,68,74$.

... 34,142 .

... 32,35 .

... 132, 133 .

... 29,140 .

... 140 .

... 107.

... $142,143$.
Mabuka

Machemba Hill ...

Machesa Hill

Machewere (Millet)

Machinga, see Yaos.

Machinjera

Machinjiri Hill ...

Mackenzie, Bishop

Madziabango

Maendaenda

Mafingi Hill

Maganga...

Magnetite

Magoma River ...

Magomero

Maguire, Capt. $\dddot{C}$. M.

Magwangwara Tribe

Mahogany

Maize

Makakwe

Makandanji

Makanga Tribe ...

Makanjira

Makololo Tribe ...
M

... 88 .

... 89 .

... 86,90 .

... $70,89,90,118,124,128$.

... 94 .

... 86.

... 10, 13, 237, 238.

... 100.

... 238.

... 6

... 131, 132, 133, 134.

... 5 .

... 68 .

... 43, 95, 97, 237, 263, 269.

... 17, 18, 19, 21, 112 .

... $29,33,36$.

... 66,68 .

.. $44,57,70,77,84,89,90,92,94$, $96,99,100,104,109,110,118$, $124,128,133,135,141,143$, $150,162-63$.

... 32 .

... 18.

... 82,85 .

... $\quad 14,19,20,21,22,35,36,45,110$, $112,133,139$.

... $12,16,31,32,36,38,82,106$. 


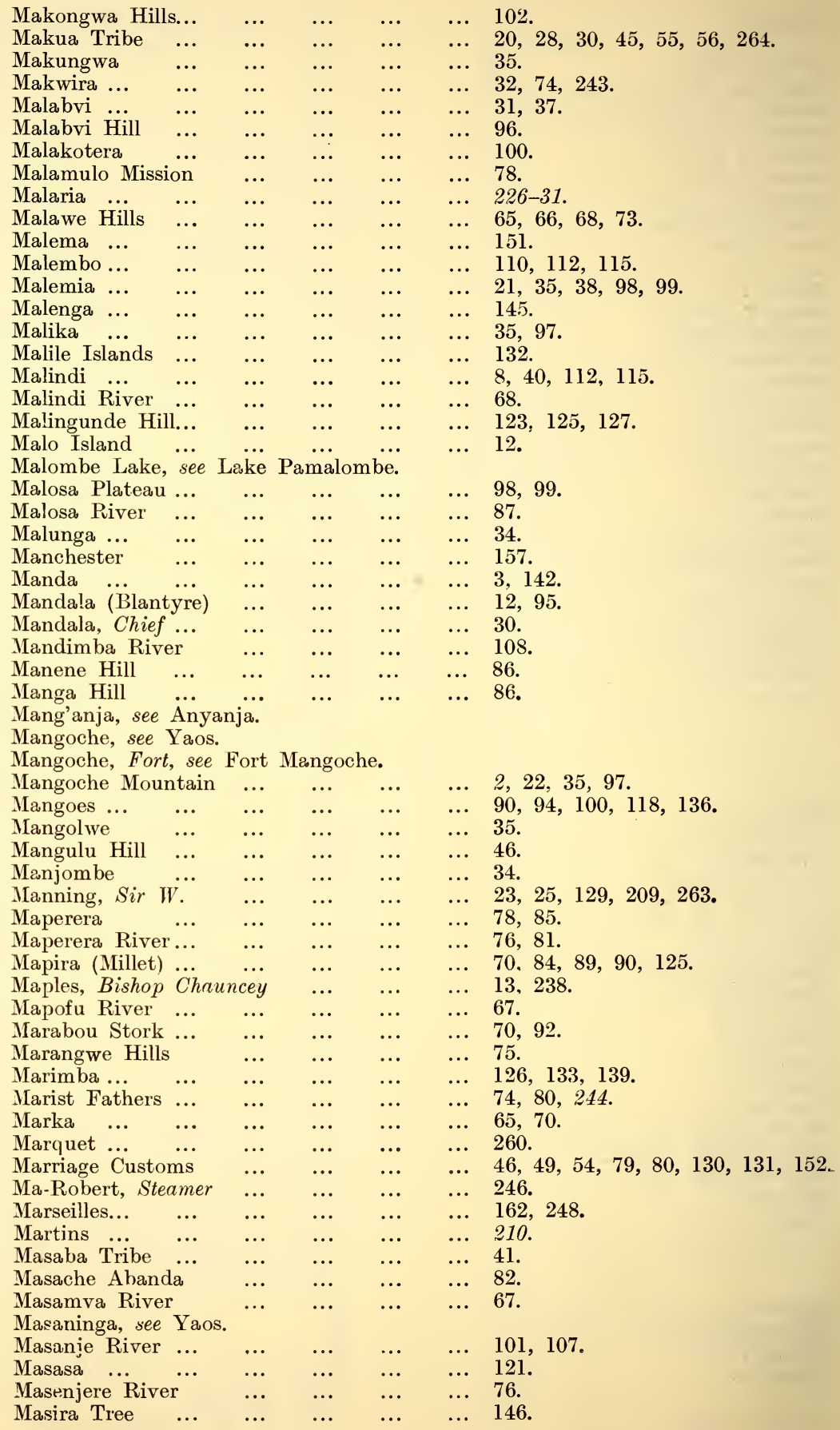


Masitu Tribe

Massoko ...

Masuku Range ..

Masula

Masumba

Mataka

Matanda...

Matekenya

Matemba Fish ..

Matengo Tribe .

Matenje ... ..

Matevu ...

Matipwiri..

Matola

Matope

Matope Hill

Matope River
Matunda Hills

Matuwi

Yaurau

Iauritius

Mauritius Hemp

Mausu

Yauwa

Nauze Hill

Mavitu Tribe

Mawere (Millet)

Mazengera

Mazongoza Forest

Mbabzi

Mbalame

Mba!ekelwa

Mbamba Bay ...

Mbanga ...

Mbango ...

Mbawa Tree

Mbela

Mbendera

Mbengo Plain .

Mberengwa

Mbeta

Mbila Tree

Mbona

Mbonduni Mountain

Mbukwa

Mbungwe Hill

Mbwadzulo

Mbwana....

IcDonald, $\boldsymbol{M} r . \ddot{H}$. . C. ...

Mchenzi River ... ...

Ichesi Rocks ...

Ichinii Hill

Mchinji Mission

Mclıisi Island

Mdoka

Ieasle

Mechanical Transport ...

Medical

Medo

Meheran

Ielon
43.

261.

209.

124,125 .

124.

238,259 。

124.

31,72 。

128.

30 .

34,94 .

142.

... $21,22,34,35,88$

... 110,111 .

$\ldots \quad 10,35,36,81,93,94,95,102$, $113,119,251$.

$$
66 .
$$

... 67.

... 75

... 106.

... 29.

... 259 .

... 161 .

... 106.

... 55 .

... 89 .

... 29,43 .

... $70,89,90,118,124,128$

... 124 .

... 77.

... 127.

... 32 .

... 30 .

... 3 .

... 85 .

... 74 .

... $83,144,146,189-9 \%$.

... 99 .

... 94 .

... 76 .

... 117.

... 99.

... 66 .

... 32, 73, 74 .

... 100 .

... 74 .

... 66,68 .

... 111.

... 145 .

... 89 .

... 126.

... 125 .

... 123 .

... $33,127,129,131$.

... $129,131$.

... 98 .

... 149 .

... 233 .

... 25, 251 .

... 226-236.

... 56 .

... 260 .

... 70 . 
Meteorology

Mica

Michiru Mountain Midima Hills ..

$\begin{array}{lllllll}\text { Mikalongwe } & \ldots & \ldots & \ldots & \ldots & \ldots & 92,96,97 .\end{array}$

$\begin{array}{lllllll}\text { Mikindani } & \ldots & \ldots & \ldots & \ldots & \ldots & 211,263 .\end{array}$

$\begin{array}{lllllll}\text { Mikoko River } & \cdots & \ldots & \ldots & \ldots & \ldots & 9,11\end{array}$

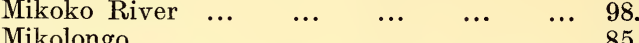

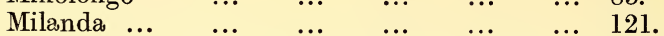

Military Forces, see Native Troops, King' $\ldots$ African Rifles, Nyasaland Volunteer Reserve.

Millet

Mineral Rights ...

Minerals ... ...

$\begin{array}{lll}\text { Mining } & \ldots & \ldots \\ \text { Misangu Thorn } & \ldots\end{array}$

Misenga Hill

Missionaries

Misuku Hills

Mitete Thorn

Mitsidi

Mkal

Mkanda ...

Mkongomwa Tree

Mkuche

Mkukula $\cdots$

Mkumbila

Mkuzo

Mlaka Hill

Mlali

Mlamba Fish

Mlambuzi

Mlanga Hill

Mlangeni ...

Mlanje

Mlanje Cedar

Mlanje Mountain

Mlanje Thrush ...

Mlauri

Mlawi Hill $\quad \cdots$

Mlima $\quad . . \quad \ldots$

$\begin{array}{lll}\text { Mlolo } & \ldots & \ldots \\ \text { Mlombwa } & \text { Tree }\end{array}$

Mlonyeni

Mlowe

Mlozi

Mluma Hill

Mlumbe ... ..

Mlungusi River ...

Mocambique

Mohamadi

Moir, Mr. F. $\ddot{M}$.
$127,128,135,138,140,144$, $147,226-27$.

$5,77,147$.$$
5 .
$$

.. $57,70,77,84,89,90,92,94,96$, $100,109,110,118,124,128$, 133. $135,141,150$.

. $7,24,59,147,186-88$.

... 4-7.

$\ldots 58,64,186-88$.

... 123.

... 98 .

... $15,24,72,80,106,115,121,127$, $131,134,136,141,144,154$, $23 \%-45$.

... 146, 147, 150 .

... 123 .

... 91 .

... 97.

... 128.

... 191 .

... 66.

... 133 .

... 98, 99, 145.

... 65,67 .

... 149 .

... 77, 124, 128.

... 94 .

... $33,119,121$.

... $10,18,20,21,22,28,31,35,36$, $37,38,43,44,45,55,74,76$, $86-91,96,97,100,159,186$, $187,209,211,236,241,256$ 263. 264 .

.. $88,189-97$.

... $2,4,6$.

... 88,209 .

... 16,36 .

... $66,71,73$.

... 133 .

... 74,78 .

... 123, 144, 146, 191.

... 128 .

... 145 .

$\ldots 13,14,17,22,39,150,154$.

... 116 .

.. $35,98,99$.

... $1,8,9,11,13,15,16,17,30$, 248,264 .

88.

... 12,14 .
... 142 .

... 65,66 .

... 38 . 
Moir, Mr. J.

Mombasa

Mombe River ...

Mombera

Momberas District

Mombo Tree

Monclaro

Mongoose..

Mongorwe Hills

Monkey ... ...

Monkey Bay

Mopea ...

Morogoro

Morumbala Mountain

Moses

Mosquito, $\ddot{H} . M . \dot{S}$

Mosquitoes

Mossamedes

Motor Traffic

Mountains

Mpalale ..

Mpalapala Hill .

Mpale

Mpama ... ...

Mpambe (God) ...

Mpanda Mountain

Mpando

Mpapa Tree

Mpata

Mpemba .

Mpende Fish

Mperembe

Mpezeni

Mpezo

Mphuta Fish

Mpilisi

Mpimbi

Mpindimbi Tree

Mpinganjila

Mpira River

Mpofu Hill

Mponda

Mponera ...

Mposa

Mpunzi Mission

Mpunzi Mountain

Mputa

Mpwiri River

Tsakamberva

Msakambewa

Msalemu ...

Msali

Msamara

...

Msemela

Mseula Beans

Msewa Tree

Msipa Fish

Msopa Tree

Msuku Tree

Msumpi ..

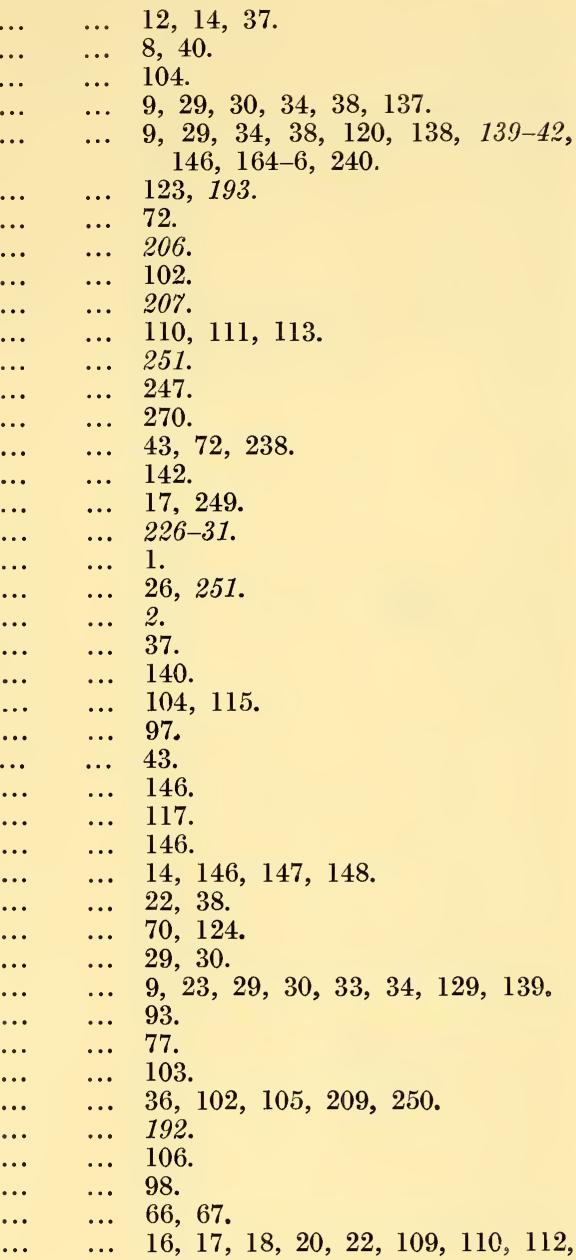

113, 114, 243.

.. 133.

... 99.

... 121.

... 120 .

... 30,33 .

... 98 .

... 33, 133 .

... 22 .

... 103.

... 19 .

... 123.

... 106.

... 89.

... 192 .

... 150 .

... 191.

... 192 .

... 73 . 


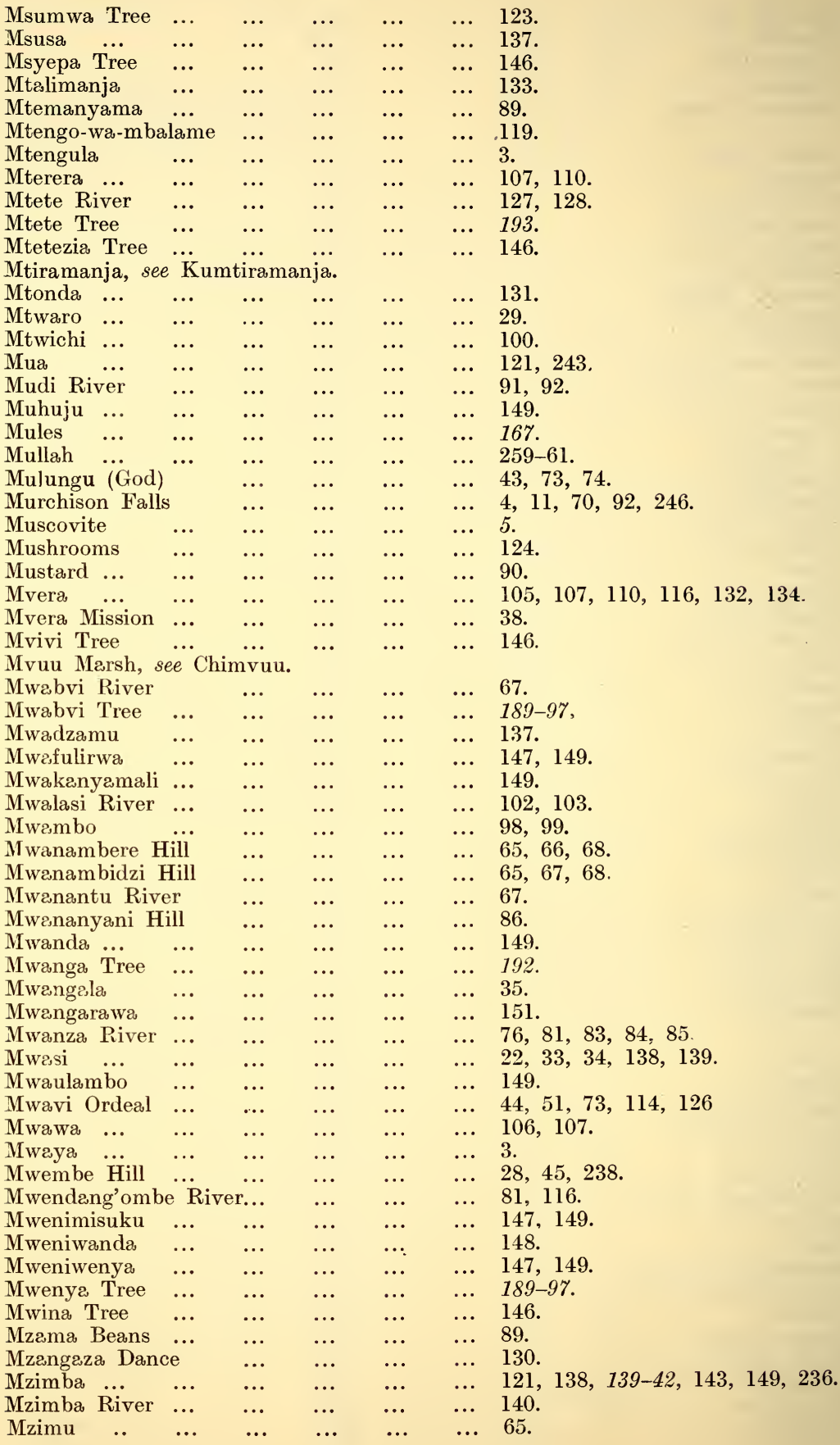


$\begin{array}{lllllll}\text { Naartjes } \ldots & \ldots & \ldots & \ldots & \ldots & \ldots & 91 .\end{array}$

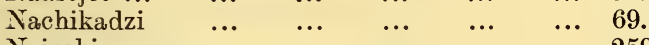

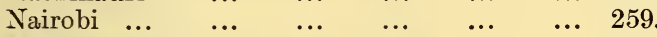

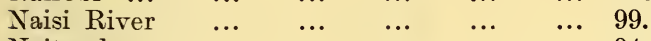

$\begin{array}{lllllll}\text { Naitanda } & \ldots & \ldots & \ldots & \ldots & \ldots & 94 .\end{array}$

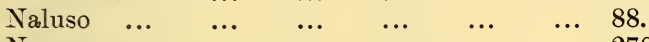

$\begin{array}{lllllll}\text { Namacurra } & \ldots & \ldots & \ldots & \ldots & \ldots & 270 .\end{array}$

$\begin{array}{llllllll}\text { Namadzi } . . . & \ldots & \ldots & \ldots & \ldots & \ldots & \ldots & \\ & & \ldots & \ldots & 100 .\end{array}$

$\begin{array}{lllllll}\text { Namadzi River } \ldots & \ldots & \ldots & \ldots & \ldots & \ldots & 86,91,92,96,98 .\end{array}$

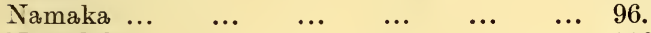

$\begin{array}{lllllll}\text { Namalaka } & \ldots & \ldots & \ldots & \ldots & \ldots & 110 .\end{array}$

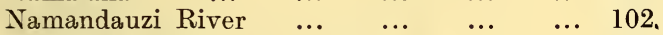

$\begin{array}{llllll}\text { Namanjasi River } & \ldots & \ldots & \ldots & \ldots & 76 .\end{array}$

$\begin{array}{llllll}\text { Namatope River } & \ldots & \ldots & \ldots & \ldots & 32\end{array}$

$\begin{array}{llllll}\text { Nambadzi River } & \ldots & \ldots & \ldots & \ldots & 98,99\end{array}$

$\begin{array}{llllll}\text { Nambere River ... } & \ldots & \ldots & \ldots & \ldots & 103 .\end{array}$

$\begin{array}{llllllll}\text { Nambuma River } & \ldots & \ldots & \ldots & \ldots & 122 & 125,133 .\end{array}$

$\begin{array}{lllllll}\text { Namikungulu } & \ldots & \ldots & \ldots & \ldots & \ldots & 76 .\end{array}$

$\begin{array}{llllll}\text { Naminga River } \ldots & \ldots & \ldots & \ldots & \ldots & 98 .\end{array}$

$\begin{array}{lllllll}\text { Namitawa } & \ldots & \ldots & \ldots & \ldots & \ldots & 6 .\end{array}$

$\begin{array}{lllllll}\text { Namitembo } & \ldots & \ldots & \ldots & \ldots & \ldots & 100 .\end{array}$

Namitembo River $\quad \ldots \quad \ldots \quad \ldots \quad \ldots \quad \ldots .99$.

$\begin{array}{llllll}\text { Namitete River... } & \ldots & \ldots & \ldots & \ldots & 122,124 .\end{array}$

$\begin{array}{lllllll}\text { Namiwawa } & \ldots & \ldots & \ldots & \ldots & \ldots & 100 .\end{array}$

$\begin{array}{llllll}\text { Namiwawa River } & \ldots & \ldots & \ldots & \ldots & 99 .\end{array}$

$\begin{array}{lllllll}\text { Namlangeni } & \ldots & \ldots & \ldots & \ldots & \ldots & 30 .\end{array}$

$\begin{array}{lllllll}\text { Namonde } & \ldots & \ldots & \ldots & \ldots & \ldots & 99 .\end{array}$

$\begin{array}{lllllll}\text { Nampuli } . . . & \ldots & \ldots & \ldots & \ldots & \ldots & 103 .\end{array}$

$\begin{array}{lllllll}\text { Namwera } & \ldots & \ldots & \ldots & \ldots & \ldots & 107,109,110,111,115 .\end{array}$

$\begin{array}{lllllll}\text { Nanchengwa } & \ldots & \ldots & \ldots & \ldots & \ldots & 212 .\end{array}$

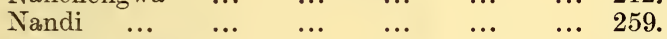

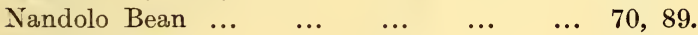

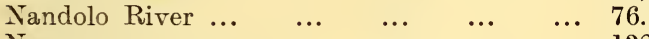

$\begin{array}{llllllll}\text { Nangoa } & \ldots & \ldots & \ldots & \ldots & \ldots & \ldots & 132 .\end{array}$

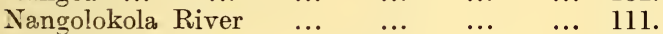

$\begin{array}{lllllll}\text { Nanjiri River } & \ldots & \ldots & \ldots & \ldots & \ldots & 124 .\end{array}$

$\begin{array}{lllllll}\text { Nankumba } & \ldots & \ldots & \ldots & \ldots & \ldots & 110 .\end{array}$

$\begin{array}{lllllll}\text { Nankunda } & \ldots & \ldots & \ldots & \ldots & \ldots & 244 .\end{array}$

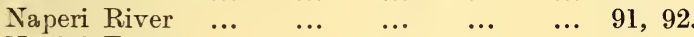

$\begin{array}{lllllll}\text { Napini Tree } & \ldots & \ldots & \ldots & \ldots & \ldots & 192 .\end{array}$

$\begin{array}{llllllll}\text { Naples } & \ldots & \ldots & \ldots & \ldots & \ldots & \ldots & 247 .\end{array}$

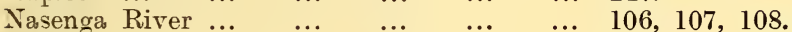

$\begin{array}{llllllll}\text { Natal } & \ldots & \ldots & \ldots & \ldots & \ldots & \ldots & 106,1 \\ & \ldots & \ldots & \ldots & 28 .\end{array}$

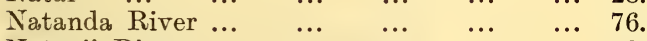

$\begin{array}{lllllll}\text { Natenji River } & \ldots & \ldots & \ldots & \ldots & \ldots & 124 .\end{array}$

National Bank of South Africa $\quad \ldots \quad \ldots \quad$... 185.

Native Affairs, see District Administration.

$\begin{array}{lllllll}\text { Native Troops } & \ldots & \ldots & \ldots & \ldots & \ldots & 20,21,22,24 .\end{array}$

$\begin{array}{llllll}\text { Nativity Customs } & \ldots & \ldots & \ldots & \ldots & 56,152 .\end{array}$

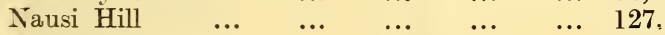

$\begin{array}{lllllll}\text { Nazombe } & \ldots & \ldots & \ldots & \ldots & \ldots & 76 .\end{array}$

$\begin{array}{lllllll}\text { Nchenga Tree } & \ldots & \ldots & \ldots & \ldots & \ldots & 193 .\end{array}$

$\begin{array}{lllllll}\text { Ncheni Fish } & \ldots & \ldots & \ldots & \ldots & \ldots & 77 .\end{array}$

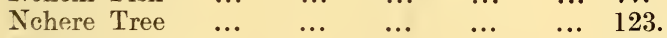

Ncheu

Nchisi Hill

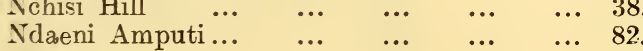

Ndamera 


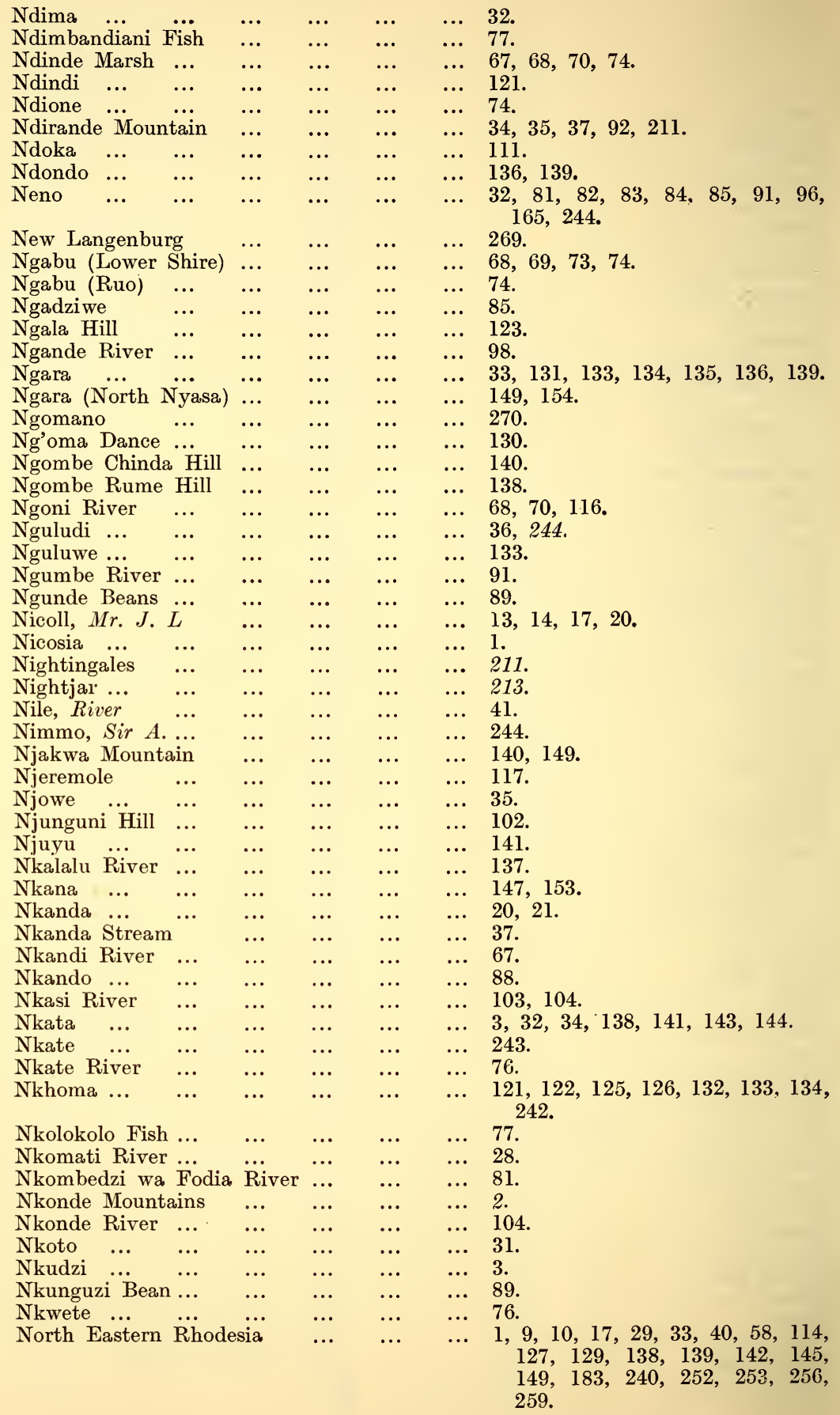


Northern Province

Northey, General E.

North Nyasa

North Western Rhodesia

Nose Button

Nsampa Hills

Nsangusangu Tree

Nsindo Dance ...

Nsuka River

Nswadzi River...

Nswala

Ntabeni

Ntache Angondo

Ntakataka

Ntalire

Ntangatanga Tree

Ntenje

Ntoko ... ...

Ntonda ... ...

Ntondo $\ldots . .$.

Ntondo Tree ...

Ntondwe River ...

Ntonia Hills ...

Ntundu River ...

Ntutu

Nyachipere River

Nyachirenda River

Nyakamwa River

Nyakatola River

Nyala

Nyamatute River

Nyamazere River

Nyambadwe Hill

Nyambi

Nyambidzi River

Nyamkhowa Mountain

Nyamuka

Nyamyala River

Nyanda Fish

Nyantoko Hill ...

Nyap๘mbere

Nyapyulo Hills ...

Nyasa Industrial Baptist Mission

Nyasa Lake, see Lake Nyasa.

Nyasaland Field Force

Nyasaland O. in C., 1907, 19012

Nyasaland Volunteer Reserve

Nyaserera

Nyatando

Nyemba Beans

Nyenyezi River

Nyika Plateau

Nyimbo

Nyiza

Nyondo

Nyungwe

Nyungwe Tribe...

Nzama

Nzongwe $\dddot{\text { Fibre ... }}$
138-54.

$268,269,270,271$

$6,7,13,14,16,17,20,22.39$, $42,138,139,142,144,145-54$, 163, 164-66, 209, 253, 256.

243.

$\ldots \quad 46,56,114$.

... 68 .

... 193.

... 130 .

... 98 .

... 75, 76, 78, 91, 92, 94 .

... $71,105,112,125$.

... 29 .

... 82 .

... $121,243,256$.

... 147,149 .

... 94 .

... 192 .

... 94 .

... 72 .

... 65 .

... 67,70 .

... 193 .

... $32,35,99$.

... 99 .

... 68 .

... 29 .

... 66,68 .

... 66,68 .

... 68 .

... 68 .

... 149 .

... 65,67 .

... 68,70 .

... 92 .

... 99, 110.

... 68 .

... 146 .

... 36,37 .

... 67 .

... 77 .

... 66 .

... 78 .

... 103.

... $80,243$.

... 267-72.

... $25,59,60$.

… 262-63, 267-72.

.. $20,21,89$.

... $69,70,71$.

... 128 .

... 98, 107.

... 2, 140, 146, 147, 149, 165, 209. 211,

... 149 .

... 119.

... 147.

... 149 .

... 42 .

... 244 .

... $161,193$. 
O

\begin{tabular}{|c|c|c|c|c|c|c|}
\hline Oak Trees & $\cdots$ & $\cdots$ & & $\cdots$ & ... & $196-9 \%$ \\
\hline Odete & $\ldots$ & $\ldots$ & $\ldots$ & $\ldots$ & $\ldots$ & 22,23 . \\
\hline Oil & $\ldots$ & $\ldots$ & $\ldots$ & $\ldots$ & $\ldots$ & $84,188$. \\
\hline Oil Seeds & $\ldots$ & $\cdots$ & $\ldots$ & $\ldots$ & $\ldots$ & 44. \\
\hline Old Residency & $\cdots$ & $\ldots$ & $\ldots$ & $\ldots$ & $\ldots$ & 101. \\
\hline O'Neill, Consul & $\ldots$ & $\ldots$ & $\ldots$ & $\ldots$ & $\ldots$ & 13. \\
\hline Onions $\quad \ldots$ & $\ldots$ & $\ldots$ & $\ldots$ & $\ldots$ & $\ldots$ & 109. \\
\hline Oranges $\ldots$ & $\ldots$ & $\ldots$ & $\ldots$ & $\ldots$ & $\ldots$ & 90. \\
\hline Orders in Coun & & $\ldots$ & $\ldots$ & $\ldots$ & $\ldots$ & $58-63$. \\
\hline Oribi & $\ldots$ & $\ldots$ & $\cdots$ & $\cdots$ & $\cdots$ & $90,100,120,125,134,202$. \\
\hline Orioles $\quad \ldots$ & $\ldots$ & $\ldots$ & $\ldots$ & $\ldots$ & $\ldots$ & $209-13$. \\
\hline Osprey $\quad \ldots$ & ... & ... & $\cdots$ & $\cdots$ & $\cdots$ & 211. \\
\hline Otter & $\cdots:$ & $\cdots$ & $\cdots$ & $\cdots$ & $\cdots$ & 205. \\
\hline Overtoun Insti & tution & $\cdots$ & $\cdots$ & $\cdots$ & $\ldots$ & 154,240 . \\
\hline Oxen & $\ldots$ & $\ldots$ & $\ldots$ & $\ldots$ & $\ldots$ & $40,164-6 \%$ \\
\hline
\end{tabular}

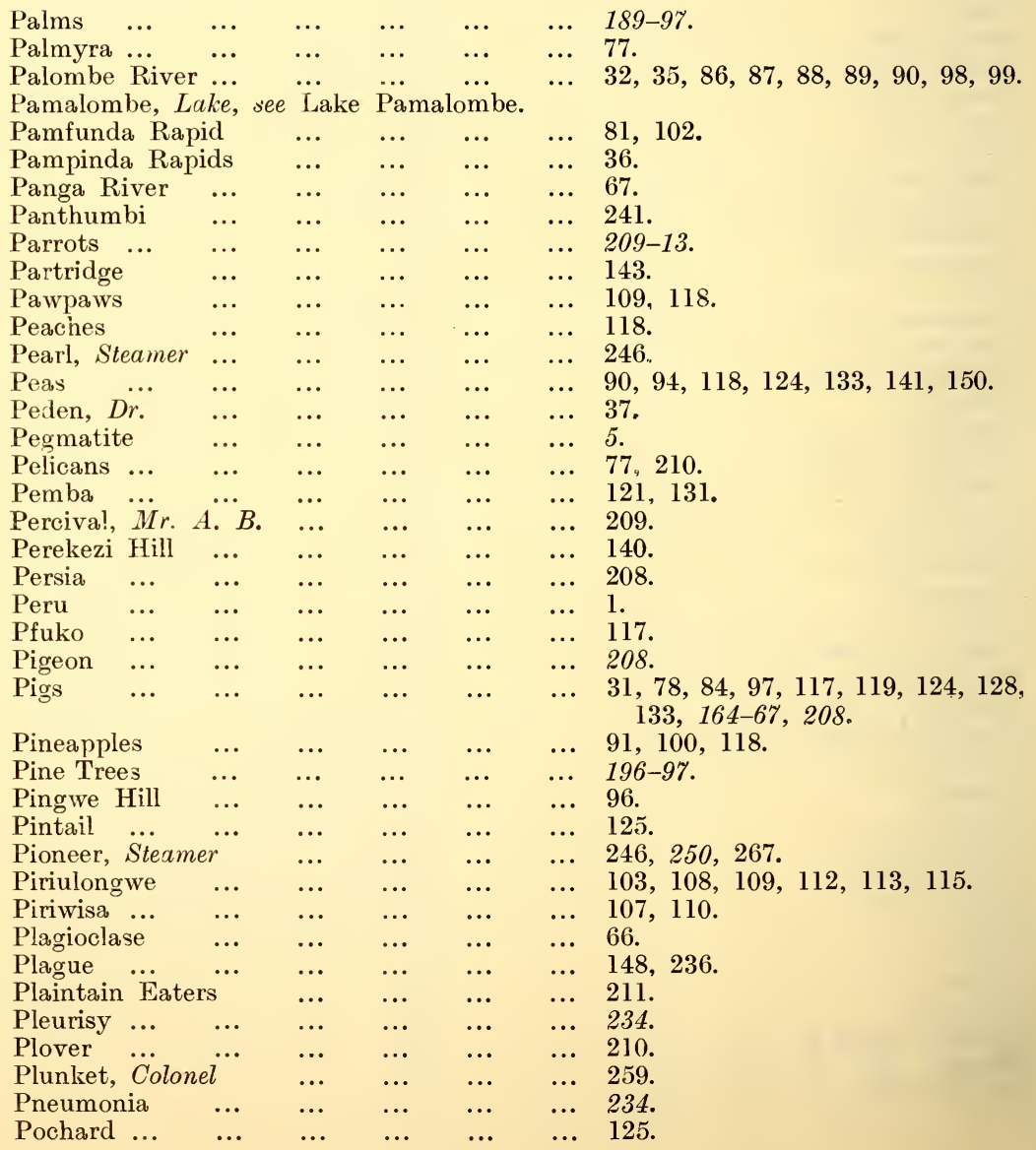


$\begin{array}{llllllll}\text { Pokera } & \ldots & \ldots & \ldots & \ldots & \ldots & \ldots & 76 .\end{array}$

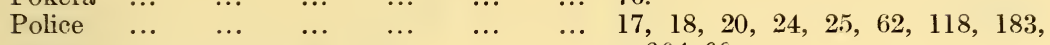

$\begin{array}{lllllll}\text { Pondomali } & \ldots & \ldots & \ldots & \ldots & \ldots & 94 .\end{array}$

Population, Asiatic $\quad \ldots \quad \ldots \quad \ldots \quad \ldots \quad 25,73,80,95,97,102,106,120$, $127,144,153$

Population, European ... $\quad \ldots \quad \ldots \quad \ldots \quad 25,71,73,80,85,95,97,102$,

Population, Native $\quad \ldots \quad \ldots \quad \ldots \quad \ldots \quad 40,69,73,80,82,85,86,95,97$, $102,106,126,130,131,141$, $144,147$.

Port Herald

$4,25,36,65,67,68,69,70,71$, $72,74,75,212,236,242,244$, $249,250,263$.

$\begin{array}{lllllll}\text { Portugal } \ldots & \ldots & \ldots & \ldots & \ldots & \ldots & 1,16\end{array}$

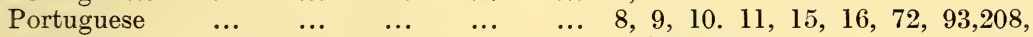

Portuguese East Africa 247,248 .

$\ldots \quad 1,20,22,27,28,30,37,45,51$, $55,65,71,73,74,80,86,89$, $97,100,108,111,112,117$, $119,120,121,126,239,253$, $256,270,271$.

Post Office $\quad \ldots \quad \ldots \quad \ldots \quad \ldots \quad \ldots \quad 24,64,142,248,253-55$.

Potatoes ... $\quad \ldots \quad \ldots \quad \ldots \quad \ldots \quad \ldots \quad \ldots \quad 84,90,94,100,109,135,143$, 150.

$\begin{array}{llllllll}\text { Prisons } & \ldots & \ldots & \ldots & \ldots & \ldots & \ldots & 264-66 .\end{array}$

$\begin{array}{lllllll}\text { Privv Council } & \ldots & \ldots & \ldots & \ldots & \ldots & 268 \\ \text { Pubic Seal } & \ldots & \ldots & \ldots & \ldots & \ldots & 63 .\end{array}$

$\begin{array}{lllllll}\text { Public Seal } & \ldots & \ldots & \ldots & \ldots & \ldots & 60 .\end{array}$

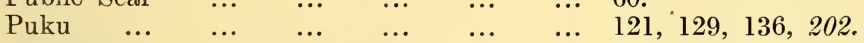

$\begin{array}{lllllll}\text { Pumpkins } & \ldots & \ldots & \ldots & \ldots & \ldots & 121,129,130,202 . \\ & & \ldots & \ldots & \ldots & \ldots & 70,77,89,90,118,124 .\end{array}$

$\begin{array}{lllllll}\text { Pwazi River } & \ldots & \ldots & \ldots & \ldots & \ldots & 70, \\ & & & \ldots & \ldots & \ldots & 140 .\end{array}$

\section{Quail}

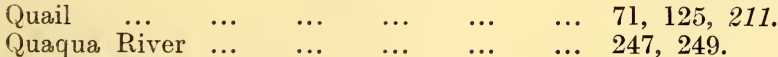

$\begin{array}{lllllll} & & & & & & \\ \text { qua River } & \ldots & \ldots & \ldots & \ldots & \ldots & 247,249 .\end{array}$

$\begin{array}{llllllll}\text { Quartz } & \ldots & \ldots & \ldots & \ldots & \ldots & \ldots & 5,66 .\end{array}$

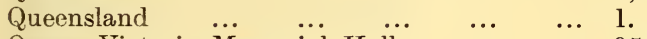

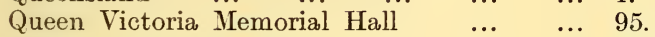

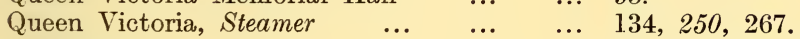

Quelimane

… $10,31,35,55$,

$0,31,35,55,241,247,248,249$,

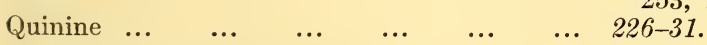

\section{$\mathrm{R}$}

\begin{tabular}{|c|c|c|c|c|c|}
\hline Prafia Palm & $\cdots$ & $\cdots$ & $\cdots$ & $\ldots$ & $68,189-9 \%$ \\
\hline Railways & $\ldots$ & $\ldots$ & $\ldots$ & $\ldots$ & $249-50$ \\
\hline Ramakukane & $\cdots$ & 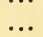 & $\ldots$ & $\ldots$ & 12 . \\
\hline Pamie Fibre & $\ldots$ & $\ldots$ & $\ldots$ & $\ldots$ & 161. \\
\hline Rankin, Mr. D.... & ... & $\ldots$ & $\ldots$ & $\ldots$ & 12,15 \\
\hline Rat $\quad \ldots \quad \ldots$ & $\ldots$ & ... & $\ldots$ & $\ldots$ & 207. \\
\hline Raven $\quad \ldots \quad \ldots$ & $\ldots$ & $\ldots$ & $\ldots$ & $\ldots$ & 213. \\
\hline Ray, Mr. G. C. L. & $\ldots$ & $\ldots$ & $\ldots$ & $\ldots$ & 90. \\
\hline Redbreast, H.M.S. & $\ldots$ & $\ldots$ & $\ldots$ & $\ldots$ & 249 \\
\hline Red Sea... & ... & .. & ... & $\ldots$ & 40. \\
\hline Reedbuck & ... & ... & $\ldots$ & $\ldots$ & $\begin{array}{l}71,100,105,120,125,134,136 \text {, } \\
143,149,202\end{array}$ \\
\hline
\end{tabular}


$\begin{array}{llllllll}\text { Regone } & \ldots & \ldots & \ldots & \ldots & \ldots & \ldots & 270 .\end{array}$

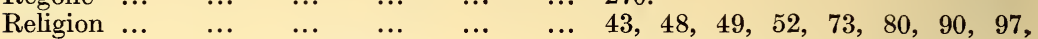
$102,106,114,126,130,141$, $144,237-45$.

Rendall, $\operatorname{Dr} P$.

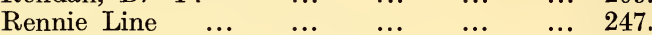

Resthouses $\quad \ldots \quad \ldots \quad \ldots \quad \ldots \quad \ldots \quad 85,104,111,126,252$.

$\begin{array}{lllllll}\text { Rheumatism } & \ldots & \ldots & \ldots & \ldots & \ldots & 234 .\end{array}$

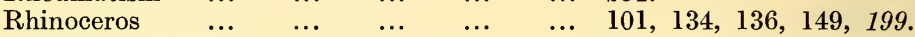

Rhoades, Com. $\dddot{E}$. L. L. ... $\quad \ldots . \quad \ldots . \quad \ldots \quad 267$.

Rhodes, Mr. Cecil $\quad \ldots \quad \ldots \quad \ldots \quad \ldots \quad \ldots \quad 11,15,153$.

Rhodes, Mr. H. $\quad \ldots . \quad \ldots \quad \ldots . \quad \ldots \quad 11,12$.

Rice

$\begin{array}{lllllll}\text { Rifu } \quad \ldots & \ldots & \ldots & \ldots & \ldots & \ldots & 21,35,112,132 . \\ \text { Rinderpest } & \ldots & \ldots & \ldots & \ldots & \ldots & 141,149,164-67 .\end{array}$

Ringworms $\quad \ldots \quad \ldots \quad \ldots \quad \ldots \quad \ldots .234$.

$\begin{array}{llllll}\text { Rivi-Rivi River } & \ldots & \ldots & \ldots & \ldots & 103,116 .\end{array}$

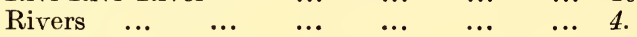

Roads $\quad \ldots \quad \ldots \quad \ldots \quad \ldots \quad \ldots \quad \ldots \quad 24.70,71,78,79,84,85,90$, $95-6,100,104,110,119,121$, $124-5,128-9,133,135,138$, $141,143,148,252-53$.

Roan Antelope ... $125,129,134,136,139,143,149$, 200.

$\begin{array}{lllllll}\text { Rock Bunting } & \ldots & \ldots & \ldots & \ldots & \ldots & 212 .\end{array}$

$\begin{array}{lllllll}\text { Rollers } \quad \ldots & \ldots & \ldots & \ldots & \ldots & \ldots & 211 .\end{array}$

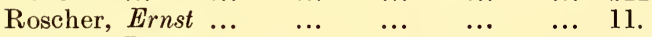

Rovuma River ... $\quad \ldots \quad \ldots . \quad \ldots \quad \ldots \quad$ 9, 270, 271.

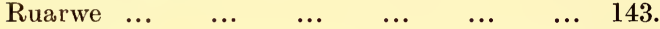

$\begin{array}{lllllll}\text { Rufiji River } & \ldots & \ldots & \ldots & \ldots & \ldots & \\ \end{array}$

Rukuru River

Rumpi River ...

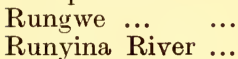

Ruo District ...

Ruo River

Rusa River

$\ldots \quad 3,4,29,34,140,141,142,145$, $146,147,149,151$.

... 146

... 164 .

... $140,146$.

... 31, 32, 34, 68, 71, 74-80, 165, 187.

... $1,2,4,15,16,70,74,76,77,79$, $86,87,88,90,91,92,238,249$.

Sable

Sachi Hill

Safwa Tribe

Sahara

Saidi Mwazungu

Salimo

Salisbury $\cdots \quad \cdots$

Samisanje

Sand Grouse

Sangadzi ...

Sangazi River

Sani Hill

Sanjika Fish

Sankulani

Sanseviera Fibre

Sante

$90,100,105,120,121,125.12 !$ $134,136,143,149,200$.

... 132 .

... 141 .

... 208 .

... 19, 22, 111, 139 .

... 149 .

... $155,253$.

... 73 .

... 210 .

... 85 .

... 106, 108, 111.

... 136 .

... 124 .

... 78,109 .

... 161, 192 .

... 129 . 
Sanya Tree

Sawawa ...

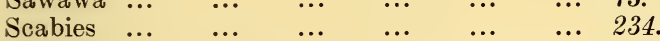

Schists $\quad \ldots \quad \ldots \quad \ldots \quad \ldots \quad \ldots \quad \ldots \quad \ldots \quad 4-5,77,147$.

Sclater, Lieut. B. L. $\quad \ldots . \quad \ldots . \quad \ldots \quad \ldots \quad \ldots .18$.

Scotland...

Scott, Rev. D. C.

Scott, Rev. H. E

Sebastopol

Secretariat

Sena

Sena Sugar Estates

Senegal

Country

$\cdots \quad \cdots \quad \cdots$

Serpa Pinto, Major $\quad$...

Serpentine $\quad \ldots \quad \ldots . \quad \ldots$

Serval $\ldots \quad \ldots \quad \ldots \quad \ldots$

Seventh Day Adventist Mission

Sharpe, Sir A. ... ... ...

Sheep

Shipping ...

Shire Highlands

Shire Highlands Railway

Shire River

Shirwa, Lake, see Lake Shirwa.

Shrike $\quad . . \quad \ldots \quad \ldots . \quad \ldots$

$\begin{array}{lllll}\text { Shrike } & \ldots & \ldots & \ldots & \ldots \\ \text { Sikhs } & \ldots & \ldots & \ldots & \ldots\end{array}$

$\begin{array}{lllll}\text { Silver } & \ldots & \ldots & \ldots & \ldots \\ & \ldots & \ldots & \ldots & \ldots\end{array}$

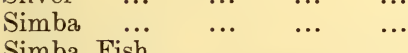

Simba Fish $\quad \ldots \quad \ldots . \quad \ldots$

Simon Likongwe

Sisal

Slave Trade

Sleeping Sickness

Smallpox

Smith, Sir G.

Smythies, Bishop

Snake Bite

Snipe

Soche Mountain

Soche Reserve

Somaliland

Somba

Sombani River ... $\begin{array}{lllll}\ldots & \ldots & \ldots & \ldots & 133,236 .\end{array}$

$\begin{array}{lllll}\ldots & \ldots & \ldots & \ldots & 25 .\end{array}$

$\begin{array}{lllll}\ldots & \ldots & \ldots & \ldots & 238 .\end{array}$

$\begin{array}{lllll}\ldots & \ldots & \ldots & \ldots & 235 .\end{array}$

$\begin{array}{lllll}\ldots & \ldots & \ldots & \ldots & 77,210\end{array}$

... 32, 34, 35, 211 .

... 91 .

... 258-61.

... 94 .

... $86,87,88,89$. $\begin{array}{lllll}\ldots & \ldots & \ldots & \ldots & 236 .\end{array}$ 


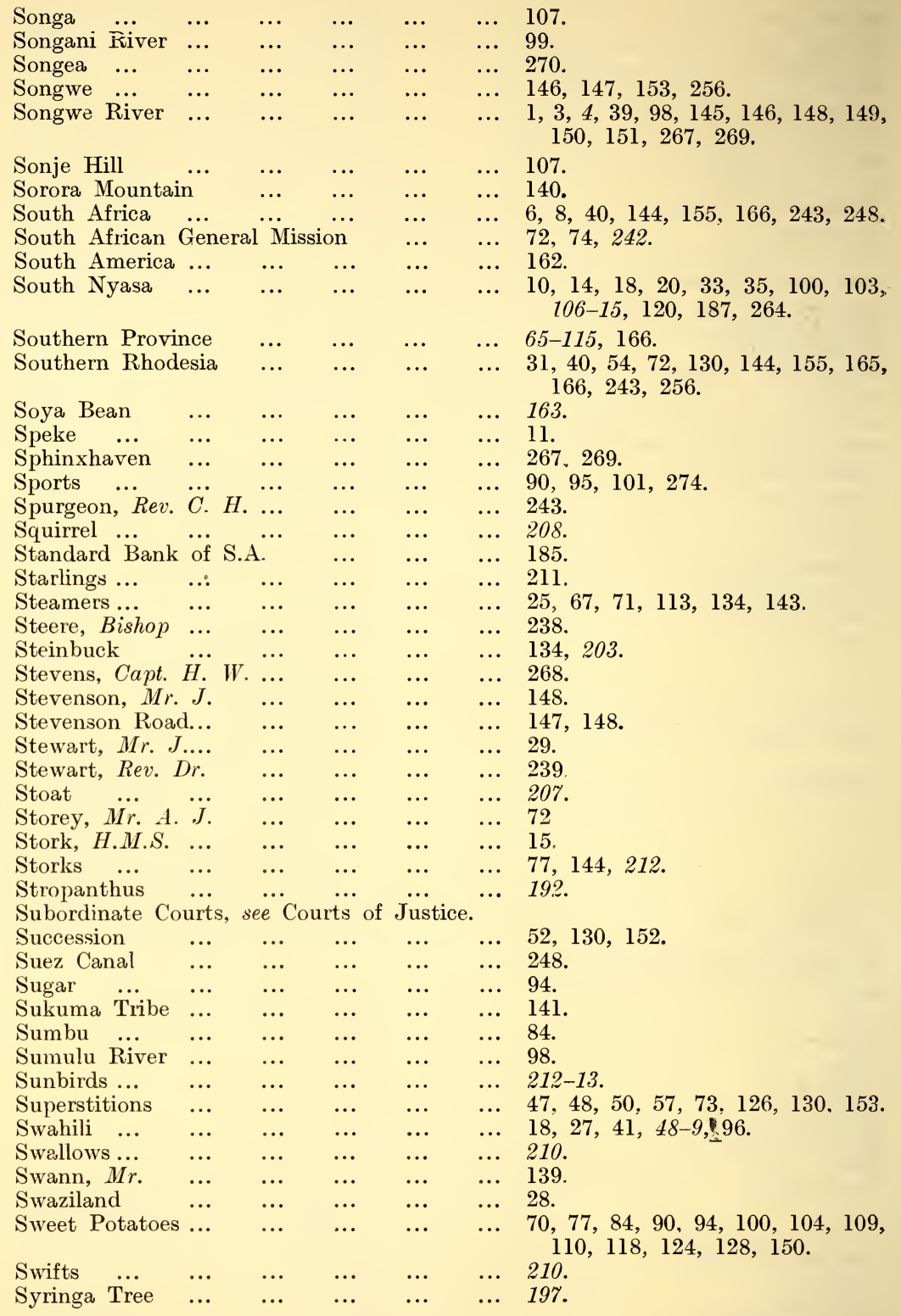

$\begin{array}{llllll}\text { Table Mountain } & \ldots & \ldots & \ldots & \ldots & 146 .\end{array}$

$\begin{array}{llllllll}\text { Taboo } & \ldots & \ldots & \ldots & \ldots & \ldots & \ldots & 131 .\end{array}$

$\begin{array}{llllllll}\text { Tabora } & \ldots & \ldots & \ldots & \ldots & \ldots & \ldots & 131 . \\ & & & \ldots & \ldots & \ldots & \ldots & 261,270 .\end{array}$ 
Talc

Tamanda Plains

Tamankokwe River

$\begin{array}{lllll}\ldots & \ldots & \ldots & \ldots & 108,111\end{array}$

$\begin{array}{llllll}\ldots & \ldots & \ldots & \ldots & \ldots & 22,33,107,121\end{array}$

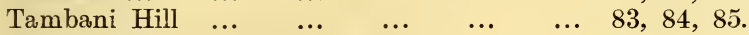

$\begin{array}{llllllll}\text { Tambo } & \ldots & \ldots & \ldots & \ldots & \ldots & \ldots & 83,\end{array}$

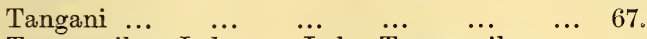

Tanganyika, Lake, see Lake Tanganyika.

Tanganyika Plateau

Tanganyika Territory ...

Tangasi River

Tattooinu

Tawakali Sudi ...

Tea

Teak Tree

Teal

Tekerani $\dddot{\text { River }}$...

Telegraphs

Telephones

Tengani ...

Tengani (Lower Shire)

Tengani, (Ruc) ...

Tengasi River ... ...

Termites, see White Ants.

Tete

Thornwood Estate

Thrushes...

Tiger Fish

Tin

Tiramanja

Tiza

Tobacco

Totemism

Tourmaline

Tozer, Bishop $\quad \ldots \quad$... $\quad$...

Traction Engines

Trade and Commerce ...

Trade Marks

Trans-Zambesia Railway

Treasurer

Tribal Markings

Trogons ...

Trout

Trower, Bishop ...

Trypanosomiasis

Tsetse Fly

Tuberculosis

Tuchila Rive

Tuma Hill

Tumbuka Tribe

Turkey ...

Turkhana
.. $146,148,150,256$

.. $1,3,145,148,149,164,239,256$, $258,261,265,267-72$.

$$
76 .
$$

... 46, 151.

... 136 .

.. $24,90,92,123,144,15.9-60$, $172-3,188$

.. 197 .

... 77,125 .

... 76

... 113, 122, 131, 248, 256-5\%.

... 253 .

... 32 .

... 69,74 .

... 74 .

... 67 .

.. $1,8,9,11,29,30,42,72,210$, $248,251,256$.

$$
87 .
$$

... 209-13.

... $70,77,198$.

... 7 .

... 88 .

... 73 .

... $24,78,84,85,90,92,96,[99,104$, $106,109,115,117,120,121$, $123,127,128,138,144,159$, $169,1 \% 1$. 130.

$\begin{array}{lll}\ldots & \ldots & 130 \\ \ldots & \ldots & 7 .\end{array}$

... $\quad \ldots \quad 238$.

... $\quad \ldots \quad 251$.

... $\quad \ldots \quad 168-85$.

... $\quad \ldots 64$.

$\ldots \quad \ldots \quad 25,183-85,248,250$.

... $\quad \ldots 61$.

$\ldots \quad \ldots \quad 46,55,113,114,130$.

$\begin{array}{lll}\ldots & \ldots & \\ \ldots & \ldots & 211 .\end{array}$

... $\quad$.. 198

... $\quad \ldots \quad 238$,

... $\quad \ldots \quad 149,164-67$.

... 72, 109, 117, 121, 125, 127, 128 . $129,133,139,143,164-6 \%, 253$, 44.

.. $\quad 35,75,76,86,87,88,90,91,92$, $94,96,97,249$.

$\begin{array}{lll}\ldots & \ldots & 132 . \\ \ldots & \ldots & 28,29,38,39,42,141,150 .\end{array}$

$\begin{array}{lll}\ldots & \ldots & 28, \\ \ldots & \ldots & 208 .\end{array}$

... $\quad \ldots \quad 260$. 


\section{U}

\begin{tabular}{|c|c|c|c|c|c|c|}
\hline Ubena & & $\cdots$ & $\cdots$ & $\cdots$ & $\cdots$ & 270. \\
\hline Uganda & $\ldots$ & $\ldots$ & $\ldots$ & ... & $\ldots$ & $1,41,55,256,258,263$. \\
\hline Ukinga & Mountains & $\ldots$ & $\ldots$ & $\ldots$ & $\ldots$ & 39,151 \\
\hline Ulcers & $\ldots$ & $\ldots$ & $\ldots$ & $\ldots$ & $\ldots$ & 235. \\
\hline Ulongwe & e ... & $\ldots$ & $\ldots$ & $\ldots$ & $\ldots$ & 103. \\
\hline Ulumba & $\ldots$ & $\ldots$ & $\ldots$ & $\ldots$ & $\ldots$ & 32. \\
\hline Umtali & $\ldots$ & $\ldots$ & $\ldots$ & $\ldots$ & $\ldots$ & 256. \\
\hline Undi's & Country ... & $\ldots$ & $\ldots$ & $\ldots$ & $\ldots$ & 43. \\
\hline Union $\mathrm{C}$ & Castle Line & $\ldots$ & $\ldots$ & & $\ldots$ & 247,254 . \\
\hline United & Free Church & of Scotla & land & Mission & $\ldots$ & $154,239-40$ \\
\hline United & Kingdom & $\ldots$ & $\ldots$ & $\ldots$ & $\ldots$ & 253,254 . \\
\hline Universi & ities Mission & to Centr & & & $\cdots$ & $\begin{array}{l}3,10,13,14,43,95,113,114, \\
134,136,137,237-39,245,250 .\end{array}$ \\
\hline Unyago & Ceremony & $\cdots$ & $\cdots$ & $\cdots$ & $\cdots$ & $47,56,114$. \\
\hline Upper $s$ & Shire & ‥ & $\cdots$ & $\ldots$ & $\cdots$ & $\begin{array}{c}4,8,10,11,20,33,34,48,91, \\
102,110,120,243,249,251 .\end{array}$ \\
\hline Usisya & .. & .. & $\cdots$ & $\cdots$ & 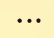 & $39,145$. \\
\hline Utale & ... & ... & $\ldots$ & $\ldots$ & $\cdots$ & 244 \\
\hline
\end{tabular}

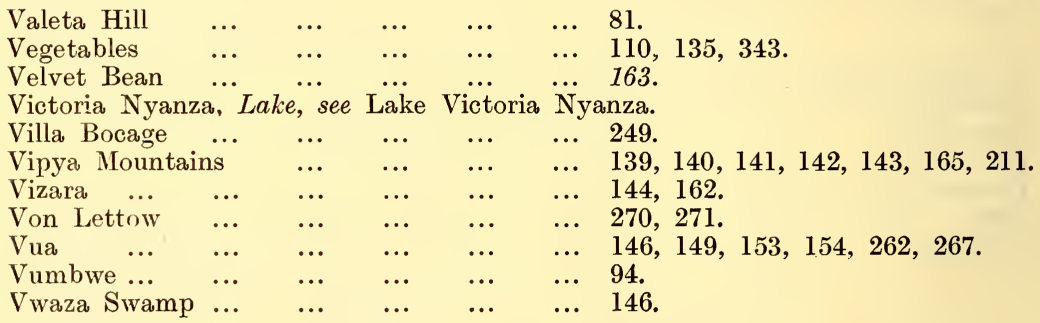

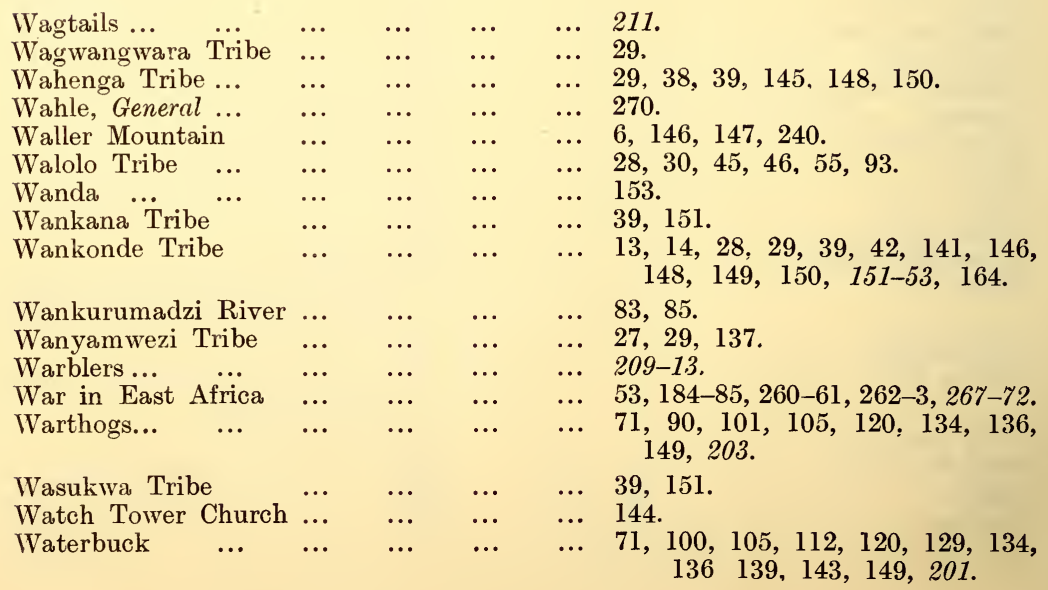




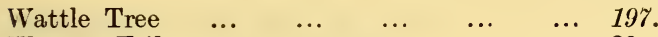

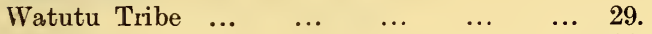

$\begin{array}{lllllll}\text { Weavers } \ldots & \ldots & \ldots & \ldots & \ldots & \ldots & 29 . \\ \text { West Africa } & \ldots & \ldots & \ldots & \ldots & \ldots & 209-13 .\end{array}$

$\begin{array}{lllllll}\text { West Africa } & \ldots & \ldots & \ldots & \ldots & \ldots & 209-13 \\ \end{array}$

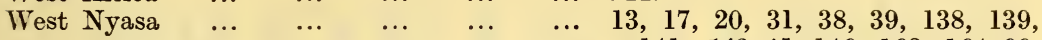
$141,142-45,146,162,164-66$, 192.

West Shire $\quad \ldots \quad \ldots \quad \ldots \quad \ldots \quad \ldots \quad 6,32,33,34,38,67,74,81-85,91$. Wheat $\quad \ldots \quad \ldots \quad \ldots \quad \ldots \quad \ldots \quad \ldots \quad 78,117,121,123,128,133,135$,

$\begin{array}{lllllll}\text { Wheatear... } & \ldots & \ldots & \ldots & \ldots & \ldots & 211 .\end{array}$

$\begin{array}{lllllll}\text { Whinchat... } & \ldots & \ldots & \ldots & \ldots & \ldots & 211 . \\ \end{array}$

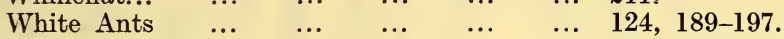

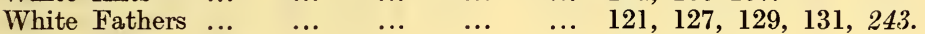

Whyte, Mr. Alex. $\quad \ldots \quad \ldots \quad \ldots \quad \ldots \quad 18,209,211$.

$\begin{array}{lllllll}\text { Wild Cat } & \ldots & \ldots & \ldots & \ldots & \ldots & 206 .\end{array}$

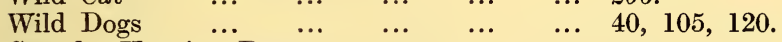

See also Hunting Dogs.

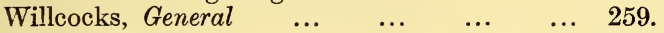

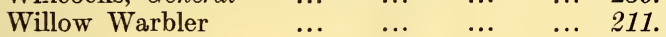

$\begin{array}{lllllll}\text { Wintgens } & \ldots & \ldots & \ldots & \ldots & \ldots & 271 . \\ & \text { Witghe } & \ldots & \ldots & \ldots & \ldots & 270 .\end{array}$

$\begin{array}{lllllll}\text { Witcheraft } & \ldots & \ldots & \ldots & \ldots & \ldots & 270 . \\ & & \ldots & \ldots & \ldots & \ldots & 50-52,57,114,126 .\end{array}$

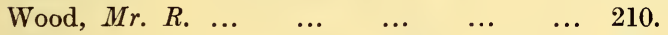

$\begin{array}{llllllll}\text { Worms } & \ldots & \ldots & \ldots & \ldots & \ldots & \ldots & 235 .\end{array}$

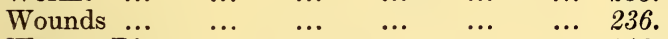

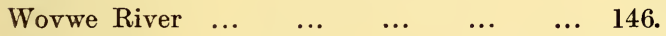

Wozi Hill $\quad \ldots \quad \ldots \quad \ldots \quad \ldots \quad \ldots \quad \ldots 140$.

Yaos

Yellowbill

$\begin{array}{llllll}\ldots & \ldots & \ldots & \ldots & \ldots & 125 .\end{array}$

$\begin{array}{llllll}\text { Yohane Champiti } & \cdots & \ldots & \ldots & \ldots & 142 .\end{array}$

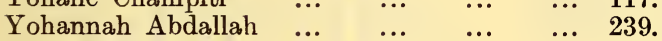

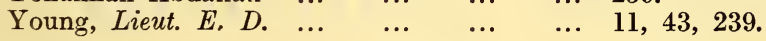

Zambawe

Zambesi Industrial Mission

Zambesi River
$9,10,11,12,14,16,17,18,19$, $20,21,22,23,28,29,30,32$, $33,34-37,38,42,43,44,45-48$, $56,72,80,82,85,90,93,95$, $97,102,106,110,112,113$, $114,121,134,137,151,237$, 258, 264, 265.

Z 


\begin{tabular}{|c|c|c|c|c|c|c|}
\hline Zebra & $\cdots$ & $\cdots$ & $\cdots$ & $\cdots$ & $\cdots$ & $\begin{array}{l}90,100,105,120,129,134,136, \\
139,143,203 .\end{array}$ \\
\hline Zedi Hill & $\cdots$ & $\cdots$ & $\cdots$ & $\cdots$ & $\cdots$ & 96 \\
\hline Zeole & $\ldots$ & $\ldots$ & $\ldots$ & $\ldots$ & $\ldots$ & 34. \\
\hline Zimbili River & $\ldots$ & $\ldots$ & $\ldots$ & $\ldots$ & $\cdots$ & 76. \\
\hline Zirimbuzi Hill & $\ldots$ & $\ldots$ & $\therefore$ & $\ldots$ & $\ldots$ & 102,116 \\
\hline Zitonga $\ldots$ & $\ldots$ & $\ldots$ & $\ldots$ & ... & $\ldots$ & 117. \\
\hline Zoa Falls... & $\cdots$ & $\cdots$ & $\cdots$ & $\cdots$ & $\cdots$ & $4,70,76$. \\
\hline Zomba $\quad \ldots$ & $\ldots$ & $\ldots$ & $\ldots$ & ... & $\ldots$ & $\begin{array}{l}10,18,19,21,32,33,35,36,37, \\
38,45,86,89,91,96,98-102, \\
103,104,109,110,112,119, \\
121,124,125,128,138,141, \\
187,209,211,236,239,241, \\
253,254,256,262,263,264, \\
267,269,274 .\end{array}$ \\
\hline Zomba Mission & & $\cdots$ & ... & $\cdots$ & .. & 241. \\
\hline Zomba Mountair & & $\cdots$ & $\cdots$ & $\cdots$ & $\cdots$ & 2. \\
\hline $\begin{array}{l}\text { Zongandaba } \\
\text { Zorille } \quad . . .\end{array}$ & $\cdots$ & $\cdots$ & $\cdots$ & $\cdots$ & $\cdots$ & $28,29,30,33,34$. \\
\hline $\begin{array}{l}\text { Zorille } \text { Zulu, Chief } \\
\text { Zulu }\end{array}$ & $\cdots$ & $\begin{array}{l}\cdots \\
\cdots\end{array}$ & $\begin{array}{l}\cdots \\
\cdots\end{array}$ & $\begin{array}{l}\cdots \\
\ldots\end{array}$ & $\begin{array}{l}\cdots \\
\cdots\end{array}$ & $\begin{array}{l}206 . \\
127 .\end{array}$ \\
\hline $\begin{array}{l}\text { Zulu, Chief } \\
\text { Zululand }\end{array}$ & $\ldots$ & $\ldots$ & $\ldots$ & $\ldots$ & $\ldots$ & 33,58 \\
\hline Zulus $\quad \ldots$ & $\ldots$ & $\therefore$ & $\ldots$ & $\ldots$ & $\ldots$ & $9,28,130,259$. \\
\hline Zumbo & $\ldots$ & $\ldots$ & $\ldots$ & $\ldots$ & $\ldots$ & 29 . \\
\hline Zwide & $\ldots$ & $\ldots$ & $\ldots$ & $\ldots$ & $\ldots$ & 28. \\
\hline
\end{tabular}




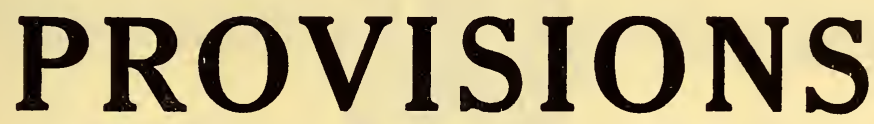
and

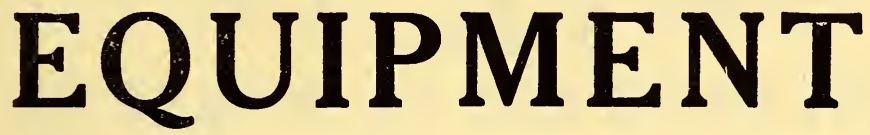

Every Possible kind of Groceries, Provisions, Wines, SPIRITS; also MEDiCAL Stores of the Highest Qualities. Complete Outfits and Equipment of Every Description for Residents in the Tropics.

"C HO P BOX E S" a Speciality.

\section{Griffiths, McAlister} $\& \mathrm{CO}$.

29 \& 31, Manesty's Lane,

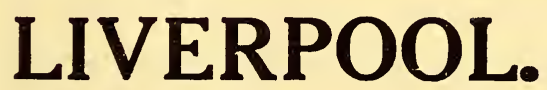

LONDON SHOWROOM :-

10,Warwick Street, Regent Street, London, W.1

TELEPHONE-REGENT 2159.

Established 1880 


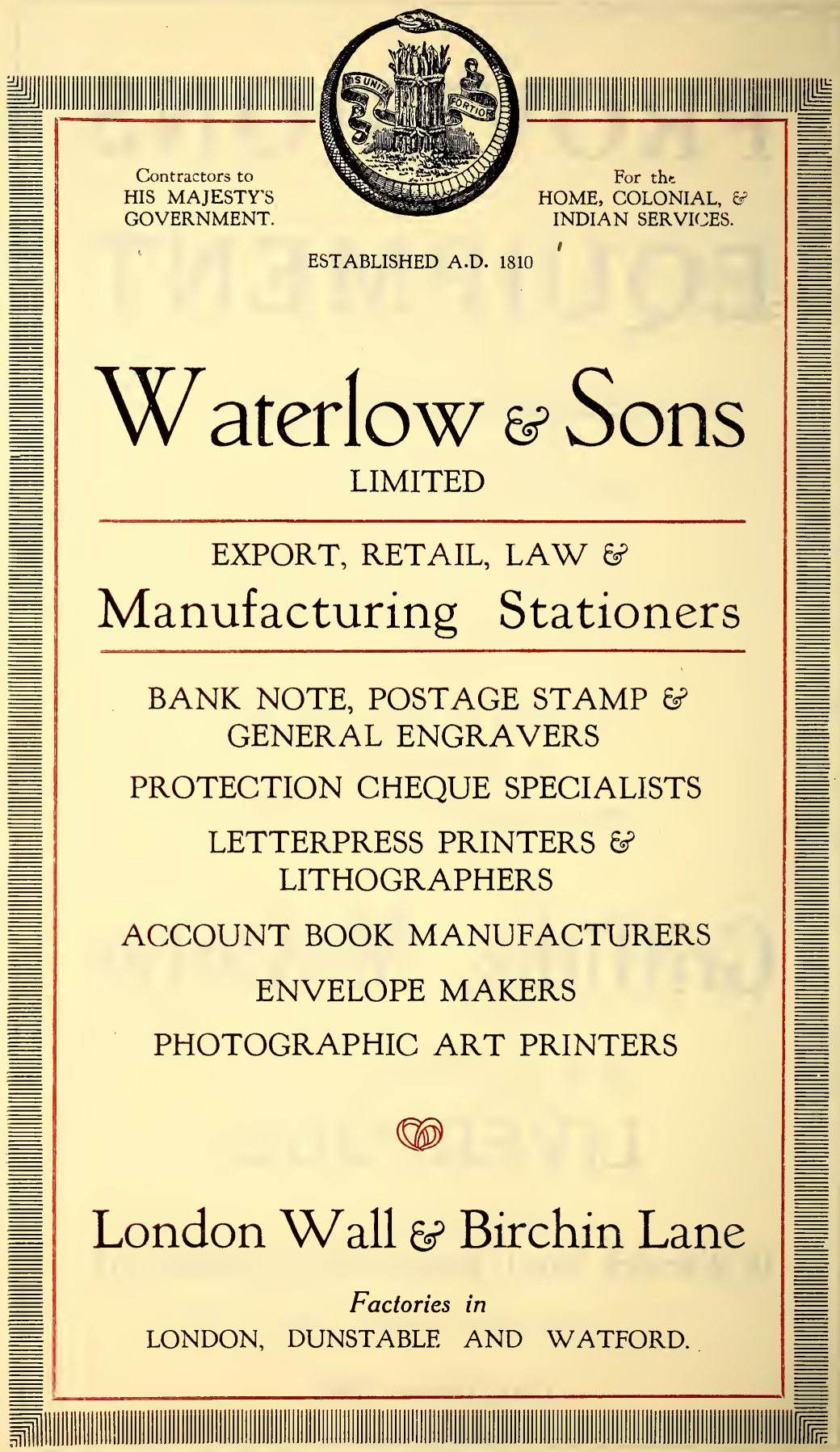




\section{BENJAMIN EDGINGTON'S}

\section{DOUBLE ROOF}

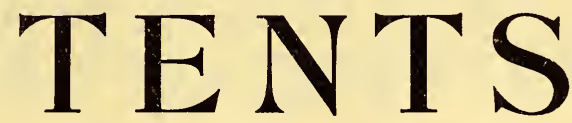

\section{for AFRICA and HOT CLIMATES}

Fitted with VERANDAH, BATHROOM, \&c.

As used by eminent Travellers, and supplied to H.M. Government for East, West, Central, and South Africa, \&c.

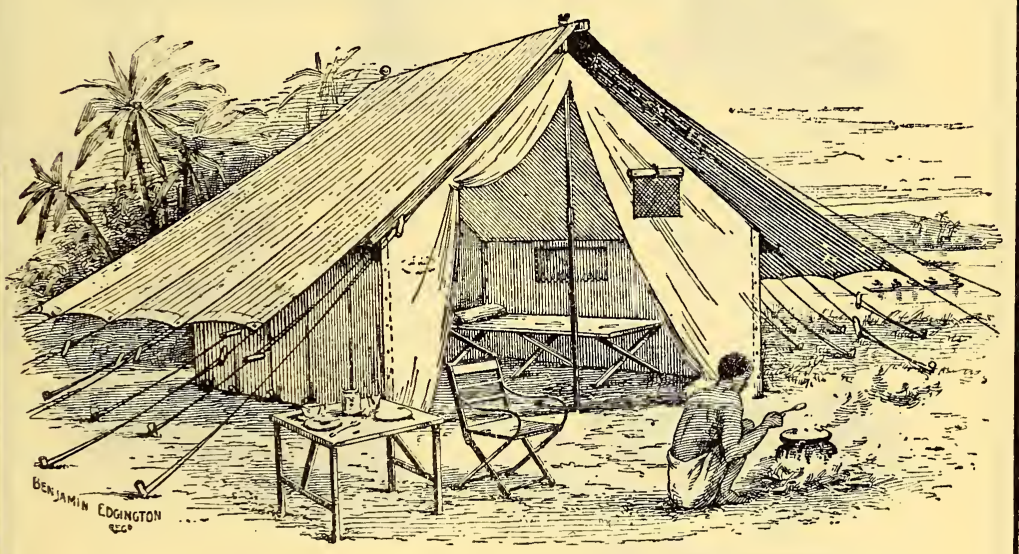

\section{COMPLETE EQUIPMENTS.}

CLOTHING, WATERTIGHT BOXES, PORTABLE FURNITURE, \&c.

EVERY NECESSARY for VOYAGE \& OVERSEAS.

SIR H. H. JOHNSTON, K.C.B., wrote from Zomba :-

"Nothing could be more serviceable or thoroughly good than the tents supplied by you in August, 1893."

\section{S. W. SILVER \& CO. \& BENJ. EDGINGTON,} LIMITED,

1, DUKE ST., LONDON BRIDGE, S.E., and KING WILLIAM HOUSE, LONDON E.C.3.

Telephone Nos.: Minories 1410 ; Hop 604. Telegrams : Benjamin Edgington, London. 


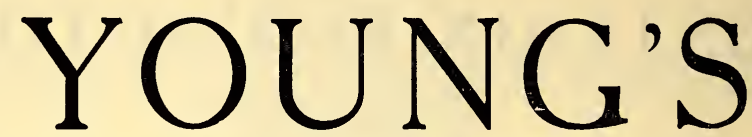

CRANES, CRABS, BLOCKS, JACKS, PUNCHES, BENDERS, RUNNERS, TOBACCO PRESS SCREWS, ETC.

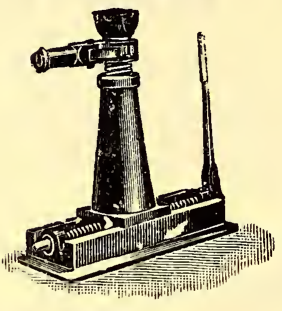

"A" Bottle Traverse Jack.

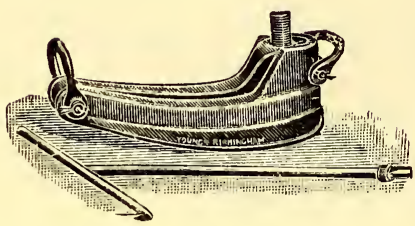

"Universal" Rail Lifter.

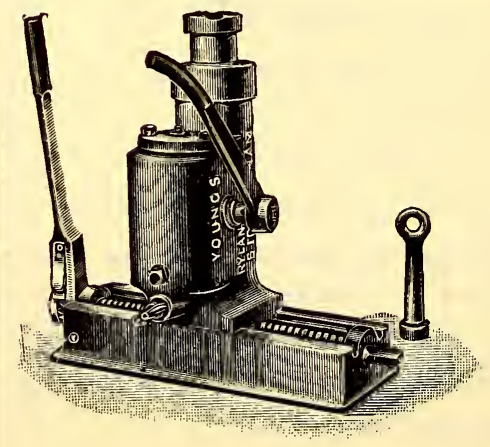

Hydc. "Loco." Jack.

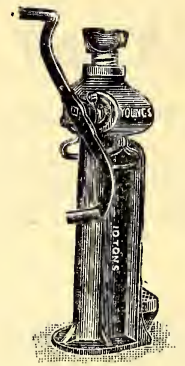

Iron Haley Jack.
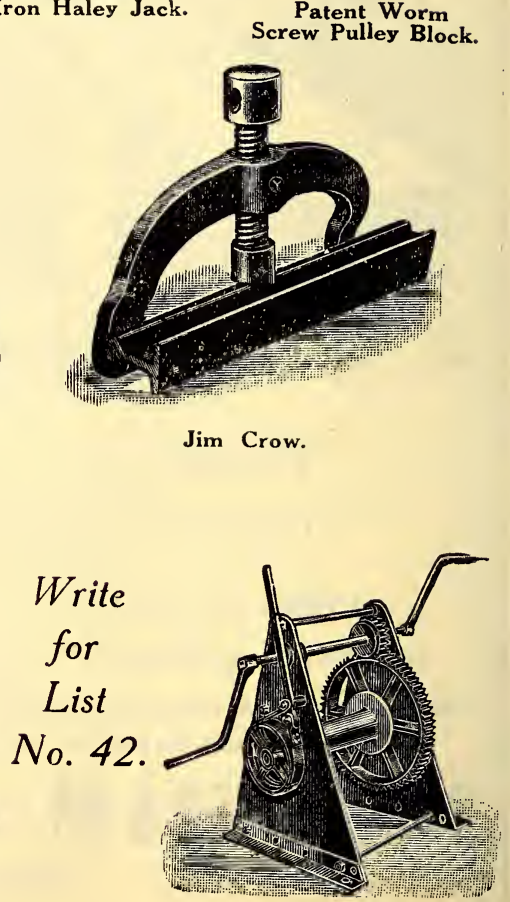

Crab Winch.

RYLAND STREET WORKS. BIRMINGHAM, ENGLAND. 


\section{Colonial Outfits for India AND THE TROPICS.}

Officers and Civilians taking up appointments in the Colonies would find it to their advantage to obtain their outfit from J. G. Plumb \& Co., who are specialists in requirements for above, including the White Civil Service Uniforms.

White Unshrinkable Gabardine (Palm Beach) Suits £1 186

Extra Trousers to same 2150

Khaki Drill Jackets ...

Khaki Drill Slacks.

Khaki Drill Shorts ... ... . .

Bush Shirts (Flannel) $\quad \ldots \quad \ldots \quad \ldots \quad \ldots$

Drill Shirt Jumper (Short Sleeves, Spine Pad attached) $\quad 1 \quad 1 \quad 1 \quad 0$

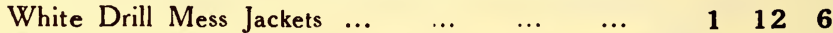

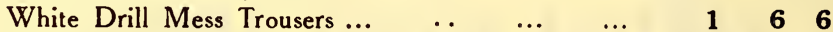

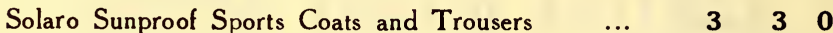

Palm Beach Suits (Duro Fast Dye) stocked in Grey,

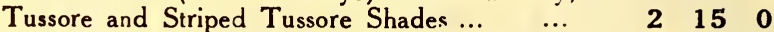

Waterproof Willesden Mail Canvas Kit Bags $\ldots . \quad 2 \quad 10 \quad 0$

Unshrinkable White Flannel Trousers as used at Royal Military Academy $\quad . . . \quad \ldots \quad \ldots$

Wolseley Helmets, White and Khaki $\ldots$

Cawnpore Tent Club Pith Helmet

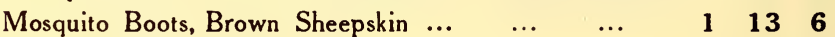

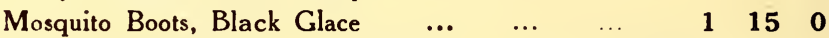

A large Selection of the above articles Ready to Wear is always kept in Stock.

When Ordering, please state Height, Chest \& Waist Measurements. SELF-MEASUREMENT FORMS AND PATTERNS SENT ON APPLICATION. MOSQUITO NETTING \& ALL CAMP EQUIPMENTS. Satisfaction Guaranteed. Terms, Cash with Order.

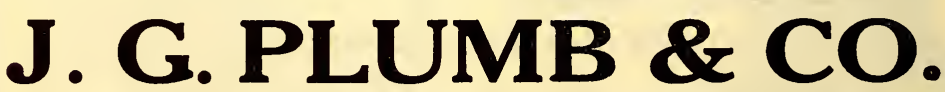

Army and Navy Tailors and Civil Outfitters,

By Appointment to

THE ROYAL MILITARY ACADEMY, WOOLWICH. THE QUETTA \& WELLINGTON COLLEGES, INDIA. VICTORIA HOUSE, 117, VICTORIA ST., LONDON, S.W.1, ENG. 


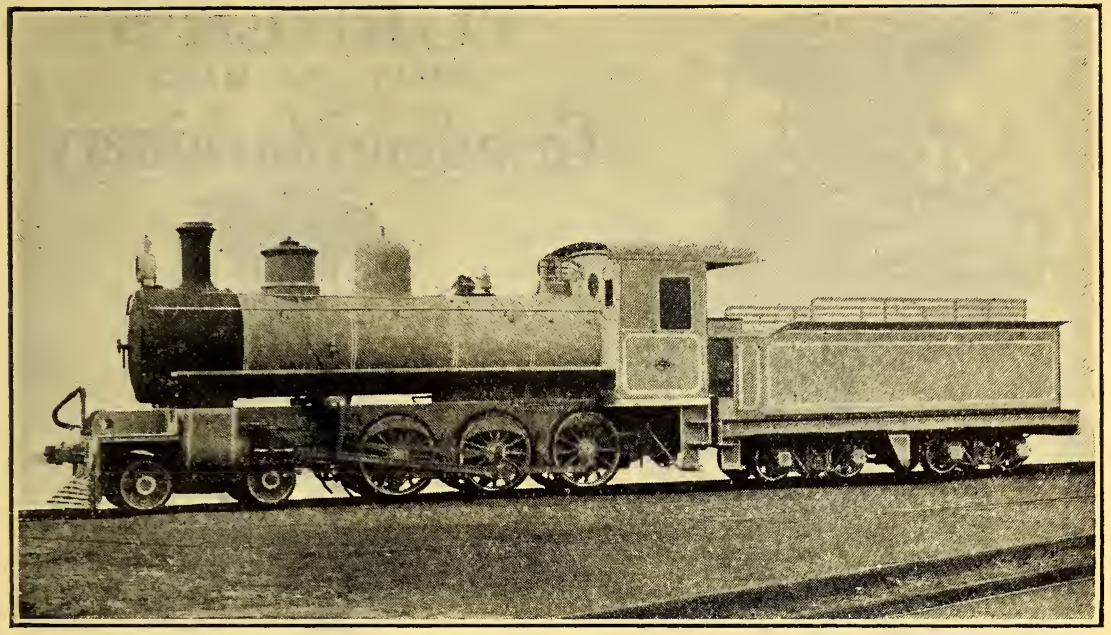

4-6-0 Type Tender Engine 1 Metre Gauge.

Built for the

Southern San Paulo Railway Co.

BY

\section{THE HUNSLET ENGINE} COMPANY, LIMITED, Makers of

\section{LOCOMOTIVE ENGINES}

of all sizes up to 50 tons to suit any gauge.

N arrow Gauge Locomotives a Speciality.

\section{Hunslet Engine Works, LE E D S,}

Telegraphic and Cable Address:

"ENGINE, LEEDS."

Telephone No. 20877.8 .

London Office :

I, BROAD STREET PLACE, FINSBURY CIRCUS, E.C.2

Telegrams:

"JIMCROW, LONDON." Telephone 7985 London Wall. 


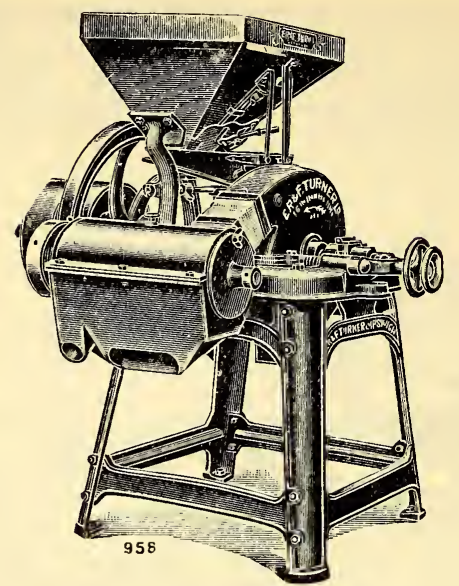

Turner's Celebrated

“Inkoos" Mill, with Metal Plates, fitted with Sifter.

Will grind Wheat, Maize, \&c. Hundreds in use throughout the African continent.

Made in 5 sizes. Catalogues Free.

\section{TURNER'S WHEAT AND MAIZE Grinding Machinery}

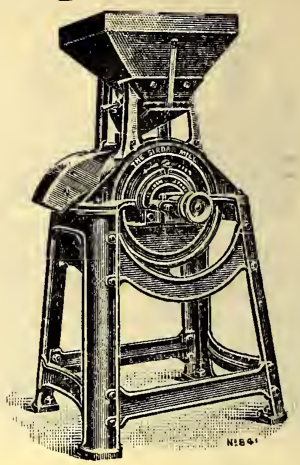

Turner's "Sirdar" Mill.

With vertical stones for producing Soft Meal from Wheat, Maize, etc. Made in 4 sizes.

\section{E.R.\&F.Turner,Ltd.,Ipswich, England}

\section{HAYWARDS LIGHTS AND BUILDING SPECIALITIES}

Pavement Lights, Iron Staircases, Heating and Ventilating Plant, Steel Casements and Sashes, Collapsible Gates, Fireproof Doors, Puttyless Roof Glazing, Skylights and Lanterns, Lead Lights and "Copperlights" Architectural Metalwork, etc., etc., etc

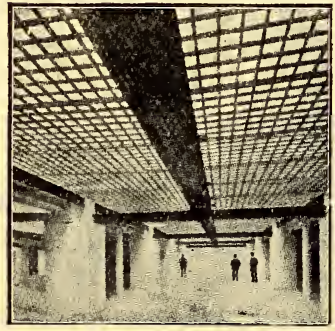

Hay waıds Lights at Admiralty Stores.

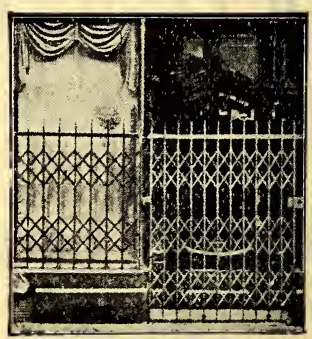

Steel Collapsible Gates.

\section{HAYWARDS Ltd UNION STREET, BOROUGH, LONDON, S.E.I.}

Contractors to the Admiralty, War Office, H.M. Office of Works, \&c. Crown Agents for the Colonies.

Telephone: Hop 3642 (3 lines) Telegrams: "Hayward Brothers, London." 


\section{ELDER DEMPSTER LINES TO AFRICA.}

Steamers of the

African Steam Ship Co., and

The British \& African Steam Navigation Co., Ltd., maintain regular services to and from LIVERPOOL, :: LONDON, :: HAMBURG, ROTTERDAM, ANTWERP, NEW YORK, MONTREAL and WEST AFRICAN PORTS.

\section{CANADA to SOUTH AFRICA}

(Under Contract with the Canadian Government for the conveyance of Cargo and Mails and the development of Trade with South Africa.)

\section{Monthly Sailings}

taking Cargo for Cape Town, Port Elizabeth, East London, Durban and Delagoa Bay.

\section{LIVERPOOL to GALVESTON-GALVESTON, LIVERPOOL \& HAVRE}

ELDER DEMPSTER \& CO., LTD., COLONIAL HOUSE, LIVERPOOL ; 4, St. Mary Axe, London, E.C.3 ; Manchester ; Cardiff ; Birmingham ; Hull ; Hamburg; Montreal ; New Orleans; and Galveston. P. A. Van Es \& Co., Rotterdam; Agence Maritime Internationale S.A. 67, Rempart Ste Catherine, Antwerp ; and Daniel Bacon, 26, Beaver Street, New York.

THE

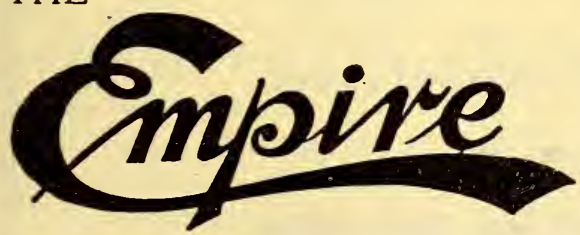

TYPEWRITER.

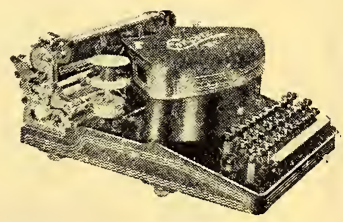

Prices Low. No machine will give better service! The Empire lasts well, and does not get out of order easily.

Accurate alignment a special feature.

Over 8,000 supplied to British Government.

THE EMPIRE TYPEWRITER CO., Ltd. - 77, Queen Victoria Street, London, E.C.4 


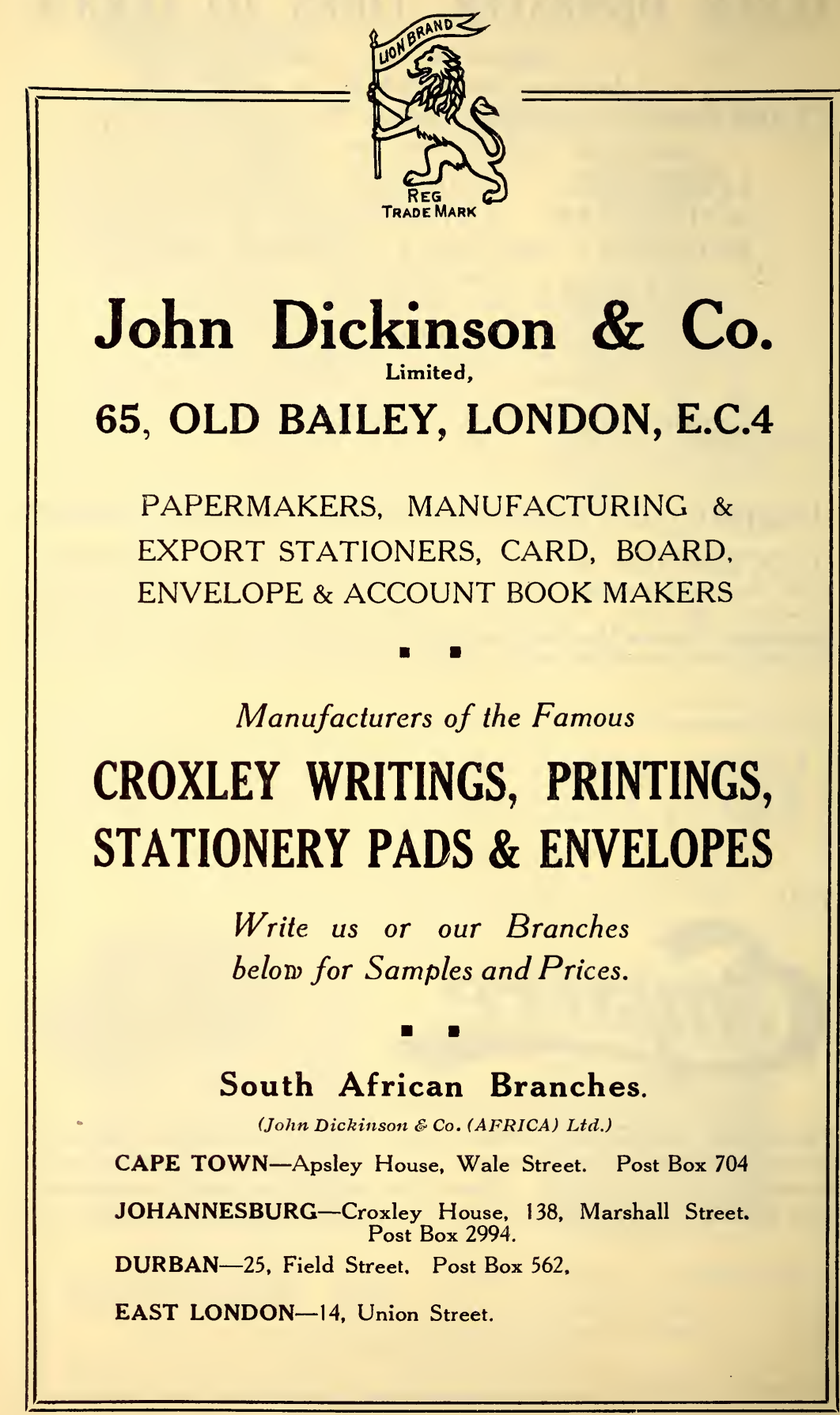




\section{The "GARRETT"}

\section{Portable Steam Engines}

Unequalled for

ECONOMY AND RELIABILITY.

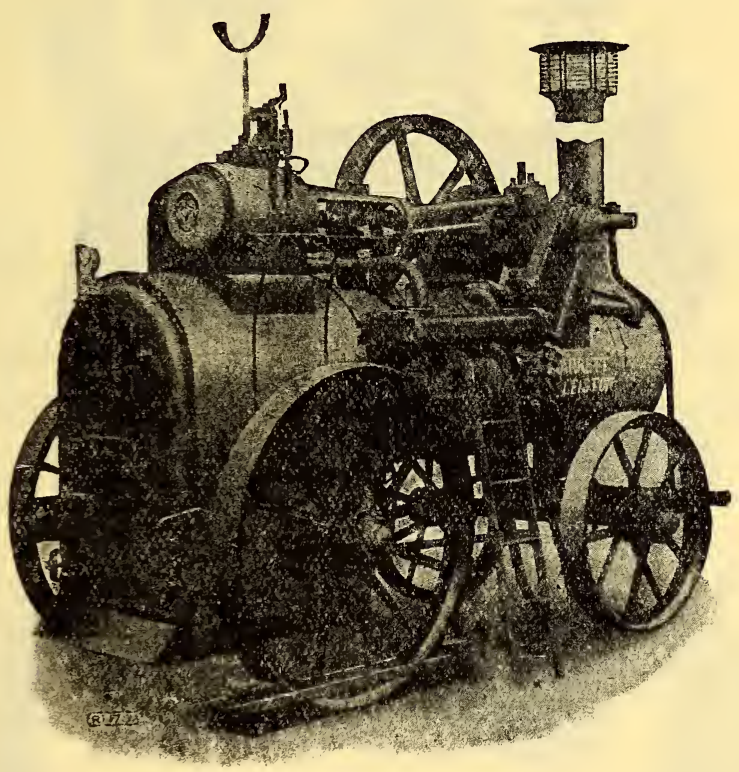

Fitted with Piston Valve Gear and Crankshaft Governor. Also Makers of :

Steam Wagons, Traction Engines, Tractors, Road Rollers, Cross-tube and Loco. Type Boilers, Electric Vehicles, Trailer Wagons, Sleeping Vans, Threshing Machines, Clover Hullers, Maize Shellers, Straw Elevators and Stackers, Superheated Steam Power Plants, etc.

Richard Garrett \& Sons, Limited (Established 1778)

LEISTON WORKS, LEISTON, SUFFOLK, - - ENGLAND. 


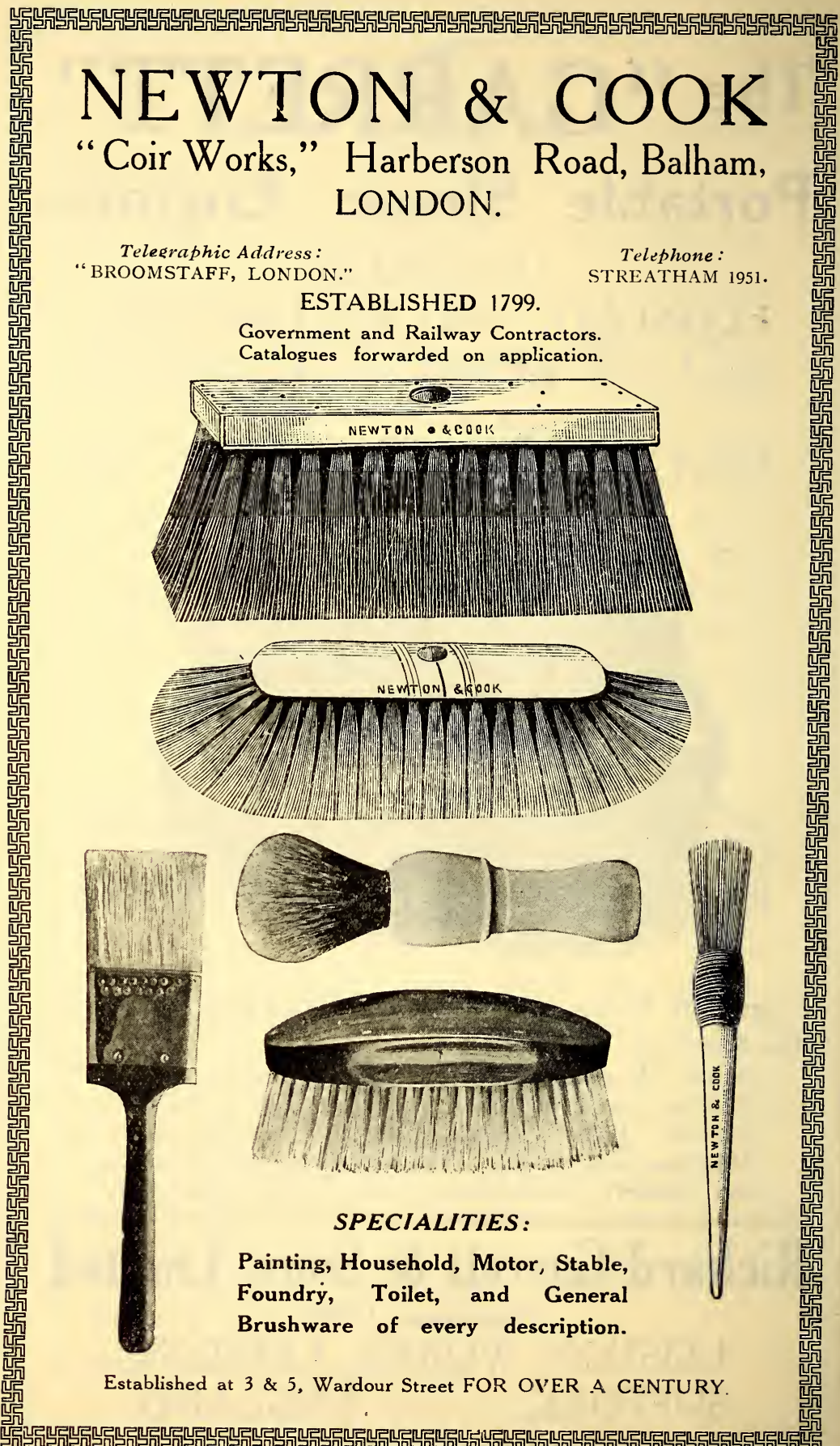

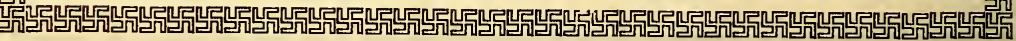




\section{HARD, SALT, OR POLLUTED WATERS}

used for dilution will not destroy the composition or the disinfecting powers of

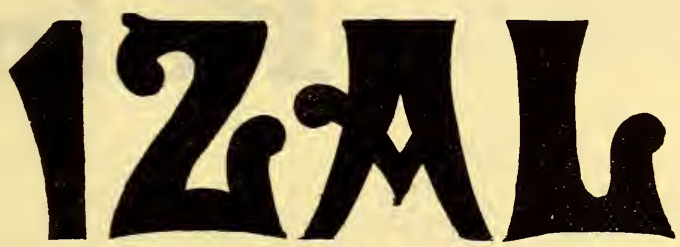

THE HIGH-POWER GERMICIDE

IZAL also retains its germicidal activity when mixed with Organic Matter, Urine, and even : : : Limewash : : :

\section{INVALUABLE IN THE TROPICS} for both Domestic and Public use

Apply for Samples and copies of Scientific Reports to

\section{NEWTON, CHAMBERS \& CO. LIMITED,}

THORNCLIFFE . . . . Nr. SHEFFIELD 


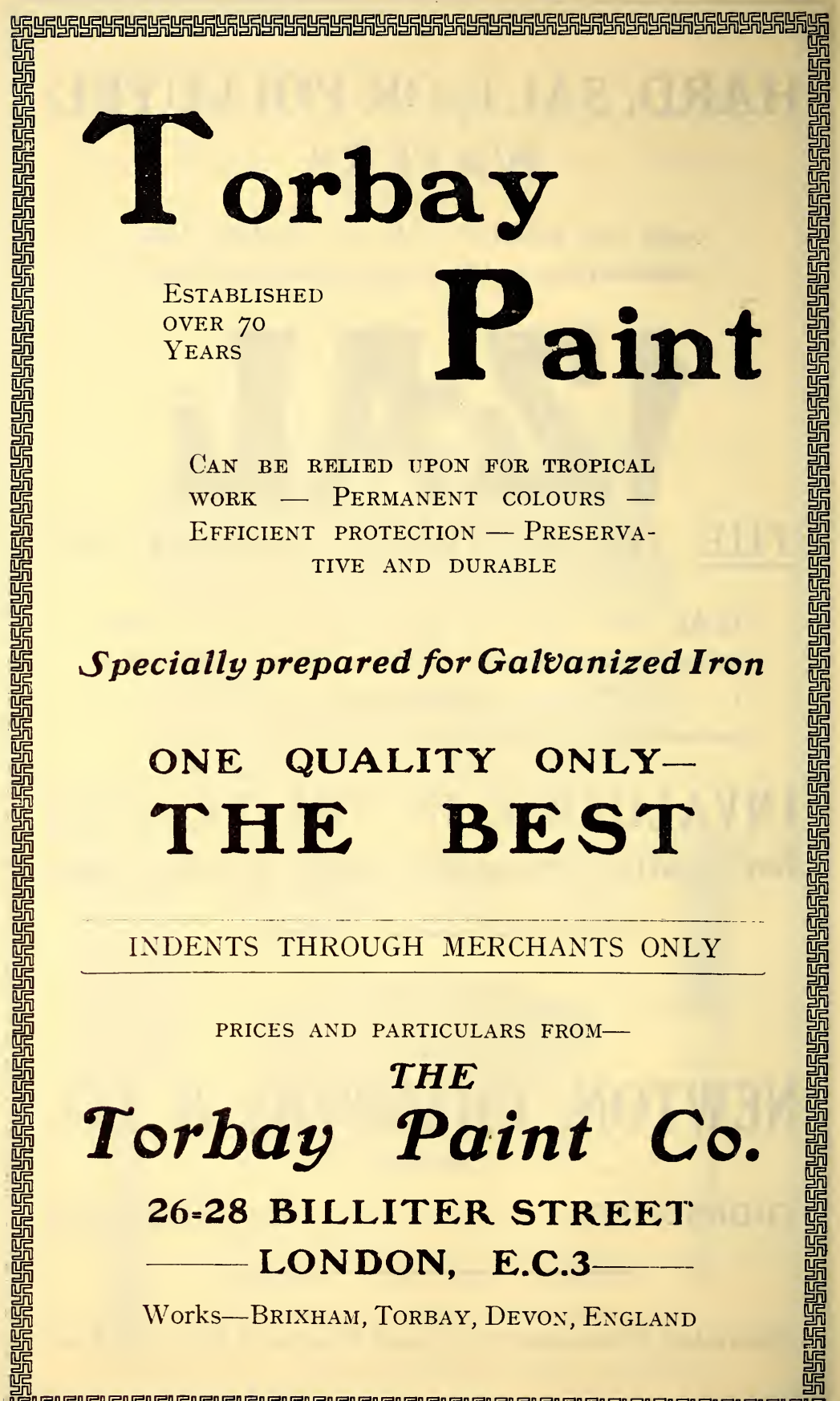


REGULAR

Mail, Passenger \& Freight

SERVICES.

\section{$\mathrm{P} \& \mathbf{O}_{\text {and }}$ BRITISH INDIA LINES}

\section{From LONDON and (*) MARSEILLES-}

To Malta. *Egypt, *Aden and *Bombay every

To Colombo, Madras and Calcutta f week.

To East and South Africa (B.I. Line), every four weeks, alternating with monthly sailings of Union Castle Line.

To Straits, China and Japan direct every fourteen days.

To *Australia, Tasmania and New Zealand monthly, alternating with the four-weekly sailings of the Orient Line ; also Persian Gulf, Seychelles, Mauritius, Burma, Siam, Manila, Borneo, Queenslancl, \&c., \&c.

Handbooks and Maps on application.

* Steamers call at Marseilles a week after leaving London.

\section{ROUND-THE-WORLD BUSINESS TOURS.}

The combined services of the P.\& O., British India and associated lines offer three ways round the world with access to all the chief business centres of the British Empire in both hemispheres. Itineraries may be arranged and all information obtined at the Chief Passenger Offices, as below.

For Freight and General Information apply:

P. \& O. and B.I. Offices, 122, Leadenhall Street, London, E C. 3

(B.I. Agents, Gray, Dawes \& Co., 122, Leadenhall Street, E.C. 3.)

Chief Passenger Offices :

P. \& 0. House, 14-16, Cockspur St., London, S.W. 1. 


\section{THE \\ BRITISH "BULL" LIGHTING SET}

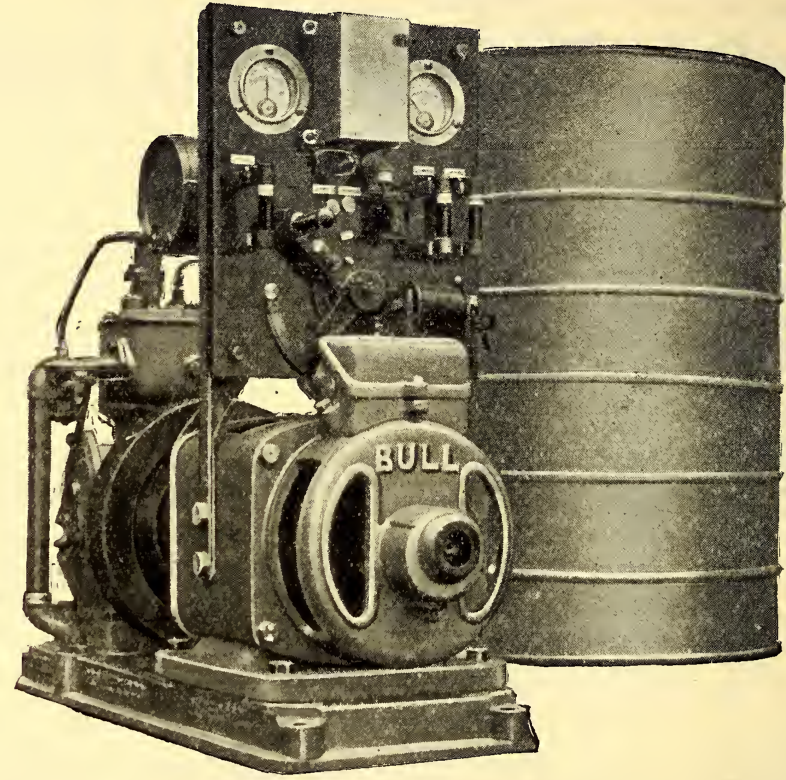

STARTS BY PULLING OVER A SWITCH. STOPS ITSELF WHEN THE BATTERY IS CHARGED. TELLS YOU WHEN TO RE-START IT.

Price complete with battery, water tank and connections, delivered c.i.f. Beira.

25 volt set for house with 20 lights $\quad \ldots \quad £ 157$

25 , , , , , , $35 \quad, \quad$. $\quad £ 168$

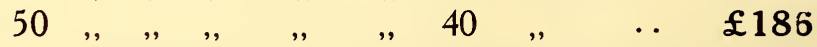

Send a postcard for 20 page catalogue . to the makers. .

PETER BROTHERHOOD Ltd., CENTRAL HOUSE KINGSWAY, LONDON, W.C.2 Works-PETERBOROUGH, - ENGLAND. 
STEAM

HAULAGE

ENGINES, STEAM

LORRIES and TRAILERS.

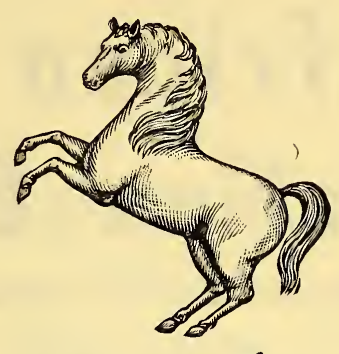

सिracs
STEAM PLOUGHING TACKLES, \&c., \&c., \&c.

\section{AVELING \& PORTER, Ltd., ROCHESTER, ENGLAND.}

Manufacturers of

STEAM ROAD ROLLERS, 5 tons to 20 tons. 


\section{The African Lakes Corporation Limited.} Allan F. Kidney, Manager.

\section{Steamship Owners, Merchants and :: Planters ::}

Agents for: Lloyd's, Union Castle Line, Life, Fire and Marine Insurance Companies.

\section{Transport Department.}

Tobacco, Cotton and other Produce transported from all parts of Nyasaland to London, Liverpool and other Ports, and sold to the best advantage in the Home Markets on behalf of Clients.

Passengers and Cargo transported from Blantyre to all parts of Nyasaland, also to Northern Rhodesia and Tanganyika Territory.

\section{Trading Department.}

Importers of all kinds of European and Native Trade Goods, Trading Stations and Stores throughout Nyasaland and Northern Rhodesia.

\section{Planting Department.}

Growers of Cotton, Rubber, Tea and Tobacco.

Bankers : THE NATIONAL BANK OF SOUTH AFRICA, LTD.

Head Office :

14, St. Vincent Place, Glasgow.
Chief Office in Africa :

Mandala, Blantyre, Nyasaland. 
Cables :

"Nyasa, Blantyre."
Telegrams :

"Nyasa, Blantyre."

\section{THE}

\section{African Lakes Corporation LIMITED,}

Mandala, Blantyre, Nyasaland.

\section{TRADING DEPARTMENT.}

Stores and Trading Stations throughout Nyasaland and Northern Rhodesia.

Importers of all kinds of European and Native goods.

WE carry a large stock of all the leading manufacturers' goods, and are in a position to supply all ordinary needs of the public-our selection comprising upwards of 7,000 different kinds of goods.
Where to buy the pick of the World's Markets at the most favourable rates.

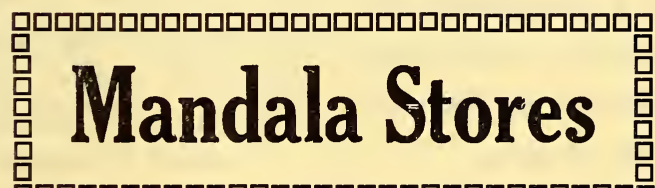

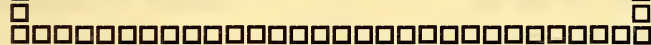
for SATISFACTION
The most comprehensive and up-to-date selection of high-class Merchandise in the country.

\section{AGENCIES :}

Ransomes, Sims \& Jefferies, Ltd., Agricultural Implements.

"Triumph," "B.S.A." and "Douglas" Motor Cycles.

Ardath Cigarettes, Cigars and Tobacco.

Dunlop Tyres, Tubes and Sundries.

Bates Tyres, Tubes and Sundries.

Pasteur Filters, etc., etc. 


\section{THE}

British

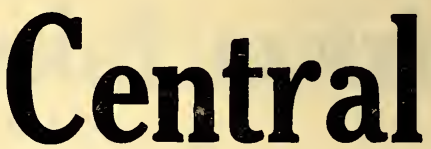

Africa

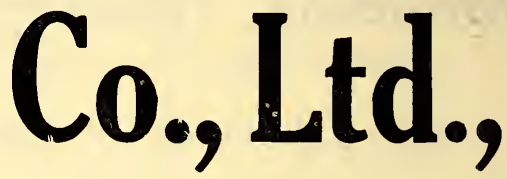

Planters, Merchants, Steamship Owners, Cotton Ginners, and Insurance Agents.

Cotton Ginned and Baled ct the Company's Ginneries at Makandi, Mitoli, and Lintipe.

\begin{tabular}{|c||c|}
\hline Mechanical & Wheelwrights, \\
Repairs executed in & $\begin{array}{c}\text { Furniture and Cabinet- } \\
\text { completely equipped } \\
\text { Making Departments. } \\
\text { Wrticles made, if re- } \\
\text { quired, to Customers' } \\
\text { own bechanics. }\end{array}$ \\
\hline
\end{tabular}

ENQUIRIES TO

THE BRITISH CENTRAL

:: AFRICA CO., LTD. ::

LIMBE.

G. COLVILLE DUNCAN, General Manager. 


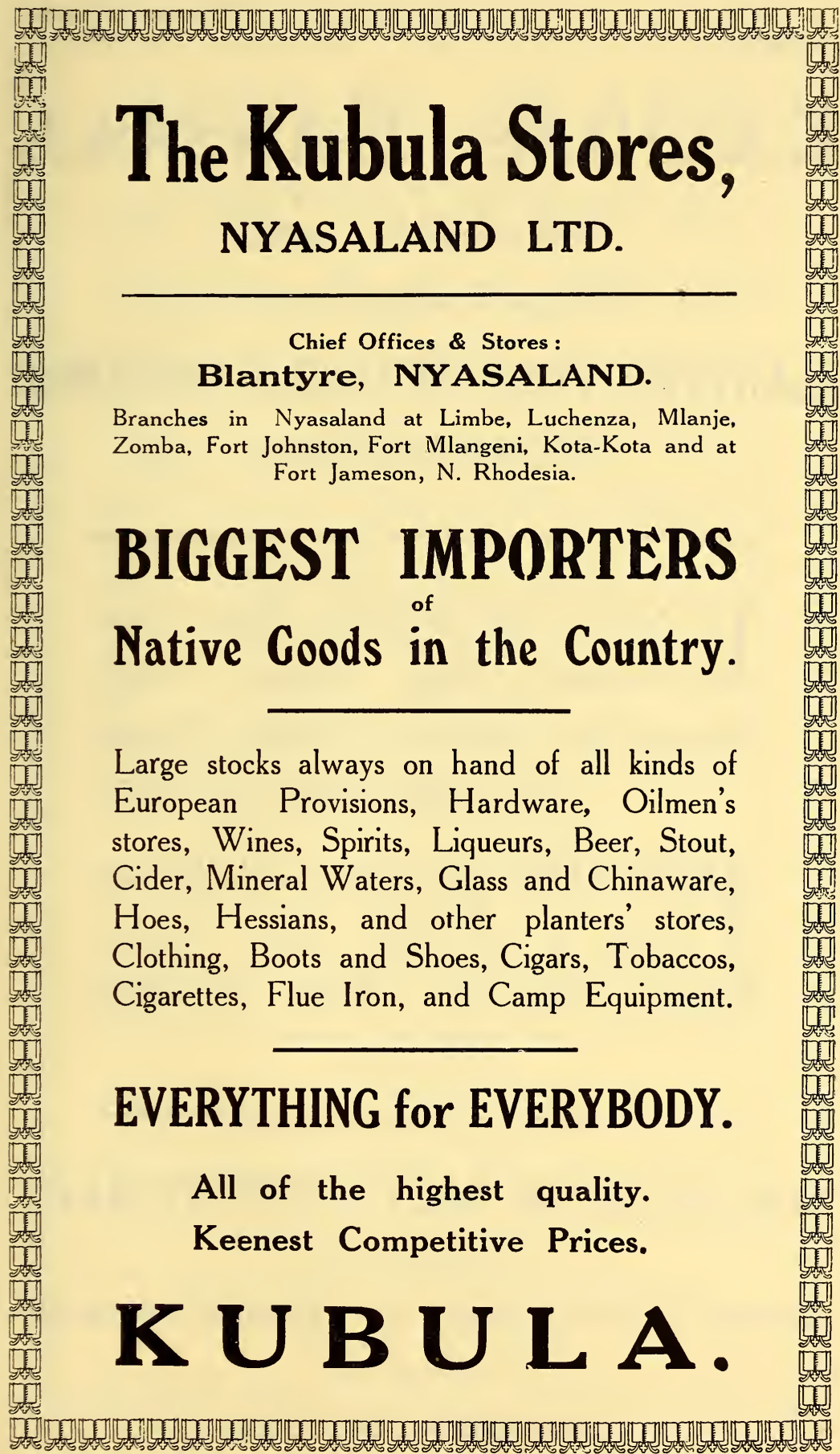




\section{KALIDAS HANSRAJ,}

Wholesale and

Retail Merchant,

\section{BLANTYRE, PORT HERALD \& CHIROMO, NYASALAND.}

XPORTER of Maize, Maize Flour, C. Ground Nuts, Sesame Seeds, Strophanthus, Beeswax, Cotton, Tobacco and Castor Seed.

IMPORTER of Cotton and Woollen 1 Goods of all kinds. Soaps, Candles, Bangles, Stationery, Beads, Provisions and Hoes.

SPECIALIST IN SALT \& GUNNY BAGS.

Goods kept in Bond for transit purposes. 


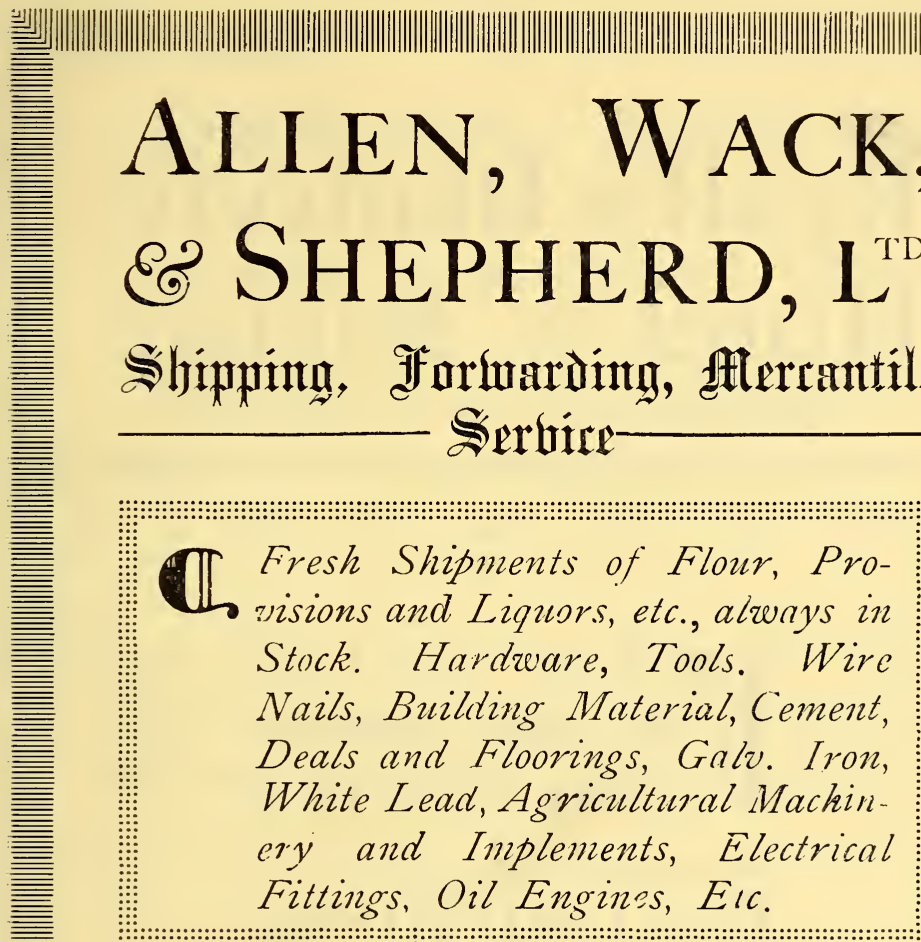

\section{STEAMSHIP AGENTS for}

The British India Siteam Navigation Co., Ltd.

INDIAN SERVICE: Beira to Bombay in 16 days.

COASTW1SE SERVICE: Mombasa, Zanzibar, Dar es Salaam, Mocambique, Beira, Delagoa Bay, and Durban. FreIgHT and PASSAGE information on application.

\section{Also representing}

SWALLOW \& ARIEL, LTD., Biscuits, Cakes, etc. HEINZ'S Specialities, Condiments, etc. LAZENBY'S well-known Preserves, Pickles, etc. JAMES FINLAY \& Co., CalcutTa, Gunnies, Twine, etc. BRITISH GENERAL ELECTRIC CO., Electrical Goods. JOHN LYSAGHT, LTD., of Bristol, Corrugated and Flat Galvanized Irons, Wire Netting.

\section{Distributing Agents for}

\section{The Vacuum Oil Company ${ }_{\text {Africa }}^{\text {of South }}$ Ltd.}

Laurel and Sunflower Paraffins. Pratt's Genuine Spirits of Turpentine. Pegasus Motor Spirit, Gargoyle Mobiloils, Lubricating Oils and Greases.

Our direct connections in leading commercia? centres give us facilities denied our competitors, and promote

\section{QUICK SERVICE.}

Cables and Telegrams: "Thaine, BEIRA." $\quad$ P.O. Boxes, 270, 28? \& 290. 


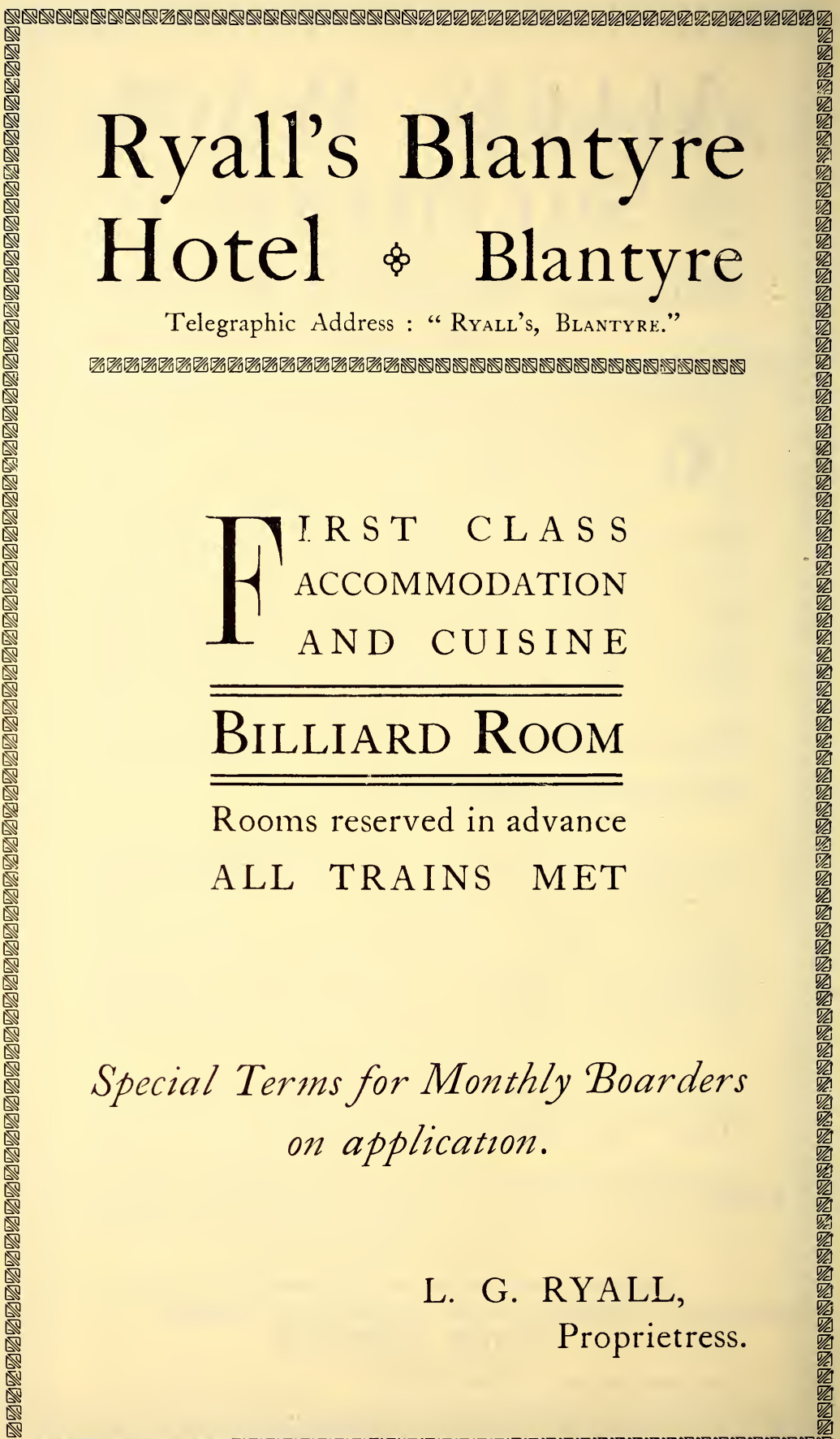


Telegrams and Cables :

P.O. Box No. 14

"OSMAN, BLANTYRE."

BLANTYRE, NYASALAND.

\section{OSMAN A D AM,}

Direct Importer and Exporter,

IS OPEN TO PURCHASE IVORY.

Prices on Application.

\section{CHEAPEST SALT MERCHANT}

WHOLESALE : Piece Goods of every description; Soap Tablets and Bars ; Thread, Reels, Balls and on Cards; Matches, Candles, Bangles, Combs, Enamel and Hardware, Writing Pads and Note Paper, Pencils, Cigarette Papers, Playing Cards, Pipes, Hoes, Buttons, etc., etc.

RETAIL: Chinese, Japanese and Tussore Silk, Muslin, Velvet, Fancy Handkerchiefs, Shawls, Nainsook, Carpets, Fancy Tea and Coffee Sets, etc.

BUYER OF BEESWAX, GROUND NUTS, SESAME SEEDS, NATIVE SEED or LINT COTTON, CAPSICUMS, CHILLIES, etc.

\section{N S U R E}

YOUR

DWELLING HOUSE, FURNITURE, TOBACCOCURING BARNS, BULKING SHED, CATTLE KRAAL, STORE or OTHER BUILDING and CONTENTS with the

\section{North British \& Mercantile Insurance CO., LTD.}

Agent for NYASALAND-

\section{A. J. STOREY}

From whom Rates can be obtained. 


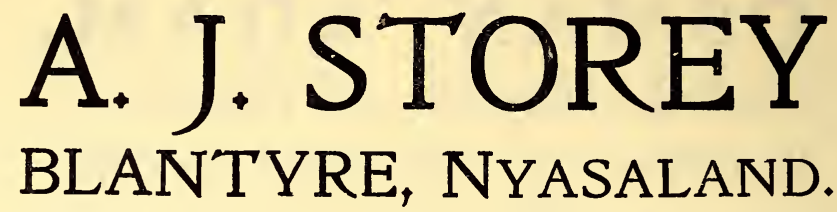

Telegrams and Cables: "Storey, Blantyre," Nyasaland.

Branches:-ZOMBA, PORT HERALD and FORT JOHNSTON.

London Agents (Import Produce only) :-

DICKSON, ANDERSON \& Co., Ltù., 139, Cannon St., E.C.4

General Export Agent:-

P, G. STOREY, Bromley Grove, Shortlands, Kent,

Dealer in the following produce: Tobacco Leaf, Lint Cotton, Beeswax, Hides, Chillies, Capsicums, Coffee, Tea, Strophanthus, etc., which are Bought for Cash, or sold for Planters on Commission. Advances made. $\square$

Sole Agent for :-Messrs. Wm, Tanner, Boxwell \& Co., Cotton Brokers, Liverpool ; The North British \& Mercantile Insurance Co.; White Horse Whisky; Humber Cycles; Slates' - Tobacco Seed; Sena Sugar Estates.

\section{W H O L E S A L E :}

Native Trade Goods, Calico, Blankets, Hoes, Cement, Galvanized Iron, Beads, Matches, Stationery, Enamelware, Salt, etc.

GARAGE opened at both Blantyre and Zomba, Cars on hire at shortest notice. Cargo carried by Packard or light lorries. REPAIR SHOP at Blantyre. Work done promptly.

Bankers-National Bank of South Africa, Ltd., Blantyre. Codes-A.B.C. \& Bentley. Goods can be supplied in Transit or Ex. Bond. for N.E. Rhodesia or Portuguese Territory. 


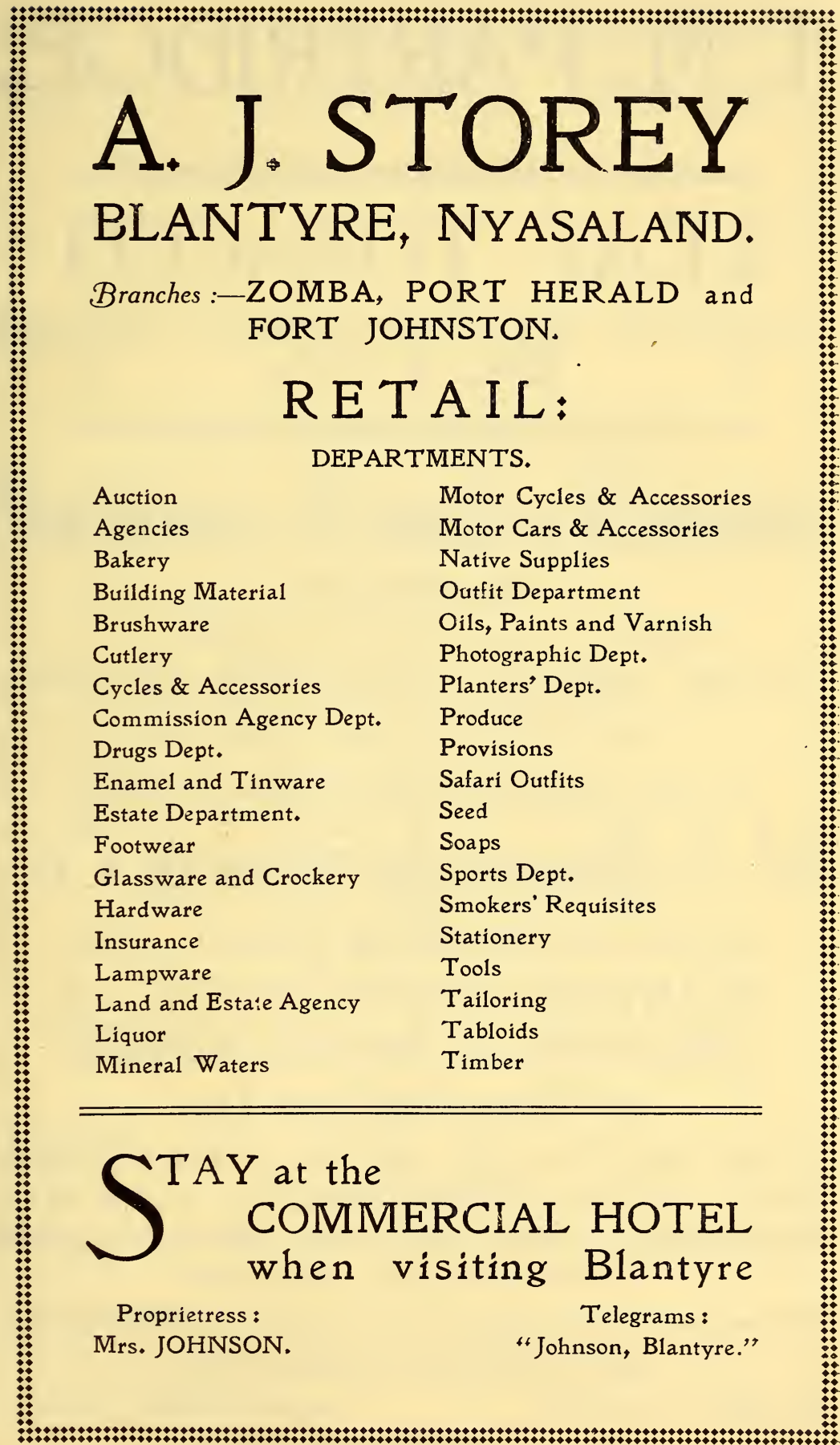




\section{T. M. PARTRIDGE,}
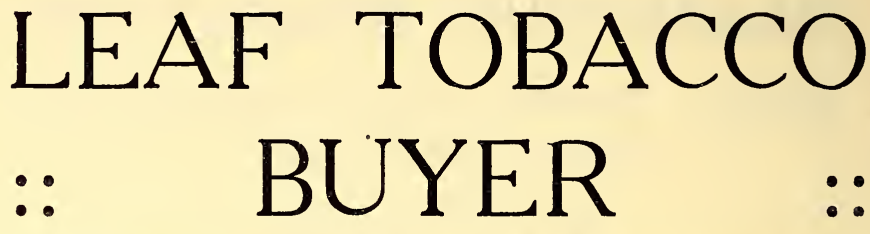

IMPORTER AND EXPORTER.

Cables :

"Partridge," Limbe.
Codes :

A.B.C. 5th Edn. and Bentley's.

By Special Appointment to H.H. The Sultan of Zanzihar.

M. S. Simon de Silva \& Co., MANUFACTURING JEWELLERS, BLANTYRE, IVORY CARVERS, and

Dealers in Ebony, Curiosities, Brassware, $:: \quad$ and Ceylon Hand-made Lace. ::

A large variety of Diamond and Gem-Set ENGAGEMENT RINGS, NECKLETS, BROOCHES, Etc., Etc., IVORY BEAD NECKLACES, IVORY BROOCHES, PENDANTS, SILK KIMONOS, Etc., Etc., always in stock.

Elephant Feet mounting as Liquor Cases, Boxes, etc., specially undertaken. SATISFACTION GUARANTEED.

Head Office: ZANZIBAR.

Telegraphic Address : "Jewellers."

Orders by Correspondence promptly carried out. 


\section{THE LONDON \& BLANTYRE SUPPLY COMPANY, LIMITED.} BLANTYRE, NYASALAND.

Importers, Exporters \& General Merchants.

Large assortment of specially selected

Native

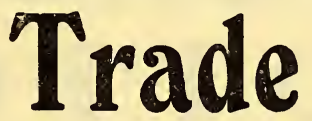

Goods

of the Best Quality always in stock.

Bonded Stores at Blantyre.

Goods supplied Duty free to N.E. Rhodesia and Portuguese Territory - -

Calicoes, Scarves, Handkerchiefs, Beads, Soap, Hoes, also Best - Portland Cement - -

\section{WHOLESALE ONLY.}

SAMPLES AND PRICES ON APPLICATION. Enquiries Solicited.

Branch at Lilongwe, Central Angoniland.

Registered Office and Agents :

H. J. GARDINER \& CO., 70, Basinghall Street,
WM. TAYLOR,

Manager.

LONDON, E.C.2. 


\section{NORTHERN ASSURANCE CO., LTD.} ESTABLISHED 1836.

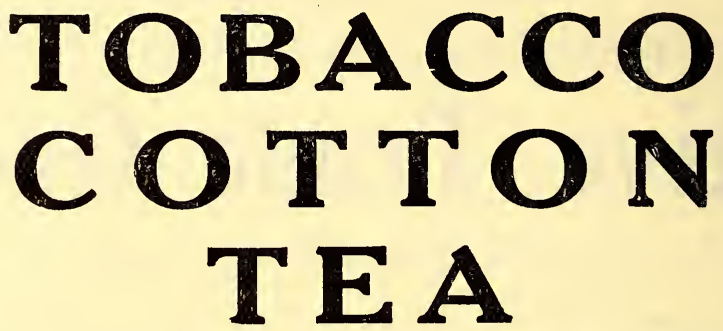

INSURE WITH THE NORTHERN, INSURE TO-DAY, INSURE ALWAYS

- NGTIR YOUR DWELlings, NoURE BUILDINGS, STOCK, CATTLE, FURNITURE, CLOTHES, PRODUCE, MOTOR CARS AND CYCLES, ETC.

For Particulars apply to the Agents:

GE0. de R. ENGELBACH, or H. B. WILSON,

Solicitor, BLANTYRE.
Barrister-at-Law, BLANTYRE. 


\section{Companhia do Boror Ltd.,}

Telegrams : BOROR

P.O. Box No. 27

\section{Head Office : \\ 18, Rua da Prata - LISBON \\ Rue Breteuil 12 - MARSEILLES}

SEAT OF ADMINISTRATION
I N A F R I A A-QUELIMANE.

WHOLESALE PIECE GOODS of every description. PRODUCE MERCHANTS

SALT SELLERS (from our own salterns at MACUSE) PRICE WITHOUT POSSIBLE COMPETITION

\section{PRINTING OFFICE Rua Ferrer.}

Bookbinding, General Printing, Visiting Cards, etc., Labour Tickets a speciality, Paper Bag Makers. .

\section{Shipping Agents Commission Consignation ipping Agents Exporters Importers} Bonded Stores : $\left\{\begin{array}{l}\text { Rua } 31 \text { de Janeiro } \\ \text { Rua do Comercio } \\ \text { Rua Miguel Bombarda }\end{array}\right.$

Offices and Retail Stores: Rua da Republica \& Rua Ferrer

The most important stores in Chinde for the retail sale of Preserves of all kinds, Wines, Beers, Whiskies, Spirits, Tobaccos, Arms and Ammunition, Watches, Sewing Machines (Singer), Office furniture, Lampware, Glassware, Enamelware, Toilet requisites, Flour, Tools, Hardware, Timber, Cement, Lime, Mosquito wire, Wire netting, Enamel paints, Oil paints, Red Oxide paints, White 'Zinc paint, Nails, Screws, Corrugated iron, Galvanized screws and nails, Galvanized washers, etc., etc. 


\section{BEIRA'S LEADING HOTEL}

THE SAVOY

THREE STORIED BRICK BUILDING REPLETE WITH ALL MODERN CONVENIENCES

CENTRAL POSITION : ON SEA FRONT

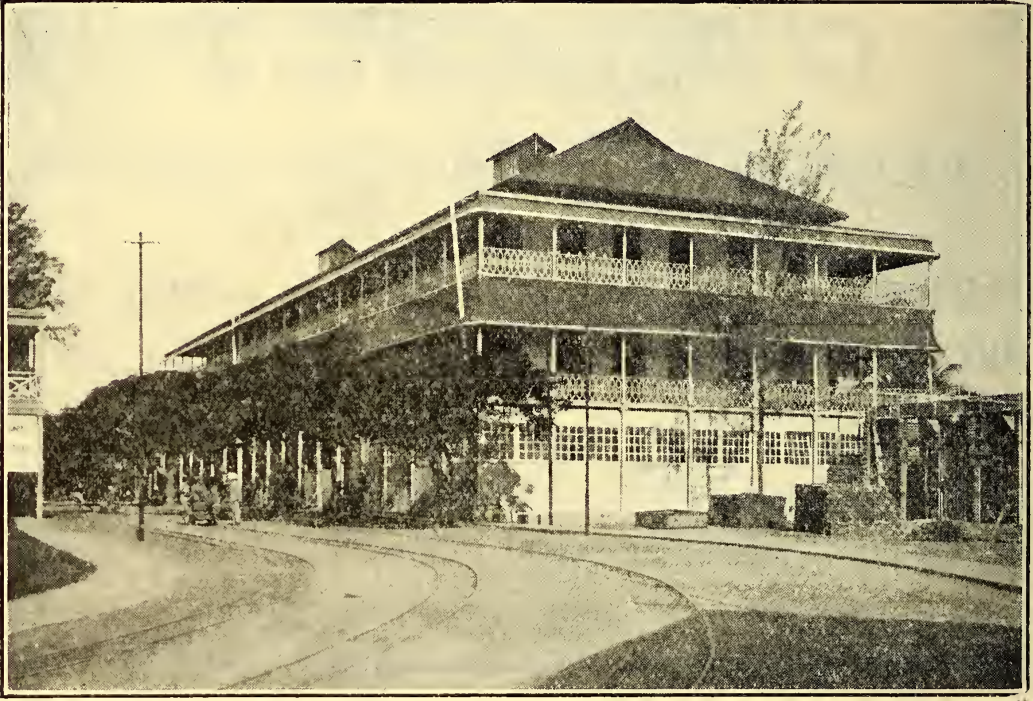

Well Ventilated Bedrooms opening on to Spacious Verandahs. Guest Night Every Month. Bathrooms and Lavatories on all floors. Electric Light throughout.

\section{Provisions and $W$ ines Specially Imported :: Best Quality}

TERMS - 25/- PER DAY. 


\section{STANDARD BANK of SOUTH AFRICA, LTD.}

(With which is Incorporated the African Banking Corporation, Ltd.)

\section{ESTABLISHED 1862.}

Bankers to the Government of the Union of South Africa in Cape Province; to the Imperial Government in South Africa and to the Administration of Rhodesia.

\section{LONDON OFFICES :}

10, Clement's Lane, Lombard Street.

E.C.4. (H.O.),

63, London Wall, E.C.

17, Northumberland Avenue, W.C.2.

\section{HEAD OFFICE IN AFRICA : CAPETOWN.}

New York Agency Rotterdam Branch

Amsterdam Branch

$\begin{array}{ccc}\cdots & \cdots & \cdots \\ \cdots & \cdots & \cdots \\ \cdots & \cdots & \cdots\end{array}$

68, Wall Street.

Hamburg Agents :

Bank of British West Africa, Ltd., 49 to 53 , Schauenburger Strasse.

$\begin{array}{lllr}\text { Authorised Capital } & \ldots & £ 10,000,000 \\ \text { Subscribed Capital } & \ldots & £ 8,916,660 \\ \text { Paid-up Capital } & \ldots & \ldots & £ 2,229,165 \\ \text { Reserve Fund } & \ldots & \ldots & £ 2,893,335\end{array}$

BANKING BUSINESS OF EVERY DESCRIPTION transacted at all Branches and Agencies.

BILLS NEGOTIATED and COLLECTED. DRAFTS issued, MAII, and TELEGRAPHIC REMITTANCES made.

LETTERS OF CREDIT and COMMERCIAL CREDITS established.

TRAVELLERS' LETTERS OF CREDIT issued, available in all parts of the world.

PURCHASE and SALE of Stocks and Shares effected.

DIVIDENDS, ANNUITIES, etc., received, and COUPONS COLLECTED.

EXECUTOR and TRUSTEE Business undertaken.

COMMERCIAL SERVICE.-The Bank has over 430 Branches and Agencies in Africa, and other Offices, Agents and Correspondents throughout the World. The closest touch with Trade and Industrial conditions, both local and overseas, is maintained, and special attention given to commercial enquiries received from customers. 


\section{A. JAY WILLIAMS,}

THE B.C.A. SHOPS, LIMBE.

AGENT IN NYASALAND FOR FORD PRODUCTS-MADE IN CANADA.

\section{d The FORD CAR}

has proved to be the most suitable car for Nyasaland conditions, and its cost and upkeep are within the means of all.

\section{The FORD TON TRUCK}

with pneumatic tyres and worm drive, is indispensable to every settler who wishes to make profits. In temporate climates it is rapidily supplanting the farmer's waggon and team-in Nyasaland, where there are no horses it is a necessity on every estate. It is small in cost and upkeep, can be used in all weathers and over the worst of bush roads. It is immune to cattle sickness, and does not leave its job at critical times for higher pay elsewhere.

\section{(I) The FORDSON TRACTOR}

Hand labour in Plantations will be replaced by mechanical aids. For its weight and cost, the Fordson is the triumph of the age of mechanics applied to agriculture. It will plough and do all land operations, drive machinery, and, fitted with disc wheels and rubber tyres, will haul tons and tons of produce to market. Its light weight is suitable to our light soils and its cost to our pockets.

Engineering work of all sorts is done at the B.C.A. SHOPS at Limbe. Ford Repair work is a special Section in the hands of specialists under my direct supervision.

A. JAY WILL.IAMS,

The B.C.A. Shops, LIMBE. 


\section{The National Bank of South Africa Limited.}

(Registered in the Transvaal.)

\section{CAPITAL AND RESERVE - $£ 4,265,000$. \\ HEAD OFFICE: PRETORIA.}

The Bank has Branches and Sub-Branches in the principal Towns in the UNION OF SOUTH AFRICA, SOUTH WEST PROTECTORATE, RHODESIA, NYASALAND, PORTUGUESE EAST AFRICA, KENYA COLONY, AND TANGANYIKA TERRITORY.

Agents in all the Principal cities of the World.

LONDON OFFICES: Circus Place, London Wall, London, E.C, 2. West End Office: 25, Cockspur Street, S, W, 1,

NEW YORK OFFICE; 44, Beaver Street, Wall Street District.

BOMBAY OFFICE; Eruckshaw Buildings, Hornby Road.

Also Branches at

ANTWERP (Belgium). ST. HELENA (Jamestown). MAURITIUS (Port Louis). ROTTERDAM and AMSTERDAM (Holland).

FRANCE.-This Bank is affiliated with Messrs. Cox \& Co. (France). Ltd., with offices at Paris, Algiers, Amiens, Boulogne, Cannes, and principal towns in France.

Officials of the Bank are bound to secrecy in regard to the transactions of any of its customers. 



The solution used in binding this book has been specially prepared in order to render the work impervious to the ravages of insects. 
SMITHSONIAN INSTITUTION LIBRARIES

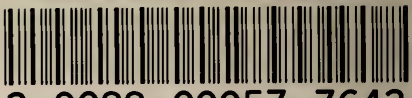

39088 000577643 